\title{
Stratigraphy and Structure
} Death Valley, California

GEOLOGICAL SURVEY PROFESSIONAL PAPER 494-A 


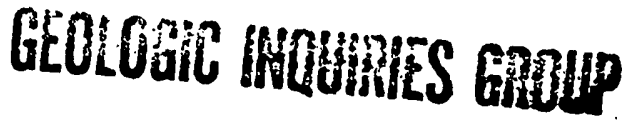

Stratigraphy and Structure Death Valley, California

By CHARLES B. HUNT and DON R. MABEY

GENERAL GEOLOGY OF DEATH VALLEY, CALIFORNIA

GEOLOGICAL SURVEY PROFESIONAL PAPER 494-A

Stratigraphy and structural geology, both of the surficial deposits and bedrock. Two companion reports describe the hydrology, saltpan, and plant ecology.

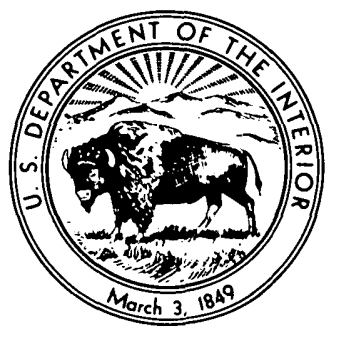

UNITED STATES GOVERNMENT PRINTING OFFICE, WASHINGTON : 1966 


\section{UNITED STATES DEPARTMENT OF THE INTERIOR}

STEWART L. UDALL, Secretary

GEOLOGIGAL SURVEY

William T. Pecora, Director

For sale by the Superintendent of Documents, U.S. Government Printing Office

Washington, D.C. 20402 


\section{CONTENTS}

Abstract............. Introduction, by Charles B. Hunt.......... Location and description of the valley .........

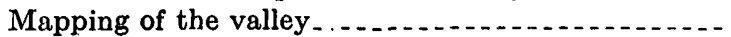
Acknowledgments.................

Stratigraphy, by Charles B. Hunt.....

Precambrian System ...............

Rocks of the crystalline basement.........

Pahrump Series............................... Crystal Spring Formation................

Beck Spring Dolomite................... Kingston Peak(?) Formation. . . . . . . . . .

Noonday Dolomite...........

Johnnie Formation ............................

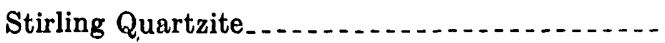

Cambrian System......................................

Wood Canyon Formation .................

Zabriskie Quartzite.........

Carrara Formation ... ...........

Bonunza King Formation.........

Nopah Formation.........

Ordovician System

Pogonip Group . .

Eureka Quartzite. . . . .

Ely Springs Dolomite. . . . . . . . . . . . . . . . .

Silurian and Devonian Systems-Hidden Valley Dolomite.

Devonian System-Lost Burro Formation . . . . . . -

Mississippian System-Tin Mountain Limestone and younger limestone . . . . . . . . . . . . . . . . . .

Mississippian and Pennsylvanian(?) Systems-Rest

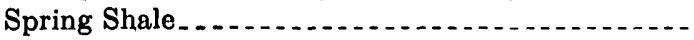

Pennsylvanian and Permian Systems-Formations at east foot of Tucki Mountain . . . . . . . . . .

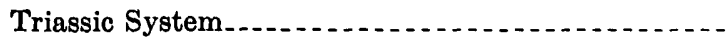

Cretaceous or Tertiary Systems........ Granitic intrusions.............................. Chaotic complex along Amargosa thrust fault.

Tertiary System ............................... Formations in the Black Mountains ........ Formations around Cottonball Basin . .......

Oligocene(?) formations.

Miocene(?) formations.............

Pliocene formations....................... Pliocene and Pleistocene(?) deposits-Funeral Formation . . . . . . . . . . . . . .

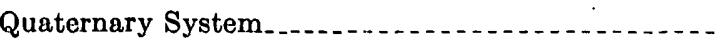

Pleistocene deposits. . . . . . . .

No. 2 gravel . . . . . . . . .

Debris avalanche........................

Lake deposits. . . . . . . . Valley fill

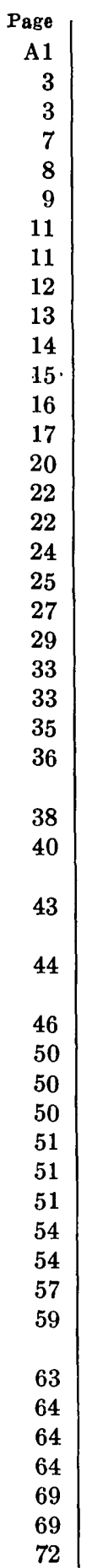

Stratigraphy, by Charles B. Hunt-Continued Quaternary System-Continued Page

Pleistocene(?) and Recent(?) deposits ......... A76

Sand and silt in the playa............. 76

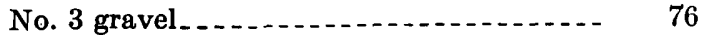

Deposits of travertine and caliche cement in gravel................. 78

Recent deposits............... 79

Shoreline features of the Recent lakes.... $\quad 79$

Older salines............... 83

Massive rock salt $\ldots \ldots \ldots \ldots$

Rough silty rock salt

Smooth silty rock salt_............... 83

Massive gypsum

Saline deposits forming at present........ 84

Flood-plain deposits.............. 84

Marsh deposits................. 84

No. 4 gravel.

Alluvium along Amargosa River and Salt Creek

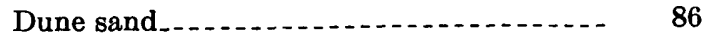

Archeology of the deposits..... 87

Physiography of the fans............ 87

Desert varnish .......... 90

Erosion and sedimentation..................... 93

Damage to roads and flood-control ditches and other features in 25 years............... 93

Damage to trails about 50 years old.......... 95

Damage to prehistoric archeological features... $\quad 96$

Damage to Recent fault scarp along foot of

Black Mountains...........

Weathering, erosion, and sedimentation on Quaternary deposits.

Structural Geology, by Charles B. Hunt and Don R.

Mabey

Structural setting of Death Valley ................ 98

Recent and late Pleistocene structural geology ...... 100

Structural features of the saltpan and gravel

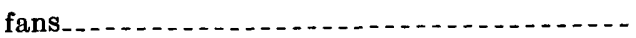

Recent tilting of the saltpan . .........

Recent anticlines and faults affecting the saltpan ........................... 100

Faults and folds on the gravel fans........ 103

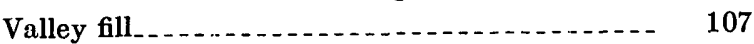

Gravity features........... 107

Magnetic features..................... 108

Changes in the altitudes of bench marks..... 110

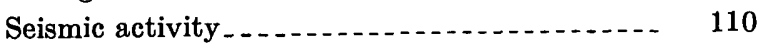

Tiltmeter measurements, by Gordon W. Greene_ 112

Methods............ 112

Measurements_._._. 112 
Structural Geology-Continued

Recent and late Pleistocene structural geology-Con. Tiltmeter measurements-Continued

Relation between tilting movements and seismic activity

Early Pleistocene structural features

A114

Miocene(?) and early Tertiary structural features...

Granitic intrusions.

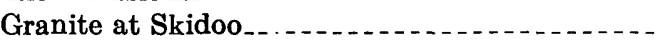

Granite at Hanaupah Canyon............

Chaotic complex along the Amargosa thrust........ -

Indicated granitic rock under the Panamint Range.-
Structural Geology - Continued

Structure of Precambrian and Paleozoic rocks

Tucki Mountain klippe

Southern part of the Panamint Range

Black Mountains fenster....................

Funeral Mountain's fenster and Funeral Moun-

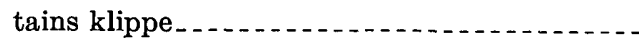

Southern Grapevine Mountains..............

Origin of the structural features.....

Summary of the structural features. References...

Index

\section{ILLUSTRATIONS}

Plate 1. General geologic map of Death Valley, Calif .......... In pocket

2. Maps illustrating some differences in dissection of gravel fans along the east foot of the Panamint Range. . . . . . . .

3. Tectonic diagram and Bouger gravity map, Death Valley ......... In pocket

Figure 1. Relation of Death Valley to the southern Great Basin, northern Mojave Desert, and Sierra Nevada.................

2. Block diagram of Death Valley

3. View west across Death Valley to the Panamint Range.

4. View southeast across Death Valley to the south end of the saltpan and mouth of the Amargosa River

5. View northeast across Death Valley to the Black Mountains and Funeral Mountains ....

6. Diagram illustrating distribution and possible structural relationship of the three formations of the Pahrump Series in the Panamint Range......

7. View of Crystal Spring Formation

8. Micrographs of quartzite and dolomite in Crystal Spring Formation...................

9. Structures suggestive of Scolithus tubes in Noonday Dolomite

10. Micrographs of Noonday Dolomite.....

11. View of Johnnie Formation

12. Micrographs of rock types in Johnnie Formation

13. View of Stirling Quartzite

14. Micrograph of Stirling Quartzite . . .

15. View of interbedded shale, quartzite, and dolomite in upper part of Wood Canyon Formation.

16. Micrographs of shale and quartzite from Wood Canyon Formation

17. Micrograpb of Zabriskie Quartzite . . . .

18. View of Zabriskie Quartzite, Carrara Formation, and base of Bonanza King Formation

19. Fragments of bioclastic "trilobite trash" bed typical of lower part of Carrara Formation.

20. Micrographs of Cambrian carbonate rocks.

21. Linguloid brachiopods and trilobites from shaly zone near the middle of the Bonanza King Formation

22. Thin-bedded limestone member near the middle of the Bonanza King Formation . .....

23. Bioclastic bed with fragments of trilobites and brachiopods from base of Nopah Formation.

24. View of Pogonip Group in Trail Canyon ...

25. Micrographs of Ordovician dolomite and quartzite

26. Large gastropods in dolomite in upper part of Pogonip Group

27. View of Eureka Quartzite and overlying Ely Springs Dolomite at mouth of Little Bridge Canyon.

28. View of Ordovician, Silurian, and Devonian formations on south side of Tucki Mountain -

29. Micrograph of Lost Burro Formation.

30. Stromatoporoid and Amphipora(?) beds, Lost Burro Formation . . .

31. Limestone containing Cyrtospirifer

32. Diagrammatic sections of Devonian and Mississippian syringoporoid corals.

Page 
Figdre 33. Micrographs of limestone from Tin Mountain Limestone and unnamed younger Mississippian formation

34. Golfball-like nodules of dark chert in Rest Spring Shale

35. Micrograph of limestone from Rest Spring Shale . .

36. View of thin-bedded limestone and dolomite near base of unnamed formation of Pennsylvanian age, east foot of Tucki Mountain.

37. Micrograph of limestone from unnamed formation of Pennsylvanian age................

38. Geologic map of Badwater turtleback and adjacent areas. . . . . . . .

39. Micrographs of thin sections of felsite and explosion breccia in Artist Drive Formation.....

40. Sketch map of Tertiary formations around Cottonball Basin . .

41. View of fractured cobble conglomerate in the Titus Canyon(?) Formation......

42. Micrograph of thin section of greenish clay from Titus Canyon( $($ ) Formation.............

43. Micrographs of thin sections of four sedimentary rocks from Miocene(?) formations.....-

44. View of Furnace Creek Formation at north end of Black Mountains .

45. Micrographs of thin sections of playa deposits in the Furnace Creek Formation.........

46. Gravel fill in former channel of Furnace Creek Wash

47. Escarpment along front of north end of Black Mountains.

48. Map and profile across mudflows on Starvation Canyon fan

49. Boulders disintegrating to slabs and flakes .

50. Desert pavement. . .

51. Desert pavement interrupted by terracettes.

52. Gravel bar of Lake Manly

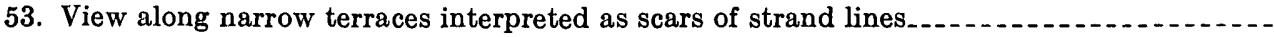

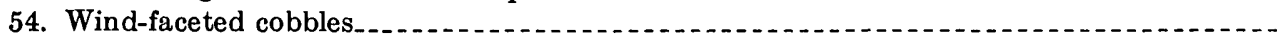

55. No. 2 gravel displaced by fault that is overlapped by No. 3 gravel.

56. Travertine deposit along Furnace Creek Wash

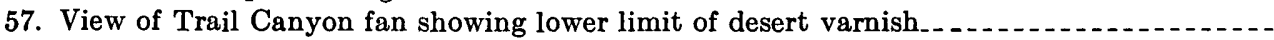

58. Shoreline of Recent lake in cove north of West Side Borax Camp

59. Shoreline cut in alluvial bank

60. Shoreline at foot of Artists Drive fault block

61. Shoreline at foot of fan north of Coffin Canyon.

62. Contrast between No. 4 and No. 3 gravels . . .

63. No. 2 gravel overlapped by fan of No. 4 gravel .

64. Diagram illustrating downfan shift in position and overlap of younger gravels on older

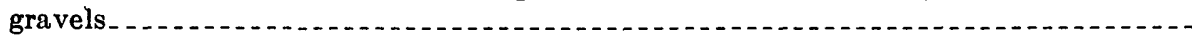

65. Map illustrating differences in drainage pattern on the older and younger gravels......

66. Fan patterns at the foot of the Black Mountains and the Panamint Range.............

67. Sections illustrating depth of fill in Death Valley . .

68. Map showing the Death Valley subsection of the Great Basin . . .

69. Map showing seismic epicenters in southwestern United States. . .

70. Bouguer gravity-anomaly map of southwestern United States..

71. Sketch map showing principal Quaternary structural features in Death Valley.........

72. Recent fault scarp at foot of Black Mountains

73. Map of Indian sites along the escarpment of a Recent fault at foot of Black Mountains....

74. Map showing drainage deflected at the projected axes of turtlebacks in the Black Mountains.

75. Oblique aerial view of the Salt Creek Hills

76. Escarpments of late Pleistocene and Recent faults west of Shortys Well

77. Hanging valleys at front of Black Mountains....

78. Hanging valley at Gower Gulch at front of Black Mountains

79. Section from Funeral Mountains southwestward across Texas Spring syncline and Black Mountains ...

80. View along southwest flank of anticline at Mustard Canyon Hills . . . . . . . . . .

81. Diagram illustrating gravity anomaly produced by a prism

82. Gravity and inferred bedrock profile across Badwater Basin . . . . . . . . . . .

83. Aeromagnetic profiles across Death Valley

84. Relative changes in altitudes of bench marks in Death Valley between level surveys in 1907 and 1933 and in $1942-43$.

85. Diagrams showing tilting observed in the Death Valley areat

86. Section of Tucki Mountain

87. Section of the Copper Canyon turtleback fault .

88. Diagrammatic section illustrating probable thinning and offlap of Tertiary and Quaternary formations from the Black Mountains northeastward to the Texas Spring syncline

Page

A 45 
FIaURe 89. Section north of Trail Canyon

90. Cross section of the granite at Hanaupah Canyon..

91. Fence diagram illustrating inferred shape of granite at Skidoo $\ldots \ldots 124$

92. Micrographs of thin sections of granite at Skidoo

93. Sketch of hand specimen of porphyry facies of granite at Skidoo

94. Fence diagram illustrating inferred shape of granitic intrusion at Hanaupah Canyon

95. Micrographs of thin sections of granitic instrusion at Hanaupah Canyon

96. Map of Amargosa thrust complex along east foot of Panamint Range

97. View of dike swarm in Amargosa thrust complex

98. View of chaoslike formation in Amargosa thrust complex....

99. View of augen gneiss in Amargosa thrust complex.

100. Specimen of augen gneiss from Amargosa thrust complex

101. Diagrammatic section illustrating flattening of foliation of augen gneiss eastward from

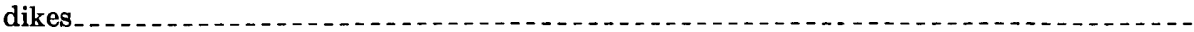

102. Granitized metasediment and incompletely replaced metasediment in Amargosa thrust complex . -

103. Zircons from Amargosa thrust complex

104. Micrograph of thin section of granitic rock in Amargosa thrust complex

105. Felsite plug in granite in Amargosa thrust complex

106. Micrographs of thin sections of volcanic rocks in Amargosa thrust complex

107. Sketch of Copper Canyon turtleback

108. Section of Black Mountains, Death Valley, and Panamint Range showing supposed extent of Amargosa thrust and relations of granitic intrusions and volcanism to it..........

109. Isometric fence diagram of Tucki Mountain klippe........

110. Topographic and geologic map of exhumed surface of Trellis Canyon fault . . . . . . . . .

111. Diagram illustrating difference between actual dip and effective dip in series of fault blocks.

112. Fracture cleavage in shale member of the Stirling Quartzite

113. Burro Trail fault. View north from the divide north of Starvation Canyon

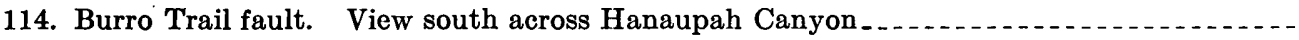

115. Burro Trail fault. View north between Death Valley and Trail Canyons............

116. Burro Trail fault on south side of Trail Canyon

117. View north across tear fault in Starvation Canyon

118. Turtleback fault surface marking Keane Wonder fault

119. Section of west end of Funeral Mountains klippe

120. Section from Virgin Valley to Colorado Plateau showing low-angle faults.............

\section{TABLES}

TABle 1. Precambrian, Paleozoic, and Triassic formations exposed in the Death Valley area....... 2-18. Trace elements in-

2. Precambrian metamorphic rocks

3. Crystal Spring Formation.

4. Kingston Peak(?) Formation.

5. Noonday Dolomite

6. Johnnie Formation

7. Stirling Quartzite ..........

8. Wood Canyon Formation

9. Zabriskie Quartzite

10. Carrara Formation . . .

11. Bonanza King Formation, Panamint Range.

12. Nopah Formation.......

13. Ordovician units, Panamint Range...

14. Devonian and younger Paleozoic formations.

15. Volcanic rocks in the Artists Drive area.

16. Beds correlated with the Titus Canyon(?) Formation of Stock and Bode (1935) -...

17. Miocene(§) deposits . . .

18. Furnace Creek Formation

19. Logs of wells drilled by Pacific Coast Borax Co

20. Trace elements in spring-deposited travertine and in calcite vein in the Funeral Formation.-

Page 
TABLE 21. Semiquantitative spectrographic analyses of desert varnish
22. Erosion, in 20 years, of road shoulder 6 inches high along old bladed road from Beatty Junction south along the foot of the gravel fans.

23. Erosion of flood control embankments in 25 years

24. Erosion along old trails in the last half century

25. Trace elements in the granites at Skidoo and at Hanaupah Canyon

26. Trace elements in the Amargosa thrust complex . . 


\title{
GENERAL GEOLOGY OF DEATH VALLEY, CALIFORNIA
}

\section{STRATIGRAPHY AND STRUGTURE}

\author{
By Charles B. Hunt and Don R. Mabey
}

\begin{abstract}
Death Valley is in southeastern California at the south edge of the Great Basin. The valley and the mountains around it have been the site of three major geosynclines-one formed during late Precambrian time, another during the Paleozoic, and a third during the early part of the Mesozoic Era.

During late Mesozoic and early Cenozoic time the southern Great Basin was part of a geanticline that was folded, thrust faulted, and invaded by granitic intrusions, and that shed sediments to surrounding regions. Later in Cenozoic time the southern Great Basin, including Death Valley, became fragmented, mostly by block faulting, into basins and ranges, and during this time sediments that were eroded from the ranges collected in the basins.
\end{abstract}

The rocks exposed in Death Valley and the adjoining mountains aggregate more than 60,000 feet in thickness, which is only a little more than half the aggregate thickness formed during the geosynclinal and other episodes in this part of the Great Basin. The rocks that are missing probably once were present, but they have been removed by erasion (represented by unconformities) or are concealed by structural discontinuities.

Precambrian rocks are in three major groups. The oldest, which are metamorphic rocks representing the crystalline basement complex, have a structural and topographic relief of more than 3,000 feet.

Overlying the basement complex is the Pahrump Series, which comprises much younger and only slightly metamorphosed formations that are mostly clastic sedimentary rocks, but they include some limestone and dolomite and some diabase. These formations total at least 10,000 feet in thickness. They are not exposed one above the other in this area, and their stratigraphy is inferred from known relations elsewhere. Westward across the Panamint Range, each of the three formations of the series rests in turn on the metamorphic basement complex, probably as a result of thrust faulting rather than stratigraphic changes.

The third and youngest group of rocks included in the Preoambrian are sedimentary formations, mostly clastic, but they include considerable dolomite and some limestone. These rocks are slightly less metamorphosed than thase of the Pahrump Series; the metamorphism is about the same-as that of the Cambrian rocks. However, these formations lie below the Olenellus fauna, which is taken to mark the base of the Cambrian. Their thickness aggregates 7,000 feet.

An unusually complete section of Paleozoic formation is exposed in Tucki Mountain where rocks ranging in age from Early Oambrian to Permian, and representing all the intervening systems, are more than 20,000 feet thick. The Lower Cambrian formations are mostly clastic sedimentary rocks, but the rest of the Paleozoic formations are chiefly limestone and dolomite. The Permian rocks include much conglomerate or breccia de- rived from Paleozoic formations at least as old as Early Devonian and as young as Late Pennsylvanian. Evidently there was considerable deformation during Permian time; it may have begun in Pennsylvanian time.

At the south end of the Panamint Range, only a mile outside the area being reported upon, Triassic formations total 8,000 feet thick. These formations are composed of volcanic and cliastic sedimentary rocks, and represent a return to conditions like those of the Precambrian. Moreover, the thick remnants of the Triassic, like the thick remnants of the Precambrian Pahrump Series, are restricted to a northwest-trending belt approxiately coinciding with the edge of the Sierra Nevada batholith.

Two granitic intrusions that seem to be eastern satellites of the Sierra Nevada batholith lie within the mapped area. They are referred to as the granites at Hanaupah Canyon and Skidoo, and probably are floored intrusions that spread laterally along thrust faults and made the space they occupy by doming the rocks of the upper plates of the thrusts.

The intrusions of the batholith in the Sierra Nevada are Late Jurassic and Cretaceous in age. The granitic intrusions in the Death Valley area are closely related to the volcanism, which is of middle Tertiary age and these granites are younger than the main part of the batholith. This raises a philosophical question as to how widely apart in time and space individual plutons can be and still be part of a composite batholith.

Evidence for a close relationship between the granitic intrusions and the volcanics in the Death Valley area is found along the east foot of the Panamint Range. There a complex of may kinds of igneous, metamorphic, and sedimentary rocks occurs along a thrust fault believed to be the westward extension of the A.margosa thrust. Precambrian augen gneiss cut by a granitic intrusion and a swarm of still younger dikes, underlies the thrust fault. A similar augen gneiss and similar granitic intrusion underlie the Amargosa thrust at the Virgin Springs district 20 miles to the southeast across Death Valley. Zircons in the Precambrian rocks differ from those in the dikes; the granite contains both kinds.

Overlap of lavas and associated eruptives onto Paleozoic rocks of the Panamint Range shows that the eastward tilting of the Range occurred half before, and half after, the eruptives were deposited.

That the volcanic rocks along the belt of the Amargosa thrust complex are Tertiary is indicated by the stratigraphy of the very similar volcanic rocks in the Tertiary formations along the east and north sides of Death Valley. Tertiary formations in the Black Mountains east of Death Valley are at least 12,000 feet thick. The older deposits, volcanics 5,000 feet thick in the Artists Drive area, are quite like those in the Amargosa thrust complex. They are faulted onto the Precambrian core of the mountains. Northward these volcanics grade laterally into 
playa and other sedimentary deposits. They dip northward and thin under a syncline separating the Black and Funeral Mountains. Where the older formations rise again on the north flank of the syncline, at the base of the Funeral Mountains, they are very similar to the Titus Canyon Formation (Oligocene) of Stock and Bode (1935), and are tentatively correlated with it.

In the trough of the syncline is the Furnace Creek Formation of Pliocene age, which is capped by and intertongues with the late Pliocene and early Pleistocene(?) Funeral Formation. Between the outcrops of the Furnace Creek and Titus Canyon(?) Formations is a faulted belt of different-looking sedimentary deposits which, on the basis of structural position, are assumed to be of an intermediate age and accordingly designated Miocene (?).

The oldest deposits in Death Valley classed as Quaternary are cemented fan gravels included with the Funeral Formation. In places the Funeral Formation is conformable on and intertongues with the playa deposits of the Furnace Creek Formation of Pliocene age, but more commonly the Funeral rests with angular unconformity on the older rocks. The Funeral Formation has been displaced thousands of feet by faulting and tilting during the late stages in the structural development of Death Valley and the bordering mountains.

Subsequent to most of that deformation huge gravel fans were built from the mountains to the floor of the valley. Some of these are 6 miles long and more than a thousand feet high. The oldest of these fan gravel deposits, referred to as the No. 2 gravel, still has a distinct fan form which the older Funeral Formation has lost because of deformation and erasion. Both the No. 2 gravel and Funeral Formation have smooth surfaces of desert pavement. Boulders and cobbles on these surfaces are deeply weathered and have disintegrated to produce a new mantle of angular rock fragments. The No. 2 gravel is surely late Pleistocene in age, but it may be pre-Wisconsin.

Other deposits of late Pleistocene age include a debris avalanche at the front of the Black Mountains and some isolated poorly developed beach deposits of a late Pleistocene lake, which had a maximum depth of about 600 feet. The lake, though, was of brief duration and evidently its level fluctuated rapidly, so that beach deposits and other shore features are poorly developed as compared with those around other Pleistocene lake basins in the Great Basin.

Younger gravels on the fans, referred to as No. 3, may include some late Pleistocene deposits and certainly include some Recent deposits.

Other deposits that may be of approximately this age are mounds of travertine at springs on the gravel fans. Some travertine, of course, is being deposited at present, but the occurrence on these mounds of stone artifacts representing the earliest human occupation of the area indicates that the main parts of the mounds have considerable antiquity.

The youngest gravel on the fans, the No. 4 gravel, is along the washes. These deposits are loose gravel composed of firm rocks without desert varnish.

During the Recent, but probably during the 3 millenia preceding the Christian Era, lakes flooded the floor of Death Valley to a maximum depth of 30 feet. The salt deposits comprising the saltpan were formed as a result of this lake.

The principal structural features of Quaternary age are (1) the north-south trough that is Death Valley and the bordering upfaulted mountain blocks; (2) the northwesttrending Furance Creek fault zone and the downwarp that extends along Furnace Creek and northwestward across the northern part of Death Valley; (3) the northwest-trending
Confidence Hills fault zone that extends into the south end of Death Valley; and (4) some features of Copper Canyon and Butte Valley. Deformation is going on at present, as indicated by measurable tilt at seven tiltmeter stations that have been established in the valley.

The composition and extent of the Furnace Creek Formation of Pliocene age indicate that it was deposited in a narrow trough that extended southeastward from Mesquite Flat across the Salt Creek Hills and Cottonball Basin and along the Texas Spring syncline and north end of the Black Mountains. The plays in which the formation was deposited existed long enough to accumulate 5,000 feet of beds.

Much or mast of the uplift of the Black Mountains occurred after the Furnace Creek Formation was deposited because the formation dips $45^{\circ}$ or more off the north end of the mountains. Gravity data, however, indicate that the formation probably thins northward under the Texas Spring syncline, and presumably the thinning is by offlap from the mountains. If so, part of the uplift of the Black Mountains occurred while the Furnace Creek Formation was being deposited. It is inferred that roughly 4,000 feet of uplift at the Black Mountains occurred while the Furnace Creek Formation was being deposited, that another 3,500 feet of uplift occurred during early Pleistocene time, and the last 2,500 feet of uplift occurred in late Pleistocene and Recent time.

The Miocene(?) and older Tertiary formations exposed in fault blocks between the Funeral Mountains and the trough in which the Furnace Creek Formation was deposited are mostiy coarse clastics that were derived from the Funeral Mountains The mountains and the adjoining basin therefore were in existence in mid-Tertiary time.

The basins and ranges in this part of the Great Basin are at least as old as the Titus Canyon and Artist Drive Formations, although the structural limits of those basins and ranges probably were different from the present ones.

The structural history of the region during the earlier geanticlinal stage is obscure. The principal features are the westward-directed Amargosa thrust, the chaos that accompanies it, the smoothly exhumed surfaces of the thrust faults locally known as turtlebacks, and the granitic intrusions that seem to have spread along the thrust faults.

A short segment of the Amargosa thrust is exposed along the east foot of the Panamint Range. The lower plate there, composed of Precambrian metamolphic rocks, is cut by a granitic intrusion. The metamorphic rocks include an augen gneiss; locally the augen are collected into small pegmatitic masses that grade into the dikes of Tertiary age that cut all the rocks in the lower plate. Part of the metamorphism of the lower plate of Precambrian rocks may have occurred at the time the granitic intrusion was emplaced.

The Paleozoic and late Precambrian sedimentary rocks in the mountains bordering Death Valley occur in a series of thrust plates of the Amargosa thrust system. The thrusting moved younger rocks westward onto older ones. Within a thrust plate the rocks have uniform homoclinal dips, almost invariably to the east. The major structural units are grouped into four klippen and three fensters.

The most completely exposed klippe is at Tucki Mountain where Paleozoic formations ranging in age from Early Cambrian to Permian have been thrust westward onto the Kingston Peak (?) Formation of late Precambrian age. The klippe is divided into four plates by thrust faults that, towards the east, branch upward from the main one at the base. Along these branch faults the displacement is 4 miles westward; 
along the main fault the displacement must be very much more than that.

The Panamint Range south of Tucki Mountain also is a klippe of east-dipping Paleozoic rocks thrust westward onto the Precambrian. The thrust fault at the base, the Amargosa thrust, is exposed at the east foot of the range. There Paleozoic formations in the upper plate dip east and rest on Precambrian metamorphic rocks in the lower plate. Other thrust faults within the Paleozoic formations also seem to be branches extending upward from the Amargosa thrust. Some of these branch faults are intruded by sills from the granite at Hanaupah Canyon.

The south end of the Funeral Mountains and the southern part of the Grapevine Mountains comprise klippen of Paleozoic formations thrust westward onto the Precambrian. Between these two thrust plates is a fenster of Precambrian formations forming the northern part of the Funeral Mountains. The two klippen may join under the Amargosa desert east of the Funeral Mountains.

The fenster in the northern part of the Funeral Mountains is formed by anticlinally domed Precambrian formations. So also is the west side of Tucki Mountain, another fenster, and the Black Mountains. The uplift at the Black Mountains is divided into three fensters, each a smooth-surfaced dome or turtleback.

It is suggested that the thrust plates of the Amargosa thrust system in part are detachment blocks, and that the turtleback fault surfaces were denuded tectonically.

Over the main part of the Panamint Range, Bouguer gravityanomaly values are lower than over the mountains east of Death Valley and lower than those over the Slate Range to the southwest, suggesting that the Panamint Range is underlain by a granitic mass. In terms of deep crustal structure the geologic and gravity data suggest two possibilities. One is that deep under the Panamint Range is a large granitic intrusion that connects westward with the Sierra Nevada batholith and forms a bulbous thickened edge of the batholith. A second possibility is that the edge of the batholith is in the area that is seismically active west of the Panamint Range and that the deeply buried granite is mostly Precambrian. By the latter interpretation the granites at Skidoo and Hanaupah Canyon, and other granitic intrusions, could be attributed to palingenesis of the Precambrian granitic rocks.

\section{INTRODUCTION}

By Charles B. Hunt

\section{LOCATION AND DESCRIPTION OF THE VALLEY}

Death Valley, one of the valleys of the Basin and Range province, is at the south edge of the Great Basin, about midway between the Colorado River and the Sierra Nevada. Just to the south is the Mojave Desert (fig. 1).

The valley trends north-south between block faulted mountains (fig. 2). In the main part of the valley, the floor is a flat playa crusted with salts, one of the great natural saltpans of the world. The saltpan covers more than 200 square miles and is $250-280$ feet below sea level. It is the sink for drainage from a hydrologic basin covering 8,700 square miles. An arm of Death
Valley extends 60 miles north-northwestward from the saltpan and rises to about 3,000 feet in altitude. Discharging into the south end of the saltpan is the Amargosa River which rises northeast of Death Valley, flows southward along a valley 25 miles to the east, and then makes a great U-turn to discharge into the south end of Death Valley.

The mountains bordering Death Valley are northtrending fault blocks. Largest and highest of these blocks is the Panamint Range along the west side (fig. 3). Its highest peak, which is more than 11,000 feet above sea level, is only 12 miles from the edge of the saltpan. Both in terms of local relief and local ruggedness, this is one of the roughest terrains in the United States.

Along the east side of the saltpan are the Black Mountains which rise precipitously from the edge of the saltpan to a summit at about 6,000 feet in altitude (fig. 4). Northeast of the saltpan and set back from it by long gravel fans are the Funeral Mountains (fig 5). To the north are the Grapevine Mountains which lie along the east side of the northwest arm of Death Valley.

Death Valley is a desert area. The floor of the valley in fact is the hottest and driest part of the United States. Annual rainfall is only 1.65 inches; the evaporation rate is 150 inches annually! On the floor of the valley a maximum summer temperature of $134^{\circ} \mathrm{F}$ has been recorded. Minimum temperatures in winter almost never reach as low as freezing. The mountains, of course, have more moderate temperatures and considerably more precipitation; the summit of the Panamint Range is covered with snow most of each winter. Additional climatic data are given by Hunt and Robinson (in Hunt and others, 1965).

There is little surface water in Death Valley, but springs with potable water are surprisingly numerous.

Death Valley below an altitude of about 5,000 in part of the Lower Sonoran zone, characterized by the creosotebush. Vegetation is scanty, and there are almost no trees except for some mesquite around the edge of the saltpan where there is a zone of springs. The saltpan, covering more than 200 square miles, is without vegetation. The Panamint Range above 7,500 feet is wooded with piñon pine and juniper; limber and bristlecone pines grow at the summit.

The archeologic record in Death Valley reveals a long series of prehistoric occupations, or seasonal visitors, going back to early Recent and perhaps to late Pleistocene time. The first recorded entrance of white people into the valley was in 1849 when a party of emigrants, heading for the gold fields in California, left their caravan, sought a short cut, and became lost. One of the groups gave the name to the valley. During the next 


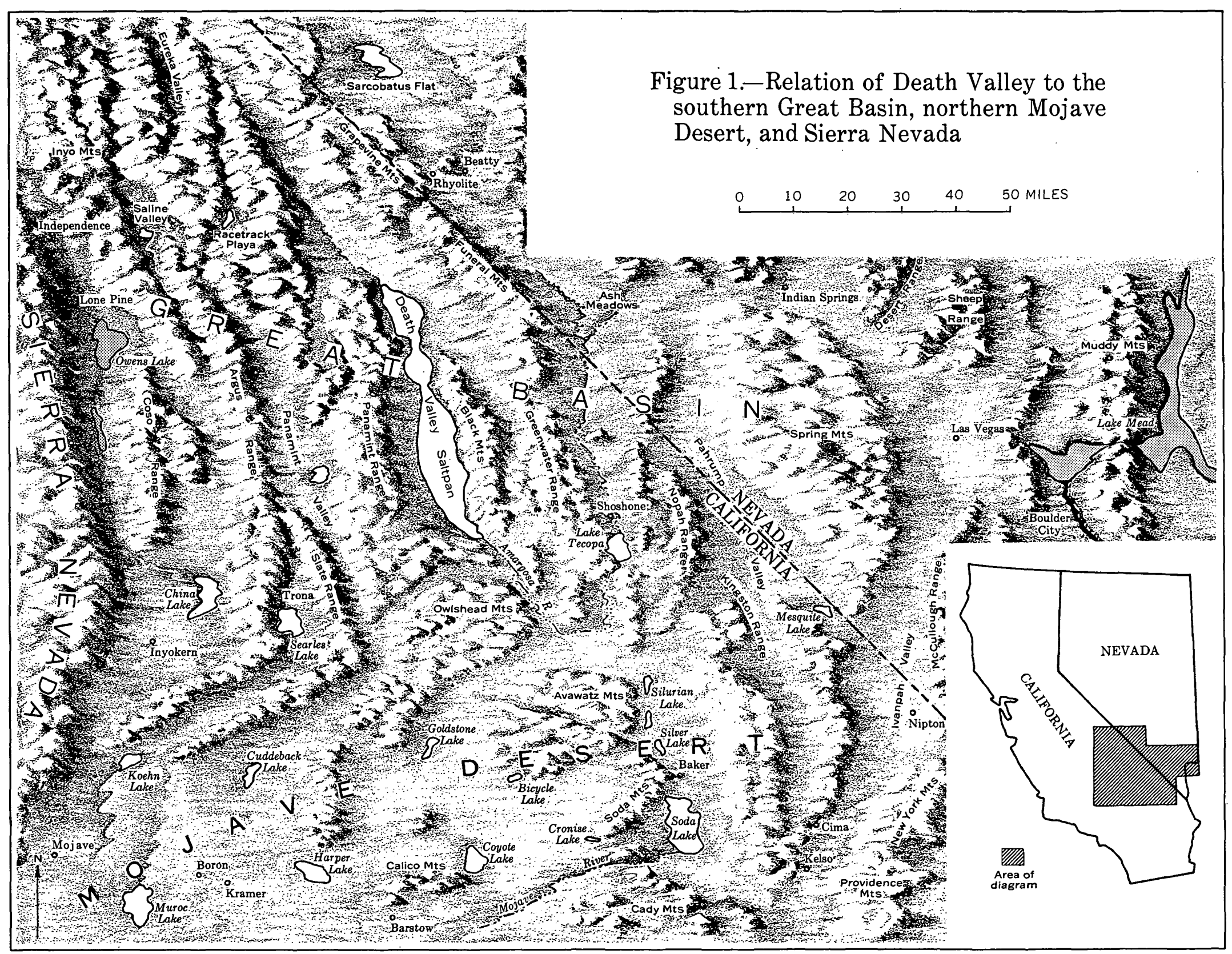




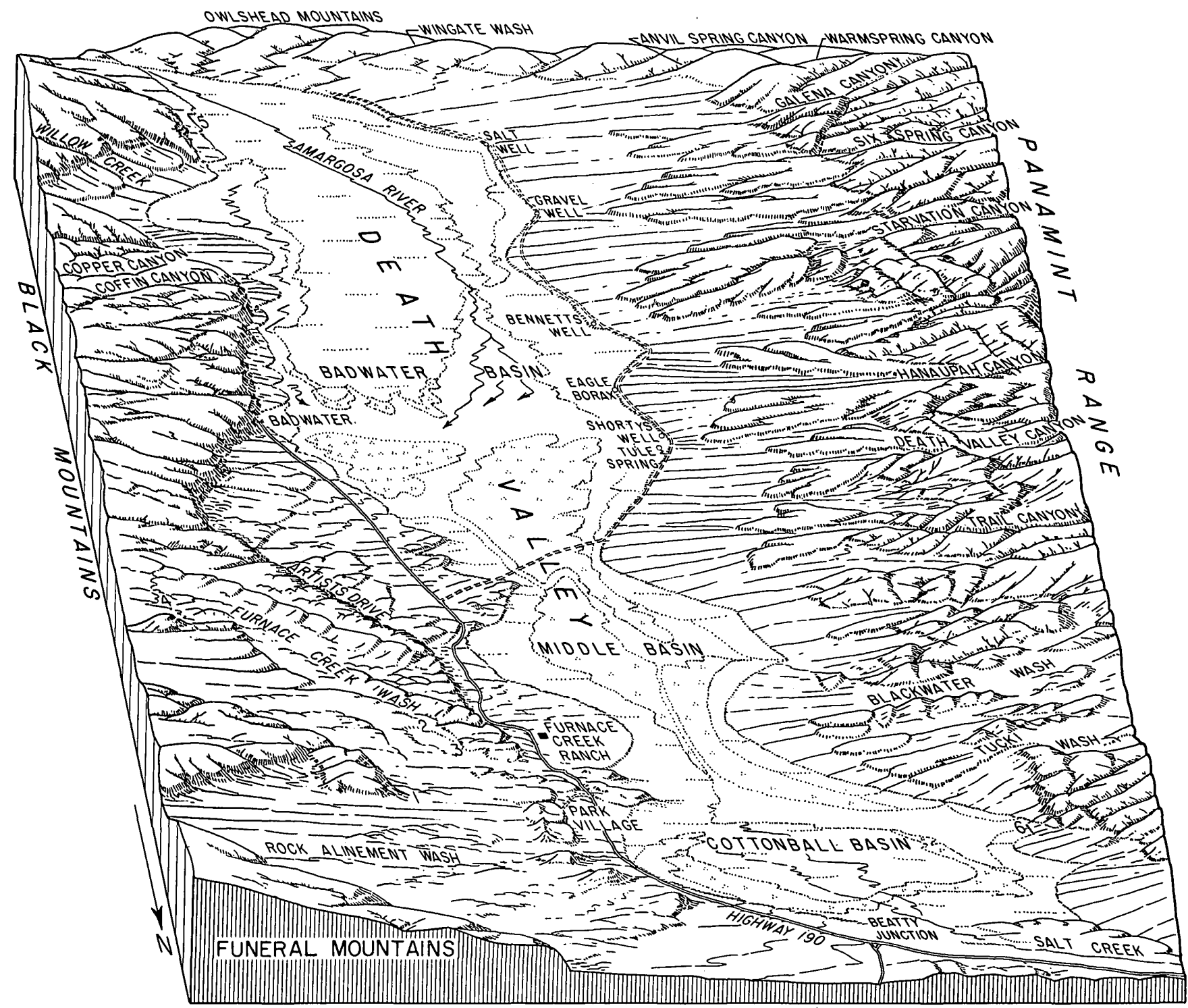

1. Nevares Spring.

2. Travertine Spring.
Fiaure 2.-Block diagram of Death Valley, Callf., looking south.
3. Texas Spring.
4. Corkscrew Canyon.

5. Coyote Hole.

6. West Side Borax Camp (Shoveltown). 


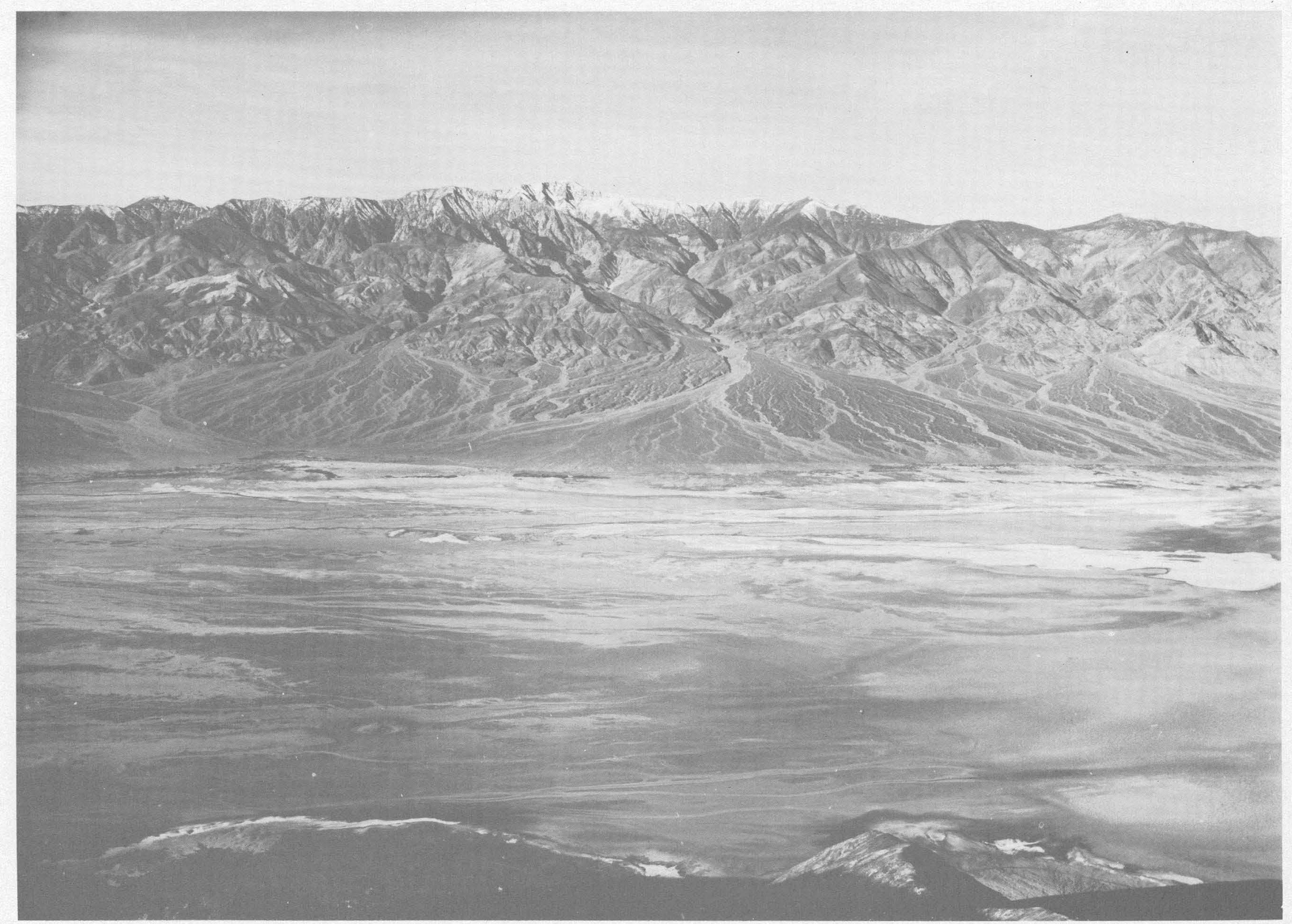




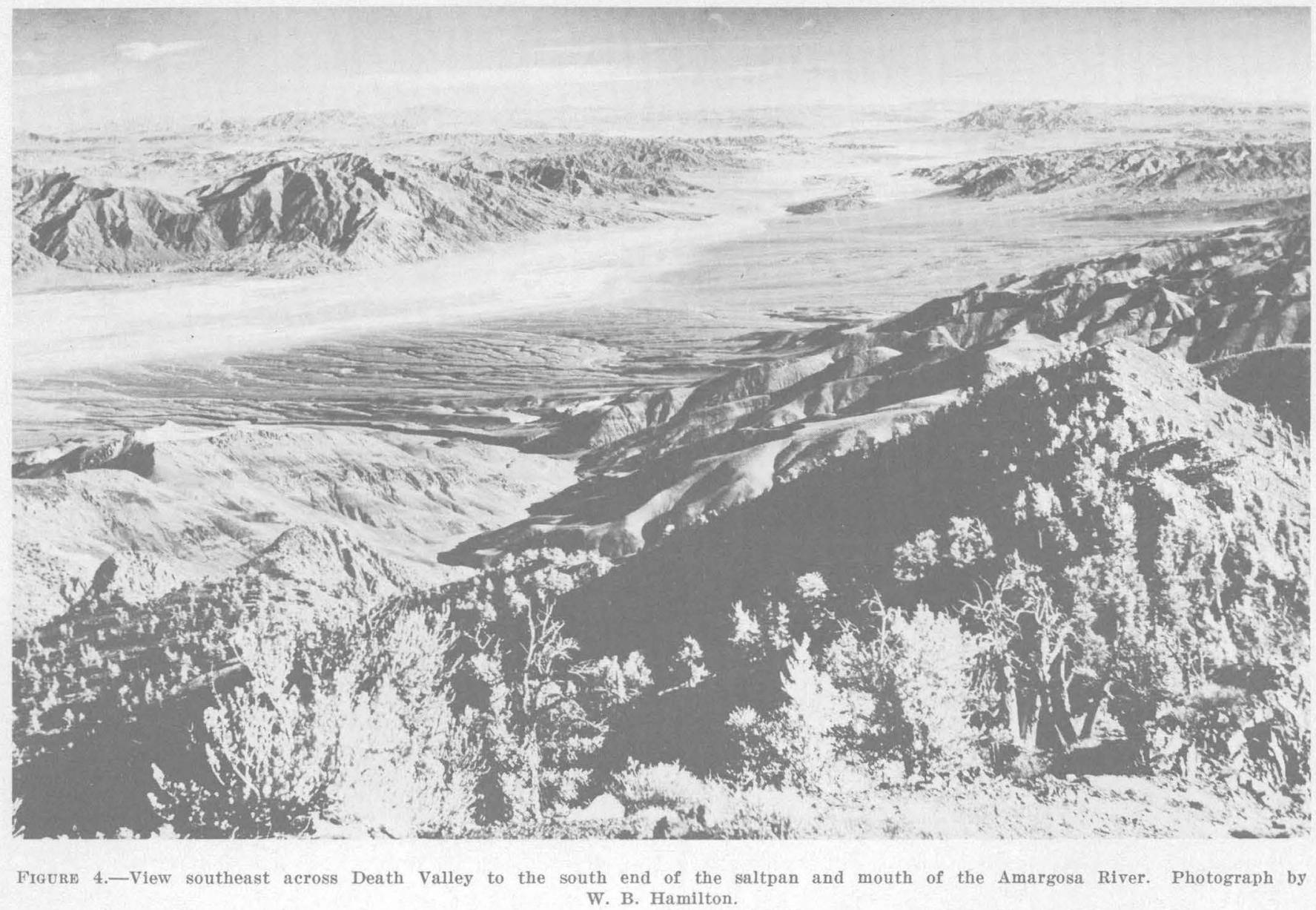

30 years prospectors searching for metal mines visited the mountains bordering Death Valley, and many of the local place names were given by them or commemorate their excursions.

Early in the 1880 's borax was discovered on the Death Valley saltpan and the discovery led to production. In the next year or two richer deposits were found in the northern part of the Black Mountains and production shifted there. Produce from these mines was hauled to Mojave by the well-advertised 20 -mule teams. In the first decade of this century the Skidoo mining district produced a little gold, but the Death Valley area has produced very little metal. Since the midtwenties mining activity has been slight, except for the production of talc in the mountains bordering the south end of Death Valley.

Land surveys in Death Valley were begun in 1857. The fact that the valley floor is below sea level seems to have been discovered about 1861 as a result of barometric observations by one of the several Nevada-California Boundary Commissions. This was confirmed in the midseventies by the Wheeler Surveys when satisfactory maps of the area first became available. During 1905-06 the first topographic map of the area was pre- pared and the altitude of the valley floor determined instrumentally.

Death Valley was made a National Monument in 1933. It has become a popular winter resort, and good highways lead to it from all directions.

Two major scientific contributions have come from Death Valley, one in the field of plant ecology, the other in geology. The ecology contribution was made in 1893 by Frederick V. Coville, a member of the Death Valley expedition. His report on the botany and its relationship to the environment is a classic.

The major contribution in geology was by Levi $\mathrm{F}$. Noble (1941) who was the first to demonstrate clearly the existence of westward-directed thrust faults in the southern part of the Great Basin.

\section{MAPPING OF THE VALLEY}

Different parts of the geologic map (pl. 1) were prepared in very different ways and they are of quite different quality.

The saltpan was mapped by traverses across the valley floor at 1-mile intervals. The ground changes were plotted on aerial photographs, and the boundaries traced along the valley floor to tie into the preceding day's 


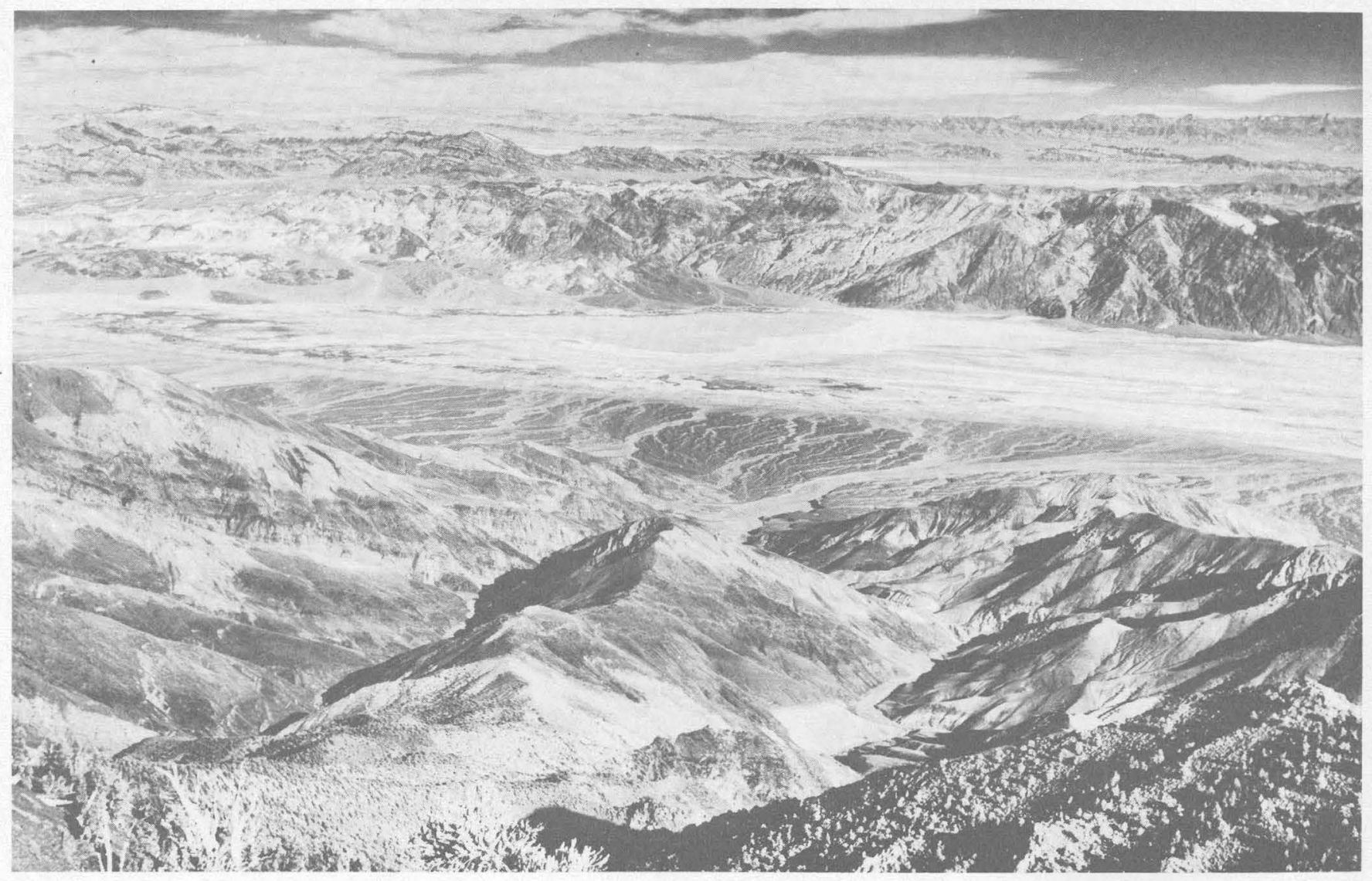

Frgure 5.-View northeast across Death Valley to the Black Mountains and Funeral Mountains. Photograph by W. B. Hamilton.

traverse. The boundaries then were projected directly from the photographs onto the topographic base maps.

Mapping of the gravel fans involved sufficient traverses on each fan to identify the gravel deposits according to their distinctive color and tone on the aerial photographs. The boundaries of the several formations then were sketched with much generalization on the photographs, and these lines were transferred by projection and inspection to the topographic base. In general, the boundaries of the older of the late Pleistocene gravel (No. 2 gravel) are shown by the contours; the younger gravels commonly are in such small areas that a great deal of generalization was necessary, so much so that accurate projection onto the topographic base seemed an overrefinement.

The lower parts of the mountains were mapped on the ground. For the most part the traverses were along the valleys and along the ridges, although this is at right angles to the contacts. The higher parts of the mountains were mapped by helicopter. Within limits, this mapping from the air could be checked by tracing the formations to the lower parts of the mountains where mapping had been done on the ground and where fossil collections had helped control it. Later, some of the most questionable areas were checked by traverses down the ridges and canyons from the summit of the Panamint Range to the floor of Death Valley.

In the course of mapping the Paleozoic formations, about 100 collections of fossils were obtained. Their locations are shown on the geologic map, and the contents of most of the collections are described with the formations. It is expected that future work will show that the formations in some fault blocks have been incorrectly identified, but the fossil collections show the limits to which such corrections may be extended.

Fieldwork was interrupted while parts of the study still were incomplete. In particular, the Tertiary formations, the granitic intrusions, and the older of the Precambrian sedimentary formations need more study.

\section{ACKNOWLEDGMENTS}

Numerous specialists have contributed to various parts of this general report on the geology of Death Valley, and their contributions are acknowledged in the sections dealing with the particulars of the geology. Acknowledgment here is made to James Gilluly who was largely responsible for getting the project launched and persuading me to undertake it. T. S. Lovering visited the project each of the first 5 years and contributed ideas and other assistance on many phases of the 
geology; his encouragement and guidance were a very real benefit to the project.

My wife, Alice P. Hunt, studied the archeology while I was working on the geology. We found that working together in the field was of mutual benefit, and each of us was able to assist the other.

We were headquartered in the field with the staff of the National Park Service. Their many favors and hospitality greatly assisted the project and made the field seasons most pleasurable.

\section{STRATIGRAPHY}

By Charles B. Hunt

Precambrian rocks exposed in the mountains bordering Death Valley include at least 3,000 feet of rocks belonging to the crystalline basement and a sequence of much younger and but slightly metamorphosed sedimëntary rocks, mostly clastic, totaling roughly 10,000 feet thick, referred to as the Pahrump Series. Overlying the Pahrump, and also included in the Precambrian are three formations-the Noonday Dolomite, Johnnie
Formation, and Stirling Quartzite, totaling about 7,000 feet thick.

Paleozoic rocks, mostly carbonate rocks and representing all the periods from Cambrian to Permian, aggregate about 20,000 feet thick. Triassic formations 8,000 feet thick are exposed just outside the mapped area; they include carbonate rocks, fine-grained clastic rocks, and volcanics. Table 1 summarizes the formations recognized in the area and nearby.

The mapping in the Panamint Range and Funeral Mountains on which this report is based was done by Hunt, partly by conventional ground methods and partly by helicopter (Hunt, 1960). The mapping of the Precambrian rocks in the Black Mountains was done by Harald Drewes (1963). The distribution of the formations is shown on the geologic map (pl. 1). Most of the identifications of Cambrian fossils are by Palmer; most of the identifications of Ordovician fossils are by Ross. Other palentologists who identified and reported on the fossils include Ellis $\mathrm{L}$. Yochelson,

TABLE 1.-Precambrian, Paleozoic, and Triassic formations exposed in the Death Valley area

\begin{tabular}{|c|c|c|c|c|}
\hline System & Series & Formation & Lithology and thickness & Characteristic fossils \\
\hline Triassic & & $\begin{array}{l}\text { Butte Valley for- } \\
\text { mation of } \\
\text { Johnson (1957). }\end{array}$ & $\begin{array}{l}\text { Exposed in Butte Valley } 1 \text { mile south } \\
\text { of this area, } 8,000 \mathrm{ft} \text { of metasedi- } \\
\text { ments and volcanics. }\end{array}$ & $\begin{array}{l}\text { Ammonites, smooth-shelled } \\
\text { brachiopods, belemnites, and } \\
\text { hexacorals. }\end{array}$ \\
\hline \multirow{3}{*}{ 胥 } & $\begin{array}{l}\text { Pennsylvanian } \\
\text { and Permian }\end{array}$ & $\begin{array}{l}\text { Formations at } \\
\text { east foot of } \\
\text { Tucki Moun- } \\
\text { tain. }\end{array}$ & $\begin{array}{l}\text { Conglomerate, limestone, and some } \\
\text { shale. Conglomerate contains cob- } \\
\text { bles of limestone of Mississippian, } \\
\text { Pennsylvanian, and Permian age. } \\
\text { Limestone and shale contain } \\
\text { spherical chert nodules. Abundant } \\
\text { fusulinids. Thickness uncertain on } \\
\text { account of faulting; estimate 3,000 } \\
\text { ft + ; top eroded. }\end{array}$ & $\begin{array}{l}\text { Beds with fusulinids, especially } \\
\text { Fusulinella. }\end{array}$ \\
\hline & $\begin{array}{l}\text { Mississipian } \\
\text { and Penn- } \\
\text { sylvanian(?) }\end{array}$ & Rest Spring Shale & $\begin{array}{l}\text { Mostly shale, some limestone; abun- } \\
\text { dant spherical chert nodules. Thick- } \\
\text { ness uncertain because of faulting; } \\
\text { estimate } 750 \mathrm{ft} \text {. }\end{array}$ & None. \\
\hline & Mississipian & $\begin{array}{l}\text { Tin Mountain } \\
\text { Limestone and } \\
\text { younger lime- } \\
\text { stone. }\end{array}$ & $\begin{array}{l}\text { Mapped as } 1 \text { unit. Tin Mountain } \\
\text { Limestone, } 1,000 \mathrm{ft} \text { thick, is black } \\
\text { with thin-bedded lower member and } \\
\text { thick-bedded upper member. Un- } \\
\text { named limestone formation, } 725 \mathrm{ft} \\
\text { thick, consists of interbedded chert } \\
\text { and limestone in thin beds and in } \\
\text { about equal proportions. }\end{array}$ & $\begin{array}{l}\text { Mixed brachiopods, corals, and } \\
\text { crinoid stems. Syringopora } \\
\text { (open-spaced colonies), } \\
\text { Caninia cf. C. cornicula. }\end{array}$ \\
\hline Devonian & $\begin{array}{l}\text { Middle and } \\
\text { Upper Devo- } \\
\text { nian. }\end{array}$ & $\begin{array}{l}\text { Lost Burre for- } \\
\text { mation. }\end{array}$ & $\begin{array}{l}\text { Limestone in light and dark beds } 1-10 \\
\mathrm{ft} \text { thick give striped effect on moun- } \\
\text { tainsides. Two quartzite beds, } \\
\text { each about } 3 \mathrm{ft} \text { thick, near base; } \\
\text { numerous sandstone beds } 800-1,000 \\
\mathrm{ft} \text { above base. Top } 200 \mathrm{ft} \text { is well- } \\
\text { bedded limestone and quartzite. } \\
\text { Total thickness uncertain because } \\
\text { of faulting; estimated } 2,000 \mathrm{ft} \text {. }\end{array}$ & $\begin{array}{l}\text { Brachiopods abundant, espec- } \\
\text { ially Spirifer, Cyrtospirifer, } \\
\text { Productilla, Carmarotoechia, } \\
\text { Atrypa. } \\
\text { Stromatoporoids. } \\
\text { Syringopora (closely spaced } \\
\text { colonies). }\end{array}$ \\
\hline $\begin{array}{l}\text { Silurian } \\
\text { and Devonian }\end{array}$ & $\begin{array}{l}\text { Silurian and } \\
\text { Lower De- } \\
\text { vonian. }\end{array}$ & $\begin{array}{l}\text { Hidden Valley } \\
\text { Dolomite. }\end{array}$ & $\begin{array}{l}\text { Thick-bedded, fine-grained, and even- } \\
\text { grained dolomite; mostly light color. } \\
\text { Thickness } 300-1,400 \mathrm{ft} \text {. }\end{array}$ & $\begin{array}{l}\text { Crinoid stems abundant, includ- } \\
\text { ing large types. Favosites. }\end{array}$ \\
\hline
\end{tabular}


TABle 1.-Precambrian, Paleozoic, and Triassic formations exposed in the Death Valley area-Continued

\begin{tabular}{|c|c|c|c|c|}
\hline System & Series & Formation & Lithology and thickness & Characteristic fossils \\
\hline . & $\begin{array}{l}\text { Upper Ordovician } \\
\text { Middle and } \\
\text { Upper(?) Ordo- } \\
\text { vician. } \\
\text { Lower and Mid- } \\
\text { dle Ordovician. }\end{array}$ & $\begin{array}{l}\text { Ely Springs Dolo- } \\
\text { mite. } \\
\text { Eureka Quartzite } \\
\text { Pogonip Group }\end{array}$ & $\begin{array}{l}\text { Massive black dolomite; } 400-800 \mathrm{ft} \\
\text { thick. } \\
\text { Massive quartzite, with thin-bedded } \\
\text { quartzite at base and top; } 350 \mathrm{ft} \\
\text { thick. } \\
\text { Dolomite, with some limestone, unit } \\
\text { at base; shale unit in middle; mas- } \\
\text { sive dolomite unit at top. Thick- } \\
\text { ness, } 1,500 \mathrm{ft} \text {. }\end{array}$ & $\begin{array}{l}\text { Streptelasmatid corals: Grew- } \\
\text { ingkia, Bighornia. Brachio- } \\
\text { pods. } \\
\text { None. } \\
\text { Abundant large gastropods in } \\
\text { massive dolomite at top: } \\
\text { Palliseria and Maclurites, } \\
\text { associated with Receptaculites. } \\
\text { In lower beds: Protopliomer- } \\
\text { ops, Kirkella, Orthid brachio- } \\
\text { pods. }\end{array}$ \\
\hline \multirow[t]{2}{*}{ 宽 } & $\begin{array}{l}\text { Middle and } \\
\text { Upper Cam- } \\
\text { brian. }\end{array}$ & $\begin{array}{c}\text { Bonanza King } \\
\text { Formation. }\end{array}$ & $\begin{array}{l}\text { Highly fossiliferous shale member } 100 \\
\text { ft thick at base; upper } 1,200 \mathrm{ft} \text { is } \\
\text { dolomite in thick alternating black } \\
\text { and light bands about } 100 \mathrm{ft} \text { thick. } \\
\text { Total thickness of formation } 1,200- \\
1,500 \mathrm{ft} \text {. } \\
\text { Mostly thick-bedded and massive } \\
\text { dark-colored dolomite; a thin- } \\
\text { bedded limestone member } 500 \mathrm{ft} \\
\text { thick } 1,000 \mathrm{ft} \text { below top of the for- } \\
\text { mation; } 2 \text { brown-weathering shaly } \\
\text { units, the upper one fossiliferous, } \\
\text { about } 200 \text { and } 500 \mathrm{ft} \text {, respectively, } \\
\text { below the thin-bedded member. } \\
\text { Total thickness uncertain because } \\
\text { of faulting; estimated about } 3,000 \mathrm{ft} \\
\text { in Panamint Range; } 2,000 \mathrm{ft} \text { in } \\
\text { Funeral Mountains. }\end{array}$ & $\begin{array}{l}\text { In upper part, gastropods. In } \\
\text { basal } 100 \mathrm{ft} \text {, trilobite trash } \\
\text { beds containing: Elburgia, } \\
\text { Pseudagnostus, Homagnostus, } \\
\text { Elvinia, Apsotreta. } \\
\text { The only fossiliferous bed is the } \\
\text { shale below the limestone } \\
\text { member that occurs near the } \\
\text { middle of the formation. } \\
\text { This shale contains linguloid } \\
\text { brachiopods and trilobite } \\
\text { trash beds with fragments of } \\
\text { "Ehmaniella." }\end{array}$ \\
\hline & $\begin{array}{l}\text { Lower and Mid- } \\
\text { dle Cambrian. } \\
\text { Lower Cambrian }\end{array}$ & $\begin{array}{l}\text { Carrara Forma- } \\
\text { tion. }\end{array}$ & $\begin{array}{l}\text { An alternation of shaly and silty mem- } \\
\text { bers with limestone members; } \\
\text { transitional between the underlying } \\
\text { clastic formations and the overlying } \\
\text { carbonate ones. Thickness about } \\
1,000 \mathrm{ft} \text { but variable because of } \\
\text { shearing. } \\
\text { Quartzite, mostly massive and granu- } \\
\text { lated due to shearing; locally in } \\
\text { beds } 6 \text { in. to } 2 \mathrm{ft} \text { thick; not much } \\
\text { crossbedded. Thickness more than } \\
150 \mathrm{ft} \text {; variable because of shearing. }\end{array}$ & $\begin{array}{l}\text { Numerous trilobite trash beds in } \\
\text { lower part yield fragments of } \\
\text { olenellid trilobites. }\end{array}$ \\
\hline 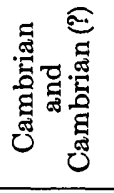 & $\begin{array}{l}\text { Lower Cambrian } \\
\text { and Lower } \\
\text { Cambrian(?). }\end{array}$ & $\begin{array}{c}\text { Wood Canyon } \\
\text { Formation. }\end{array}$ & $\begin{array}{l}\text { Basal unit is well-bedded quartzite } \\
\text { about } 1,650 \mathrm{ft} \text { thick; shaly. unit } \\
\text { above this } 520 \mathrm{ft} \text { thick contains } \\
\text { lowest olenellids in the section; top } \\
\text { unit of dolomite and quartzite } 400 \\
\text { ft thick. }\end{array}$ & $\begin{array}{l}\text { A few scattered olenellid trilo- } \\
\text { bites and archaeocyathids in } \\
\text { the upper part of the forma- } \\
\text { tion. } \\
\text { Scolithus? tubes. }\end{array}$ \\
\hline 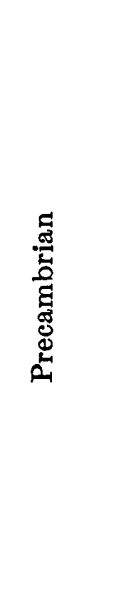 & & $\underset{\text { Jion }}{\text { Johnnie Forma- }}$ & $\begin{array}{l}\text { Well-bedded quartzite in beds } 1-5 \mathrm{ft} \\
\text { thick comprising thick members of } \\
\text { quartzite 700-800 ft thick separated } \\
\text { by } 500 \mathrm{ft} \text { of purple shale; crossbed- } \\
\text { ding conspicuous in quartzite. Maxi- } \\
\text { mum thickness about } 2,000 \mathrm{ft} \text {. } \\
\text { Mostly shale, in part olive brown, in } \\
\text { part purple. Basal member } 400 \mathrm{ft} \\
\text { thick is interbedded dolomite and } \\
\text { quartzite with pebble conglomerate. } \\
\text { Locally, tan dolomite near the mid- } \\
\text { dle and at the top. Thickness more } \\
\text { than 4,000 ft. } \\
\text { In southern Panamint Range, dolomite } \\
\text { in indistinct beds; lower part cream } \\
\text { colored, upper part gray. Thickness } \\
800 \mathrm{ft} \text {. Farther north where map- } \\
\text { ped as Noonday(?) Dolomite, con- } \\
\text { tains much limestone, tan and white, } \\
\text { and some limestone conglomerate. } \\
\text { Thickness about } 1,000 \mathrm{ft} \text {. }\end{array}$ & Scolithus? tubes. \\
\hline
\end{tabular}


Table 1.-Precambrian, Paleozoic, and Triassic formations exposed in the Death Valley area-Continued

\begin{tabular}{|c|c|c|c|c|}
\hline Bystem & Series & Formation & Lithology and thickness & Characteristic fossils \\
\hline \multirow{4}{*}{ 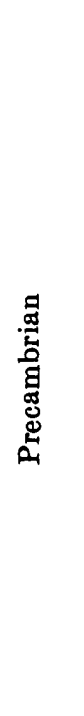 } & Pahrump Series & $\begin{array}{l}\text { Kingston Peak(?) } \\
\text { Formation }\end{array}$ & $\begin{array}{l}\text { Mostly conglomerate, quartzite, and } \\
\text { shale; some limestone and dolomite } \\
\text { near middle. At least } 3,000 \mathrm{ft} \\
\text { thick. Although tentatively assigned } \\
\text { to the Kingston Peak Formation, } \\
\text { similar rocks along the west side of } \\
\text { the Panamint Range have been } \\
\text { identified as Kingston Peak. }\end{array}$ & None. \\
\hline & & $\begin{array}{l}\text { Beck Spring Dolo- } \\
\text { mite }\end{array}$ & $\begin{array}{l}\text { Not mapped; outcrops are to the west. } \\
\text { Blue-gray cherty dolomite; thick- } \\
\text { ness estimated about } 500 \mathrm{ft} \text {. Iden- } \\
\text { tification uncertain. }\end{array}$ & None. \\
\hline & & $\begin{array}{l}\text { Crystal Spring } \\
\text { Formation }\end{array}$ & $\begin{array}{l}\text { Recognized only in Galena Canyon } \\
\text { and south. Total thickness about } \\
2,000 \mathrm{ft} \text {. Consists of a basal con- } \\
\text { glomerate overlain by quartzite that } \\
\text { grades upward into purple shale and } \\
\text { thinly bedded dolomite; upper part, } \\
\text { thick-bedded dolomite, diabase, and } \\
\text { chert. Talc deposits where diabase } \\
\text { intrudes dolomite. }\end{array}$ & None. \\
\hline & & $\begin{array}{l}\text { Rocks of the } \\
\text { crystalline base- } \\
\text { ment }\end{array}$ & $\begin{array}{l}\text { Metasedimentary rocks with granitic } \\
\text { intrusions. }\end{array}$ & None. \\
\hline
\end{tabular}

P. E. Cloud, Jr., W. A. Oliver, Jr., Chas. W. Merriam, Mackenzie Gordon, Jr., and Richard Rezak.

I have illustrated a number of the formations with pictures of slabs of fossiliferous rock, which some may find helpful as lithologic guides to the formations, as pointed out 30 years ago by Noble $(1934$, p. 175). 'Trilobites are the most abundant fossils in the Cambrian beds ; gastropods in the Lower Ordovician beds; corals in the Upper Ordovician, Silurian, and Devonian; and crinoids in the Mississippian. Such generalized observations are very helpful in identifying rock formations that have been severely faulted and crumpled.

\section{PRECAMBRIAN SYSTEM}

ROCKS OF THE CRYSTALIINE BASEMENT

Precambrian rocks of the crystalline basement in this area are most extensive in the steep front of the Black Mountains. Some smaller outcrops are at the head of Galena Canyon and along the east foot of the Panamint Range north of Hanaupah Canyon.

The outcrop of the Precambrian in the head of Galena Canyon is mostly schist. The foliation in the schist, which is about vertical, is cut off discordantly by conglomerate at the base of the Crystal Spring Formation, the lowest formation in the Pahrump Series. The contact is thought to be depositional.

The outcrop of Precambrian metamorphic rock along the east foot of the Panamint Range north of Hanaupah Canyon marks the lower plate of a thrust fault, probably the Amargosa thrust; this lower plate has been the site of much igneous activity. The rocks are referred to as the Amargosa thrust complex and are described more fully on page A 129.

The Precambrian in the Amargosa complex is mostly gneiss, much of which is highly distinctive augen gneiss like that underlying the Amargosa thrust southeast of Mormon Point (Noble, 1941). The augen are feldspar, $1 / 4-1$ inch long, and constitute from 10 to 40 percent of the rock. The matrix is quartz and coarse-grained mica, mostly biotite. Enclosed in the augen gneiss are crushed lenses of biotite schist and some muscovite schist.

Above the augen gneiss is a crush zone consisting of mylonite and breccia along a thrust fault, probably the Amargosa thrust. The upper plate here is Stirling Quartzite.

The gneiss is cut by a swarm of northward-trending felsite dikes; their strike parallels the foliation in the gneiss.

Northward the gneiss extends under interlayered volcanic and Paleozoic rocks suggestive of the "chaos" as described by Noble (1941). Underlying the gneiss is a granitic intrusion.

Much interest attaches to the age of the metamorphism of this gneiss, because part of the metamorphism may have occurred during the early or middle Tertiary when the thrust faulting occurred and the granitic intrusion became emplaced.

The rocks of the Black Mountains have been described by Drewes (1963) who has mapped the Funeral Peak quadrangle. The following descriptions are summarized from his report. 
The rocks comprise metadiorite and smaller bodies of metasedimentary schist, gneiss, and marble. The schist, gneiss, and marble underlie the lower parts of northwest-trending mountain spurs at Mormon Point and the mountain southeast of Copper Canyon. The schist and gneiss are in about equal proportions. Near Mormon Point, marble is equally abundant, but elsewhere it is less so. The thickness of the metasedimentary rocks is unknown, but is of the order of many hundreds of feet.

The schist generally consists of quartz $(10-25$ percent), plagioclase ( $15-25$ percent), chlorite $(30-60$ percent), biotite (10-20 percent), and sericite; it has minor amounts of magnetite, sphene, and possibly potassium feldspar.

The gneiss consists largely of quartz ( $20-40$ percent), plagioclase feldspar (15-40 percent), and potassium feldspar (as much as 40 percent) in light-colored layers, mostly less than 1 inch thick, alternating with thin dark layers of biotite. Some facies of the gneiss have layers of muscovite instead of biotite. The layers are mostly even and distinct. In places the gneiss contains feldspar augen $1 / 2-1$ inch long. Veins and irregular masses of epidote are common.

The marble is white to light olive gray and weathers yellowish gray to pale yellowish brown. It occurs in lenticular beds ranging from a few feet to a few tens of feet thick interbedded with the schist or gneiss. Most of the marble is coarsely crystalline calcite, but some at Mormon Point is dolomitic.

Most of the front of the Black Mountains is Precambrian metadiorite. This rock, which is not foliated, and consists largely of plagioclase feldspar (40-65 percent), hornblende (20-40 percent), and biotite (3-15 percent). It appears to be intrusive into the metasedimentary rocks.

In the course of my survey, samples were collected from all the formations for spectrographic scanning for trace elements. Table 2 lists the trace elements found in a piece of schist from Galena Canyon and in a piece of gneiss from the Black Mountains above Badwater. Analyses of the augen gneiss and biotite gneiss in the Amargosa thrust complex at the east foot of the Panamint Range north of Hanaupah Canyon are given in table 26.

The trace elements in the schist and gneiss are remarkably alike, considering the very different lithologies and locations of the rocks. They differ from the gneisses in the Amargosa thrust complex in containing more lead, manganese, cobalt, vanadium, titanium, boron, and gallium.
TABle 2.-Trace elements in Precambrian metamorphic rocks [Analyses of the metamorphic rocks in the Amargosa thrust complex, where the rocks may have been subject to Tertiary alteration, are given in table 26 . Semi quantitative spectrographic analyses by Uteana Oda, U.S. Geol. Survey. Values parts per million, except $\mathrm{Mg}$, which is given in percent]

\begin{tabular}{|c|c|c|}
\hline Element & $\begin{array}{c}\text { Schist in } \\
\text { Galena } \\
\text { Canyon }\end{array}$ & $\begin{array}{c}\text { Gneiss above } \\
\text { Badwater }\end{array}$ \\
\hline 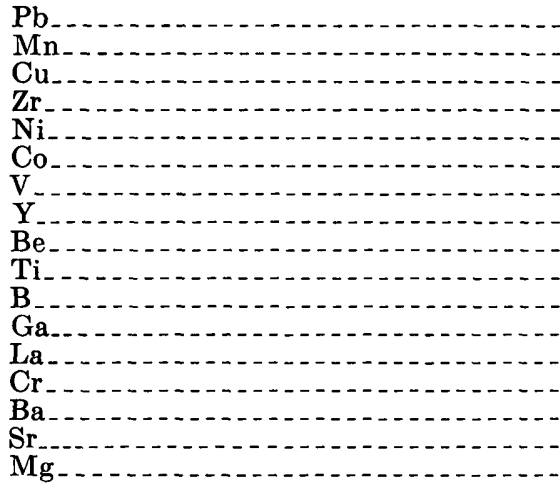 & $\begin{array}{r}30 \\
500 \\
50 \\
150 \\
50 \\
20 \\
150 \\
20 \\
3 \\
5,000 \\
70 \\
70 \\
70 \\
100 \\
700 \\
20 \\
1.5\end{array}$ & $\begin{array}{r}30 \\
700 \\
30 \\
100 \\
30 \\
70 \\
300 \\
20 \\
1 \\
10,000 \\
70 \\
30 \\
50 \\
30 \\
2,000 \\
700 \\
5\end{array}$ \\
\hline
\end{tabular}

Nore. - Also found: W, $<20 ; \mathrm{Nb},<10 ; \mathrm{Zn},<200 ; \mathrm{La},<50 ; \mathrm{Sc},<10 ; \mathrm{Mo},<2$ or less; $\mathrm{Ag},<1 ; \mathrm{Bi},<5 ; \mathrm{Sn},<10 ; \mathrm{As},<500 ; \mathrm{Sb},<50$.

Metamorphism of schist under the Pahrump Series in the southern Panamint Range is dated as 1,700 million years by potassium-argon methods and 1,480 million years by strontium-rubidium methods (Wasserburg and others, 1959). A comparable age has been determined for the augen gneiss zircon in the Amargosa thrus' complex (T. W. Stern, written commun., $1965)$

\section{PAHRUMP SERIES}

The Pahrump Series, named for Pahrump Valley 50 miles east of Death Valley (see index map, fig. 1; Hewett, 1940, 1956), in its type area consists of three formations. At the base is the Crystal Spring Formation, about 2,000 feet thick, consisting of a basal quartzitic member overlain by thick-bedded dolomite, diabase, and chert. Above the Crystal Spring Formation is the Beck Spring Dolomite, 1,100 feet thick, which is made up mostly of beds of light-blue-gray dolomitte $2-4$ feet thick. At the top, in the type area, is the Kingston Peak Formation, 1,000-2,000 feet thick, which consists of sandstone and shaly sandstone at both the top and base, separated by a middle unit of conglomerate with cobbles as much as 10 inches in diameter (Hewett, 1956).

In the Silurian Hills, southeast of Death Valley, the rocks assigned to the Pahrump Series are more than 11,000 feet thick, but correlation with the type section is uncertain (Kupfer, 1960, p. 188). In the Alexander Hills of Pahrump Valley, rocks assigned to the Pahrump total 8,000 feet thick and appear to represent all three of the formations recognized in the type section (Wright, 1954). 
A section of the Pahrump Series very similar to that in the type area is present also in the Ibex Hills in the southern part of Death Valley (Wright, 1952), an area about midway between the type locality and the southern part of the Panamint Range.

In the southern part of the Panamint Range, both in Galena Canyon and in the section of Warm Springs Canyon south of the area I studied, only the Crystal Spring Formation is present. It rests with angular unconformity on schist of the crystalline basement and is overlain by Noonday Dolomite. This contact between the Crystal Spring Formation and the Noonday Dolomite probably is a thrust fault and not a depositional contact. In any case, younger formations of the Pahrump Series are not present in the southeastern part of the Panamint Range, but they are present along the summit and west slope of the range.

On the west side of the Panamint Range the Kingston Peak Formation rests on the Precambrian crystalline basement; the Crystal Spring Formation is absent there (Johnson, 1957, p. 360). Locally, a dolomitic limestone that is much crushed occurs along the contact between the Kingston Peak Formation and underlying crystalline rocks (Murphy, 1932, p. 343); this dolomitic limestone may correlate with the Beck Spring Dolomite.

The spatial relationships of the three formations and their possible structural relations are illustrated on figure 6 .

\section{CRYBTAL SPRING FORMATION}

The Crystal Spring Formation in Galena Canyon is about 2,000 feet thick. It consists of basal conglomerate overlain by quartzite that grades upward into purple shale and thinly bedded dolomite. The upper part of the formation consists of thick-bedded dolomite, diabase, and locally, massive chert (fig. 7). The following is a section of the Crystal Spring Formation measured in Galena Canyon.

\section{Section of Crystal Spring Formation in Galena Canyon}

Top of section is base of Noonday Dolomite; the contact is concealed and may be a thrust fault (see fig. 6 ).

Diabase

Ohert, dense, greenish

Dolomite, weathers light brown; lower $50 \mathrm{ft}$ in beds $6-$ $20 \mathrm{ft}$ thick, upper $125 \mathrm{ft}$ massive. Talcose at base

Diabase, much-weathered, calcareous; red iron oxide along fissures.

Dolomite, well-bedded and thin-bedded; beds 1 in to $2 \mathrm{ft}$ thick; finely granular, grains less than $0.1 \mathrm{~mm}$ with vugs and veinlets of coarse dolomite (grains $0.5 \mathrm{~mm}$ ); quartz grains (about $0.5 \mathrm{~mm}$ in diameter) at center of vugs (fig. $8 B$ ) ; chert lenses; weathers light brown; talcose where intruded by diabase sills.

Purple argillite or shale, some brown-weathering dolomitic shale, some quartzite with sericitic groundmass..

Quartzite, crossbedded, beds 1 in to $3 \mathrm{ft}$ thick; in part conglomeratic with pebbles of quartzite, red chert, and gneiss as much as 6 in. in diameter. Well-rounded grains of quartz and microcline and clastic biotite in dolomitic groundmass (fig. $8 A$ ). Some beds weather white ; others are black, especially those with carbonate in matrix

Conglomerate, light gray to white but weathers brown; quartz pebbles as much as $1 \mathrm{in}$. in diameter, but most of the unit is grit rather than conglomerate. Beds 6 in. to $2 \mathrm{ft}$ thick

Total thickness of Crystal Spring Formation including $750 \mathrm{ft}$ of diabase

Base. Angular unconformity. The basal conglomerate overlies steep to vertical foliation in Precambrian schist.

Table 3 shows the trace elements found in several different rock types in the Crystal Spring Formation. These samples are from Galena Canyon and are to be compared with the analysis of the schist from there (table 2). The quartzite and shale are most like the schist, but they contain substantially less of most trace elements, especially nickel, cobalt, vanadium, titanium, gallium, and chromium.

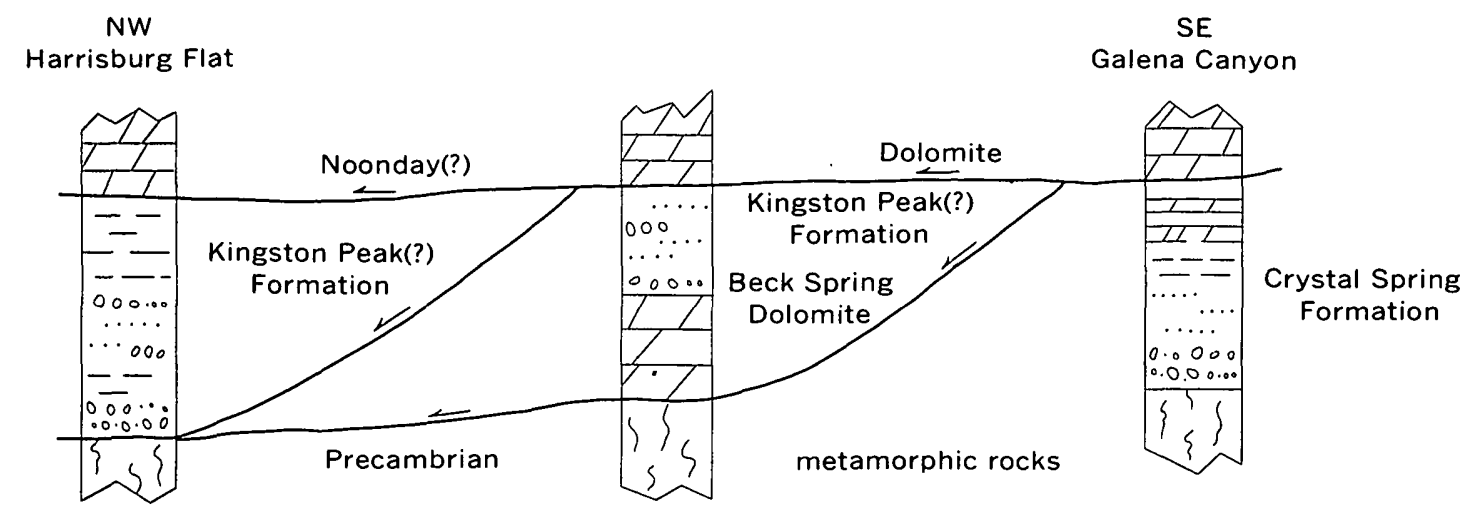

Fraure 6.-Idealized diagram illustrating distribution and possible structural relationship of the three formations of the Pahrump Series in the Panamint Range. 


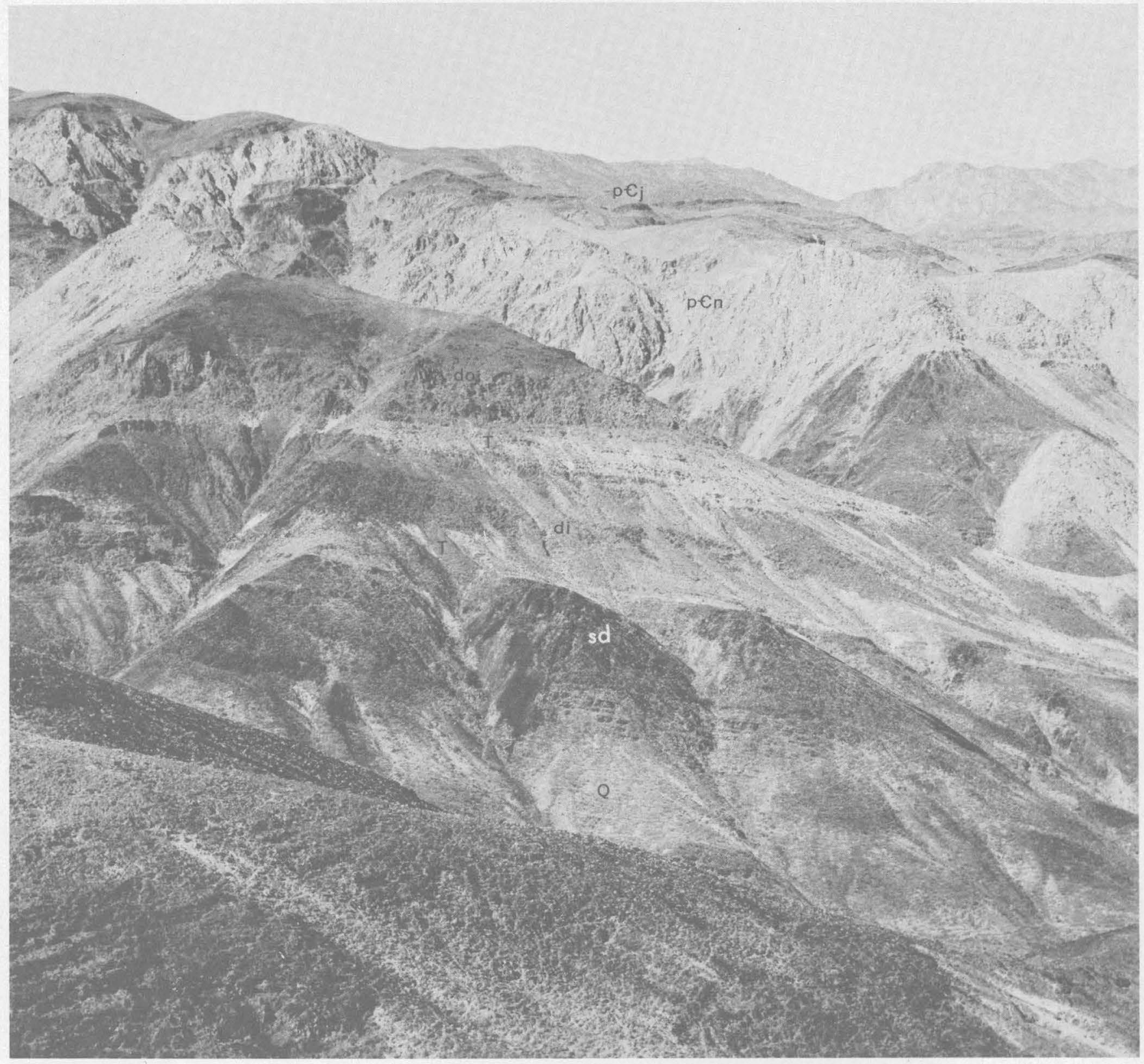

Figure 7.-Crystal spring Formation in Galena Canyon, view northwest. Q, quartzite member; sd, purple shale and thin-bedded dolomite; di, diabase sill with talcose beds $(T)$ where the sill is in contact with dolomite; do, massive dolomite at top of the formation. In distance is Noonday Dolomite ( $p € n$ ) capped by Johnnie Formation ( $p € j$ ).

The Crystal Spring Formation is of much interest economically because it contains highly productive deposits of talc. The commercial product, which consists of the mineral talc $\left[\mathrm{H}_{2} \mathrm{Mg}_{3}\left(\mathrm{SiO}_{3}\right)_{4}\right]$ and tremolite $\left[\mathrm{CaMg}_{3}\left(\mathrm{SiO}_{3}\right)_{4}\right]$ with accessory serpentine and calcite (Wright and others, 1954), occurs as an alteration product of dolomite where the dolomite is intruded by diabase (fig. 7).

The fact that diabase sills do not occur in formations younger than the Crystal Spring, even where younger formations of the Pahrump Series are present, has led to the interpretation that the sills and the alteration associated with them predate deposition of the Beck Spring Dolomite (Wright, 1952, p. 15).

\section{BECK SPRING DOLOMITE}

Rocks probably equivalent to the Beck Spring Dolomite, locally referred to as the Marvel Dolomitic Limestone by Murphy (1930), crop out at a dozen places along the west side of the Panamint Range west of the mapped area between the Kingston Peak Formation and underlying basement rocks (Murphy, 1932, p. 343). 
It is a bluish-gray cherty rock containing about 30 percent $\mathrm{CaO}$ and 20 percent $\mathrm{MgO}$, it also contains tremolite and muscovite (Murphy, 1932, p. 343). The for-

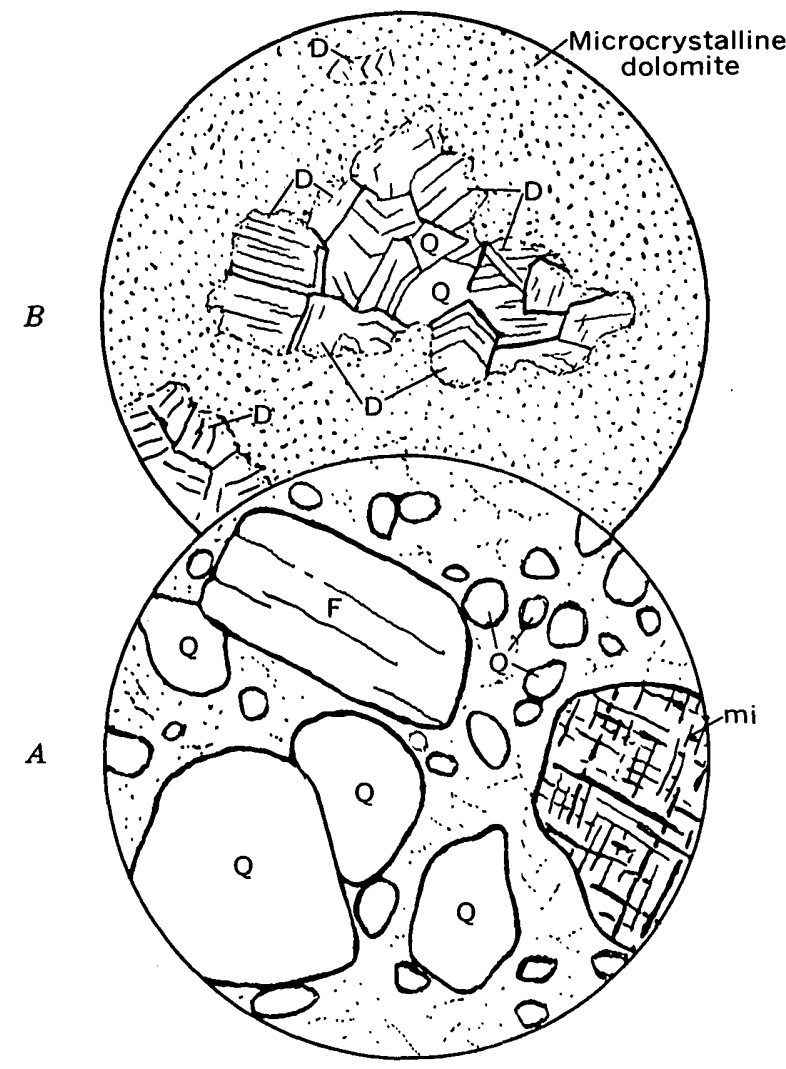

Fiaure 8.-Micrographs of quartzite $(A)$ and dolomite $(B)$. in Crystal Spring Formation. The quartzite consists of wellrounded grains of quartz $(Q)$ and microcline $(M)$ and other feldspar (F) in a dolomitic and sericitic matrix. The dolomite is finely granular with vugs of coarse dolomite (D) at the center of which are grains of quartz $(Q)$. Diameter of fleld, $2.5 \mathrm{~mm}$.

TABLE 3.-Trace elements in the Crystal Spring Formation [Semiquantitatilve spectrographic analyses by Uteana Ods, U.S. Geol. Survey.

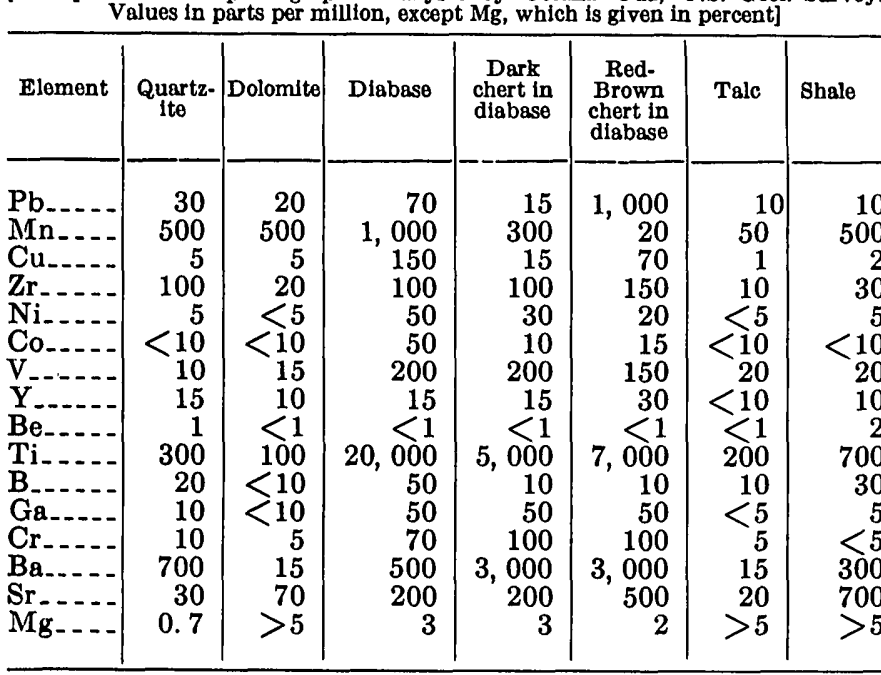

Note.-Also found: La, 50 or less; $\mathrm{Zn}, 200 ; \mathrm{Sc}, 15$ in diabase, 10 or less in others; Mo, $<2$; Bl, $<1$; Sn, <10; As, <500; Sb, <50; W, <20; Nb, <10. mation is very much sheared and contorted-too much so to determine the thickness. The Crystal Spring Formation is absent in that area. An interpretation of the structural relationships is illustrated diagrammatically on figure 6 .

\section{KINGSTON PEAK(?) FORMATION}

The youngest formation of the Pahrump Series, the Kingston Peak Formation, crops out extensively along the west side of the Panamint Range. Similar rocks tentatively assigned to this formation occur at Harrisburg Flat, Tucki Mountain, and the northern part of the Funeral Mountains.

Along the west side of the Panamint Range, the Kingston Peak Formation has been divided into three members (Johnson, 1957, p. 360). The lower member, $370-1,600$ feet thick, is conglomeratic graywacke; above this is limestone $30-170$ feet thick, and at the top is conglomerate, sandstone, and shale 260-1,000 feet thick (Johnson, 1957, p. 360-361).

In the northern part of the Panamint Range, in the vicinity of Harrisburg Flat, the rocks mapped as Kingston Peak (?) Formation are intruded by the granite at Skidoo in addition to being much faulted and folded. The stratigraphy there has not been determined satisfactorily. The most distinctive rocks are the stretchedpebble conglomerates. Some of these have a quartzite matrix, others have a sandy dolomitic matrix. The clasts are of quartzite and limestone. Much of the formation is platy quartzite, and there is some limy dolomite and limestone. In places the upper part is dark shale. Overlying these dominantly clastic beds is a thick section of carbonate rocks mapped as Noonday (?) Dolomite, and probably separated from the Kingston Peak (?) Formation by a flat fault. On Tucki Mountain some carbonate rocks below the thrust fault are doubtfully included in the Kingston Peak(?) Formation. Beds assigned to the Kingston Peak (?) Formation are at least 3,000 feet thick.

Six samples of the Kingston Peak(?) Formation were collected for spectrographic analysis. Three were obtained from the vicinity of Harrisburg Flat in the Panamint Range and three from the base of the Funeral Mountains. The analyses are given in table 4. The trace elements in the various rock types are quite different in the two areas. The limestone in the Panamint Range samples contains a greater concentration of trace elements than does the limestone from the Funeral Mountains. The quartzites differ less and their differences are more spotty. The differences, despite the small number of samples, cast further doubt on the correlation of the Kingston Peak(?) Formation between the Panamint Range and the Funeral Mountains. 
$\mathrm{T}_{\mathrm{ABLE}}$ 4.-Trace elements in the Kingston Peak(9) Formation. [Semiquantitative spectrographic analyses by Uteana Oda and E. F. Cooley, U.S. Geol. Survey. Values in parts per million, except $\mathrm{Mg}$, which is given in percent]

\begin{tabular}{|c|c|c|c|c|c|c|}
\hline \multirow{2}{*}{ Element } & \multicolumn{3}{|c|}{ Funeral Mountains } & \multicolumn{3}{|c|}{ Panamint Range } \\
\hline & $\begin{array}{l}\text { Dolo- } \\
\text { mite }\end{array}$ & $\begin{array}{l}\text { Lime- } \\
\text { stone }\end{array}$ & Quartzite & Limestone & Shale & $\underset{\text { ite }}{\text { Quartz- }}$ \\
\hline 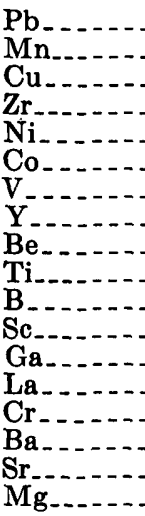 & $\begin{array}{r}15 \\
1,500 \\
2 \\
30 \\
5 \\
<10 \\
10 \\
10 \\
<1 \\
300 \\
10 \\
<10 \\
<5 \\
<50 \\
7 \\
100 \\
1,000 \\
>5\end{array}$ & $\begin{array}{r}20 \\
200 \\
10 \\
10 \\
7 \\
<10 \\
20 \\
20 \\
<1 \\
300 \\
<10 \\
<10 \\
<20 \\
<50 \\
10 \\
50 \\
200 \\
>5\end{array}$ & $\begin{array}{r}300 \\
500 \\
150 \\
200 \\
50 \\
20 \\
100 \\
20 \\
1 \\
10,000 \\
20 \\
<10 \\
20 \\
<50 \\
50 \\
1,000 \\
100 \\
1.5\end{array}$ & $\begin{array}{r}10 \\
1,000 \\
100 \\
500 \\
70 \\
15 \\
200 \\
50 \\
1 \\
10,000 \\
15 \\
20 \\
<20 \\
50 \\
100 \\
1,000 \\
700 \\
5\end{array}$ & $\begin{array}{r}30 \\
2,000 \\
150 \\
700 \\
100 \\
30 \\
200 \\
50 \\
1 \\
>10,000 \\
200 \\
50 \\
<20 \\
50 \\
500 \\
1,500 \\
200 \\
5\end{array}$ & $\begin{array}{r}50 \\
700 \\
200 \\
700 \\
10 \\
10 \\
70 \\
70 \\
1 \\
7,000 \\
15 \\
<10 \\
<20 \\
50 \\
30 \\
3,000 \\
150 \\
1\end{array}$ \\
\hline
\end{tabular}

Note.-Also found: Mo 10 in shale in Panamint Range: $<5$ in other samples; $\mathrm{Sn}$

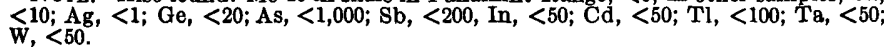

\section{NOONDAY DOLOMITE}

Overlying the Pahrump Series is the Noonday Dolomite. At its type locality at the south end of the Nopah Range, about 50 miles east of the Panamint Range, the formation consists of about 1,500 feet of light-creamcolored dolomite with sandy beds near the top (Hazzard, 1937b, p. 300).

In the southern part of the Panamint Range, in Galena and Six Spring Canyons, the Noonday Dolomite rests on the Crystal Spring Formation of the Pahrump Series. The contact between the 2 formations, which is concealed by rubble from the dolomite, probably is a flat fault that removed the upper 3,500 feet of the Pahrump Series and that cuts across at least 600 feet of the upper part of the Crystal Spring Formation (fig. 6). The Noonday Dolomite is conformably overlain by the Johnnie Formation.

The Noonday Dolomite in Galena and Six Spring Canyons consists of a light-cream-colored lower member about 500 feet thick and a gray upper member about 300 feet thick. Indistinct bedding in both members is characteristic of the formation throughout the region. Structures suggestive of Scolithus tubes were found in the dolomite in the fault block forming the foot of the mountain at the east tip of the spur south of Galena Canyon (loc. F-89, NE1/4 NE1/4 sec. 17, T. 22 N., R. 1 E.; fig. 9). Similar structures are present in the Noonday Dolomite in the southern Nopah Range.
The lower member of the Noonday Dolomite is a granular recrystallized fine-grained dolomite mottled with spots of coarse-grained dolomite in euhedral grains (fig. $10 \mathrm{~A}$ ). The spots of coarse-grained dolomite have quartz, evidently secondary, at their centers. Petrographically this rock resembles the thick-bedded dolomite in the underlying Crystal Spring Formation (fig. 8).

The upper gray member of the Noonday Dolomite is coarser grained than the lower member; the grains are uniform in size, about $0.3 \mathrm{~mm}$ in diameter (fig. 10B). Through the rock are numerous grains of euhedral magnetite partially altered to hematite.

In this area, as elsewhere in the region, the Noonday Dolomite contains small irregular deposits of lead minerals; these have been prospected at numerous places along the mountaintop south and west of Galena Canyon (table 5). So far as known, none of the deposits has been productive.

Farther north in the Panamint Range, from Johnson Canyon northward to Tucki Mountain, a series of carbonate rocks 1,000 feet or more thick, lying below the Johnnie Formation, is assigned questionably to the Noonday Dolomite. The formation seems to be at the stratigraphic position of the Noonday, but it is enough different lithologically to warrant further study to confirm or correct the identification. The formation differs from the Noonday farther south in containing a great deal of limestone as well as dolomite and in having the dominant colors tan and white. In addition, there are beds of limestone conglomerate in which clasts of limestone 1-3 inches in diameter are contained in sandy dolomitic matrix.

A highly generalized section on the west side of Rogers Peak showed the following:

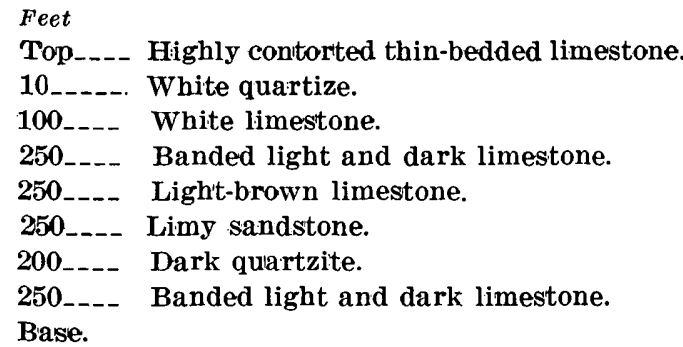

The Noonday(?) Dolomite seems to be equivalent to the series of dolomitic limestone on the west side of the range that Murphy (1932, p. 349) referred to as the Sentinel Dolomite (base), Radcliff Formation, and Redlands Dolomitic Limestone (top). Johnson (1957, p. $370)$ correlated these beds with the Noonday.

Table 5 lists the trace elements in eight samples from the Noonday Dolomite. In the southern part of the 


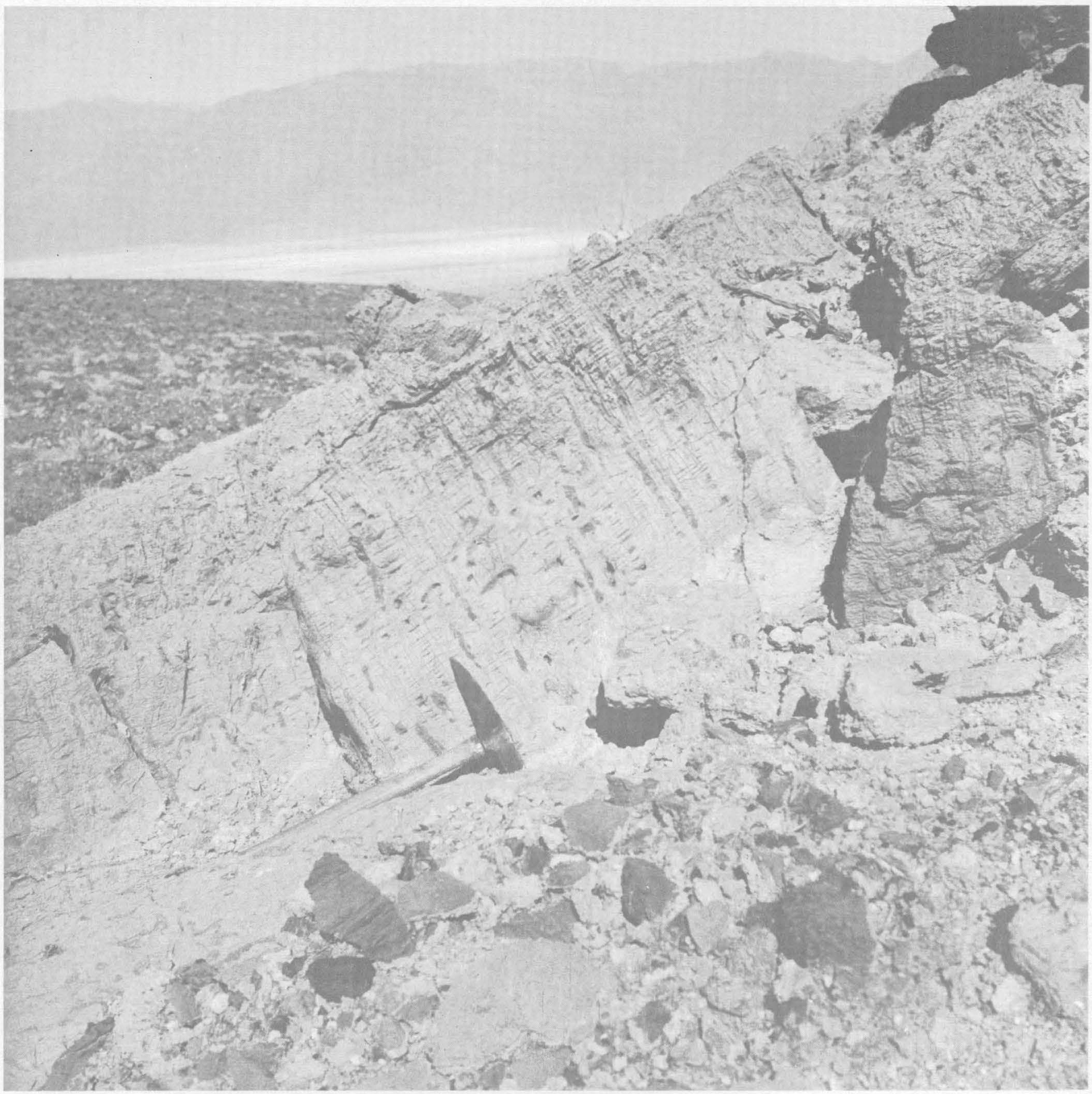

Figure 9.-Noonday Dolomite showing structures suggestive of Scolithus tubes. Location is at east foot of the mountain at the spur south of Galena Canyon.

Panamint Range the dolomite is highly mineralized, notably with lead and zinc. The sample of light facies differs little from the dark one. A much larger number of samples would be needed to suggest whether the Noonday (?) Dolomite should be correlated with the Noonday. The trace element content of the Noonday(?) Dolomite is about the same as that of the limestone in the Kingston Peak(?) Formation in the northern part of the Panamint Range.

\section{JOHNNIE FORMATION}

The Johnnie Formation at its type locality, near the town of Johnnie about 50 miles east of Death Valley, is mostly shale and is 4,500 feet thick (Nolan, 1929, p. $461)$. 


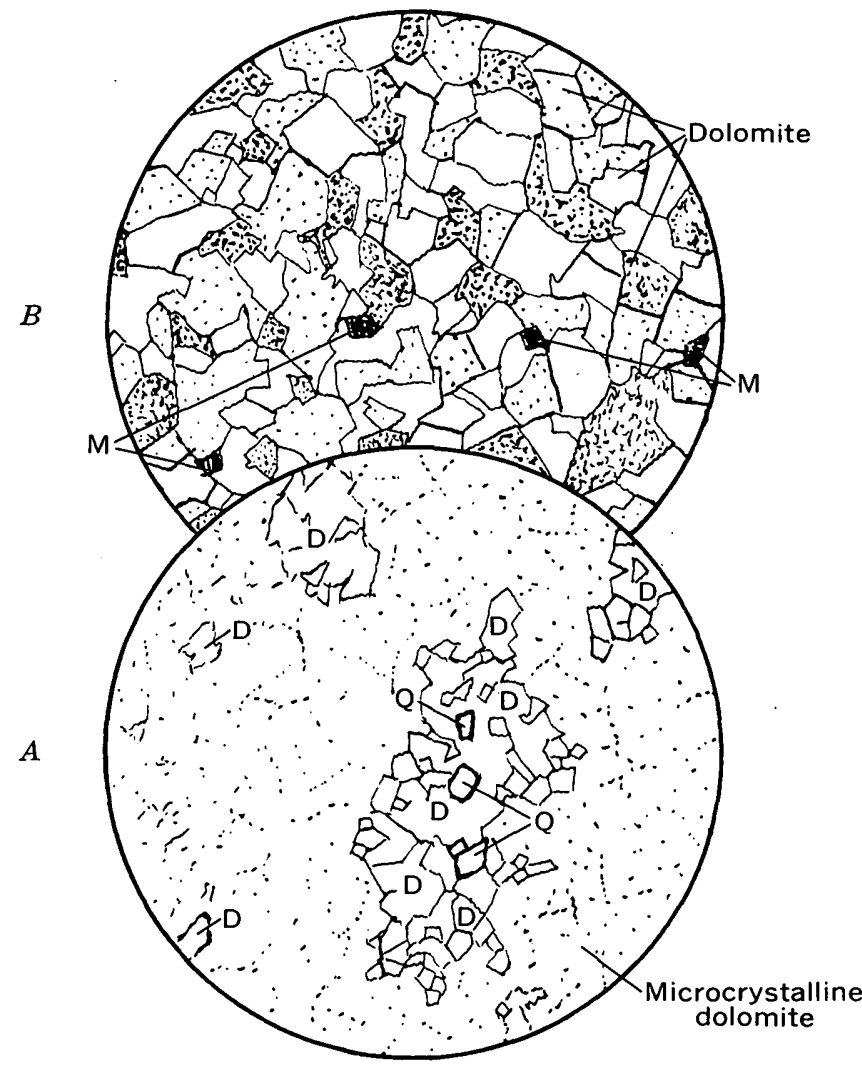

Figure 10.-Micrographs of Noonday Dolomite. $A$, Lower member, a fine-grained dolomite mottled with coarse dolomite (D). Quartz grains $(Q)$ occur at the center of some of the areas of coarse dolomite. $B$, Upper member, a medium-grained dolomite in which the grains are of uniform size and contain scattered grains of magnetite (M). Diameter of field, $2.5 \mathrm{~mm}$.

In the Panamint Range, where it has been referred to as the Hanaupah Formation (Murphy, 1932, p. 349), it is mostly shale, and its thickness is more than 4,000 feet.

The Johnnie Formation is conformable on the Noonday Dolomite and is gradational with it, for the lower part of the formation consists of interbedded dolomite and quartzite. The contact is taken at the lowest quartzite, as has been done elsewhere (Hazzard, 1937b, p. 303 ; Johnson, 1957, p. 373).

In the southern part of the Panamint Range the lower third of the formation consists of interbedded dolomite and sandstone or quartzite. The dolomite is thin bedded and ripple marked. Some of the quartzite is conglomeratic with pebbles as much as 1 inch in diameter.

The middle third of the formation is light-colored shale capped by dolomite; the upper third is purple shale with interbedded quartzite (fig. 11). A composite section of the Johnnie Formation in the southern part of the Panamint Range is as follows:
TABLE 5.-Trace elements in the Noonday Dolomite Semiquantitative spectrographic analyses by Uteana Oda and E. F. Cooley, U.S Geol. Survey. Values in parts per million, except $\mathrm{Mg}$, which is given in percent]

\begin{tabular}{|c|c|c|c|c|c|c|c|c|}
\hline \multirow{4}{*}{ Element } & \multicolumn{6}{|c|}{ Southern part of Panamint Range } & \multicolumn{2}{|c|}{$\begin{array}{c}\text { Northern part } \\
\text { of Panamint } \\
\text { Range }\end{array}$} \\
\hline & \multicolumn{6}{|c|}{ Noonday Dolomite } & \multirow{2}{*}{\multicolumn{2}{|c|}{$\begin{array}{l}\text { Noonday(?) } \\
\text { Dolomite }\end{array}$}} \\
\hline & $\begin{array}{l}\text { Light } \\
\text { dolo- }\end{array}$ & $\begin{array}{l}\text { Dark } \\
\text { dolo- }\end{array}$ & \multicolumn{4}{|c|}{ Prospects } & & \\
\hline & $\mathbf{A}$ & B & C & D & $\mathbf{E}$ & F & G 1 & $\mathrm{H}^{2}$ \\
\hline $\begin{array}{l}\mathrm{Pb} \\
\mathrm{Zn} \\
\mathrm{Mn} \\
\mathrm{Cu} \\
\mathrm{Zr} \\
\mathrm{Ni} \\
\mathrm{Co} \\
\mathrm{V} \\
\mathrm{Y} \\
\mathrm{Be} \\
\mathrm{Ti} \\
\mathrm{B} \\
\mathrm{Mo} \\
\mathrm{Gr} \\
\mathrm{Cr} \\
\mathrm{Ba} \\
\mathrm{Sr} \\
\mathrm{Mg}\end{array}$ & $\begin{array}{r}200 \\
<200 \\
150 \\
7 \\
20 \\
<5 \\
<10 \\
10 \\
<10 \\
<1 \\
100 \\
<10 \\
<2 \\
<5 \\
<5 \\
70 \\
300 \\
>5\end{array}$ & $\begin{array}{r}15 \\
<200 \\
100 \\
10 \\
<10 \\
<5 \\
<10 \\
10 \\
<10 \\
<1 \\
50 \\
<10 \\
<2 \\
<5 \\
<5 \\
10 \\
50 \\
>5\end{array}$ & $\begin{array}{r}15 \\
5,000 \\
500 \\
7 \\
<10 \\
7 \\
<10 \\
<10 \\
<10 \\
<1 \\
10 \\
70 \\
<2 \\
<5 \\
<5 \\
30 \\
50 \\
5\end{array}$ & $\begin{array}{r}10,000 \\
3,000 \\
200 \\
7 \\
<10 \\
7 \\
<10 \\
<10 \\
<10 \\
<1 \\
15 \\
50 \\
5 \\
<5 \\
<5 \\
20 \\
300 \\
3\end{array}$ & $\begin{array}{r}3,000 \\
300 \\
3,000 \\
7 \\
20 \\
7 \\
<10 \\
<20 \\
10 \\
<1 \\
200 \\
10 \\
7 \\
<5 \\
<5 \\
100 \\
<20 \\
0.2\end{array}$ & $\begin{array}{r}50 \\
700 \\
100 \\
7 \\
<10 \\
7 \\
<10 \\
<10 \\
<10 \\
<1 \\
30 \\
70 \\
<2 \\
<5 \\
<5 \\
<0 \\
<20 \\
0.5\end{array}$ & $\begin{array}{r}20 \\
\text { nd } \\
200 \\
10 \\
10 \\
7 \\
<10 \\
20 \\
20 \\
<1 \\
300 \\
<10 \\
<5 \\
<20 \\
20 \\
100 \\
3,000 \\
5\end{array}$ & $\begin{array}{r}50 \\
\text { nd } \\
2,000 \\
200 \\
500 \\
100 \\
30 \\
200 \\
50 \\
<1 \\
10,000 \\
70 \\
<5 \\
<20 \\
500 \\
3,000 \\
3,000 \\
>5\end{array}$ \\
\hline
\end{tabular}

1 This sample also contained $\mathrm{Ag}, 70 ; \mathrm{B1}, 50 ; \mathrm{As}, 1,500 ; \mathrm{Sb},>10,000$. 2 This sample also contained $\mathrm{Sc}, 50$.

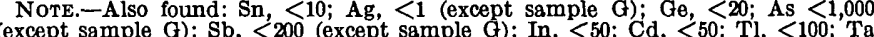
<50; W, $<50 ;$ La 50 or less; Sc, $<10$ (except sample H).

Composite section of Johnnie Formation in Six Spring Canyon and Johnson Canyon

Top. Base of Stirling Quartzite.

Feet

Purple shale member. Shale, mostly purple, some red, some green ; fissile. Upper $100 \mathrm{ft}$ includes interbedded quartzite and shale; beds transitional with overlying Stirling Quartzite. The purple shale contains fine sand grains $0.1 \mathrm{~mm}$ in diameter in sericitic matrix (fig. 12D); the quartzite interbedded with the shale near the top of the member is fine grained (grains about $0.2 \mathrm{~mm}$ in diameter) with sericitic laminae and in a sericitic clay matrix

Yellow member. Olive-brown shale capped by yellow silicified dolomite about $25 \mathrm{ft}$ thick in 1 or 2 beds; dolomite contains thin beds of quartzite. The dolomite is very fine grained $(0.01 \mathrm{~mm})$ with vugs of coarser dolomite $(0.1 \mathrm{~mm})$ (fig. $12 C)$. The shale is sandy or silty with quartz grains in sericitic laminae (fig. 12B)

Dolomite member. Basal $200 \mathrm{ft}$ consists of thin-bedded dolomite interbedded with ripple-marked sandstone, overlain by $35 \mathrm{ft}$ of brown-weathering dolomite; upper $150 \mathrm{ft}$ is well-bedded and thin-bedded quartzite and sandstone; at top is $5 \mathrm{ft}$ of pebble conglomerate with pebbles as much as $1 \mathrm{in}$. in diameter. The dolomite is like that in the overlying yellow member but contains scattered quartz grains about $0.1 \mathrm{~mm}$ in diameter. The quartzite has rounded quartz grains with irregular sides due to recrystallization, and there is considerable as sociated microcline; the qartz shows strain shadows; there is very little matrix around the grains (fig. 12A) --

Total thickness of Johnnie Formation 1,400 


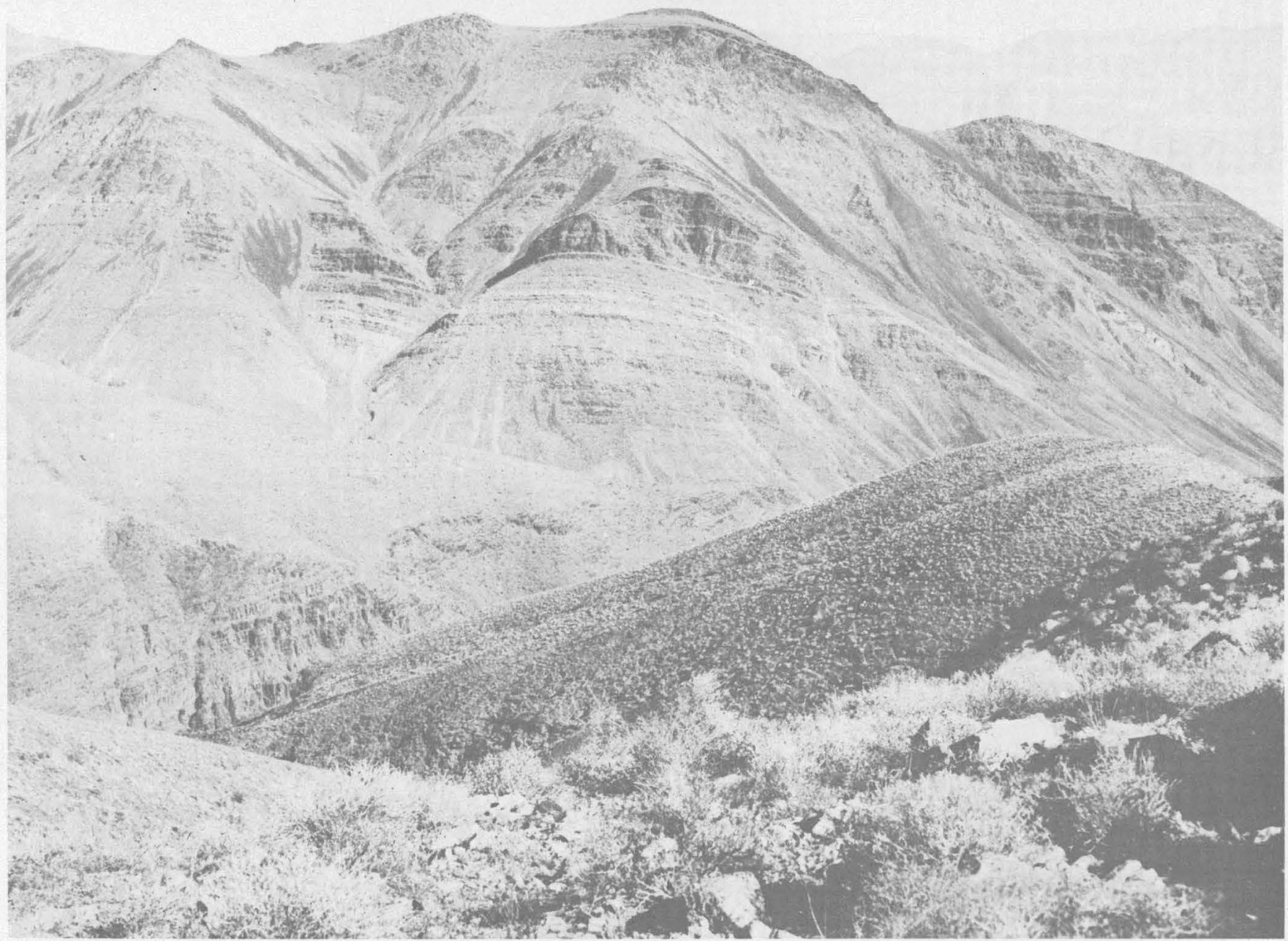

FIGURE 11.-Johnnie Formation on the north side of Six Spring Canyon. The hilltops are capped by Stirling Quartzite. Dark beds forming the upper half of the hillside are the purple shale member; light beds in the middle and lower half are the shale member capped by dolomite.

Northward along the Panamint Range the Johnnie Formation thickens and the lithology changes. In Hanaupah Canyon and farther north the Johnnie Formation is mostly shale. A section measured along the main (south) fork of Hanaupah Canyon is 2,300 feet thick, as follows:

Section of Johnnie Formation in Hanaupah Canyon, from Narrows at west edge of Bennetts Well quadrangle to mine workings at end of road.

Top. Base of Stirling Quartzite.

1. Quartzite, thin-bedded; some argillite

2. Limestone, interbedded with banded purple argillite

3. Argillite, purple; upper part banded

4. Argillite, weathers tan, greenish on fresh surfaces; contorted bedding

5. Interbedded argillite, sandstone, and a few beds of thinbedded, laminated, and highly micaceous dolomite; beds as much as $1 \mathrm{ft}$ thick 700
Section of Johnnie Formation in Hanaupah Canyon, from Narrows at west edge of Bennetts Well quadrange to mine workings at end of road-Continued

6. Interbedded dolomite and argillite; argillite greenish, weathers light $\tan$; dolomite beds 2 in to $1 \mathrm{ft}$ thick; this is a transition zone between units 5 and the Noonday (?) Dolomite

Total thickness of Johnnie Formation 2,325

Base. Top of Noonday(?) Dolomite, white or lighteream color; much altered; no original structures left $50 \mathrm{ft}+$ exposed.

In the north fork of Hanaupah Canyon (Chuckwalla Canyon on the maps), there is a light-brown dolomite, about 200 feet thick, forming the top of the Johnnie. Below this is 50 feet of ripple-marked purple shale, and below this, 250 feet of fissile shale. The main part of the formation is argillite, as it is farther south. 


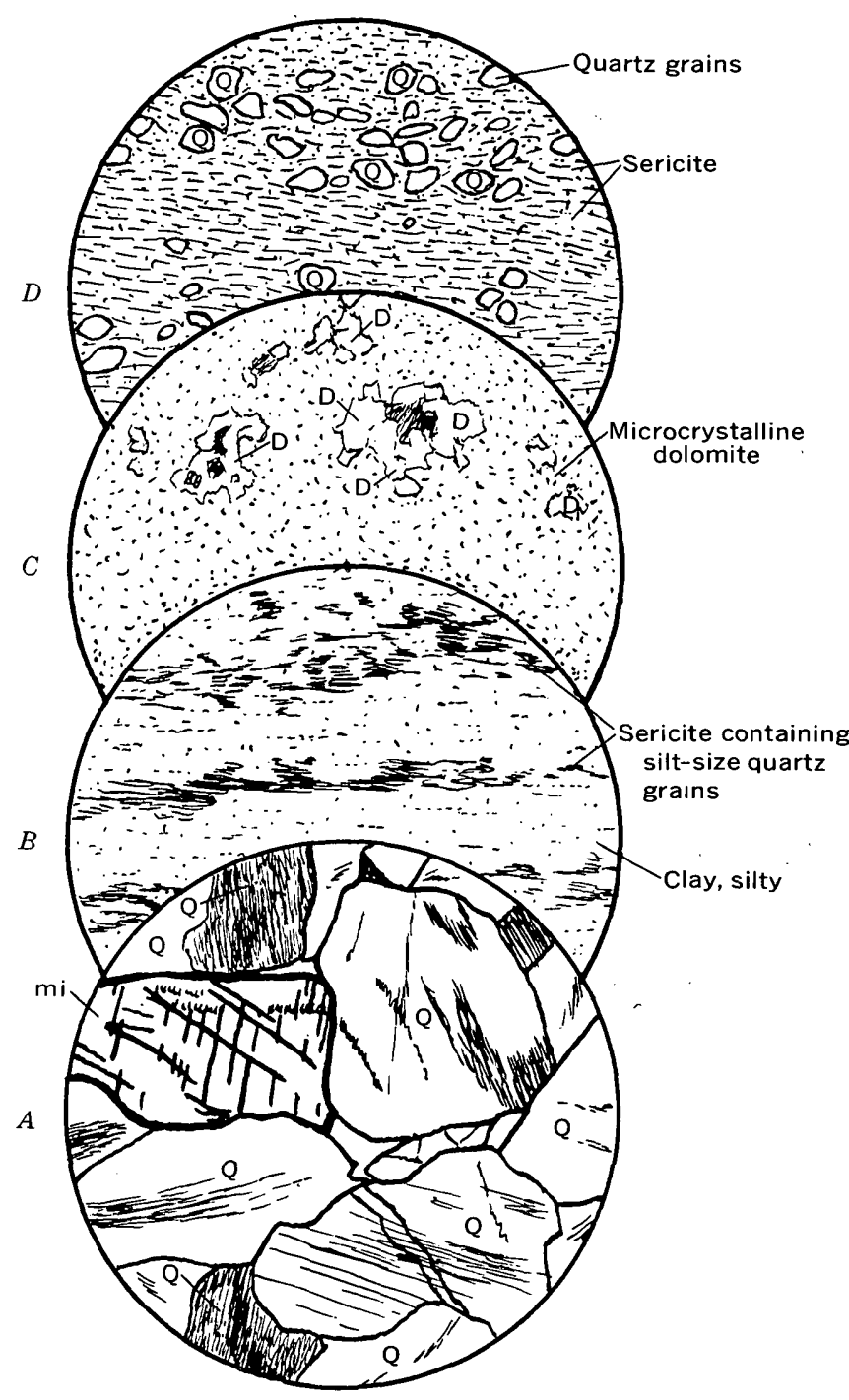

Figure 12.-Micrographs of rock types from the Johnnie Formation. $A$, Quartzite from basal dolomitic member ( $Q$, quartz with strain shadows; mi, microcline). Very little matrix between the grains.

$B$, Shale from yellow shale member. $C$, Dolomite from top of the yellow shale member, mostly very fine grained dolomite but mottled with vugs flled with coarser dolomite (D). $D$, Sandy sericitic purple shale. Diameter of fleld, $2.5 \mathrm{~mm}$.

In Death Valley Canyon, dolomite at the top of the Johnnie Formation is white, but probably this color change is due to hydrothermal alteration. Lightcolored dolomite was not seen elsewhere in the Johnnie Formation.

At the head of Trail Canyon the Johnnie Formation is about 4,000 feet thick. The beds are in a muchfaulted and steeply dipping monocline, and the stratigraphy there is uncertain.

The following is an approximate section:

\footnotetext{
Feet

Top_-_-_tirling Quartzite overlain by Wood Canyon Formation.
}

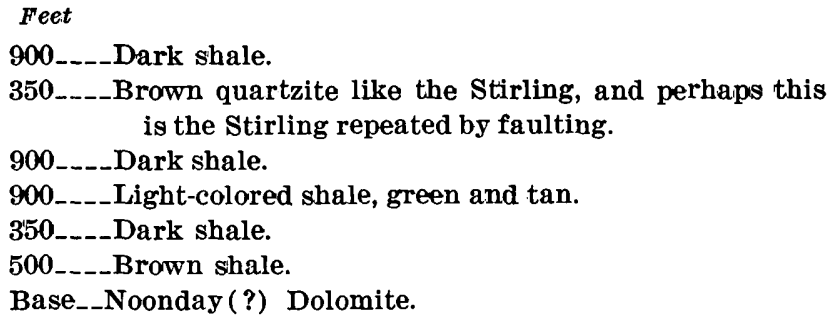

In the northern part of the Panamint Range the formation is mostly shale without evident marker beds of dolomite or coarse clastics. The thickness is uncertain on account of faulting and other deformation, but probably it is 4,000 feet or more.

Table 6 gives the results of analyses of trace elements in 18 samples from various rock types in the Johnnie Formation. Dolomite in the Johnnie Formation has about the same trace elements as does the Noonday Dolomite, but it averages more zirconium. The shale has about the same trace elements as does the shale in the Kingston Peak(?) Formation in the northern part of the Panamint Range (table 4).

\section{STIRLING QUARTZITE}

At the mouth of Johnson Canyon and along both sides of Starvation Canyon, the Stirling Quartzite consists of three members. At the base is. 700 feet of reddish-brown-weathering quartzite that is in part conglomeratic. Albout this is 500 feet of purple shale with thin beds of quartzite; at the top is brownweathering quartzite 800 feet thick. This section is very similar to that in the Nopah Range (Hazzard, 1937b, p. 306-307).

The quartzites are vitreous; most of the beds are coarse grained. Pebbles in the conglomeratic layers are as much as 1 inch in diameter, but most are smaller, $1 / 4^{-1 / 2}$ inch in diameter. The pebbles are mostly white quartz; a few are red jasper. There has been much recrystallization and quartz veining, and the beds are firmly indurated. Smooth surfaces show fine layering due to size sorting of the sediments; individual beds are cross-bedded (fig. 13) and many are ripple marked. Figure 14 is a micrograph of a thin section of the quartzite.

Individual grains are subround and encased in secondary quartz. Both the original grain and the quartz deposited around it show strain shadows. Associated with the quartz is coarsely twinned microcline and some sericite. The rock is a true quartzite and breaks across the quartz grains.

The purple shale separating the upper and lower quartzite members of the Stirling consists of finegrained well-rounded quartz in laminae of sericite; it is similar to that in the Johnnie Formation (fig. 12). 
STRATIGRAPHY AND STRUCTURE

TABLE 6.-Trace elements in the Johnnie Formation

[Semiquantitative spectrographic analyses by Uteana Oda and E. F. Cooley, U.S. Geol. Survey. Values in parts per million, except Mg, which is given in percent]

\begin{tabular}{|c|c|c|c|c|c|c|c|c|c|c|c|c|c|c|c|c|c|c|}
\hline \multirow{2}{*}{$\begin{array}{l}\text { Element } \\
\mathrm{Pb}\end{array}$} & \multicolumn{8}{|c|}{ Shale or schist } & \multirow{2}{*}{ Chaos } & \multirow{2}{*}{\multicolumn{2}{|c|}{ Conglomerate }} & \multirow{2}{*}{$\begin{array}{l}\text { Dolo- } \\
\text { mitic } \\
\text { sand }\end{array}$} & \multirow{2}{*}{\multicolumn{2}{|c|}{$\begin{array}{l}\text { Dolomitic } \\
\text { shale }\end{array}$}} & \multicolumn{4}{|c|}{ Dolomite } \\
\hline & \multicolumn{5}{|c|}{ Dark } & Green & \multicolumn{2}{|c|}{ Yellow } & & & & & & & & & & \\
\hline $\begin{array}{l}\mathrm{Pb} \\
\mathrm{Mn} \\
\mathrm{Cu} \\
\mathrm{Zr} \\
\mathrm{Ni} \\
\mathrm{Co} \\
\mathrm{V} \\
\mathrm{Y} \\
\mathrm{Be} \\
\mathrm{Ti} \\
\mathrm{B} \\
\mathrm{Sc} \\
\mathrm{Ga} \\
\mathrm{Cr} \\
\mathrm{Ba} \\
\mathrm{Sr} \\
\mathrm{Mg}\end{array}$ & $\begin{array}{r}50 \\
200 \\
150 \\
100 \\
50 \\
10 \\
100 \\
70 \\
1 \\
10,000 \\
300 \\
30 \\
<20 \\
200 \\
700 \\
150 \\
1.5\end{array}$ & $\begin{array}{r}10 \\
2,000 \\
100 \\
1,500 \\
100 \\
30 \\
500 \\
150 \\
1 \\
>10,000 \\
150 \\
50 \\
<20 \\
300 \\
2,000 \\
100 \\
>5\end{array}$ & $\begin{array}{r}20 \\
700 \\
100 \\
700 \\
200 \\
100 \\
300 \\
150 \\
2 \\
>10,000 \\
200 \\
70 \\
<20 \\
700 \\
5,000 \\
70 \\
>5\end{array}$ & $\begin{array}{r}30 \\
200 \\
30 \\
500 \\
70 \\
10 \\
150 \\
30 \\
2 \\
7,000 \\
70 \\
20 \\
50 \\
150 \\
700 \\
20 \\
1\end{array}$ & $\begin{array}{r}30 \\
700 \\
30 \\
200 \\
20 \\
<10 \\
100 \\
20 \\
3 \\
7,000 \\
70 \\
15 \\
50 \\
70 \\
500 \\
30 \\
2\end{array}$ & $\begin{array}{r}200 \\
300 \\
500 \\
100 \\
50 \\
15 \\
50 \\
20 \\
2 \\
2,000 \\
30 \\
10 \\
20 \\
50 \\
300 \\
20 \\
1.5\end{array}$ & $\begin{array}{r}1,500 \\
100 \\
100 \\
200 \\
50 \\
10 \\
70 \\
20 \\
3 \\
5,000 \\
70 \\
15 \\
50 \\
70 \\
500 \\
20 \\
1\end{array}$ & $\begin{array}{r}30 \\
70 \\
70 \\
200 \\
30 \\
<10 \\
100 \\
20 \\
2 \\
5,000 \\
70 \\
15 \\
50 \\
100 \\
500 \\
30 \\
1\end{array}$ & $\begin{array}{r}20 \\
700 \\
100 \\
700 \\
20 \\
<10 \\
500 \\
150 \\
1 \\
>10,000 \\
50 \\
50 \\
<20 \\
700 \\
7,000 \\
1,000 \\
3\end{array}$ & $\begin{array}{r}30 \\
100 \\
300 \\
150 \\
5 \\
<10 \\
20 \\
<10 \\
<1 \\
2,000 \\
20 \\
<10 \\
5 \\
20 \\
300 \\
20 \\
0.2\end{array}$ & $\begin{array}{r}300 \\
50 \\
20 \\
700 \\
5 \\
<10 \\
30 \\
10 \\
<1 \\
10,000 \\
15 \\
<10 \\
<5 \\
30 \\
500 \\
<20 \\
0.5\end{array}$ & $\begin{array}{r}20 \\
7,000 \\
100 \\
10 \\
5 \\
10 \\
20 \\
10 \\
<1 \\
200 \\
<10 \\
<10 \\
<20 \\
20 \\
50 \\
200 \\
>5\end{array}$ & $\begin{array}{r}30 \\
5,000 \\
150 \\
700 \\
150 \\
20 \\
200 \\
100 \\
<1 \\
10,000 \\
150 \\
50 \\
<20 \\
500 \\
2,000 \\
2,000 \\
>5\end{array}$ & $\begin{array}{r}500 \\
200 \\
150 \\
300 \\
50 \\
15 \\
100 \\
20 \\
<3 \\
3,000 \\
20 \\
10 \\
20 \\
70 \\
500 \\
<20 \\
0.5\end{array}$ & $\begin{array}{r}10 \\
2,000 \\
150 \\
100 \\
10 \\
<10 \\
20 \\
10 \\
<1 \\
300 \\
<10 \\
<10 \\
<20 \\
20 \\
100 \\
100 \\
>5\end{array}$ & $\begin{array}{r}20 \\
100 \\
5 \\
10 \\
5 \\
<10 \\
10 \\
<10 \\
<1 \\
70 \\
<10 \\
<10 \\
<5 \\
5 \\
15 \\
500 \\
0.5\end{array}$ & $\begin{array}{r}150 \\
3,000 \\
30 \\
70 \\
<5 \\
<10 \\
10 \\
<10 \\
<1 \\
3,000 \\
<10 \\
<10 \\
<5 \\
5 \\
50 \\
50 \\
5\end{array}$ & $\begin{array}{r}70 \\
150 \\
7 \\
10 \\
<5 \\
<10 \\
10 \\
<10 \\
<1 \\
200 \\
<10 \\
<10 \\
<5 \\
5 \\
70 \\
70 \\
>5\end{array}$ \\
\hline
\end{tabular}

NoтE.-Also found: $\mathrm{Zn},<200 ; \mathrm{La},<50 ; \mathrm{Mo},<2 ; \mathrm{Ag},<1 ; \mathrm{Bi},<5 ; \mathrm{Sn},<10 ; \mathrm{As},<500 ; \mathrm{Sb},<50 ; \mathrm{W},<20 ; \mathrm{Nb},<10$.

In places, there are some thin beds of shale and dolomite about $30-50$ feet below the top of the formation. These beds are like those in the lower part of the Wood Canyon Formation.

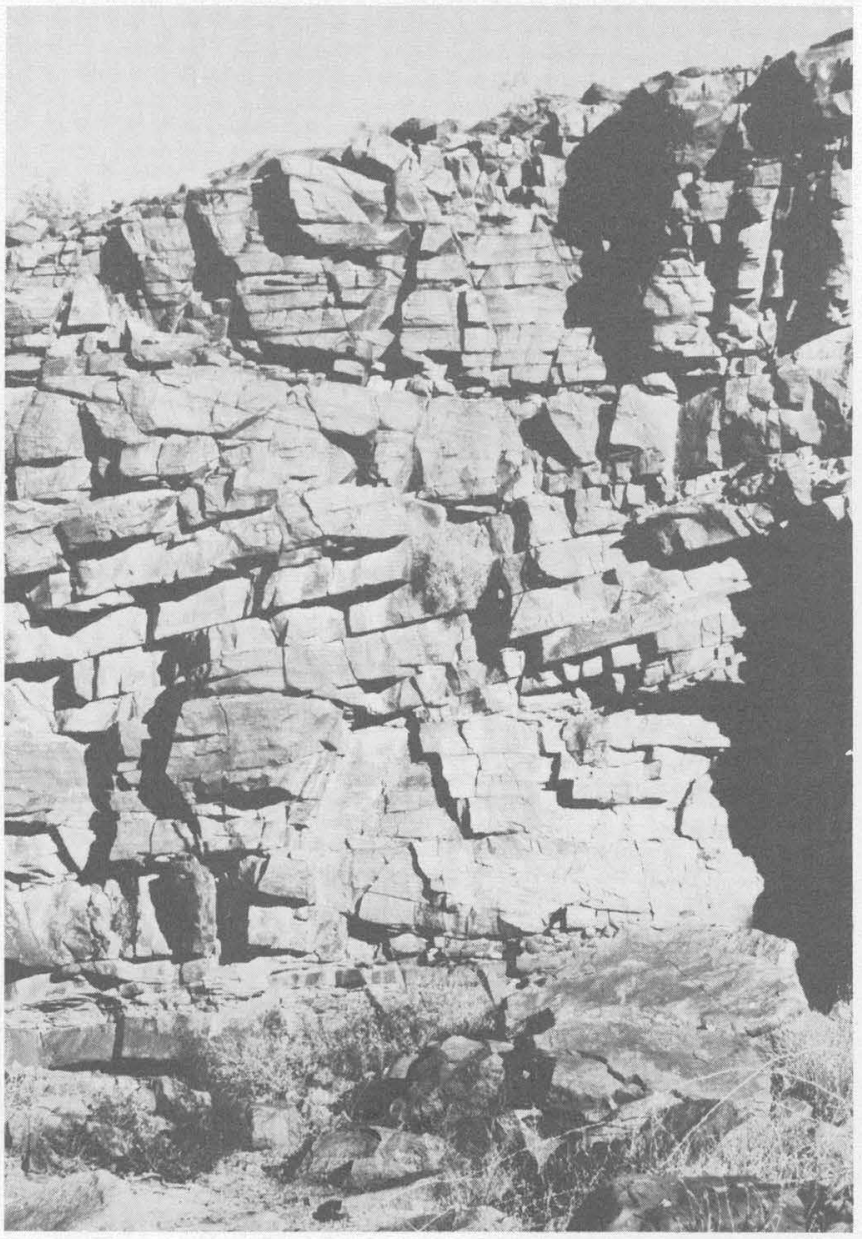

FIGURE 13.-Detail of bedding in Stirling Quartzite at mouth of Johnson Canyon. Beds are 3-12 inches thick.

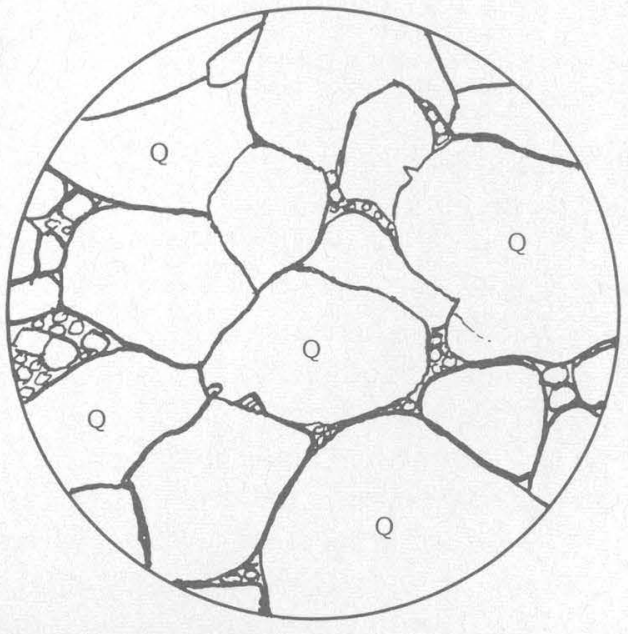

FIGURE 14.-Micrograph of Stirling Quartzite. The grains of quartz $(Q)$ are rounded but also irregularly intergrown. Strain shadows conspicuous under cross nicols. Between the large grains is secondary quartz. In most beds sericitized feldspar and some muscovite occurs with the quartz grains. Diameter of field, $2.5 \mathrm{~mm}$.

Trace elements in 9 samples of the Stirling Quartzite are given in table 7. Trace elements in the quartzite and shale facies are like those in the conglomerate and shale, respectively, of the Johnnie Formation (table 6). The quartzite differs from that of the Kingston Peak (?) Formation in the Panamint Range (table 4) in having less copper, barium, and strontium. The quartz veins in the Stirling contain trace elements only in small amounts compared to the parent quartzite.

In the Death Valley area the Stirling Quartzite has a maximum thickness of about 2,000 feet. At the type locality in the Spring Mountains (Nolan, 1929, p. 463) it is 3,700 feet thick. The boundaries of the formation, as shown on the geologic map of the Panamint Range (pl. 1), imply considerable variation in thickness of the 
TABLE 7.-Trace elements in the Stirling Quartzite [Semiquantitative spectrographic analyses by Uteana Oda and E. F. Cooley, U.S. Geol. Survey. Values in parts per million, except $\mathrm{Mg}$, which is given in percent]

\begin{tabular}{|c|c|c|c|c|c|c|c|c|c|}
\hline \multirow{3}{*}{ Element } & \multicolumn{6}{|c|}{ Quartzite } & \multirow{3}{*}{$\begin{array}{c}\begin{array}{c}\text { Shale } \\
\text { bed }\end{array} \\
G\end{array}$} & \multicolumn{2}{|c|}{ Quartz vein } \\
\hline & & & & & & & & \multirow{2}{*}{$\frac{\text { Clear }}{\mathrm{H}}$} & \multirow{2}{*}{$\frac{\text { White }}{\mathrm{I}}$} \\
\hline & A & B & C & D & $\mathbf{E}^{1}$ & F & & & \\
\hline & & & & & & 10 & & 20 & \\
\hline $\begin{array}{l}\mathrm{Mn} \text { - } \\
\mathrm{Cu}\end{array}$ & $\begin{array}{r}50 \\
2\end{array}$ & $\begin{array}{r}20 \\
3\end{array}$ & $\begin{array}{r}300 \\
30\end{array}$ & $\begin{array}{l}700 \\
150\end{array}$ & $\begin{array}{r}50 \\
100\end{array}$ & $\begin{array}{l}70 \\
50\end{array}$ & $\begin{array}{l}100 \\
100\end{array}$ & $\begin{array}{r}15 \\
2\end{array}$ & $\begin{array}{c}50 \\
5\end{array}$ \\
\hline & 500 & 100 & 150 & 200 & 2,000 & 300 & 1,500 & 10 & 100 \\
\hline & $<10$ & $<10^{5}$ & $<10$ & $\begin{array}{l}20 \\
10\end{array}$ & $<10$ & $<10$ & 100 & $<0^{5}$ & $<1^{5}$ \\
\hline v. & & 10 & 15 & 20 & 500 & 20 & 200 & $<10$ & $\begin{array}{r}10 \\
10\end{array}$ \\
\hline$\cdots$ & & $<10$ & 10 & 10 & 150 & 50 & 100 & $<10$ & $<10$ \\
\hline & 1,500 & 300 & 500 & 1,500 & $>10,000$ & 7,000 & $>10,000$ & 30 & $<00$ \\
\hline.- & & 10 & 20 & 15 & 200 & 150 & & 10 & 20 \\
\hline & $<10$ & $<10$ & $<10$ & $\leq 10$ & $\begin{array}{r}70 \\
<00\end{array}$ & $<10$ & <0 & $<10$ & $<10$ \\
\hline -. & $\begin{array}{l}10 \\
30\end{array}$ & $\begin{array}{r}-0 \\
5\end{array}$ & 15 & 10 & 300 & 30 & 300 & $<5$ & 5 \\
\hline 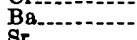 & 700 & 100 & $\begin{array}{r}500 \\
50\end{array}$ & 300 & 1,500 & 1,000 & 2,000 & 30 & 100 \\
\hline $\mathrm{Mg} . .$. & $\begin{array}{l}0 \\
0.5\end{array}$ & 0.2 & 0.2 & 0.15 & $\begin{array}{l}100 \\
1\end{array}$ & & $\begin{array}{r}50 \\
2\end{array}$ & 0.02 & 0.1 \\
\hline
\end{tabular}

$1 \mathrm{La}, 100$; Mo, 15; sample $\mathrm{E}$ is from the base of the upper plate of the Amargose thrust fault and has been hydrothermally altered.

NotE-Also found La, $<50$ (except sample E); Mo $<2$ (except sample E) $\mathrm{Ag},<1$ $\mathrm{Bl},<5 ; \mathrm{Sn},<10 ; \mathrm{As},<500 ; \mathrm{Sb},<50 ; \mathrm{W},<20 ; \mathrm{Nb},<10$.

quartzite; but this variation is attributable to lack of consistency in picking the boundary between the Stirling and overlying Wood Canyon Formation, the basal part of which also is quartzitic. It is difficult to distinguish the Stirling Quartzite from the thin-bedded quartzites that are included in the lower part of the Wood Canyon Formation, especially where there is granulation of the quartzite along faults.

The Stirling Quartzite coincides with a surface of flat faulting at its type locality (Nolan, 1929, p. 463, 470), and in the Funeral Mountains and Panamint Range. In the Funeral Mountains the flat fault is exposed at Echo Mountain and from Hells Gate to Daylight Pass. In the Panamint Range the Stirling Quartzite forms the base of the upper plate of the fault at the mouth of Mosaic Canyon and the top of the lower plate in Tucki Wash along the south and east sides of the Tucki Mountain thrust. As a result of this and other faulting, the Stirling Quartzite locally is absent, but such absence is attributable to deformation and not to stratigraphic thinning. Similarly, no stratigraphic significance can be placed on the variations in thickness that can be observed in short distances within this area. The thinning from the type area to the Nopah Range and westward to the Panamint Range may be real, because this thinning is accompanied by an increase in shale and thinner bedding westward in the formation.

\section{CAMBRIAN SYSTEM}

A.bout 8,500 feet of beds representing all parts of the Cambrian System are present in the Death Valley region. These include the Wood Canyon Formation of Early Cambrian and Early Cambrian(?) age, the Za- briskie Quartzite of Early Cambrian age, the Carrara Formation of Early and Middle Cambrian age, the Bonanza King Formation of Middle and Late Cambrian age, and the Nopah Formation of Late Cambrian age.

The oldest beds in the Death Valley region containing animal remains are in the Wood Canyon Formation. The top of the Cambrian System lies somewhere near the top of the Nopah Formation, but it cannot be located more precisely because of the lack of fossils in this part of the section. For mapping, the upper and lower boundaries of the Cambrian System are placed at the formation boundaries.

\section{WOOD CANYON FORMATION}

The Wood Canyon Formation of Early Cambrian and Early Cambrian(?) age conformably overlies the Stirling Quartzite of Precambrian age, both at the type locality in the Spring Mountains (Nolan, 1929, p. 463) and in the mountains adjoining Death Valley. The top of the Wood Canyon in Death Valley is taken at the base of the Zabriskie Quartzite. At the type locality the top of the Wood Canyon Formation is at the base of a 20 -foot bed of white quartzite which probably is equivalent to the Zabriskie (Hazzard, 1937b, p. 313). In the Nopah Range the Zabriskie Quartzite has been included as a member in the Wood Canyon Formation together with 630 feet of overlying beds (Hazzard, $1937 \mathrm{~b}$, p. 310 ). In this report the beds overlying the Zabriskie Quartzite are treated separately as part of the Carrara Formation.

The basal unit of the Wood Canyon Formation, about 465 feet thick, consists mostly of thin-bedded quartzite, but contains considerable shale and dolomite. Above this is 1,200 feet of quartzite in thicker beds. No fossils other than possible Scolithus tubes and possible algal structures have been found in the lower part of the formation in Death Valley or in the surrounding regions.

The upper member of the Wood Canyon Formation, about 900 feet thick, consists of shaly and dolomitic beds as well as thin beds of siltstone and quartzite (fig. 15). Fossils found in this member include fragmentary trilobites representing Nevadella gracile (Walcott), indeterminate molds of brachiopods, and molds of cystid plates in a unit of thin sandstones that generally lies just below a zone of oolitic and pelmatazoan dolomites and limestones. Thin sections of some of these pelmatazoan limestones in Death Valley and at Daylight Pass show the presence of fragmentary archaeocyathids. The association of sandstones with fragmentary trilobites and brachiopods and oolitic and pelmatazoan carbonates characterizes the upper part of the Wood Canyon Formation throughout the Death Valley region and as far north as the Groom district in Nevada (Palmer, oral commun., 1961). 


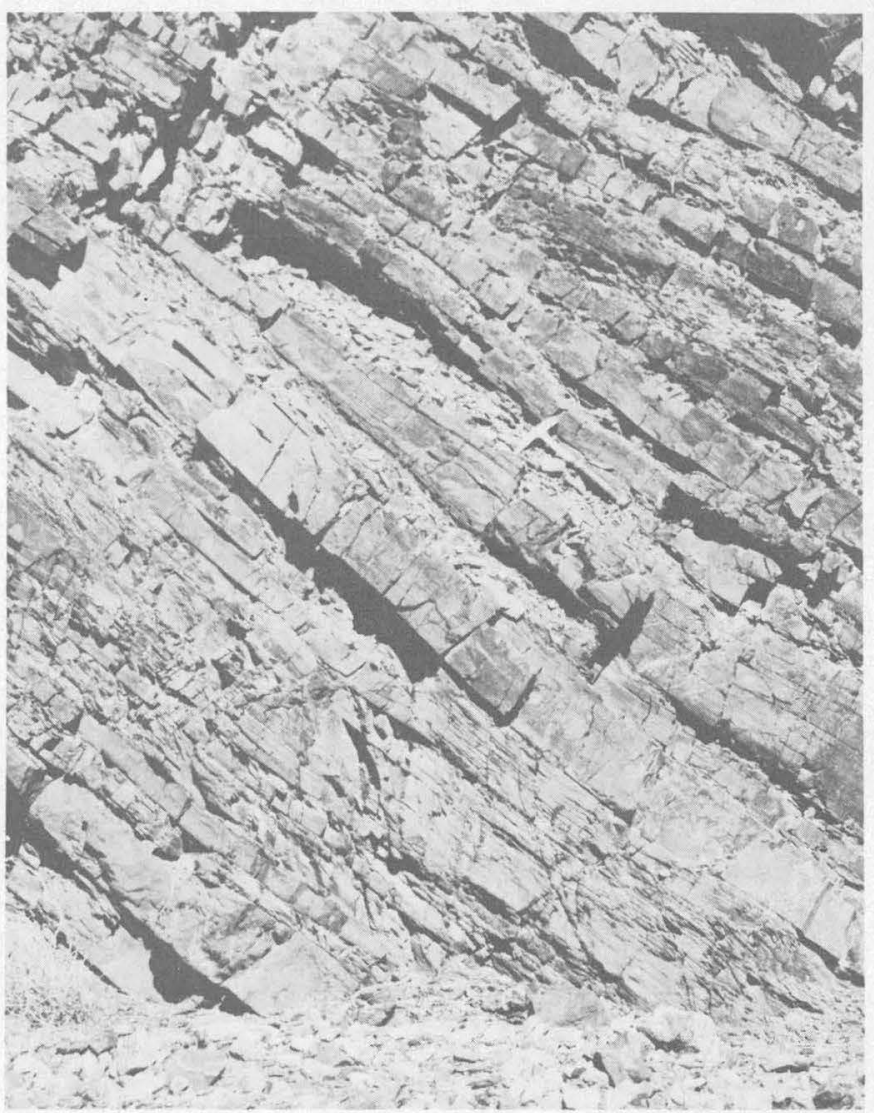

Figure 15.-Detail of interbedded shale, quartzite, and dolomite in the upper part of the Wood Canyon Formation in the ridge along the north side of Blackwater Wash. The thick bed in the upper right is dolomite; below this is quartzite and shale.

Collections from these beds in Death Valley were studied by A. R. Palmer, who has reported on them as follows (locations are indicated on the geologic map) :

F-31. Above Quartzite Spring, north side of Starvation Canyon, Bennetts Well quad. ( $W^{1 / 4} \mathrm{NW}^{1 / 4}$ sec. 12 , T. 21 S., 46 E.)

"Olenellid scraps; certainly Early Cambrian age, but species not determinable."

F-64 (3104-CO). 1.5 miles south of Panamint Burro Spring; same general fault block as F-31, Bennetts Well quad. (2,000 ft north of NW cor. sec. 1, T. 21 S., R. 46 E.), estimated 500 ft below the Zabriskie Quartzite. "Nevadella gracile? (Walcott)."

F-36. Southeast side Hanaupah Canyon, alt $3,100 \mathrm{ft}, 2$ miles above mouth of Canyon. Bennetts Well quad. "Olenellid scraps, certainly Early Cambrian in age, but species not identifiable."

F-29 (2453-CO). East base of west butte of the Death Valley Buttes, Stovepipe Wells quad. $(2,500 \mathrm{ft}$ northeast of NE cor. sec. 36, T. 14 S., R. 45 E.). Pelmatazoan calcarenite. Indeterminate archaeocyathid.

F-50. Base of Zabriskie Quartzite in Blackwater Wash, top of hill 951, west side Furnace Creek quad. "Kutorgina? sp."

A section of the Wood Canyon Formation, measured along the north side of Blackwater Wash (Furnace Creek quad.) follows:
Section of Wood Canyon Formation along north side of Blackwater Wash

[Measured by Charles B. Hunt, A. R. Palmer, and R. J. Ross, Jr.]

Top. Base of Zabriskie Quartzite.

1. Brown-weathering dolomite and quartzite, some greenish shale. Dolomite and quartize beds $1-10 \mathrm{ft}$ thick; shale beds less than $1 \mathrm{ft}$ thick ( fig 15). Dolomite crossbedded, in part strikingly oolitic. Tubes suggestive of Scolithus tubes about $200 \mathrm{ft}$ above the base_

2. Shaly member. Lower $70 \mathrm{ft}$ mostly green siltstone interbedded with dark-weathering quartzite in beds $5 \mathrm{ft}$ thick. Overlying this is $210 \mathrm{ft}$ of siltstone that is reddish along shear zones but greenish away from them. Above this is $105 \mathrm{ft}$ of dark-weathering quartzite; 35 $\mathrm{ft}$ of green shale and siltstone, and, at the top, $100 \mathrm{ft}$ of greenish micaceous fine-grained quartzite and siltstone. Some tubes suggestive of Scolithus in the uppermost unit

3. Quartzite member. Beds 1-3 ft thick; light gray on fresh fracture but weathers dark. Micaceous. Numerous gritty beds; some conglomeratic with pebbles as much as $3 / 4$ in. in diameter; most of these are milky quartz; some are red jasper. Lower $200 \mathrm{ft}$ includes much grit and numerous shale beds about $1 \mathrm{ft}$ thick; purple and green; increasing amount of shale downward. Two hundred feet above base is 50 - $\mathrm{ft}$ bed of grit and conglomerate. Upper $700 \mathrm{ft}$ is mostly fine-grained quartzite. This unit of section crossed by some faults and thickness is uncertain, estimate

4. Quartzite with interbedded shale, fine-grained, thinbedded, transitional between units 3 and 5

5. Quartzite with interbedded siltstone and some finegrained thin-bedded shale; a few thin beds of brownweathering dolomite, light brown on fresh surfaces. Eighty feet above base is 10-ft bed of gray dolomite overlain by $15 \mathrm{ft}$ of light-tan thin-bedded dolomite. Quartzite is light brown, weathers dark brown; micaceous. Twenty feet below top is a thin bed of dolomite having floating sand grains and pebbles of carbonate rock; intraformational conglomerate

6. Shale and quartzite. Quartzite beds are 1-12 in thick, finely laminated, micaceous, light brown on fresh surfaces, reddish brown on weathered surfaces. Shale is olive green on weathered surface ; also micaceous_.

7. Shale, sandstone, and dolomite. Shale and sandstone green and brown; dolomite dark blue on fresh surface; weathers brown. Dolomite beds 1-2 ft thick -

Total thickness of Wood Canyon Formation

Base. Top of Stirling Quartzite. Contact gradational and taken at top of highest massive light-colored quartzite. There are thin beds of shale and dolomite $30-50$ ft below the contact.

Thin sections of the quartzite and shale beds of the Wood Canyon Formation are illustrated on figure 16 . The shale contains muscovite (or sericite) and magnetite in addition to minute quartz grains that occur both scattered and in layers. The quartzite has interlocking 


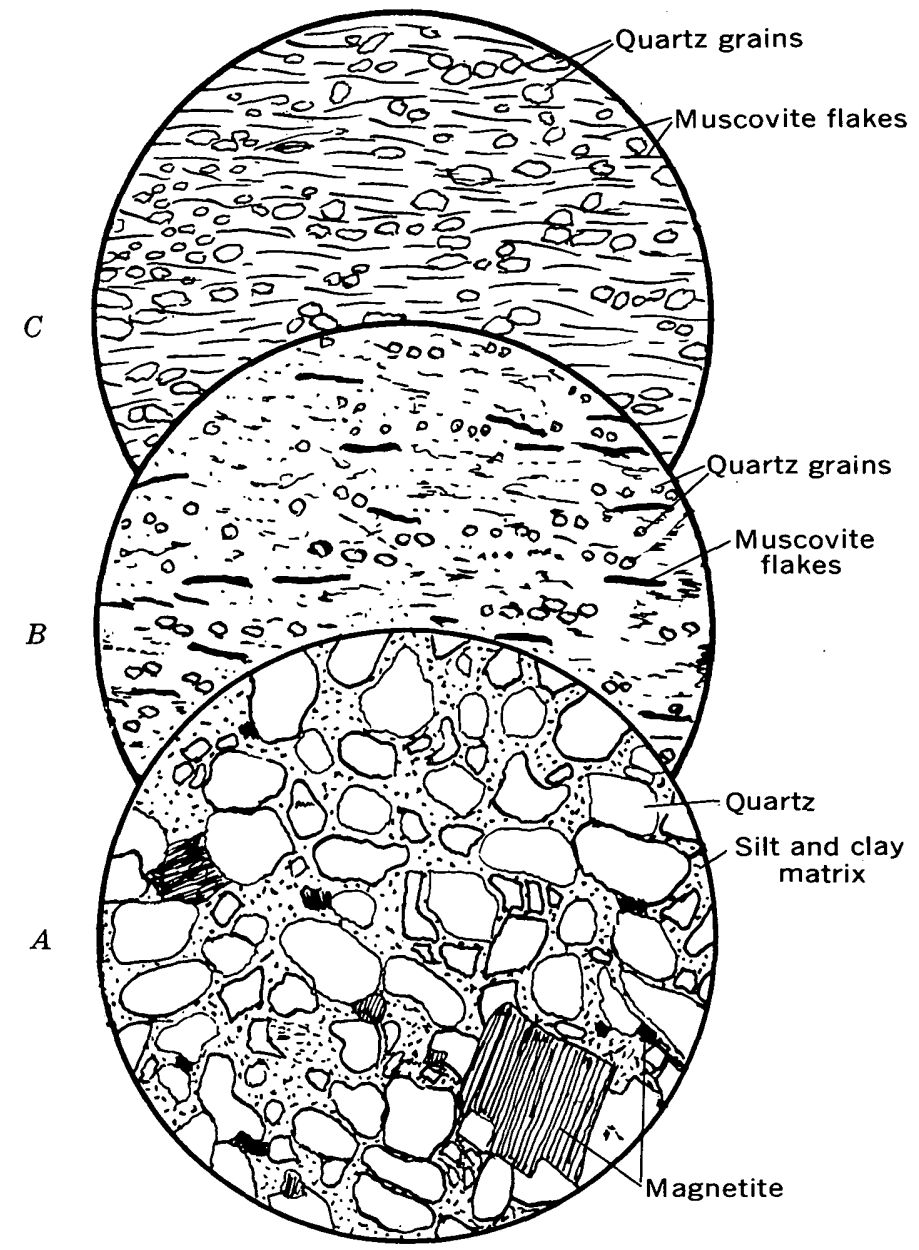

Figurb 16.-Micrographs of rock types in the Wood Canyon Formation. A, Quartzite from basal member. Other quartzite has much less interstitial materlal and resembles the Stirling Quartzite. $B$, Shale composed largely of silt and clay. $C$, Shale composed largely of muscovite and sand grains. Diameter of fleld, $2.5 \mathrm{~mm}$.

TABLE 8.-Trace elements in the Wood Canyon Formation.

[Semiquantitative spectrographic analyses by Uteana Oda and E. F. Cooley, U. S Geol. Survey. Values in parts per million, except $\mathrm{Mg}$, which is given in percent.

\begin{tabular}{|c|c|c|c|c|c|c|c|c|c|c|c|}
\hline \multirow{2}{*}{$\begin{array}{c}\text { Ele- } \\
\text { ment }\end{array}$} & \multicolumn{10}{|c|}{ Wood Canyon Formation } & \multirow{2}{*}{$\begin{array}{c}\text { Dolo- } \\
\text { mitic } \\
\text { quartz- } \\
\text { ite }\end{array}$} \\
\hline & Lime- & & Shale & & & ndy sh & hale & & Quartz & ite & \\
\hline 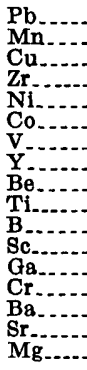 & $\begin{array}{r}20 \\
10,000 \\
3 \\
30 \\
7 \\
<10 \\
15 \\
10 \\
<1 \\
1,500 \\
10 \\
<10 \\
7 \\
30 \\
150 \\
100 \\
5\end{array}$ & $\begin{array}{r}150 \\
2,000 \\
30 \\
2,000 \\
30 \\
10 \\
30 \\
70 \\
1 \\
7,000 \\
50 \\
15 \\
10 \\
70 \\
150 \\
100 \\
3\end{array}$ & $\begin{array}{r}20 \\
15 \\
3 \\
70 \\
<5 \\
<10 \\
<10 \\
<10 \\
5 \\
300 \\
20 \\
10 \\
10 \\
5 \\
500 \\
700 \\
0.2\end{array}$ & $\begin{array}{r}20 \\
7,000 \\
30 \\
100 \\
50 \\
10 \\
10 \\
30 \\
1 \\
1,500 \\
15 \\
<10 \\
5 \\
10 \\
200 \\
50 \\
0.7\end{array}$ & $\begin{array}{r}10 \\
2,000 \\
30 \\
30 \\
20 \\
10 \\
10 \\
20 \\
1 \\
1,000 \\
15 \\
10 \\
10 \\
15 \\
100 \\
200 \\
0.7\end{array}$ & $\begin{array}{r}15 \\
150 \\
200 \\
200 \\
70 \\
20 \\
100 \\
30 \\
1 \\
7,000 \\
50 \\
<10 \\
30 \\
100 \\
500 \\
50 \\
2\end{array}$ & $\begin{array}{r}100 \\
1,000 \\
30 \\
150 \\
7 \\
<10 \\
30 \\
10 \\
2 \\
1,500 \\
70 \\
<10 \\
20 \\
20 \\
1,000 \\
1,500 \\
0.5\end{array}$ & $\begin{array}{r}70 \\
1,000 \\
5 \\
300 \\
5 \\
<10 \\
20 \\
30 \\
1 \\
1,500 \\
20 \\
<10 \\
5 \\
20 \\
700 \\
70 \\
0.2\end{array}$ & $\begin{array}{r}50 \\
150 \\
5 \\
100 \\
7 \\
<10 \\
50 \\
10 \\
<1 \\
1,500 \\
20 \\
<10 \\
10 \\
10 \\
500 \\
20 \\
0.5\end{array}$ & $\begin{array}{r}10 \\
1,500 \\
20 \\
200 \\
5 \\
<10 \\
15 \\
50 \\
<1 \\
2,000 \\
20 \\
10 \\
5 \\
20 \\
700 \\
50 \\
0.3\end{array}$ & $\begin{array}{r}10 \\
<10,000 \\
50 \\
15 \\
<5 \\
<10 \\
10 \\
20 \\
<1 \\
700 \\
<10 \\
<10 \\
<20 \\
10 \\
100 \\
500 \\
5\end{array}$ \\
\hline
\end{tabular}

Note.-Also found: $\mathrm{La}, 50 ; \mathrm{Mo}, 2 ; \mathrm{Ag}, 1 ; \mathrm{Bi}, 5 ; \mathrm{Sn}, 10 ; \mathrm{As}, 500 ; \mathrm{Sb}, 50 ; \mathrm{W}, 20 ; \mathrm{Nb}, 10$. grains of quartz with associated magnetite and traces of mica.

Trace element concentrations in quartzite in the Wood Canyon Formation (table 8) are about the same as in the Stirling Quartzite (table 7), except that the Wood Canyon quartzite averages higher in manganese. A comparison of shales in the Wood Canyon Formation and in the Johnnie shows that the Wood Canyon contains more manganese and less vanadium, boron, gallium, and barium than does the Johnnie. The proportions of trace elements in the limestone are quite different from the proportions in dolomite in the Johnnie Formation (table 6).

\section{ZABRISKIE QUARTZITE}

The Zabriskie Quartzite, originally named and described as a member of the Wood Canyon Formation by Hazzard (1937b, p. 309), consists of white quartzite in laminated beds about 6 inches to 2 feet thick interbedded with micaceous purple shale, sandstone, and siltstone. The quartzite beds show little crossbedding; mostly they are evenly laminated. The quartzite contains few impurities; the rock consists of closely interlocked grains of quartz with little other foreign matter (fig. 17).

The Zabriskie Quartzite, like the Stirling Quartzite, has been subject to major deformation due to shearing along flat faults that approximately parallel the bedding. As a consequence the formation varies greatly in thickness, but the variation is attributable to tectonic deformation-not to stratigraphic changes.

Along the north side of Blackwater Wash, the $\mathrm{Za}$ briskie Quartzite is 160 feet thick and is mostly massive

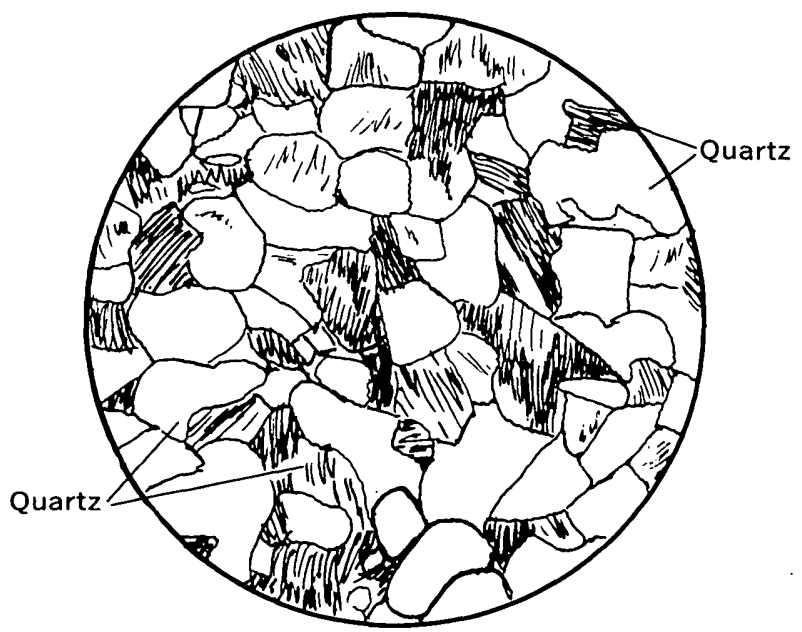

Figure 17-Micrograph of the Zabriskie Quartzite. The rock consists of closely interlocked grains of quartz with almost no interstitial material. Quartz grains are rounded but show signs of irregular intergrowth. Diameter of fleld, $2.5 \mathrm{~mm}$. 
brecciated quartzite stained lavender. Fifty-five feet below the top is a 2-foot layer of mustard-colored shale and siltstone.

A thickness of 70 feet has been reported for the Zabriskie Quartzite at Aguereberry Point; gray quartzite just below the base of the Zabriskie contains rodlike structures several inches long oriented perpendicular to the bedding, possibly Scolithus tubes (Hopper, 1947, p. 406).

In the Funeral Mountains, north of Echo Canyon and at the east edge of the Furnace Creek quadrangle, the Zabriskie Quartzite is several hundred feet thick, mostly quartzite breccia. About a hundred feet of undisturbed beds at the top showed the following section:

Section of Zabriskie Quartzite north side of Echo Canyon center north side $N W 1 / 4$ sec. $15, T .27 N ., R$. $2 E$.

Top. Base of Carrara Formation.

1. Quartzite; interbedded white, black, and reddish beds 6 in to $2 \mathrm{ft}$ thick, evenly laminated, not much crossbedding

2. Shale, siltstone, and sandstone, purple, micaceous.

3. Quartzite, white, vitreous; in beds $1 \mathrm{ft}$ thick ; grains as much as $1 \mathrm{~mm}$

4. Tectonically crushed quartzite Total thickness uncertain because of brecciation and faulting.

Base. Wood Canyon Formation.

Five samples of Zabriskio Quartzite analyzed for trace elements contain similar amounts of the several elements (table 9). The quantities are very much less than in the Stirling Quartzite (table 7), but the proportions appear not to be greatly different.

A block of sheared granulated quartzite surrounded by volcanic rocks near the north end of the Artists Drive fault blocks is represented by the two samples $F$ and $G$ in table 9. The quartzite probably is the Zabriskie, but it could be the Eureka (table 13). Its low content of trace elements makes it unlike any of the known Precambrian quartzites.

The Zabriskie Quartzite is considered Early Cambrian in age.

\section{CARRARA FORMATION}

The Carrara Formation was named by Cornwall and Kleinhampl (1962) for exposures at Bare Mountain, Nev., just north of Death Valley. The Carrara Formation represents a sequence of beds transitional between the underlying clastic formations (Zabriskie Quartzite and Wood Canyon Formation) and the overlying carbonate ones (Bonanza King and younger formations). The Carrara is widespread in the Death Valley region where it is characterized by an alternation of shaly or
TABLE 9.-Trace elements in the Zabriskie Quartzite

[Semiquantitative spectrographic analyses by Uteana Oda and E. F. Cooley, U.S. Geol. Survey. Values in parts per million, except $\mathrm{Mg}$, which is given in percent]

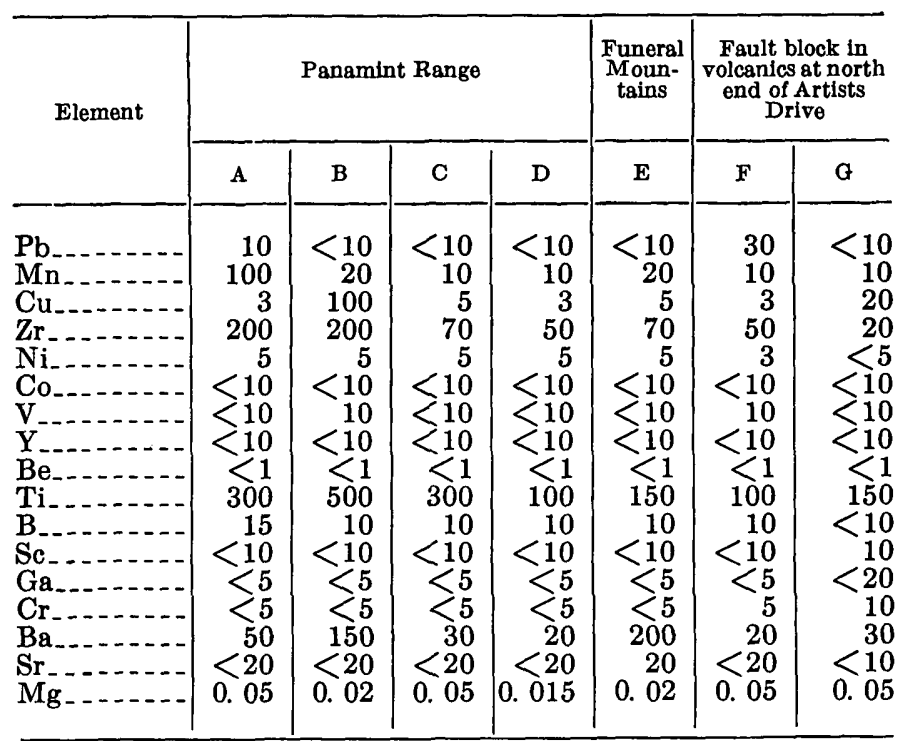

Nore. - Also found: $\mathrm{La},<50 ; \mathrm{Mo},<2 ; \mathrm{Ag},<1 ; \mathrm{Bi},<5 ; \mathrm{Sn},<10 ; \mathrm{As},<500 ; \mathrm{Sb},<50$ $\mathrm{W},<20 ; \mathrm{Nb},<10$.

silty mem'bers and limestone members. Thin generally yellowish limestone beds composed mostly of fragmentary olenellid trilobites representing species of Bristolia, Fremontia, and Peachella are found throughout the region near the bottom of the formation. In the $\mathrm{Fu}$ neral Mountains and at Bare Mountain, a prominent blue-gray limestone member with many "Girvanella" beds is found near the top of the Lower Cambrian part of the formation. This member is separated from an upper limestone member by an interval of shales and siltstones. The upper member includes one or two massive limestone units overlain by a yellow- or whiteweathering thin-bedded limestone unit with some thin shale interbeds. Although no fossils were obtained from this thin-bedded unit in Death Valley, trilobites of the Middle Cambrian Glossopleura zone were collected from it at Eagle Mountain to the southeast and Lathrop Wells to the east (A. R. Palmer, oral commun., 1961).

In the Funeral Mountains and Panamint Range, the Carrara Formation varies greatly in thickness, probably due to crushing and shingling as a result of deformation. The best section, given below, is in Echo Canyon in the Funeral Mountains where the formation is more than 1,200 feet thick.

In the Manly Peak quadrangle, southwest of the area covered in this report, the carbonate rocks above the Zabriskie Quartzite aggregate 4,800 feet thick and are referred to the Lotus Formation by Johnson (1947, p. 380). 
Section of Carrara Formation in Funeral Mountains, in Echo Canyon at east edge of the Furnace Creek quadrangle, sec. $15, T .27 N ., R .2 E$.

[Measured by Charles B. Hunt, A. R. Palmer, and R. J. Ross, Jr.]

Top. Base of Bonanza King Formation; dark dolomite Feet forms cliff.

1. Probably limestone; inaccessible cliff; blue beds as much as $20 \mathrm{ft}$ thick interbedided with well-bedded tan beds 30 ft thick; estimated thickness

2. Variegated shaly beds, pink, tan, and yellow; not accessible ; estimated thickness.

3. Limestone, massive, thick-bedded; dark blue below, top 25 ft is white; forms cliff. Thickness estimated

4. Sandstone, limy, and standy limestone; some shaly beds near base ; limestone thick bedded toward top; $\tan$ weathering

5. Shale, olive-green Colln. F-56 (3097-CO), from base :

$$
\text { olenellus sp. }
$$

6. Limestone, cliff former; Iower part thin bedded and grades downward to unit 7 ; upper part consists of 2 thick-bedded units separated by a thin-bedded one ; "Girvanella" common

7. Limestone, well-bedded; silty, mottled; abundant "Girvanella"

8. Limestone, blue-gray ; cliff former ; well bedded ; beds about 3 in. thick

9. Covered

10. Shale, like unit 11; with thin interbeds of bioclastic limestone that weathers light tan; the number of limestone beds increase upward

Colln. F-55 (3101-CO), from this unit: Bristolia cf. B. insolens (Resser)

Peachella sp.

Paedeumias sp.

11. Shale

Colln. F-83 (3148-CO), from lower $15 \mathrm{ft}$ :

Paedeumias nevadensis Resser

Fremontia sp.

12. Transition beds; mostly thin-bedded quartzite, $1 \mathrm{ft}$ of brown-weathering limestone at base; other beds of limestone less than 6 in. ithick

Total thickness

Base. Zabriskie Quartzite.

Figure 18 is a view of the Carrara Formation at the mouth of Death Valley Canyon. Figure 19 shows one of the bioclastic "trilobite-trash" beds characteristic of the lower part of the Carrara Formation.

Limestone beds in the Carrara Formation are fine grained, commonly $0.01-0.05 \mathrm{~mm}$ in diameter. With the calcite are scattered grains of quartz and some muscovite (fig. 20A). Some of the carbonate grains are brownish and may be siderite.

Eleven collections of fossils have been made from the Carrara Formation in the Death Valley area. They were studied by A. R. Palmer who has reported on them as follows (locations of collections are shown on the geologic map) :
$F-2(2434-C O)$. Dark-blue limestone about $100 \mathrm{ft}$ above Zabriski Quartzite, north foot of Tucki Mountain between Mosaic and Grotto Canyons, Stovepipe Wells quad. (NE1/4 NE1/4. sec. 7, T. 16 S., R. 45 E.) "Scraps of olenellid trilobites are definitely of Early Cambrian age. The scraps are not identifiable as to genus, but the olenellid is a long-eyed form and most probably is late Early Cambrian in age." A collection of fossils from this location but from the $100 \mathrm{ft}$ of interbedded shale and sandstone overlying the Zabriski Quartzite included Olenellus gilberti Meek (Hopper, 1947, p. 406).

F-30 (2454-CO). About $150 \mathrm{ft}$ above top of Zabriski Quartzite on hill 4213, east edge of Furnace Creek quad., 1/2 mile south of the northeast corner of the quadrangle. "At least two species of olenellid trilobites, one definitely referable to Olenellus, and the other to one of the small-eyed olenellids. The age is probably late, but not latest Early Cambrian."

F-34 (3100-CO). Carrara Formation, $150 \mathrm{ft}$ above base; $1 / 2$ mile northeast of Nevares Spring, Chloride Cliff quad. NE cor. sec. 36, T. 28 N., R. 1 E. "Bristolia sp. ; Peachella sp."

F-38 (3102-CO). Hill above Chuckawalla Spring, 2.4 miles west of NW cor. sec. 6, T. 20 S., R. 47 E., Bennetts Well quad. "Peachella sp., Dictyonina sp., silicified baby olenellids."

F-39 (3905-CO). North side of Hanaupah Canyon; hill 3780, 3.75 miles west of the SW cor. sec. 6, T. 20 S., R. 47 E., Bennetts Well quad. "Fremontia sp."

F-52 (3091-CO). About $15 \mathrm{ft}$ above the Zabriskie Quartzite in ridge north of Blackwater Wash (see section following). Furnace Creek quad. "Dictyonina sp; silicified baby olenellids."

$F-55(3101-C O)$. Bioclastic beds $110-180 \mathrm{ft}$ above base of Carrara Formation. (See also F-83.) North side of Echo Canyon, about $500 \mathrm{ft}$ upstream from the narrows at the edge of the Furnace Creek quad. (NE1/4 NW $1 / 4$ sec. 15, T. 27 N., R. 2 E.). See measured section.

$F-56(3097-C O)$. Shale at top of cliff-forming limestone; 485 ft above base of Carrara Formation; see measured section. Echo Canyon, just below narrows at east edge of the Furnace Creek quad. Center NW1/4 sec. 15, T. 27 N., R. 2 E.

$\mathbf{F}-57$. Lowermost Carrara Formation, probably same horizon as F-55; in Echo Canyon $1 / 2$ mile downstream from the narrows at the east edge of the Furnace Creek quad. (Center west side NW1/4 sec. 15, T. 27 N., R. 2 E.). "Olenellid scraps, certainly of early Cambrian age, but the scraps are not identifiable."

F-60 (3105-CO). At flat fault in Funeral Mountains, south side of the mouth of the northernmost canyon (unnamed) in the Furnace Creek quad.; estimated 100 ft above Zabriskie Quartzite but position uncertain because of faulting. (750 ft northeast of SW cor. sec. 5, T. 27 N., R. 2 E.). "Bristolia sp., unidentifiable pytchoparoid."

$F-83(3148-C O)$. Shale $20-35 \mathrm{ft}$ above top of Zabriskie Quart zite (see measured section) in Echo Canyon, north side, about $750 \mathrm{ft}$ upstream from the narrows at the east edge of the Furnace Creek quad. (North edge, NW1/4. sec. 15, T. 27 N., R. 2 E.).

Trace elements in 8 samples of the limestone and shale beds of the Carrara Formation are given in table 10. Samples of limestone from the Funeral Mountains are much like those from the Panamint Range. The proportions and amounts of the trace elements are somewhat different from those in a single specimen of limestone from the Wood Canyon Formation (table 8), but 


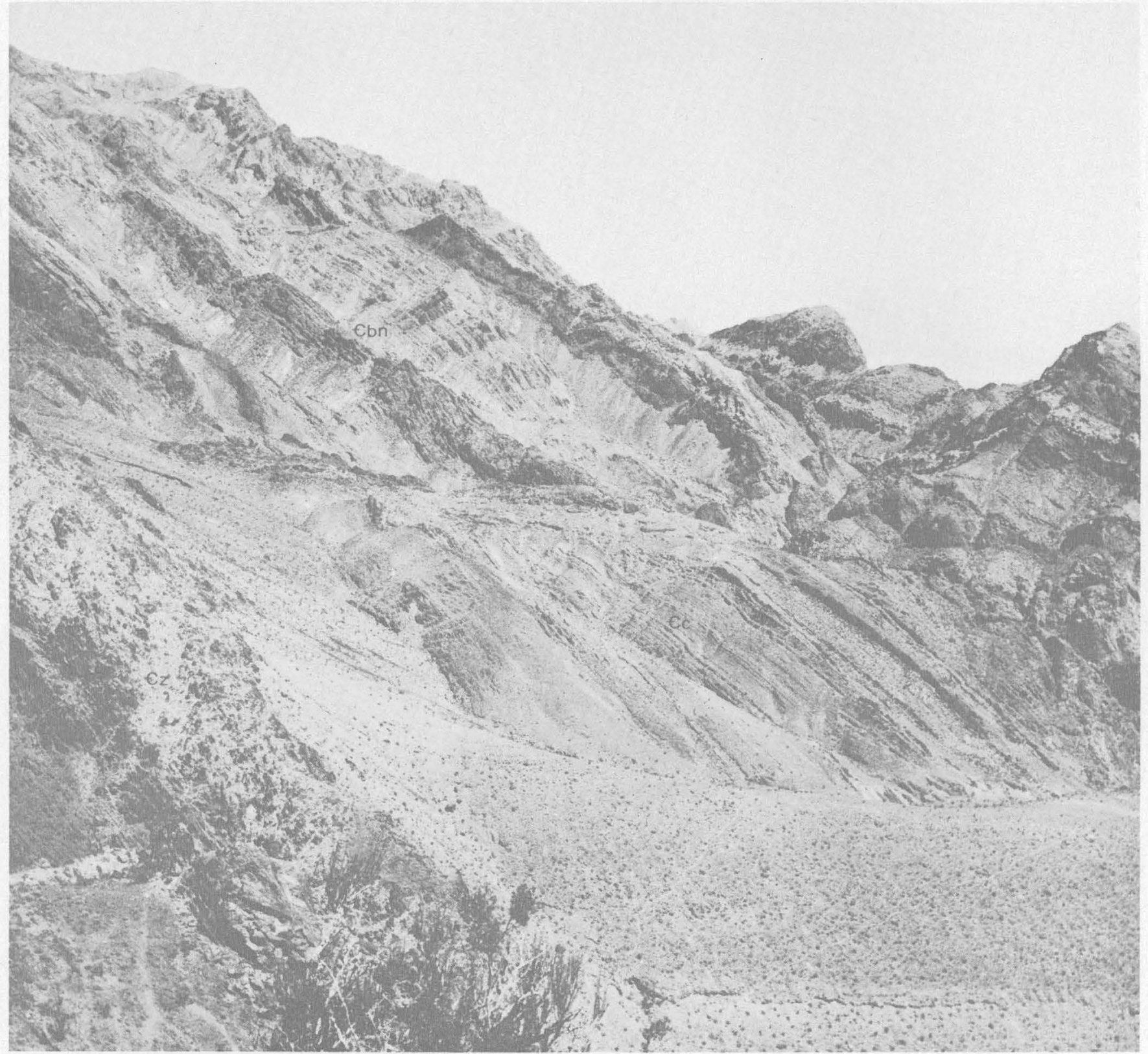

Figure 18.-Cambrian formations at the mouth of Death Valley Canyon, view north. In left foreground is Zabriskie Quartzite ( $€ z$ ). To right of this and below the flat fault is 1,000 feet of shale and thin-bedded sandy shale and limestone of the Carrara Formation ( $€ \mathrm{c}$ ) The upper plate of the fault is mostly thick-bedded dolomite belonging to the Bonanza King and Nopah Formations (Cbn).

they are more like those in the Precambrian dolomite (tables 4-6).

\section{BONANZA KING FORMATION}

The Bonanza King Formation at the type locality in the Providence Mountains is about 2,000 feet thick (Hazzard and Mason, 1936, p. 234) and is of Middle and Late Cambrian age (Palmer and Hazzard, 1956, p. 2498 ). In the Nopah Range, 1,500 feet of rocks were originally assigned to the Bonanza King Formation (Hazzard, 1937b, p. 277), but the section there has recently been revised to include in the Bonanza King over- lying rocks that had been assigned to the Cornfield Springs Formation (Palmer and Hazzard, 1956, p. 2495), giving a total thickness of almost 4,500 feet for the Bonanza King Formation in the Nopah Range.

In the Quartz Spring area in the northern Panamint Range equivalent beds, designated the Racetrack Dolomite, are more than 1,900 feet thick, but the base there is not exposed (McAllister, 1952, p. 9).

In the mountains adjoining Death Valley the Bonanza King Formation is about 3,000 feet thick. In Trail Canyon the computed thickness is 3,500 feet, but this 


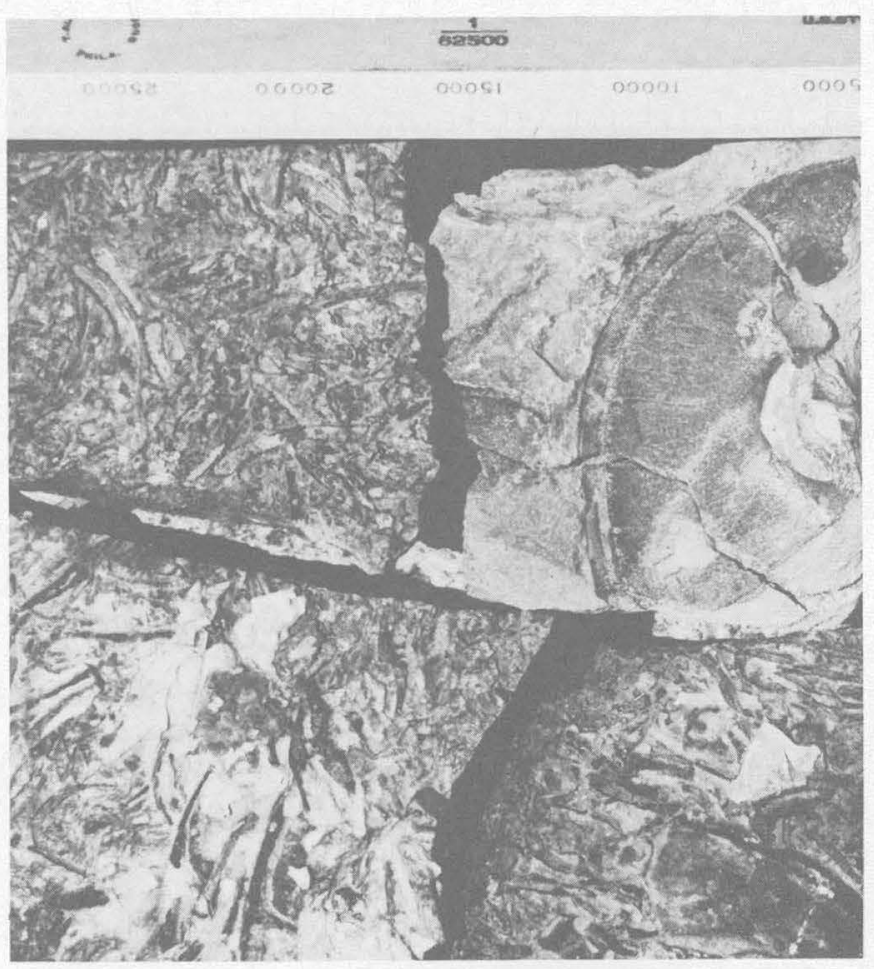

Figure 19.-Fragments of bioclastic "trilobite-trash" bed typical of the lower part of the Carrara Formation. The trilobites are olenellids.

thickness includes some beds that appear to be duplicated by faulting. The lower half of the formation in Trail Canyon is thick-bedded dark dolomite. Near the middle of the formation there are 2 light-tan shaly and sandy zones, each less than 50 feet thick and about 200 feet apart stratigraphically. The upper of these zones

TABLE 10.-Trace elements in the Carrara Formation

[Semiquantitative spectrographic analyses by Uteana Oda and E. F. Cooley, U.S. Geol. Survey. Values in parts per million, except $\mathrm{Mg}$, which is given in percent]

\begin{tabular}{|c|c|c|c|c|c|c|c|c|}
\hline \multirow{3}{*}{ Element } & \multicolumn{5}{|c|}{ Panamint Range } & \multicolumn{3}{|c|}{ Funeral Mountains } \\
\hline & \multicolumn{5}{|c|}{ Limestone } & \multicolumn{2}{|c|}{ Limestone } & \multirow{2}{*}{$\begin{array}{c}\text { Shale } \\
\mathrm{H}\end{array}$} \\
\hline & A & B & C & $\mathrm{D}^{1}$ & $\mathrm{E}$ & F & G & \\
\hline $\begin{array}{l}\mathrm{Pb} \\
\mathrm{Mn} \\
\mathrm{Cu} \\
\mathrm{Zr}- \\
\mathrm{Ni}- \\
\mathrm{Co} \\
\mathrm{V} \\
\mathrm{Y} \\
\mathrm{Be} \\
\mathrm{Ti} \\
\mathrm{B} \\
\mathrm{Sc} \\
\mathrm{Ga} \\
\mathrm{Cr}- \\
\mathrm{Ba} \\
\mathrm{Sr}- \\
\mathrm{Mg}\end{array}$ & $\begin{array}{r}20 \\
1,500 \\
3 \\
20 \\
7 \\
>10 \\
<10 \\
20 \\
<1 \\
300 \\
20 \\
<10 \\
5 \\
5 \\
70 \\
500 \\
0.5\end{array}$ & $\begin{array}{r}10 \\
70 \\
2 \\
<10 \\
<5 \\
<10 \\
<10 \\
<10 \\
<1 \\
100 \\
<10 \\
<10 \\
<5 \\
<5 \\
15 \\
500 \\
0.7\end{array}$ & $\begin{array}{r}15 \\
100 \\
2 \\
10 \\
<5 \\
<10 \\
<10 \\
<10 \\
<1 \\
100 \\
<10 \\
<10 \\
<5 \\
5 \\
30 \\
500 \\
0.5\end{array}$ & $\begin{array}{r}15 \\
2,000 \\
20 \\
30 \\
20 \\
10 \\
15 \\
20 \\
1 \\
500 \\
15 \\
10 \\
10 \\
15 \\
100 \\
200 \\
1\end{array}$ & $\begin{array}{r}20 \\
3,000 \\
50 \\
200 \\
<5 \\
<10 \\
50 \\
50 \\
<1 \\
1,500 \\
<10 \\
<10 \\
<20 \\
20 \\
100 \\
5,000 \\
5\end{array}$ & $\begin{array}{r}30 \\
300 \\
2 \\
<10 \\
5 \\
<10 \\
10 \\
<10 \\
<1 \\
150 \\
10 \\
<10 \\
<5 \\
10 \\
30 \\
300 \\
0.5\end{array}$ & $\begin{array}{r}20 \\
500 \\
2 \\
20 \\
10 \\
<10 \\
10 \\
10 \\
<1 \\
300 \\
20 \\
<10 \\
5 \\
10 \\
30 \\
500+ \\
0.7\end{array}$ & $\begin{array}{r}100 \\
300 \\
20 \\
70 \\
20 \\
15 \\
50 \\
30 \\
5 \\
3,000 \\
70 \\
15 \\
20 \\
70 \\
300 \\
50 \\
0.7\end{array}$ \\
\hline
\end{tabular}

${ }^{1}$ Sample $D$ is from the Burro Trail fault at Chuckwalla Spring. NoTE.-Also found: Sn, $<10 ; \mathrm{Ag},<1 ; \mathrm{Ge},<20 ; \mathrm{As},<1,000 ; \mathrm{Sb},<200$; $\mathrm{In},<50$; Cd,
$<50$; Ti, $<100$; Ta, $<50$; W, $<50$; Mo, $<2$.

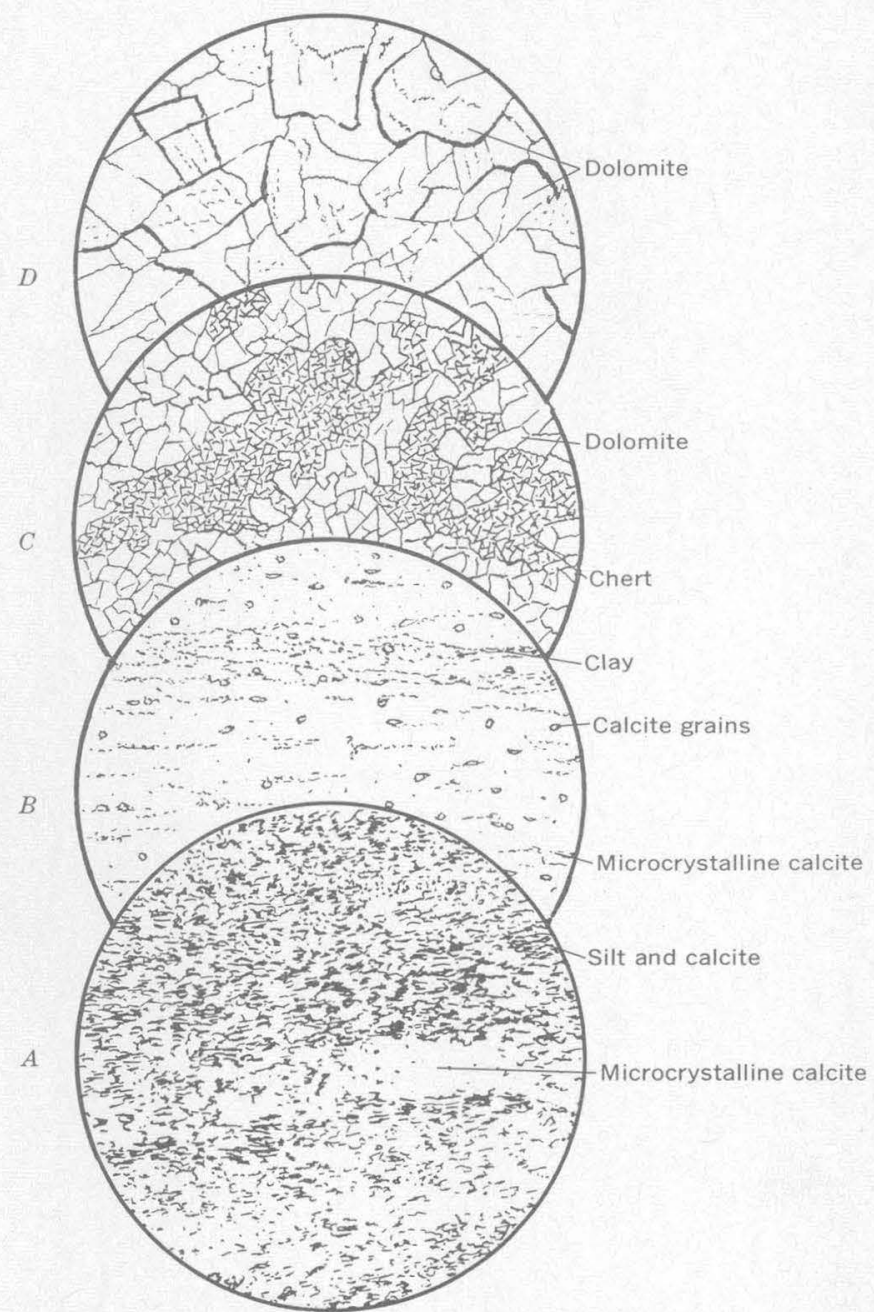

Figure 20. Micrographs of earbonate rocks from Cambrian formations. $A$, Silty limestone, Carrara Formation. $B$, Limestone from middle member of Bonanza King Formation; this limestone is dense and contains little silt or clay. $C$, Dark-colored dolomite with chert from Nopah Formation. $D$, Light-colored dolomite,

Nopah Formation. Diameter of field, $2.5 \mathrm{~mm}$.

is fossiliferous and contains, in addition to indeterminate linguloids, the Middle Cambrian trilobite "Ehmaniella" sp. (colln. F-41, 3099-CO; fig. 21). In the Nopah Range, shaly beds at about this same stratigraphic position have yielded the trilobite Ehmania (Hazzard, 1937b, p. 319). The overlying beds are now included in the Bonanza King Formation, although originally referred to the Cornfield Springs Formation (Palmer and Hazzard, 1956, p. 2498).

Overlying this fossiliferous zone in Trail Canyon is about 100 feet of dark thick-bedded dolomite, which is overlain by a distinctive unit, almost 600 feet thick, consisting of well-bedded and comparatively thinbedded limestone with only a few beds of dolomite (fig. 22). An intensive search of these beds failed to dis- 


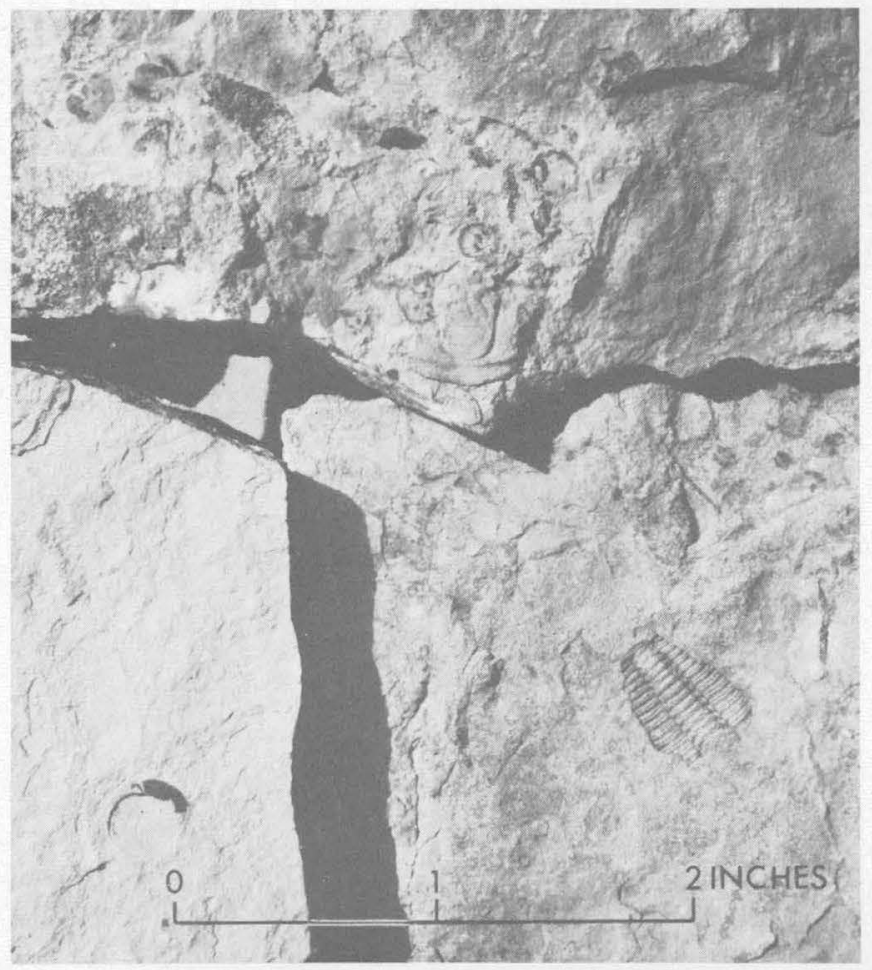

FIGURE 21.-Linguloid brachiopods and trilobites ("Ehmaniella" sp.) from shaly zone near the middle of the Bonanza King Formation, Trail Canyon.

cover any fossils other than stromatolites. Figure $20 B$ shows a micrograph of this limestone.

The top 1,000 feet of the Bonanza King Formation in Trail Canyon consists of drab-colored massive dolomite in four beds, two of which are dark gray and two lighter gray. The dark beds are poorly bedded; the lighter gray beds are well bedded in beds $1-3$ feet thick and striped with a few dark beds. The top of the Bonanza King Formation is well marked here and elsewhere in the Death Valley area by the fossiliferous shale at the base of the Nopah Formation.

At the north foot of Tucki Mountain, between Mosaic and Grotto Canyon, the thickness of the Bonanza King Formation is computed as 3,000 feet. The well-bedded limestone unit about 1,000 feet below the top of the formation crops out at the mouth of Grotto Canyon, but the fossiliferous shaly and sandy layers that occur below it in Trail Canyon were not found.

An attempt to measure the thickness of the Bonanza King Formation in Echo Canyon in the Funeral Mountains gave a figure of only 2,050 feet. This figure is of doubtful stratigraphic significance, however, because the section along the canyon crosses several faults having displacements that are not well known. The fossiliferous zones were not found in that section.
More careful work in the Panamint Range probably will make it possible to subdivide the Bonanza King Formation into upper and lower thick-bedded dolomitic members separated by a middle thin-bedded limestone and shale member.

Table 11 gives the trace elements in samples from the Bonanza King Formation. The analyses suggest that the limestone has about the same trace elements as the more prevalent dolomite. The trace elements differ but slightly from those in the Carrara Formation (table 10).

TABLE 11.-Trace elements in the Bonanza King Formation, Panamint Range

[Semiquantitative spectrographic analyses by Uteana Oda and E. F. Cooley, U.S Geol. Survey. Values in parts per million, except $\mathrm{Mg}$, which is given in percent]

\begin{tabular}{|c|c|c|c|c|}
\hline \multirow[t]{2}{*}{ Element } & Sandy & Limestone & \multicolumn{2}{|c|}{ Dolomite } \\
\hline & $\begin{array}{r}30 \\
700 \\
7 \\
150 \\
20 \\
10 \\
50 \\
30 \\
2 \\
2,000 \\
50 \\
15 \\
20 \\
50 \\
700 \\
200 \\
0.7\end{array}$ & $\begin{array}{r}15 \\
100 \\
30 \\
<10 \\
<5 \\
<10 \\
20 \\
10 \\
<1 \\
150 \\
<10 \\
<10 \\
<20 \\
10 \\
15 \\
500 \\
>5\end{array}$ & $\begin{array}{r}15 \\
300 \\
3 \\
<10 \\
5 \\
10 \\
<10 \\
<10 \\
<1 \\
20 \\
10 \\
10 \\
<10 \\
5 \\
10 \\
100 \\
>5\end{array}$ & $\begin{array}{r}10 \\
20 \\
50 \\
<10 \\
<5 \\
<10 \\
20 \\
15 \\
<1 \\
30 \\
10 \\
<10 \\
<20 \\
10 \\
20 \\
500 \\
>5\end{array}$ \\
\hline
\end{tabular}

Note. - Also found: $\mathrm{Sn},<10 ; \mathrm{Ag},<1 ; \mathrm{Ge},<20 ; \mathrm{As},<1,000 ; \mathrm{Sb},<200 ; \mathrm{In},<50 ; \mathrm{Cd}$ $<50$; Ti, $<100$; Ta, $<50$; $\mathrm{W},<50$.

\section{NOPAH FORMATION}

The Nopah Formation at the type locality in the Nopah Range is 1,740 feet thick (Hazzard, 1937b, p. 276,320 ) and consists of a basal shaly member about 100 feet thick overlain by alternating light- and darkgray dolomites. In the northern Panamint Range the sequence of lithologies is similar to that in the Nopah Range, and the thickness is about 1,600 feet (McAllister, 1952 , p. $9 ; 1955$, p. $10 ; 1956)$. At both locations fossils indicative of Late Cambrian age occur in shaly beds at the base of the formation. Indeterminate gastropods of possible latest Cambrian age have been found in the upper 700 feet of the Nopah Formation in the Amargosa Range and in the northern Panamint Range (McAllister, 1952, p. 10). The Nopah Formation is correlated with the Cornfield Springs Formation in the Providence Mountains (Palmer, 1956, p. 673).

The Nopah Formation in the mountains bordering Death Valley is very similar lithologically to that at 


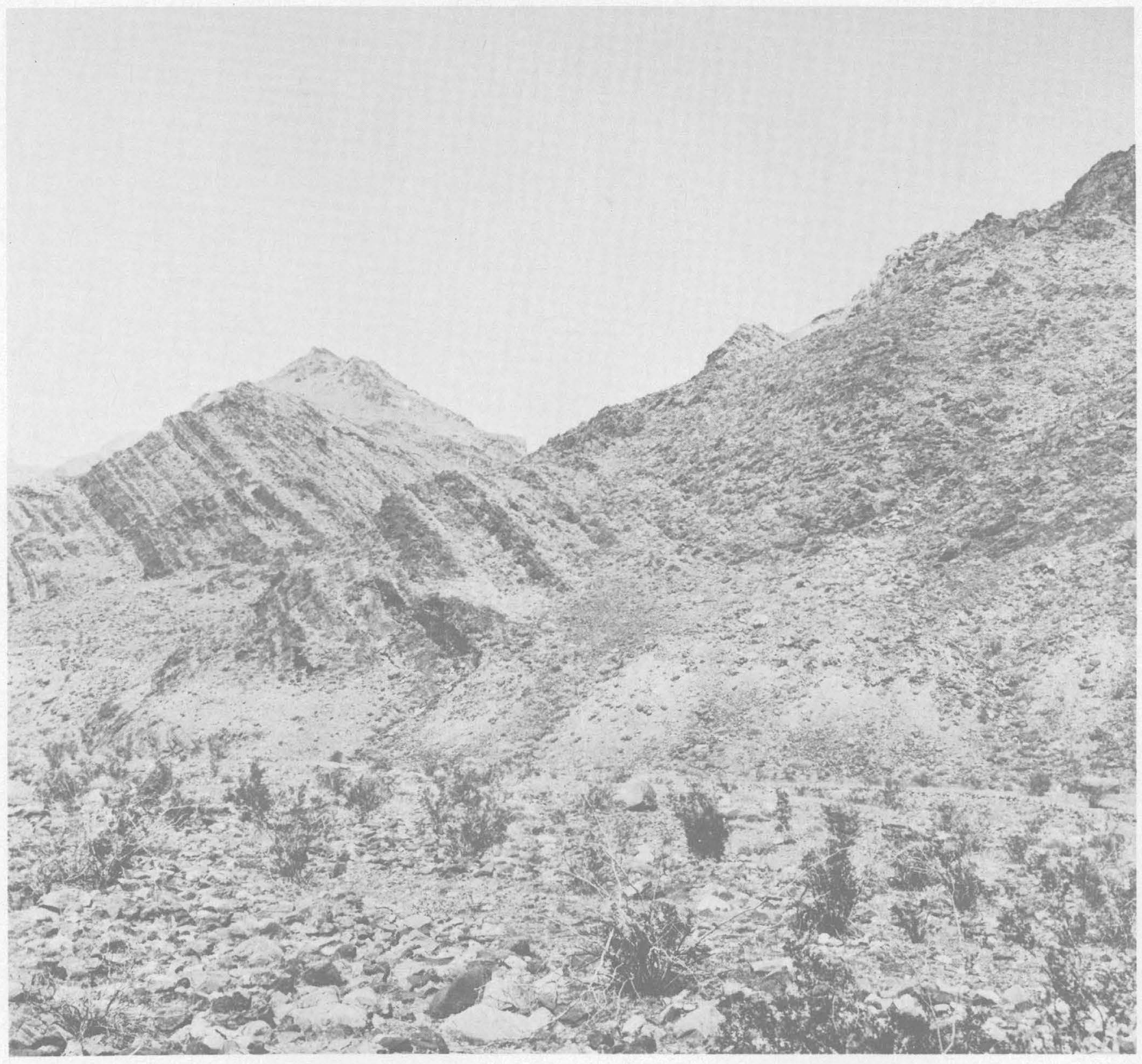

Figure 22.-Thin-bedded middle member of the Bonanza King Formation on the north side of Trail Canyon, view north. This member, about 600 feet thick, forms a distinctive unit separating massive thick-bedded dolomite comprising the upper and lower members of the formation.

the type section and in the northern Panamint Range, and the characteristic fossils occur in the shaly beds at the base (fig. 23). The formation is about 1,500 feet thick in the Funeral Mountains, but it appears to be somewhat thinner in Tucki Mountain and in the southern part of the Panamint Range. Several computed thicknesses average about 1,200 feet. Sections through the whole formation and through the characteristic basal shale member are given below.
Figure 24 is a view of the banded light- and darkcolored dolomite forming most of the Nopah Formation. Much of this dolomite is o y, the chert occurring as nodules distributed along bedding planes and as irregular lumps that seem to have little or no relation to the bedding. Figure 20 shows some micrographs of the light dolomite and of the dark dolomite and chert. A section of the Nopah Formation measured in Trail Canyon follows. 


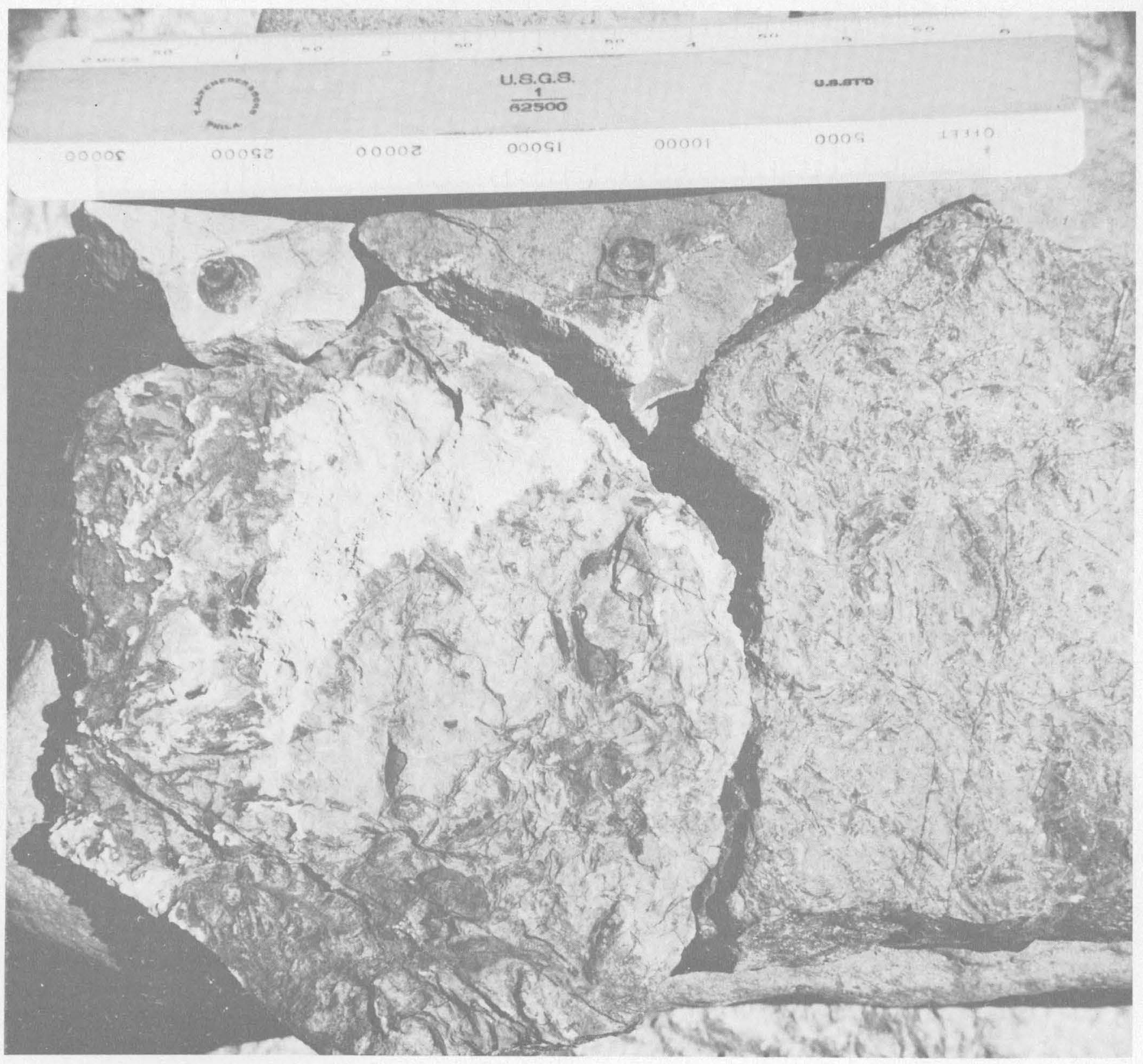

Figure 23.-Bioclastic bed with fragments of trilobites and brachiopods from shale unit at base of Nopah Formation (colln. F-54-3098-CO).

Section of Nopah Formation, north side of Trail Canyon 2 miles above the canyon mouth

[Section measured by Charles B. Hunt and A. R. Palmer]

Top. Base of Pogonip Group.

1. Dolomite, black, thick-bedded

2. Dolomite, gray, in thick beds

3. Dolomite, black, massive

4. Dolomite, light-colored

5. Dolomite, black, massive

6. Dolomite, light-colored

7. Dolomite, banded black and light-colored

8. Dolomite, light-colored, thin-bedded

9. Dolomite, black, massive
Feet

75

275

50

120

75

110

60

60
Section of Nopah Formation, north side of Trail Canyon 2 miles above the canyon mouth-Continued

10. Dolomite, light-colored, thin-bedded, forms slope_-_-

11. Shale and limestone. Shale greenish or brown in beds $1-4 \mathrm{ft}$ thick; some shale has nodules of limestone. Limestones brown and in beds 6 in to $2 \mathrm{ft}$ thick. Many are trilobite breccias; others are echinoderm breccias. Linguloid brachiopods in the shale

Colln. F-68, (3143-CO), top of unit: Cheilocephalus sp.

Undetermined dokimocephalinid.
Feet

110 
Section of Nopah Formation, north side of Trail Canyon 2 miles above the canyon mouth-Continued

11. Shale and limestone-Continued

Colln. F-67, (3142-CO ), 20 ft below top of unit : Apachia sp.

Undetermined pterocephalinid

Colln. F-66, (3141-CO), at base of unit :

Homagnostus obesus (Belt)

Strigambitus utahensis (Resser)

Dunderbergia variagranula Palmer

Apsotreta $\mathbf{s p}$.

Dysoristus sp.

12. Concealed

Total thickness of Nopah Formation 1,120

Base. Thick-bedded dolomite, top of Bonanza King Formation.

Section of shale member at base of Nopáh Formation, east side of mouth of Grotto Canyon, NE1/4NE1/4 sec. 8, T. 16 S., R. 45 E., alt. 1,175 ft

Top. Thick-bedded dolomite of Nopah Formation.

Thin-bedded limestone and tan shale. Shale mostly in laminae separating thin beds of limestone, but some shale beds are $10 \mathrm{ft}$ thick. Basal $15 \mathrm{ft}$ is brown limestone; higher ones blue gray, in beds 1 in to $2 \mathrm{ft}$ thick. Nodular limestone and shale $40 \mathrm{ft}$ above base

Colln. F-69 (3144-CO) top of unit: Elburgia quinnensis (Resser) Sigmocheilus sp. Cheilocephalus brachyops? Palmer Apachio sp.

Colln F-1 (2433-CO), near middle of unit:

Elburgia quinnensis (Resser)

Cheilocephalus sp.

Strigambitus? blepharina Palmer

Homagnostus sp.

Morosa brevispina Palmer

Colln. F-71 (3146-CO), $15 \mathrm{ft}$ above base of unit; Dunderbergia variagranula Palmer strigambitus utahensis (Resser) Homagnostus sp.

Colln. F-70 (3145-CO), basal limestone of unit: Minupeltis conservator Palmer Cernuolimbus granulosus Palmer Pseudagmostus sp.

Base. Massive dolomite at top of Bonanza King Formation.

Section of shale member at base of Nopah Formation, south side Echo Canyon one-half mile above the canyon mouth

[Measured by Charles B. Hunt, A. R. Palmer, and R. J. Ross, Jr.]

'Top. Base of lowest cliff-forming dolomite in Nopah Formation.

1. Limestone, dark-brown to black; in beds $1 \mathrm{ft}$ thick; Feet cherty

Colln. F-82, (3147-CO), from top of unit: Pterocephalia? punctata Palmer

Pseudagnostus sp.

"Acrotreta" spinosa Walcott
Section of shale member at base of Nopah Formation, south side Echo Canyon one-half mile above the canyon mouth-Con.

2. Shale, tan limy; in part sandy

Colln. F-54, (3098-CO), 15-25 ft above base of unit:

Elburgia quinnensis? (Resser)

Strigambitus? blepharina Palmer Apsotreta sp.

3. Limestone pebble conglomerate and coarse bioclastic beds; some limestone beds $1 / 2$ in thick; some silt beds $1 / 4$ in thick; chert._. 50

4. Covered

Total thickness

Base. Massive dolomite, top of Bonanza King Forma160 tion.

Two other collections of fossils from the Nopah Formation were reported upon by Palmer as follows:

$F-53(3109-C O)$. North side of Echo Canyon, $1 / 4$ mile above mouth, Furnace Creek quad. (SW1/4 SW1/4 sec. 16, T. 27 N., R. 2 E.). "Apsotreta sp.; abundant siliceous sponge spicules, a part of this collection is essentially a spiculite."

$F-58(3039-C O)$. Ridgetop south of Echo Canyon about 1 mile above the mouth of the canyon, alt 2,950 ft, Furnace Creek quad., probably near middle of the shale unit (SW1/4 SW1/4 sec. 15, T. 27 N., R. 2 E.). "Elburgia quinnensis (Resser); Pseudagnostus communis (Hall and Whitfield) ; Homagnostus tumidosus (Hall and Whitfield) ; Morosa brevispina Palmer; Strigambitus? blepharina Palmer; Apsotreta sp.; 'Acrotreta' spinosa Walcott ; conodont."

Trace elements in the Nopah Formation are listed in table 12. The samples from the Funeral Mountains are limestone from the base of the formation; those from

TABLE 12.-Trace elements in the Nopah Formation

-Semiquantitative spectrographic analyses by Uteana Oda and E. F. Cooley, U.S. Geol. Survey. Values in parts per million, except $\mathrm{Mg}$, which is given in percent]

\begin{tabular}{|c|c|c|c|c|c|}
\hline \multirow{2}{*}{ Element } & \multicolumn{3}{|c|}{ Panamint Range } & \multirow{2}{*}{\multicolumn{2}{|c|}{$\frac{\text { Funeral Mountains }}{\text { Limestone }}$}} \\
\hline & & Dolomite & & & \\
\hline 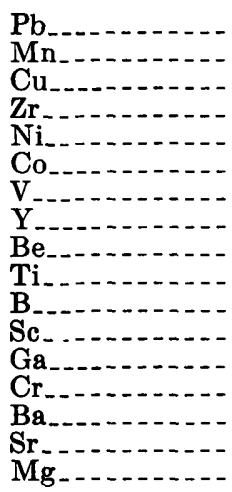 & $\begin{array}{r}<10 \\
10 \\
2 \\
<10 \\
5 \\
<10 \\
10 \\
10 \\
<1 \\
<10 \\
<10 \\
<10 \\
<5 \\
5 \\
10 \\
150 \\
>5\end{array}$ & $\begin{array}{r}70 \\
50 \\
5 \\
70 \\
5 \\
<10 \\
<10 \\
<10 \\
<1 \\
50 \\
<10 \\
<10 \\
<5 \\
5 \\
15 \\
200 \\
5\end{array}$ & $\begin{array}{r}20 \\
70 \\
50 \\
<10 \\
<5 \\
<10 \\
20 \\
20 \\
<1 \\
30 \\
<10 \\
<10 \\
<20 \\
10 \\
20 \\
300 \\
>5\end{array}$ & $\begin{array}{r}10 \\
700 \\
5 \\
<10 \\
5 \\
<10 \\
<10 \\
<10 \\
<1 \\
200 \\
10 \\
<10 \\
<5 \\
10 \\
70 \\
700 \\
0.7\end{array}$ & $\begin{array}{r}10 \\
1,000 \\
2 \\
20 \\
<5 \\
<10 \\
<10 \\
<10 \\
<1 \\
300 \\
10 \\
<10 \\
5 \\
5 \\
50 \\
1,000 \\
0.7\end{array}$ \\
\hline
\end{tabular}

Nore. - Also found: $\mathrm{Sn},<10 ; \mathrm{Ag},<1 ; \mathrm{Ge},<20 ; \mathrm{As},<1,000 ; \mathrm{Sb},<200 ; \mathrm{In},<50 ; \mathrm{Cd}$ $<50 ; \mathrm{Tl},<100 ; \mathrm{Ta},<50 ; \mathrm{W},<50 ; \mathrm{Nb},<10$. 
the Panamint Range are dolomite from the upper part of the formation. Whereas limestone and dolomite in the Bonanza King Formation have about the same content of trace elements (table 11), the limestone and dolomite of the Nopah Formation have quite different proportions of some constituents; notably, manganese, titanium, barium, and strontium are very much more abundant in the limestone than in the dolomite. Dolomite in the Nopah Formation has about the same amount and proportions of trace elements as does the dolomite in the Bonanza King Formation.

\section{ORDOVICIAN SYSTEM}

POGONIP GROUP

The name Pogonip originally was applied to the considerable thickness of carbonate rocks lying above quartzite of Cambrian age and extending up to the Eureka Quartzite of Ordovician age (King, 1878, p. 188). The name has been redefined several times and now is restricted to rocks of Ordovician age; underlying rocks of Cambrian age now are separated from the
Pogonip (Hazzard, 1937b; Hintze, 1949, 1951; Easton and others, 1953; McAllister, 1952; Nolan, Merriam, and Williams, 1956). In the Death Valley area the Pogonip Group overlies the Nopah Formation and is overlain by the Eureka Quartzite. According to Ross (oral commun., 1961) the Pogonip Group of this area probably is roughly equivalent to the Yellow Hill and Tank Hill Limestones of the Pioche district (Westgate and Knopf, 1932, p. 14).

In the Death Valley area the Pogonip Group is about 1,500 feet thick. In Trail Canyon it is composed of three distinct members. The lower member consists of thinbedded dolomite, the upper of thick-bedded dolomite; the middle member is shaly (fig. 24). Very little limestone is found in this section, and there seems to be evidence of a considerable amount of secondary dolomitization, which makes comparison with measured sections in other areas difficult. In the northern part of Tucki Mountain the Pogonip may be represented in a limestone facies, but outcrops are in disjointed fault slices which make stratigraphic placement almost impossible.

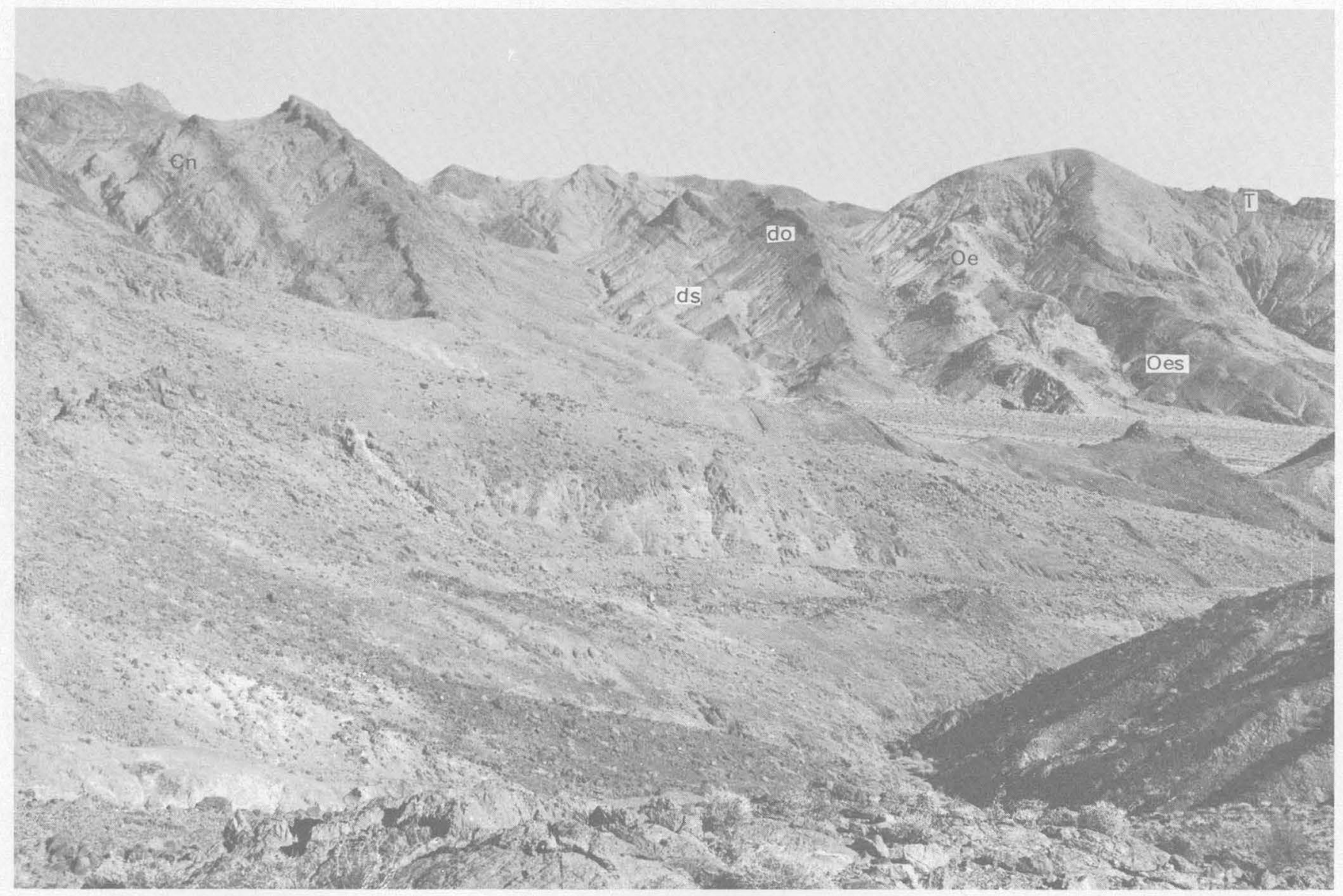

Figure 24.-View of Pogonip Group in Trail Canyon. View is north. At left is light- and dark-colored dolomite of the Nopah Formation $\left(\complement_{n}\right)$. Thin-bedded dolomite and shale $(d s)$ in the lower and middle part of the Pogonip Group form the saddle; thick-bedded dolomite (do) in the upper part of the Pogonip forms the dark ridge dipping under the light-colored Eureka Quartzite (Oe) at the right. Hill at extreme right is capped with Tertiary lavas $(T)$; at the base of the hill is dark Ely Springs Dolomite (Oes). 
A threefold division of the Pogonip is possible in several nearby areas; the three subdivisions according to Ross (oral commun., 1961), are roughly equivalent to the shaly limestones of the Goodwin Formation, overlain by the limy shales of the Ninemile Formation, which, in turn, are overlain by the more massive limestones of the Antelope Valley Limestone, all of the central Nevada Eureka district (Nolan and others, 1956, p. 24-25). Hazzard (1937b, p. 276) has recognized a similar tripartite division of the Pogonip Group in the Nopah Range. Similar subdivisions have been reported in the northern part of the Panamint Range by McAllister (1952, p. 11), and at Bare Mountain to the north of Death Valley (Cornwall and Kleinhampl, 1962), as well as in the general area of the Nevada Test Site farther to the east.

In the Death Valley area the basal unit of the Pogonip Group is mostly dolomite; but this may be due to metamorphism, because this member elsewhere includes considerable limestone. In adjacent areas it is mostly limestone. The middle unit of the Pogonip Group in the

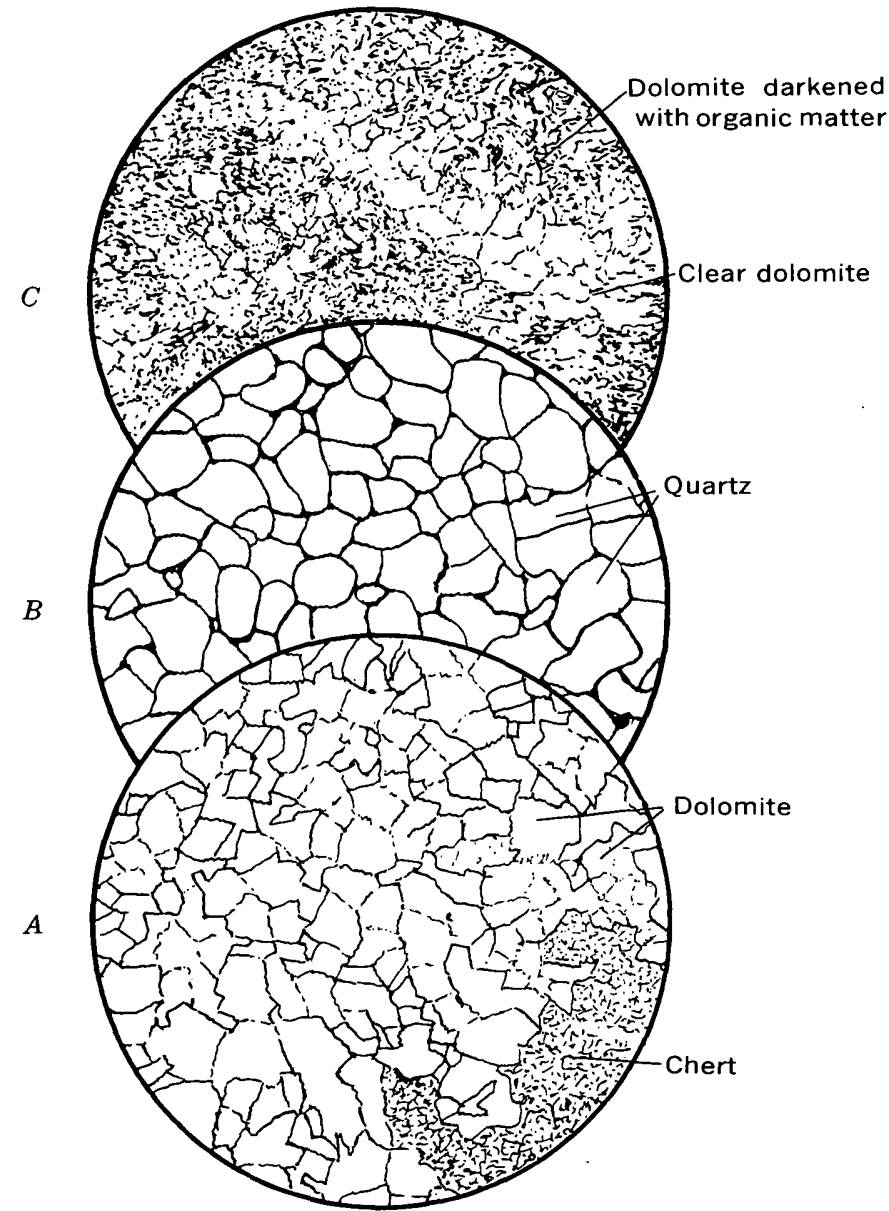

FIGURE 25.-Micrographs of rocks from Ordovician formations. $A$ Dolomite, with chert, from upper unit of Pogonip Group. $B$, Eureka Quartzite. $\sigma$, Ely Springs Dolomite. Diameter of fields, $2.5 \mathrm{~mm}$.
Death Valley area is reddish; this probably also is attributable to metamorphism, because relict sedimentary structures, such as intraformational conglomerate, coarse bioclastic beds, and occasional crossbedding in calcarenites, can be found. Also, numerous dikes cut the Pogonip Group from south of Trail Canyon to Blackwater Wash. Figure $25 \mathrm{~A}$ is a micrograph of dolomite from the Pogonip Group.

No fossils were found in the lower and middle parts of the Pogonip Group, but the cliff-forming dolomite comprising the upper third of the formation at many places contains large gastropods in such abundance as to be a lithologic guide to the dolomite (fig. 26).

Fossils from the Pogonip Group were collected at 10 localities in the Death Valley area, as follows:

$F-3(D 6 / 3-C O)$. Dolomite in upper part of Pogonip Group; south side of canyon north of Trail Canyon, Furnace Creek quad.; 2.1 miles west and 0.3 mile north of SW $1 / 4$ sec. 31 , T. 18 S., R. 47 E., alt 1,280 ft. Identifications by R. J. Ross, Jr., Receptaculites? sp.: Palliseria? sp. Probably high Pogonip and equivalent to the Antelope Valley Limestone of the Eureka area, Nevada."

$F-5$ (not cataloged). Dolomite, upper part of Pogonip Group, north base of Tucki Mountain below mouth of Trellis Canyon, Stovepipe Wells quad. ( $S E 1 / 4$ SE1/4 sec. 23 , T. 16 S., R. 45 E., alt $1,280 \mathrm{ft}$ ). Identification by $\mathrm{E}$. L. Yochelson, "The material consists of two pieces of dark-gray dolomite showing poor cross sections of three gastropods; one saw cut to determine the third dimensions shows a profile suggestive of Palliseria, a guide to the Antelope Valley Limestone of central Nevada."

$F-13(D 645-C O)$. Dolomite in upper part of Pogonip Group, north side of Trail Canyon, alt 1,600 ft, Furnace Creek quad. Identification by R. J. Ross, Jr., "Palliseria sp."

F-27 (D641-CO). Dolomite in upper part of Pogonip Group, north side of second ridge south of the mouth of Trail Canyon, alt 1,600 ft, Furnace Creek quad. Identification by R. J. Ross, Jr., "Probably Palliseria."

F-28 $(D 642-C O)$. Same as F-27, lower in gulch, alt about 1,500 ft. Identification by R. J. Ross, Jr., "Receptaculites sp., Palliseria sp. Unquestionably high Pogonip."

$F-40(3626-C O)$. Pogonip Group at flat fault 11/4 miles south of Trail Canyon, 1.2 miles east of hill 4889, Furnace Creek quad. Identification by E. L. Yochelson, "Cross section of sponge?; Maclurites sp. indet.; Palliseria robusta Wilson. Palliseria Robusta, confined to the second oldest faunal zone in the Antelope Valley Limestone of central Nevada, is a guide to early Middle Ordovician age."

F-42 (D587-CO). Fault block under Eureka Quartzite, 11/2 miles south of Trail Canyon, alt 1,000 ft, Furnace Creek quad. $(7,500 \mathrm{ft}$ south of west of $\mathrm{SW}$ cor. sec. 7, T. 19 S., R. $47 \mathrm{E}$.). Identification by R. J. Ross, Jr., "Very poorly preserved gastropods and trilobite fragments. None can be identifled. Small brachiopod species suggests Diparelasma; it and the lithology suggest Pogonip."

$F-43(D 588-C O) .1,000 \mathrm{ft}$ northeast of $\mathrm{F}-42$ and apparently overlying it. Identification by R. J. Ross, Jr., Unidentifiable gastropods; abundant Girvanella? Age indeterminate."

$F-47(3625-C O)$. 11/2 miles southwest of "Dinosaur," $21 \frac{1}{2}$ miles southwest of SW cor. sec. 6, T. 18 S., R. 47 E. At south base of hill 430, Furnace Creek quad. Identification by E. L. Yoch- 


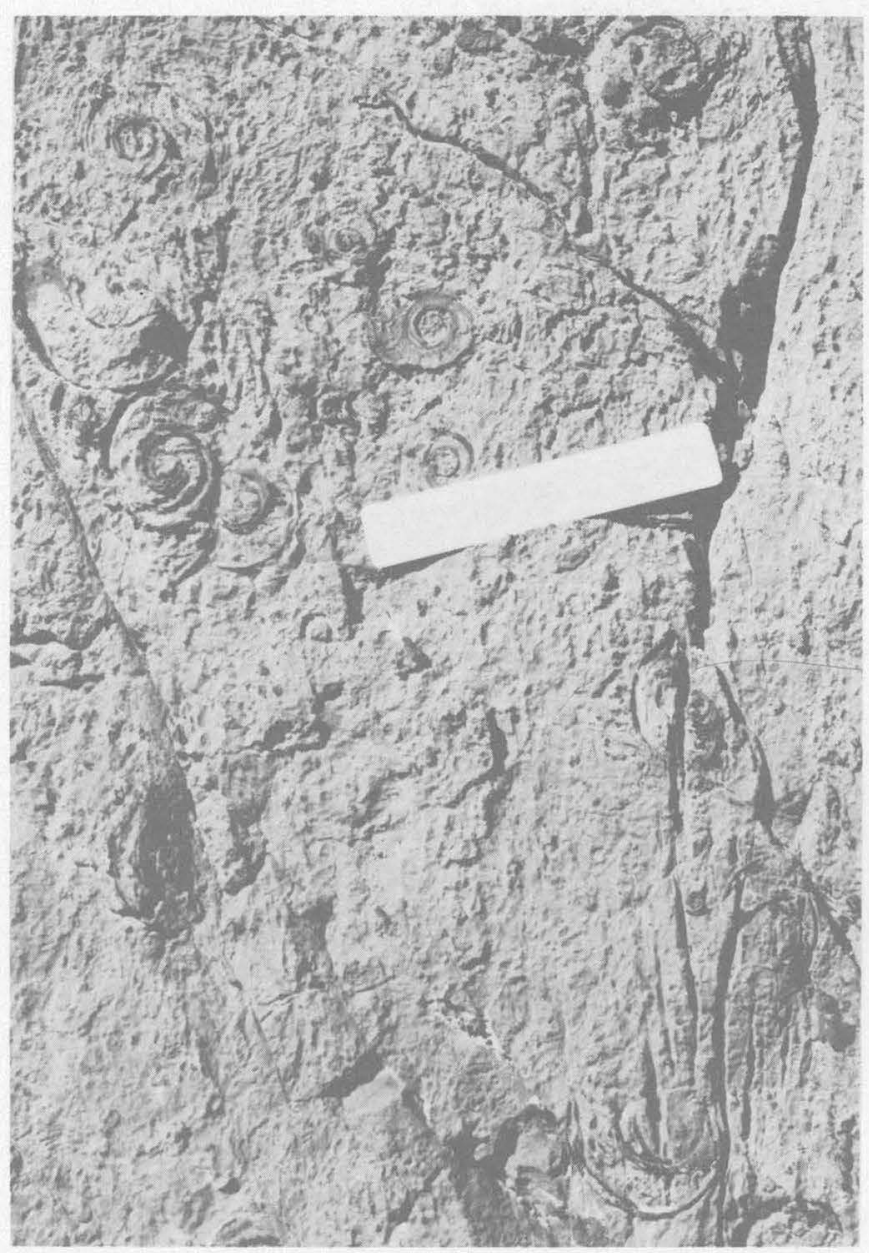

Figure 26.-Large gastropods (Palliseria sp.) in dolomite in upper part of the Pogonip Group.

elson, "Receptaculites sp., Maclurites, incomplete but suggestive of $M$. magnus; Palliseria robusta Wilson. The Palliseria is guide to early Middle Ordovician (see comment for F-40)." Also in this collection, according to R. J. Ross, Jr., is Syntrophopsis? sp.

Colln. F-61 (D589-CO). From fault block, probably Pogonip Group, in Red Amphitheater breccia at mouth of second canyon isouth of Echo Canyon, Furnace Creek quad. (Center, east side, SE $1 / 4$ NE $1 / 4$ sec. 21 , T. 27 N., R. 2 E.). According A. R. Palmer, "This collection contains orthoid brachiopods, gastropod cross sections, and an asaphid trilobite pygidium which collectively Indicate an Ordovician age." According to R. J. Ross, Jr., "The trilobite segments are very characteristic of Ordovician proparian types, and a few brachiopod outlines suggest Anomalorthis."

Fossils collected in the Funeral Mountains (C. A. Richards ${ }^{1}$ ), in the Panamint Range (McAllister, 1952, p. $11 ; 1956$ ), in the Nopah Range (Hazzard, 1937b, p. 276) and on the Nevada Test Site (Johnson and Hibbard, 1957, p. 346-347) indicate that the upper dolo-

\footnotetext{
1 Richards, C. A., 1959, Geology of part of the Funeral Mountains : Unpub. manuscript on file at Death Valley Natl. Monument and Univ. Southern California.
}

mitic unit in the Death Valley area correlates with the Antelope Valley Limestone.

The Pogonip Group is considered to be Early and Middle Ordovician in age.

In the Death Valley area the contact between the Pogonip Group and Eureka Quartzite appears to be gradational for it is marked by a series of interbedded quartzites and dolomites.

The following section of the Pogonip Group was measured in Trail Canyon (fig. 24).

\section{Section of Pogonip Group, south side of Trail Canyon}

[Measured by Charles B. Hunt, R. J. Ross, Jr., and A. R. Palmer]

Top. Base of Eureka Quartzite; contact gradational. Contact taken at base of first quartzite; above this is $120 \mathrm{ft}$ of interbedded thin-bedded quartzite and sandy dolomite transitional to overlying massive quartzite.

1. Upper dolomite unit: mostly thick-bedded dolomite; bottom $75 \mathrm{ft}$ is thin bedded, but the dolomite above this is massive with a few thin lenses of friable sandstone; abundant "Girvanella"; top 100 ft thinner bedded; several intraformational eonglomerates; abundant Palliseria. Colln. F-3, F-13, F-27, and F-28 from this unit

2. Middle shaly unit; interbedded shale, siltstone, and dolomite; the clasties weather red and brown, probably because of metamorphism. Black limestone, 25-50 ft above base, with silt partings containing unidentifiable trilobites, brachiopods, and gastropods. Bed with eystid plates is $200-225 \mathrm{ft}$ above base

3. Basal dolomite unit. Top $320 \mathrm{ft}$ is thin-bedded dolomite interbedded with siltstone and shale; increasing shale upward gradational to unit 2. Lower $460 \mathrm{ft}$ is thin-bedded dolomite, mostly weathering rustry brown; beds 2-4 in. thick; much black chert in lenses and in nodules elongated parallel to bedding; some blocky chert; a striking bed of thin-bedded blocky chert occurs $270 \mathrm{ft}$ above the base. Intraformational conglomerate in beds 1-2 ft thick. Much of the dolomite is finegrained calcarenite-

Total thickness

Base. Top of Nopah Formation; contact taken at base of the thin-bedded dolomites.

Trace elements in four specimens from Ordovician units are given in table 13. The single sample of dolomite from the Pogonip Group is similar to those of the Ely Springs Dolomite and to those of the dolomite rather than the limestone of the Nopah Formation (table 12).

\section{EUREKA QUARTZITE}

The name Eureka Quartzite was first used in central Nevada (Hague, 1883, p. 262; 1892, p. 54-57; see also, Kirk, 1933), and the formation has been widely recognized in the Great Basin southward to the Death Valley region. It is a massive vitreous quartzite that serves as a valuable easily recognized marker bed in the midst 
TABle 13.-Trace elements in Ordovician units, Panamint Range [Semiquantitative spectrographic analyses by Uteana Oda and E. F. Cooley, U.S. Geol. Survey. Values in parts per million, except $\mathrm{Mg}$, which is given in percent]

\begin{tabular}{|c|c|c|c|c|}
\hline Element & $\begin{array}{c}\text { Pogonip } \\
\text { Group } \\
\text { Dolomite }\end{array}$ & $\begin{array}{c}\text { Eureka } \\
\text { Quartzite }\end{array}$ & Ely Sprir & mite \\
\hline 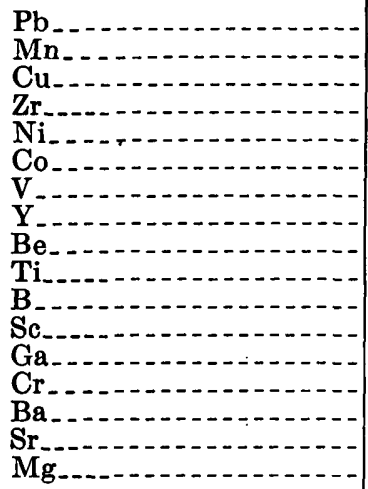 & $\begin{array}{r}15 \\
70 \\
3 \\
<10 \\
5 \\
<10 \\
10 \\
10 \\
<1 \\
20 \\
<10 \\
<10 \\
<5 \\
5 \\
10 \\
150 \\
>5\end{array}$ & $\begin{array}{r}<10 \\
<10 \\
2 \\
30 \\
<5 \\
<10 \\
<10 \\
<10 \\
<1 \\
200 \\
15 \\
<10 \\
<5 \\
<5 \\
15 \\
<20 \\
0.05\end{array}$ & $\begin{array}{r}10 \\
30 \\
2 \\
10 \\
<5 \\
<10 \\
<10 \\
<10 \\
<1 \\
20 \\
10 \\
<10 \\
<5 \\
5 \\
20 \\
200 \\
>5\end{array}$ & $\begin{array}{r}10 \\
50 \\
50 \\
10 \\
<5 \\
<10 \\
20 \\
20 \\
<1 \\
20 \\
<10 \\
<10 \\
<20 \\
10 \\
20 \\
200 \\
>5\end{array}$ \\
\hline
\end{tabular}

Note.-Also found: Sn, $<10 ; \mathrm{Ag},<1 ; \mathrm{Ge},<20 ; \mathrm{As},<1,000 ; \mathrm{Sb},<200 ; \mathrm{In},<50$; $\mathrm{Cd},<50 ; \mathrm{Tl},<100 ; \mathrm{Ta},<50 ; \mathrm{W},<50 ; \mathrm{Nb},<10$.

of the thick section of carbonate formations (figs. 24, 27).

In Tucki Mountain the Eureka Quartzite is very much crushed and granulated, so that sections there cannot be regarded as meaningful for stratigraphic study. In this respect the Eureka Quartzite in that part of the area resembles the Stirling and Zabriskie Quartzites. In Trail Canyon, however, the formation seems to be less deformed. The quartzite there is not severely granulated (fig. $25 B$ ), and on the ridge south of Trail Canyon a measured section, which follows, indicates that the formation there is 350 feet thick.

\section{Section of Eureka Quartzite, ridge south of the mouth of} Trail Canyon

[Measured by Charles B. Hunt, R. J. Ross, Jr., and A. R. Palmer]

Top. Base of Ely Springs Dolomite; contact concealed by rubble.

1. Quartzite, well-bedded in beds $2-5 \mathrm{ft}$ thick

2. Quartzite, massive; weathers brown

3. Quartzite, mostly thin-bedded but with 2 ledges each about $15 \mathrm{ft}$ thick; thin beds between the ledges fucoidal and mottled red.

4. Quartzite and sandy dolomite, interbedded; gradational downward to dolomite unit at top of Pogonip Group; colors variegated.

Total thickness Eureka Quartzite_._._._._._. 350

Base. Top of Pogonip Group; Contact taken at base of lowest bed of vitreous quartzite.

Another section was measured across the crushed quartzite in Little Bridge Canyon (fig. 27). There the contact with the Ely Springs Dolomite is sharp but seems to have been sheared. The massive vitreous quartzite is 140 feet thick, and under this unit is 35 feet of thin-bedded very fine grained quartzite with a few thin beds of dolomite. The beds are 6 inches to 1 foot thick, the colors are variegated; the weathered surfaces are mottled red and green. The quartzite at this location undoubtedly is thinned by shearing.

In the northern part of the Panamint Range the Eureka Quartzite attains a thickness of 400 feet (McAllister, 1952 , p. 12), in the Beatty area it is 350 feet thick (H. R. Cornwall, written commun., 1960), and in the Funeral Mountains it is about 360 feet thick (C. A. Richards ${ }^{2}$ ). In the Nopah Range the thickness is 265 feet (Hazzard, 1937b, p. 276), and at the Nevada Proving Grounds it is 285 feet (Johnson and Hibbard, 1957 , p. 349-350).

No fossils have been found in the Eureka Quartzite in this area, but the age is restricted to Middle or early Late(?) Ordovician by the fossils in the underlying Pogonip Group and overlying Ely Springs Dolomite.

A single specimen of Eureka Quartzite, analyzed for trace elements (table 13), contains even less trace elements than does the Zabriskie Quartzite (table 9), which it most resembles.

\section{ELY SPRINGS DOLOMITE}

The name Ely Springs Dolomite was first applied to a formation of dark dolomite about 600 feet thick in the Ely Springs Range about 125 miles northeast of Death Valley (Westgate and Knopf, 1932, p. 15). The formation has since been widely recognized in the southern Great Basin. Its thickness ranges from 400 to 940 feet: in the Nopah Range, 800 feet (Hazzard, 1937 b, p. 276); in the Beatty area, 400 feet (H. R. Cornwall, written commun., 1960); in the northern Panamint Range 940 feet (McAllister, 1952); and in the Darwin area 920 feet (Hall and MacKevett, 1958, p. 7). At most of these places and in the Death Valley area, the Ely Springs Dolomite contains Late Ordovician fossils; it overlies the Eureka Quartzite and is overlain by dolomite containing Middle Silurian fossils.

In the Death Valley area the thickness of beds assigned to the Ely Springs Dolomite is substantially less than in the surrounding region. In Trail Canyon the thickness is 425 feet; in the Funeral Mountains 403 feet of beds was assigned to the formation (C. A. Richards ${ }^{3}$ ). The formation is comparably thin at the north base of Tucki Mountain. At the widest place in the outcrop belt of the formation, at the south side

2 See footnote, p. A35.

3 See footnote, p. A35. 


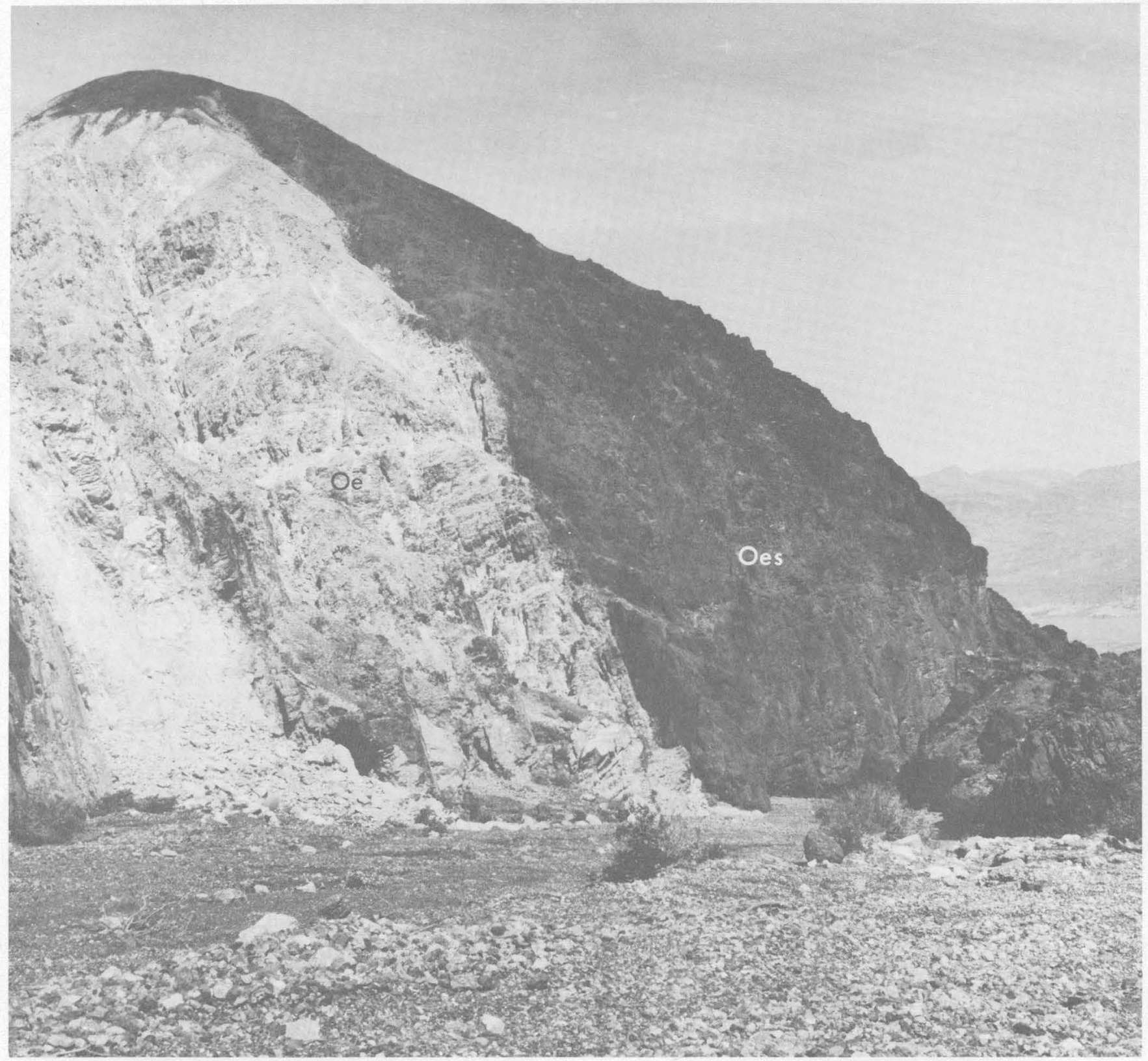

Figure 27.-View of Eureka Quartzite (Oe) and overlying Ely Springs Dolomite (Oes) at mouth of Little Bridge Canyon. The quarzite is much more crushed and granulated than is the dolomite and as a result has been eroded to form the valley in the foreground; earbonate formations form the ridges on either side.

of Tucki Mountain overlooking Tucki Wash, the computed thickness is 825 feet. More detailed work will be required to determine whether the differences in thickness are due to stratigraphic changes or to cutting out of beds by shearing along the bedding. Only a small part of the differences in thickness can be attributed to differences in boundaries selected for the formation. The basal contact with the Eureka Quartzite, though generally covered, can be located within a few feet (fig. 27). The boundary with the overlying light-colored dolomites, some of which contain Silurian fossils, is gradational through a zone of perhaps 100 feet.

The Ely Springs Dolomite in the Death Valley area is dark, thick bedded, and forms conspicuous cliffs above the light-colored Eureka Quartzite. The formation contains considerable dark-brown to black chert that occurs as nodules and as irregular lenses. The dark dolomite is streaked with curving light-colored lines 2-5 $\mathrm{cm}$ long and 1-5 $\mathrm{mm}$ wide, suggestive of scattered strands of spaghetti. Figure $25 C$ is a micrograph of Ely Springs Dolomite. 
The Ely Springs Dolomite has yielded a considerable fauna indicative of Late Ordovician (Richmond) age. Seven collections were made, as follows:

$F-8$ (D438-CO). Ely Springs Dolomite, $10 \mathrm{ft}$ above base of the formation, in Little Bridge Canyon, Stovepipe Wells quad. (NW1/4 NW $1 / 4$ sec. 15, T. 16 S., R. 45 E.). Identifications by R. J. Ross, Jr., "Lepidocyclus ef L. laddi Wang; Austinella sp.; strophomenid brachiopod; dalmanellid brachiopod; unidentified coral. The age is probably Late Ordovician, but it might be late Middle Ordovician."

F-12 (D644-CO). Lower part of Ely Springs Dolomite, south side of Trail Canyon, alt 1,340 $\mathrm{ft}$ at north base of butte with peak at $1,680 \mathrm{ft}$.

$F-17(D 151-S D)$. Middle of the formation; 1 mile east of the mouth of Trellis Canyon, alt 1,200 ft, north foot of Tucki Mtn:, Stovepipe Wells quad. ( $\mathrm{NE}_{4} / \mathrm{NE}_{1} / 4$ sec. 26 , T. 16 S., R. $45 \mathrm{E}$.).

Collections F-12 and F-17-58 were examined by $W$. A. Oliver, Jr., who states "they consist, respectively, of 7 and 6 fragments of small simple horn corals, mostly streptelasmatoids. These are very poorly preserved and cannot be identified. They could be of either Ordovician or Silurian age but not pre-Middle Ordovician."

$F-44$ (not catalogued). 11/2 miles north of Trail Canyon, fault block at east end of the ridge dividing the valley; alt 1,800 ft. This collection, examined by E. L. Yochelson, yielded only isolated crinoidal columns.

F-45 (3622-CO). Upper part of Ely Springs Dolomite, north side of canyon next north of Trail Canyon and $23 / 4$ miles west of SW cor. sec. 30, T. 18 S., R. 47 E., Furnace Creek quadrangle. Identifications by $\mathbf{W}$. A. Oliver, Jr.,

"Tollina [manipora] sp.; streptelasmatical horn corals. The genus Tollina is known only from rocks of Late Ordovician age. One of the two specimens is very well preserved and is specifically distinct from representatives of the genera that I have previously seen or seen illustrated. The genus is known from the Montoya Dolomite in Texas and the Red River Formation of Manitoba as well as from the U.S.S.R. Streptelasmatid horn corals of this type range from the Middle Ordovician to the Silurian and Devonian."

$F-49$ (3623-CO). Corals from black dolomite believed to be Ely Springs near the middle of the formations; Captured Canyon at hill $800 \mathrm{ft}$ in altitude near the mouth of the canyon; $23 / 4$ miles west of SW cor. sec. 18, T. 25 N., R. 1 E., Furnace Creek quad. Identification by W. A. Oliver, Jr., "Streptelasma? sp., one specimen; streptelasmatid horn corals, three specimens. This collection may well be Upper Ordovician since streptelasmatids are common in rocks of this age. They are not diagnostic, however, and the age will have to be based on other criteria."

F-74 (3624-CO). Middle of Ely Springs Dolomite, 3/4 mile south of Trail Canyon; saddle $500 \mathrm{ft}$ west of hill 1932. Identification by W. A. Oliver, Jr.,

"Bighornia sp., two specimens; Grewingkia sp., one specimen; angulate streptelasmatid, one specimen; other streptelasmatoids, four specimens; small branching bryozoans. This assemblage is certainly Upper Ordovician as the genera Bighornia and Grewingkia are so limited. These corals are characteristic of the Ely Springs, Bighorn, and Red River Formations in western North America."
At F-75, an isolated hill at the mouth of Trellis Canyon (SE-NE-sec. 23, T. 16 S., R. 45 E.) dolomite thought to be Ely Springs, or possibly Silurian, contains biconvex cross sections.

Receptaculites has been reported from Ely Springs Dolomite at the east foot of the Panamint Range along Trail Canyon (Hopper, 1947, p. 407). The Ely Springs Dolomite was correctly identified by Hopper; but if the Receptaculites came from that formation, it is the only recorded occurrence of the genus in the formation in this entire region. Perhaps the fossil came from a fault block of dolomite belonging to the upper part of the Pogonip Group, which contains abundant $R e$ ceptaculites.

The Ely Springs Dolomite is considered to be Late Ordovician in age.

Trace elements in two samples of the Ely Springs Dolomite are given in table 13. The amounts and proportions are about the same as in dolomite from the Pogonip Group.

\section{SILURIAN AND DEVONIAN SYSTEMS-HIDDEN VALLEY DOLOMITE}

The Hidden Valley Dolomite, named for exposures in the northern Panamint Range (McAllister, 1952, p. 15) where it is 1,365 feet thick, is a light-colored formation that contrasts strikingly with the dark underlying Ely Springs Dolomite (fig. 28). Throughout the region the Hidden Valley Dolomite is conformable on the Ely Springs Dolomite. At the type locality the upper contact is conformable (McAllister, 1952, p. 15), but in some areas the top of these beds is an unconformity (Hazzard, 1937b, p. 327).

In the Panamint Range, south from Tucki Mountain, the Hidden Valley Dolomite is of variable thickness. It has a computed thickness of 750 feet at the north base of Tucki Mountain between Little Bridge Canyon and Trellis Canyon. It has a computed thickness of slightly less than 600 feet at the south side of Tucki Mountain. In the ridge south of Trail Canyon it has a measured thickness of only 300 feet. In the Funeral Mountains east of Death Valley a thickness of 1,473 feet is indicated (C. A. Richards ${ }^{4}$ ). I have not determined whether these differences in thickness are due to stratigraphic changes or to crushing and shingling of the beds because of the intense structural deformation.

In this area the formation is light colored, thick bedded (fig. 28), fine grained, and even grained. Many beds contain crinoid stems; fragments of some large

$\checkmark$ See footnote, p. A35. 


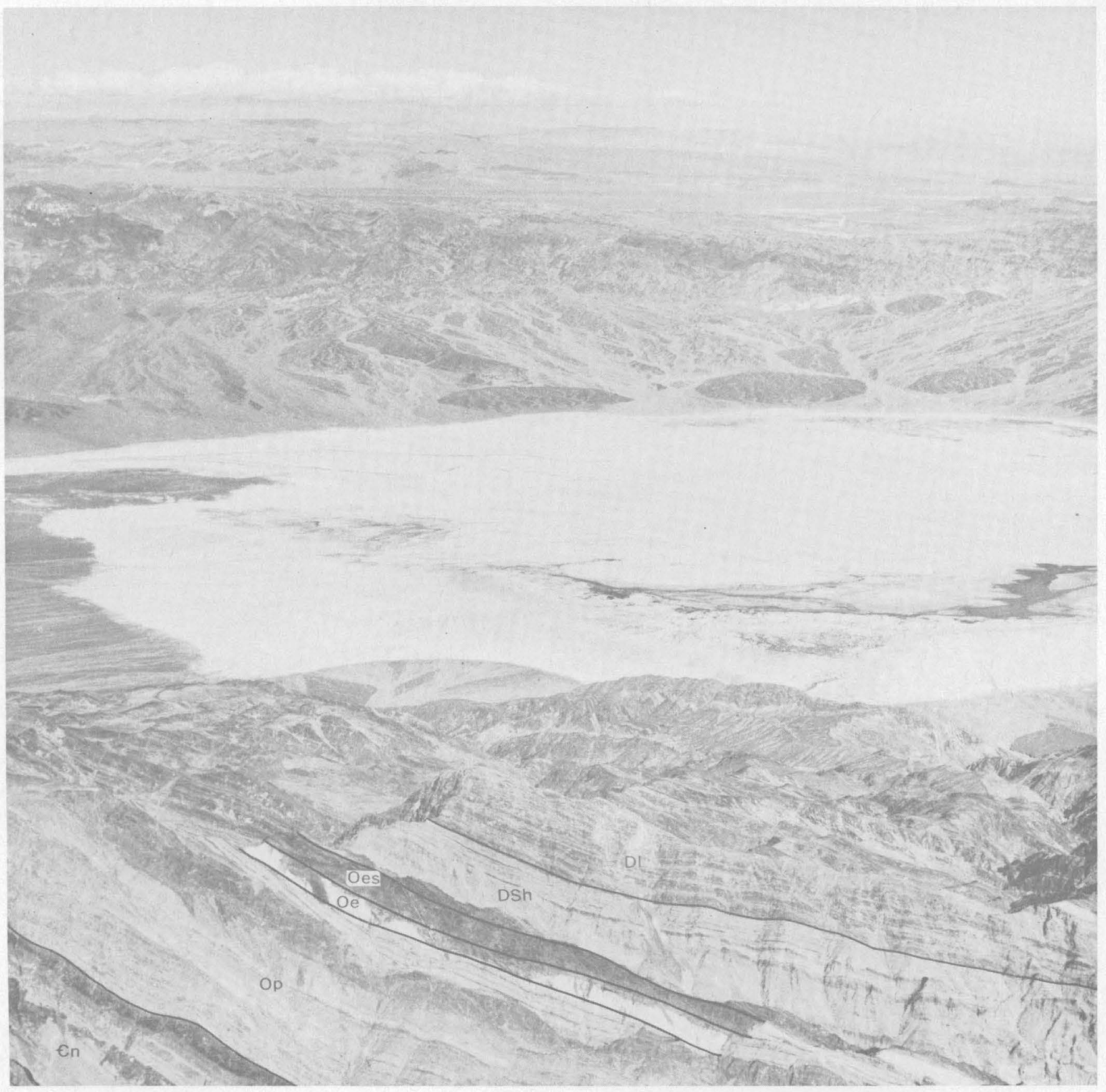

Figure 28.-View of Ordovician, Silurian, and Devonian formations on the south side of Tueki Mountain. At left is Nopah Formation ( $€ n$ ) overlain by Pogonip Group $\left(\mathrm{O}_{\mathrm{p}}\right)$. Eureka Quartzite $\left(\mathrm{Oe}_{\mathrm{e}}\right.$ forms the light band under the dark Ely Springs Dolomite (Oes). The gray slope above the Ely Springs Dolomite is Hidden Valley Dolomite (DSh); the striped slope is formed by the Lost Burro Formation (DI). Photograph courtesy of John H. Maxson.

ones are as much as half an inch in diameter. The top of the formation is taken at the base of the first quartzite beds that characterize the lower part of the Lost Burro Formation in this area.

No fossils, except crinoid stems, were found in the Hidden Valley Dolomite, but search was restricted to the Trail Canyon area and the north base of Tucki Mountain.

At the type locality and other nearby places in the northern Panamint Range, fossils in the lower part of the formation include (McAllister, 1952, p. 16-17):

Halysites catenularia (Linnaeus)

mieroporus (Whitfield)

Favosites cf. F. niagarensis Hall
Porpites porpita (Linnaeus) 
Fragments of bryozoa and a few brachiopods of Silurian affinities.

Fossils from beds 15-65 feet below the top of the formation in the northern Panamint Range, indicating an Early Devonian age, include (McAllister, 1952, p. 17) :

$\begin{array}{cc}\text { Favosites } \text { sp. } & \text { Branching Cladopora } \\ \text { Papiliophyllum elegantulus } & \text { Heliolites sp. } \\ \text { (Stumm) } & \text { Acrospirifer kob e hana } \\ \text { Breviphyllum lonensis } & \text { (Merriam) } \\ \text { (Stumm) } & \text { Meristella robertsensis } \\ \text { Unidentifiable cup corals } & \text { Merriam } \\ & \text { Platyceras sp. }\end{array}$

In the Funeral Mountains, on the east side of Death Valley, the lower 200 feet of the formation yielded (C. A. Richards ${ }^{5}$ ) :

$\begin{array}{ll}\text { Syringopora sp. } & \text { Crinoid stems } \\ \text { Plectatrypa sp. } & \text { Rhynchonella sp. } \\ \text { Heliolites sp. } & \text { Cladopora } \text { sp. } \\ \text { Favosites sp. } & \text { Stromatopora } \text { sp. } \\ \text { Rugose corals } & \end{array}$

Richards also reports the following from beds 200550 feet above the base of the Hidden Valley Dolomite:

$\begin{array}{ll}\text { Halysites sp. } & \text { Meristella? sp. } \\ \text { Syringopora } \text { sp. } & \text { Eospirifer sp. } \\ \text { Plectatrypa } \text { sp. } & \text { Pentameroid brachiopod, } \\ \text { Heliotites sp. } & \text { Virgiana? sp. } \\ \text { Favosites } \text { sp. } & \text { Brachiopod fragments } \\ \text { Rhynchonella } \text { sp. } & \text { Gastropods } \\ \text { Cladopora } \text { sp. } & \text { Rugose corals } \\ \text { Stromatopora sp. } & \text { Crinoid stems } \\ \begin{array}{l}\text { Cornutites sp. on Syntro- } \\ \text { phina? sp. }\end{array} & \end{array}$

From a 10-foot fossiliferous dolomite about 200 feet below the top of the Hidden Valley Dolomite, Richards obtained:

$\begin{array}{ll}\text { Halysites of } \mathrm{H} \text {. labyrinthica } & \text { Heliolites sp. } \\ \text { (Goldfuss) } & \text { Zaphrenitid-type corals } \\ \text { Favosites sp. } & \end{array}$

The fossils obtained from the formation in areas near Death Valley indicate a Silurian and Early Devonian age.

No samples of the Hidden Valley Dolomite were collected for trace-element analysis.

\section{DEVONIAN SYSTEM-LOST BURRO FORMATION}

The Lost Burro Formation at the type locality in the northern Panamint Range is 1,525 feet thick and consists chiefly of light-gray dolomite striped with nearly black dolomite, and limestone with some thin quartzite beds (McAllister, 1952, p. 18). In the Darwin area the thickness of the formation is more than 1,700 feet and may be as much as 2,400 feet (Hall and MacKevett,

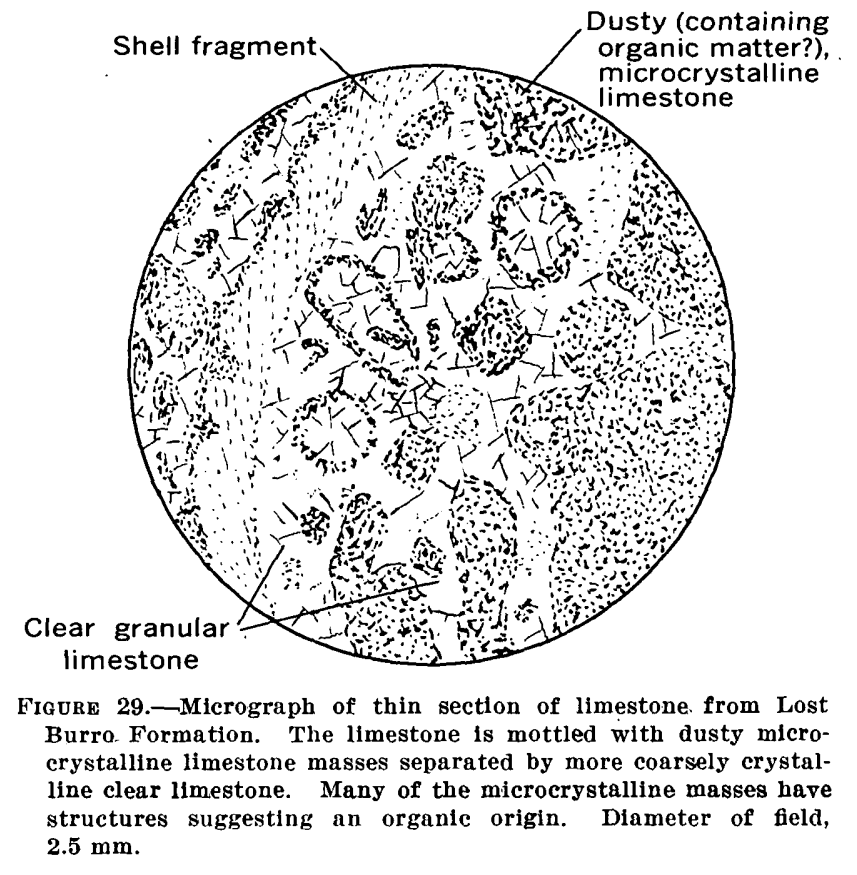

1958, p. 8). Only the lower 750 feet is present in the Funeral Mountains, the upper part having eroded (C. A. Richards ${ }^{6}$ ). In the Nopah Range beds of Devonian age, referred to as the Sultan Limestone, are 1,720 feet thick (Hazzard, 1951, p. 1503).

In the Death Valley area, on Tucki Mountain, the formation has the striped appearance (fig. 28) so characteristic of the type locality. The formation is mostly limestone (fig. 29) with only minor amounts of dolomite and thin beds of sandstone and quartzite. Many of the dark beds are mottled by whitish bodies resembling chopped spaghetti.

An attempt was made to measure a section of the Lost Burro Formation along the north foot of Tucki Mountain eastward from the mouth of Trellis Canyon, but the attempt was only partly successful because of faults. The indicated thickness is about 2,000 feet.

The base, which seems to be of Middle Devonian age, was taken just below a pair of quartzite beds, each about 3 feet thick and separated by 20 feet of carbonate rocks. These quartzites are overlain by 800 feet of alternating light and dark limestone in beds 1-10 feet thick, the striped beds. Above this striped unit is 200 feet of limestone and dolomite with numerous thin beds of sandstone or quartzite. The quartzite, mostly medium grained, occurs in pods and in beds 2 inches to 3 feet thick. Fossil collection $\mathrm{F}-16$ is from the top of this unit.

Above this unit are massive dolomitic beds, but the section appears to be duplicated by faulting. The

See footnote, p. A35.

S See footnote, p. A35. 
upper 200 feet of the formation consists of well-bedded and even-bedded limestone and quartzite in beds 5 and 6 feet thick. An unknown thickness of beds, but probably not over 500 feet, lies below this unit and the bed represented by fossil collection F-16. The top of the Lost Burro Formation is taken at a quartzite immediately underlying limestone of Mississippian age represented by collection F-93 (p. A44). The top of the Lost Burro Formation seems to be of early Late Devonian age.

Fossils from the base of the Lost Burro Formation were obtained at two locations.

F-18. Base of Lost Burro Formation, light-colored dolomite
overlying the lowest quartzite on ridgetop (alt 1,600 ft) 1 mile east of Trellis Canyon, Stovepile Wells quad. ( NE1/4 NE1/4 sec. 26, T. 16 S., R. 45 E.). Report by Jean M. Berdian,

"This collection contains brachiopods referable to Emanuella and small specimens of Atrypa. Although the genus Atrypa has 'a long range, occurring from the Silurian through the early Upper Devonian, according to Cooper (in Shimer and Shrock, 1944, p. 329) Emanuella is indicative of Middle or Upper Devonian. This collection, therefore, is probably Middle or early Late Devonian in age."

17-46. Base of Lost Burro Formation on south slope of ridge $2 \frac{1}{2}$ miles north of Trail Canyon and $23 / 4$ miles west of SW cor. sec. 30, T. 18 S., R. 47 E., Furnace Creek quad. Report by C. W. Merriam,

"cyathophyllid rugose coral, deep calyx; Stringocephalus sp. cf. S. burtini Defrance; indeterminate gastropods, at least two genera. One large individual of Stringocephalus is fairly well preserved, showing the characteristic rodlike cardinal process of the dorsal valve. The rock contains abundant fragmentary silicified shell fragments of Stringocephalus and other smooth-shelled brachiopods, some of which could be the terebratuloid Rensselandia. These shells come out with acid but are not complete enough for positive identification. This collection represents the late Middle Devonian 'Stringocephalus' zone now recognized widely in the Great Basin."

Other collections of fossils, obtained from the middle or upper part of the Lost Burro Formation, include:

F-4. Probably near middle of the Lost Burro Formation. Limestone butte below the mouth of Trellis Canyon. Stovepipe Wells quad. (SW1/4 sec. 13, T. 16 S., R. 45 E.). Report by C. W. Merriam, "stromatoporoids; Atrypa cf. A. missouriensis fine-ribbed form, abundant; Tabulophyllum sp. early Late Devonian."

F-6. Near middle of Lost Burro Formation; $1 / 2$ mile northeast of mouth of Little Bridge Canyon, Storepipe Wells quad. (north side SE1/4 sec. 10, T. 16 S., R. 45 E.). Report by C. W. Merriam, "stromatoporoids; Amphipora sp., Atrypa sp. Age : late Middle or early Late Devonian."

F-7. Near F-6. Report by C. W. Merriam, "stromatoporoids : abundant small indeterminate pelecypods resembling the genus Edmondia; Spirifer cf. S. utahensis Meek; abundant small indeterminate rugose corals with deep calyx. Age: Early Late Devonian."

F-16. Lost Burro Formation, about $1,000 \mathrm{ft}$ above the base;

11/2 miles east of mouth of Trellis Canyon, Stovepipe Wells $776-623$ O-66-4 quad. (SE1/4 NW $1 / 1$ sec. 24, T. 16 S., R. 45 E.). Report by C. W. Merriam, "stromatoporoids; Syringopora sp.; ?Orecopia mccoyi (Walcott) : indeterminate rugase coral. Age: Early Late Devonian."

Merriam goes on to report, "Rocks represented by coll. $\mathrm{F}-4,6,7$, and 16 are seemingly correlative with middle and upper parts of the Devils Gate Limestone of central Nevada."

$F-65$. Brachiopods and corals from near the top of the Lost Burro Formation; overlies red limy shale and siltstone. In butte isolated from Tucki Min., NE1/4 sec. 14, T. 16 S., R. $45 \mathrm{E}$. Mackenzie Gordon has reported as follows :

"Horn corals, genus and species indet.

Stromatoporoid cf. Stachyodes or Idiostroma sp. indet.

Cyrtospirifer or Cyrtiopsis sp."

"W. A. Oliver, Jr., says that the corals are simple types that are known to range through Silurian and Devonian rocks but not diagnostic of any one particular zone. Helen Duncan says that the corals are not Carboniferous types and that the small stromatoporoid is of a type characteristic of Devonian rocks. Jean Berdan confirms my belief that the silicified brachiopods are Late Devonian types and belong in one of the two mentioned genera, though they are not complete enough to be sure which."

F-90. North base, Tucki Mountain. Stromatoporoid reef about $750 \mathrm{ft}$ above the base of the Lost Burro.

Stromatoporoid- and Amphipora(?)-bearing beds are particularly abundant near the middle of the Lost Burro Formation (fig. 30). Beds containing numerous brachiopods, including the diagnostic $C y r t o-$ spirifer (fig. 31), mark the top of the Lost Burro Formation. Syringoporoid corals are present in both Devonian and Mississippian limestones. The Devonian forms can be distinguished from the Mississippian forms on gross morphology (fig. 32) and can be useful field guides for distinguishing formations of these ages.

At the type locality in the northern Panamint Range the uppermost 35 feet of the Lost Burro Formation contains the following Late Devonian fossils (McAllister, 1952, p. 19) :

\section{Cyrtospirifer cf. C. monticola (Haynes) disjunctus (Sowerby) \\ Tylothyris? cf. T.? raymondi Haynes \\ "Camarotoechia" aff. "C." duplicata (Hałl) \\ Cleiothyridina cf. C. devonica Raymond \\ Productella sp.}

The Lost Burro Formation as mapped in this area is considered to be Middle and Late Devonian in age.

Trace elements in some samples from Devonian and younger formations are given in table 14. Most of the formations are represented by only a single sample. The samples suggest that the younger rocks have the greater concentrations of elements. 

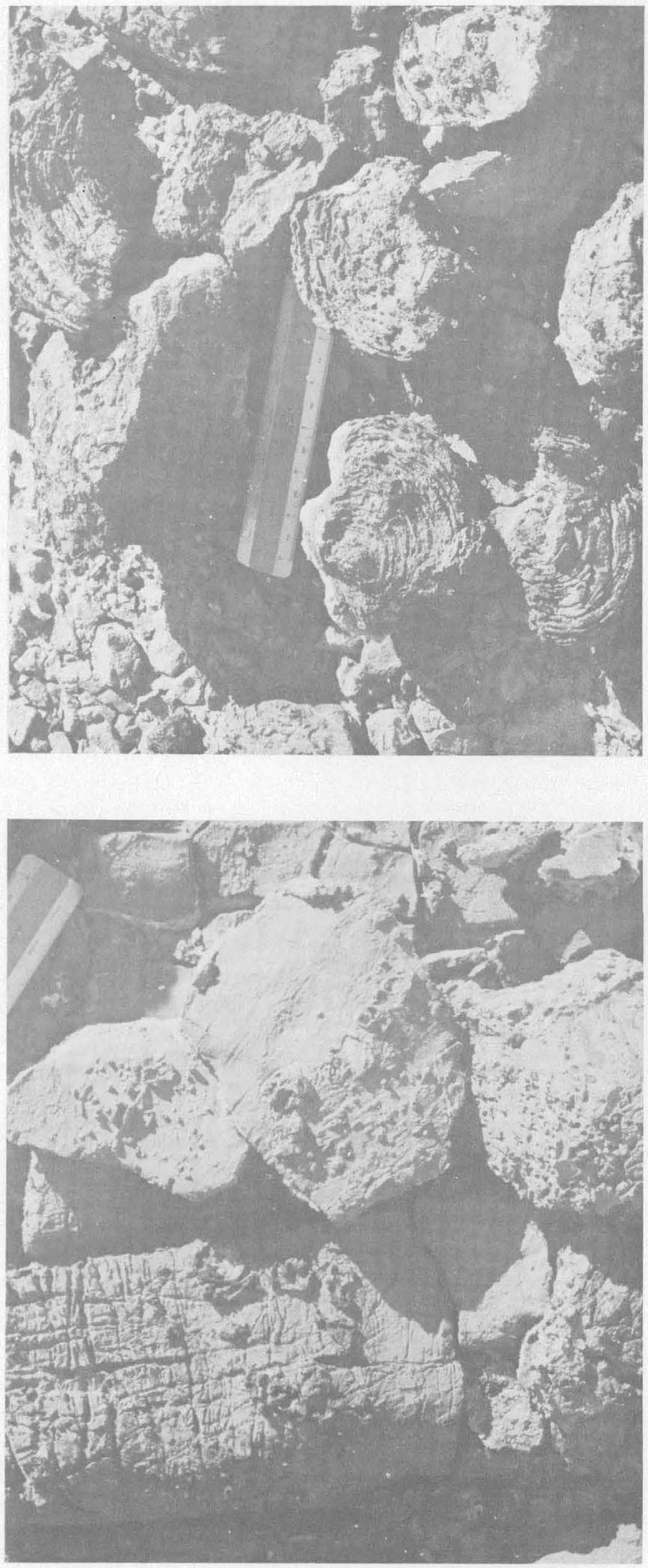

Figure 30.-Stromatoporoid (upper) and Amphipora (?) (lower), beds are abundant in the middle of the Lost Burro Formation.

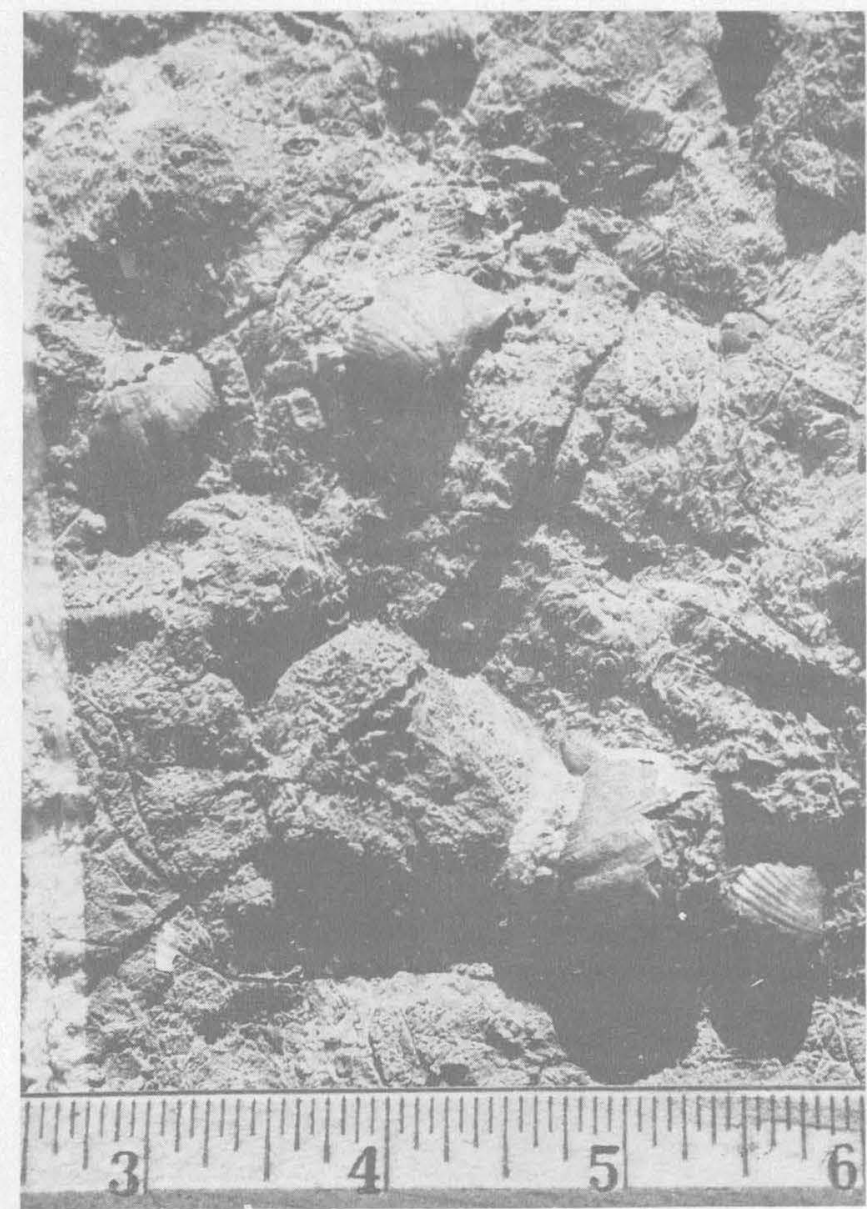

FIgurn 31.-Limestone containing Oyrtospirifer, which is diagnostic of the uppermost Devonian. A somewhat similar appearing spirifer is present in the lower part of the Tin Mountain Limestone.

TABLe 14.-Trace elements in Devonian and younger Paleozoic formations

[Semiquantitative spectographic analyses by Uteana Oda and E. F. Cooley, U.S. Geol. Survey. Values in parts per million, except $\mathrm{Mg}$, which is given in percent]

\begin{tabular}{|c|c|c|c|c|c|c|c|c|c|}
\hline \multirow{2}{*}{$\begin{array}{l}\text { Ele- } \\
\text { ment }\end{array}$} & \multirow{2}{*}{$\begin{array}{c}\text { Lost } \\
\text { Burro } \\
\text { For- } \\
\text { ma- } \\
\text { tion } \\
\text { Lime- } \\
\text { stone }\end{array}$} & \multirow{2}{*}{$\begin{array}{l}\text { Tin } \\
\text { Moun- } \\
\text { tain } \\
\text { Lime- } \\
\text { stone }\end{array}$} & \multirow{2}{*}{$\begin{array}{l}\text { Limestone } \\
\text { from upper } \\
\text { part of the } \\
\text { Mississip- } \\
\text { pian }\end{array}$} & \multicolumn{2}{|c|}{$\begin{array}{l}\text { Rest Spring } \\
\text { Shale }\end{array}$} & \multicolumn{4}{|c|}{$\begin{array}{l}\text { Pennsylvanian and Permian } \\
\text { formations on Tucki Mountain }\end{array}$} \\
\hline & & & & $\begin{array}{l}\text { Lime- } \\
\text { stone }\end{array}$ & Shale & Lime & tone & & \\
\hline & $\begin{array}{r}<10 \\
50 \\
7 \\
<10 \\
<5 \\
<10 \\
20 \\
<10 \\
<1 \\
100 \\
<10 \\
<10 \\
<20 \\
<10 \\
10 \\
300 \\
0.2\end{array}$ & $\begin{array}{r}10 \\
100 \\
7 \\
<10 \\
<5 \\
<10 \\
20 \\
10 \\
<1 \\
150 \\
<10 \\
<10 \\
<20 \\
10 \\
10 \\
1,000 \\
1\end{array}$ & $\begin{array}{r}<10 \\
30 \\
<5 \\
<10 \\
<5 \\
<10 \\
10 \\
10 \\
<1 \\
10 \\
10 \\
<10 \\
<20 \\
<10 \\
10 \\
100 \\
0.1\end{array}$ & $\begin{array}{r}<10 \\
100 \\
50 \\
20 \\
10 \\
<10 \\
20 \\
15 \\
<1 \\
500 \\
50 \\
<10 \\
<20 \\
70 \\
30 \\
700 \\
5\end{array}$ & $\begin{array}{r}10 \\
7,000 \\
10 \\
150 \\
100 \\
30 \\
70 \\
100 \\
<1 \\
1,500 \\
300 \\
10 \\
<20 \\
50 \\
300 \\
500 \\
1.5\end{array}$ & $\begin{array}{r}<10 \\
20 \\
10 \\
10 \\
7 \\
<10 \\
30 \\
10 \\
<1 \\
200 \\
<10 \\
<10 \\
<20 \\
100 \\
500 \\
2,000 \\
3\end{array}$ & $\begin{array}{r}500 \\
15 \\
5 \\
10 \\
<5 \\
<10 \\
10 \\
<10 \\
<1 \\
20 \\
10 \\
<10 \\
<5 \\
10 \\
15 \\
300 \\
0.2\end{array}$ & $\begin{array}{r}>10,000 \\
50 \\
>500 \\
30 \\
10 \\
<10 \\
10 \\
10 \\
1 \\
300 \\
<150 \\
<10 \\
10 \\
15 \\
200 \\
200 \\
0.1\end{array}$ & $\begin{array}{r}>10,000 \\
10 \\
100 \\
20 \\
<5 \\
<10 \\
<10 \\
<10 \\
<1 \\
200 \\
<100 \\
<10 \\
<5 \\
10 \\
500 \\
300 \\
0.03\end{array}$ \\
\hline
\end{tabular}
NoTE. - Also found: In Sn, $<10 ; \mathrm{Ag},<1 ; \mathrm{Ge},<20 ; \mathrm{As},<1,000 ; \mathrm{Sb},<200 ; \mathrm{In},<50$;
Cd, $<50$; Tl, $<100 ; \mathrm{Ta},<50$; W, $<50 ; \mathrm{Nb},<10$. 

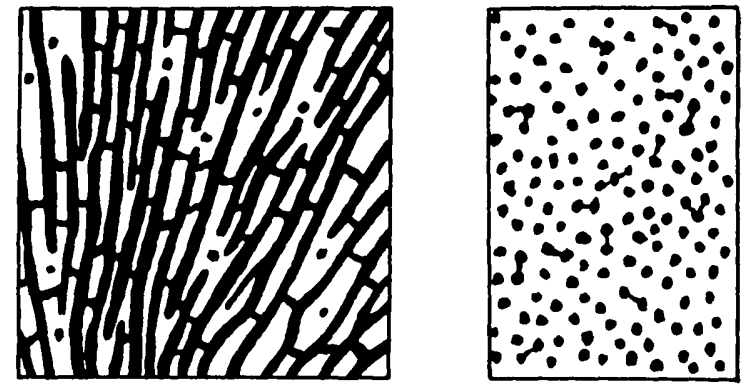

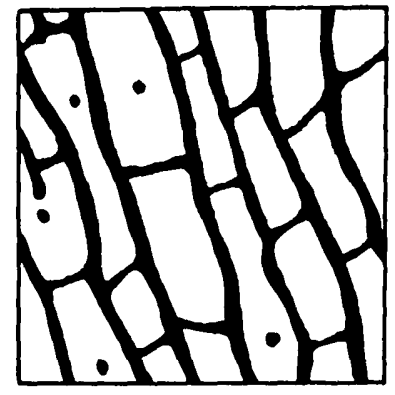

Longitudinal section

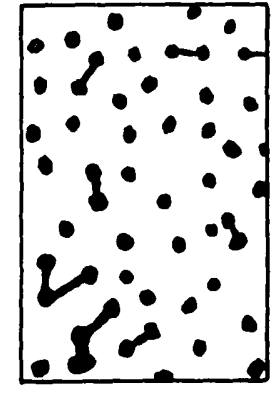

Transverse section 1 inch
Frourn 32.-Diagrammatic sections of Devonian (upper) and Misslssipplan (lower) syringoporold corals. In the Devonlan corals the corullites and connecting tubes are closely spaced; in the Mississipplan corals they are widely spaced.

MISSISSIPPIAN SYSTEM-TIN MOUNTAIN LIMESTONE AND YOUNGER LIMESTONE

Mississippian formations in the northern part of the Panamint Range north of the area shown on plate 1, include the Tin Mountain Limestone, 475 feet thick, of Early Mississippian age and the Perdido Formation, about 600 feet thick, of Early and Late Mississippian age. The Tin Mountain Limestone consists largely of thin-bedded dark limestone with thin interbeds of shale. The Perdido Formation contains more shale, siltstone, sandstone, and chert and lithologically is transitional to the overlying Rest Spring Shale (McAllister, 1952, p. $20-24 ; 1956)$. Equivalent beds in the Darwin area have about the same thickness (Hall and MacKevett, 1958 , p. 8-9). To the east, however, the thickness is much greater, for it is about 1,600 feet in the Nopah Range (Hazzard, 1951, p. 1503).

On Tucki Mountain, in the Death Valley area, about 1,725 feet of limestone ranging from Early to Late Mississippian in age overlies the Lost Burro Formation and is overlain by the Rest Spring Shale. The limestone of Late Mississippian age has little shale, and is sharply separable from, rather than transitional to, the overlying Rest Spring Shale. It was not mapped sepa- rately from the older Mississippian limestone, although its base can readily be determined by an absence of chert in the limestone below. The scarcity of shale in the younger limestone formation could be due either to facies changes or to squeezing out of the incompetent beds on account of the structural deformation. The lower limestone assuredly is equivalent to the Tin Mountain, but the younger limestone formation has not yet been correlated with formations in other parts of the region. Accordingly, these limestone beds on Tucki Mountain together are referred to as the Tin Mountain Limestone and younger limestone.

Beds regarded as equivalent to the Tin Mountain Limestone include a lower member, 600 feet thick, consisting of thin-bedded gray limestone with reddish beds of sandstone, and an upper member, 400 feet thick, of thick-bedded dark limestone. The overlying beds, in part at least of Late Mississippian age, consist of a lower cherty limestone, 475 feet thick, overlain by 250 feet of light-gray limestone interbedded with some sandstone and shale.

Several collections of fossils were obtained from various horizons in the formation. They have been reported on by Mackenzie Gordon, Jr., as follows :

In the following collections, for the most part only generic identifications have been made. This is sufficient to give the necessary age determinations and is practically mandatory as so little work has been done on the Carboniferous and Permian paleontology of this region.

In the faunal lists, Helen Duncan has identified the corals and bryozoans, Raymond Douglass the fusulinids, Ellis Yochelson the gastropods, and Mackenzie Gordon, Jr., the rest of the fauna.

F-15 (17293-PC). Dark-gray limestone with brown cherty lenses, about $500 \mathrm{ft}$ thick, underlying thinly bedded limestone represented by F-14-58. SE1/4 SE1/4 sec. 24 , T. 16 S., R. 45 E., Death Valley, Calif. Collector, C. B. Hunt, 1958.

Homalophyllites sp. Spirifer sp.

Vesiculophyllum? sp. Spiriferoid brachiopod inCyathaxonia sp.

Aulopora sp.

Syringopora cf. S. aculeata Girty

Crinoid columnals

Rhipidomella sp.

Camarotoechia sp. det. (Juvenile)

Cyrtina sp.

Crurithyris sp.

Torynifer sp.

Hustedia sp.

Gleiothyridina 2 sp.

Platyceras sp. Winchell

This collection contains the typical Early Mississippian fauna found in the Tin Mountain Limestone in this region.

F-21. Crinoidal limestone, $400 \mathrm{ft}$ thick. Underlies red beds unit represented by F-20. Center sec. 31, T. 16 S., R. 46 E., alt $400 \mathrm{ft}$, Stovepipe Wells quad., California. Collector, $\mathrm{C}$. B. Hunt, 1958.

Crinoid columnals.

No diagnostic fossils found. 
$F-76(19135-P C)$. Tin Mountain Limestone, about $500 \mathrm{ft}$ above the base; north side Tucki Mtn. east of mouth of Trellis Canyon, NE1/4 SE1/4 SE1/4 sec. 24 , T. 16 S., R. 45 E., Stovepipe Wells quad., California.

$\begin{array}{lc}\text { Cyathaxonia? sp. } & \text { Spirifer sp. } \\ \text { Rylstonia } \text { sp. } & \text { Cleiothyridina sp. } \\ \text { Aulopora sp. } & \text { Compositoid brachiopod in- } \\ \text { Syringopora sp. } & \text { det. } \\ \text { Crinoid columnals } & \text { Platyccras (Orthonychia) } \\ \text { Rhipidomella sp. } & \text { sp. } \\ \text { Camarotoechia } \text { sp. } & \end{array}$

This is the typical fauna of the Tin Mountain Limestone, as represented also by field colls. F-15 and F-91.

$F-91(19990-P C)$. About $75 \mathrm{ft}$ above wash on north basal edge of Tucki Mtn., 11/2 miles east of Trellis Canyon, in the SE $1 / 4$ SE $1 / 4$ sec. 24 , T. 16 S., R. 45 E., Stovepipe Wells quad. California. Fossils through about $15 \mathrm{ft}$ of gray limestone and dark-brown nodular chert, $60 \mathrm{ft}$ stratigraphically below base of thick reddish-brown cherty limestone unit. Collectors, C. B. Hunt and M. Gordon, Jan. 2, 1961.

$\begin{array}{ll}\text { Homalophyllites sp. } & \text { Rhipidomella sp. } \\ \text { Cyathoxonia sp. } & \text { Cranaena? sp. } \\ \text { Rylstonia? sp. } & \text { Camarotoechia sp. } \\ \text { Aulopora sp. } & \text { Spiriferinid brachiopod, genu } \\ \text { Syringopora cf. S. surcu- } & \text { and species indet. } \\ \quad \text { laria Girty. } & \text { Cyrtina sp. } \\ \text { Beaumontia sp. } & \text { Spirifer cf. s. centronatus } \\ \text { Fistuliporoid bryozoan, } & \text { Winchell } \\ \quad \text { genus and species indet. } & \text { Hustedia sp. } \\ \text { Ramiporalia sp. } & \text { Cleiothyridina sp. } \\ \text { Cystodictya sp. } & \text { Platyceras sp. } \\ \text { Crinoid columnals } & \text { Gattendorfia? sp. } \\ \text { Chometes sp. } & \text { Trilobite pygidium } \\ \text { Marginatia? sp. } & \\ \text { Small spinose productid, } & \\ \text { genus and species indet. } & \end{array}$

This and the following collection are Lower Mississippian typical of the fauna found in the Tin Mountain Limestone.

F-92 (19991-PC). Syringopora in place about $3 \mathrm{ft}$ above base of outcrop, $150 \mathrm{ft}$ southwest of F-91 and about $100 \mathrm{ft}$ stratigraphically lower. Collectors, M. Gordon and C. B. Hunt, Jan. 2, 1961.

Syringopora cf. S. aculeata Girty

$F-93(19992-P C) . \quad 500 \mathrm{ft}$ west of F-91 at north foot of Tucki Mitn., 11/2 miles east of the mouth of Trellis Canyon, SE $1 / 4$ SE1/4 sec. 24 , T. 16 S., R. 45 E., Stovepipe Wells quad., California. 10-foot zone of gray limestone about $10 \mathrm{ft}$ stratigraphically above brown quartzite at top of Lost Burro Formation. Collectors, C. B. Hunt and M. Gordon, Jan. 1, 1961.

Rylstonia? sp.

Dissepimented horn coral, indet.

Syringopora sp.

Syringopora cf. S. aculeata Girty

Crinoid columnals

Chonetes sp.

This collection is Early Mississippian in age. The rocks from which it was collected represent the basal part of the Tin Mountain Limestone.
$F-96(19995-P C)$. Limestone bed $50 \mathrm{ft}$ below top of the beds mapped as Tin Mountain Limestone and younger limestone. Collectors, M. Gordon and C. B. Hunt, Jan. 3, 1961.

Faberophyllum sp. $\quad$ Fish dentition
Syringopora sp.

Faberophyllum in the Rocky Mountain region, according to Helen Duncan, characterizes a zone that occurs approximately in the middle of the Upper Mississippian. It is not known to occur in lower Meramec or upper Chester equivalents. It is found, for example, in the upper part of the Humbug Formation and lower part of the Great Blue Limestone in central Utah. This would indicate that the upper beds of the Mississippian limestone sequence on Tucki Mountain are middle Late Mississippian in age.

The following is a section of the Mississippian formations, measured along the north foot of Tucki Mountain 3 miles northwest of Shoveltown.

Section of Tin Mountain Limestone and younger limestone 3 miles northwest of Shoveltown.

Top. Rest Spring Shale ; contact much deformed by-bedding faults. Limestone, younger than the Tin Mountain in part of Late Mississippian age.

Light-gray partly recrystallized encrinital limestone interbedded with sandstone, shale, and thin-bedded limestone. F-96 (19995-PC) from $50 \mathrm{ft}$ below top_-

Mostly dark-gray fine-grained limestone and brown weathering chert in beds $2-6$ in. thick; at base is 30-40 ft of banded and bedded chert that weathers in gray blocks.

Tin Mountain Limestone :

Upper member: mostly thick-bedded limestone; at base is $40 \mathrm{ft}$ of dark fossiliferous limestone, $\mathrm{F}-\mathbf{7 6}$ (19135-PC)

Lower member: upper $100 \mathrm{ft}$ is thin-bedded gray limestone interbedded with reddish sandstone; lower $100 \mathrm{ft}$ includes some black limestone in thick beds but containing chert partings and lenses parallel to the bedding F-15 (17293PPC) and F-91 (19990-PC), $300 \mathrm{ft}$ above base; F-92 (19991-PC) is $250 \mathrm{ft}$ above base; F-93 (19992-PC) is from the base -.- 500

Total thickness

Base. Top of Iost Burro Formation.

Micrographs of the limestone from the Tin Mountain Limestone and younger limestone are illustrated on figure 33.

Compared to other late Paleozoic formations, trace elements in a specimen of Tin Mountain Limestone were intermediate in amount, and least in a specimen from the limestone above the Tin Mountain (table 14).

\section{MISSISSIPPIAN AND PENNSYLVANIAN(?) SYSTEMS- REST SPRING SHALE}

The type locality of the Rest Spring Shale is in the northern Panamint Range, where the formation is largely shale and siltstone but includes some sandstone 


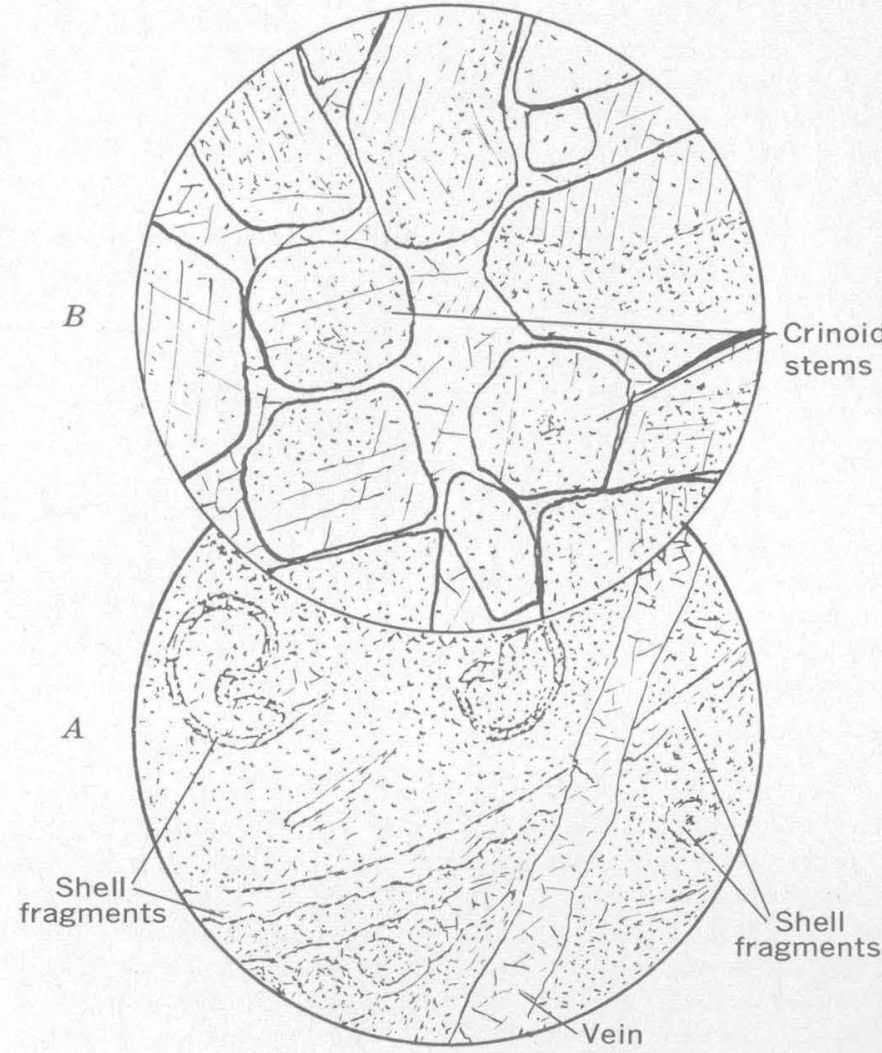

Figure 33.-Micrographs of limestone from Tin Mountain Limestone $(A)$ and unnamed younger Mississippian formation $(B)$. The limestone from the Tin Mountain is a bioclastic bed with many shell fragments set in a matrix of dusty (organic rich?) and more finely microcrystalline limestone. The limestone from the unnamed younger Mississippian formation is coarsely granular. Organic structures, probably large crinoid stems, are obscured as a result of the recrystallization of the limestone. Diameter of field, $2.5 \mathrm{~mm}$.

and vitreous quartzite (McAllister, 1952, p. 25). The thickness at the type locality is uncertain (perhaps $400 \mathrm{ft}$ ) because the formation is incompetent and is greatly pinched and swollen in zones of folds and faults (McAllister, 1952, p. 26).

In the area covered by this report the beds referred to the Rest Spring Shale are restricted to a narrow strike valley half a mile from the east base of Tucki Mountain. The width of the outcrop belt is about 750 feet; the beds are practically vertical. This indicates a thickness for the formation of 750 feet, but as at the type locality, this thickness is uncertain because the formation is greatly crushed between the more competent underlying and overlying formations.

The formation is mostly light-gray to black shale and siltstone interrupted with beds of black limestone 1-5 feet thick. The beds contain rounded nodules, like golf balls, of dark chert (fig. 34). At the base is 35 feet of black shale; the beds above this are mostly shale and siltstone. Some of the siltstone is ripple marked. Poorly preserved brachiopods are common in the shale, particularly toward the base. Near the middle of the formation is 50 feet of dolomitic and dark cherty limestone (fig. 35). The upper half of the formation contains increasing limestone and calcareous cement in siltstone. The siltstone and limestone weather reddish. At the top is 15-30 feet of shale, crushed under coarse conglomerate of the Pennsylvanian and Permian formations.

Trace elements in the Rest Spring Shale are given in table 14.

Fossils collected at several places across the formation where it is exposed in the previously described strike valley, have been reported on by Mackenzie Gordon, Jr., and Helen Duncan, as follows:

$F-20$ (17294-PC) Center sec. 31, T. 16 S., R. 46 E., alt. 400 ft. Top of ridge on north side of first canyon north of Shoveltown. Brachiopods, ete., from crumbly limestone and red-bed unit, about $800 \mathrm{ft}$ thick; overlies light-gray crinoidal limestone. Collector, C. B. Hunt, 1958.

\begin{tabular}{|c|c|c|}
\hline $\begin{array}{l}\text { Flexaria sp. } \\
\text { Inflatia sp. } \\
\text { Rhipidomella } \\
\quad \text { (Meek) }\end{array}$ & nevadensis & $\begin{array}{l}\text { Schizophoria? sp .indet. } \\
\text { Reticulariina campestri } \\
\quad \text { (White)? } \\
\text { Spirifer sp. }\end{array}$ \\
\hline
\end{tabular}

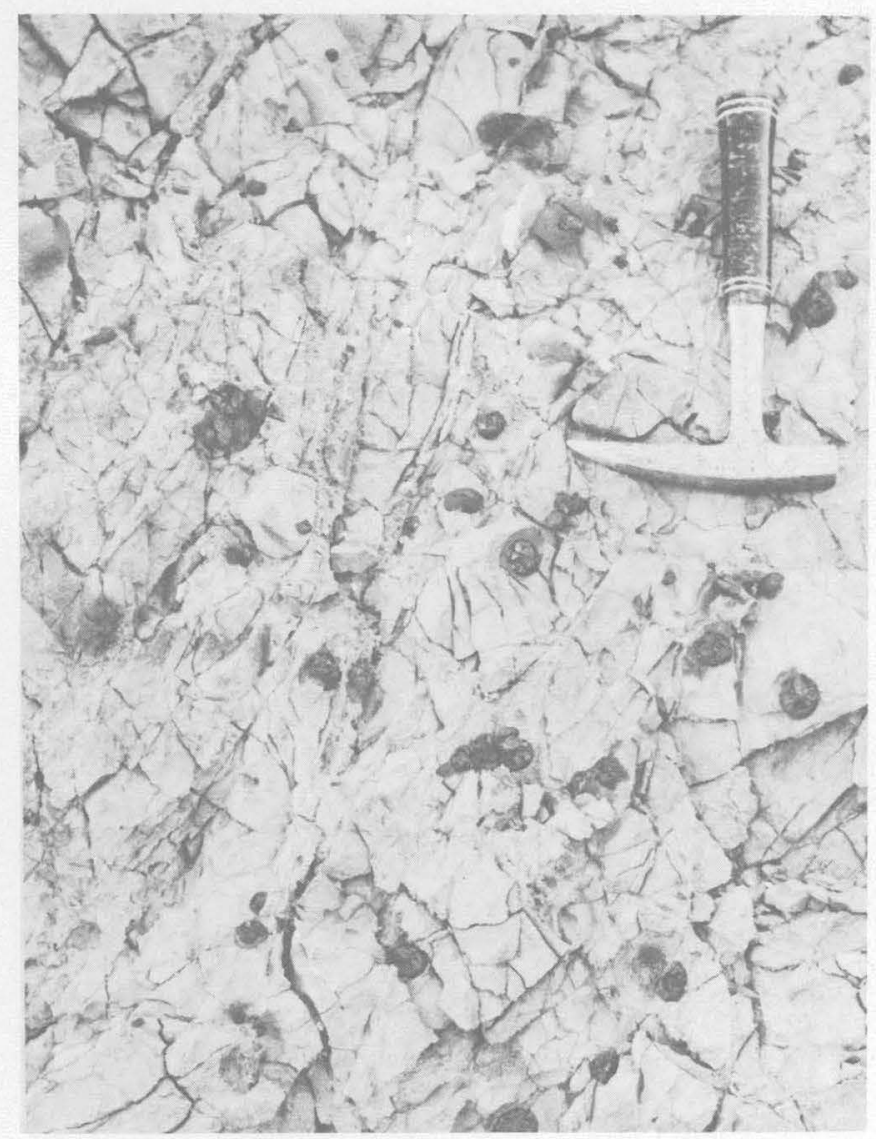

Figure 34-Golfball-like nodules of dark chert are a characteristic lithologic feature of the Rest Spring Shale and basal part of the overlying limestone of Pennsylvanian age. 


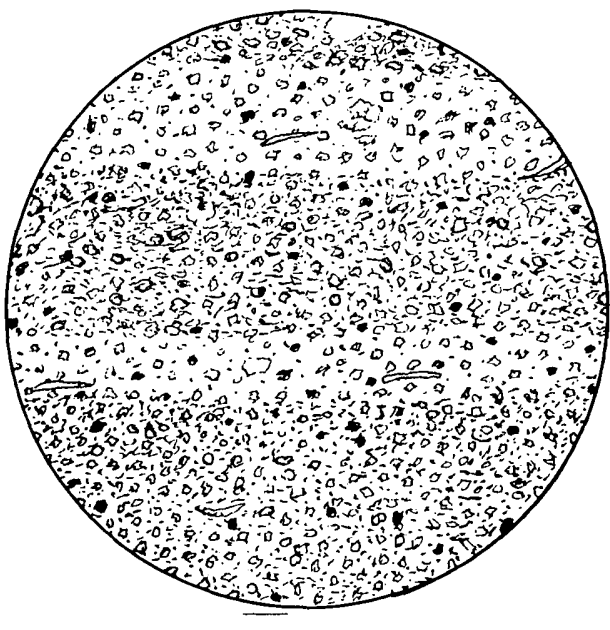

Figure 35.-Micrograph of limestone from Rest Spring Shale. The limestone is very fine grained, grain size 25 microns. The grains are mostly of calcite, many of them euhedral. About 10 percent are quartz, and 1 or 2 percent are iron oxide. The grains are set in a calcitic paste darkened with organic matter and (or) clay. Shell fragments are few ; there are some circular structures, apparently composed of silica. Diameter of field, $2.5 \mathrm{~mm}$.

In the Carboniferous rocks of the Great Basin, Rhipidomella nevadensis (Meek) is found in the uppermost Upper Mississippian and the lowermost Lower Pennsylvanian. The assemblage here does not contain any undoubted Pennsylvanian forms but has, rather, a Mississippian aspect. The containing beds are probably equivalent roughly to some part of the upper two or three hundred feet of the Chainman Shale as typically developed in east-central Nevada and western Utah.

$F-\gamma \%$. Rest Spring Shale, limestone beds near middle of unit, 2 miles northwest of West Side Borax Camp (Shoveltown), center sec. 31, T. 16 S., R. 46 E., Stovepipe Wells quad., California.

Chonetid brachiopod indet. Spirifer cf. S. arkansanus Girty?

F-78. Same location as F-77 ; from basal shale of Rest Spring Shale; $0-35 \mathrm{ft}$ above the base.

Lissochonetes? sp.

Fish scale

Spinose productid brachiopod

F-80. Same location as F-77. Shaly beds, $700 \mathrm{ft}$ above the base of the Rest Spring Shale.

Lissochonetes? sp.

Spiriferoid brachiopod ef. Torynifer

Compositoid brachiopod indet.

The collections from the Rest Spring Shale, above, are poorly preserved and do not permit determination as to possible Mississippian or Pennsylvanian age. The smooth chonetids suggest a Pennsylvanian age for the rocks, but some of the other brachiopods suggest Mississippian forms.

F-81 (17296). Same location as F-77, cherty limestone

Rhomboporoid bryozoan Small spinose productid indet.

Lissochonetes? sp.

Small Linoproductid brachiopods

Conocardium sp.

Hyolithes sp.
This is the best preserved collection from the Rest Spring Shale. Although the forms are not strictly diagnostic of either Pennsylvanian or Mississippian age, the collection is notable for the presence of a number of well-preserved specimens of Hyolithes, a long-ranging early Paleozoic genus that is rare in the late Paleozoic.

F-97 (19996). Bottom of same gulch as F-77, possibly from the same bed, about $750 \mathrm{ft}$ to south. Rest Spring Shale, near middle.

Button coral?

Chonetes? sp.

Echinocoelia sp.
Pleurotomariid gastropod indet., with spiral ornament

This unusual assemblage is a facies faunule expressing the special conditions of deposition of the shale sequence. These forms are not found commonly enough to be clearly indicative of either Mississippian or Pennsylvanian age. The brachiopod Echinocoelia is known elsewhere in Devonian and Mississippian rocks. To the best of our knowledge it has not been reported from rocks of Pennsylvanian age.

In a comment on these collections, Gordon states,

The Rest Spring Shale on Tucki Mountain appeans to be the same as that in the Quartz Spring area. Diagnostic fossils, however, are few. In the type area the Rest Spring has Cravenoceras merriami Youngquist in the basal few feet. This shows it to be Late Mississippian in age, at least in the lower part. The one datable fauna in the Rest Spring on Tucki Mountain (F-20) is very late Mississippian in age; the fauna with Rhipidomella nevadensis (Meek) that elsewhere in the Great Basin is found a short distance above the beds with Cravenoceras merriami. The fossils came from the middle of the shale. Whether or not the upper part of the Rest Spring on Tucki Mountain is of Pennsylvanian age is not presently known.

\section{PENNSYLVANIAN AND PERMIAN SYSTEMS-FOR- MATIONS AT EAST FOOT OF TUCKI MOUNTAIN}

Formations at the east foot of Tucki Mountain include thin-bedded limestone, at least 2,500 feet thick, largely, if not wholly, of Pennsylvanian age, and limestone conglomerate, at least 3,000 feet thick, that is largely, if not wholly, of Permian age.

The formations crop out in a belt about 3,000 feet wide along the east foot of the mountain. They stratigraphically overlie the Rest Spring Shale; but the contact must be a fault, because towards the south the shale is overlain by the limestone of Pennsylvanian age, whereas towards the north it is overlain by the conglomerate which is Permian.

These formations are at the lower edge of the upper plate of the Tucki Mountain thrust fault, and they are turned up steeply and even overturned. They rest on Precambrian quartzite in the lower plate of the thrust fault. Because of the deformation, the thicknesses cited are little better than guesses. Intensive detailed work will be required to resolve the many uncertainties in the stratigraphy of the formations, and until that 


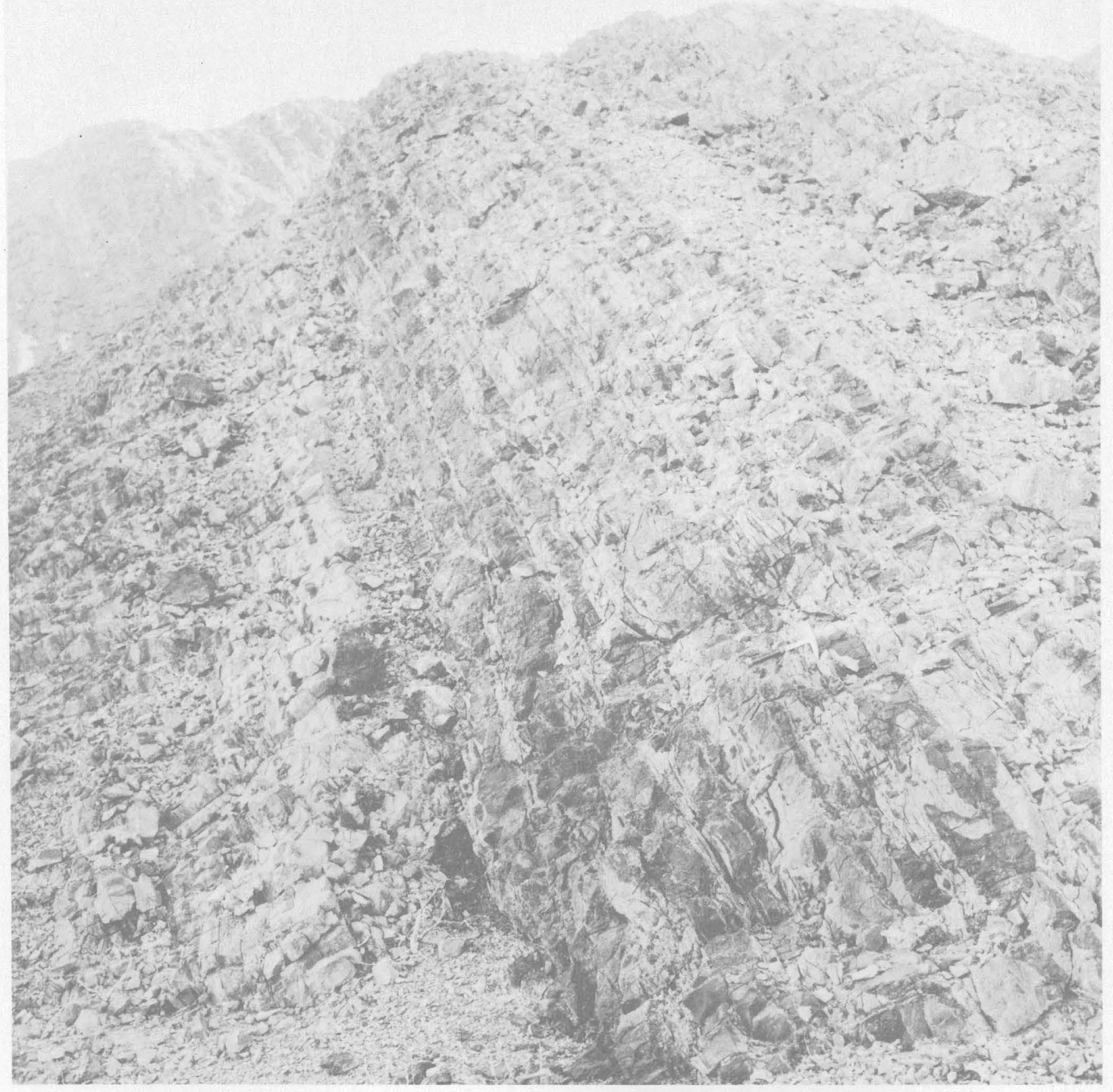

Frgure 36.-Thin-bedded limestone and dolomite near the base of the unnamed formation of Pennsylvanian age at the east foot of Tucki Mountain. These beds are overturned; their base is to the right.

work is done, it seems best to adopt an informal nomenclature.

At the south end of the outcrop of these formations the lowest exposed beds are thin-bedded limestone with some dolomite (fig. 36), which are estimated to be about 1,000 feet thick. These beds, which are vertical or overturned and lie against crushed, faulted, and contorted Rest Spring Shale, probably are Pennsylvanian in age (see colln. F-85, 87). Northward this belt of limestone narrows and in its place occurs coarse limestone conglomerate. The northward thinning of the limestone probably is due to faulting. Mountainward from Shoveltown (at Salt Springs) and farther north the formations are very largely conglomerate with comparatively thin lenses of limestone (fig. 37) and are mostly of Permian age (see colln. F-95 (19994- 


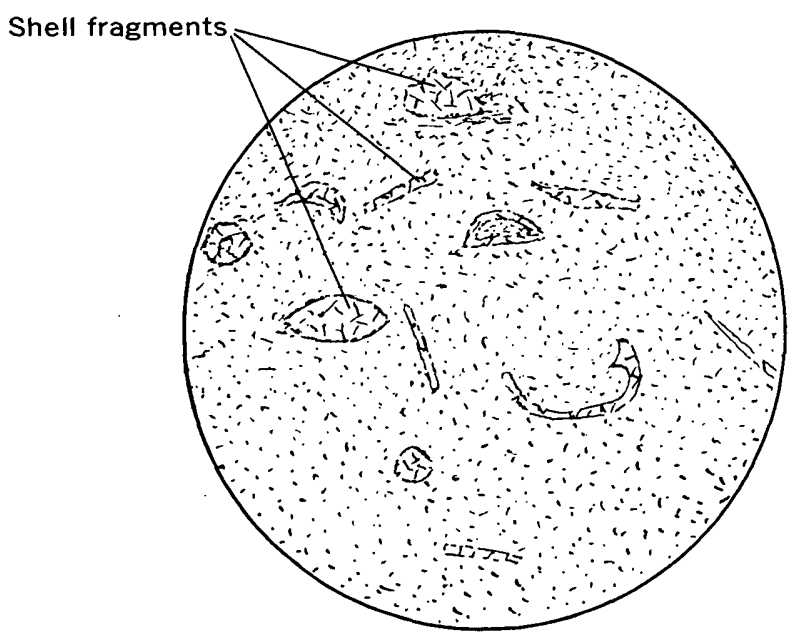

Figure 37.-Micrograph of limestone from the unnamed formation of Pennsylvanian age that overlies the Rest Spring Shale. The limestone is uniformly microcrystalline (grain size, 25 microns) and consists of interlocking anhedral grains of calcite and almost no quartz or iron oxide. Fragments of shells in the paste are more coarsely crystalline. Diameter of field, $2.5 \mathrm{~mm}$.

$\mathrm{PC})$ ). The deformation, though, is too intense to be certain which lenses of limestone are interbedded with the conglomerate and which are faulted in with it.

The conglomerate consists of cobbles and small boulders as much as 1 foot in diameter. They are mostly of limestone and dolomite, but they include some quartzite. The beds of conglomerate are 5-10 feet thick; the bedding is indistinct except for differences in size of the cobbles. In most beds the cobbles, which are well rounded, touch one another, and in many beds there is almost no matrix. The conglomerate weathers reddish, perhaps because of alteration along closely spaced zones of shearing and crushing.

Trace elements in samples from these formations are given in table 14. The two samples of "altered rock at thrust fault" are from a prospect at the southeast corner of Tucki Mountain where the late Paleozoic formations form the upper plate of a thrust and rest on Stirling(?) Quartzite.

Several collections of fossils were obtained from the limestone of Pennsylvanian age south of Shoveltown.

$F-84$. Formation $1 / 4$ mile southwest of Shoveltown; limestone bed in a shaly unit; estimated 2,500 ft above base of the formation. Alt $200 \mathrm{ft}, 0.9$ mile south-southwest of $\mathrm{SW}$ cor. sec. 33, T. 16 S., R. 46 E., Chloride Cliff quad., California. Reported on by Mackenzie Gordon, Jr., as follows :

"Horn coral fragments, indet.

"This collection is too poor to be of value in dating the containing bed."

F-85. Fusulinids and silicified brachiopods from base of the shale and limestone represented by $\mathbf{F}-84$. According to $\vec{R}$. C. Douglass, this sample contains Fusulinella sp. and represents Middle Pennsylvanian age.
$F-87$ (19193-PC). Bryozoa, from limestone estimated 1,000 ft thick in the canyon 1 mile south of Shoveltown; fossils are from the middle of the unit, probably $750 \mathrm{ft}$ above the base of the limestone. Examined by Helen Duncan who reports as follows:

"The sample collected contains a good deal of echinoderm and bryozoan debris. Preservation of the bryozoan material is poor, owing to partial silicification and recrystallization. Most of the fragments that can be identified as to genus are Fenestella. So far as one can tell from the types of meshwork noted, several species of the genus are probably represented, but structural details are not sufficiently well preserved to furnish data for specific identification. A few examples referable to Polypora and Cystodictya were found as well as an indeterminate rhomboporoid and a laminar fistuliporoid.

"The bryozoan material does not furnish objective evidence for precise dating. The assemblage of genera might occur anywhere from Devonian to Permian. However, bryozoans are not known to be prevalent in the Devonian and Lower Mississippian in this part of the Great Basin; and the generic association is one that commonly occurs in the later Mississipian and Pennsylvanian. The absence of genera (Rhombotrypella, Rhomboporella, Ascopora) that are diagnostic of and very common in the Middle and Upper Pennsylvanian of the Great Basin suggests that the interval may be older-Early Pennsylvanian or Late Mississippian. With the exception of one genus, which is not present in your material, I have not yet discovered criteria that can be used to distinguish Late Mississippian from Early Pennsylvanian bryozoan faunas. On the evidence available, a Pennsylvanian(?) assignment seems to be a reasonable one."

Collections of fossils from the conglomerate in the northern part of the outcrop belt indicate that it is mostly of Permian age and that it contains cobbles ranging in age from Early Mississippian to Late Pennsylvanian. The collections were studied by Mackenzie Gordon and Helen Duncan, who reported on them as follows:

$F-23(17295-P C)$. Corals, brachiopods, etc., from limestone breccia, probably high Carboniferous. The hill back of Shoveltown $1 / 2$ mile southwest of $\mathrm{SW}$ cor. sec. 33 , T. $16 \mathrm{~S}$., R. 46 E., Chloride Cliff quad., California. Collector, C. B. Hunt, 1958.

$\begin{array}{ll}\text { Horn corals } & \text { Spirifer sp. indet. } \\ \text { Cyathaxonia sp. } & \text { Syringothyroid indet. } \\ \text { Syringopora cf. S. surcu- } & \text { Hustedia sp. } \\ \text { laria Girty } & \text { Platyceras } \text { sp. } \\ \text { Crinoid columnals } & \text { Fish dentition }\end{array}$

"This collection no doubt represents a block or blocks of Tin Mountain Limestone of Early Mississippian age incorporated in the conglomerate sequence."

F-86 (19136-PC). Same location as F-84; float on hillside derived from weathering of 500 -ft-thick conglomerate west of, and probably faulted against, the block of Pennsylvanian rocks represented by F-84 and F-85. This float represents cobbles from the conglomerate, and the cobbles may have a wide range in age. Age of cobbles should be considered separately. 
Bradyphyllum $\mathrm{sp}$. Neokoninckophyllum? sp. Zaphrentoid coral indet. Multithecopora? sp. Goniocladia sp. Crinoid columnals Productid fragments indet.
Spirifer fragments indet. Crurithyris sp. Peruvispira sp. Platyceras sp.

Gastropod fragments indet. Trilobite fragments indet.
Another block of crinoidal limestone contains the following:

Wedekindellina? sp.

"The last block containing small fusulinids that either represent an advance form of Fusulinella or an early form of Wedelkindellina indicate, according to Raymond Douglass, a Middle Pennsylvanian (Des Moines) age for the limestone block.

"The major part of the list includes forms that are found both in Pennsylvanian and Permian rocks. According to Helen Duncan, the bryozoan genus Goniocladia generally indicates Permian age for the rock. Peruvispira is, according to Ellis Yochelson, limited to rocks of Permian age and particularly to the Lower Permian of present Geological Survey usage. Part of the fauna is the same as that found in coll. F-95, and a Lower Permian (Wolfcamp) age for it is therefore indicated.

F-94 (19993-PC). Saddle between Shoveltown Ridge and Tucki Mtn., southwest corner Chloride Cliff quad., California. Scattered loose blocks. Collectors, M. Gordon and C. B. Hunt, Jan. 3, 1961.
F'usulinella? sp.

Caninia sp. indet.

Fistuliporoid bryozoan, genus and species indet.

F'enestella? sp.

Rhabdomeson? sp.

Prismopora sp.
Crinoid columnals Derbya sp.

Linoproductus sp. Juresania sp.

Rhynahopora sp.

spirifer rockymontanus Marcou
Another loose block contains-

Triticites sp.

"As these are loose blocks from a conglomerate, they may be, and in fact are, in part, of different ages. For this reason the one block with Triticites is recorded separately. Raymond Douglass says that this species is definitely of Late Pennsylvanian age and probably of Virgil age. The fossils in the list above are Middle Pennsylvanian in age, possibly Atoka. The Fusulinella? is associated with the poorly preserved caninoid corals. The Prismopora, Linoproductus, and Spirifer are assoclated in a single block.

"Of the bryozoans, Miss Duncan reports as follows: 'The only potentially signiflcant bryozoan is Prismopora. This genus ranges from the Devonian to the Permian, but in the West its occurrence seems to be confined to the Pennsylvanian and largely to the Middle Pennsylvanian. Prismopora is a common fossil in the Middle Pennsylvanian of the Rocky Mountain region, but it is apparently rare in Pennsylvanian assemblages from the Great Basin. In fact, I believe that this is the first time that $I$ have seen the genus in a collection made west of the Wasatch and Oquirrh Mountains in Utah, and none are recorded in Girty's reports on Carboniferous faunas from Nevada and California.'

"This collection is of particular significance because it indicates that rocks as young as probable Virgil age are incorporated as boulders in this conglomerate."
$F-95$ (19994-PC). Limestone and dolomite beds making up a unit $350 \mathrm{ft}$ thick the east foot of Tucki Mtn., on spur about $1,000 \mathrm{ft}$ southeast of $\mathrm{SW}$. cor. sec 31, T. $16 \mathrm{~S}$., R. $46 \mathrm{E}$., Stovepipe Wells quad., California. Fusulinids are from zone $50-100 \mathrm{ft}$ below top of $350-\mathrm{ft}$ section. Collectors, M. Gordon and C. B. Hunt, Jan. 3, 1961.
Triticites sp.
Pseudofusulinella sp.
Caninia sp.
Multithecopora? sp.
Trepostomatous bryozoan, genus and species indet.
Fistuliporoid bryozoan, genus and species indet. Crinoid columnals
Small strophomenoid
brachiopod, genus and
species indet..

\author{
Echinoconchoid productid \\ fragments \\ Kochiproductus? sp. \\ (fragments) \\ Horridonia? sp. \\ Rhynchopora sp. \\ Composita? sp. \\ Peruvispira sp. \\ omphalotrochus sp.
}

"Although the Rest Spring Shale on Tucki Mountain appears to grade upward into the overlying conglomerate beds, somewhere there must be a considerable hiatus. This is because the present evidence indicates that the conglomerate was laid down largely in Early Permian time, although deposition may have begun during Late Pennsylvanian. The fossils collected in place in nonconglomerate beds are of probable Wolfcamp age. Loose blocks from the conglomerate or in float on its surface contain fossils as late as probable Virgil (very Late Pennsylvanian) age. The conglomerate, therefore, appears to be related to the Permian Owens Valley Formation of the Inyo Range, which likewise contains conglomerate beds, although temporally it may be more directly equivalent with the upper beds of the Keeler Canyon Formation, which underlies the Owens Valley.

"Rocks of Bird Spring age, a formation which is roughly equivalent to the Keeler Canyon, are incorporated as blocks in the conglomerate on the east base of Tucki Mountain. The uppermost Bird Spring may be in part temporally equivalent to the conglomerate. However, it would be misleading to use the name Bird Spring for the conglomerate as the type Bird Spring is a well-bedded limestone sequence. The conglomerate on the other hand appears to be tied in with an orogenic belt that lay to the west and north.

"The fusulinids Triticites and Pseudofusulinella are forms, according to Raymond Douglass, that occur in rocks of late Virgil to Wolfcamp age. The occurrence of the snails Omphalotrochus and Peruvispira in association is, according to Ellis Yochelson, indicative of Wolfcamp age. Omphalotrochus has been found also in the Uddenites zone of Texas, considered by some geologists to be late Virgil in age. Peruvispira, however, has not yet been found as low as the Uddenites zone but occurs also in post-Wolfeamp rocks. On these grounds an Early Permian (Wolfcamp) age for the containing rocks is indicated by this collection. However, the possibility of a very Late Pennsylvanian age cannot be definitely excluded."

Mackenzie Gordon (written commun., 1961) has added the following comment about the significance of these collections:

The collections from the great carbonate rock conglomerate sequence cast considerable light upon its possible age. The collection of loose blocks from the saddle north of Shoveltown Ridge (F-94) include those of Middle Pennsylvanian and one 
of Late Pennsylvanian, probably Virgil age. The collection (F-95) from the 350-foot section of bedded limestone and dolomite about 1,500 feet above the base of the formation is probably Lower Permian (Wolfeamp) in age. These collections indicate that the conglomerate did not begin to be deposited until very Late Pennsylvanian or perhaps not until Early Permian time. The nearest contemporaneous equivalent is probably the upper part of the Keeler Canyon Formation, although the conglomeratic aspect is more like that of the overlying Owens Valley Formation.

As noted by Gordon, above, conglomerate like that at the east foot of Tucki Mountain occurs west of Death Valley, but to the east the Pennsylvanian and Permian formations are limestone with shale. In the Goodsprings quadrangle, Nevada, the Bird Spring Formation, comprising a sequence of well-bedded limestone 2,500 feet thick (Hewett, 1931, p. 21-30), is Pennsylvanian in age but is thicker in the Las Vegas quadrangle, where it includes beds of Permian age (Helen Duncan, written commun., 1964). The name was extended to an incomplete section of similar rocks of Pennsylvanian age in the Nopah Range (Hazzard, 1937b, p. 337) and to beds of Pennsylvanian and Permian age aggregating at least 5,000 feet thick in the northern part of the Panamint Range (McAllister, 1956). Merriam and Hall (1957) further revised the age of the Bird Spring to Late Mississippian to Permian.

The beds of Pennsylvanian and Permian age in the northern Panamint Range, according to McAllister (1956), consist largely of limestone and shale, but locally there is a lenticular conglomerate several hundred feet thick. In the southern part of the Panamint Range, in Butte Valley 35 miles south of Tucki Mountain, Permian rocks, 4,100 feet thick, also consist of limestone and shale, but they are apparently without conglomerate (Johnson, 1957, p. 382-383). The dominance of limestone and scarcity of shale in the formations at the east foot of Tucki Mountain may be due to squeezing out of the incompetent beds because of the severe deformation there.

Westward from Death Valley the formations equivalent to those at the east foot of Tucki Mountain are increasingly conglomeratic (Merriam and Hall, 1957, p. 4; Hall and MacKevett, 1958, p. 9-10; Bowen, 1954, p. $36-42)$.

The relationships of the conglomerates northward and southward along the Panamint Range and eastward and westward from there need study, not only for dating the onset of the deformation they record but for determining whether some of the mountain blocks have been moved long distances from their original position. As brought out in the section on "Structural geology" (p. A142), the Pennsylvanian and
Permian formations at the east foot of Tucki Mountain have been thrust some miles westward along the Tucki Mountain thrust fault. Perhaps the position from which the fault moved them was not their original position either.

These conglomerates of Permian age are intermediate in type between those of the older Paleozoics and those of the Triassic in this region.

\section{TRIASSIC SYSTEM}

Rocks of Triassic age are not represented in the area covered by this report, but they are exposed in Warm Spring Canyon and Butte Valley only 1 mile to the south. There carbonate rocks of Permian age are overlain by metasediments and volcanic rocks aggregating 8,000 feet thick and containing fossils suggestive of an Early Triassic age (Johnson, 1957, p. 384-388). Triassic sedimentary rocks largely of volcanic origin also are known farther west, in the Inyo Mountains (Kirk, in Knopf, 1918, p. 47-48), to the south in Soda Mountains (Grose, 1959, p. 1523), and to the southeast in the Providence Mountains (Hazzard, 1937a, p. 329).

The Triassic rocks record a striking change in kind of sediments being deposited and in the location and trend of the troughs in which the sediments were deposited. The Triassic troughs apparently trended northwest at about the position of the Precambrian trough, and these may have become the site of the Sierra Nevada batholith. The troughs containing the Paleozoic carbonate formations trend north into the Great Basin.

\section{CRETACEOUS OR TERTIARY SYSTEMS} GRANITIC INTRUSIONS

Death Valley is at the northeast edge of a belt of isolated granitic intrusions like the granitic plutons composing the Sierra Nevada batholith and are evidently eastern satellites of it. Three granitic intrusions in the Death Valley area, referred to as the granites at Skidoo and at Hanaupah Canyon, and another in the Amargosa thrust complex, seem to be floored intrusions that spread laterally, probably along thrust faults, and made the space they occupy by doming the upper plates of the thrust. These intrusions are mostly quartz monzonite and represent one of the more potassic types of the batholith. They are younger than the batholith and are closely related to, and only slightly earlier than, the volcanism in Death Valley, which is Tertiary. ${ }^{7}$

These intrusions are described on page $120 \mathrm{ff}$.

7 Since this manuscript was prepared, lead-alpha age determinations on zircon from some of these intrusions, and potassium-argon determinations on their feldspars, indicate that these intrusions probably are Middle Tertiary (T. W. Stern, written commun., 1965). 
Cha OTIC COMPLEX ALONG THE AMARGOSA THRUST FAULT

The relation of the granites to the thrust faults and to the volcanics is best shown along the east foot of the Panamint Range between Starvation Canyon and Blackwater Wash, where a complex of many kinds of igneous, metamorphic, and sedimentary rocks occurs along the outcrop belt of a thrust fault. The fault is probably the westward extension of the Amargasa thrust, and the rocks along it are referred to informally as the chaotic complex along the Amargosa thrust fault, or, for short, as the Amargosa thrust complex; they are described on page $129 \mathrm{ff}$.

\section{TERTIARY SYSTEM}

The volomic rocks in the Amargosa thrust complex closely resemble some of the Tertiary formations to the east and north of Death Valley and are probably part of the same volcanic sequence.' The Tertiary formations eist of Death Valley include the "chaos" and related formations along the Amargosa thrust fault at the south end of the Black Mountains (Noble, 1941) and a thick sequence of volcanics that grade northward into playa deposits at the north end of the mountains. The playa deposits and interbedded volcanics dip northward off the Black Mountains and under a syncline separating the Black and Funeral Mountains. Where the formations rise again on the flank of the Funeral Mountains, they resemble the Titus Canyon Formation (Oligocene) of Stock and Bode (1935) and are tentatively correlated with it. The youngest of the Tertiary deposits are mostly playa deposits and are of Pliocene age.

\section{FORMATIONS IN THE BLACK MOUNTAINS}

Tertiary formations in the Black Mountains have been studied and reported on by Noble (1941), Curry (1939, 1954), and Drewes (1963), and by J. F. McAllister (written commun., 1960). These formations were given little attention by me, and the descriptions that follow are summarized from the work of the others.

At the south end of the Black Mountains, in the Virgin Springs district (Noble, 1941), the Tertiary rocks include conglomerate, fanglomerate, shale, freshwater limestone, rhyolite, quartz latite, andesite, and tuff. These rocks originally were part of a volcanic and sedimentary sequence like that at the north end of the Black Mountains, but they now are masses in a breccia, the "chaos," along the Amargosa thrust fault. With these Tertiary rocks are blocks of late Precambrian sedimentary formations and breccia of Tertiary(?) granite, and the whole has been thrust onto Precambrian gneiss and other metamorphic rocks.

Individual blocks in the breccia may be as long as 1,000 feet and as thick as 300 feet. They are thrust one on the other, giving a shingled structure that dips east. The thrust was towards the west-towards the Panamint Range.

Tertiary formations at the north end of the Black Mountains have an aggregate thickness of at least 13,000 feet. They overlap and are faulted against Precambrian gneiss at a turtleback above Badwater (fig. 38). The Tertiary formations consist of volcanic rocks and sedimentary rocks. The percentage of sedimentary rocks increases northward.

The Precambrian gneiss under the turtleback surface is cut by a swarm of Tertiary dikes (Curry, 1954) trending N. $30^{\circ} \mathrm{E}$. In places their volume exceeds that of the gneiss. These dikes do not extend into the upper plate. They are restricted to the gneiss underlying the turtleback surface and seem to be sheared-off feeders to volcanic rocks that once reached higher levels (Curry, 1954, p. 57).

The Tertiary formations north of the Badwater turtleback can be divided into an older set of deposits, the Artist Drive Formation ${ }^{8}$ of Noble and Wright (1954) (Oligocene (?) to early Pliocene) and a younger set, the Furnace Creek Formation (Pliocene). For about 2 miles north from the turtlebacks, the Artist Drive of Noble and Wright is largely volcanic rocks, mostly felsitic flows, lapilli tuffs, and some explosion breccias (fig. 39). The lower 4,000 feet is dark-purple felsite; the upper 1,000 feet is variegated felsite and white tuffs. Northward the volcanic members thin and the sedimentary members thicken. A partial section across the upper 1,000 feet of the formations, where they consist of both volcanic and sedimentary units, shows the following:

Partial section, upper part of formations in the Artists Drive area at divide above Artists Palette and above the head of 20 Mule Team Canyon

Top. Tan playa beds.

Conglomerate; includes cobbles of granite, upper Paleozoic rocks, and volcanics-_-_._- 50

Basalt -..--_- 125

Purple and green, "calico" beds ; mostly volcanic-derived playa deposits_-_- 100

Tan playa beds

Red felsite-1-_- 250

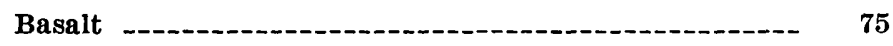

Red felsite and greenish; probably volcanic-derived playa beds

Tan playa beds 300 playa beds.

8 The correct place name, as approved on official maps of the U.S Geological Survey, is Artists Drive. Preferred local usage (the guidIng rule in adopting place names) is in the possessive, Artist's Drive. As used originally by Noble (1941), "Artist" is in the singular ; consequently, the formal formation name retalns this spelling. 


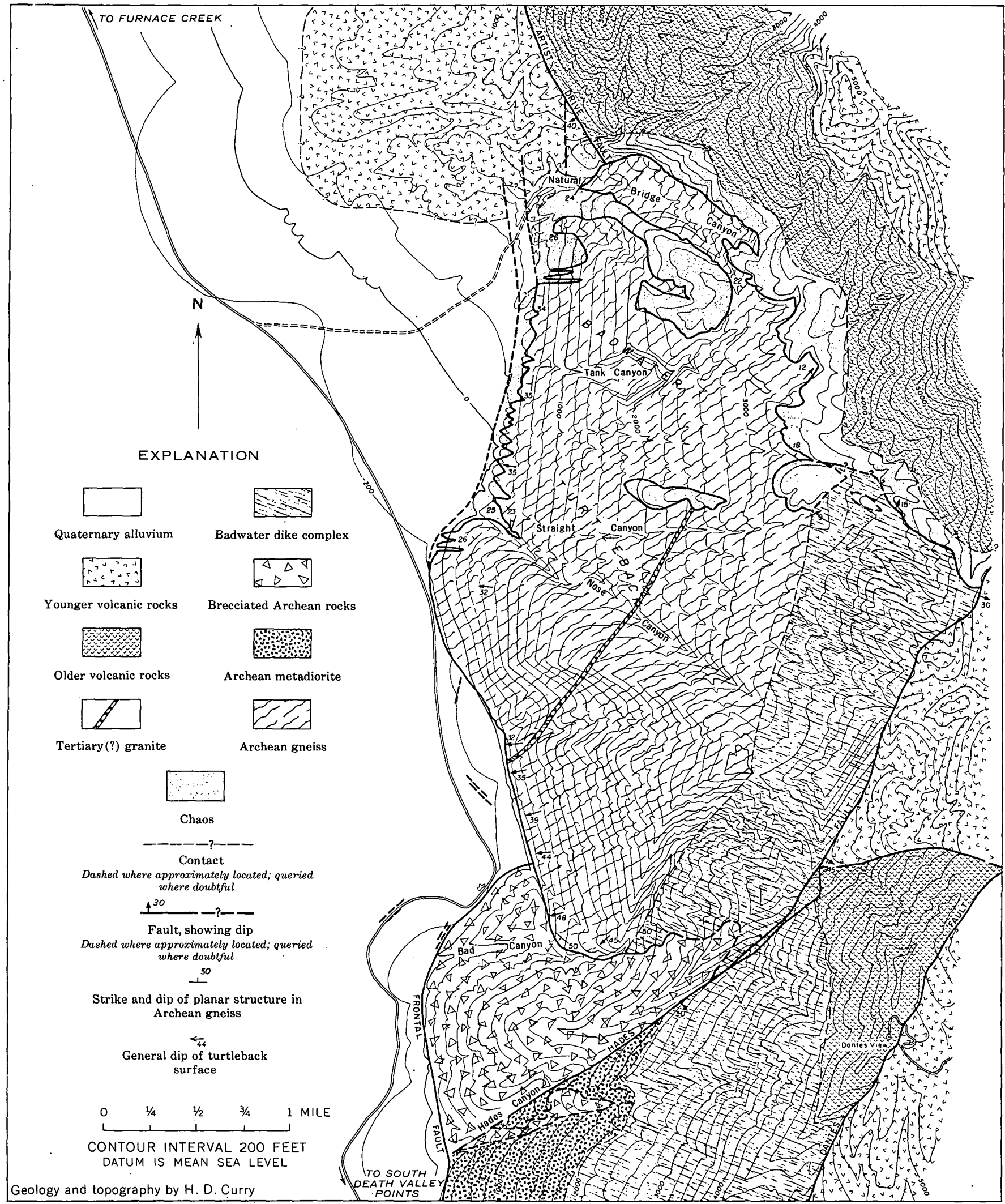

FiguRn 38.-Geologic map of Badwater turtleback and adjacent areas. From Curry, 1954. 


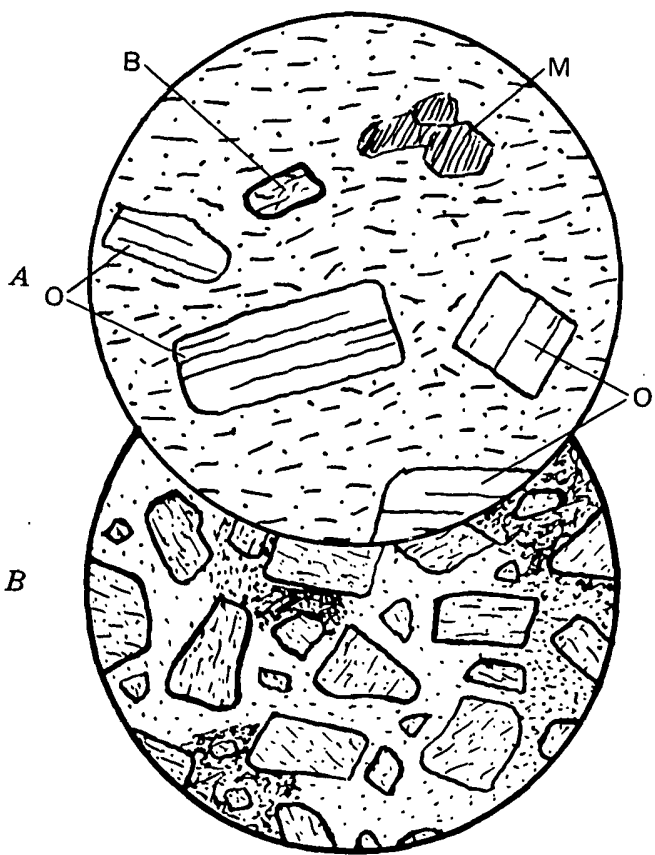

Fradre 39.-Micrographs of thin sections of felsite $(A)$ and explosion breccia $(B)$ from the Artist Drive Formation. The felsite has phenocrysts of oligoclase (O), magnetite $(M)$, and a much-altered mineral, probably originally biotite $(B)$ in a glassy groundmass containing microlites of oligoclase and tiny spects of finely disseminated iron oxide which colors this felsite red. The explosion breccin consists of sharply outlined randomly oriented fragments of glassy rocks in a glassy matrix spotted and streaked bright red and yellow. Dlameter of fleld, $2.5 \mathrm{~mm}$.

The sedimentary deposits are mostly fine-grained clastics, probably playa deposits. The conglomerates, as much as 100 feet thick, contain cobbles of granite and some fossiliferous late Paleozoic formations as well as volcanics.

The nearest area having late Paleozoic formations and granite is to the northwest, across Death Valley, in the northern part of the Panamint Range. Moreover, because some conglomerates thin and become finer grained southeastward, as they rise onto the Black Mountains, it seems likely that the late Paleozoic and granite cobbles were brought from the northwest. The volcanic cobbles came probably from the Black Mountains because the sedimentary beds intertongue southeastward with volcanics which are quite like those occurring as cobbles. Probably, therefore, at the time the formations in the Artists Drive area were accumulating, the site of the north end of the Black Mountains was a low area. To the southeast was higher ground where volcanics were accumulating and perhaps being raised structurally as well. To the northwest, across Death Valley, there already were mountains at the site of the northern part of the Panamint Range.
Trace elements in volcanic rocks from the Artists Drive area are given in table 15 . The amounts and proportions are similar to those in the felsitic rocks along the foot of the Panamint Range northward from Death Valley Canyon to Tucki Wash (table 26), part of which is dated by the potassium-argon method as late Miocene and by lead-alpha age determinations on the zircon in these rocks as middle Tertiary (T. W. Stern, written commun., 1965). They also resemble the tuffs in the Titus Canyon (?) Formation of Stock and Bode (1935) (table 16).

TABLE 15.-Trace elements in volcanic rocks in the Artists Drive area

[Semiquantitative spectrographic analysis by E. F. Cooley, U.S. Geol. Survey. Values in parts per million, except $\mathrm{Mg}$, which is given in percent

\begin{tabular}{|c|c|c|c|}
\hline Element & Rhyolite & $\begin{array}{l}\text { Perlite in } \\
\text { agglomerate }\end{array}$ & $\begin{array}{l}\text { Purple } \\
\text { felsite }\end{array}$ \\
\hline $\begin{array}{l}\mathrm{Pb} \\
\mathrm{Mn}^{\mathrm{M}} \mathrm{C} \\
\mathrm{Cu} \\
\mathrm{Zr} \\
\mathrm{Ni} \\
\mathrm{Co}\end{array}$ & $\begin{array}{r}20 \\
200 \\
30 \\
200 \\
20 \\
5 \\
20 \\
15 \\
<1 \\
3,000 \\
100 \\
50 \\
<10 \\
50 \\
1,000 \\
300 \\
0.5\end{array}$ & $\begin{array}{r}20 \\
200 \\
10 \\
150 \\
10 \\
5 \\
15 \\
10 \\
<1 \\
2,000 \\
50 \\
50 \\
<10 \\
20 \\
1,000 \\
300 \\
0.7\end{array}$ & $\begin{array}{r}20 \\
300 \\
15 \\
300 \\
30 \\
5 \\
50 \\
15 \\
<1 \\
2,000 \\
70 \\
70 \\
<10 \\
70 \\
1,000 \\
300 \\
0.5\end{array}$ \\
\hline
\end{tabular}

Nore.-All samples showed: $\mathrm{As}<1,000 ; \mathrm{Zn}<200 ; \mathrm{Sn}<10 ; \mathrm{Ge}<20 ; \mathrm{Cd}<50 ; \mathrm{Bl}<10$ In $<10 ; \mathrm{Sb}<200 ; \mathrm{Tl}<100 ; \mathrm{Nb}<50 ; \mathrm{Ta}<50 ; \mathrm{W}<100$.

At the north end of the Black Mountains the formations in the Artists Drive area are overlain unconformably by the Furnace Creek Formation of Pliocene age.

The age of the greater part of the formations in the Artists Drive area and to the north is in doubt, but the uppermost tongue of playa beds in the Artist Drive Formation has yielded diatoms indicating an early Pliocene age. The fossils were obtained by K. E. Lohman (written commun., 1961), of the U.S. Geological Survey, who has reported as follows:

Loc. 3967. Hard thin limestone from center of $\mathrm{W} 1 / 2 \mathrm{NE1/4}$ sec. 7, T. 26 N., R. 2 E., Furnace Creek 15-minute quad. Assigned to early Pliocene on basis of incomplete, partly altered diatom assemblage.

The formations in the Artists Drive area also are represented in several large downfaulted blocks in a belt 10 miles long and 2 miles wide at the foot of the Black Mountains north of the Badwater turtleback. The exposed beds, like those in the Black Mountains, are volcanic towards the south, and interbedded volcanic and sedimentary rocks at the north. They are 
from the upper part of the formations, and the displacement must be about 5,000 feet down towards Death Valley. If the Tertiary formations were as resistant to erosion as the Precambrian gneiss, this part of the front of the Black Mountains would also be a turtleback surface.

These downfaulted blocks in the Artists Drive area are overlapped unconformably by the Pliocene and early Pleistocene(?) Funeral Formation and basalts interbedded with it.

\section{FORMATIONS AROUND COTTONBALL BASIN}

Tertiary formations around Cottonball Basin at the north end of the Death Valley saltpan range probably from Oligocene to Pliocene. They occur in fault blocks protruding through and largely concealed by the Quaternary fan gravels. No fossils were found, and the outcrops are too isolated for satisfactory reconstruction of a stratigraphic succession. The stratigraphy of these deposits is uncertain; the structural geology necessarily even more so.

The deposits are in three principal belts (fig. 40). At the north, between the Kit Fox Hills and the Funeral Mountains and extending southeast in a narrow belt along the fault at the foot of the Funeral Mountains, are clastic deposits believed to correlate with the Titus Canyon Formation of Stock and Bode (1935) and accordingly thought to be Oligocene. Deposits believed to be somewhat younger, perhaps Miocene, form an intermediate belt at the Kit Fox Hills and southeastward along the northeast side of Cottonball Basin. The third belt extends northwest and southeast from Cottonball Basin and is represented by the Furnace Creek Formation of Pliocene age.

\section{OLIGOCENE( $($ ) FORMATIONS}

Shale, sandstone, grit, and conglomerate thought to correlate with the Titus Canyon Formation of Stock and Bode (1935) from isolated hills protruding through the Quaternary fan gravels between the Kit Fox Hills and Funeral Mountains. These beds also occur in a narrow belt along the fault at the foot of the Funeral Mountains and on a turtleback fault surface on Paleozoic formations in the southern part of the Funeral Mountains. Most of the formation is dark red or dark brown; many clayey beds are light green. The bedding is highly lenticular. The total thickness of the Titus Canyon(?) Formation in these areas can only be guessed, because the outcrops are not continuous and the formation is very much faulted. At least 1,500 feet of beds is exposed, and the total thickness may greatly exceed this.
Of the several kinds of lithologies that are included in the formation, three are distinctive: conglomerates in which the cobbles are fractured; green clayey and silty beds that contrast strikingly with the enclosing thicker and more coarsely clastic beds; and a bright-red conglomerate along the faults at the foot of the Funeral Mountains.

The conglomerate having fractured cobbles occurs in beds $10-25$ feet thick at many horizons through the middle 1,000 feet of the formation. Cobbles are as much as 6 inches in diameter and are displaced as much as one-fourth inch by fractures oriented normal to the bedding. Many of the fractures are healed, and the fractured cobbles can be removed intact. The fractured cobbles may touch one another, or they may be isolated in a matrix of gritty silt (fig. 41).

The distinctive greenish clayey beds, mostly less than 10 fet thick, are tuffaceous (fig. 42). They are conspicuous because most of the formation is dark red or dark brown.

The red conglomerate and sandstone is at least 500 feet thick and occurs along the faults at the foot of the Funeral Mountains. The conglomerate contains wellrounded cobbles and pebbles of quartzite along with the more angular boulders of limestone and dolomite. It is faulted against the Cambrian and Precambrian formations that form the foot of the mountain. The reddening may be due to hydrothermal alteration along the fault zone.

The following is a typical but partial section of the Titus Canyon(?) Formation:

Partial section, Titus Canyon(?) Formation, measured about midway between the Kit Fox Hills and Funeral Mountains

Top covered. About $750 \mathrm{ft}$ of beds like units 1 and 2 up to top of this member.

1. Sandstone, gritty, with scattered cobbles; some cobbles as much as 3 in. in diameter; weathers dark brown

2. Interbedded tan siltstone and dark-brown grit and cobble conglomerate. Cobbles as much as 3 in. in diameter ; fractured. Some tuff.

3. Sandstone, gritty, with scattered cobbles; some cobbles as much as 3 in. in diameter; weathers dark brown.-

4. Tan beds like unit 2

5. Grit, sandstone, and conglomerate with pebbles as much as 2 in. in diameter of quartz, quartzite, carbonate rocks, black chert; no pebbles of volcanic rocks; dark brown. Possible tuff layers. Thin beds; apparently some interbeds of greenish shale.

6. Greenish shale in beds $5-10 \mathrm{ft}$ thick with 1 - to 6-in. beds of tan limestone and silt and a bed of reddish cemented clay or silt.

7. Like unit 5 ; weathers dark brown but is gray on fresh fracture. Across wash to southeast the top of this units is cut off discordantly by unit 6 ; this may be a flat fault and not an unconformity 


\section{EXPLANATION}

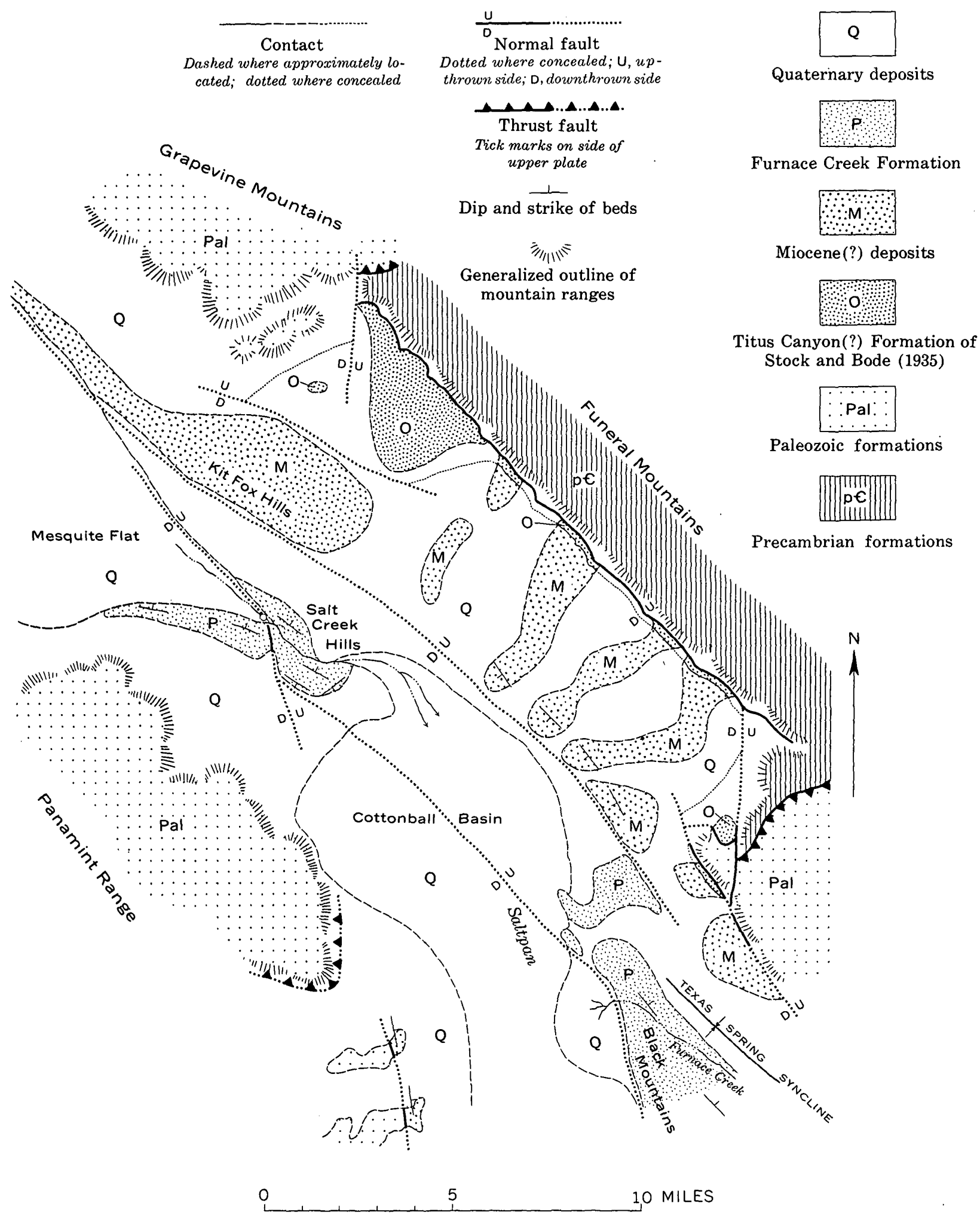

FIGURE 40. - Sketch map of Tertlary formations around Cottonball Basin. 


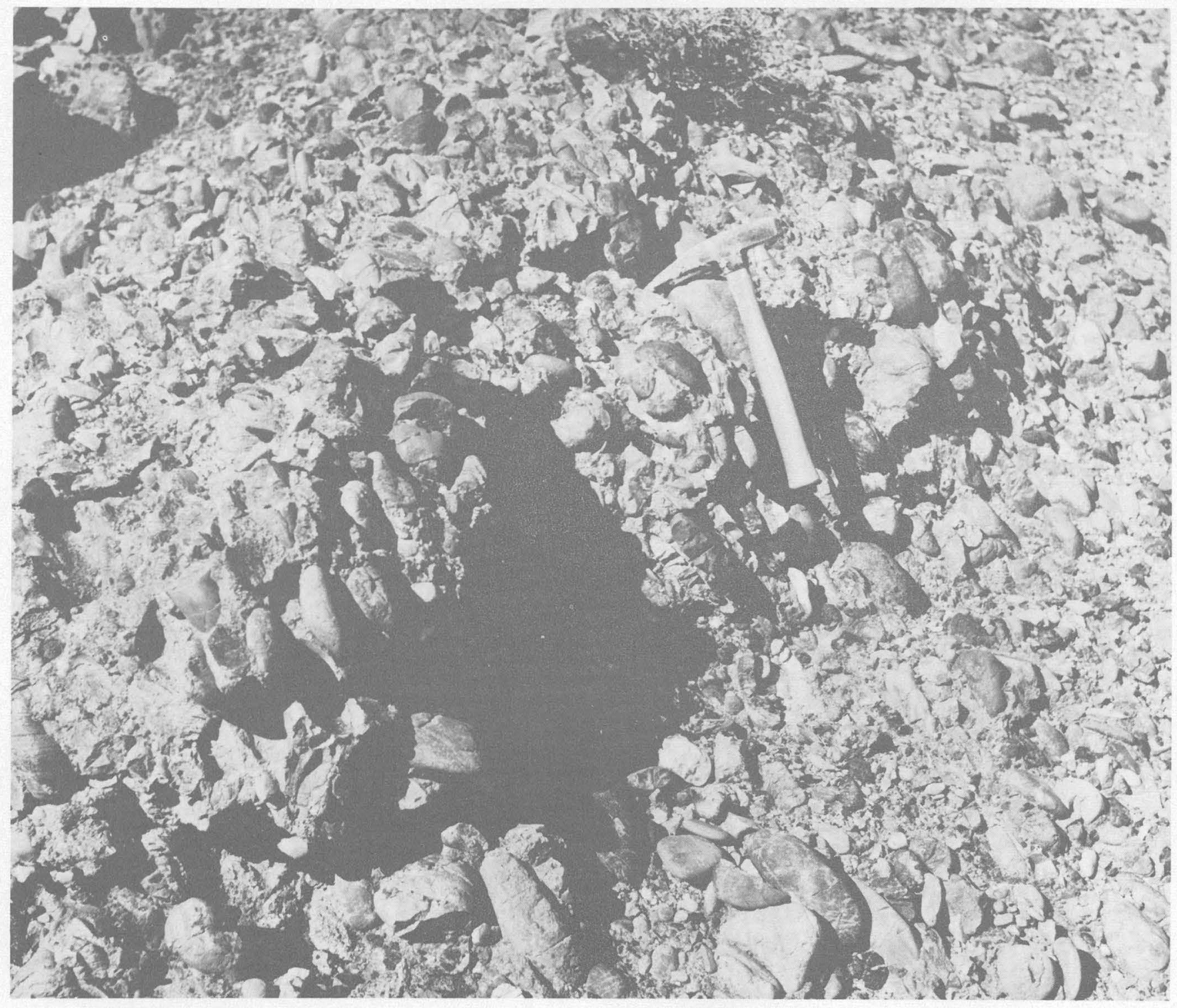

Figure 41. - View of fractured cobble conglomerate in the Titus Canyon(?) Formation of Stock and Bode (1935). The fractures extend through the cobbles and some cross from one cobble to another. They are oriented at right angles to the bedding, which approximately parallels the elongation of the cobbles. Displacements along the fractures are mostly less than a quarter of an inch.

Partial section, Titus Canyon(?) Formation, measured about midway between the Fit Fox Hills and Funeral MountainsContinued

8. Interbedded sandstone, grit, shale, and fine conglomerate. Pebbles of Precambrian rocks as much as $3 / 4$ in. in diameter. Gray unit with salt-and-pepper appearance

9. Conglomerate, with fractured cobbles as large as 6 in. Brown sandstone above and below.

Base concealed.

The uppermost beds in the Titus Canyon(?) Forma tion, estimated to be about 500 feet thick, are light colored and fine grained. The beds are mostly silt and Freet 25 15 sand, in part limy, and very well bedded - even laminated. Dominant colors are yellow and light green. Other beds are platy limestone, mostly brownish, but some are light gray. All these beds are cut by veinlets of gypsum and anhydrite.

Along the northeast side of the Kit Fox Hills the texture of these beds ranges from clay to medium sand. The sandy beds are thickest, some are 8 inches thick; parently is a montmorillonite. Colors are mostly pastel shades of lavender, brown, and red. Overlying these beds are red and buff sandy beds at the base of the buff conglomerate forming the Kit Fox Hills and mapped as Miocene(?). 


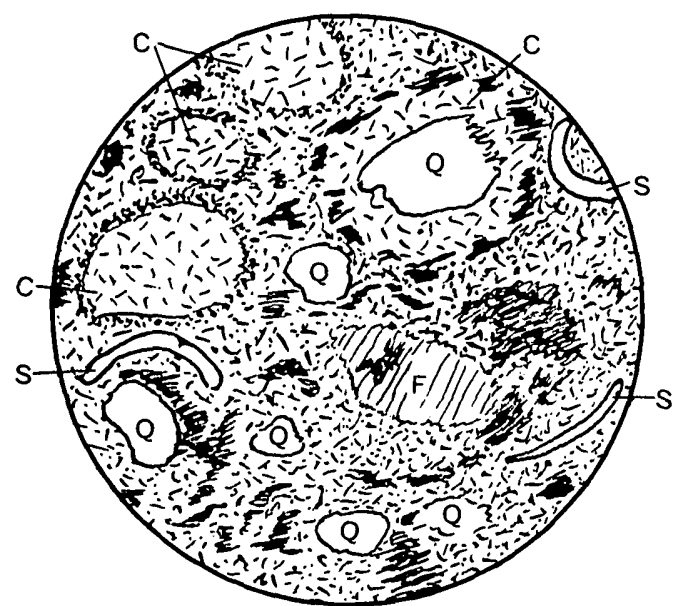

Froure 42.-Micrograph of thin section of greenish clay from the Titus Canyon(?) Formation of Stock and Bode (1935). Diameter of fleld, $2.5 \mathrm{~mm}$. Well-rounded microcrystalline crains, probably chalcedony (C) have cryptocrystalline (or posstbly argillized glass?) rims. Rounded quartz grains $(Q)$ and some feldspar (F) occur in the groundmass; some, like the example in the northenst quadrant, are surrounded by microcrystalline material that is surrounded by an irregular discontinuous rim of highly birefrigent material, probably a clay mineral (black areas). Scattered through the rock are isotropic shards $(S)$; many of these now are holes through the slide as if their glass had been removed by solution. Some rounded grains (not shown) are greenish and might be pollen, but more likely they are stained rims on grains of chalcedony.

In brief, the lowest part of the Titus Canyon (?) Formation appears to be fanglomerate. The middle part contains conglomerate interbedded with fine-grained beds. The upper part seems to be largely a playa deposit.

Some analyses of trace elements in beds of the Titus Canyon(?) Formation are given in table 16. The tuff is similar to the volcanics in the Artists Drive Formation (table 15).

As noted by Noble and Wright (1954, p. 149), these beds are similar to the Titus Canyon Formation which, in the Grapevine Mountains north of this area, has yielded Oligocene vertebrate fossils (Stock and Bode, 1935). The beds probably also correlate with the lower part of the formations in the Artists Drive area (Noble and Wright, 1954, p. 149) in the northern part of the Black Mountains.

The faults along the foot of the Funeral Mountains north of Echo Mountain dip $25^{\circ}-30^{\circ}$ towards Death Valley. The Titus Canyon(?) Formation was deposited against the fault surface and subsequently faulted down against it.

\section{MIOCENE(?) FORMATIONS}

Tertiary deposits in the Kit Fox Hills and in the fault blocks southeastward to the foot of the Funeral
TABLE 16.-Trace elements in beds correlated with the Titus Canyon(?) Formation of Stock and Bode (1935)

[Semiquantitative spectrographic analyses, by E. F. Cooley, U.S. Geol. Survey. Values in parts per million, except $\mathbf{M g}$, which is given in percent]

\begin{tabular}{|c|c|c|c|c|}
\hline Element & \multicolumn{2}{|c|}{ Greenish beds } & \multirow{2}{*}{$\begin{array}{r}\text { Tuff } \\
10\end{array}$} & \multirow{3}{*}{$\frac{\begin{array}{c}\text { Gritty } \\
\text { sandstone, } \\
\text { brown }\end{array}}{20}$} \\
\hline $\mathrm{Pb} \ldots \ldots$ & 50 & 70 & & \\
\hline Mn $\ldots \ldots$ & 150 & 500 & 200 & \\
\hline $\mathrm{Cu}_{\ldots} \ldots \ldots$ & 70 & 100 & 5 & 100 \\
\hline $\mathrm{Zr}$ & 500 & 300 & 300 & 100 \\
\hline $\mathrm{Ni}_{-}$ & $<5$ & 50 & 5 & 10 \\
\hline Con_-n- & $<10$ & 10 & $<10$ & 10 \\
\hline 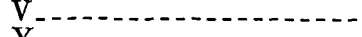 & 30 & 200 & 10 & 100 \\
\hline 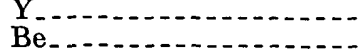 & 100 & 50 & 20 & 20 \\
\hline 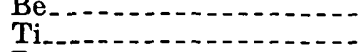 & 3,000 & 7. 000 & 2,000 & 3,000 \\
\hline B $-\ldots-1, \ldots$ & 200 & 700 & 200 & 100 \\
\hline La & 50 & 50 & 50 & $<50$ \\
\hline 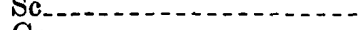 & $<10$ & 20 & $<10$ & $<10$ \\
\hline Cr & 20 & 150 & 10 & 70 \\
\hline $\mathrm{Ba}_{\ldots} \ldots \ldots \ldots$ & 700 & 700 & 500 & 2,000 \\
\hline 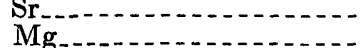 & $\begin{array}{r}300 \\
1\end{array}$ & $\begin{array}{r}300 \\
5\end{array}$ & $\begin{array}{l}70 \\
0.3\end{array}$ & 1,000 \\
\hline & & & & \\
\hline
\end{tabular}

Note-All samples showed: As $<1,000 ; \mathrm{Sn}<10$; $\mathrm{Ge}<20$; $\mathrm{Ga}<20$; $\mathrm{Cd}<50$; In $<50 ; \mathrm{Sb}<200 ; \mathrm{Tl}<100 ; \mathrm{Ta}<50 ; \mathrm{W}<50 ; \mathrm{Ag}<1$.

Mountains constitute an intermediate belt between the outcrops of the Titus Canyon(?) Formation of Stock and Bode (1935) and those of the Furnace Creek Formation (fig. 40). The deposits, estimated to aggregate about 4,000 feet thick, are thought to overlie the Titus Canyon(?) Formation and to underlie the Furnace Creek Formation, but because of the faulting, this sequential relationship has not been established, and the stratigraphic position is assumed.

The color of these deposits tends towards buff and light red; it is suggestive of coarse facies of the Muddy Creek Formation-which is considered to be of Pliocene(?) age and which is extensive east of Death Valley. The Titus Canyon (?) Formation tends to be much darker, and the Furnace Creek Formation tends to be much lighter.

In the Kit Fox Hills the deposits are mostly reddish conglomerate containing quartzite and chert cobbles. Limestons, dolomite, and volcanic cobbles make up a minor part. A pebble count near the north side of the hills showed the following percentages: Red and purple quartzite and chert, 40; sandstone, 40; shale, 10; schist, 5 ; other, 5 . This suggests a source in the northern part of the Funeral Mountains.

Along the south side of the Kit Fox Hills the felsite cobbles increase to about 15 percent, and limestone and dolomite to about 10 percent. Southeastward along the Kit Fox Hills the volcanic rocks in the cobbles increase to 35 percent; at one place a count showed 60 percent volcanic rocks. The other materials are chiefly quartzite and chert rather than carbonate rocks. 
Northwestward the lower part of the conglomerate grades into fine-grained sedimentary deposits, and this, too, suggests a source to the northeast. Probably the conglomerate was thin, if ever present, northeastward across the belt of the Titus Canyon(?) Formation. Very possibly that area was a pediment that ended along a southward-facing fault scarp at about the position of the present northeast-facing edge of the Kit Fox.Hills; if so that area could have been bypassed by the Miocene (?) deposits.

Along the northeast side of Cottonball Basin are three bare hills of red conglomerate similar to that in the Kit Fox Hills. The conglomerate is about 1,400 feet thick at the southeasternmost hill, 1,000 feet thick at the middle one, and about 900 feet thick at the northwest one. Three-quarters of the cobbles and pebbles are quartzite and chert; the remainder are volcanics and carbonate rocks. This conglomerate, like that in the Kit Fox Hills, probably was derived from the northern part of the Funeral Mountains. Fossiliferous limestone and dolomite from the Paleozoic formations, which compose a large fraction of the conglomerates in the Furnace Creek Formation, are notably lacking in these Miocene (?) deposits.

This conglomerate is overlain by about 350 feet of white and gray tuffaceous beds containing thin reddish beds with pebbles, perhaps reworked from the conglomerate and marking an unconformity. Overlying these beds and marking the top of the deposits mapped as Miocene(?) is a brown sandstone unit about 1,500 feet thick.

The brown sandstone unit consists of brown limy grit, limy sand, friable sandstone, thin-bedded limestone, and a little greenish silt and shale. A few layers are pebbly. Limy beds are a few inches thick and are strikingly ripple marked. Sandy beds are 1-8 feet thick. Figure $43 D$ is a micrograph of a thin section of a limy sandstone bed. Unidentifiable stem fragments of monocotyledonous plants are common, and animal tracks have been reported in these brown beds (H. D. Curry, oral commun., 1960), but no identifiable fossils have been found.

The light-colored tuffaceous beds and the brown sandy beds that overlie the conglomerates and that have been taken as the top of the deposits mapped as Miocene(?) are transitional between the Miocene(?) and Furnace Creek Formation. They could as well have been included with the Furnace Creek Formation.

Underlying the conglomerate that forms the bare hills northeast of Cottonball Basin, and between those hills and the Funeral Mountains, is a series of sandy and tuffaceous beds aggregating about 3,000 feet thick. A section northeastward from Cottonball Basin shows the following:

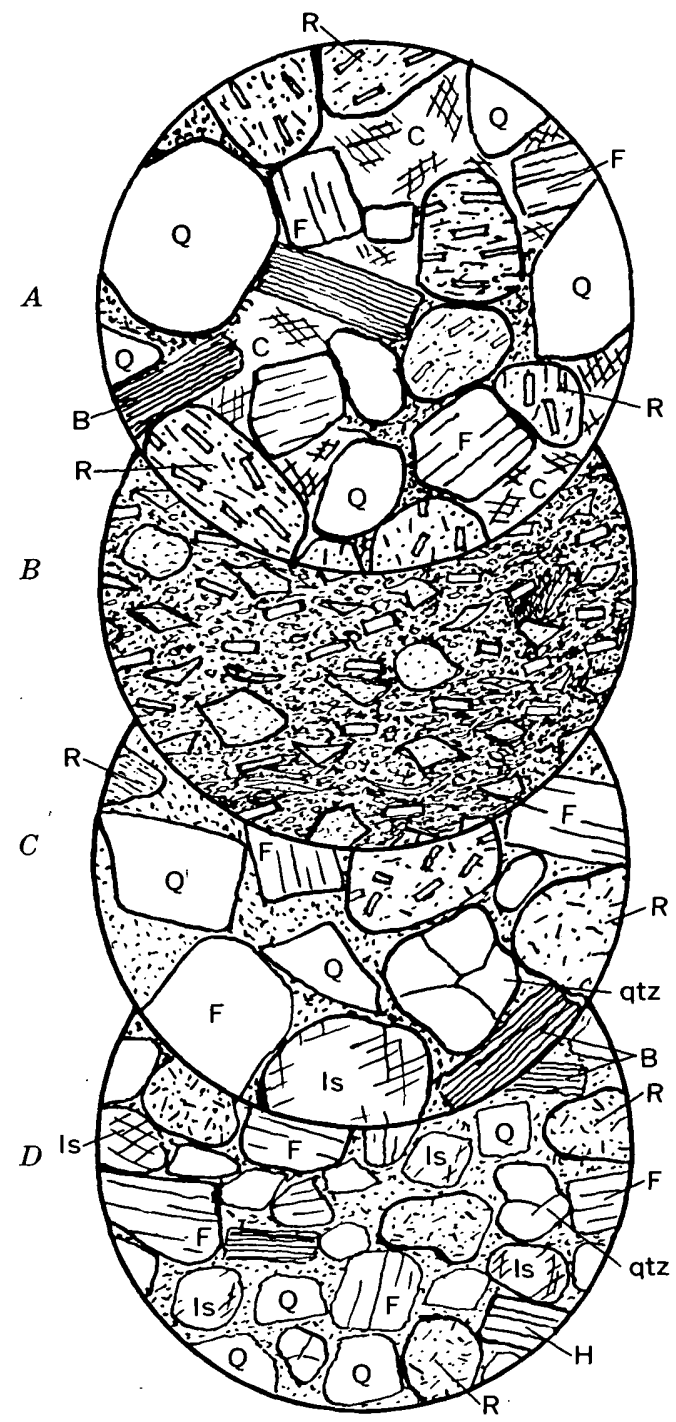

Figure 43.-Micrographs of thin sections of sedimentary rocks from Miocene(?) formations northeast of Cottonball Basin. Q, quartz; $F$, feldspars ; $H$, hornblende ; $B$, blotite ; $C$, calcite ; $R$, volcanic rock ; atz, quartzite ; Is, limestone or dolomite. Diameter of fields, $2.5 \mathrm{~mm}$. $A$, Crystal tuff from lower part of the Miocene(?) beds. The matrix is calcite, fine glass fragments, and clay. Crystals are quartz, feldspars, blotite, and fragments of glassy volcanic rocks. $B$, Clayey tuff. Rectangular crystals are mostly feldspar, some mica. Shards of glass are angular. Matrix clay. C, Arkose from near the middle of the Miocene(?) formations. Differs from $A$ in having greater variety of volcanic rock fragments, quartzite, limestone or dolomite, both argillized orthoclase and plagioclase feldspar; also has quartz and biotite. Matrix silty clay. $D$, Brown calcareous sandstone at top of the Miocene (?) formations. Grains are quartz, argillized orthoclase, microcline, and plagioclase feldspar, hornblende, biotite, limestone or dolomite, quartzite, volcanic rocks of several kinds. Matrix is calcareous clay. 
Section northeastward from Cottonball Basin to the Funeral Mountains

Top. Red conglomerate forming bare hills at northeast edge of the basin.

1. White and light-gray tuffaceous sandstone, some grit, very little conglomerate; pebbles isolated from one another. Beds 1-2 ft thick and well laminated..--

2. Brown limy sandstone, grit, conglomerate, and interbedded tuffaceous sandstone. Brown limy beds comprise about half the unit; they are resistant and form the most conspicuous outcrops. Conglomerate beds are pebbly, with only a fow cobbles. Pebbles are well rounded, partly polished; mastly various kinds of felsite and not many are of Precambrian or Paleozoic rocks

3. Buff and yellow arkosic sand and silt (fig. $43 C$ ), some thin beds of gray.tuffactous sandstone. Well bedded and finely laminated.

4. Conglomerate, reddish; subround and subangular pebbles, cobbles, and boulders as much as $5 \mathrm{ft}$ in diameter; boulders larger than 2 ft not common; most large boulders are a banded purple quartzite containing quartz veins as wide as $1 / 2$ inch; also present are cobbles of bull quartz. Source evidently was the Chloride Cliff district in the Funeral Mountains. Other materials include red and green banded quartzite, sandy dolomite. Sorting poor; beds are 1-3 ft thick and contain all sizes of materials. Many boulders and cobbles are slabby ; their long axes parallel the bedding. Estimated size proportions: 15 percent larger than 6 in. ; 45 percent $1-6$ in. ; 40 percent less than 1 in., including matrix

The conglomerate at the base of the section is a resistant unit that forms hills along the foot of the Funeral Mountains and in places lies against the frontal fault. Away from the fault the conglomerate seems to grade into and be intertongued with red sandstone that is in part tuffaceous (fig. $43 A, B$ ). The tuffaceous layers are as much as 5 inches thick, and are separated by beds of fine-grained sandstone $1 / 2-2$ inches thick. The sandstone contains shale laminae and is silty; it grades downward into light-colored beds thought to be the upper unit of the Titus Canyon(?) Formation.

The composition of the tuffaceous rocks varies widely, depending on the proportion of volcanic debris to the clastics from the Precambrian. In table 17 the contrast is illustrated by analyses of three random samples from this part of the section.

In the Artists Drive area and in the Amargosa thrust complex the tuff differs in composition from the felsites, being notably higher in strontium and lower in titanium. Systematic chemical analyses of these volcanic rocks might help determine whether they are more closely related to those in the Amargosa thrust complex in the Black Mountains or to those in the rhyolite district northeast of the Funeral Mountains.
Table 17.-Trace elements in the Miocene(?) deposits [Semiquantitative spectrographic analyses by E. F. Cooley, U.S. Geol. Survey. Values in parts per million, except $\mathrm{Mg}$; which is given in percent]

\begin{tabular}{|c|c|c|c|}
\hline Element & $\begin{array}{c}\text { Tuffa- } \\
\text { ceous } \\
\text { sandstone }\end{array}$ & Tuff & $\begin{array}{c}\text { Tan limy } \\
\text { sandstone } \\
\text { at top } \\
\text { of for- } \\
\text { mation }\end{array}$ \\
\hline 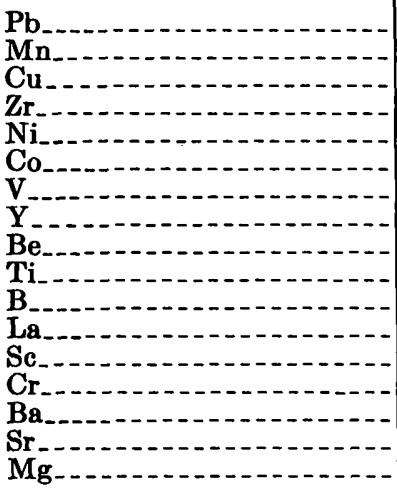 & $\begin{array}{r}15 \\
1,000 \\
30 \\
200 \\
20 \\
7 \\
70 \\
20 \\
<1 \\
5,000 \\
100 \\
50 \\
10 \\
70 \\
500 \\
300 \\
1.5\end{array}$ & $\begin{array}{r}10 \\
50 \\
10 \\
50 \\
<5 \\
<5 \\
10 \\
10 \\
1 \\
700 \\
70 \\
<50 \\
<10 \\
15 \\
300 \\
1,000 \\
0.5\end{array}$ & $\begin{array}{r}20 \\
1,000 \\
70 \\
300 \\
10 \\
10 \\
100 \\
50 \\
<1 \\
5,000 \\
100 \\
50 \\
10 \\
20 \\
1,500 \\
700 \\
3\end{array}$ \\
\hline
\end{tabular}

Nore.-All samples showed: As $<1,000 ; \mathrm{Zn}<200 ; \mathrm{Sn}<10 ; \mathrm{Ge}<20 ; \mathrm{Ga}<20 ; \mathrm{Cd}<50$

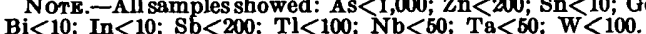

Despite uncertainties, the stratigraphy of these Miocene(?) deposits around Cottonball Basin does help in interpreting the structural history. The northwesttrending Furnace Creek fault zone is suspected to have had considerable lateral displacement (Noble and Wright, 1954, p. 153), but these Miocene(?) deposits are not offset laterally from their probable source in the Funeral Mountains. However, there may have been lateral displacement along faults farther to the southwest.

\section{PLIOCENE FORMATIONS}

Pliocene deposits are represented by the Furnace Creek Formation, which outcrops at the north end of the Black Mountains and northward from there to the fault along the southwest side of the Miocene(?) deposits (fig. 40). The formation probably underlies Cottonball Basin, for it reappears northwest of there in the anticlinal uplift at the Salt Creek Hills.

At the north end of the Black Mountains the formation is more than 5,000 feet thick and consists in large part of fine-grained light-colored playa deposits (fig. 44). Interbedded with the playa deposits are conglomerates and some basalts.

The formation consists of a basal conglomerate of variable thickness, but averaging perhaps 200 feet, overlain by 2,500 feet of light-colored fine-grained playa beds. Some of these beds are highly tuffaceous; others are clastic sand or silt (fig. 45). Interbedded with these are basalts and conglomerate beds. Some of the latter thicken westward toward the west front of the Black 


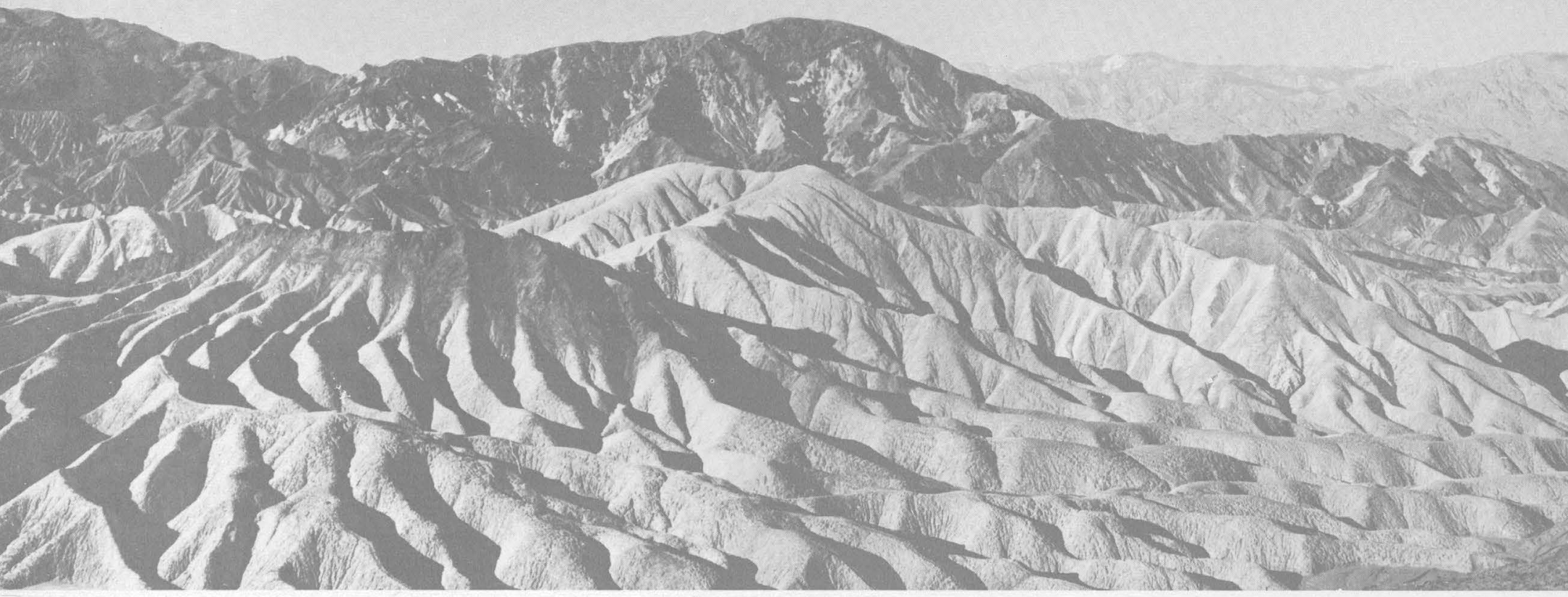

Mountains. The playa beds are overlain by the conglomerate seen at the right side of figure 44. This conglomerate reaches a maximum thickness of about 2,000 feet at the mouth of Furnace Creek. It is overlain by another series of playa beds about 1,300 feet thick. Younger units of the formation, if any, are concealed under the Pliocene and Pleistocene(?) Funeral Formation in the trough of the Texas Spring syncline (fig. 40).

The basal conglomerate is composed mostly of cobbles of Palezoic limestone and dolomite, and there are boulders as much as a foot in diameter. Among these cobbles are fossiliferous rocks from upper Paleozoic formations - fusulinid limestone from Pennsylvanian or Permian formations; granular limestone containing large crinoid fragments, almost certainly from the Tin Mountain Limestone or younger limestone; black dolomite like that of the Tin Mountain; and limestone containing Cyrtospirifer from the Lost Burro Formation. These fossiliferous cobbles may have been brought from the northwest, possibly from Tucki Mountain but more likely from farther north in the Panamint Range. About 65 percent of the cobbles are Paleozoic carbonate rocks; 10 percent are quartzite, 20 percent are volcanics, and a few percent are granite and miscellaneous other types. The granite does not look like the granites at
Frguri 44.-View of Furnace Creek Formation at north end of the Black Mountains. Vlew is southwest and west from Zabriskie Point, an overlook by Highway 190 about 3 miles up Furnace Creek Wash from Furnace Creek Inn. The base of the Furnace Creek Formation is at the topographic break between the badlands and the rougher and higher ground in the distance at the left. Light-

Skidoo or at Hanaupah Canyon, and it is different in its trace elements. It contains a tenth as much lead and five times as much copper as do the Skidoo and Hanaupah granites. Its content of zirconium is only a fifth as great, and it contains 10 times as much boron, 10 times as much strontium, 4 times as much vanadium and cobalt, and twice as much nickel as do the other granites.

The percentage of volcanic rocks among the cobbles is low, considering that this basal conglomerate unconformably overlaps volcanic and other deposits of formations in the Artists Drive area. The proportion of voleanic rocks may increase southeastward, but such change was not determined.

Whereas the basal conglomerate of the Furnace Creek Formation seems to have been derived in large part from the northwest, the conglomerate that outcrops at the mouth of Furnace Creek Wash and caps the lower playa beds member of the formation, seems to have been derived mostly from the Black and Funeral Mountains. 'This conglomerate thins southeastward. At the mouth 


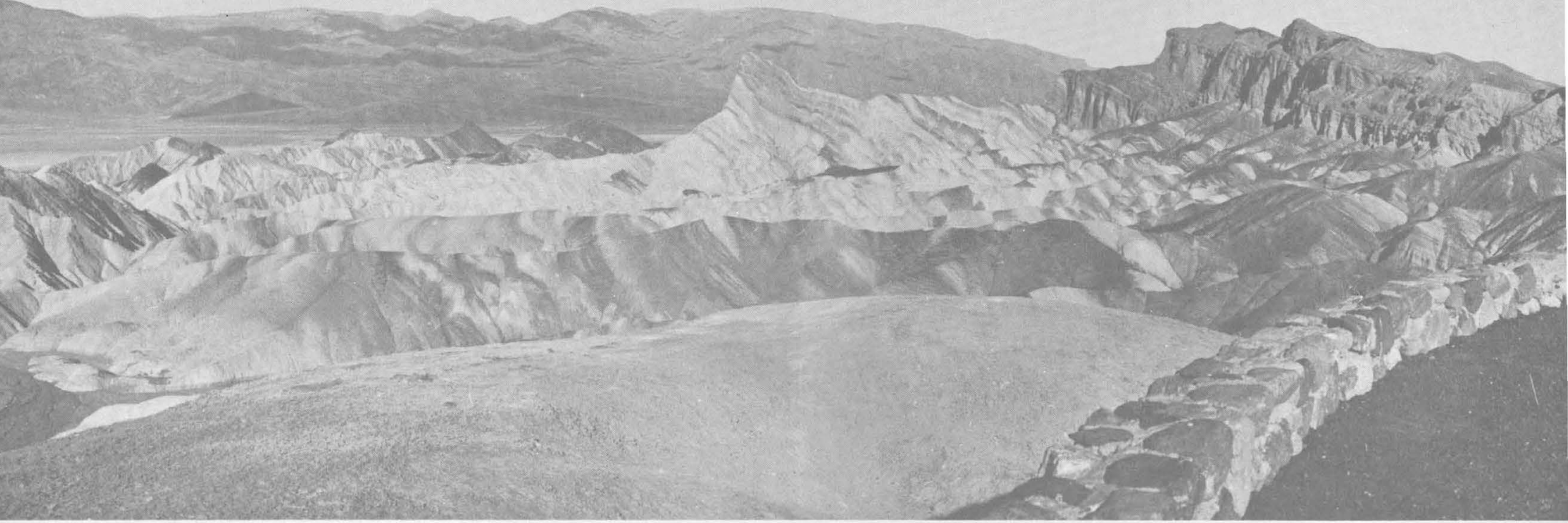

colored playa beds about 2,500 feet thick extend to the base of a conglomerate which forms the dark cliff at the right. The beds are dipping to the right (north) into the Texas Spring syncline. Center of the picture looks west across Death Valley to the Panamint Range at Aguereberry Point; Tucki Mountain is at the right. Panorama by John Stacy.

of Furnace Creek it is 1,800 feet thick. Two miles southeast from there it is 1,600 feet thick, and in another 2 miles it is only 1,000 feet thick.

On the other hand, the proportion of volcanic rocks in the conglomerate increases southeastward as the conglomerate thins, from 10 percent at the mouth of Furnace Creek to 20 percent where the formation is 1,600 feet thick and to 40 percent where the thickness is down to 1,000 feet. The proportion of quartzite and carbonate rocks changes irregularly. At the mouth of Furnace Creek there is 75 percent carbonate and 15 percent quartzite and other clastics; 2 miles southeastward the percentages are 30 and 45 , respectively; and where the formation is 1,000 feet thick, the percentages are 50 and 10. These rocks look like early Paleozoic types and probably came from the southern part of the Funeral Mountains.

Another conglomerate, perhaps 200 feet thick, is found along the west front of the Black Mountains in the playa beds about half way between the basalt conglomerate and the one that crops out at the mouth of Furnace Creek. This conglomerate is composed very largely of volcanic debris and thins southeastward, as if from a source at the site of Death Valley, or a source west of the valley, perhaps, in the Amargosa thrust complex.

The contrast in sources of the different materials also shows well in some of the fine-grained playa beds(fig. $45)$. Some of these beds are largely of volcanic materials; others are largely from Precambrian or Paleozoic formations.

Probably there was a playa elongated northwestward at the present site of the north end of the Black Mountains, formerly the north base of a pile of felsitic volcanics (formations at Artists Drive) that had accumulated on the Precambrian rocks farther south in the Black Mountains. Most of the fine-grained sediments deposited in the playa were derived from the volcanic pile to the south, but deposition was interrupted by influxes of coarse gravels from the northwest, presumably in response to structural movements in that area. During the second half of the time represented by the Furnace Creek Formation an increasing amount of sediment was brought from the south end of the Funeral Mountains.

Lateral changes in thickness and geochemistry of the playa beds suggest that the central part of the Pliocene playa was a short distance east of the present edge of 


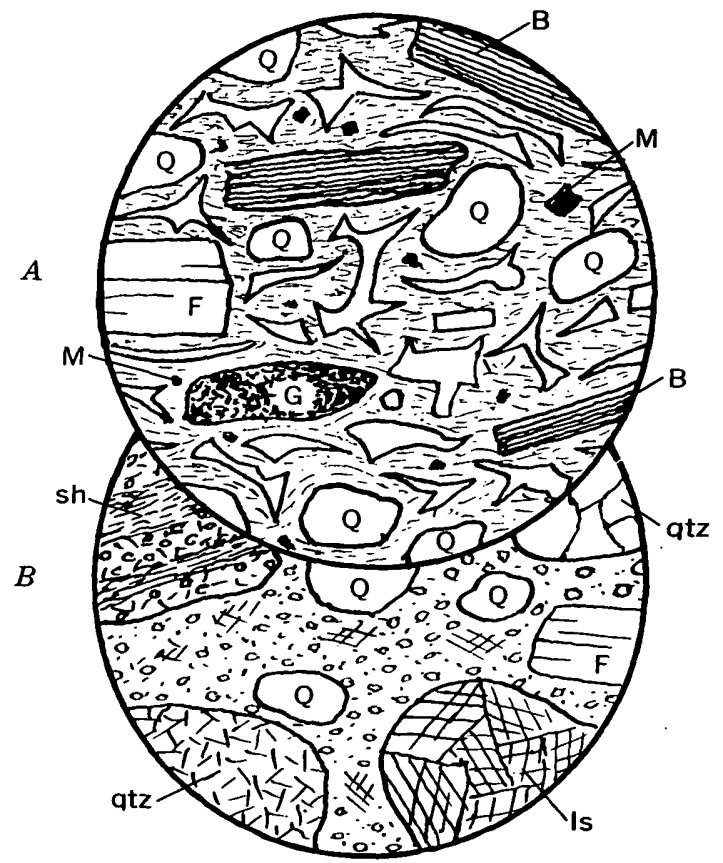

Figorn 45.-Micrographs of thin sections of playa deposits in the Furnace Creek Formation. Q, quartz; $F$, feldspar ; $B$, biotite ; $M$, magnetite ; $G$, volcanic glass ; $a t z$, quartzite; Is, dolomite or limestone; sh, shale or schist. Diameter of fields, $2.5 \mathrm{~mm}$, $A$, tuff layer an ash fall. Angular shards of volcanic glass mixed with grains of quartz, blotite, feldspar, magnetite, and rounded grains of volcante glass are in a matrix of sericite, quartz, and feldspar. $B$, poorly sorted sandy silt of clastic sediments, probably derived chiefly from the Funeral Mountains. The large grains are quartzite, both fine grained and coarse grained, dolomite or limestone, shale or schist, and scattered small grains of quartz and feldspar in a calcareous clay with minute grains of quartz.

the saltpan in Cottonball Basin. Playa beds there are highly saline. At the East Coleman Hills, which are at the north tip of the outcrop area at the north end of the Black Mountains (fig. 40), the upper playa beds are at least 2,400 feet thick and contain sulfates and borates. About a mile southeast the upper playa beds are about 1,300 feet thick, and some contain abundant veins of gypsum. Farther to the southeast, along the flank of the Texas Spring syncline, these beds continue to thin to about 650 feet and contain less sulfate, almost no chlorides, and more carbonate and granular tuff.

The lower playa beds of the formation contain thick deposits of gypsum and of borates that were productive during the days when the 20 -mule teams operated. These deposits are southeast of those in the upper playa beds as if the sulfate-borate zone shifted northwestward towards Cottonball Basin. Today it is located at the edge of the saltpan.

At the Salt Creek Hills, about 2,500 feet of lightcolored playa beds of the Furnace Creek Formation are
TABLE 18.-Trace elements in the Furnace Creek Formation [Semiquantitative spectrographic analyses by E. F. Cooley, U.S. Geol. Survey. Values in parts per million, except $\mathrm{Mg}$, which is given in percent]

\begin{tabular}{|c|c|c|c|c|c|}
\hline Element & Tuff & Basalt & Element & Tuft & Basalt \\
\hline 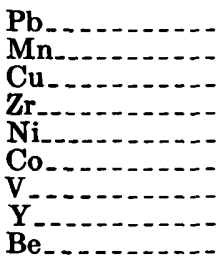 & $\begin{array}{r}70 \\
500 \\
50 \\
50 \\
10 \\
<5 \\
10 \\
15 \\
3\end{array}$ & $\begin{array}{r}20 \\
1,000 \\
70 \\
150 \\
200 \\
70 \\
150 \\
20 \\
<1\end{array}$ & $\begin{array}{l}\text { Ti } \\
\mathbf{B} \\
\mathrm{L} \mathbf{B} \\
\mathrm{Se} \\
\mathrm{Cr} \\
\mathrm{Ba} \\
\mathrm{Sr} \\
\mathrm{Mg}\end{array}$ & $\begin{array}{r}500 \\
100 \\
<50 \\
<10 \\
20 \\
30 \\
70 \\
0.2\end{array}$ & $\begin{array}{r}10,000 \\
100 \\
100 \\
20 \\
300 \\
1,500 \\
3,000 \\
5\end{array}$ \\
\hline
\end{tabular}

Note-Both samples showed: As $<1,000 ; \mathrm{Zn}<200 ; \mathrm{Sn}<10 ; \mathrm{Ge}<20 ; \mathrm{Gr}<20$; Cd $<50$; $\mathrm{Bi}<10$; In $<10$; $\mathrm{Sb}<200$; $\mathrm{Ti}<100 ; \mathrm{Nb}<50$; $\mathrm{Ta}<50$; $\mathrm{W}<100$.

exposed in an asymmetrical anticline. Westward along Salt Creek, basaltic (or andesitic) lavas and conglomerate are inter bedded with the playa beds. The conglomerate contains boulders of granite that may be part of a boulder train extending southeastward to the north end of the Black Mountains.

Analyses of trace elements in a tuff and a basalt from the Furnace Creek Formation are given in table 18. The tuff has more lead, manganese, and copper, and less barium and strontium than does the tuff near the base of the Miocene(?) deposits (compare with table 17). The basalt differs from those in the Amargosa thrust complex (compare with table 26) in its higher content of nickel, boron, lanthanum, chromium, and strontium.

Diatoms collected from the top and base of the Furnace Creek Formation indicate that it spans much of Pliocene time. The diatoms were collected by $\mathrm{K}$. E. Lohman (written commun., 1961), of the U.S. Geological Survey. A collection near the base of the formation is described as follows:

Loc. 4159. Hard calcareous tufa immediately overlying intrusive basalt, SW1/4NE1/4 sec. 27 , T. 26 N., R. 2 E., Ryan 15-minute quad. Assigned to early Pliocene on basis of incomplete, partly altered diatom assemblage.

The collection from near the top of the formation is described as follows (written commun., 1961) :

Loc. 40\%0. 1.15 miles northwest of Travertine Point on Highway 190 , roadcut in south side. Ryan 15-minute quad. Hand gray limestone containing an abundant and well-preserved diatom assemblage extraordinarily similar to a diatom assemblage from a diatomite in Sand Pedro Valley, Ariz., which has yielded a vertebrate fauna of middle Pliocene age. Loc. 4070 has therefore been assigned to the middle Pliocene.

Other plants from the Furnace Creek Formation, reported by Axelrod (1940), also indicate a Pliocene age for this formation. 
PLIOCENE AND PLEISTOCENE( ( ) DEPOSTTS-FUNERAI FORMATION

The Funeral Formation crops out extensively in the fault blocks that extend northwest from Furnace Creek along the east side of Cottonball Basin, in small areas in the Artists Drive fault blocks and near Mormon Point, and in an extensive area along Emigrant Wash and about as far as its head.

In Furnace Creek Wash and around Cottonball Basin, fanglomerate of the Funeral Formation rests conformably on the light-colored playa deposits of the Furnace Creek Formation. On the Artists Drive fault blocks the fanglomerate overlies volcanic and other rocks of the Artist Drive Formation with an angular unconformity. At Mormon Point the fanglomerate overlaps Precambrian rocks and is faulted against them. Along Emigrant Wash the fanglomerate overlies and is faulted against the turtleback surface on the west foot of Tucki Mountain (p. A143), and it overlies and is faulted against the west flank of the granite at Skidoo.

In the absence of fossils, it is doubtful that these widely separated deposits are of the same age. On the basis of diatoms in the upper part of the Furnace Creek Formation, it seems likely that the overlying Funeral Formation there is Pliocene and early Pleistocene(?). A Miocene age originally was assumed for the fanglomerate at the head of Emigrant Wash (Hopper, 1947), but more recently a Pliocene age has been inferred for those deposits on the basis of pollen obtained from them (Axelrod and Ting, 1960).

Included in the Funeral Formation at the north end of the Artists Drive fault blocks is a mass of quartzite breccia believed to be a chaotic breccia derived from the Zabriskie Quartzite (p. A25). How it became emplaced remains a mystery. Other blocks of Paleozoic rocks in that area are found along faults and are far removed from masses of the Paleozojc formations that might have supplied them. Perhaps they are blocks of chaos associated with low-angle faulting. The beds mapped as the Funeral Formation in the Salt Creek Hills have been regarded by Curry (1939) as Pleistocene on the basis of tracks found in them.

In Emigrant Wash the Funeral Formation is at least 3,000 feet thick; it was originally referred to as the Nova Formation (Hopper, 1947). It consists in large part of cobbles and boulders of Precambrian rocks like those on the high part of the Panamint Range; consequently, the formation has been thought to have been derived from that direction. However, Axelrod and Ting (1960') report that the formation becomes coarser grained westward and indicate a western source from the direction of Panamint Valley. This interpretation involves major topographic changes like those indicated by the southeastward-thinning gravels in the Furnace Creek Formation in the Black Mountains (p. A60). The Funeral Formation at the head of Emigrant Wash may record similar changes, but I gave the deposit there only cursory examination.

On the Artists Drive fault blocks the Funeral Formation is composed largely of debris from the volcanic formations. The Funeral unconformably overlaps the much-faulted and tilted rocks of the Artists Drive formation and includes flows of basaltic lava and some beds of volcanic ash as much as 4 feet thick. It dips westward under the playa where a drill hole on the floor of the saltpan opposite Artists Drive encountered 400 feet of fanglomerate with basaltic cobbles believed to be the Funeral. This hole, the $\log$ of which is given on page $A 74$, did not reach the base of the formation. The Black Mountains must already have been high ground, shedding debris westward, but the vulcanism was continuing while these fanglomerate beds of the Funeral Formation were being deposited.

Along Furnace Creek only about 150 feet of fanglomerate of the Funeral Formation is exposed in the trough of the Texas Spring syncline and in the fault blocks farther north. A mile east of Zabriskie Point the fanglomerate is composed largely of volcanic rocks, commonly as much as 2 feet in diameter. Northward from Furnace Creek Wash the gravel contains increas. ing proportions of Paleozoic carbonate rocks and lower Paleozoic clastic rocks reflecting the composition of the source rocks in the Funeral Mountains. Near Echo Canyon the gravel contains about 70 percent carbonate rocks and 30 percent quartzite; from Echo Canyon north to Nevares Spring the proportions are reversed, carbonate rocks 30 percent, quartzite 70 percent. At Rock Alinement Wash and farther north the gravels are very largely quartzite, only 5-10 percent is carbonate rock. Clearly the Funeral Mountains were in existence and shedding debris into Death Valley when fanglomerate of the Funeral Formation in this area was being deposited, but the faulting and the downfolding into the Texas Spring syncline shows that much of the uplift of the mountains, especially the Black Mountains, was later. I assume that the fanglomerate was being deposited while the mountains were being elevated.

In the East Coleman and Salt Creek Hills the fanglomerate contains boulders of coarse-grained granitic rocks as large as 5 feet in diameter. Their source probably was to the northwest, in the northern Panamint Range, like that of the granite and upper Paleozoic cobbles in the conglomerates of the Furnace Creek Formation (p. A60). 
Except for these granitic boulders, the fanglomerate is not very bouldery. North of Echo Canyon, for example, the common large size is 1 foot in diameter. At one outcrop 11/2 miles from the mountain front (in SE cor. sec. 13 , T. 27 N., R. 1 E.) a cliff 30 feet high and 30 feet long contains only 30 boulders as large as 1 foot in diameter; that is, only 1 per 30 square feet of outcrop. The common large size of the gravel is 6 inches in diameter, and even these cobbles are few. An outcrop 10 by 10 feet exposed 50 such cobbles; that is, 1 per 2 square feet. Three-quarters of a mile downstream the gravel is even less coarse and contains only a third as many small boulders. Similar proportions were found along Echo Canyon Wash.

At most places the fanglomerate is firmly cemented with calcium carbonate. The cemented layers are several feet thick and extend for hundreds of feet along the outcrops, especially where the gravel overlies finegrained sediments so that ground water can be perched on top of the impermeable beds. The cemented layers are particularly thick and extensive in an area extending 2 miles southeastward from Park Village, an area that has many springs. The gravel also is cemented in the axis of the Texas Spring syncline down dip from Travertine Spring and Texas Spring (fig. 2, locs. 2,3).

Where the fanglomerate is cemented with calcium carbonate it is cut by numerous veins of banded calcite, locally referred to as Mexican onyx. These veins, which generally parallel the principal faults, are a few inches to a few feet wide and may be several hundred feet long. Trace elements in the veins are the same and in about the same amounts as in the travertine mounds at springs. Analyses are given in table 20.

Caliche in the Funeral Formation in the Artists Drive area is mostly gypsum rather than calcium carbonate.

The surface of the fanglomerate has developed smooth desert pavement (fig. 50), a surface described more fully in connection with the No. 2 gravel where it is best developed.

The fanglomerate is so faulted, folded, and dissected that its remnants no longers retain their fan form. In the Park Village area, for example, the fanglomerate is in a fault block that forms a ridge about 350 feet high and trends north roughly along the contour of the fans that rise eastward to the Funeral Mountains (figs. 53, 62). Drainage down the fans has become incised across the ridge, and younger gravel deposits lie on both sides of it. The incised gorges are older than Lake Manly ( $p$. A69). At the Salt Creek Hills the Funeral Formation is raised in a faulted structural dome having at least 250 feet of structural relief. Salt Creek is incised across this dome.
In both these areas fanglomerates of the Funeral unconformably overlie deposits of late Pliocene age that are uplifted more than the fanglomerate. The deformation clearly began in Pliocene time and then continued. Very likely the deformation progressed in small increments over a long period of time, and the drainage probably is antecedent-or anteposed (Hunt, 1956, p. 65)-across the uplifts. That is to say, the drainage incised across the uplifts probably was dammed repeatedly as uplift progressed, but the ponded streams overflowed along their old channels. The result is aggradation upstream from the dam, giving some suggestion of superposition in that direction; but downstream the drainage would be antecedent or consequent.

\section{QUATERNARY SYSTEM}

PLEISTOCENE DEPOSITS

NO. 2 GRAVEL

The No. 2 gravel unconformably overlaps fanglomerate of the Funeral Formation along Furnace Creek Wash and differs from it in being less well consolidated, more bouldery, and less faulted, tilted, and dissected, so that it retains its fan form. The No. 2 gravel lacks calcite veins; but it does have layers cemented with calcium carbonate, although these are thinner and less extensive than in the Funeral Formation. The No. 2 resembles the Funeral in having surfaces mantled with smooth desert pavement composed of disintegrating blocks, slabs, and flakes.

The No. 2 gravel can be distinguished from the younger ones, Nos. 3 and 4 , in at least six ways:

1. The No. 2 gravel forms the highest benches above the present drainage.

2. The low parts of the No. 2 gravel are overlapped by the younger gravels.

3. The No. 2 gravel is more bouldery than the younger ones.

4. The No. 2 gravel is more cemented.

5. The surface of the No. 2 gravel is smooth desert pavement, whereas the younger gravels have rough surfaces.

6. The streamworn cobbles and boulders on the surfaces of the No. 2 gravel have disintegrated to produce a new crop of angular rock fragments.

Along the foot of the Panamint Range and in front of the Funeral Mountains the No. 2 gravel forms benches 100 feet above the present washes (pl. 2). Toward the saltpan these benches commonly slope more steeply than the average slope of the gravel fans, and their lower edges extend under and are overlaped by the No. 3 and No. 4 gravels (fig. 64). 
The No. 2 gravel contains considerable sand, but mixed with it are boulders many feet in diameter, as well as pebbles and cobbles of intermediate size. The largest granitic boulders are on the fans of Hanaupah and Starvation Canyons where many are more than 10 feet in diameter and some are as large as 30 feet. They are distributed along the entire length of the fan, down to 250 feet below sea level.

These abundant large boulders may indicate exterior drainage at the time they were deposited. No matter what mechanism is considered, vast amounts of water would be required to deposit such coarse debris in sufficient volume to build fans 6 miles long and 3 miles wide. With so much water, there should have been a lake, and had there been a lake, the bouldery deposits should have formed deltas, not fans. These coarse deposits in such large volume, though, pose no problem if Death Valley had exterior drainage to the south at the time they were deposited.

On the fans of Hanaupah and Starvation Canyons granitic rock comprises about 20 percent of the gravel. Sixty percent in quartzite, and about 10 percent is carbonate rocks and argillite.

On Trail Canyon fan, where the gravels contain about equal proportions of quartzite and carbonate rocks and only minor amounts of igneous and metamorphic rocks, the common large size of boulders is 2 feet in diameter, although some are 6 feet. On Johnson Canyon fan, where the gravel consists of about 80 percent quartzite, 10 percent monzonite, and 10 percent carbonate rocks and argillite, the boulders are small like those on Trail Canyon fan.

Northeast of Cottonball Basin the No. 2 gravel contains considerable salt, more salt than occurs in the gravel around the other sides of the saltpan. This is attributed to the winds transporting salt northeastward from the saltpan.

A gravel-filled former channel of Furnace Creek is well exposed along Furnace Creek Wash (fig. 46). Opposite Zabriskie Point this fill contains almost 90 percent carbonate rocks. This differs from fanglomerate of the Funeral in the area, which here contains a high proportion of volcanic rocks; it also differs from the fan gravels derived from the Funeral Mountains north of here, which contain a high proportion of quartzite. The principal source of this channel fill apparently was in the southern part of the Funeral Mountains; the principal source of fanglomerate of the Funeral in the area apparently was the northern part of the Black Mountains.

The downcutting that followed deposition of this channel gravel probably was caused by structural uplift of the wash relative to the present Furnace Creek fan, because the surface of the gravel fill, if projected, would extend about 50 feet above the fan. This uplift probably is the same deformation that raised the small gravel terraces along the west foot of the hills just north and just south of the mouth of Furnace Creek (fig. 47) and that produced hanging valleys along the foot of the Black Mountains farther south (fig. 77).

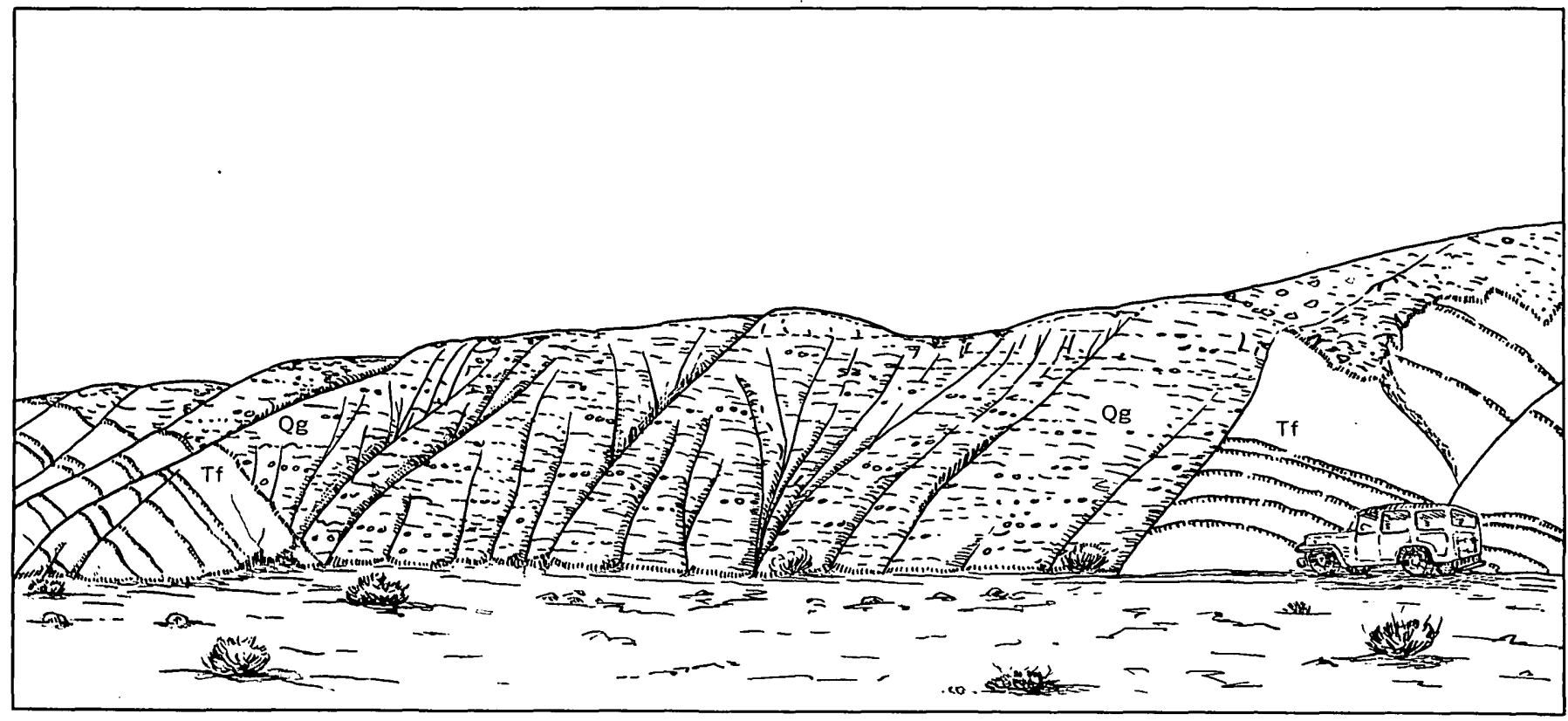

Ficule 46.-Gravel fill in former channel of Furnace Creek Wash. The channel is eroded in Furnace Creek Formation (Tf), which dips steeply northeast (right), and the bottom is below the level of the present wash. The fill ( $\left.Q_{g}\right)$ is about 50 feet thick. Vlew is north in tributary to Furnace Creek Wash opposite Zabriskie Point. 


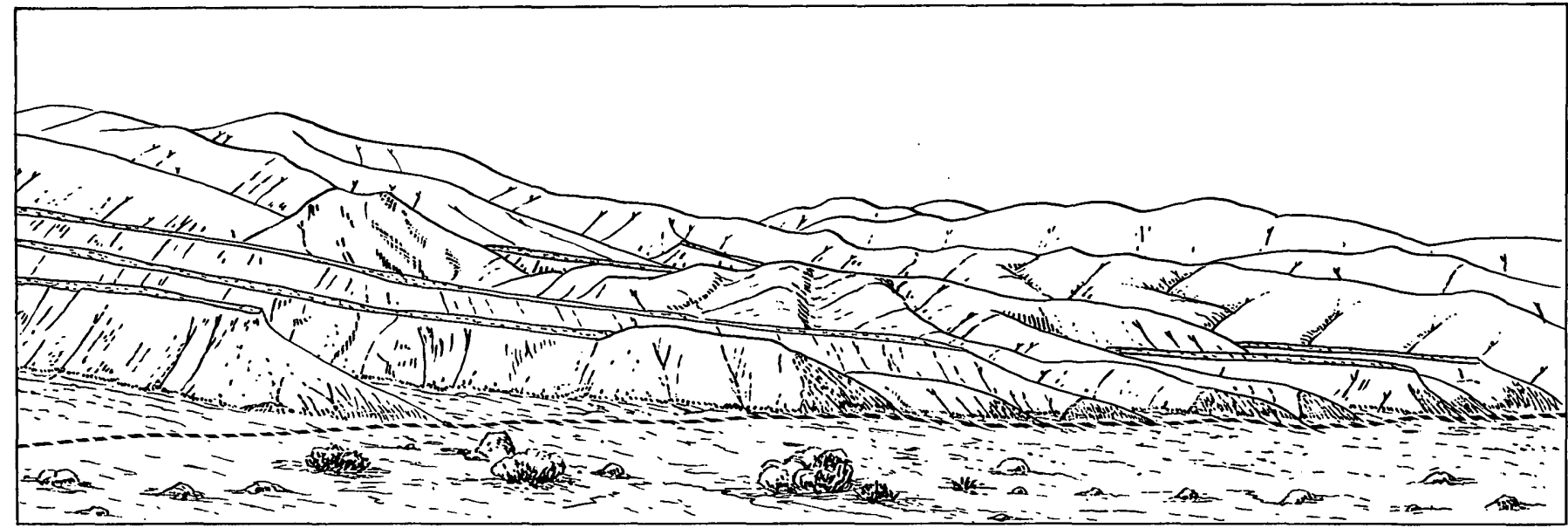

Figdrb 47.-Escarpment along the front of the north end of the Black Mountains a quarter of a mile south of Furnace Creek. The terraces, capped with No. 2 gravel, have been faulted upward about 75 feet.

Other deposits of No. 2 gravel occur in the canyons in the Panamint Range, considerably upstream from the gravel fans. There are sizable remants in most of the canyons, and these remnants are 50-100 feet higher than the present canyon bottoms. Evidently the canyons had been eroded to their present depth before the gravel was deposited, then buried to a depth of 100 feet or more with this gravel and subsequently re-excavated. Interbedded with the gravel in the south fork of Six Spring Canyon is a bed of volcanic ash as much as 4 feet thick.

Drainage on the No. 2 gravels reflects the fan form of the remants of that gravel. Washes are parallel and consequent. Moreover, washes that are a few hundred feet wide and more than about 10 feet deep commonly have low terraces of No. 3 gravel along them.

Karstlike solution features are common where Tertiary rocks are overlain by the No. 2 gravel, such as near Furnace Creek Ranch. On the west side of Death Valley, along the north edge of the wash a mile north of Hanaupah Canyon, there is a depression 15 feet deep, locally referred to as "the crater" in the No. 2 gravel. The depression has a floor of silt about 50 feet in diameter and 60 feet higher than the wash which is on the south side of the depression. This depression probably is due to water seeping from the gravel bench to the wash, dissolving calcium carbonate caliche from the gravel, and allowing the gravel above to collapse.

The fan of No. 2 gravel at Starvation Canyon has three tremendous ridges radiating down the fan and evidently marking old mudflows (fig. 48). The ridges, large enough to show on the topographic contours, are 2-3 miles long, 500-1,000 feet wide, and 50-75 feet high. Their volumes are 8-25 million cubic yards. Each ridge has a narrow crest with a wash along it; the sides are strewn with huge boulders and slope evenly to the adjoining fan surfaces.

The surface of the No. 2 gravel is smooth desert pavement. Boulders and cobbles on these surfaces have disintegrated to produce an entirely new crop of angular rock fragments - the kind that no longer are properly classified as water worn. They are better described as blocks, the equivalent of boulders; as slabs, the equivalent of cobbles; and as flakes, the equivalent of pebbles (Woodford, 1925, p. 183; see also Pettijohn, 1949, p. 12-15). These desert pavements composed of slabs and flakes are the smoothest in the valley.

On a typical surface on the No. 2 gravel, and also on fanglomerate of the Funeral Formation, 75 percent or more of the boulders and cobbles have lost their original roundness. On some surfaces practically every boulder is fractured or crumbled. Although the kind and degree of weathering varies considerably, depending on the composition and texture of the rock, no rock has been spared, whether coarse or fine grained (fig. 49).

The disintegration of these gravels is most advanced where the gravels extend into the zone of abundant salts. Striking examples of the effectiveness of salts in accelerating disintegration are provided by the concrete bases of bench marks along the highway crossing the saltpan and extending along its west side. Concrete in locations that are frequently wetted with saline water is badly disintegrated. The disintegration is less advanced at equally saline locations where the wetting and drying is less frequent, and the concrete still is sound at locations that are dry and not notably saline.

But disintegration of stones on the No. 2 surfaces is general and not confined to the toes of the fans which are impregnated with salts. The disintegration occurs all the way to the mountains. It is a near-surface phe- 
nomenon because boulders and cobbles more than 2 or 3 feet deep in these deposits are sound.

The desert pavement consist of a single layer of closely spaced blocks, slabs, and flakes as illustrated on figure 50. Beneath it is a layer of vesicular sand and silt, 1-6 inches thick, containing as much as a tenth of a percent of salts. Gravel under this layer is cemented with salt and iron oxide. Stones forming the pavement creep down the slope, as is indicated by terracettes (fig. 51) and by trains of slabs extending downslope from blocks that are disintegrating.

An individual pebble on the desert pavements is subjected to three very different microclimates. The upper surface, exposed to maximum temperature and maximum temperature change, in general is being eroded, as shown by partial removal of desert varnish. Around the side of the pebble is a narrow band where the temperatures probably are less extreme and where there is maximum wetting, by dew as well as by other surface water. This narrow zone has a dense population of microorganism, and even some megascopic ones-algae. The underside of the pebble has moderate temperatures and soil moisture condenses on it. This surface is red with iron oxide. In an environment. like Death Valley these differences in microclimate are extreme, and probably are an important factor in the continued weathering and disintegration of the No. 2 gravels.

Desert pavement may develop in a very short time. Where the ground consists of loose sand or silt containing pebbles, only a few windstorms are needed to blow away the fine materials and collect the coarse as a pavement of pebbles. Such very young pavements do not have a silt layer under the pebbles. On some of the archeological sites, however, a silt layer one-fourth inch thick occurs beneath the layer of pebbles. The thickest silt layer that I found on pavement developed on No. 3 gravel is about an inch, but no systematic search for thicker layers was made. The silt layer under the pebbles on the No. 2 gravel commonly is a few inches thick. The evidence is pretty good that the thickness of the

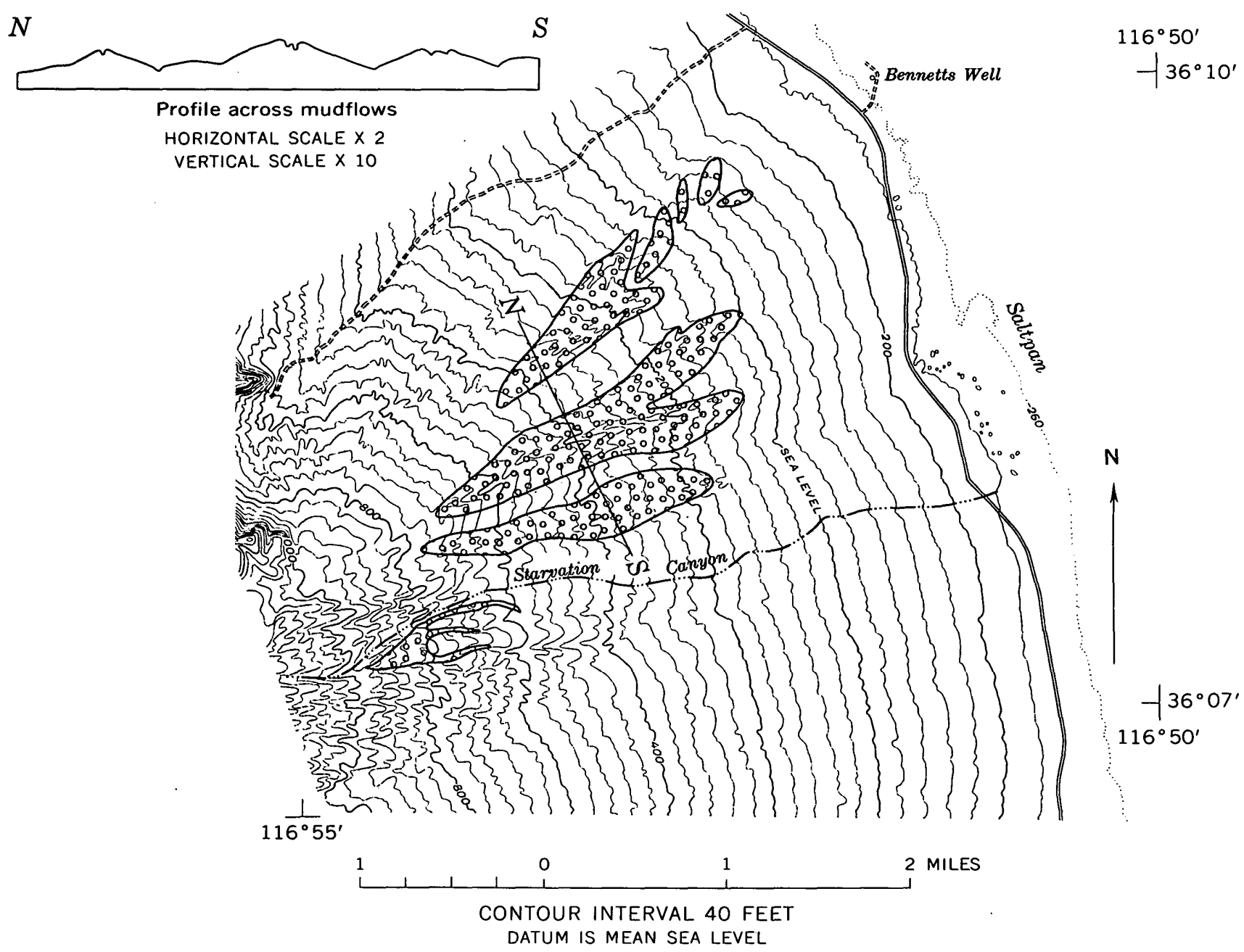

Figure 48.-Map and profle across mudflows on Starvation Canyon fan. Topography from U.S. Geological Survey topographic quadrangle ; Bennetts Well, 1952. 

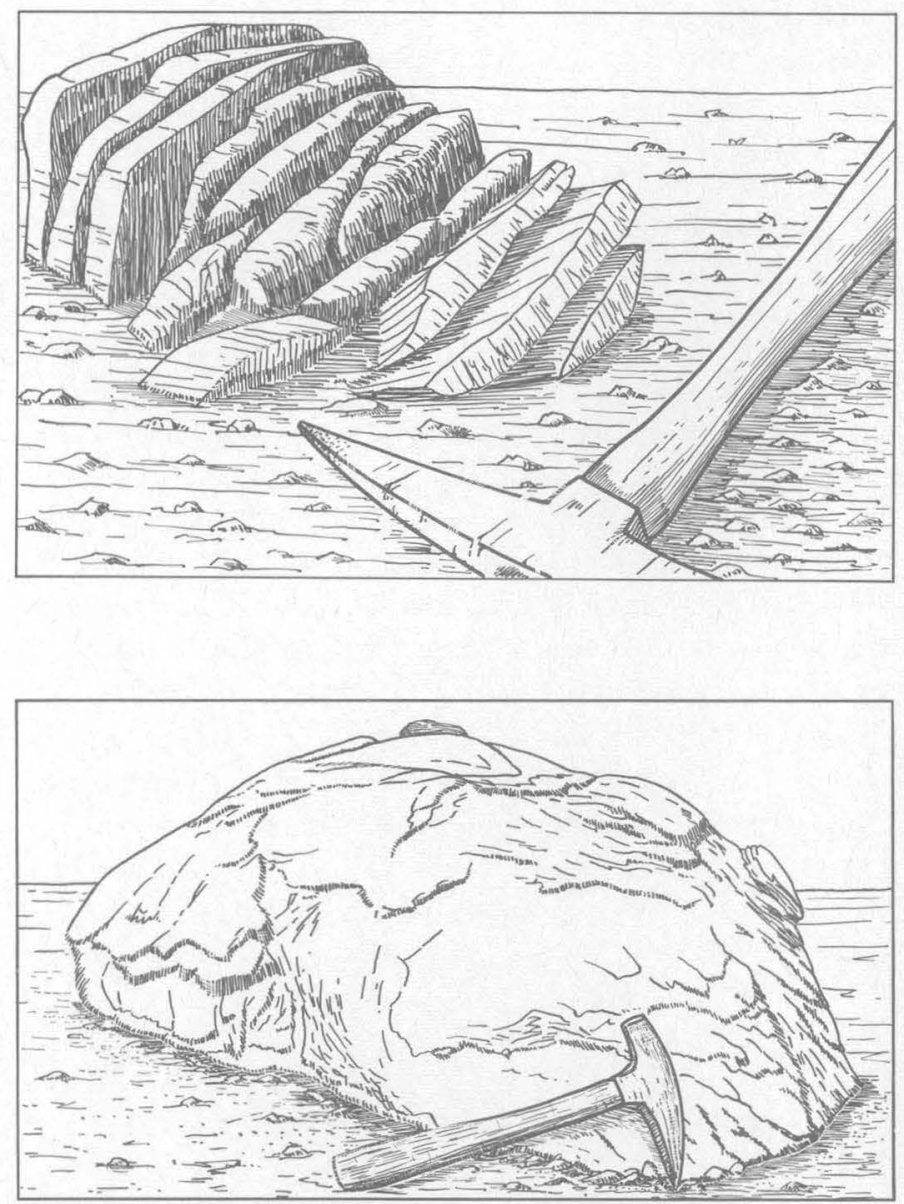

FIGURE 49.-Boulders disintegrating to slabs and flakes on the oldest gravel deposits (Funeral Formation and No. 2 gravel). Upper, Quartzite boulders commonly break into slabs along transverse fractures. Lower, Massive rocks like the porphyry boulders on the fans of the Hanaupah and Starvation Canyons exfoliate and crumble.

silt layer on old surfaces is greater than on young ones.

The terracettes on the No. 2 gravel commonly have treads 1-5 feet wide and risers 1-6 inches high (fig. 51). The surface inch or two on the treads commonly contains 1 percent or more of water-soluble salts whereas the adjacent stable surface without terraces contains as little as 500 parts per million of water-soluble salts. These ground patterns are described more fully by Hunt and Washburn (in Hunt and others, 1965).

Only once during the 6 years of the field study did I witness a rain that thoroughly soaked into the gravel. On February 16, 1959, 1 inch of rain fell in 24 hours, and the silt layer under gravel pavement on the Hanaupah Canyon fan became soaked. Walking on the pavement involved walking ankle deep in mud, because footsteps sank into the mud underlying the gravel of the pavement. Frequent soaking like this would accelerate mass-wasting processes, but there is evidence that these processes operate very slowly under the present

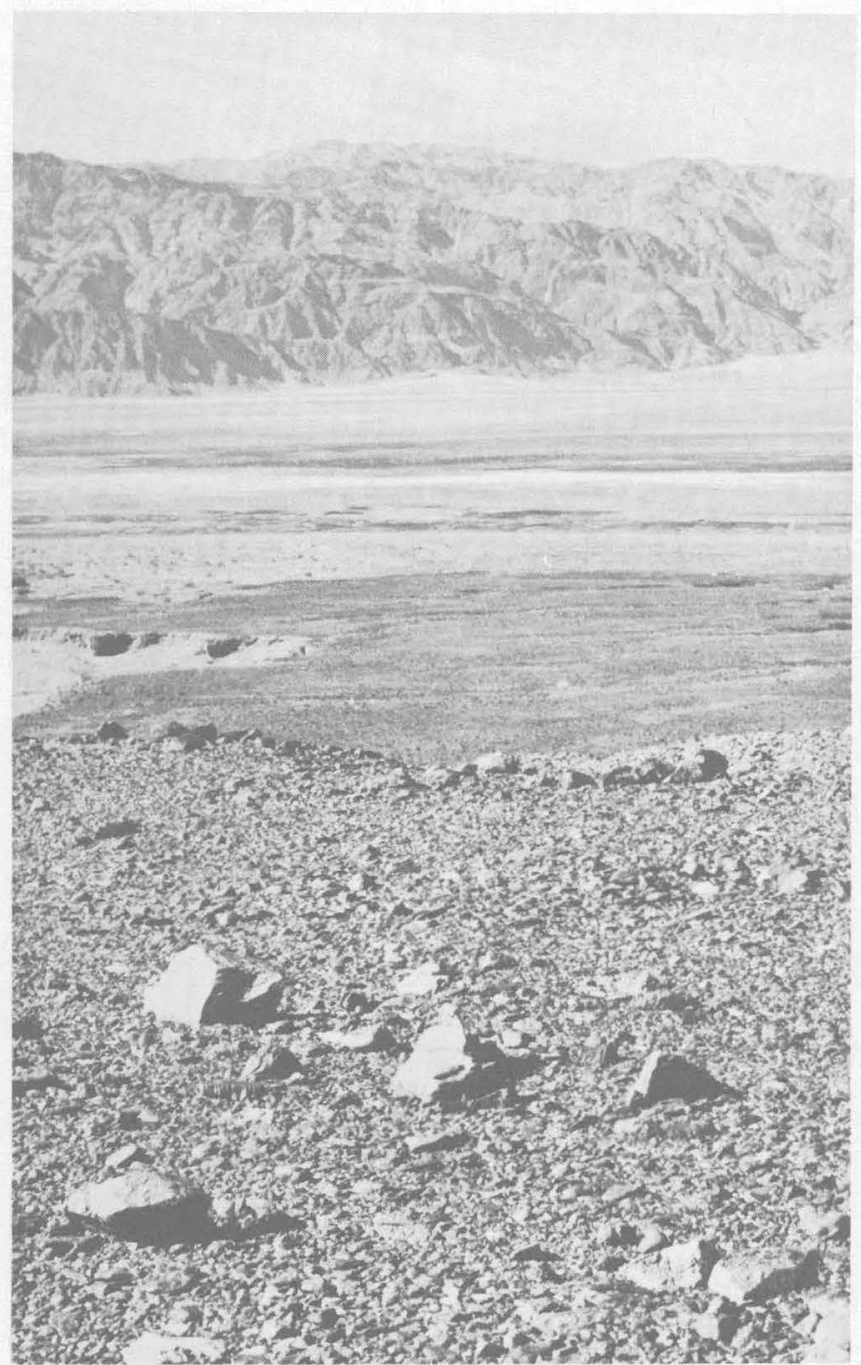

Figure 50.-Desert pavement, foreground. View west from Park Village fault block. Weathering of boulders and cobbles at the surface has produced a new mantle of blocks, slabs, and flakes, forming a smooth desert pavement in which the stones are closely spaced but barely or not at all shingled. Photograph by John R. Stacy.

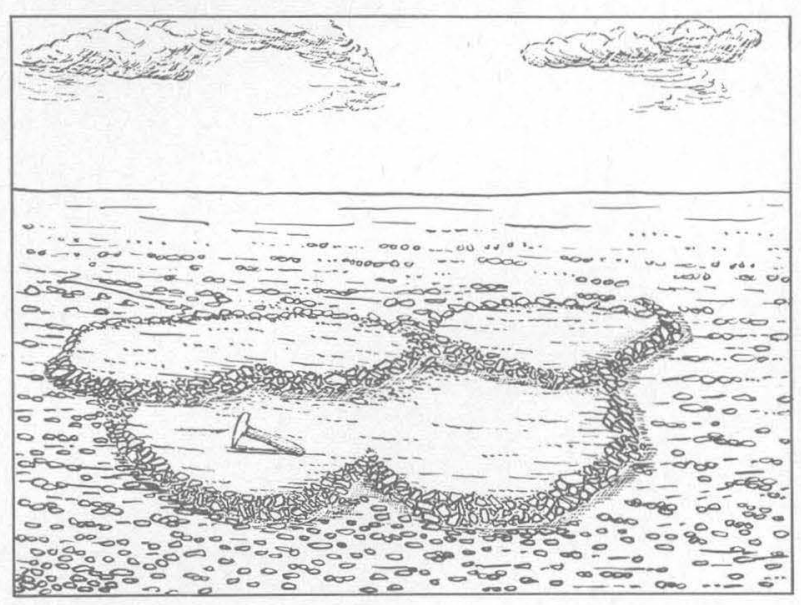

FIGURE 51. -No. 2 gravel with desert pavement interrupted by terracettes. 
climate (Hunt and others, 1965). Most of the terracettes and other patterned ground probably are relicts from a wetter period.

\section{DEBRIS AVALANCHE}

A large avalanche of blocks and rubble of Precambrian rocks is at the foot of the Black Mountains midway between Badwater and Copper Canyon. At the source, above the debris avalanche, is a huge scar between 2,000 and 2,500 feet in altitude; the volume of the avalanche must be greater than $5,000,000$ cubic yards. No lake features were recognized across the front of the avalanche, but its lower part has been displaced by faults that seem to antedate the Pleistocene lake deposits. It is composed of blocks of Precambrian rocks tens of feet in diameter in a matrix of rubble of similar rocks.

\section{LAKE DEPOSITS}

Late Pleistocene lake features in Death Valley are few, small, and not at all distinct. That Death Valley had contained a Pleistocene lake was stated widely long before positive evidence of its existence had been found. Before 1900 both Russell $(1885,1889)$ and Gilbert (1890) had referred to a former lake in Death Valley, and Bailey (1902) named it Death Valley Lake. Yet, as late as 1914, Gale, who was a student of the Quaternary basins, wrote $(1914$, p. 401$)$ :

In spite of the immense drainage territory tributary to Death Valley there is no evidence that the waters from these streams ever accumulated in it to sufficient extent to form more than a shallow inconstant lake. A search for traces of any upper lines around the slopes leading into Death Valley has failed to reveal evidence that any considerable lake has ever existed there.

Not until 1926 was clear evidence found that a late Pleistocene lake had flooded Death Valley. Levi Noble identified the strand lines on the basalt hill, later known as Shoreline Butte, at the south end of Death Valley, and discovered other strand lines in the cove northeast of Mormon Point (Noble, 1926a, p. 69). The lake or lakes that produced these features have since been referred to as Lake Manly (Means, 1932; Blackwelder, 1933, 1954).

Small embankments of shingled gravel, evidently beach deposits or near-shore bar deposits of late Pleistocene lakes, are numerous but widely scattered along the north and east sides of Death Valley at altitudes as high as 380 feet above sea level; small horizontal terraces that may be wavecut features occur several hundred feet higher. Similar deposits or beach scars are curiously lacking along most of the west side of the valley; in fact, they are known at. only 2 localities 40 miles apart-on the basaltic hill between Tucki Wash and Blackwater Wash and on Shoreline Butte at the south end of Death Valley and south of the area mapped.

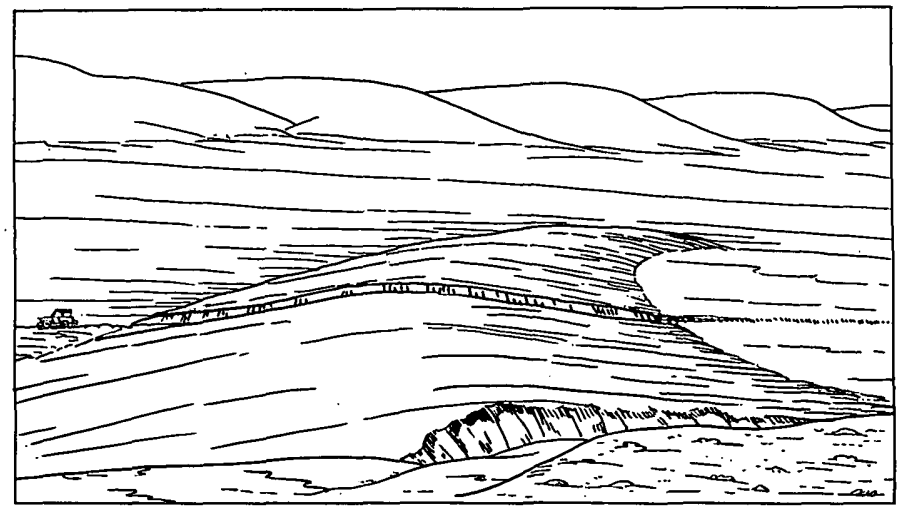

Fradre 52.-Gravel bar of late Plelstocene Lake Manly resting on older fan gravel 2 miles north of Beatty Junction. Sketch from photograph.

The most accessible and best developed gravel bar is exposed along the highway 2 miles north of Beatty Junction. This bar (fig. 52) extends nearly a quarter of a mile east from a hill of Miocene(?) rocks which formed an island at the time the bar was built. The bar, 500 feet wide and 20 feet high, is composed of well-sorted, shingled, and crossbedded gravel, most of it an inch in diameter or less, and not at all like the poorly sorted fan gravels. The top of the bar is nearly level; it is $\mathbf{1 5 0}$ feet above sea level. The deposit narrows and then eastward. Other less well-developed lake gravels crop out below sea level a mile south of the bar. These and all the other gravel deposits of the late Pleistocene lakes are composed of firm pebbles showing no sign of disintegration. The pebbles commonly have a weathering rind and are stained with desert varnish.

Three miles southeast of this bar is another welldeveloped one forming an arcuate deposit half a mile long and 500 feet wide, resting on a bench of No. 2 gravel. The bar curves through an arc of $90^{\circ}$. The gravels are shingled, crossbedded, and usually about an inch in diameter, like those in the bar above Beatty Junction. The foreset beds in the gravel dip $10^{\circ} \mathrm{NW}$. The top of this bar is nearly level and is less than 100 feet above sea level.

No other shoreline features were found between this bar and the one near Beatty Junction. The temptation is strong to assume that the 2 bars, which are similar and highly exceptional features in this area, were formed at the same time and that the difference in level is attributable to 50 feet of postlake faulting or tilting between the 2 localities.

Other shoreline features are exposed along the west face and top of the ridge of Funeral Formation in the fault blocks north of Park Village. Small deposits of shingled gravel are associated with long narrow terraces that, in part at least, are scars of old strand lines 


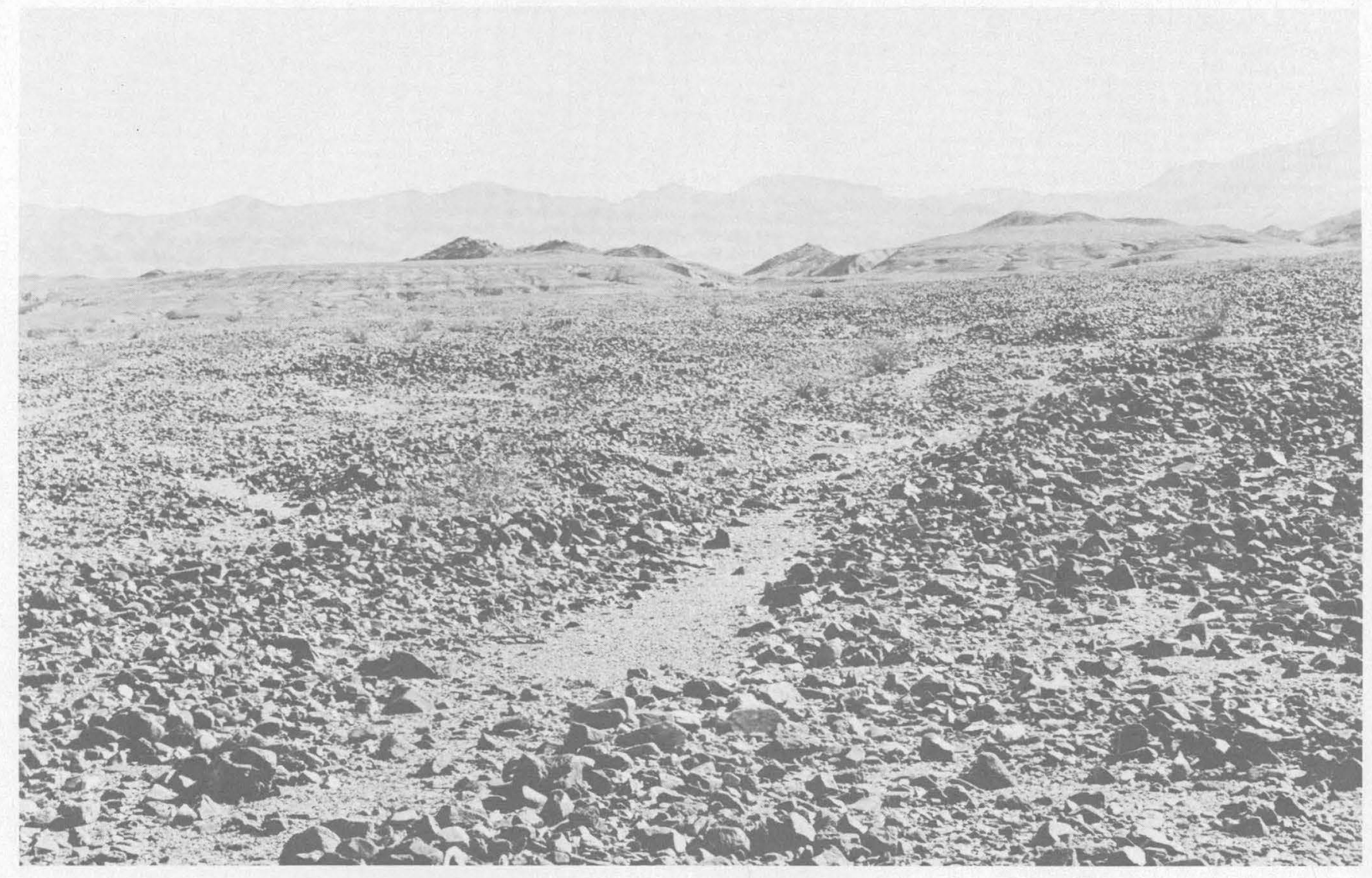

Figure 53.-View east to Park Village fault block of Funeral Formation showing long narrow terraces that are interpreted to be scars of strand lines of late Pleistocene Lake Manly. In foreground is No. 3 gravel.

(fig. 53) ; some similar terracettes, however, are attributable to mass washing. Most of the strand lines and associated deposits along the west face of the fault blocks are between sea level and 75 feet above sea level. Strand lines and associated deposits also occur on top of the fault blocks at 150 feet above sea level. Some of these lake deposits extend into the gorges across the fault block, showing that these gorges antedate the lake.

Another deposit of lacustrine gravel is at the north end of the Artists Drive fault blocks, and at the same level northward and southward from this deposit are narrow terraces, evidently wave cut, impressed on tilted strata. The deposit of gravel and the terraces are at sea level. Stone artifacts at this location have been interpreted to indicate human occupation in Death Valley at the time of the lake (Clements and Clements, 1953), but this interpretation is doubtful. No unequivocal artifacts have been found within the gravel deposit; the unequivocal artifacts are part of the desert pavement on top of the gravel and are therefore younger. Moreover, these artifacts are typologically quite like those characteristic of Recent occupations (A. P. Hunt, 1960).
Along the steep front of the Black Mountains from Badwater south to Mormon Point are numerous discontinuous horizontal embankments of gravel cemented with calcium carbonate. Most of these embankments are between sea level and 200 feet above sea level, but some are even higher. How many of them are truly lake deposits is problematical.

Well-sorted shingled lake gravel is exposed overlying a fault block of the Funeral Formation, at the north end of the steep part of the mountain front, about midway between Badwater and Bridge Canyon. The lake gravels are composed mostly of Precambrian rocks, whereas the fanglomerate contains, in addition many volcanic rocks. The lake gravels are better sorted and less well cemented than the fanglomerate. Foreset beds in the lake gravels dip north-northwest as if there had been northward shore drift at this location. The lake gravel intertongues with the lower part of a colluvial deposit that overlaps the lake beds. This colluvium is cemented with gypsum rather than calcium carbonate.

Other lake gravels are exposed at Mormon Point and extend $11 / 2$ miles eastward. These deposits, the most extensive lake deposits of gravel exposed in the valley, 
overlie the No. 2 gravel. They are at sea level and as much as 200 feet above sea level.

The only lake deposits and geomorphic features attributable to lake processes found thus far on the west side of Deuth Valley are at Shoreline Butte (Noble, 1926a ; Blackwelder, 1933, 1954) and at the basaltic hill between Tucki Wash and Blackwater Wash. At Shoreline Butte are numerous shorelines between the foot of the butte at 150 feet below sea level nearly to the top, at 400 feet above sea level. The hill between Tucki Wash and Blackwater Wash has two shorelines. The lower one is an embankment of gravel at an altitude of 160 feet. Its gravel consists of basalt and of Paleozoic rocks derived from the fans in Blackwater Wash. The embankment thins northward, and the gravels, which are $2-3$ inches in diameter at the south end of the hill, become finer northward ( $1 \mathrm{in}$. in diameter). This embankment is cemented by deposits of calcium carbonate that forms spotty masses of travertine. Both the gravel and the travertine are distributed irregularly through a vertical range of about 20 feet, but they can be followed discontinuonsly from the south to the north end of the hill.

On top of the hill, in the saddle between the peaks, at an altitude of $380 \mathrm{feet}$, is another small patch of shingle gravel derived from Paleozoic rocks.

Although the gravels from Paleozoic formations were drifted northward by shore currents across the face of this hill, the much lighter scoriaceous basalt from this hill does not occur as shore drift extending northward across the fans of No. 2 gravel in Tucki Wash. It would appear that the lake deposit is older than the No. 2 gravel, but this probably is not so. The surface of the No. 2 gravel in Tucki Wash may be younger than the lake, and if so, embankment deposits of basaltic scoriae that may have extended northward across the No. 2 gravel could have been destroyed.

The relationships at Tucki Wash illustrate the highly uncertain age of these lake deposits with respect to the No. 2 gravel. At 2 locations, Mormon Point and 2 miles north of North Side Borax Camp, the lake deposits rest on and must be younger than the No. 2 gravel. Nowhere has the reverse relationship been found. Moreover, the gravels at the surface of the No. 2 are much more weathered and disintegrated than those at the surface of the lake deposits. The difference in weathering is the kind that elsewhere in the West has been successfully used to distinguish pre-Wisconsin deposits from Wisconsin and younger ones. But why, then, are there no lake deposits or other shore features impressed on the many miles of No. 2 gravel exposed along the west side of Death Valley?
The west side of the valley was the lee side of the lake, and deposits there could have been thin and discontinuous. Even so, it is difficult to believe that all trace of them would be destroyed. Yet the evidence at the two localities where the stratigraphic relationships are certain, and the more general evidence about the difference in weathering, suggest that the No. 2 gravel every where is older than the Lake Manly deposits.

Lake Manly has been correlated with the Wisconsin (Tioga and Tahoe) stages of glaciation in the Sierra Nevada (Blackwelder, 1954; Clements and Clements, 1953), which correlate with stages of Lake Bonneville and Lake Lahontan. This correlation is supported by the fact that the pebbles on the surface are not disintegrated but are firm-suggesting an age no older than Wisconsin-yet many have developed a weathering rind that suggests an early Wisconsin (Tahoe) age.

The slight erosion and sedimentation record of Lake Manly may mean that the lake was of brief duration, and its level may have fluctuated rapidly. Whatever the cause, this California lake left one of the least distinct and most incomplete records of any Pleistocene lake in the Great Basin--another California superlative!

The water that accumulated in Death Valley to form Lake Manly has been attributed to overflow from a lake that formed in Panamint Valley when there was overflow from Searles Lake and the other lakes headward along the Owens River valley (Gale, 1914, p. 402; Blackwelder, 1954, p. 57). The overflow into Death Valley would have been by way of Wingate Pass and down Wingate Wash, but no trace remains of the floods that must have descended the wash to form Lake Manly. Perhaps much or most of the water came from the south, by way of the Mojave River and Soda Lake. This hypothesis has some support in the distribution of species of desert fish in the several drainage basins.

Owens Valley has two genera of desert fish, Siphateles and Catostomus, that are said to have come from the Lake Lahontan area; Siphateles also occurs in the Mojave River (Miller, 1948). Neither of these genera has been reported in the Death Valley-Amargosa River area. Further, a Cyprinodon that occurs in the Owens River, $C$. radiosus, is said to be more closely related to the Colorado River cyprinodonts than are any of the three species living in the Death Valley-Amargosa River area (Miller, 1948). This distribution of species suggests that the drainage system from Owens Valley to the Mojave River bypassed Death Valley.

Flooding from the direction of Soda Lake also is suggested by considering the possible tilt of the Lake Manly deposits. The principal deposits are at sea level in Mesquite Flat and along the north and east. sides of 
Death Valley as far south as Artists Drive, but they are 200 feet above sea level on the west side opposite Furnace Creek. They are 200 feet above sea level at Mormon Point, and there are large deposits as much as 300 feet above sea level at Shoreline Butte. At all these places there are higher shoreline features; the altitudes given refer to the principal deposits. They suggest an eastward tilting of 200 feet and a northward tilting of 300 feet. If such tilt is real, the lake probably extended to Soda Lake, which is where Russell (1885, pl. 1; 1889, pl. XVI), Gilbert (1890, pl. 2) and Bailey (1902) originally thought it went, and which was still considered a possibility by other later workers (Blackwelder and Ellsworth, 1936, p. 462).

\section{VALIEY FILL}

Gravity and magnetic surveys indicate that the fill in Death Valley has a maximum depth of about 9,000 feet near the west side of the valley a short distance south of Bennetts Well (p. A108). Drill holes a thousand feet deep near Badwater and in Cottonball Basin show rather uniform alternations of mud and salt to the bot- tom of the holes (table 19), and assuredly the upper thousand feet is Quaternary. I assume that about a third of the fill is Quaternary and that the rest is Tertiary.

The fill in Badwater Basin thins southward and northward. Opposite Artists Drive the fill is only about 4,000 feet thick. A drill hole in this area encountered only 50 feet of mud and salt and then went into basaltic conglomerate to a depth of 500 feet before the hole was abandoned. This conglomerate is correlated with the Funeral Formation that rises eastward onto the fault blocks at Artists Drive and there unconformably overlaps the older volcanic rocks (p. A63).

The fill thickens again northward under Cottonball Basin, thins under the Salt Creek Hills, and thickens again under Mesquite Flat.

Logs of the three deep holes are given in table 19. Logs of some shallow holes drilled by the U.S. Geological Survey in connection with the search for more potash deposits during World War I are given in Hunt and others (1965).

T $\mathrm{ABLE}$ 19.-Logs of wells drilled by Pacific Coast Borax Co. [Drillers' logs revised from mud samples]

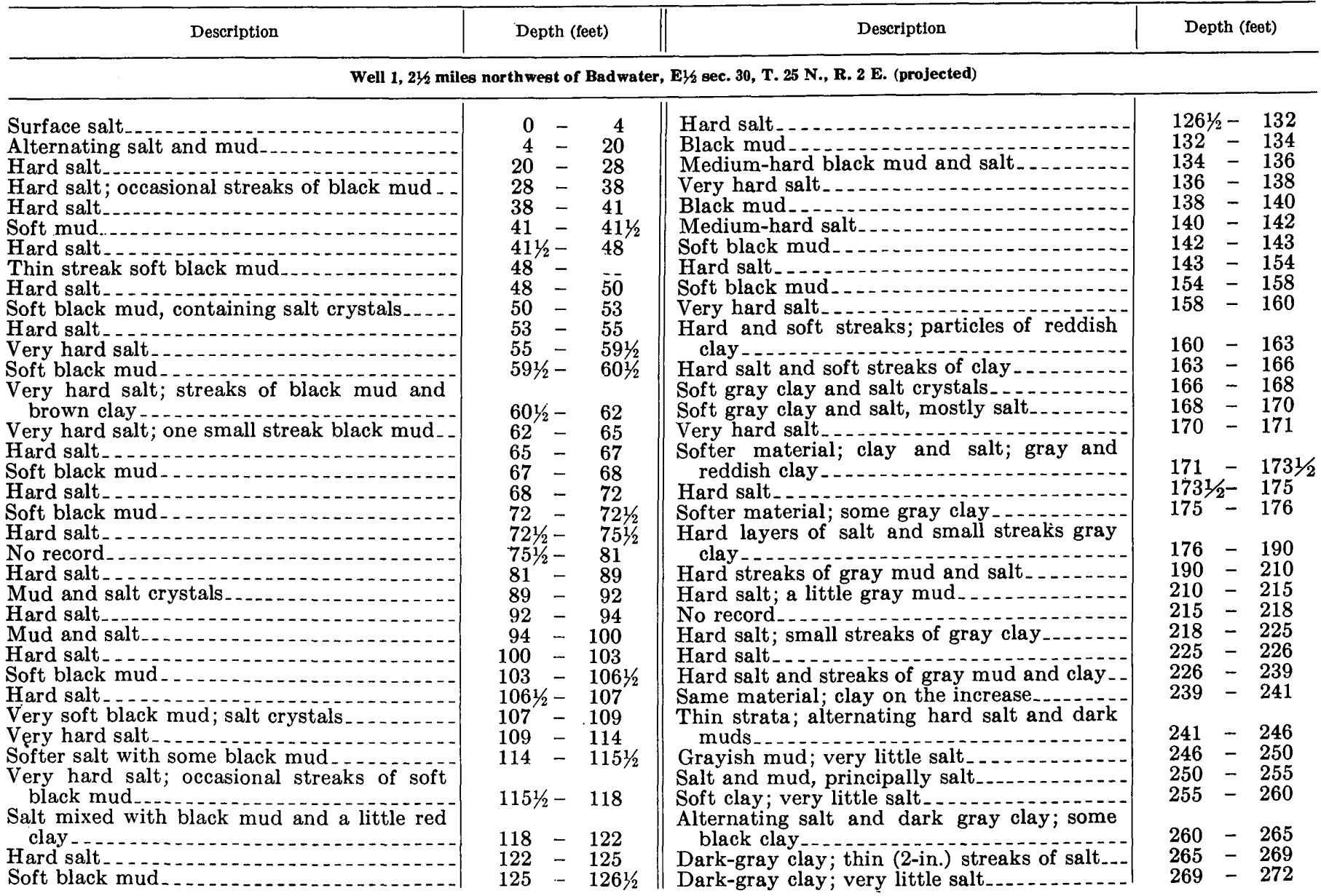


TABLE 19.-Logs of wells drilled by Pacific Coast Borax Co.-Continued

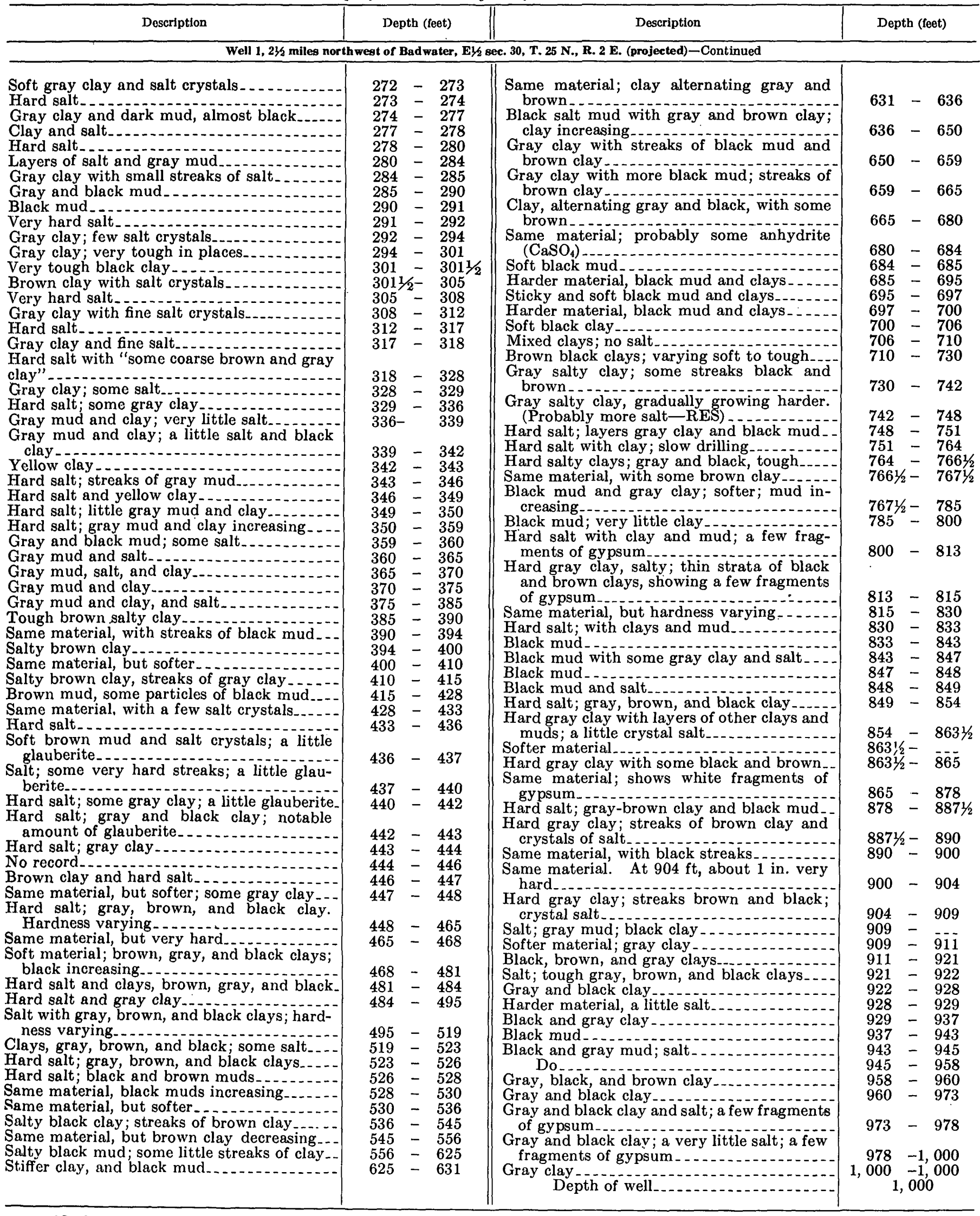


TABLE 19.-Logs of wells drilled by Pacific Coast Borax Co.-Continued

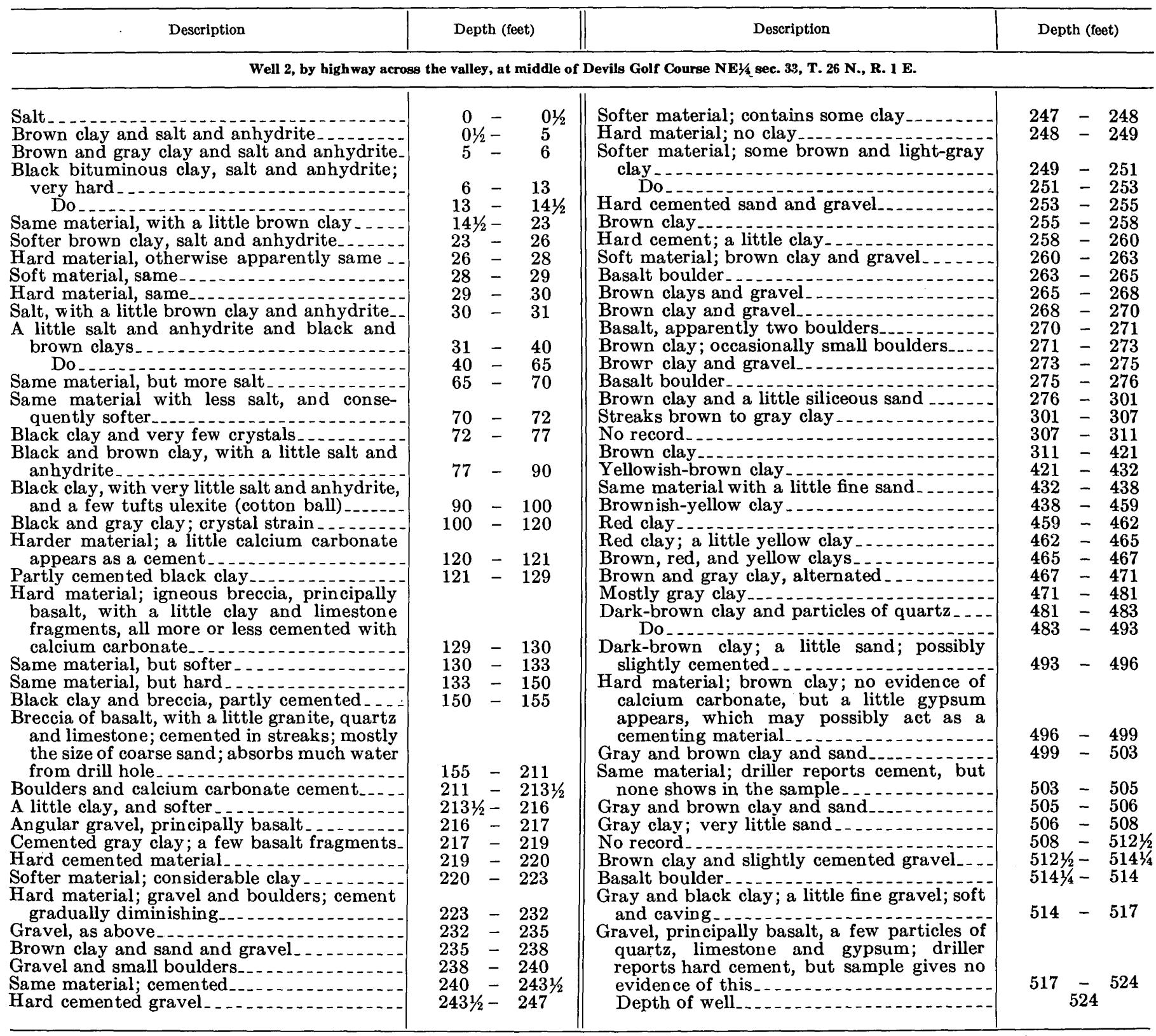

Well 3, Cottonball Basin, 2 miles northwest of Harmony Borax, SW1/4 sec. 32, T. 28 N., R. 1 E.

Salt, containing small amount of thenardite (sodium sulfate), borax, and a little yellowish-brown clay

Yellow clay.

Soft salt and yellow clay

Soft yellow clay

Soft yellow clay; a few crystals anhydrite..

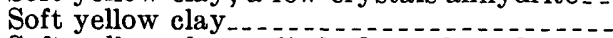

Soft yellow clay; a little fine salt and anhyBlack and green clay, with a little salt and Black and green clay, with a little salt and Brown clay and salt.

Black, green and brown clay; a few crystals of salt and anhydrite Salt and a little pale-blue clay

Salt; a little anhydrite; blue and brown clays Salt and clays, changing from brown to gray_-
Salt and gray clay; a few streaks of black clay Gray and black clay; a little salt.

$0-21 / 2$

$2 y_{2}-$

$51 / 2-18$

$18=19$

$19-31$

$31-33$

$33-37$

$37-371 / 2$

$371 / 2-38$

$38-43$
$43-44$

$44-46$
Salt; a little anhydrite; some gray clay

Black clay and salt.

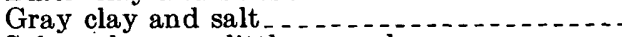

Salt and a very little gray clay

Salt and a little gray, black, and brown clay

Gray clay and very little salt...........

Salt and a little gray and brown clay; a few tufts of ulexite

Same material, except clay principally brown. Salt, with a very little clay; a few tufts of

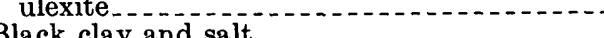

Salt and a little black clay and ulexite

Salt and a little ulexite.....................

Salt; gray and black clay; a little ulexite...-

Salt; a little ulexite; a very little gray clay.-

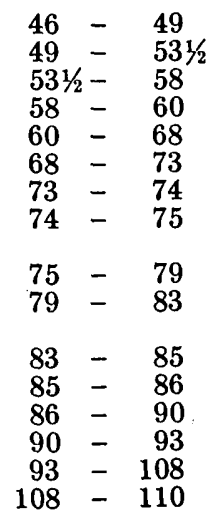


Table 19.-Logs of wells drilled by Pacific Coast Borax Co.-Continued

Well 3, Cottonball Basin, 2 miles north west of Harmony Borax, SW1/4 sec. 32, T. 28 N., R. 1 E.-Continued

Salt, and a little gray, black, and brown clayHard salt and a little ulexite.

Salt and some gray, brown, and black clay.-

Salt; black clay; a little ulexite.

Hard solt and a little gray clay

Salt; black clay; a little ulexite

Salt, and a little gray, brown, and black clay -

Salt and black clay.

Salt and very little clay (black and gray)

A little brown clay, otherwise same

Black clay and salt, varying in proportions.

Salt and very little black clay.

Salt; a little brown clay; a few crystals ulexite.

ulexite.-

Hard salt ar

Hard salt and a

Light-blue clay . -

Brown clay and salt.

Brown clay and salt and

Brown clay and salt.

Salt and a little gray clay, and considerable ulexite.

Salt and a little gray and black clay

Softer material, less salt ard salt; a little black, brown, and gray clay

Salt; considerable brown clay; a little ulexite

Salt and a little brown clay

Salt and brown and gray clays.........

Salt and brown clay, and a little ulexite.

Brown clay, containing fine crystals of salt and anhydrite

Same material, except more anhydrite

Clay, with a little salt, anhydrite and ulexite.

Brown clay and fine sand, containing a little salt and anhydrite.

Same material (sand negligible)

Brown and gray clay, and a little salt and anhydrite.

Bluish-gray clay and salt

Salt, with a little anhydrite and brown and gray clay ..-

Brown clay and salt

Hard salt, and a little anhydrite and brown

clay - Pale-greenish-gray clay, and salt.

Hard salt, with very little gray clay and ulexite.

Hard salt, and a little gray clay

Salt, and gray and brown clay in thin strata.

A little gray clay, and small crystals of salt.-

Small salt crystals, and a little gray and brown clay

Fairly soft salt; gray and a little brown clay; occasionally a few tufts of ulexite....

Hard salt and a little gray clay .

Softer material, sticky and probably wet...-

Salt and a little anhydrite

Tough black clay, with very little salt

Salt and black and brown clay and a little sand.

Same material, and sand decreasing in amount.

Hard salt and a little gray-brown clay and ulexite.................

Very hard material (probably a salt stratum)

Salt crystals, with a little gray and brown clay and sand.

Harder material. No sand.

Gray-brown clay, very sticky ..............

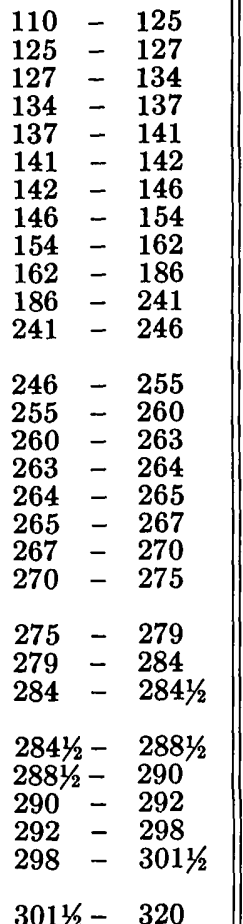

$320-323$

$323-333$

$333-345$

$345-360$

$360-369$

$369-373$

$373-375$

$375-376$

$376-3851 / 2$

$3851 / 2-392$

$392-398$

$398-400$

$400-405$

$405-410$

$410-415$

$415-465$

$465-495$

$495-514$

$514-519$

$519-520$

$520-525$

$525-538$

$538-540$

$\mathbf{5 4 0}-\mathbf{5 4 5}$

$545-5451 / 2$

$5451 / 2-570$

$570-581$

$581-592$
Coarse salt, and large crystals of anhydrite; a little brown and gray clay and traces of calcium-carbonate cement.

Coarse salt, and some anhydrite, a little black and gray clay, and a few fragments thenardite

Same material, with a little blue clay

Same material, with a little brown clay

Blue-gray clay, about 50 percent; salt, anhydrite, and thenardite in about equal proportions (see note on thenardite below) ..

Blue and soft brown clays, otherwise same material.

Brown clay; salt, anhydrite, and thenardite; a little ulexite and few borate fragments, apparently colemanite; some traces of calcium carbonate cement. . .

Tough blue clay and salt

About 50 percent clay, blue, black and brown; crystals chiefly of thenardite, with a little salt and anhydrite.

Same material; also a few nodules of clay, showing traces of cement...........

Chiefly salt and clay; a little anhydrite and

thenardite. crystals.

tals, of salt only Tough, dry clay, as above...

Brown clay and sand, with a little salt and anhydrite.

Brown clay, and a few crystals of salt and anhydrite; very little blue clay and sand

Bluish-green clay, and sand and salt...... Very little sand, otherwise same...

90 percent clay, brown, blue, and gray; crystals of salt only.

Salt stratum, hard ......................

Brown and gray clay, and a little salt

Same material, with some blue-green clay.-

Tough clays, gray, green and black; about 10 percent sand

Tough light-blue clay Clays, brown, blue, black, and gray; about 50 percent salt

No record

About 25 percent salt; remainder blue clay.

About 10 percent salt; blue and black clay -

Very little salt, and no other crystals; brown clay, with sand increasing from 0 to 50 percent.

Sand decreases from 50 to 5 percent

Brown, gray, and blue clay, and a little salt and anhydrite

Gray clay, and a little salt and anhydrite

About 10 percent salt, and very little anhydrite; remainder, gray, blue, and black clay...............

Gray, black, and brown clay, and a little salt

Brown clay and a little sand

Brown clay, and sand increasing from trace

to 25 percent. sand increasing from trace Very tough blue clay and sand......

Tough brown clay, and a little sand

About 80 percent gray and brown clay, 15 percent coarse sand, 5 percent crystals consisting of salt and very little anhydrite. Dark-brown sandy clay and a little salt; a few traces of ulexite.

Sandy gray and brown clay, otherwise same
$592-595$

$595-597$

$597-599$
$599-606$

$606-612$

$612-615$

$615-617$

$617-620$

$620-625$

$625-6281 \frac{1}{6}$

$6281 / 2-630$

$630-635$

$635-640$

$640-646$

$646-665$

$665-670$

$670-671$

$671-6771 / 2$

$6771 \frac{1}{2}-6801 \frac{1}{2}$

$6801 \%-681$

$681-690$

$690-695$

$695-704$

$704-706$

$706-720$

$720-7211 / 2$

$7211 \%$ - 724

$724-731$

$731-750$

$750-765$

$765-770$

$770-775$

$775-777$

$777-790$

$790-795$

$795-808$

$808-810$

$810-812$

$812-815$

$815-819$

$819-820$ 
TABLe 19.-Logs of wells drilled by Pacific Coast Borax Co.-Continued

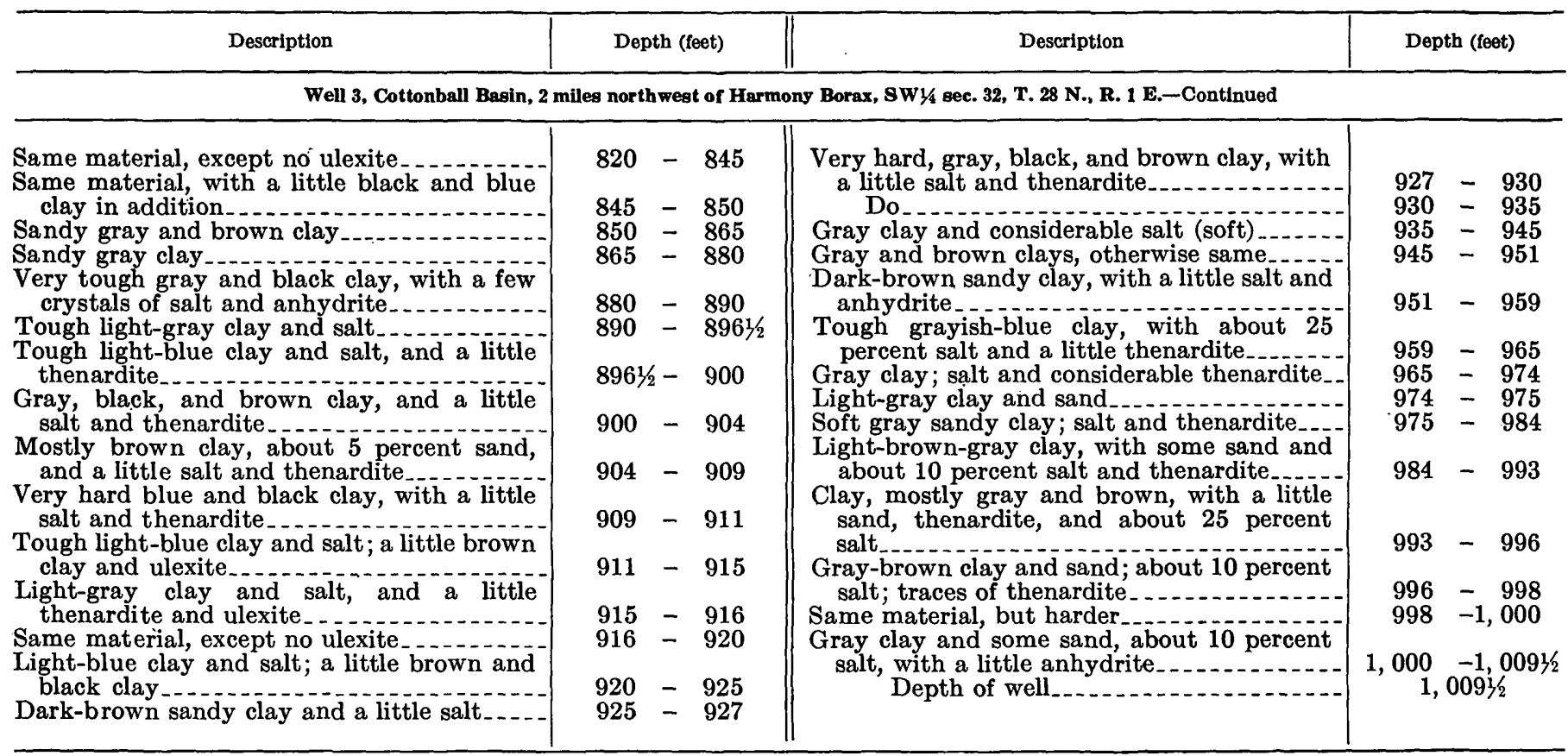

\section{PLEISTOCENE(?) AND RECENT(?) DEPOSITS}

\section{SAND AND SILT IN THE PLAYA}

Sandy playa (and lake?) deposits crop out at the edge of the saltpan and foot of the gravel fans. The sand consists of very fine grained to medium-grained brown sand, most of which is rounded or subrounded quartz. Feldspar is abundant; there is some mica and hornblende. Depending on the source, there may be considerable amounts of volcanic glass or other volcanic rocks and of clastic grains of dolomite or limestone. A calichelike layer of salts occurs about a foot below the surface.

Tho sand is 3-10 feet thick and rests on gravel. Presumably there is more sand below the bed of gravel, for the position is where the facies would intertongue.

Originally, the sand must have graded into gravel on the fans; but the transition beds have been removed by erosion, and the sand now forms a low cuesta, 2-4 feet high, facing the gravel fans. Panward the sand grades into silt, which becomes increasingly clayey toward the center of the saltpan. Borings in the middle of the saltpan indicate that the sand deposit is 35-50 feet thick. There this deposit is overlain by the crust of salts forming the present saltpan; it overlies a layer of rock salt a few feet thick.

No fossils were found in the sand or silt. The sand is older than the sand dunes that can be equated with the earliest bow-and-arrow occupations in this area. It is older than the calichelike layer of salts contained in it, which is attributed to evaporation of ground water at the time of a Recent but pre-Christian era lake (p. A79). The sand is considerably dissected. It is crossed by numerous small washes draining from the gravel fans to the saltpan, and it is being overlapped by the No. 4 gravel that is being moved panward at present.

\section{NO. 8 GRAVEL}

The No. 3 gravel (pl. 2) differs from the No. 2 in several ways. The deposits contain less caliche and generally are less well indurated. 'The cobbles and pebbles on the surface are firm and show little sign of disintegrating; the rocks are not angular but are still round. Although not disintegrated, cobbles and pebbles on some of these deposits have thin weathering rinds; other deposits lack even this. The gravels have a dark stain of desert varnish. Over a broad surface the stain may be darker than it is on the older gravels, because the No. 3 gravels are firm, whereas fanglomerates of the Funeral Formation and No. 2 gravels are crumbly and the varnish there is partly destroyed.

The No. 3 gravel is much better stratified in coarseand fine-grained layers than is the No. 2 gravel. The range in grain size is substantially less and the proportion of gravel to sand is higher, although few boulders are more than a foot in diameter. Where there is a nearby source of large boulders in erosion remnants of the No. 2 gravel, some of these are reworked into the No. 3 gravel, but such reworked boulders are few.

The surfaces on the No. 3 gravel are rough (fig. 53). The cobbles and small boulders are in ridges-natural 
levees-1 or 2 fet high and as much as 10 feet wide. Washes between the levees are about the same width as the levees. The gravels also occur in small fanlike mounds that choke washes and disrupt the drainage. Nowhere is there desert pavement on these deposits like that on the No. 2 and older gravel. The range in size of the gravels on the surface of the No. 3 is the same as within the deposit.

Three kinds of surfaces have formed on the No. 3 gravel. Surfaces that have not been subject to flooding or washing are only a little less smooth than the desert pavements on the adjacent older gravels. Such surfaces are rough only because the ill-sorted small boulders, cobbles, and pebbles stand at different heights and are distributed irregularly on the surface. The stones are darkly stained with desert varnish.

Surfaces that have been subject to flooding, but not recently, are composed of levees of small boulders along the sides of washes floored with pebbles, and both the levees and washes are darkly stained with desert varnish (fig. 53). Desert varnish is thicker and darker on stones on these first two types of surfaces than on any other gravel deposits in this part of Death Valley.

The third type of surface is like the second, except for recent washing. On these surfaces the levees are stained with desert varnish, but the pebble floor of the wash is not. This third kind of surface grades into that of the No. 4 gravel.

The surfaces on the No. 3 gravel similarly grade into those that have formed on the No. 2 gravel. Where surfaces on the No. 2 have been overriden by flash floods, a layer of firm cobbles and pebbles overlies the pavement of partly disintegrated slabs and flakes. In these places the firm cobbles and pebbles form low ridges on the pavement, and the old desert pavement forms the beds of the little washes between the natural levees. Other surfaces on the No. 2 are dissected by shallow washes which have become mantled with firm cobbles and pebbles, leaving narrow interstream areas capped with the old desert pavement. A third kind of gradation is where the No. 3 gravel has been derived by erosion of old disintegrated gravel; depending upon how far such gravel was transported, there may be enough angular stones to form a surface like that on an older deposit. Such surfaces, however, lack the silt layer that is characteristic of older desert pavement.

Much of the ground shown as No. 3 gravel actually is only a thin veneer of this gravel on an eroded surface of the No. 2. The No. 3 gravel is neither as thick nor as extensive as the No. 2.

In general, the surface of the No. 3 gravel is lower than that of the No. 2 and generally less than 10 feet above the No. 4. But the No. 3 gravel overlaps the

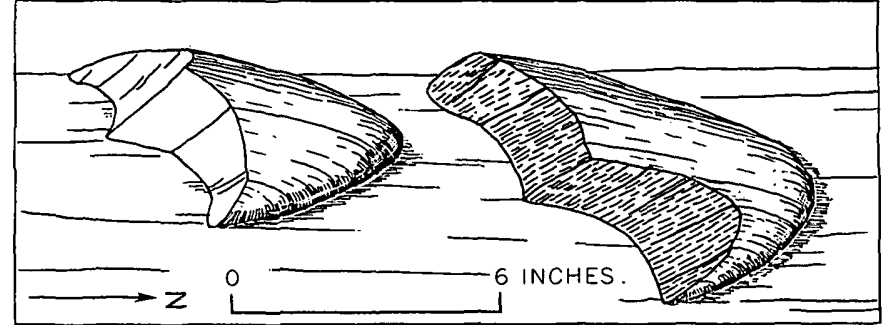

Froury 54.-Wind-faceted cobbles. Arglllite (left) is smoothly faceted; limestone (right) has rillen on the facets. Both specimens oriented as in the field.

lower edges of the No. 2, and at such places has accumulated in small fans on top of it. Conversely, the No. 3 gravel is overlapped by the No. 4 (figs. 55, 64).

The Funeral Formation and the No. 2 gravel generally are without vegetation, but the No. 3 gravel generally has a sparse growth of shrubs along the shallow washes between the natural levees of cobbles and small boulders. This reflects the difference in permeability and runoff on the two surfaces. Runoff is greater on smooth desert pavement than it is on the rougher surfaces of the No. 3 gravel, and the ground is accordingly more xeric and less suitable for plant growth (see Hunt, 1965).

Pebbles and cobbles on the surface of the No. 3 gravel are wind faceted (fig. 54) at several localities, for example, along the south side of the Hanaupah Canyon fan 1-1 1/2 miles due west of Eagle Borax, on a bench at the mouth of the wash at the north end of the Artists Drive fault blocks (NE1/4NE1/4 sec. 15, T. 26 N., R. 1 E.), and on the Salt Creek Hills. In the latter area some stone artifacts are clearly etched by sandblasting. Glass bottles that have been exposed are frosted and etched. The wind-facted pebbles may have been developing their facets over a long period of time, but certainly some of the shaping is Recent.

At several places the No. 3 gravel has been displaced by small faults. At the Hanaupah escarpment, 1 mile west of Shortys Well, the No. 3 gravel is displaced 6 feet along a fault that displaces the No. 2 gravel 75 feet (fig. 78). At most places, though, the No. 3 gravel overlaps faults without being displaced. Good examples are beside the highway 2 miles south of Bennetts Well (fig. 55) and at the south edge of the Trail Canyon fan 11/2 miles southwest of the junction of the Trail Canyon road and West Side highway.

The No. 3 gravel is old enough to have been eroded into low benches and to have developed extensive desert varnish on the surface. Numerous archeologic sites on the gravel indicate that the bow'and-arrow and pottery occupations at those places are later than the No. 3 gravel. Further, the No. 3 gravel everywhere is darkly stained with desert varnish, but archeologic sites of the bow-and-arrow occupations are not. There 


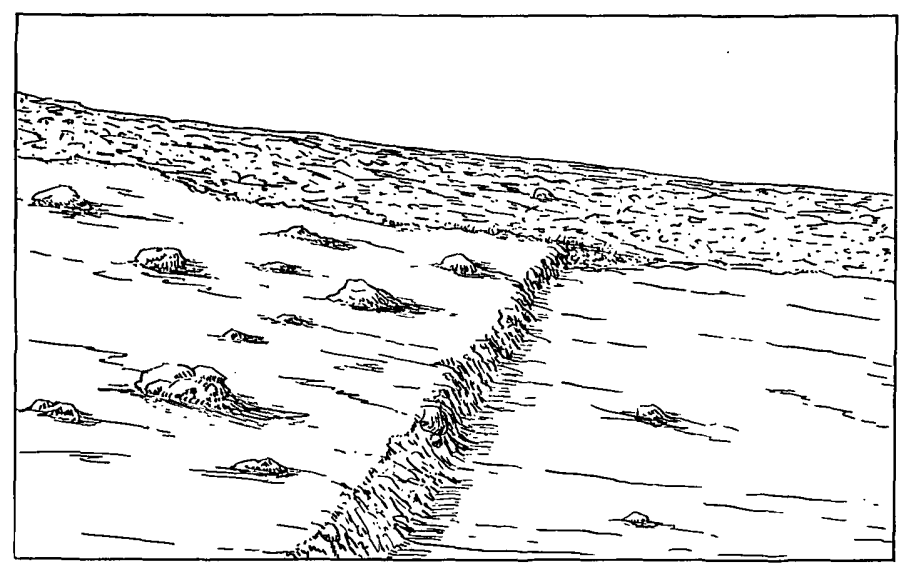

Figore 55.-No. 2 gravel (foreground) displaced 6 feet by a fault that is overlapped and buried by No. 3 gravel (distance). Locality is by West Side highway 2 miles south of Bennetts Well. View north.

is little reason to doubt that the gravel everywhere is older than these archeologic sites and antedates the Christian era. Probably the No. 3 gravel includes deposits that are early Recent in age and other deposits as old as late Pleistocene.

\section{DEPOSITS OF TRAVERTINE AND CALICHE CEMENT IN GRAVEL}

Travertine has been deposited in mounds at and near each of the large springs issuing along faults west of the Funeral Mountains, and a small mound has been built on the upper part of the Trail Canyon fan. The deposits are nearly pure calcium carbonate.

The largest deposit is at Nevares Spring at the foot of the mountains 2 miles east of Park Village.

Travertine has been deposited at Travertine and Texas Springs, and between them are some mounds of travertine that have become isolated by erosion. One of these deposits drapes over the side of Furnace Creek Wash and extends to the bed of the wash (fig. 56),

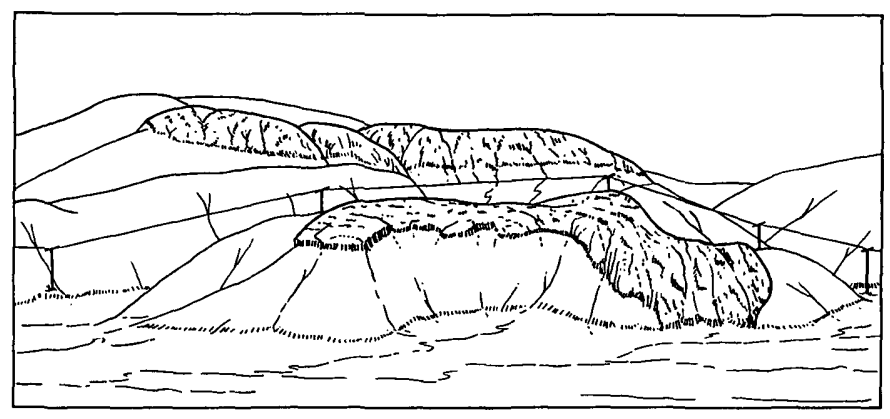

Figdre 56.-Travertine deposit overlapping the bank of Furnace |Creek Wash half a mile above the mouth of the wash. The old spring, now dry, that deposited the travertine was at the high mass of travertine that can be seen beyond the telephone line. clearly dating the travertine as younger than this part of the gorge of Furnace Creek Wash.

On the gravel fan at Trail Canyon, a mile below the mouth of the canyon, is a mound of travertine 5 feet high and $30-50$ feet in diameter. Another travertine deposit on the west side of Death Valley is at the south base of the hill of basalt south of the mouth of Blackwater Wash. The deposit is at an altitude of 200 feet in a cove at the toe of a field of basalt boulders overlying tuff. The travertine probably was derived from the carbonate caliche in the basaltic boulders up the hillside and probably dates from a time when there was a spring here.

Travertine obviously is being deposited at Nevares, Texas, Travertine, and similar springs at present, yet much, probably most, of the travertine is an old deposit, probably dating back to late Pleistocene time. Some of the deposits are at locations where springs have dried up. Other deposits are old enough to have been isolated by erosion from the spring areas. Projectile points of types characteristic of the early occupations have been found on the surface of some mounds.

A few fossils were found, but they are not meaningful. At Nevares Spring, 4 feet below the surface, 4 teeth were found and identified as mountain sheep (Ovis canadenis Shaw) by G. E. Lewis, of the U.S. Geological Survey, and C. B. Schultz and L. G. Tanner, of the University of Nebraska State Museum. Some mollusk shells from the same layers of travertine at Nevares Spring (U.S.G.S. Cenozoic loc. 21675) were identified by D. W. Taylor, of the U.S. Geological Survey as Hydrobiidae indeterminate, a fresh-water snail.

Some shells from travertine at Triangle Springs (U.S.G.S. Cenozoic loc. 21575) on the northwest side of Mesquite Flat also were identified by Taylor as follows:

Pisidium sp., a fresh-water clam

Hydrobiidae, 2 indeterminate species probably representing 2 genera of fresh-water snails

$P h y s a$, a fresh-water snail

Vertigo, a land snail

cf. Succinca, a land snail

Taylor (written commun., 1961) offers the following ecologic interpretation of these species:

The two terrestrial species are inhabitants of moist situations, such as vegetation along streams, beside ponds, or in marshy places. The fresh-water species do not inhabit wide ranges of salinity; the water certainly was fresh rather than brackish. The water temperatures may have been warm, but not hot-possibly as high as $80^{\circ} \mathrm{F}$.

The living molluscan fauna of the Death Valley area is essentially unknown. For this reason the significance of the mollusks caunot be evaluated satisfactorily. Perhaps all the species represented by the fossils are living; perhaps only some. 
Fresh-water snails in another collection from the irrigation ditch at Furnace Creek Ranch were identified by Taylor as:

Helisoma duryi seminole Pilsbry, a Floridian species, probably introduced through aquaria

Pluysa

The calcium carbonate caliche that cements layers of gravel on the fans is well developed where the gravels overlap the fine-grained Tertiary playa deposits, places favoring perched ground water. Such cemented ledges are extensive where the gravels overlap the Tertiary rocks below Nevares Spring and along the west edge of the Texas Spring syncline, where ground water comes to the surface. However, for reasons that are not obvious, the caliche also is well developed on the fans of Galena and Six Spring Canyons.

Although most of the caliche is calcium carbonate, there is considerable calcium sulfate caliche locally, especially along the foot of the Black Mountains, as had been noted in the description of the Funeral Formation on Artists Drive (p. A64). Certainly the greater part, and perhaps all, of the caliche in these gravel deposits has been deposited by ground water, or more likely, by water in the capillary fringe above the water table. The best evidence for this is the commion occurrence of welldeveloped caliche where there is a perched ephermeral water table.

That much of the caliche is old, perhaps late Pleistocene in age, is indicated by the occurrence of earliest archeological sites (Death Valley I and Death Valley II; Hunt A. P., 1960) at shelters or ledges formed by the caliche.

Trace elements in the travertine are given in table 20. They are much the same as in the calcite veins cutting the Funeral Formation.

TAвLe 20.-Trace elements in spring-deposited travertine and in calcite vein in Funeral Formation

[Spectrographic analysos by E. F. Cooley, U.S. Geol. Survey, values in parts per million, except $\mathrm{Mg}$, which is given in percent]

\begin{tabular}{|c|c|c|c|c|c|c|c|c|c|c|}
\hline & B & $\mathrm{Ba}$ & Bo & $\mathbf{B i}$ & $\mathrm{Cd}$ & $\mathrm{Co}_{0}$ & $\mathrm{Cr}$ & $\mathrm{Cu}$ & $\mathrm{Ga}$ & $\mathrm{Ge}$ \\
\hline \multirow[t]{2}{*}{$\begin{array}{l}\text { Travertine } 1 \\
\text { Calcite voin }: . . . .\end{array}$} & $\begin{array}{l}<10 \\
<10\end{array}$ & $\begin{array}{r}150 \\
10\end{array}$ & $<1$ & $\begin{array}{l}10 \\
10\end{array}$ & $\begin{array}{l}50 \\
50\end{array}$ & $<5$ & $<10$ & $\begin{array}{l}5 \\
5\end{array}$ & $\begin{array}{l}20 \\
20\end{array}$ & $\begin{array}{l}20 \\
20\end{array}$ \\
\hline & In & La & $\mathbf{M g}$ & Mn & Mo & $\mathrm{Nb}$ & $\mathrm{Ni}$ & $\mathrm{Pb}$ & $\mathrm{Sb}$ & $\mathrm{Sc}$ \\
\hline \multirow[t]{2}{*}{$\begin{array}{l}\text { Travertine } 1 \\
\text { Calcite voin } 8 . . . .\end{array}$} & $\begin{array}{l}10 \\
10\end{array}$ & $<50$. & 1.5 & $\begin{array}{l}10 \\
10\end{array}$ & $\begin{array}{l}<5 \\
<5\end{array}$ & $\begin{array}{l}<50 \\
<50\end{array}$ & $\begin{array}{l}<5 \\
<5\end{array}$ & $\begin{array}{r}10 \\
<10\end{array}$ & $\begin{array}{l}200 \\
200\end{array}$ & $<10$ \\
\hline & $\mathrm{Sn}$ & & $r$ & $\mathrm{Ta}$ & $\mathbf{T i}$ & $\mathrm{Tl}$ & $\mathrm{V}$ & $w$ & $\mathbf{Y}$ & $\mathrm{Zr}$ \\
\hline $\begin{array}{l}\text { Travertine } 1 . . . \\
\text { Calcito vein } 8 . . .\end{array}$ & $\begin{array}{l}10 \\
10\end{array}$ & & $\begin{array}{l}000 \\
500\end{array}$ & $\begin{array}{l}50 \\
50\end{array}$ & $\begin{array}{l}30 \\
10\end{array}$ & $\begin{array}{l}100 \\
100\end{array}$ & $\begin{array}{l}10 \\
10\end{array}$ & $\begin{array}{l}100 \\
100\end{array}$ & $<10$ & $<10$ \\
\hline
\end{tabular}

Travertine from Texas Spring.
Calcite voin from near foot of Funeral Mountains.

\section{RECENT DEPOSITS}

\section{SHOREIINE FEATURES OF THE RECENT LAKES}

Near the base of the gravel fans on the west side of Death Valley, at about 240 feet below sea level, the desert varnish on the fan gravels abruptly ends. The color change, from darkly varnished gravels above to light unvarnished gravels below, follows the contour and occurs within a vertical range of about 5 feet. This contour also marks the upper limit of highly saliferous ground and is interpreted to be the high watermark of a lake (fig. 57).

The shoreline shows especially well in the cove north of West Side Borax Camp on the west side of Cottonball Basin (fig. 58). The salt-impregnated ground extends to a uniform level on the fans around the head of the cove and on a little butte of limestone that was an island in the cove. Above the salt-impregnated ground is comparatively salt-free gravel on the fans and salt-free colluvium on the butte.

At the east foot of the Salt Creek Hills the shoreline is impressed on the alluvial bank of an arroyo (fig. 59).

The shoreline is distinct also where the highway crosses Death Valley at the west foot of the fans on the Artists Drive fault block. There it is marked by a striking change in salinity of the ground which coincides with a small terrace along a contour 260 feet below sea level (fig. 60). The hill of the Funeral Formation just north of the highway has a strong caliche of gypsum above the terrace, and all the ground on the hillside is heavily impregnated with gypsum. Around the foot of the hill, at and below the terrace, the ground is impregnated with rock salt. A layer of rock salt, evidently marking the capillary fringe above the old water table, extends into the gypsiferous gravel. This layer of rock salt is broken by polygonal cracks that are manifested at the surface by shallow troughs in which pebbles have collected-a type of patterned ground distinctive of this shoreline (Hunt and Washburn, in Hunt and others, 1965).

Similar changes in salinity at about this same level appear at many places along the east side of Badwater Basin (fig. 61), and in the cove south of Copper Canyon, varnished gravel extends down to this level.

Sandy or other permeable beds along the edge of the saltpan generally have a calichelike layer of salts $1-4$ inches thick and 3-15 inches below the surface. The composition of the salts varies from one part of the saltpan to another. Where little ground water moves into the saltpan, the salts in the caliche are mostly rock salt. Where much ground water moves into the saltpan, sodium chloride is flushed to the interior of the saltpan, and the caliche layer around the edge is mostly composed of sulfates. Along the north and east sides of 


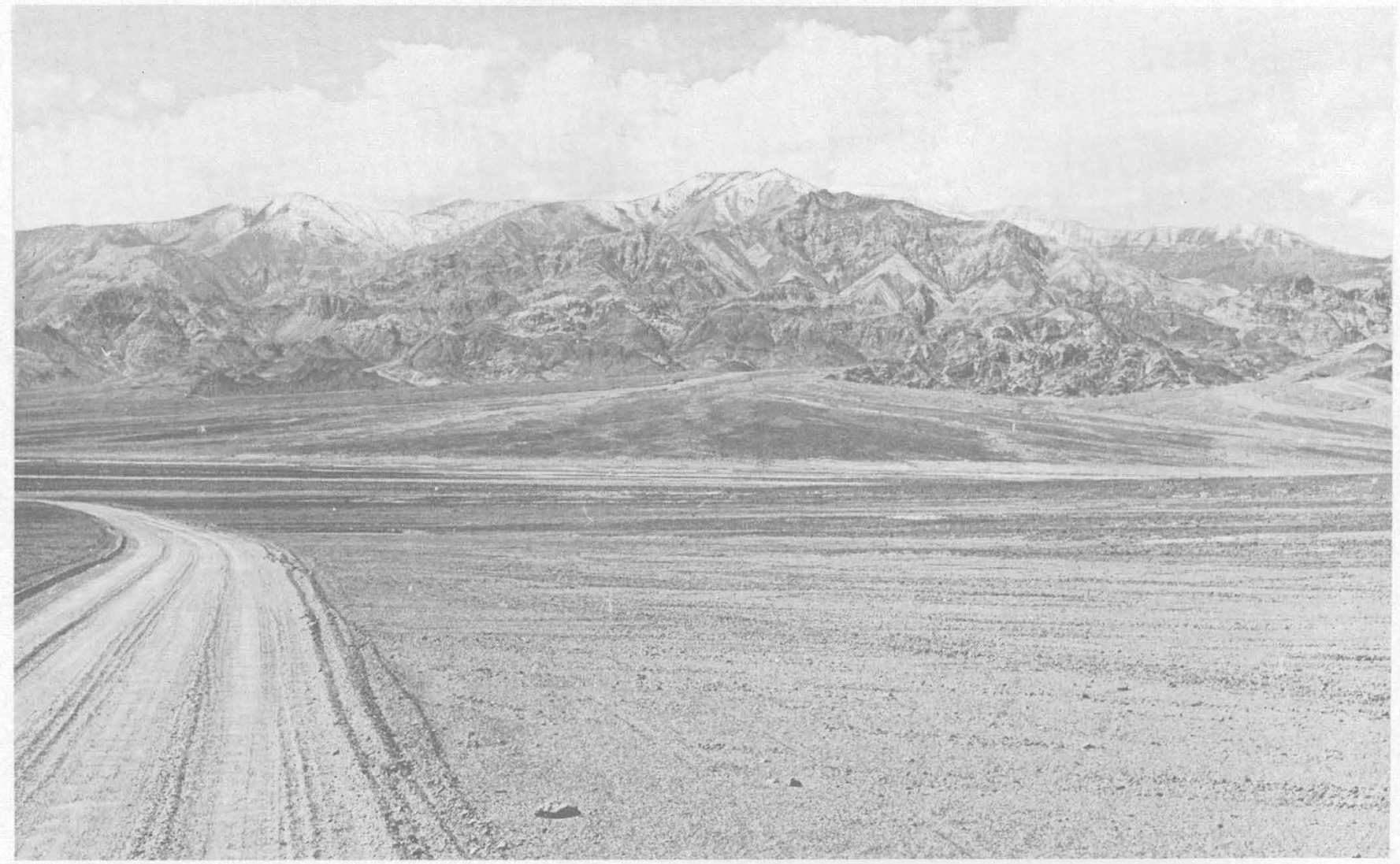

Figure 57.-View west across Death Valley to Trail Canyon fan showing how the lower limit of the desert varnish follows the contour. The light ground below the darkly varnished gravel not only is without desert varnish, it is highly saliferous.

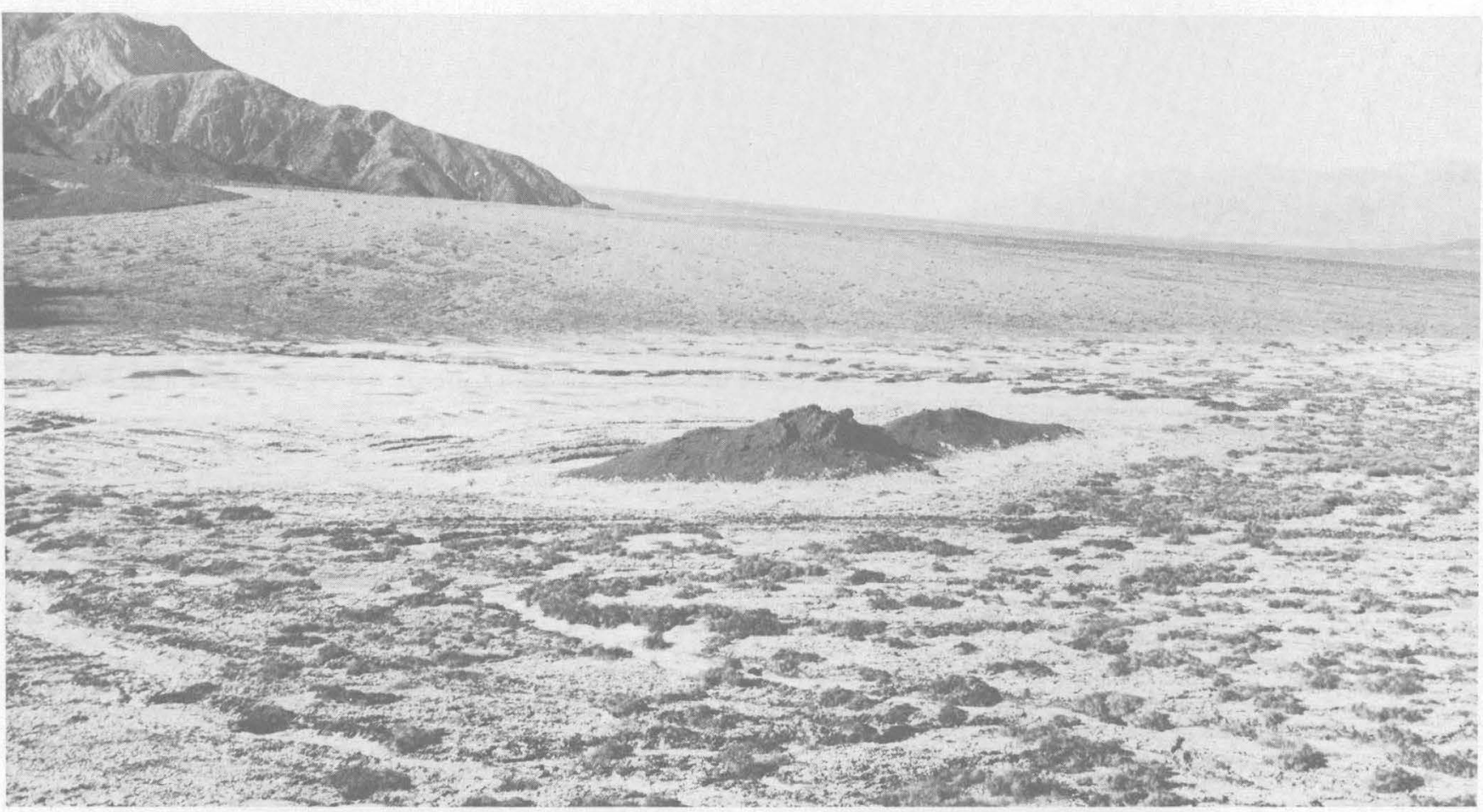

FigURE 58. - Shoreline of the Recent lake marked by change in ground. Highly saliferous ground, marked by pickleweed mounds in the foreground, forms a salt flat that ends along a contour near the foot of the gravel fans and around the base of the little hill in the center of the cove. View northwest across the cove north of the West Side Borax Camp. 


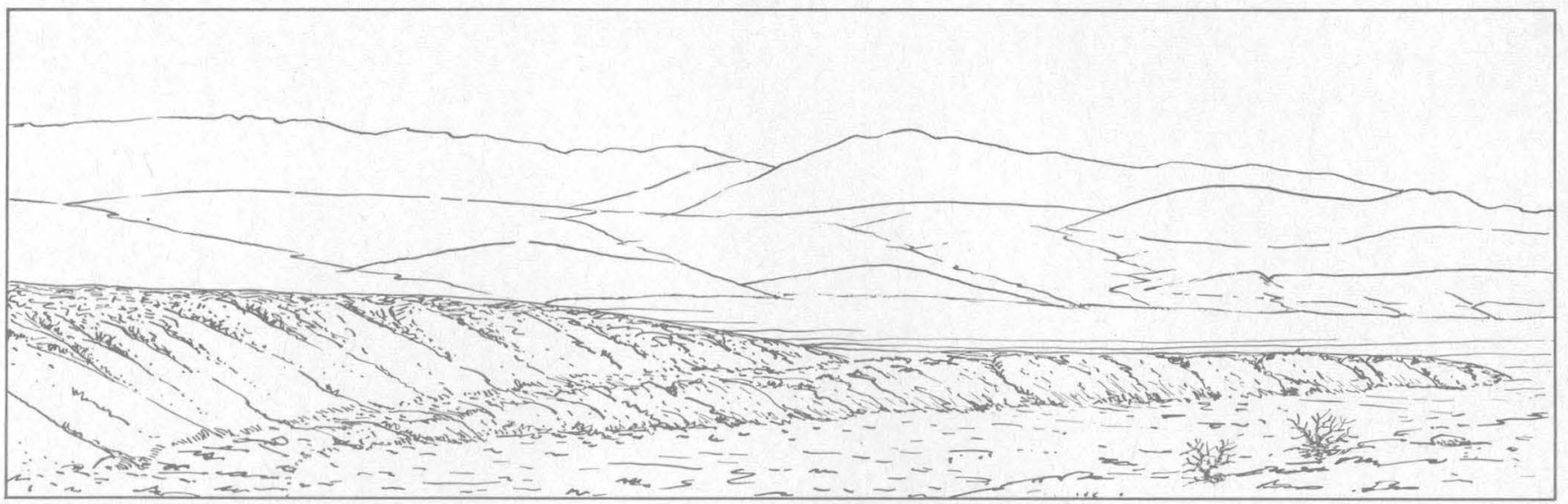

FIGURE 59.- Shoreline cut in alluvial bank of wash at east foot of the Salt Creek Hills (altitude about - 240 ft; SW $1 / 4$ SE $1 / 4$ sec. 10 , T. $16 \mathrm{~S}$. , R. 46 E.). View east.

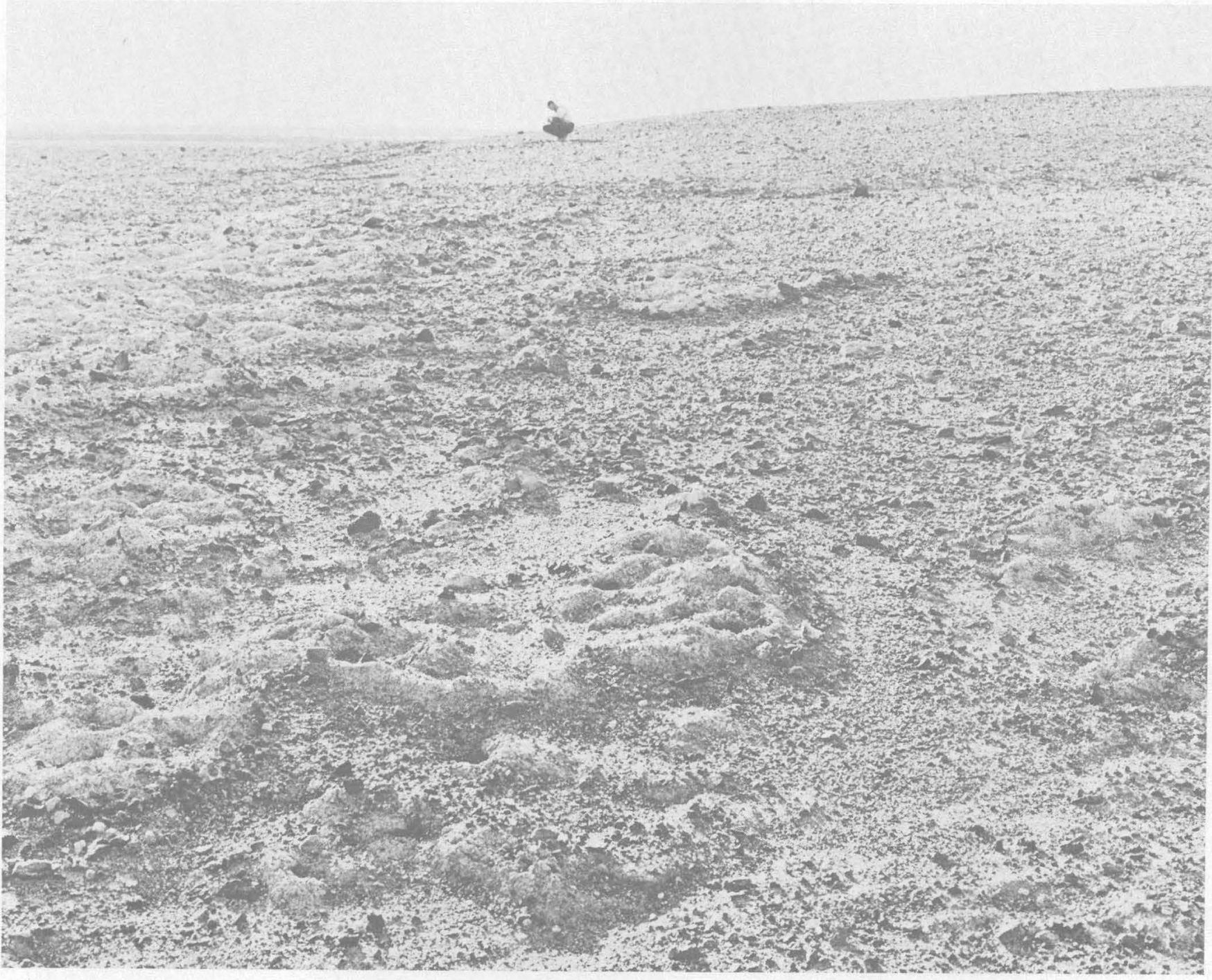

FIGURE 60.-View of narrow terrace around the foot of the Artists Drive fault block, 260 feet below sea level, which is interpreted to be the shoreline of a Recent lake. The ground below the terrace is roughened by heaving of rock salt; the ground above the terrace is smooth and impregnated with gypsum. View northwest, from half a mile north of the highway across the Devils Golf Course. 


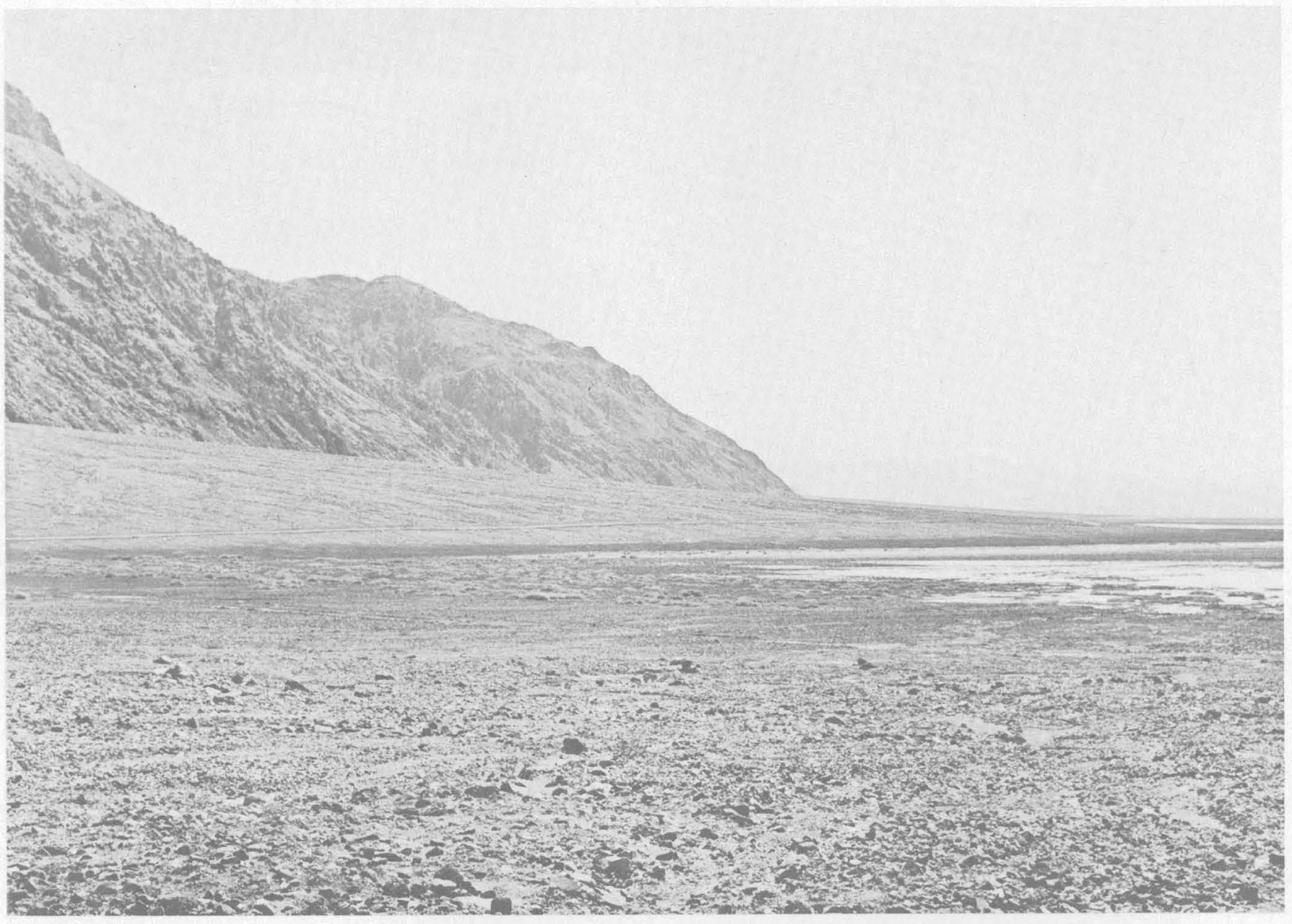

FrgURE 61. View of shoreline at foot of fan north of Coffin Canyon. The greater salt content of the ground below the shoreline helps retain moisture and appears dark.

Cottonball Basin, where the ratio of calcium to sodium is low, the sulfates are mostly sodium sulfate. Along the west side of Badwater Basin, where the calciumsodium ratio is high, the sulfates are mostly calcium sulfate.

At most places these caliche layers are 8-10 feet above the present water table and are $4-5$ feet above the present capillary fringe. There is little doubt that they formed by evaporation of ground water at a time when the water table was higher than it is now, and very probably this occurred at the time the Recent lake filled the basin. There was more moisture at that time, and the caliche deposits largely coincide with the shoreline of that lake.

The lake that produced these features antedates sand dunes (p. A86) that have formed on the old lake floor along the west side of Badwater Basin. These sand dunes must have formed during the last 2,000 years, for they contain artifacts representing late archeological sites - specifically the Death Valley IV (pottery) occupation (about A.D. 1000) and the Death Valley III (prepottery but bow-and-arrow) occupation (about
A.D. 1) (p. A87). The absence in the sand dunes of artifacts representing the pre-bow-and-arrow occupations is consistent with the idea that the dunes are younger than these occupations.

The lake must be older than the deposits of massive gypsum, for these deposits are not impregnated with rock salt, though they would have been flooded by the lake. The lake is younger than the sandy and silty beds that are exposed around the edge of the saltpan at the foot of the gravel fans, because these beds contain calichelike layers of salts and other salt impregnations that evidently were deposited when they were flooded by the young lake.

The lake probably is a feature of the Recent pluvial period that is widely represented by Recent but prepottery and pre-bow-and-arrow alluvial deposits in other parts of the Southwest (Hunt, 1953, p. 3).

Since the time of this lake the valley floor in Badwater Basin has been tilted eastward; the shoreline is 20 feet lower along the east side of that basin than it is along the west side. 
The deposits that formed in an around the edge of the lake are mostly salines and constitute the Death Valley saltpan. The pan covers more than 200 square miles, all of it below sea level and most of it between 270 and 282 feet below sea level. The salt crust on the saltpan ranges from a few inches to a few feet thick; it is underlain by silt and clay. At the center of the pan the salts in the crust are mostly chlorides. These chlorides are surrounded by a narrow discontinuous zone in which the salts are chiefly sulfates, and these, in turn, are surrounded by a sandy zone containing carbonate salts.

The deposits are a few inches to a few feet higher than the areas that are subject to flooding at present, but although the surfaces of the deposits are elevated and protected against flooding, the edges of the deposits are being eroded where subject to washing by present-day floods. The zoning of the salts in the crust reflects the differences in solubility of the salts. These deposits, described fully in Hunt and others (1965), are summarized here.

\section{OLDER SALINES}

MASBIVE ROCK BALT

The massive rock salt is at least 3 feet thick and overlies silt and clay. It covers about 8 square miles in the lowest part of the saltpan $(-280 \mathrm{ft})$, along the east side between the salt pools and Badwater (fig. 2). The deposit probably averages 95 percent or more of sodium chloride; the remaining 5 percent is mostly chlorides of calcium, magnesium, and potassium and sulfates of magnesium and sodium.

The deposit has an exceedingly rough surface of jagged pinnacles 6-10 inches wide and 1-2 feet high. The depressions between the pinnacles are 1-2 feet wide and are marked by cracks that divide the salt into polygonal slabs 4-6 feet wide. The composition and purity of the deposit, combined with the fact that it is located in the lowest part of the saltpan, suggest that it is the residue from the evaporation of a lake. This lake would have to be the youngest that has flooded Death Valley, the Recent lake.

\section{ROUGH SILTY ROCK SALT}

Peripheral to the massive rock salt and grading into it is a belt of equally rough rock salt that is silty. This rough silty rock salt is $1-3$ feet thick. It extends onto ground that is 5-10 feet higher than the massive rock salt, about -275 to -270 feet. This deposit, covering about 25 square miles, contains $20-40$ percent silt admixed with the salt. The deposit has a rough surface very much like that of the massive rock salt, and is also divided into polygonal slabs by cracks 4-6 feet apart.
Similar deposits are forming at present where perennial ground water is shallow enough for the capillary fringe to reach the surface. The resulting evaporation of water in the wet muds causes salts to precipitate in the mud, heaving it upward and producing a deposit that is mixed salt and mud. The distribution of the rough silty rock salt, peripheral to the massive rock salt, suggests that it formed in shallow parts of the lake where seasonal fluctuations of level would produce mud flats with ground water virtually at the surface.

$$
\text { SMOOTH SILTY ROCK SALT }
$$

Peripheral to the rough silty rock salt and gradational to it is a form of salt crust referred to as smooth silty rock salt. The smooth silty rock salt forms extensive smooth plains at the mouths of the principal streams discharging into Death Valley-the Amargosa River, Salt Creek, and Furnance Creek. The three areas where the deposit occurs are about 265 feet below sea level and aggregate about 50 square miles. The deposit consists of a surface layer of brown silt, 1-6 inches thick, resting on a layer of silty rock salt about 1 foot thick. This rock salt rests on clastic sediments. Panward the layer of silt thins, whereas the layer of rock salt thickens.

The salt is cracked into polygonal slabs 3-6 feet in diameter; the overlying silt is similarly cracked but also is divided by closely spaced desiccation cracks that end downward at the salt. The junctions of the polygonal cracks in the salt commonly are reflected in solution pits or depressions in the surface of the silt.

The smooth rock salt layer is interpreted as having been formed by evaporation of ground water, like the rough silty salt. This surface was smoothed, and the silt on it probably was deposited by floods from the main streams discharging onto the salt.

\section{MASSIVE GYPSUM}

Surrounding the chloride zone and slightly higher than the rough silty rock salt (at an average of about $-265 \mathrm{ft}$ on the west side of the saltpan and $-270 \mathrm{ft}$ on the east side) is a discontinuous belt of massive gypsum in deposits 1-5 feet thick. The gypsum overlies damp or wet silt and is capped by a layer of anhydrite or bassanite 1-6 inches thick.

All the present-day gypsum deposits are located near marshes, and presumably the massive gypsum was deposited in marshes at a time when the discharge of the springs was greater than it is today. At the marshes, the total of the dissolved solids is less in wet years than in dry years, chiefly because the amount and proportion of sodium chloride is less. In time of high discharge, gypsum continues to be precipitated, but the more soluble sodium chloride is flushed from this part 
of the system and transported in solution to the chloride zone.

The massive deposits of gypsum are interpreted as having formed during the period of the Recent lake when discharge from the marshes and springs would have been greater than now and great enough to keep the sodium chloride in solution and flushed out of the system. Under this interpretation the gypsum must have formed after the level of the lake had fallen below the level of those deposits, or they would have become impregnated with sodium chloride introduced by the lake water. The difference in level of the deposits on the two sides of the saltpan may be due to eastward tilting of the saltpan during the last 2,000 years (p. A100).

\section{SALINE DEPOSITS FORMING AT PRESENT}

\section{FLOOD-PLAIN DEPOSITS}

Salts and saliferous muds are being deposited at present on those parts of the saltpan that are subject to seasonal flooding, altogether about a third of the saltpan. A crust of salt is forming on the lowest parts of the flood plain where surface water collects and can escape only by evaporation. One such area is in Badwater Basin about midway between Badwater and Tule Spring. Another area is in Middle Basin, the low part of which is 1.5 feet lower than the channel that discharges from there to Badwater Basin.

The parts of the flood plain that are tributary to these low places are frequently washed by surface water, and they include extensive areas of bare mud flats. Salts that accumulate on the surface after one wetting are removed by later floods.

Much ground water, though, moves laterally from the channels to nearby areas that are flooded infrequently; the evaporation of this ground water leaves deposits of salts in the upper layers of the mud, forming a crust of silty rock salt.

\section{MARSH DEPOSITS}

Marsh deposits are forming at present at many places around the edge of the saltpan where ground water is moving laterally into the pan. The marshes are located where the sand facies grades laterally to silt; the movement of ground water is slowed by the silt, and the ground water level is held up in the adjoining sand (Hunt and Robinson, in Hunt and others, 1965).

All the marshes are depositing sulfate salts. At some marshes along the east side of Cottonball Basin, sodium carbonate is being deposited in addition to sodium sulfate. Elsewhere, the deposits are largely or wholly sulfates with some chlorides. In Badwater Basin where the calcium-sodium ratio is high, the sulfate being deposited is calcium sulfate. In Cottonball Basin where the calcium-sodium ratio is low, the sulfates that are being deposited are mostly sodium sulfate and sodiumcalcium sulfate.

The deposits consist of califlowerlike lumps of granular and porous sulfate salts having the texture of wet bread crumbs and coated by a firm layer of salts that includes much sodium chloride. In dry seasons the proportion of sodium chloride, on the lumps and in brines, may be high; in wet seasons it is low, evidently because the discharge is sufficient to transport the more soluble chloride away from the marsh to the chloride zone.

\section{NO. 4 GRAVEI}

The No. 4 gravel is along the washes on the gravel fans. Where these washes are no more than a foot or two deep and the area between is frequently flooded, the interstream gravels are included with the No. 4. The No. 4 gravels are composed of firm rocks that are without both weathering rinds and desert varnish. The deposits are loose gravel containing few large boulders and without much sand (fig. 62).

The No. 4 gravel is thin, probably nowhere more than about 10 or 15 feet thick, and the volume of this gravel is correspondingly small compared to the older ones.

Not only is the volume of the No. 4 gravel small, most of the gravel has been derived by eroding the older deposits on the fans. Very little of it seems to have been new gravel from the mountains. Evidence for this is twofold. First, the volume of the No. 4 gravel approximately equals the volume of the channels that have been eroded into the older gravels. Second, large boulders that occur locally in the No. 4 gravel are as abundant along tributary washes that rise in those gravels as they are along the main washes that extend into the mountains. The boulders in the tributary washes must have been derived from the older deposits, and probably most of those along the main washes were too.

That cloudbursts can produce floods and mudflows in the washes capable of transporting the largest boulders is clear enough. A striking example is along the main wash draining from Starvation Canyon, where a Recent flood was capable of lifting boulders 10 feet in diameter onto the bank which is 50 feet higher than the bottom of the wash. As noted above, there is adequate source for these boulders nearby in the older gravel; they need not have been moved far. They could be due entirely to reworking from the older gravel deposits along the channel.

On fans composed largely of fine-grained materials, like those on Artists Drive, flash floods and resulting mudflows are frequent. At one place, about midway between the exit from Artists Drive and the junction with the West Side highway, an old highway pavement is 


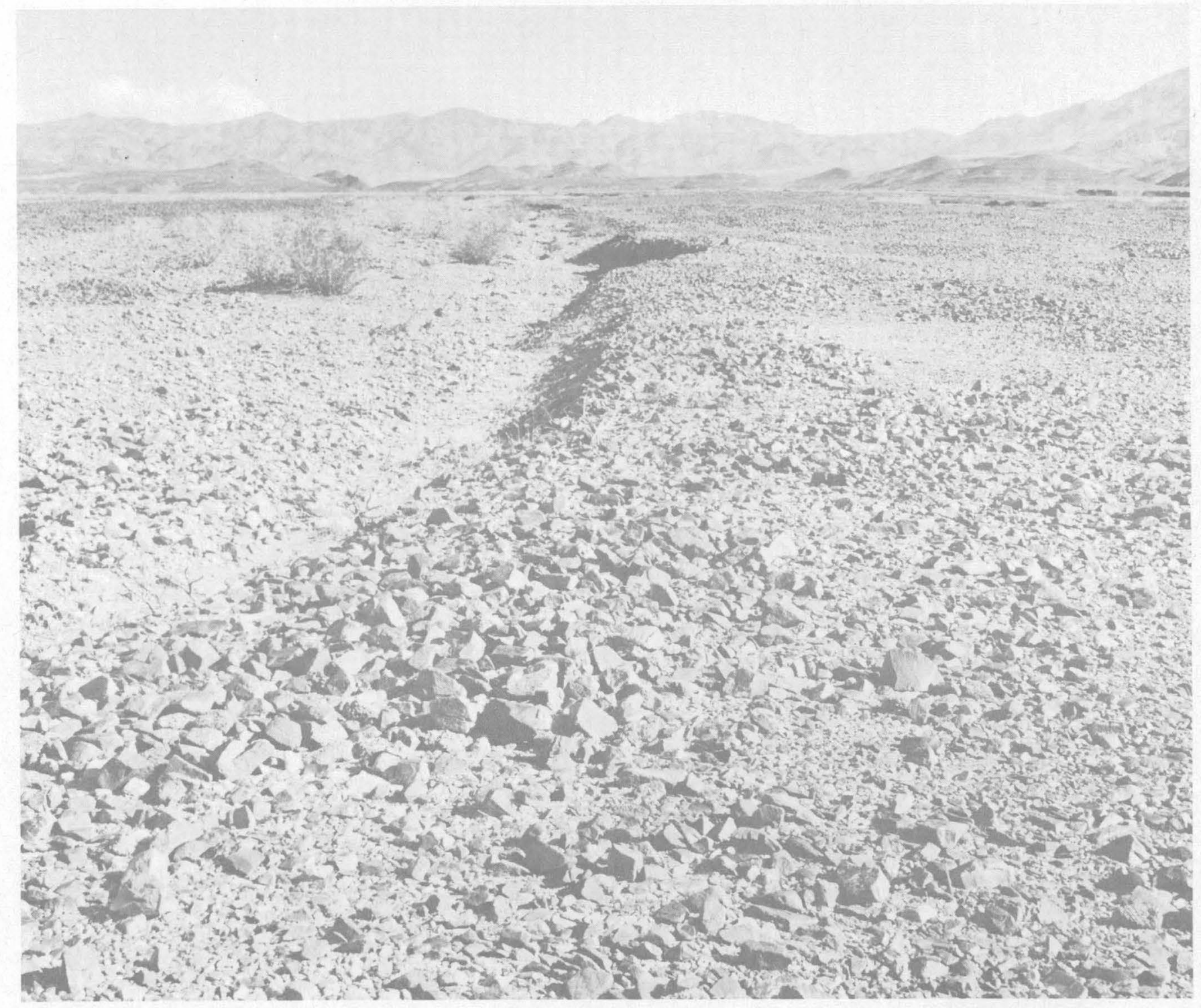

Figure 62.-Contrast between No. 4 gravel in present wash (left) and No. 3 gravel (right). Gravel in the wash is not stained with desert varnish, and it is loose. In middle distance is the ridge at Park Villa ge, composed of the Funeral Formation. Photograph by John R. Stacy.

buried under about 4 feet of mudflow on top of which is the present pavement. It was cheaper to build a new road than to excavate the old!

Such examples of recently formed mudflows are impressive and provide a yardstick for visualizing the vastly larger ones represented by the older deposits, like those on figure 48.

The No. 4 gravel does not extend onto the floor of the valley, except as short narrow stringers of fine pebbles along rills at the foot of the fans. Few of the rills are as wide as 6 feet ; most are only a foot or two wide and only a few inches deep. Although an occasional large pebble may be found along a rill a few hundred feet into the saltpan, for all practical purposes the gravels have not been moved onto the pan more than a few tens of feet, and this abrupt lower limit to the extent of the gravel coincides with a break in slope between the foot of the fans and the saltpan. The gravelly lower edges of the fans slope 2-6 percent; the stone-free edge of the saltpan slopes less than 1 percent.

On the high parts of the fans, the gravel along the present washes is lower than the older gravels, but on the lower parts of the fans the No. 4 overlaps the No. 3 and older deposits and forms fans on top of them (fig. 63). Just as the No. 3 gravel overlaps the lower edges of the No. 2, so also the No. 4 gravel overlaps the lower edges of the No. 3. Clear examples of these overlaps can be seen on practically every fan, and the position of overlap has shifted toward the foot of the fans (fig. 64). This shift could be attributed to downcutting on the high 


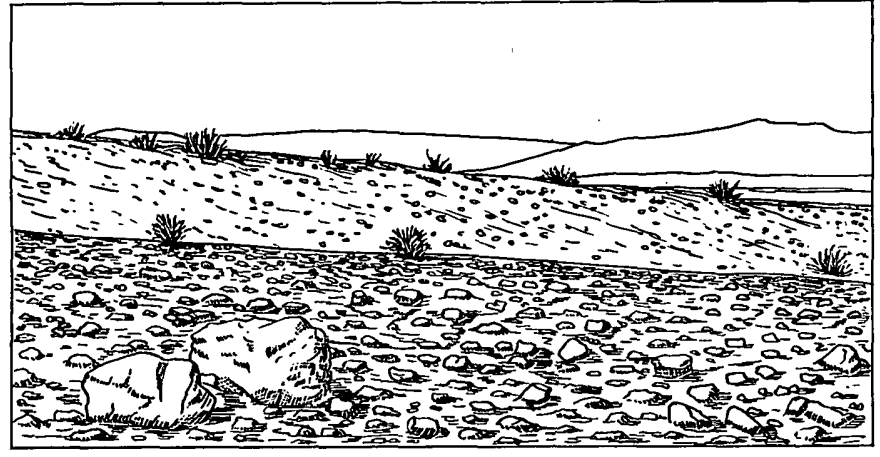

Figdre 63.-Desert pavement with angular blocks and slabs on No. 2 gravel (foreground) is overlapped by a fan of No. 4 gravel (with creosote bush) which is being built higher than the old gravel. View north from road to Hanaupah Canyon about 1 mile west of Shortys Well.

parts of the fans and the building up of base level at the foot of the fans, but the process has been complicated by eastward tilting that steepened the fans while they were being built.

\section{ALLOVIOM ALONG AMARGOSA RIVER AND SALT CREEK}

Flood-plain deposits of alluvium occur along the Amargosa River and Salt Creek. The deposits are mostly silty sand or sandy silt with a little gravel. About 10 feet of alluvium is the maximum thickness exposed, but the maximum thickness of the deposits may be very much greater than this figure.

These alluvial deposits are overlain by sand dunes that date back to prepottery times-that is, the Death Valley III occupation (p. A87). Such dunes are widespread on the alluvium in Mesquite Flat and along Salt Creek in the vicinity of McLean Springs. Others are located on the alluvium along the Amargosa River 5 miles southeast of Coyote Hole and in the Amargosa Desert 35 miles east of Death Valley. Very likely, therefore, the alluvium was laid down about the time of the Recent lake in Death Valley.

In the 2,000 years since that time, the surface of the alluvium has been modified only slightly. The main streams have become trenched as much as 10 feet into the fill. Winds locally have excavated deflation hollows on the surface and have built, and still are building, dunes on the alluvium. Washing from the side hills locally has deposited a foot or two of younger alluvium on the old.

\section{DUNE BAND}

Dune sand is of very limited extent around the Death Valley saltpan for the reason that most of the sand there is firmly cemented with salt. Dunes are moderately extensive on Furnace Creek fan and along the west side of Badwater Basin opposite the mouth of Hanaupah and Starvation Canyons. At both localities the sand facies is somewhat wider than elsewhere, because of the source rocks; also, substantial quantities of fresh water are being discharged there to the saltpan, so that the ground contains less soil salts than does the sand around the rest of the saltpan. Too, these are the places where the fan gravels contain most calcium carbonate cement, indicating that ground water discharge has been greatest at these places in past as well as present times A78. The same is true but on a much smaller scale at isolated groups of small dunes at the mouths of Cow and Salt Creeks and on the west side of Badwater Basin opposite the mouths of Johnson and Galena Canyons.

Honey mesquite grows on the dunes and helps hold them in place. The occurrence of the honey mesquite is further indication of good quality water because this phreatophyte, in Death Valley, does not grow where the salinity of the ground water exceeds about 0.5 percent (see Hunt, 1965). Where mesquite plants have died, the dunes become destroyed by wind carrying the sand away from the locality.

Dunes on Furnace Creek fan average about 75 feet in diameter and 6 feet high. They overlie alluvial sandy silt and intertongue with the top 18 inches of that silt. Dunes along the west side of Badwater Basin average twice as wide and twice as high as those on Furnace Creek fan; some are as much as 20 feet high.

The dunes are not migratory. Rather, they are heaps of sand close to the parent formation. This is indicated partly by their distribution and partly, too, by their mineralogy. The mineral composition of the dune sand and of the underlying sand formation is alike at a given location, but it changes greatly from one part of the saltpan to another. For example, from Salt Well south to the foot of the Wingate Wash fan, about

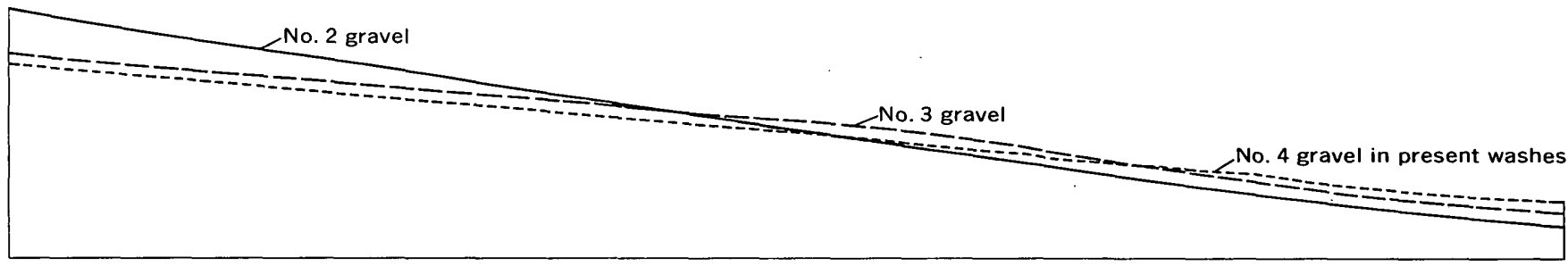

Fradre 64.-Diagrammatic profles of fans along the west side of Death Valley, lllustrating the downfan shift in position and overlap of younger gravels on older gravels. No. 4 gravel overlaps the No. 3 gravel below where the No. 3 gravel overlaps the No. 2 gravel. 
50 percent of the sand is volcanic rock, and a very little is carbonate rock. Northward from Salt Well the percentage of volcanic material decreases to 10 percent or less. At Gravel Well the sand contains numerous flakes of shale from the Johnnie Formation. On Furnace Creek fan, about 50 percent of the dune sand is volcanic rock and about 25 percent is carbonate rock. In all the dunes the grain size is about the same, commonly about $0.25 \mathrm{~mm}$ in diameter; about 65 percent is coarser than $0.15 \mathrm{~mm}$ and 35 percent is finer.

Sand dunes on Mesquite Flat are much more extensive, much larger and higher, and average finer in grain size than those along the edges of the saltpan. They rest on alluvium. Although the Mesquite Flat dunes are not stationary, they probably have not moved far, because the dunes are largest and most extensive along the sandy belt between the foot of the gravel fans and the silty flood plain that constitutes most of Mesquite Flat.

Other dunes occur along the Amargosa River and overlie the alluvium in the flood plain.

The dunes around the saltpan have developed on ground that was flooded by the Recent lake and have formed since that flooding. The dunes at Mesquite Flat and along the Amargosa River overlie alluvium. All these contain archeological remains representing the Death Valley IV (pottery) occupation and the Death Valley III (prepottery but bow-and-arrow) occupation (see below). These remains occur at all levels in the dunes and on the underyling salt-impregnated sand from which the dunes were derived. Accordingly, the dunes must have been forming throughout the last 2,000 years, and the Recent lake was before that time.

In other areas it has been possible to show that extensive dunes formed during the early part of the Recent. (See for example, Hack, 1941, 1942.) This probably also was true in Death Valley, but early Recent dunes that may have formed around the edge of the saltpan would have been destroyed by the rise and fall of the Recent lake. Relicts of the early Recent dunes would be expected in Mesquite Flat, but search there has not revealed satisfactory evidence of them. The flat was not submerged by the Recent lake, but it may have been flooded by stream wash sufficiently to level the supposej early Recent dunes.

\section{ARCHEOLOGY OF THE DEPOSITS}

Occupations of four different ages have been recognized around the Death Valley saltpan. The two early ones, called Death Valley I and II, predate the Christian era. They can be equated with the Lake Mojave, Pinto Basin, and early Amargosa cultures found elsewhere in the southern Great Basin and
Mojave Desert. These occupations were chiefly hunting cultures and antedate the bow and arrow. Death Valley III is marked by the introduction of the bow and arrow and dates from about A.D. 500. Death Valley IV is marked by the introduction of pottery into Death Valley, probably about the 11th century A.D. Death Valley III and IV were gathering rather than hunting cultures. The archeology is described in a comprehensive report by A. P. Hunt (1960).

\section{PHYSIOGRAPHY OF THE FANS}

The gravel fans that are tributary to the Death Valley saltpan can be considered in four groups. The largest, both in area and volume, are those along the east foot of the Panamint Range. These fans are 5-6 miles long; their surfaces rise from below sea level, at the edge of the saltpan, to more than 1,000 feet above sea level. The summit of the Panamint Range is 7,000 11,000 feet in altitude, and the area of the mountains draining to the fans is almost twice as great as the area of the fans. The rocks are mostly of Precambrian and Paleozoic age. Geophysical surveys indicate that these fans and the fill under them attain a miximum thickness of about 6,000 feet. The thickness is greatest at the foot of the fans. As indicated below (p. A108), probably only about a third of this fill is Quaternary gravel; the remainder is Tertiary and most of volcanic origin.

A second group of gravel fans lies in front of the northwest-trending Funeral Mountains, which extend diagonally across the north end of the part of Death Valley that contains the saltpan. These fans are as long and as high as those along the foot of the Panamint Range, but the fan form is not distinct because the fans are interrupted by numerous hills and ridges of older rocks protruding through the gravel. Also these gravel deposits average very much thinner and their volume very much less than those along the foot of the Panamint Range, no doubt because the drainage basins from which these fans were derived are small compared to those in the Panamint Range. The summit of the Funeral Mountains is only 6,000 feet in altitude, and the area of the mountains draining to Death Valley is no greater than the area of the fans. The rocks are not unlike those in the Panamint Range.

A third group of gravel fans comprise those along the foot of the Black Mountains, along the east side of the saltpan south of Badwater. In contrast to the other two groups of fans, these are small, evidently because the floor of Death Valley has been tilted eastward during Pleistocene and Recent time. These fans have been sinking and are mostly buried by overlap of the playa sediments. 
The fourth group of fans are those along the foot of the Black Mountains north of Badwater. These fans contain a high percentage of fine-grained sediments, because they were derived in large part from finegrained Tertiary playa sediments and volcanics. The area of these fans is about equal to the area of the mountains drained to them, but the mountain summit is only 2,000-4,000 feet in altitude. The fans on Artists Drive, like those in front of the Funeral Mountains, are interrupted by hills of older rocks protruding through the fans, and the gravel deposits are equally thin.

On the fans the gravels of different ages form different kinds of ground, each having a distinctive drainage pattern. The differences are best illustrated on the fans along the foot of the Panamint Range (fig. 65).

Differences in the patterns of the fans in different parts of Death Valley reflect differences in their structural history. In terms of Davis' nomenclature (1925) the foot of the Black Mountains south of Badwater is partly fan based, as at Coffin Canyon (fig. 66A), and partly fan free, as in the coves just north and south of the Coffin Canyon fan. Clearly this reflects the eastward tilting of the floor of Death Valley and the overlap of the fine-grained sediments onto the fans and even onto the bedrock front of the mountain.

Differences in fan patterns northward along the foot of the Panamint Range very possibly reflect northward tilt of the Pánamint Range. South of Johnson Canyon, at Six Spring and Galena Canyons, the foot of the range is fan bayed (fig. 66B). There the spurs are alined, and the fan gravels extend a short distance into the canyons. From Starvation Canyon northward to Trail Canyon the spurs are irregular, and the front of the range is fan frayed (fig. $66 \mathrm{C}$ ). At Blackwater and Tucki Washes, hills of bedrock are surrounded by fan gravel, and the front of the range is fan wrapped (fig. 66D).

There is a difference, too, in the degree of dissection of the old gravels northward along the fans (pl. 2). In general, the extent and depth of dissection of the old gravel increases southward as if there has been northward tilting of this stretch of Death Valley since the No. 2 gravel was deposited.

On many of the fans the main washes, which are transporting coarse material from the mountains, have steeper gradients than tributaries. The main washes with their coarse debris rise in areas of relatively high rainfall; they are discharging into an area of low rainfall where the ground is permeable and where water is lost by seepage and evaporation. The courses of these streams are being aggraded. Their tributaries though, rising at the foot of the mountains, are cutting down, especially those eroding in fine-grained rocks; such tributaries may have flatter gradients than the main streams.

A very striking small-scale example of such difference in gradient can be seen on the east side of the highway at the south edge of Cow Creek. A small tributary draining the fine-grained rocks of the Furnace Creek

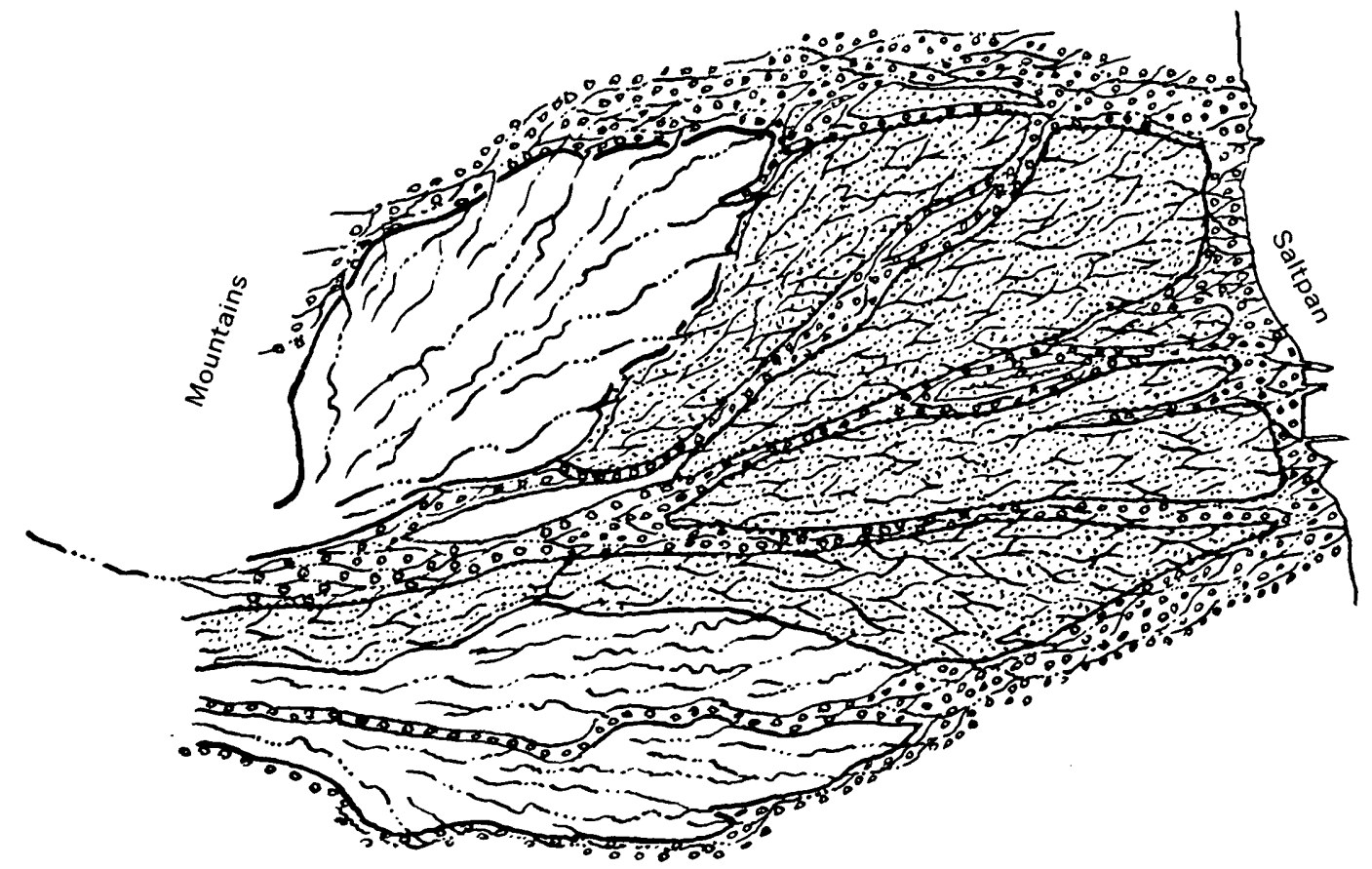

Figurn 65.-Map illustrating differences in dralnage pattern on the older and younger gravels. On the No. 2 gravel (white areas) the drainage is parallel tending towards dendritic. On the younger gravels, No. 3 (stippled areas) and No. 4 (circle pattern), the drainage is braided. 


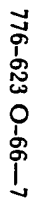

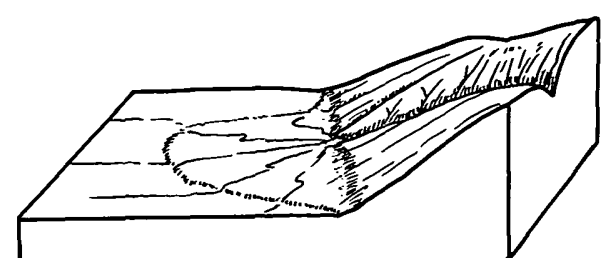

1 MILE

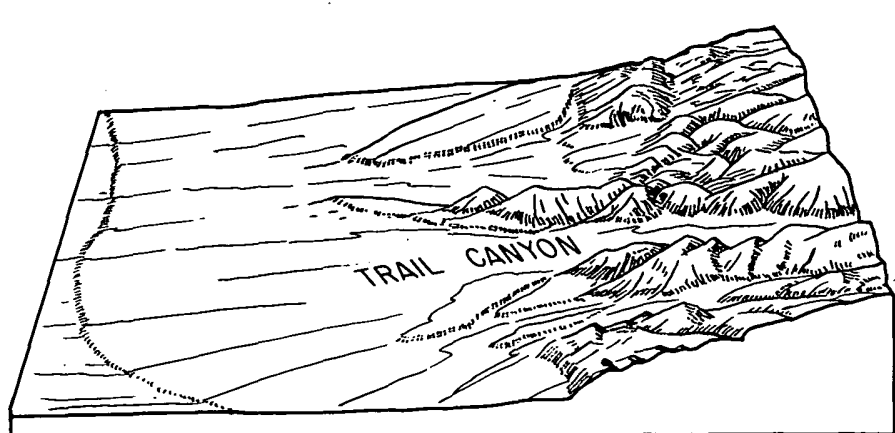

C

$$
\stackrel{1}{1} \quad 2 \quad 3 \quad 3 \quad 3 \text { MILES }
$$

Figobd 66.-Fan patterns at the foot of the Black Mountains and the Panamint Range. A, Fan-based front of Black Mountains at Coffin Canyon. View north. B, Fan-bayed east foot of the Panamint Range at Six Spring Canyon. View south. $O$, Fan-frayed east foot of the Panamint Range at Trall Canyon. Vlew south. D, Fan-wrapped east foot of the Panamint Range at Blackwater and Tucki Washes. View southwest.
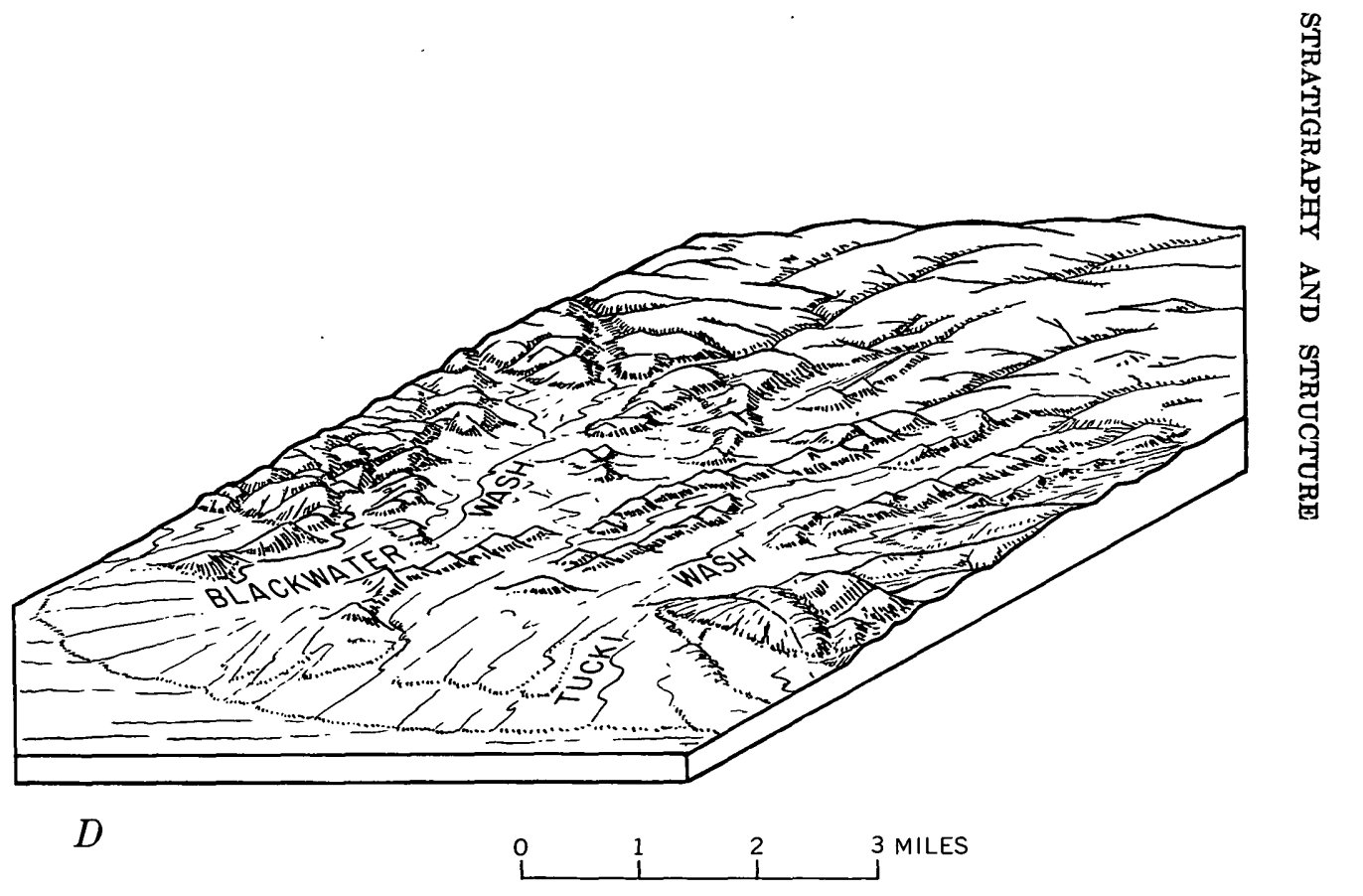
Formation has a much flatter gradient than Cow Creek, which it joins at the highway.

These relationships are similar to those better developed along the Book Cliffs (Rich, 1935) and around the Henry Mountains, Utah (Hunt and others, 1953, p. 204). A companion study of fan gravels in the Death Valley region, by C. S. Denny (written commun., 1965), has shown that gradients along the washes are proportional to the average grain size of the material being moved. Washes transporting coarse material have steeper gradients than those transporting fine material. Lawson (1915) noted that the angle of the rock slope in the desert commonly is determined by the maximum size of rock fragments shed from its surface.

Another feature of the small washes on the surfaces of the No. 2 gravel concerns differences in distribution of coarse and fine materials. Some washes are floored with coarse blocks, evidently a lag concentrate, and the banks are covered with finer gravel or flakes. A neighboring wash may have this distribution reversed. The coarse blocks may line the banks as a natural levee, and the bottom of the wash may be mostly finer gravel or flakes. Such differences may be related to the regimen of the last storm.

\section{DESERT VARNISH}

Desert varnish, a stain of iron and manganese oxides coating rock surfaces, is a conspicuous feature of the gravel fans in Death Valley. As seen from a distance, the different ages of gravel can be distinguished by the different degrees of stain (p. A76, 84).

Individual stones on the No. 2 gravel that are firm rock are stained as darkly as those on the surface of the No. 3 gravel; but a high proportion of stones on the No. 2 are crumbly, and these have light-colored surfaces. The varnish has flaked off. As seen from a distance or on an aerial photograph, therefore, these surfaces may appear less dark than do those on the younger No. 3 gravel.

As the name implies, desert varnish is best developed, or at least most conspicuous, in desert regions, but the stain is by no means restricted to such areas; iron and manganese oxides stain rock surfaces in humid regions too. The stain occurs on every type of rock, although it is less common on limestone and dolomite than on the less calcareous rocks. The surfaces stained may be the top or sides of isolated individual stones; they may be vertical or overhanging cliffs, or other surfaces splashed by rivers or wetted by seeps. The stained surfaces may be exposed to direct sunlight or surfaces never reached by the sun, such as joint planes or tunnel walls.

Engel and Sharp (1958), in an important contribution to the chemistry of desert varnish, studied the trace elements occurring with the iron and manganese stain and concluded that (1) varnish on stones in soil or colluvium is derived largely from that material, (2) varnish on large bedrock exposures comes from weathered parts of the rock, and (3) airborne material probably contributes little to the varnish.

Additional chemical studies of 15 samples or varnish removed by an ultrasonic separator from different kinds of rocks in different environments in Death Valley are presented in table 21 . These analyses indicate that the proportion of iron to manganese ranges from $1: 1$ (sample $1 \mathrm{~B}$ ) to $10: 1$ (samples $3 \mathrm{~A}, 4,7$ ). This range is comparable to that reported by Engel and Sharp (1958, p. 500).

As seen in thin section, though, the varnish occurs in layers, at least in some places. The bottom layer is brownish or reddish, and the surface layer is bluish black. Some cobbles that are losing their varnish develop a brownish or reddish band where the varnish is thin between the bluish-black surface, still coated with varnish, and the light-colored surface where the varnish has been removed. Hubert Lakin (oral commun., 1960), of the U.S. Geological Survey, experimenting with hydroxylamine hydrochloride solution to remove desert varnish, found that the color of bathed surfaces changed from bluish black to red and finally to that of the parent rock when all the varnish had been removed. These observations suggest not only that the varnish is in layers, but that the underlying layers may have more iron and less manganese than does the surface layer. The range in ratio of iron to manganese indicated by the analyses, therefore, may be due in large part to the range in composition of the layers.

The analyses on table 21 illustrate the similarity in composition of the desert varnish on different kinds of stones in single environments (compare $1 \mathrm{~A}$ with $1 \mathrm{~B}$ and $1 \mathrm{C} ; 2 \mathrm{~A}$ with $2 \mathrm{~B} ; 3 \mathrm{~A}$ with $3 \mathrm{~B}$ ) and the differences in composition of the varnish in different environments (compare group 1 with groups 2 and 3 ). For example, beryllium and molybdenum were found in the varnish on all three specimens from station 1, but they are absent at stations 2 and 3 . Cobalt and gallium were found in the varnish on stones at stations 1 and 2, but they are absent at station 3 .

Desert varnish is mostly a deposit of considerable antiquity, a relic of past environments. It is being deposited today or has formed in the very recent past only at exceptional isolated locations where conditions, still not understood, have been unusual and optimum for its deposition. Engel and Sharp (1958, p. 515-516) overemphasize a locality where they infer varnish has been deposited in 25 years. If such deposition of the stain were anything but highly exceptional, buildings and 
TABLE 21.-Semiquantitative spectrographic analyses of desert varnish

Symbols:-not looked for; 0 , looked for, but not found; d, barely detected and concentration uncertain.

Flements looked for, but not found: As, Au, Bl, Cd, Ge, Hf, Hg, In, Ir, Os, P, Pd, Pb, Re, Rh, Ru, Sb, Ta, Te, Tn, Tl, U, W, Dy, Er, Ev, Ho, Lu, Pr, Sm, Tb, Tm.

[Analyst, John C. Hamilton]

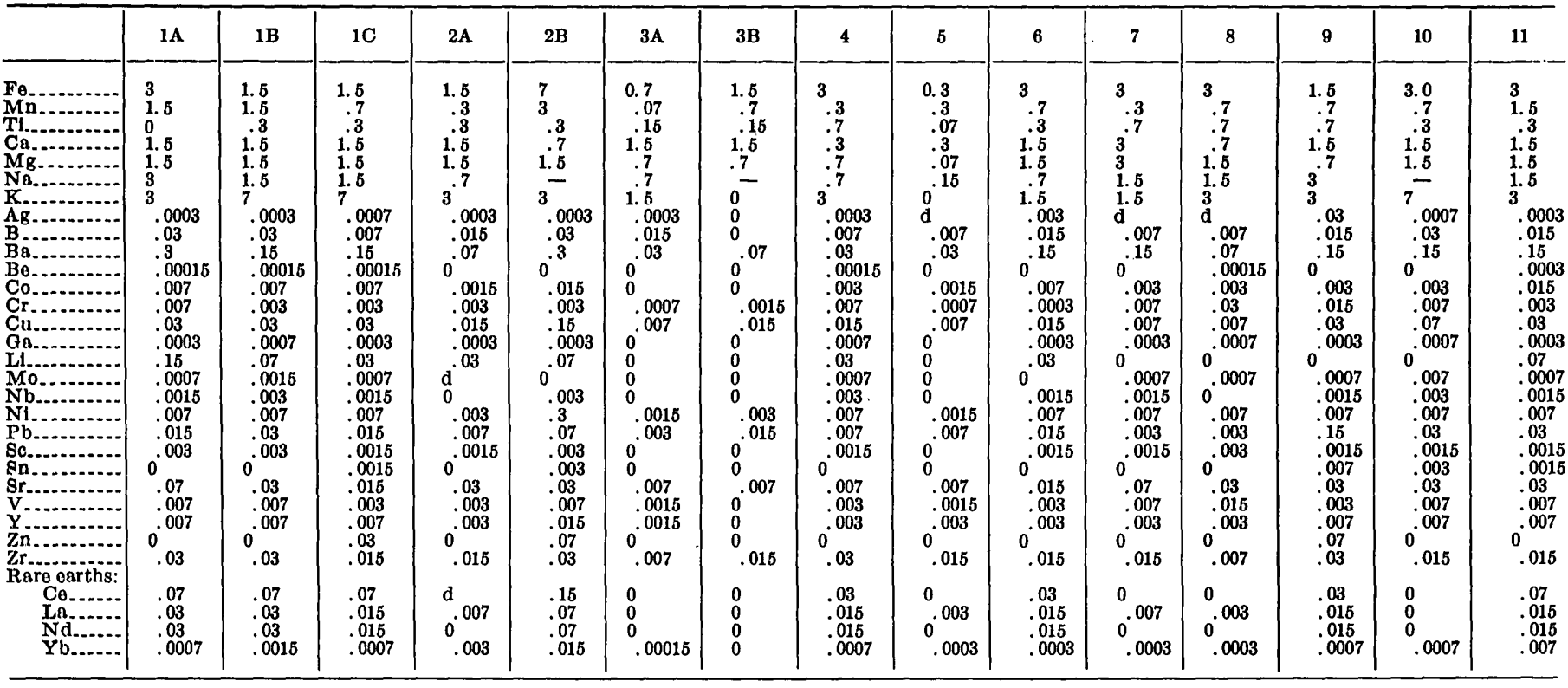

Figures are reported to the nearest number in the series $7,3,1.5,0.7,0.3,0.15$, etc., in percent. These numbers represent midpoints of group data on a geometric scale.
Comparlsons of this type of semiquantitative results with data obtained by quantitative methods, either chemical or spectrographic, show that the assigned group includes the quantitativo value about 60 percent of the time.

Description of samples

1A. Donse gray chert from desert pavement on Death Valley I site by Furnace Creek

at mouth of Corkscrew Canyon.
1B. Simllar to $A \cdot$ but moro granular; same locality.

1C. Donse brown chert; same locality. tween Travertine and Texas Springs.

2B. Quartzite stained black; from same locality as $2 A$

3A. Small light-colored chert flake from Death Valley I site on desert pavement

3B. Largo light-colored chert flake; same locality as 3A.

other surfaces, artificial and natural, that are as old as 25 years should generally be darkly stained, but such is not true.

There is, on the other hand, abundant and good evidence in Death Valley, in the Southwest generally, and in other parts of the world, indicating that very little desert varnish has been deposited during the last 2,000 years. In Death Valley, stone artifacts of the Death Valley III and IV occupations are not stained with desert varnish. Stone artifacts of the late Death Valley II occupation commonly are lightly stained. Stone artifacts of the early Death Valley II and Death Valley I occupations commonly are darkly stained. These generalizations are based on studies of hundreds of archeological sites.

The relationships observed in Death Valley are true generally through the Southwest. Pottery was introduced earlier elsewhere in the Southwest than in Death Valley-roughly 2,000 years ago. Stone artifacts and masonry dwellings of the pottery-making peoples rarely are stained with desert varnish, whereas stonework of older occupations commonly are stained. This evidence
4. Cambrian quartzite in cliff wall above Schaub

5. Pebble from face of Tertiary conglomerate at fault in NW1/4 NE1/4 sec. 7, T. 27 N. R. 2 E

6. Quarry area at megabreccia of quartzite 2 miles southeast of Echo Canyon. Basaltic cobble with weathering rind from Funeral Formation under Manly terrace at north end of Artists Drive fault blocks.

8. Granitic rock from debris avalanche, 3 miles south of Badwater.

9. Quartzite flakes from burial mound area at Tule Spring.

10. Upper Pleistocene gravel, Death Valley Canyon.

11. Choppers of volcanic rocks from quarry area at base of Dinosaur.

is regional and based on studies of thousands of sites.

Moreover, the conspicuous deposits of desert varnish today are being eroded, as on the surfaces of the No. 2 gravel in Death Valley. Whatever the rate of deposition of desert varnish, erosion is faster. The same is true on the Colorado Plateau where the varnish is preserved on the parts of cliff faces that are protected against erosion but is removed from exposed parts, such as the rounded edges of joint blocks and the upwardfacing parts of cliffs or buttes. Recent rockfalls in the canyons there leave bright scars on surfaces that otherwise are darkened with varnish. The protected undersides of isolated boulders are still coated with varnish, but it has been removed from the weathered tops and rounded edges.

The same appears to be true in arid regions in other parts of the world. Blackwelder (1948) cites evidence from Egypt indicating practically no deposition of desert varnish in 2,000 years, slight deposition in 5,000 years, and dark strain on older stonework.

The origin of desert varnish is still uncertain; but a reasonable hypothesis can be offered that is based on 
conditions at places where similar varnish is being deposited today.

Oxides of iron and manganese are being deposited at present at many springs, seeps, and other damp places in the arid Southwest. Water obviously is needed to transport the metals to the surface where they are deposited, but the restricted occurrence of newly deposited iron and manganese oxide at wet places suggests that the moisture requirements may be considerable. Little or no varnish is forming on surfaces that are infrequently wet.

The deposition occurring at wet places probably is not due solely to physical-chemical processes. The quality of the waters varies greatly from place to place, yet the oxides of iron and manganese invariably are selectively precipitated with only minor contaminants. This selective precipitation of the metals without mixing with large amounts of other salts could readily be brought about by oxidation caused by bacteria, algae, or other micro-organisms, but it seems difficult to achieve in such varied environments by physical-chemical processes alone.

The importance of micro-organisms for hastening the oxidation of pyrite in mine waters has been studied extensively and seems well established (see bibliography in Temple and Koehler, 1954). Investigators of mine waters have concluded that oxidation by physical-chemical processes is too slow to account for the quantity of ferric iron transported and deposited by the water, and they attribute the oxidation and precipitation to specific micro-organisms.

Micro-organisms in water in a diversion tunnel of the Tennessee Valley Authority also have caused deposition of manganese oxides (Pollard and Smith, 1951).

I have attempted to apply some of what has been learned about mine waters to the desert-varnish problem. Samples of water were collected at seeps and springs in the Colorado Plateau and immediately added to various kinds of solutions. One solution consisted of a medium for growing bacteria, nutrient broth, to which had been added a trace of 10 percent solution of nonsterile ferrous sulfate. Seep waters added to this solution invariably produced abundant growths of new colonies of micro-organisms, and the iron became oxidized in a matter of hours. A control solution of the same but without the seep water did not change color for days; a second solution of seep water without the broth remained clear. This experiment was duplicated at many seeps.

In another experiment sterile mineral solutions without nutrient broth were prepared with the following composition (see Leathen, McIntyre, and Braley, 1951) : In $1,000 \mathrm{ml}$ of distilled water :

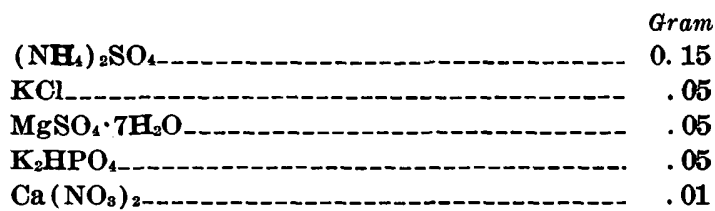

The solution was autoclaved and to it added $10 \mathrm{ml}$ of a 10 percent solution of nonsterile $\mathrm{FeSO}_{4} \cdot 7 \mathrm{H}_{2} \mathrm{O}$. The $\mathrm{pH}$ was then adjusted to 3.5 by adding. $\mathrm{HCl}$ or $\mathrm{NaOH}$ as necessary.

In this experiment, control solutions of the seep water remained clear. Control solutions of the basic medium remained clear for days. In a few cases, solutions of the basic medium to which seep water was added became discolored in about a day. No new colonies of micro-organisms were observed.

The experiments leave much to be desired, but despite obvious shortcomings the tests do indicate that microorganisms of one kind or another abound at the seeps and springs where iron and manganese oxides are being deposited, and that those organisms hasten the oxidation of the metals. It still remains to be learned whether the micro-organisms are an essential part of the process, or whether physical-chemical processes alone could deposit iron and manganese oxides containing only traces of contaminants at seeps and springs.

A study of some thin sections of desert varnish by Estella Leopold and Richard A. Scott (written commun., 1961), of the U.S. Geological Survey, did not reveal evidence favoring deposition attributable to micro-organisms. They suggest that the varnish layer may have been deposited as a silica gel around foreign particles serving as nuclei. The suggestion is favored by the fact that no extensive increment growth lines show in radial sections, but rings like liesegang rings show in tangential sections. Moreover, they found little or no penetration of the varnish into the rock in a way that would suggest surface weathering of the rock attributable to micro-organisms. A single hyphal strand bearing two branches and looking very much like fungal hyphae was found in one radial section embedded in the varnish. What appear to be cells in the strand are 7-10 microns wide.

The age of the desert varnish and the evident need for moisture lead to the conclusion that the varnish in Death Valley and elsewhere in the Southwest is largely the product of a pluvial period. The last pluvial period was the time of the Recent lake in Death Valley. At that time there may have been sufficient moisture in the form of dew to maintain microfloras that could grow and hasten the oxidation and precipitation of iron and manganese oxide whenever occasional rains soaked the soil. 


\section{EROSION AND SEDIMENTATION}

The huge gravel fans sloping from the mountains to the saltpan and the fill $11 / 2$ miles deep under the saltpan bear mute testimony to the vast amount of erosion in the mountains bordering Death Valley. Cross sections illustrating the depth of fill in the valley as estimated from gravity and magnetic surveys, and the depth and gradients of the canyons in the mountains, are shown on figure 67. The proportion of fill that is Tertiary and the proportion that is Quaternary must be inferred (p. A108), but it seems likely that half or more of the fill in Death Valley is Tertiary. The Quaternary is more than 1,000 feet thick at the localities that were drilled in Cottonball and Badwater Basins (table 19) where the total fill, as estimated from geophysical surveys, is about 4,000 feet. In the sections on figure 67 , it is assumed that the thickness of the Quaternary fill averages about half that of the Tertiary.

Based on this assumption, the volume of the Quaternary fill in Death Valley aggregates about 80 cubic miles. The correct figure can hardly be less than half nor more than twice this estimate.

This estimated volume of the Quaternary fill is about equal to the estimated volume (90 cubic miles) of the canyons draining directly to the saltpan from the Panamint Range and Black and Funeral Mountains. Although neither estimate can be firm, the two quantities seem to be of the same order of magnitude.

Moreover, Tertiary eruptives overlap the east flank of the Panamint Range and rise high onto it along the divides between the canyons. It seems likely therefore that this surface of overlap represents the limit of depth of dissection on this side of the Panamint Range at about the beginning of Quaternary time, and that the canyons were cut below that surface during the Quaternary.

In attempting to equate the volume of fill in Death Valley with the volumes of the canyons, however, there is need to consider the sediments brought into the valley from other parts of the hydrologic basin, the volume of volcanics, and the possible losses of early Pleistocene sediments to the extent that Death Valley may have had exterior drainage.

The Quaternary fill in Death Valley includes sediment brought there by the Amargosa River, by Salt Creek, and by Furnace Creek Wash from its head in Greenwater Valley. Except at the mouth of Furnace Creek, these sources did not contribute to the gravel fans, and it is doubtful that they contributed as much as half of the silt facies of the fill (fig. 67). Even this proportion would amount to only a quarter of the total fill, and probably the correct figure is nearer a tenth- a quantity that is not significant considering other uncertainties in the estimates.

The Tertiary deposits are composed very largely of volcanic debris and contain no more than a tenth, and perhaps very much less, of sediments derived from the Precambrian and Paleozoic rocks. By contrast, more than 90 percent of the Quaternary fill is derived by erosion of the older rocks, including Tertiary as well as Precambrian and Paleozoic ones, and much less than a tenth is new volcanic debris.

Nevertheless, additions brought from other parts of the hydrologic basin and other additions due to vulcanism may aggregate a fifth, or perhaps a fourth, of the whole volume. This volume would be offset, and perhaps more than offset, by losses to the degree that Death Valley had exterior drainage during the Quaternary.

There is reason to believe that most of the erosion occurred at times when more water was coming into the valley than now, because under the present climatic regimen the processes have greatly slowed. The present rate of erosion can be estimated by noting changes along datable features, such as-

A. Extent of destruction of-

1. Roads and flood-control ditches and other features that were constructed about 20-25 years ago.

2. Old trails that were abandoned about 50 years ago.

3. Archeological features.

4. The Recent fault scarp, believed to be about 2,000 years old, along the foot of the Black Mountains.

B. Extent of weathering, erosion, and sedimentation on Quaternary deposits, such as the various formations on the saltpan and the younger gravel formations.

\section{DAMAGE TO ROADS AND FLOOD-CONTROL DITCHES AND OTHER FEATURES IN 25 YEARS}

The present highway from Mormon Point to Badwater, Furnace Creek Ranch, and Beatty Junction45 miles-was paved between 20 and 25 years ago. Although no formal record has been kept of mudflows that have buried the highway, they are known to have occurred at half a dozen places. A flood in 1954 deposited 4 feet of mud on the highway half a mile south of the exit from Artists Drive; the present highway is on top of that fill. Other destructive mudflows have covered the highway at the crossing of the wash from Indian Pass, Furnace Creek Wash, at Desolation Canyon, Artists Drive between the exit and the junction with the road to the west side of the valley, and at the 

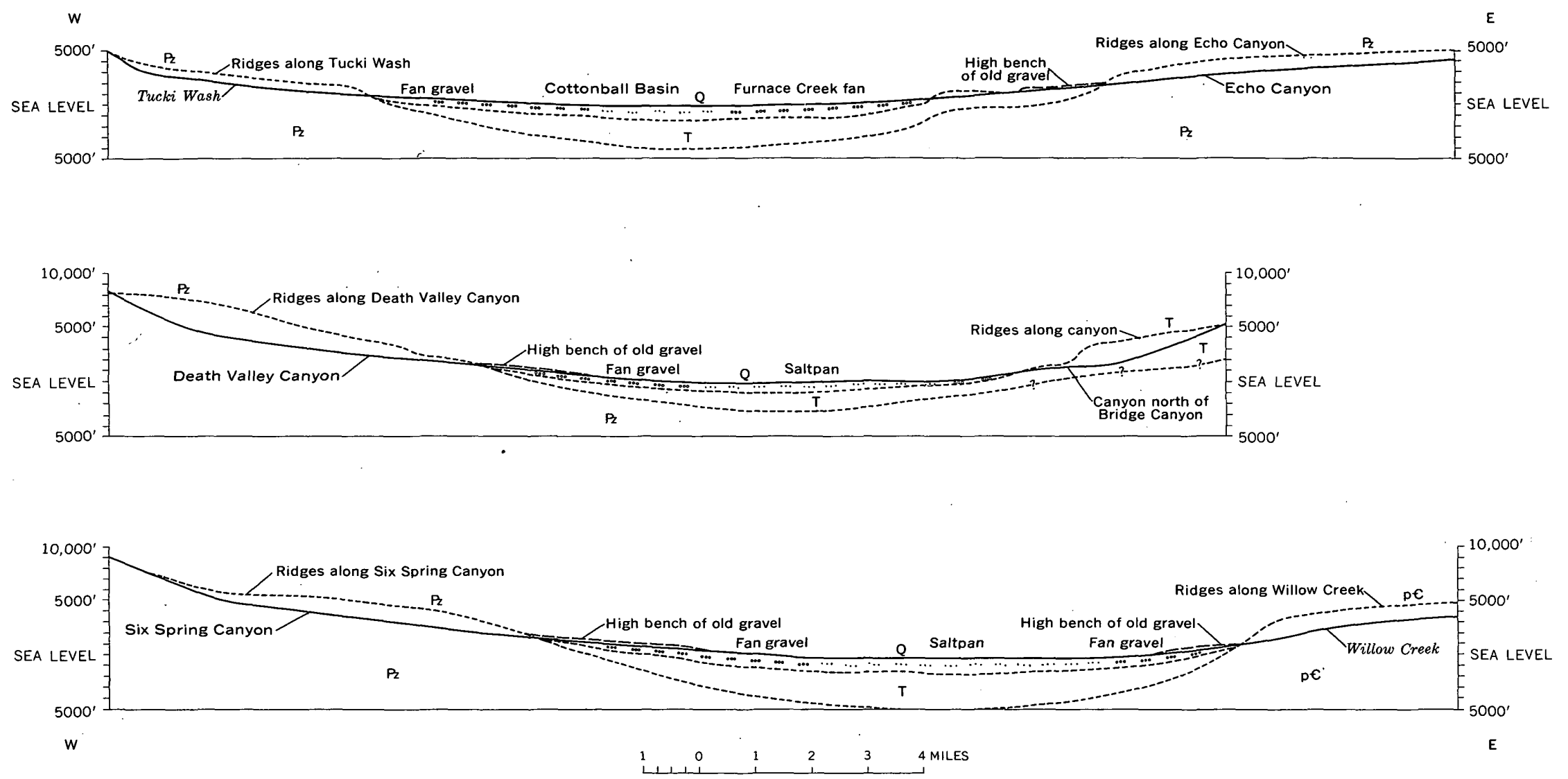

Fiadra 67. - Sections across Death Valley lllustrating depth of fill under the saltpan, slope and thickness of fan gravels, and the depth and gradient of canyons in the adjolnIng mountains. $Q$, Quaternary fill (sllt under the saltpan and gravel between there and the mountalns); $T$, Tertiary flll (in large part volcanles); $P_{z}, P a l e o z o l c$ rocks; $P C$, Precambrian crystalline rocks. 
junction of the road to the Salt Pools. No doubt there have been others, but only 1 percent or so of this 45mile stretch of highway has been washed by destructive floods in the last 20 years.

The original highway along the east side of Death Valley was along the foot of the gravel fans; it was last bladed when the present highway was paved about 20 years ago. A survey was made of damage along the stretches of this old bladed road where it has not been disturbed by later construction; the shoulder on the uphill side of the road averages about 6 inches high and perhaps a foot wide. Floods across this road in the last 20 years have destroyed about 20 percent of this little feature, as indicated in table 22.

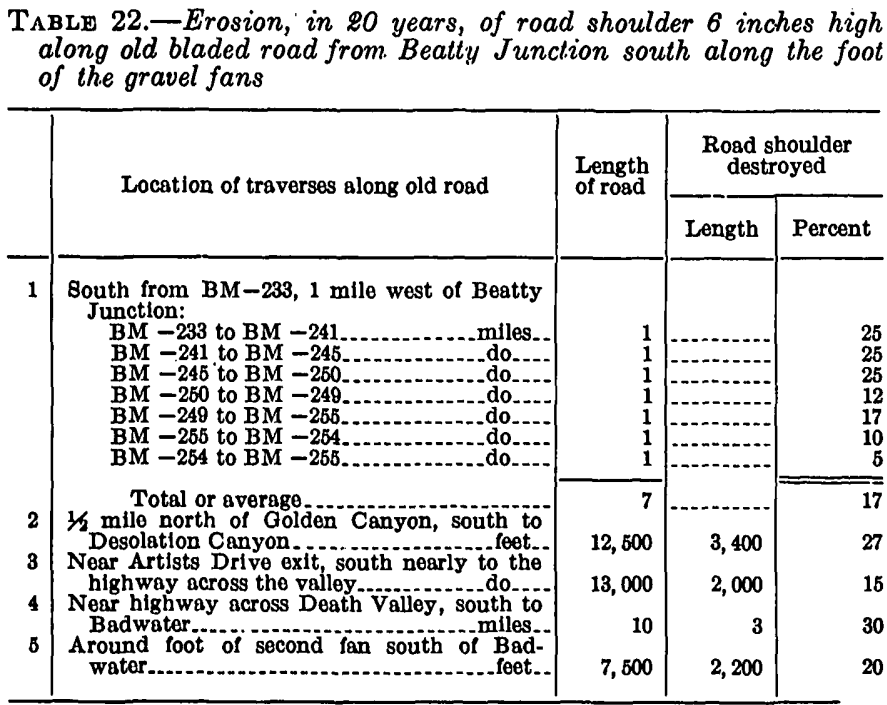

Fifteen miles of the traverses indicated in table 22 are on the fans between Badwater and Golden Canyon. These fans are composed of fine-grained sediments that are impermeable and favor runoff-far more so than the permeable gravel fans. In the last 25 years, floods on this impermeable ground have destroyed about 20 percent of a ridge of loose earth 6 inches high and 1 foot wide. The runoff, of course, has been channeled in washes, and in some washes there have been repeated floods. Nevertheless, 80 percent of the little ridge still stands.

When the new road was built, 15 flood-control ditches totaling about 5 miles in length were constructed in the northern part of the valley. The ditches were constructed at the most exposed locations. They extend diagonally across washes and are oriented about $45^{\circ}$ to the highway. Originally the ditches were about 5 feet wide and had a maximum depth of about a foot. An earth embankment about as wide as the ditch and about a foot high was constructed along the lower side of each ditch. Floods in these washes in about 25 years have
TABLE 23.-Erosion of flood-control embankments in 25 years

\begin{tabular}{|c|c|c|c|}
\hline & Locality & $\begin{array}{l}\text { Approximate } \\
\text { length of } \\
\text { embankment } \\
\text { (feet) }\end{array}$ & $\begin{array}{l}\text { Destruction } \\
\text { (percent) }\end{array}$ \\
\hline 1 & $\begin{array}{l}2.5 \text { miles northwest of Beatty } \\
\text { Junction; embankment oriented } \\
\text { slightly west of north. }\end{array}$ & 2,500 & \\
\hline 2 & $\begin{array}{l}\text { Same location; embankment } \\
\text { oriented slightly north of east }\end{array}$ & 4,000 & \\
\hline 3 & $\begin{array}{l}0.9 \text { mile southeast of Beatty } \\
\text { Junction }\end{array}$ & 2,500 & \\
\hline 4 & $\begin{array}{l}1.5 \text { miles southeast of Beatty } \\
\text { Junction } \\
1.8 \text { miles southeast of Beatty }\end{array}$ & 1,200 & \\
\hline & $\begin{array}{l}\text { Junction; embankment oriented } \\
\text { slightly west of north }\end{array}$ & 2,000 & \\
\hline 6 & $\begin{array}{l}\text { Same location; embankment } \\
\text { oriented about east }\end{array}$ & 2,000 & \\
\hline 7 & $\begin{array}{l}2.3 \text { miles southeast of Beatty } \\
\text { Junction }\end{array}$ & 2,200 & \\
\hline 8 & $\begin{array}{l}3.3 \text { miles southeast of Beatty } \\
\text { Junction }\end{array}$ & 000 & \\
\hline 9 & $\begin{array}{l}\text { 3.6 miles southeast of Beatty } \\
\text { Junction }\end{array}$ & 1000 & \\
\hline 10 & $\begin{array}{l}\text { 4.6 miles southeast of Beatty } \\
\text { Junction; embankment oriented } \\
\text { northeast. }\end{array}$ & 2,000 & \\
\hline 11 & $\begin{array}{l}\text { Same location; embankment } \\
\text { oriented southeast...... }\end{array}$ & 1,000 & \\
\hline 12 & $\begin{array}{l}\text { East side of highway opposite exit } \\
\text { from Mustard Canyon }\end{array}$ & 1,200 & \\
\hline 13 & $\begin{array}{l}1.3 \text { miles north of Furnace Creek } \\
\text { Ranch }\end{array}$ & 800 & \\
\hline 14 & 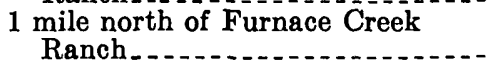 & 1,000 & \\
\hline 15 & $\begin{array}{l}0.3 \text { mile northeast of Furnace } \\
\text { Creek Ranch }\end{array}$ & 2,000 & 30 \\
\hline
\end{tabular}

destroyed about 25 percent of the embankments (table 23).

Even in washes where runoff is concentrated, after 25 years of floods about 75 percent of an earth ridge 1 foot high still stands.

On the flood plain of the saltpan at the Devils Speedway at the foot of Trail Canyon fan, some racetrack runways were scraped about 25 years ago. The area is flooded seasonally. A circular track half a mile in diameter, with a smaller one inside, was scraped north of the road across the valley; another nearly a mile long and more oval, was scraped south of the highway. At one curve an embankment about a foot high was built, but elsewhere the scraped track was bordered by only a low ridge of earth about 6 inches high. After 25 years, enough of the ridges still remain to outline plainly the position of the old tracks; there has not been enough silting or erosion on this part of the flood plain to destroy these minor artificial features.

\section{DAMAGE TO TRAILS ABOUT 60 YEARS OLD}

Old trails cross the fans diagonally or follow the contour and lead from one spring to another and to routes into and away from the valley. These trails are the original freeways, perhaps originally made by 
Pleistocene animals, then used by the Indians who came into Death Valley, and finally by the pioneers. The trails, though, have been little used in the last half century; they were abandoned when vehicular traffic became heavy enough to require roads other than those that could be followed on foot or horseback. The trails are preserved because there has been no livestock in the valley.

That the trails were used by the Indians is indicated by the concentrations of stone artifacts and other archeological signs along them. That the pioneers and early prospectors used the trails is indicated by the common occurrence of pre-1900 relics along the trails. That the trails have been little used during the last 50 years is indicated by the scarcity of litter younger than about 1900 and by the occurrence of narrow coyote trails meandering within the wider, older trails. Results of some surveys along stretches of the old trails are given in table 24 .

In general, the old trails are for the most part intact where they cross high benches on the No. 2 gravel, suggesting that in the present regimen erosion of these benches must proceed by retreat of the sides rather than by lowering of their tops.

Where the old trails cross No. 3 gravel, 10-20 percent of the alinement may be destroyed, and the destroyed stretches invariably are in the swales where runoff is concentrated. Part of this runoff originates on the No. 3 gravel, but most of it represents overflow from nearby washes.

Even where the trails cross washes with No. 4 gravel, as much as 25 percent of the alinement may be preserved. Destruction is more complete where main washes are crossed on the upper parts of the fans rather than on the lower. This may be due to the runoff being concentrated in a few channels on the upper parts of the fans, or it may be due to greater total runoff, or perhaps to both.

Reference has been made to the steps (terracettes, fig. 51) and related features resulting from mass wasting on the gravel fans, especially on the No. 2 gravel. (See p. A68; see also Hunt and Washburn, in Hunt and others, 1965.) The trails cross such features without showing signs of creep downhill.

\section{DAMAGE TO PREHISTORIC ARCHEOLOGICAL} FEATURES

More than a dozen rock alinements dating from the Death Valley III occupation are preserved at various locations on the No. 2 gravel around Death Valley (Hunt, A. P., 1960). Some of these alinements were made by laying pebbles or small cobbles in a row; others were made by scraping the gravel into a ridge 2-4 inches high. These slight features still stand despite
TABLE 24.-Erosion along old trails in the last half century.

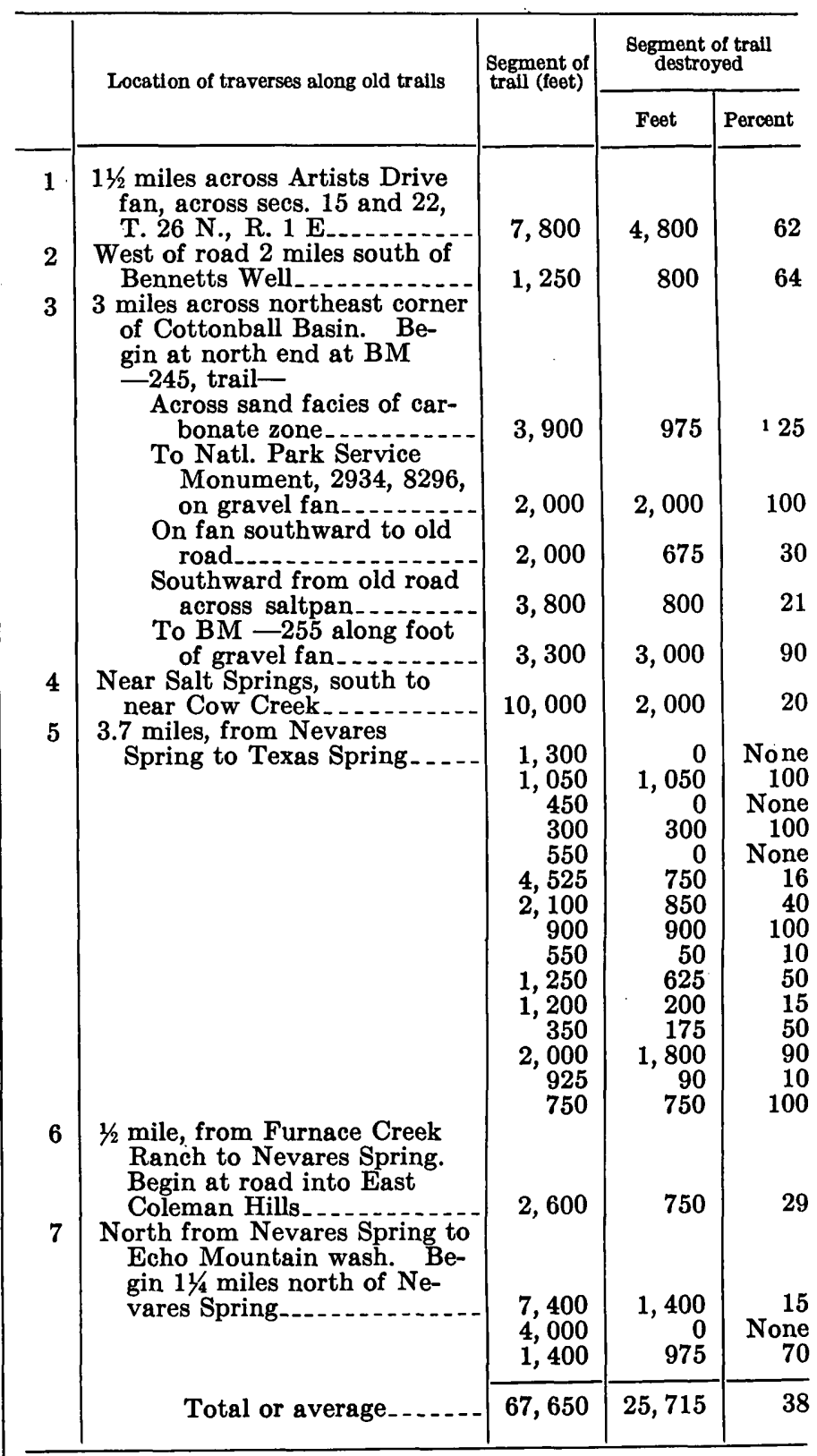

1 Hall by salt heave and about hall by erosion.

approximately 1,000 years' exposure to sheetfloods on the gravel. Perhaps there were other alinements that have been destroyed by sheetfloods, but probably no more than a few judging by the preservation of trails on the No. 2 gravel.

In addition to the alinements, there are approximately 1,500 rock circles. These are on the No. 3 as well as on the No. 2 gravel. They are not well dated; some are historic. Others are prehistoric Death Valley IV, and some probably date from Death Valley III occupation. Most of these rock circles consist of a single layer of cobbles arranged in a circle 5-7 feet in diameter. Some 
circles located along the rims of washes have been partly destroyed by undercutting of the rim, but circles back from the rim show very little sign of washing.

DAMAGE TO RECENT FAULT SCARP ALONG FOOT OF BLACK MOUNTAINS

The Recent fault that extends from the mouth of Furnace Creek 30 miles south to Mormon Point (p. A 100) forms a discontinuous escarpment 5-10 feet high. The faulting is believed to have occurred about 2,000 years ago. Since that time about 90 percent of the escarpment has been destroyed, partly by dissection of the upthrown block and partly by burial under younger alluvial-fan deposits (fig. 72).

\section{WEATHERING, EROSION, AND SEDIMENTATION ON QUATERNARY DEPOSITS}

In the present climatic regimen disintegration of stones is slow enough not to be noticeable in the No. 3 or No. 4 gravels, yet in the No. 2 and older gravel deposits, disintegration is continuing, as indicated by the accumulation of fine debris around the foot of boulders (fig. 49). This difference between the No. 2 and the younger. gravels could be attributed to difference in length of time that the gravels have been exposed at the surface, but more likely the difference is due chiefly to some changes in the processes causing disintegration-changes attributable to the climatic changes that occurred during late Pleistocene time.

Erosion and sedimentation under the present climate are slow too. Areas on the saltpan that are subject to flooding are restricted to the flood-plain areas which constitute about 30 percent of the valley floor. The salt crusts on the other 70 percent were deposited about 2,000 years ago, and the only part of this crust that has been flooded is the smooth silty rock salt, constituting about 30 percent of the crust. The smooth salt has been flooded often enough in 2,000 years to deposit 1-6 inches of silt on the salt. Only fine sand and silt is transported onto the flat valley floor; gravel is deposited at the foot of the fans. The only exception to this is provided by a few cobbles of light highly scoriaceous lava washed onto the salt flat at the foot of Furnace Creek fan.

The No: 4 gravel, covering about a third of the gravel fans, represents the part of the fans that is subject to much washing at present. The No. 3 and older gravels, darkly stained with desert varnish, have not been washed sufficiently in 2,000 years to destroy that stain, which is pre-Death Valley III occupation (p. A91). Erosion and sedimentation on the gravel fans in 2,000 years, therefore, have been restricted to about a third the area of the fans.

The volume of the No. 4 gravel is small compared to the older gravel formations and seems to be little, if any, more than the volume of the washes and channels that are eroded into the older gravels. Apparently not much gravel has been brought from the mountains to the gravel fans in 2,000 years; the No. 4 gravel seems to be derived chiefly from erosion of the older gravel formations.

Further evidence that little gravel is being transported from the mountains under the present climate is found where the No. 2 or No. 3 gravels overlap the foot of the mountains. Alluvial fans of No. 4 gravel have been built on the older gravels only at the mouths of large washes. Elsewhere, little new material has been moved from the mountainsides onto the surfaces of the old gravels.

The deposits of the last 2,000 years-the No. 4 gravel and floodplain deposits-if spread over the whole valley, would average considerably less than a foot thick, and much, perhaps most, of this is simply reworked older valley fill. Only a fraction can represent new sediment brought into the valley from the mountains... Exact figures cannot be had, but no matter what figure is assumed within the known limits, clearly the thick Quaternary fill in Death Valley could not have been deposited if the rate of erosion in the mountains had always been as slow as it has been during the last 2,000 years.

The history of erosion and sedimentation in Death Valley evidently is one of changing rates, presumably due to changing processes. Huntington (1907) offered the hypothesis that in arid regions the pluvial periods accelerate weathering and growth of vegetation. During such periods, waste is stored in the mountains. According to him, the transition to an ensuing arid period is the time when most of the waste is transported to the alluvial fans; when the supply of waste becomes exhausted, there is little new material brought from the mountains and the older fill deposits become dissected. The evidence in Death Valley fits well with Huntington's hypothesis.

\section{STRUCTURAL GEOLOGY}

By Charles B. Hunt and Don R. Mabey

The structural geology of the Great Basin, of which Death Valley is a part, has been a century-long subject of discussions and differences of opinion. One of the principal conclusions arrived at from our studies of the structural geology in Death Valley is that the discussions and differences of opinion will continue for a long time to come.

The mountains bordering Death Valley, are uplifted fault blocks of the general kind first recognized in the Great Basin by G. K. Gilbert (1875), and later, with modifications, by King (1878) and Dutton (1880). 
(For a review of early theories about Great Basin structure, see Davis, 1926, and Nolan, 1943.) But the mountains have had a complex history of early deformation and erosion that is not reflected in the shapes of the uplifted fault blocks, a complexity first clearly demonstrated in the Great Basin by Louderback (1904), although alluded to by the earlier investigators. Few today will seriously entertain the theory (Keyes, 1909) that the basins like Death Valley are chiefly erosional in origin, but many will ponder the degree to which the structural framework involves folding and thrust faulting as well as block faulting, an extreme view of which, advanced by Spurr (1901), discounts block faulting and attributes the basins and ranges to an Appalachian Mountain type structure in a desert climate. Too, our lack of knowledge allows for differences of opinion about the significance of the granitic intrusions and vulcanism to the deformation; indeed, this subject has received little attention.

Although Spurr's main thesis needs to be greatly modified, we think he was more right than wrong in his view that deformation has gone on "steadily though spasmodically from the close of the Mesozoic to the present." In the course of that long period of time, usually taken as 60 million years, the way in which the crust has yielded to stress has changed, and the earlier structures therefore are obscured by the later ones. The record admittedly is not complete enough to demonstrate continuity of the deformation.

Probably the most basic uncertainty to understanding the structural framework of Death Valley and the rest of the Great Basin is uncertainty as to whether this part of the crust has been shortened by compression or distended by tension. The evidence is conflicting in Death Valley and elsewhere in the Great Basin.

Whatever the origin and complete sequence of structural events have been, the result is a complex of strain effects superimposed on one another. We attempt to unravel these by examining the younger first, and by eliminating their effects we attempt to restore seriatim earlier structures to the way they first appeared; the effort is only partly successful, for reasons that will become apparent as we progress.

\section{STRUCTURAI SETTING OF DEATH VALLEY}

Death Valley is about centered in an area that is a subsection consisting of the southernmost tenth of the Great Basin (fig. 68). The Death Valley subsection is characterized by block mountains that are of Precam-

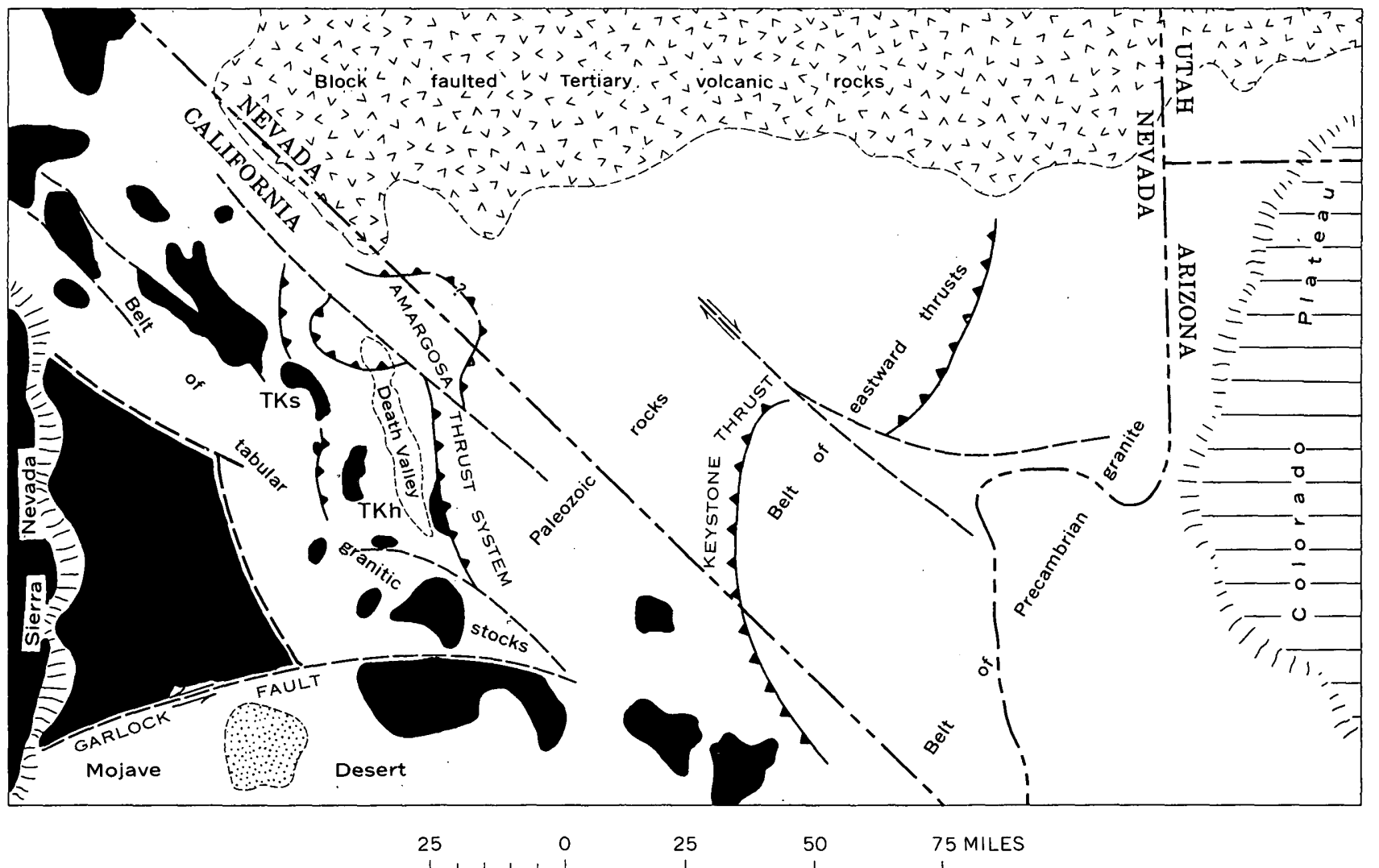

Figure 68.-Map showing the Death Valley subsection of the Great Basin. Mesozolc and Tertiary granitic intrusions shown in black. TKs, granite at Skidoo; TKh, granite at Hanaupah Canyon. 


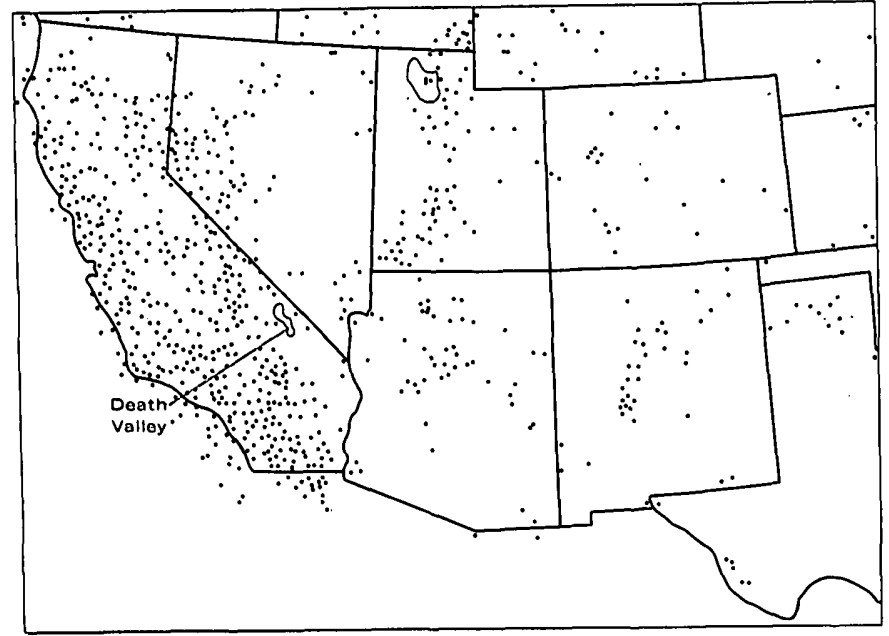

Frodra 69.-Map showing selsmic epicenters in southwestern United States. From Woollard, 1958.

brian and Paleozoic formations intruded by granitic rocks and locally capped by Tertiary volcanic rocks.

To the north, the next subsection of the Great Basin is characterized by block mountains that are almost entirely of Tertiary volcanic rocks. West of the Death Valley subsection is the Sierra Nevada batholith; to the east, along the Colorado River, is a small area that is largely Precambrian granite and assigned to the Mexican Highland; and beyond that is the Colorado Plateau. Southward the Death Valley subsection ends at the Mojave Desert (Hewett, 1955), a subsection of the Sonoran Desert.

Death Valley extends along the eastern edge of a cluster of granitic intrusions. that are satellites of the Sierra Nevada batholith (fig. 68); it is at the eastern edge of the seismically active areas that extend westward to the coast (fig. 69). Along this border of the granitic intrusions and seismically active areas is a series of curious overthrust faults, first recognized and described by Noble (1941). These faults are curious because younger rocks have been thrust westward over older ones. Because the horizontal movement is measurable in miles, we follow Noble in referring to the faults as thrust faults, although the displacement on them in fact is that of a normal fault (Longwell, 1945). Noble, and later Curry (1954), also recognized that the thrust faults have had a complex history including later folding of the faults and later block faulting. Also, Noble recognized that granitic intrusions had spread laterally at some thrust faults as if controlled by them.

The thrust fault first described by Noble was named the Amargosa thrust. Because this type of thrust faulting now is recognized widely in the Death Valley subsection (Longwell, 1945; Mason, 1948; Kupfer, 1960), we extend the term and refer to this system of faults as the Amargosa thrust system, including the faults that branch upward from the main thrust.

About 60 miles east of Death Valley, and near the eastern edge of the Death Valley subsection, is a belt of conventional overthrusts along which the thrusting has been directed eastward-opposite to that of the Amargosa thrust system. At these overthrust faults, Paleozoic formations have been thrust eastward onto Mesozoic ones and the faulting has been interpreted as Late Jurassic, Cretaceous, or early Tertiary (Longwell, 1926, 1928, 1949; Hewett, 1931, 1956).

East of this belt of conventional thrust faults is an area exposing extensive Precambrian granite-part of the Mexican Highland-and east of that is the Colorado Plateau.

The dominant structural and topographic grain of the Death Valley subsection is northerly and northwesterly. The structures however rise southward from under the Tertiary volcanics in the subsection to the north. Within the Death Valley subsection the southward rise is further reflected by the dominance of Paleozoic formations across the northern part of the subsection and the dominance of Precambrian formations across the southern part. Structurally, the Mojave Desert appears to be as high or higher than the south edge of the Death Valley subsection.

Bouguer gravity-anomaly values in the Death Valley area are irregular but high compared to those under the Sierra Nevada to the west and under the Great Basin to the northeast (fig. 70). The gravity values suggest that the crust is relatively thin under the central part of the Death Valley subsection, and that it thickens westward and northeastward.

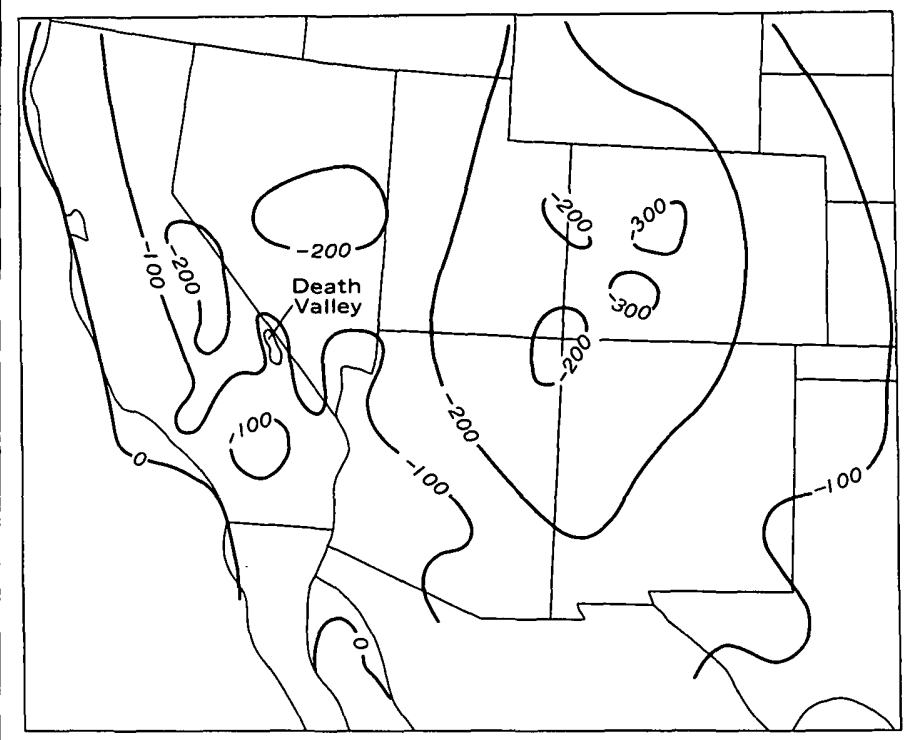

Fradre 70.-Bouguer gravity-anomaly map of southwestern United States. Contour interval, 100 milligals. Based on G. P. Woollard (unpublished data) and Mabey (1960). 
The major structural features of Death Valley and the mountains adjoining it are illustrated on plate 3.

\section{RECENT AND LATE PLEISTOCENE STRUCTURAI GEOLOGY}

\section{STRUCTURAL FGATURES OF TME SALTPAN AND} GRA VEL FANS

Recent and late Pleistocene structural features of the saltpan and gravel fans include (1) Recent eastward tilting of the saltpan and associated faulting; (2) five small Recent anticlines and five small Recent faults affecting the saltpan; (3) numerous faults including some graben structures and small folds of late Pleistocene age on the gravel fans (fig. 71).

\section{RECENT TILTING OF THE BALTPAN}

The saltpan is the product of a Recent lake about 30 feet deep, and dated archeologically about 2,000 years ago (p. A79). The eastern shoreline of this Recent lake is 20 feet lower than the western shoreline. About half the tilting may be accounted for by a 10-foot-high Recent fault scarp along the foot of the Black Mountains (fig. 72).

The eastward tilting of the saltpan is reflected also in differences in the drainage along the two sides. Along the east side of Badwater Basin the flood plain is smooth and is being aggraded; but along the west side the Amargosa River and its tributaries are entrenched in deep channels, and in places the flood plain is being dissected.

That the tilting occurred suddenly about 2,000 years ago rather than progressing gradually during that time is indicated by the arrangement of the concentric rings of salt in the saltpan, for they are crowded against the east side. That the fault scarp developed at the time of tilting is probable. The scarp is well enough preserved to leave no doubt that it is Recent, yet it has been partly destroyed by erosion and partly buried by younger gravel. That it is prehistoric is shown by the fact that Indians constructed mesquite storage pits in the colluvium that overlaps the scarp (figs. 72, 73).

The tilting, together with the faulting along the side towards which the tilting occurred, duplicates in many details the features that accompanied the earthquake at Hebgen Lake in the West Yellowstone area in 1959 (U.S. Geol. Survey, 1959), and very likely the tilting and faulting occurred equally suddenly.

\section{RECENT ANTICIINES AND FAULTS AFFECTING THE SALTPAN}

Other recognizable structures that affect the salt crust and that evidently are no more than 2,000 years old include 5 anticlines and 5 small faults. All these represent renewed movement along preexisting structures.

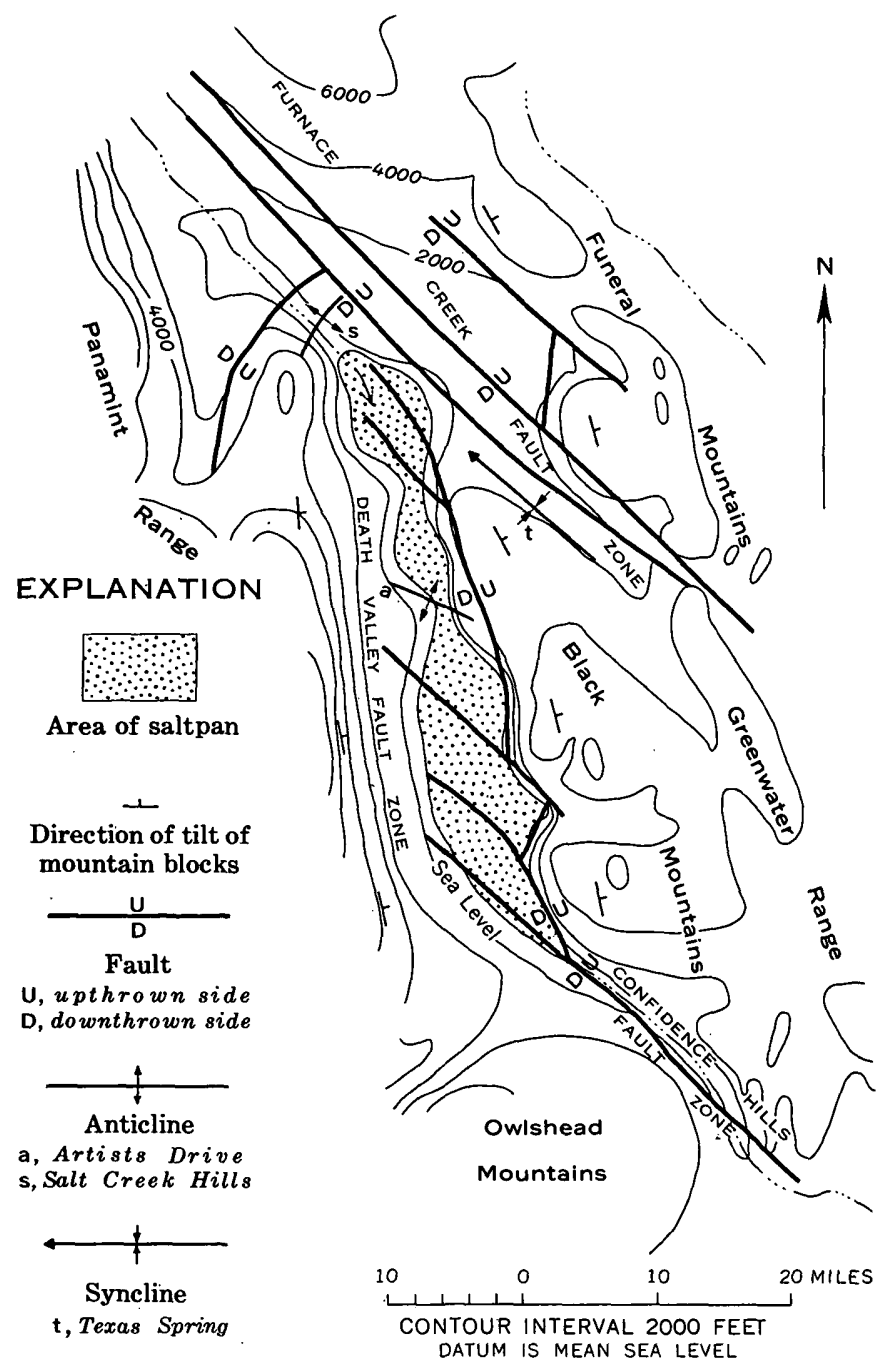

Figdre 71.-Principal Quaternary structural features in Death Valley. The Death Valley fault zone is cut off at the north by the Furnace Creek fault zone and at the south by the Confidence Hills fault zone.

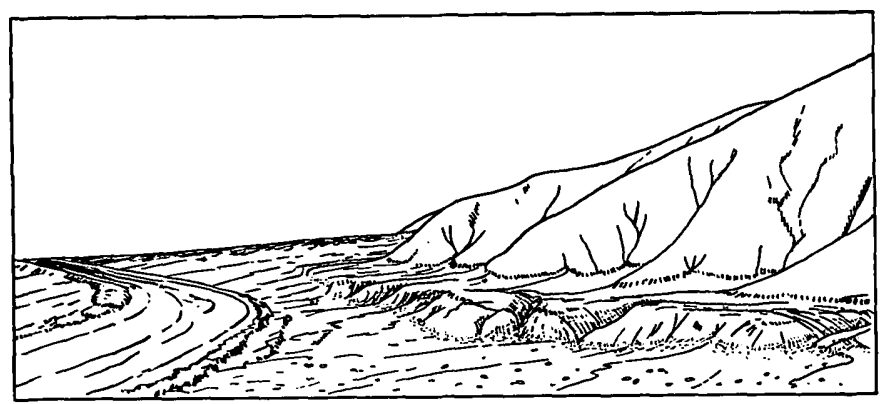

Frave 72.-Recent fault scarp at foot of Black Mountains. The far and of the escarpment is buried by debris washed from large canyons and is dissected by small washes from small gullies on the right. View is north on south side of Furnace Creek fan.

Two of the anticlines are in the southern part of the Badwater Basin (pl. 3), and both trend northwestward from anticlines in the older rocks (Precambrian), marked by turtleback ridges (Curry, 1954), in the Black 


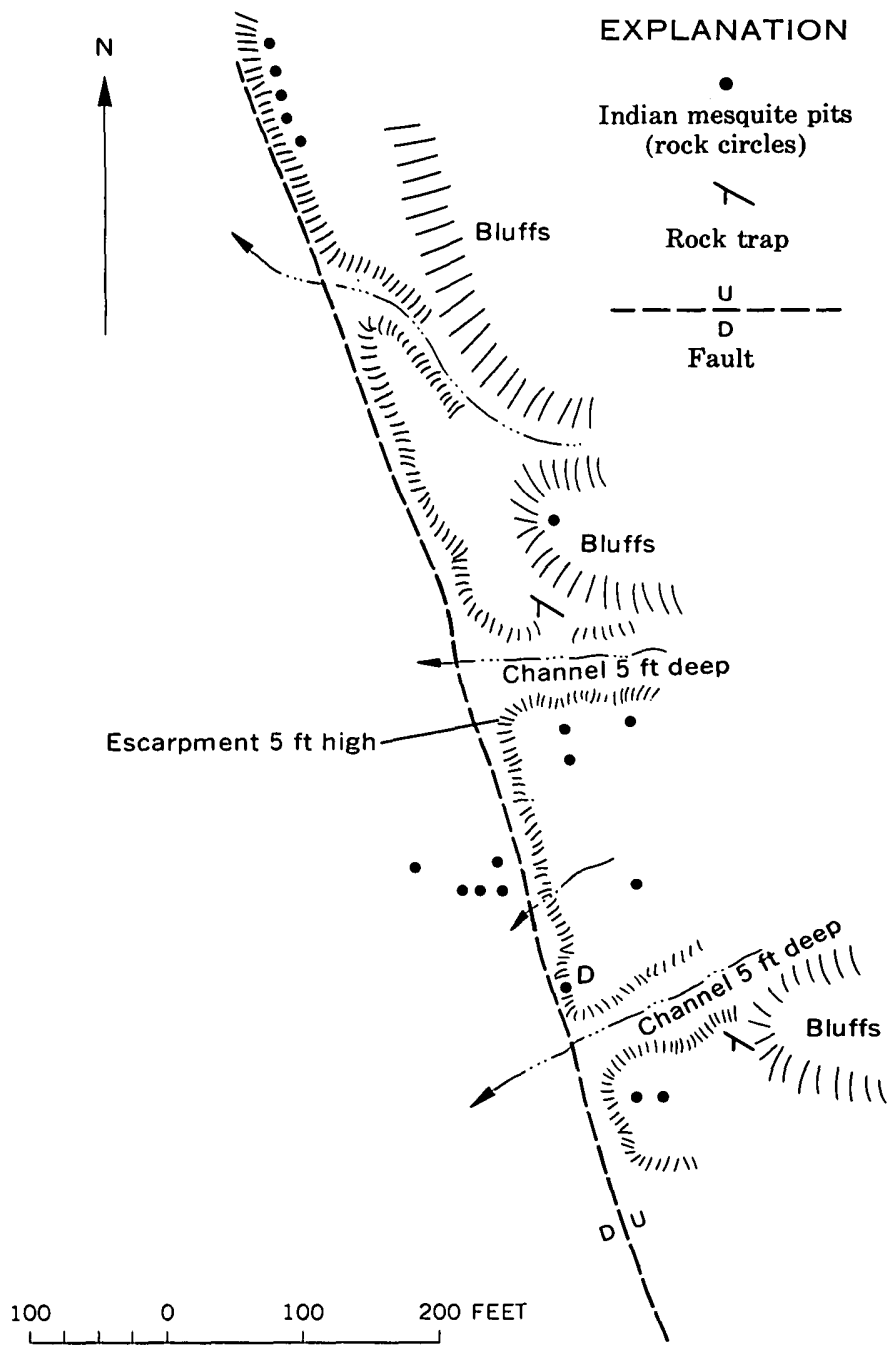

Fradre 73.-Map of Indian sites along the escarpment of a Recent fault at the foot of the Black Mountains 3 miles south of Furnace Creek Wash (modifled from A. P. Hunt, 1960). The fault and escarpment are older than the Indian mesquite storage pit at $D$, which is bullt in colluvium overlapping the scarp.

Mountains. They are expressed by sweeping curves in the drainage that lies between the foot of the mountains and the edge of the rock salt deposited by the Recent lake in the interior of the saltpan (fig. 74). The anticlines are manifested by northwest-plunging noses in the gravity contours (pl. 3); this indicates that the anticlines are underlain by highs on the surface of the bedrock, which probably is Precambrian.

A third anticline extends across the saltpan where the highway crosses it at the Devils Golf Course, west of Artists Drive. The trend of this anticline and the location of its highest part are uncertain. Nearby fault blocks of the Funeral Formation along the east edge of the saltpan trend southwest, but the anticlinal axis may or may not coincide with them. Because of Recent uplift on this fold, drainage that formerly was south to Badwater Basin now is ponded in Middle

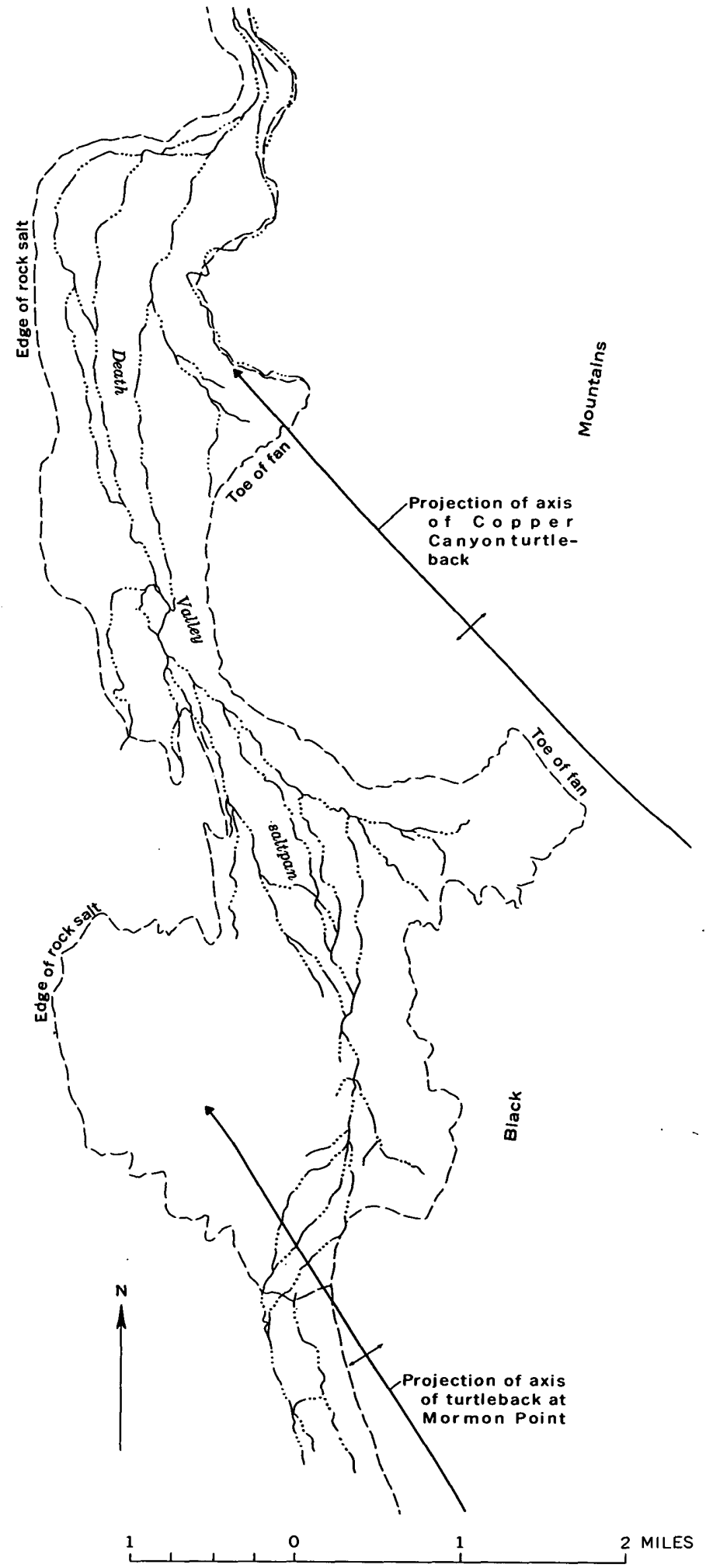

Fiaure 74.-Map showing drainage in the Death Valley saltpan deflected at the projected axes of turtlebacks in the Black Mountains.

Basin north of the fold. Leveling along the channel of Salt Creek, which extends from Middle Basin to 
Badwater Basin, indicates that the stream course has been arched 18 inches and that a pond that deep must form in Middle Basin before it will overflow again into Badwater Basin. There was no such overflow during the 6 years 1955-61. Litter along the channel is mostly pre-1900 type, that is, planks with square nails and old bottles with hand-finished necks. There is almost no modern litter; thus, it would appear that there has been no flood of consequence along this stretch of channel during the last half century.

The buried anticline separating Badwater Basin from Middle Basin is marked by a gravity high and is confirmed by drilling that encountered the Funeral Formation 120 feet below the surface of the saltpan. The drill hole is near the middle of the saltpan beside the road across it; a $\log$ of the hole is given in table
19, well 2. The drill reached a depth of about 500 feet, still in the Funeral Formation so far as known. Another hole about 7 miles southeast, toward Badwater, was drilled to a depth of 1,000 feet, and did not reach the Funeral Formation so far as can be determined from the log. It may be inferred that the Pleistocene deposits thicken southward from 120 feet above the buried anticline to more than 1,000 feet west of Badwater.

A fourth anticline is in Cottonball Basin. It lies along the projected position of the faulted anticlines of Furnace Creek Formation where the Furnace Creek fault zone (pl. 3) extends under the saltpan. In the center of Cottonball Basin the anticline is marked by a broad arch, 10 inches high in 1958 , that partly ponds drainage in the northeast corner of Cottonball Basin

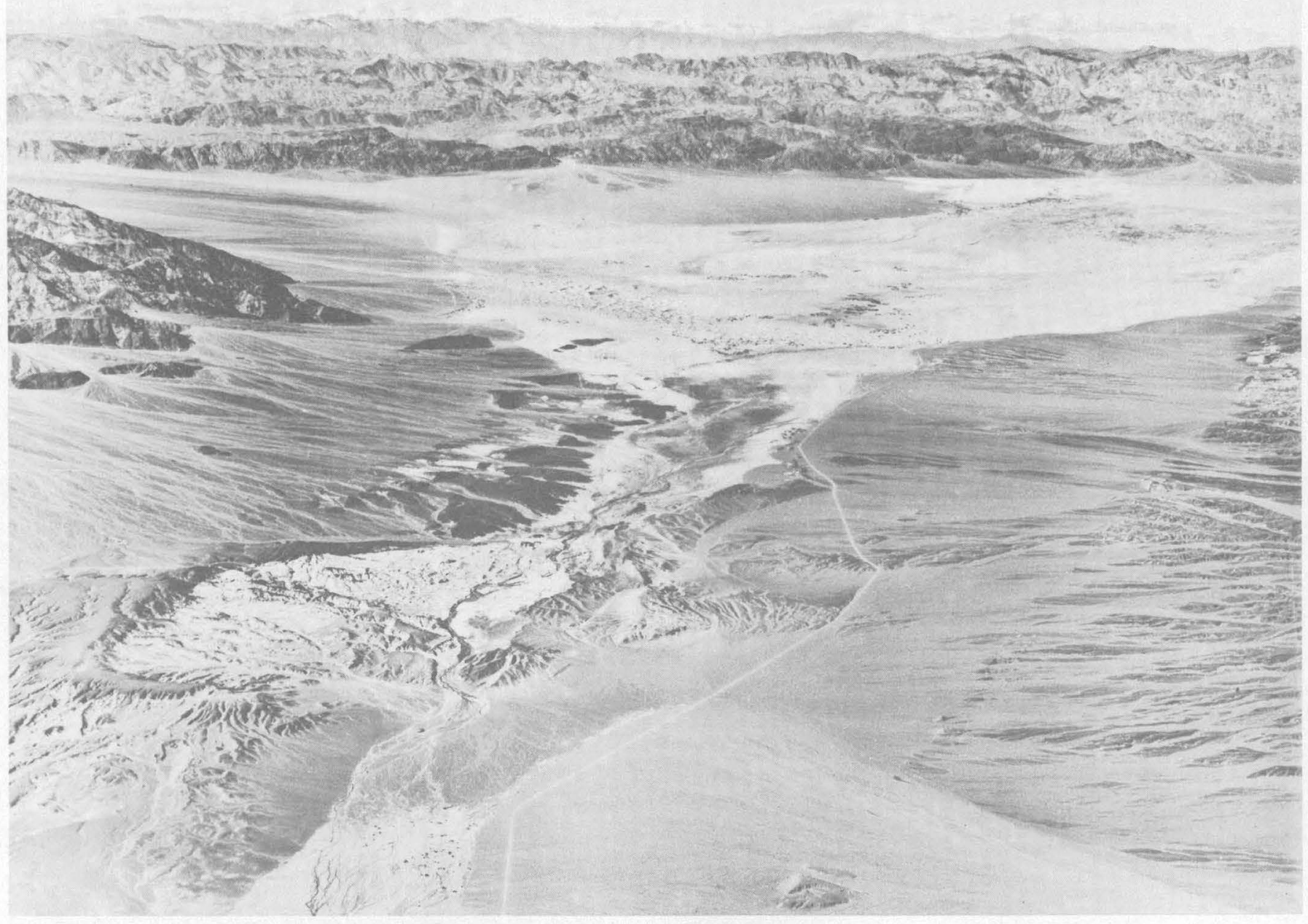

Figure 75.- Oblique aerial view of the Salt Creek Hills, an anticline of Pliocene and Pleistocene(?) beds dividing the saltpan (foreground) from the basin at Mesquite Flat (distance). View is northwest. Light-colored beds in the center of the anticline are Furnace Creek Formation. Dark gravel on the south flank of the anticline and gray gravels on the north flank are early Pleistocene and are uplifted less than the Furnace Creek Formation. Upper Pleistocene gravel forms terraces along the stream breaching the anticline from the southwest and is arched less than the lower Pleistocene gravel. Photograph courtesy of John H. Maxson. 


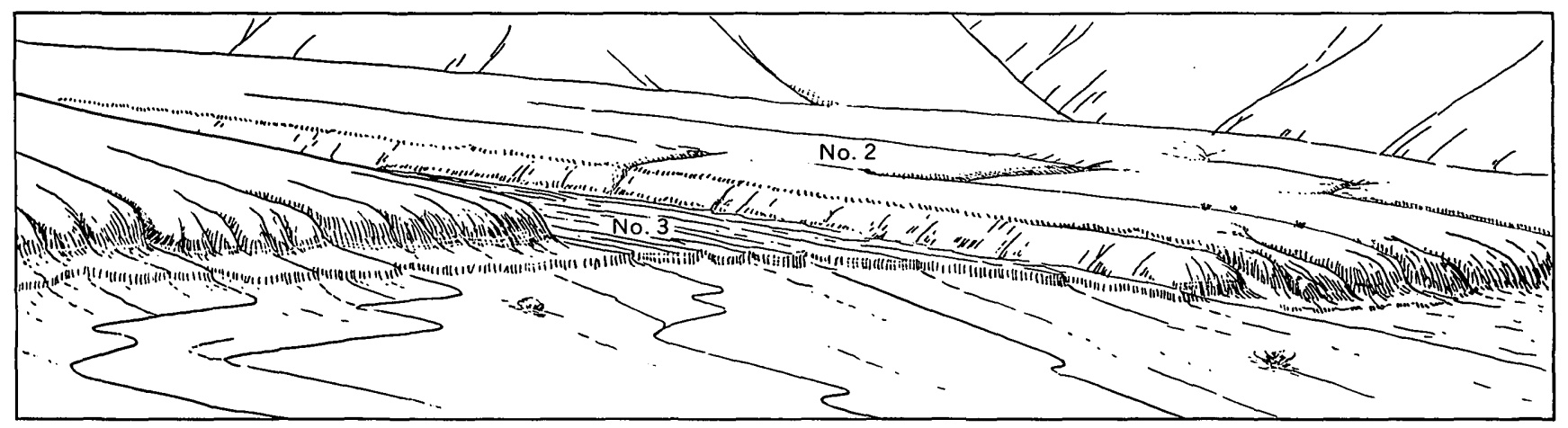

Frourd 76.-Bscarpment of a Recent fault that displaces No. 3 gravel 6 feet at the foot of a late Plelstocene escarpment that displaces No. 2 gravel 50 feet. Vlew westward from near Shortys Well.

and separates it from the main drainage southward on the playa. Only at times of major floods does the ponded water discharge across the arch, and in protracted dry periods dry salt crust forms completely across the drainage line adding to the height of the arch. The tributary drainage in this part of Cottonball Basin is northwesterly, and on the smooth silty rock salt there are some northwest-trending ridges, one of them 5 feet high. The anticline coincides with a northwest-trending gravity low, indicating that the anticline is not marked at depth by a major high on the bedrock.

That the fill in Cottonball Basin is deep is confirmed by a drill hole 1,000 feet deep near the center of Cottonball Basin and on the arch extending northwest into the basin (table 19). From surface to bottom the hole encountered alternating layers of mud and salts that, so far as can be judged from the lithologic description, are entirely Pleistocene in age.

The fifth anticline affecting the saltpan is at the Salt Creek Hills. It marks the north end of the saltpan and divides it from Mesquite Flat (fig. 75). This faulted anticline records a succession of uplifts. The latest, amounting to 10-25 feet, has raised late Pleistocene gravel which now forms terraces along the lower part of Salt Creek and along a tributary from the southwest. An earlier stage of uplift is recorded by the dome of the Pliocene and lower Pleistocene(?) Funeral Formation on which the structural relief is not less than 250 feet and probably is much more. Structural relief on the Furnance Creek Formation is at least a thousand feet, and probably more. The gravity contours indicate that relief on the bedrock basement is still greater.

The gravity data also indicate another deep basin under Mesquite Flat. The anomaly here is larger than in the saltpan, and perhaps the fill of low density rocks is thicker.

Four small faults on the saltpan disrupt the rock salt in the northern part of Badwater Basin (pl. 3). These faults are marked at the surface by linear breaks in the salt crust, but the displacement is small enough to be obscured by irregularities in the salt growths. The position of the fractures is of interest because they are on the projection of the Mont Blanco fault, a southwesttrending rift in the Black Mountains. Whatever buried structure is manifested by these features may extend southwestward to the Hanaupah escarpment on the west side of the saltpan.

\section{FAULTS AND FOLDS ON THE GRAVEL FANS}

Many small faults displace upper Pleistocene deposits on the gravel fans, and most trend roughly parallel to the contour of the fans. Many show two stages of movement. The older of the upper Pleistocene deposits, the No. 2 gravel, commonly is displaced 50-75 feet by faults that displace the latest Pleistocene gravels 5-10 feet (fig. 76). There are good examples of faults showing two stages of displacement at the Hanaupah escarpment and at many places along the foot of the Black Mountains, especially at Mormon Point and near the mouth of Furnace Creek (fig. 47). Other faulted gravel fans are at Tucki Wash and at Trail, Starvation, and Johnson Canyons.

Parallel faults in the gravels commonly bound grabens. Some, 10-25 feet deep and 500-1,000 feet wide, break the older (No. 2) of the upper Pleistocene gravels on the fans at Death Valley Canyon and Tucki Wash (pl. 3). Several small grabens only 25-50 feet wide are along the northwest side of the fan south of Badwater. The paved highway follows one of these and appears to be in a roadcut.

In connection with the eastward tilting of the saltpan; reference already has been made to the Recent fault that extends along the foot of the Black Mountains to Mormon Point. (p. A100; see also Noble, 1926b). The most recent displacement along this fault is 5-10 feet, but at many places along it, the older, No. 2, gravel is displaced 50-75 feet, as it is at the Hanaupah escarpment.

Late Pleistocene and Recent faulting along the front of the Black Mountains also is recorded by a series of 


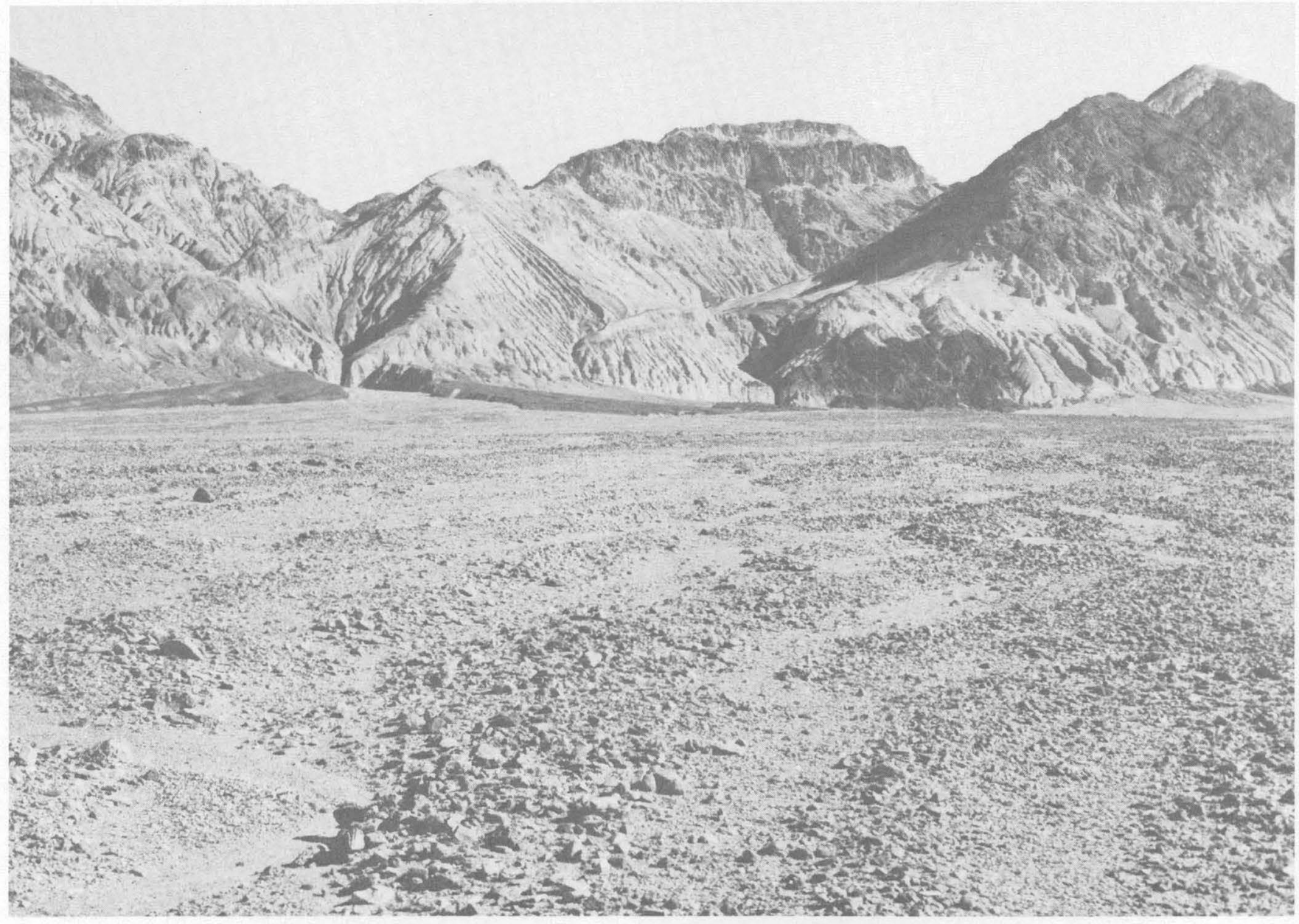

Figure 77.-Hanging valleys at the front of the Black Mountains, near the north end of the mountains at Desolation Canyon. Old valleys with U-shaped cross sections have been uplifted about 100 feet along this part of the mountain front, and the new valleys are narrow gorges incised into the bottom of the older, more open valleys. The bedrock consists of interbedded voicanic and sedimentary rocks of Miocene or Pliocene age.

hanging valleys in the mountain block (figs. 77,78 ). In the vicinity of Furnace Creek fan the hanging valleys are about level with upfaulted benches of No. 2 gravel and evidently are no younger than that gravel; they may be somewhat older.

The height of the hanging valleys increases southward, which accords with other evidence that the mountains have been tilted northward as well as being faulted upward. It is difficult, however, to obtain very meaningful figures about the heights of the hanging valleys because of differences in the kinds of rock and ease of downcutting at the valleys.

For example, at one canyon, Golden Canyon, in the northern part of the Black Mountains the hanging valley is at an altitude of -40 feet. A mile south, at Gower Gulch, the hanging valley is at sea level. About 11/4 miles farther south, at Desolation Canyon, the hanging valley is 100 feet above sea level. But the northern canyon is cut in soft beds of the Furnace Creek Formation; the middle canyon is cut into moderately resistant conglomerate at the base of the Furnace Creek Formation; and the southern canyon is cut into a resistant block of dolomite. Part of the northward decrease in height may be due to northward tilting, but part probably is due to greater erodability of the rocks northward.

Another comparison that involves less variable channels is provided by 2 gulches 1 mile apart on the side of the Badwater turtleback of Precambrian rocks. Each widens upward into a more open gulch, the northern one at an altitude of 800 feet; the southern one at an altitude of 1,200 feet. This suggested tilt of 400 feet northward is about the same as the northward tilt of the upper surface of the turtleback.

The hanging valleys do not necessarily indicate northward tilt of the Black Mountains, but at least their heights do not conflict with such tilt.

The hanging valleys are approximately the age of the No. 2 gravel; this is suggested by the occurrence of benches of No. 2 gravel near the mouth of Furnace Creek 
that are displaced by about the same amount as nearby hanging valleys (fig. 47).

The No. 2 gravel is broken by many faults having displacements of 50-100 feet, specifically at Mormon Point, Furnace Creek fan (fig. 47), East Coleman Hills, Mustard Canyon, Salt Creek Hills, Tucki Wash ( pl. 2), Blackwater Wash, Death Valley Canyon (pl. 2), Hanaupah escarpment (fig. 76 and pl. 2), and the fans at Six Spring Canyon (pl. 2) and south.

Upper Pleistocene gravels are downfolded into the northwest-plunging Texas Spring syncline separating the Black and Funeral Mountains (pl. 3). In this syncline Pleistocene deposits are less folded than the Pliocene and lower Pleistocene(?) Funeral Formation, and the fanglomerate, in turn, is less folded than the Furnace Creek Formation (fig. 79)-further evidence that the deformation occured in multiple stages.
Upper Pleistocene gravel is folded and faulted at many places along the Furnace Creek fault zone where the zone plunges under the saltpan at the edge of Cottonball Basin. At Mustard Canyon Hills, for example, upper Pleistocene gravel unconformably overlies and is anticlinally folded above upper Pliocene deposits (fig. 80). Strike faults along the flank of this dome have displacements $5-10$ feet down in the direction of the dip. This late Pleistocene doming is 100 feet or more.

Reference has already been made to the doming of the upper Pleistocene gravel at Salt Creek Hills across Cottonball Basin from the Mustard Canyon Hills.

Evidence about tilting of shorelines of the upper Pleistocene lake, Lake Manly, is not at all satisfactory. Two hundred feet of eastward tilt and 300 feet of northward tilt since Lake Manly time is indicated-

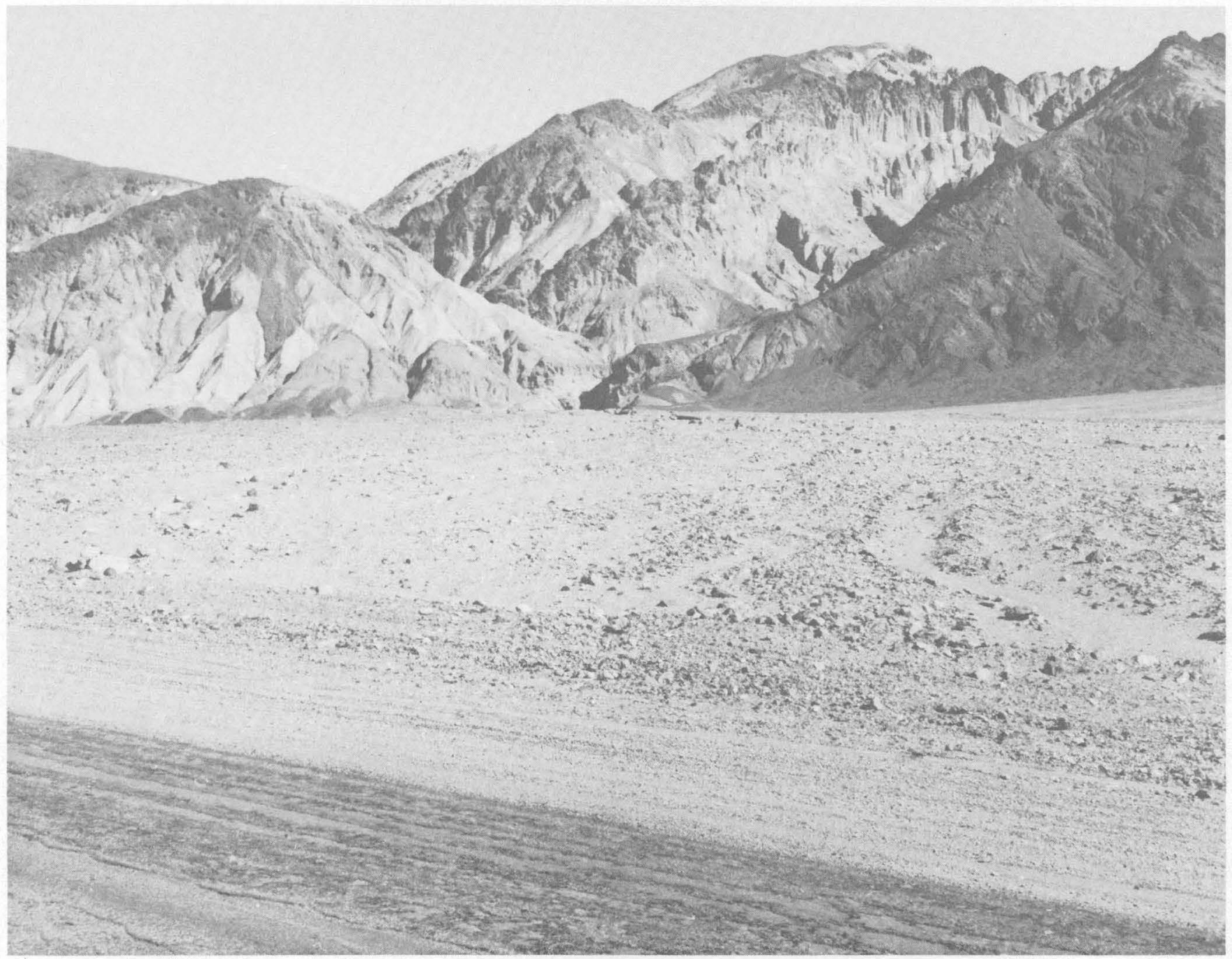

Figure 78.-Hanging valley at Gower Gulch at the front of the Black Mountains. The floor of the old valley has been raised 50-75 feet above the apex of the fan. Furnace Creek Formation (extreme left) overlies Artist Drive Formation. 


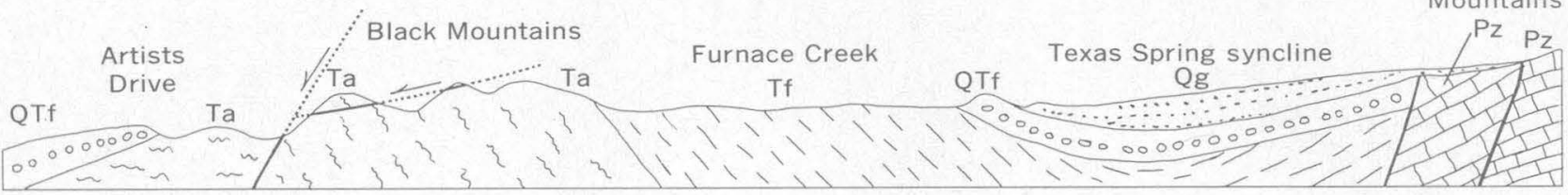

$1,1 / 2,0012$ MILES

Figure 79.- Section from the Funeral Mountains southwestward across the Texas Spring syncline and Black Mountains to the fault blocks at Artists Drive. Pz, Paleozoic formations; Ta, Artist Drive Formation; Tf, Furnace Creek Formation; QTf, Funeral Formation; Qg, upper Pleistocene fan gravel. The Artist Drive Formation is more deformed than is the Furnace Creek Formation, and the latter is more deeply folded under the Texas Spring syncline than is the Funeral Formation. Upper Pleistocene gravel is slightly folded in the syncline. Vertical scale not exaggerated.

(p. A71) a reasonable supposition. But the deposits are discontinuous, and the correlations along and between the two sides of Death Valley are uncertain. About all that can be concluded from the evidence provided by the upper Pleistocene lake deposits is that this evidence does not conflict with what is known about the structural history. The same seems to be true of Panamint Valley (Maxson, 1950, p. 107).

Evidence of late Pleistocene deformation also is provided by the geomorphology of the gravel fans. The fans on the two sides of Death Valley are strikingly different; those at the foot of the Black Mountains are small, whereas those sloping from the Panamint Range are long and high. There is similar difference between the two sides of the Panamint Range (Murphy, 1932, p. 353). The differences assuredly reflect the eastward tilting, probably not of the whole area but of individual fault blocks.

Also, differences in the fans along the foot of the Panamint Range suggest there is a northward component in the tilting of that range. The fans at the north extend far into the mountains whereas those at the south extend only to the mountain front (fig. 66 and pl. 2).

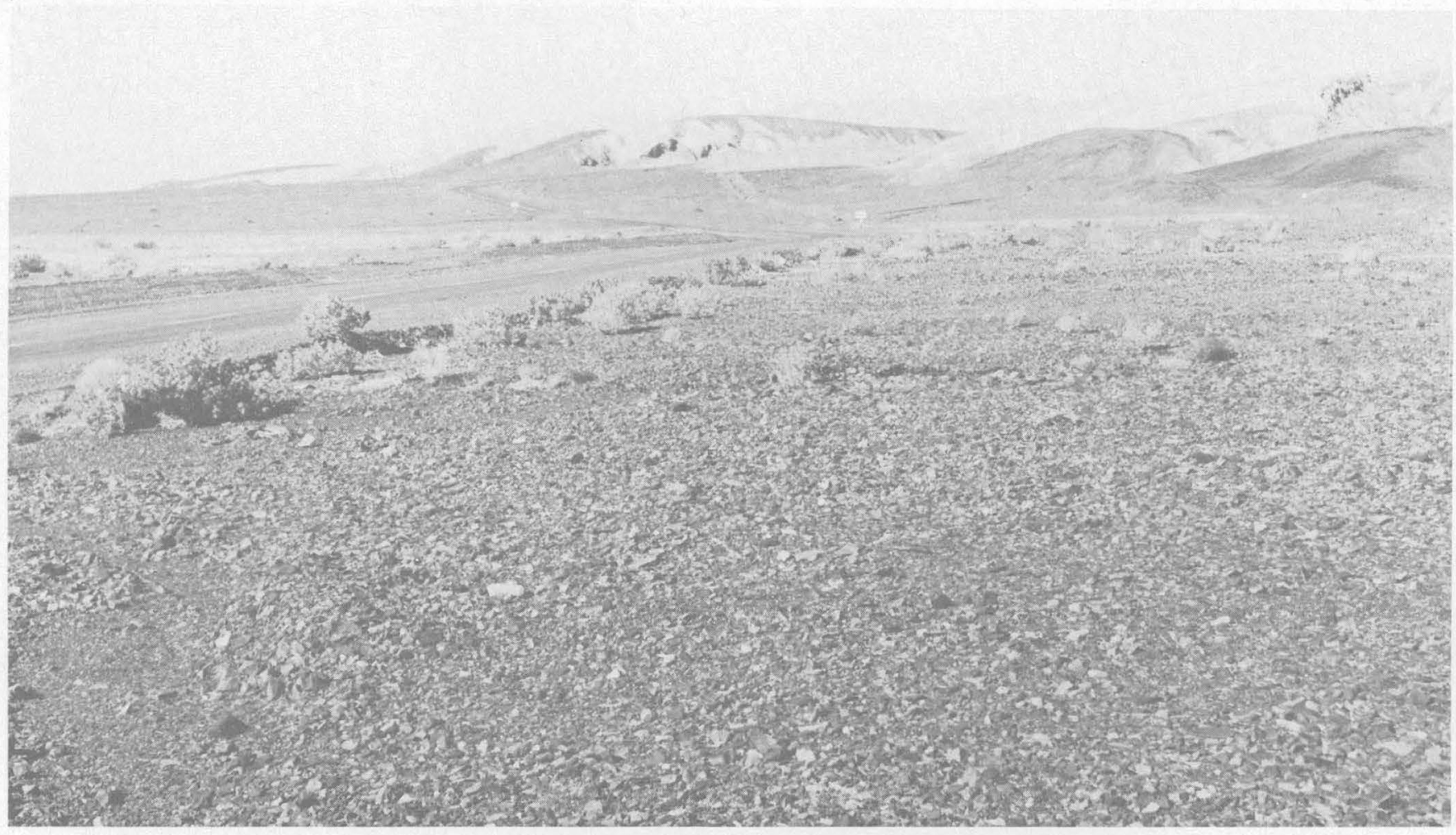

Figure 80.-View along the southwest flank of the anticline at the Mustard Canyon Hills. Upper Pleistocene gravel (dark beds) unconformably overlaps the Furnace Creek Formation (light-colored beds) and is turned up $20^{\circ}$ along the flank of the anticline. Photograph by John R. Stacy. 


\section{VALIEY FILL}

\section{GRAVITY FEATURES}

The gravity contours shown on plate 3 are based on the complete Bouguer anomaly values. The data were reduced with an assumed density of $2.67 \mathrm{~g}$ per $\mathrm{cm}^{3}$ (grams per cubic centimeter). The terrain corrections are large over all the area and locally extreme (more than 70 mgals at Telescope Peak); however, the terrain corrected data are considered accurate enough to justify the 5- and 10-milligal intervals used in contouring.

The large local gravity lows in the valley are produced primarily by the relatively low-density Cenozoic fill in the troughs. The more extensive variations are produced by density variations in the older rocks and perhaps by effects deep within the crust or in the upper mantle. The quantitative interpretation of the gravity data is limited by uncertainties in the density of the rocks producing the anomalies. Horizontal and vertical changes in the density of basin fill produce gravity variations that cannot be distinguished from effects of relief on the bedrock-fill interface. In parts of Death Valley the problem of interpretation is further complicated by large gravity anomalies due to variation in the bedrock. Although the bedrock anomalies are more extensive than the basin anomalies, the two cannot always be separated satisfactorily. Despite these limitations, the gravity data can be used to estimate the approximate thickness of the basin fills and to indicate structures that produce relief on the interface between the Cenozoic rock and the more dense older rock. Some of the gravity effects produced by deeper mass anomalies are also useful in studying the structural geology.

In a basin several times as wide as it is deep, the amplitude of the gravity anomaly between Cenozoic fill and the dense older rocks primarily depend upon the density contrast and thickness of the fill. Computations of the thickness of fill are no more accurate than the assumed density contrast. In Death Valley there are no drill hole or seismic depths to bedrock to serve as control for interpreting the gravity data, and densities are inferred from surface samples. Gravity studies elsewhere in the Great Basin indicate that the average density contrast between the Cenozoic fill and the older rocks is about $0.4 \mathrm{~g}$ per $\mathrm{cm}^{3}$. The contrast may range from near zero to about $0.7 \mathrm{~g} \mathrm{per} \mathrm{cm}^{3}$. If the contrast is $0.4 \mathrm{~g} \mathrm{per} \mathrm{cm}^{3}$, a gravity anomaly of about 5 milligals will be produced by each 1,000 feet of fill. If the density contract is as great as $0.7 \mathrm{~g}$ per $\mathrm{cm}^{3}$, the actual thickness will only bo about 60 percent as great as computed assuming a contrast of $0.4 \mathrm{~g} \mathrm{per} \mathrm{cm}^{3}$. However, if the density contrast approaches zero, the actual thickness may be several times greater than the depth computed, using a contrast of $0.4 \mathrm{~g}$ per $\mathrm{cm}^{3}$ (fig. 81). The depths

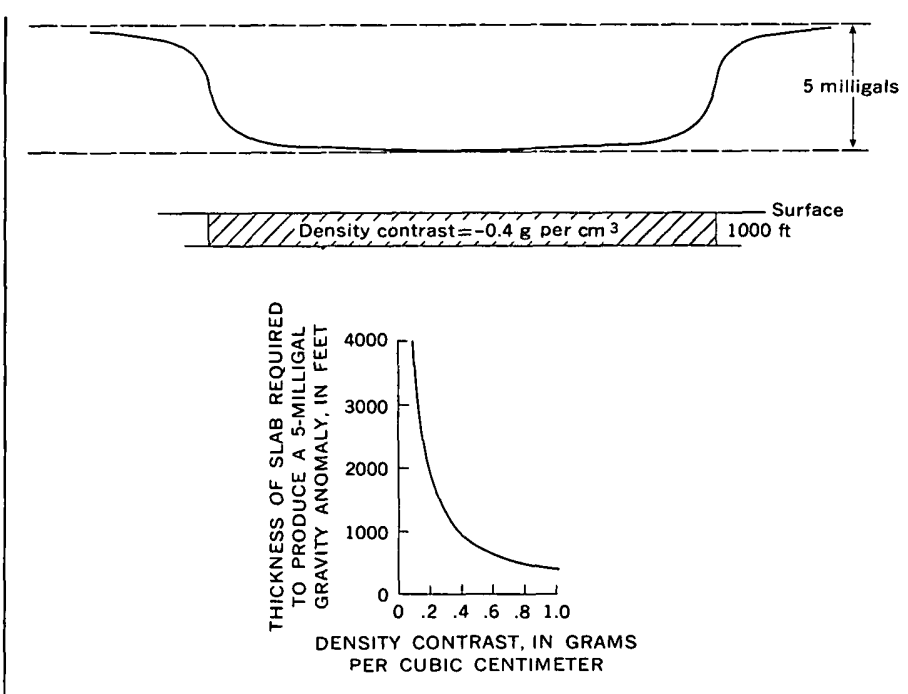

Figure 81.-Diagram illustrating the gravity anomaly produced by two-dimensional prism and the relationship between the amplitude of the anomaly and the density contrast between prism and the enclosing material.

we infer from the gravity data are based on an assumed density contrast of about $0.4 \mathrm{~g} \mathrm{per} \mathrm{cm}^{3}$.

A gravity low extends the entire length of Death Valley. This low is divided into three principal areas of low gravity closure separated by the two high trends across the valley. The low areas are in Mesquite Flat, Cottonball Basin, and Badwater Basin; the two high trends coincide with the anticlines at the Salt Creek Hills and opposite Artists Drive.

The gravity low in Mesquite Flat has the greatest relief of any of the lows in Death Valley. A part of this negative anomaly is probably related to the low anomaly values in the Cottonwood Range, but a local anomaly of 40-50 milligals is produced by rocks underlying the basin. This is the largest residual anomaly in the region, and it indicates a subsurface basin containing about 2 miles of Cenozoic fill with the thickest section near the center of the basin.

Near the south and east edges of Mesquite Flat are steep gravity gradients, which are interpreted as indicating faults with large vertical displacement. The fault indicated by the gravity data along the northeast side of the basin is part of the Furnace Creek fault zone. The steep gradient north of the front of Tucki Mountain probably indicates a fault trending a few degrees north of east. Not enough gravity data were obtained along the west side of the basin to define adequately the gravity gradient; however, a steep gradient, probably related to faulting, is indicated about 5 miles north of the mouth of Marble Canyon.

The minimum anomaly values in Cottonball Basin are near the center of the valley along the east side of the playa. The maximum gravity-anomaly relief between the floor of the valley and stations on bedrock in 


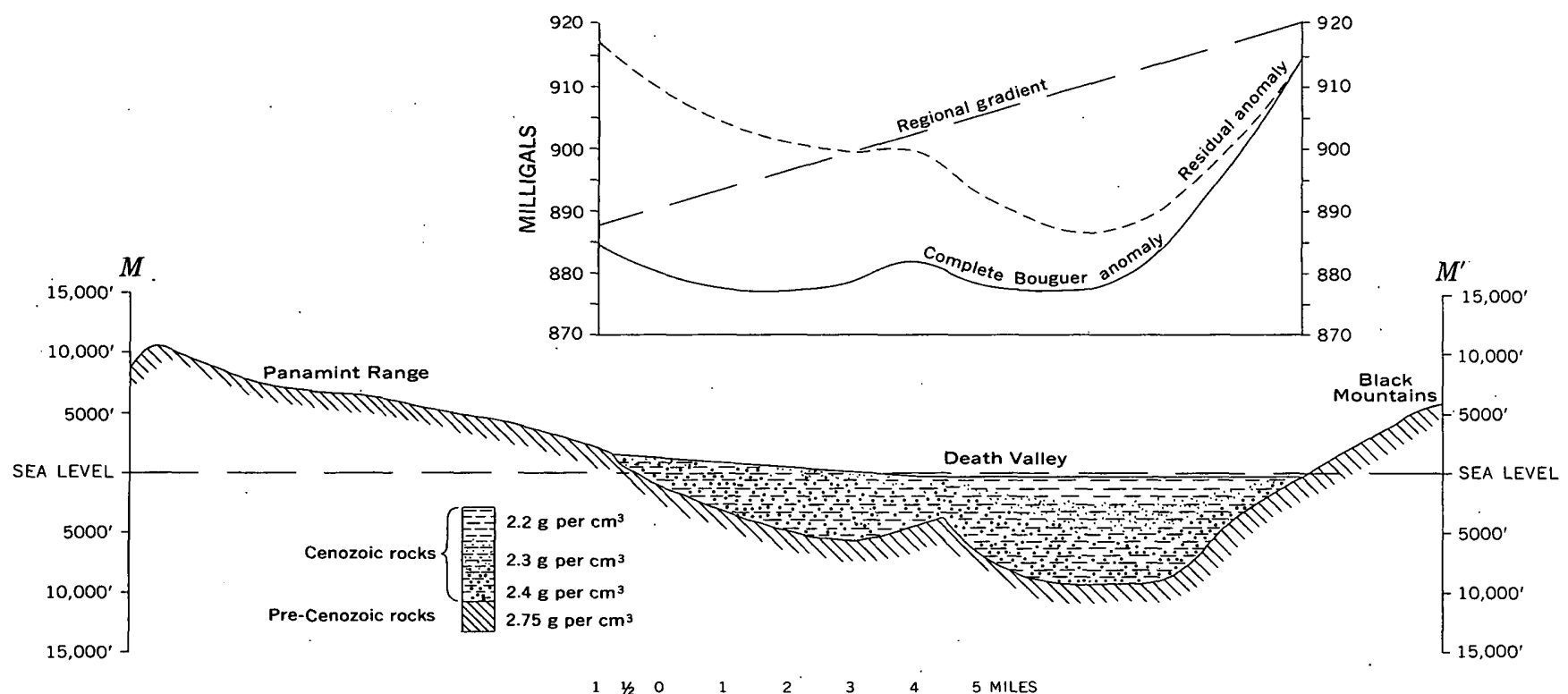

Figure 82.-Gravity and inferred bedrock profle across Badwater Basin.

the Funeral Mountains is 43 milligals. Along the northeast side of the Furnace Creek basin the gravity data indicate vertical displacement along more than one fault of the Furnace Creek fault zone.

To the south the gravity anomaly bifurcates with one branch trending south down Death Valley and the other trending southeast along the Furnace Creek fault zone under the Texas Spring syncline. The gravity data indicate a considerable thickness of Cenozoic rock; under the Texas Spring syncline most of it must be Tertiary. This Cenozoic rock thins southeastward. The gravity data do not indicate faulting along the northeast side of the Black Moutains.

The main branch of the gravity low in the Cottonball Basin continues down Death Valley to the Devils Golf Course opposite Artists Drive where a gravity saddle separates the low anomaly in the north from the low in Badwater Basin. This coincides with the buried anticline that has been confirmed by drilling (p. A102).

The low gravity anomaly in Badwater Basin consists of two areas of low closures separated by a northtrending high down the west side of the saltpan, but the significance of these gravity data is obscured by the large regional gravity variation across the valley (fig. 82). We infer a structural high along the west side of the saltpan separating two areas of deep fill. The fill under the saltpan is computed to be 9,000 feet deep, of which two-thirds is estimated to be Tertiary. The interpretation of the western half of the profile is very doubtful because a major change from the assumed regional gradient would substantially alter the residual anomaly.
South of Mormon Point and south of the area shown on plate 3 the axis of the gravity anomaly trends a little east of south and extends down the center of the narrow part of the valley between the Owlshead Mountains and the Black Mountains. In the Confidence Hills the minimum anomaly values occur directly over the hills, indicating that the greatest thickness of Cenozoic rock occurs under the hills and that the surface relief is not reflected on the bedrock surface. Gravity evidence indicates faulting on both sides of the valley in this area. The low anomaly diminishes to the south to a small low gravity closure north of the Avawatz Mountains.

\section{MAGNETIC FEATURES}

Aeromagnetic data were obtained along profiles in Death Valley flown at an altitude of 3,500 feet above sea level. One profile is along the axis of the valley and six are at widely spaced intervals across the valley (fig. 83).

The local magnetic relief at the south end of profile $A-A^{\prime}$ is produced by Tertiary volcanic rocks. The general rise in the total magnetic intensity toward the north is about equal to the normal regional magnetic gradient. The gentle undulations several miles in extent with relief of less than 100 gammas probably reflect deep features, either relief on the top of basement complex or, more probably, compositional changes within the basement rock. The local anomaly between Badwater Basin and Cottonball Basin coincides with the buried anticline there. The anomaly is produced by a relatively shallow feature, probably volcanic material within the basin fill. 


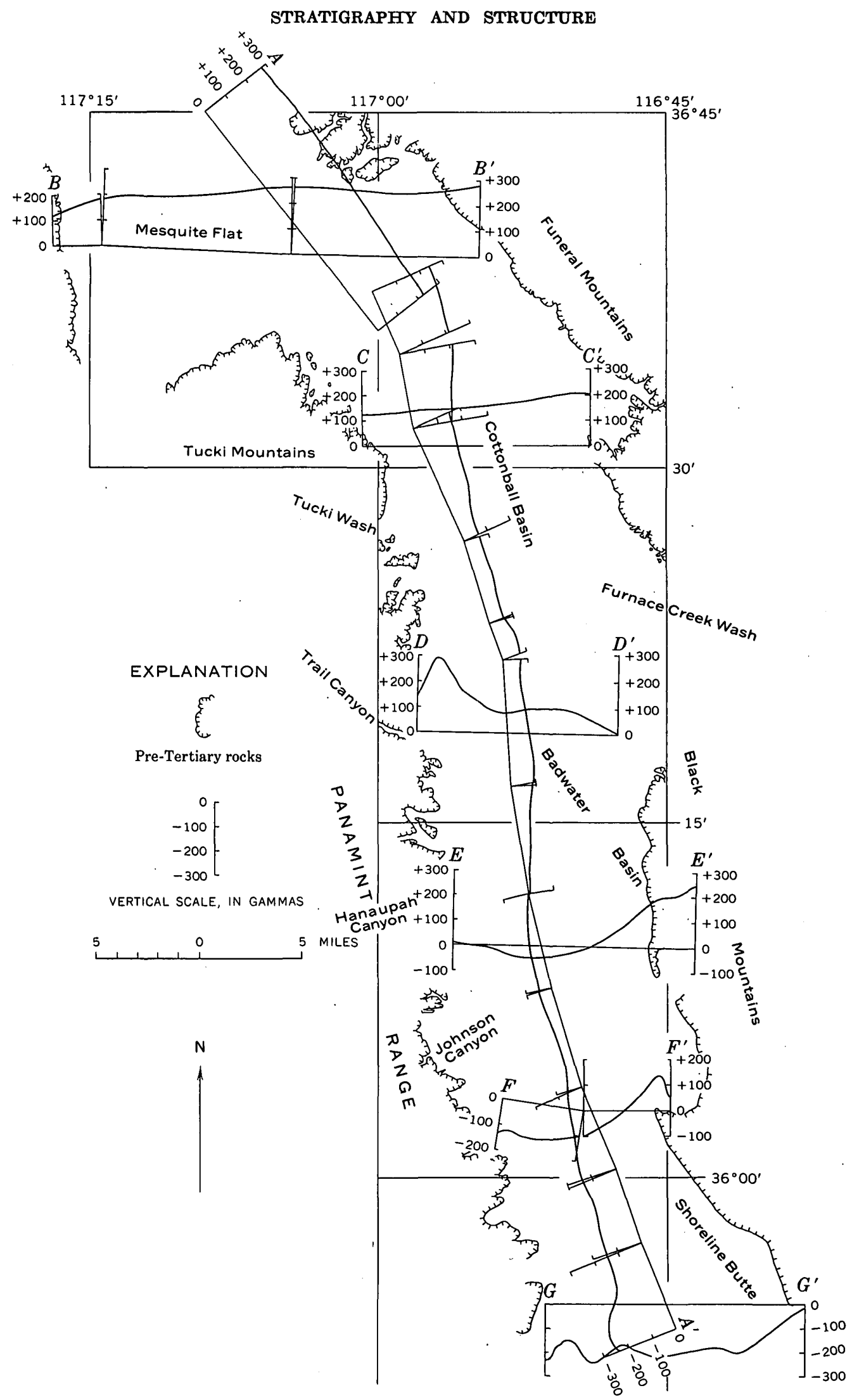

Fraure 83.-Total intensity aeromagnetic profles across Death Valley. Fifght level is 3,500 feet above sea level. 
Profiles $B-B^{\prime}$ and $C-C^{\prime}$ show the normal regional gradient across the valley without any large local anomalies. On profile $C-C^{\prime}$ there is an indication of the south end of the positive anomaly along the northeast side of Mesquite Flat, probably produced by the basement rocks.

Profiles $D-D^{\prime}, E-E^{\prime}$, and $F-F^{\prime}$ across the Badwater Basin show considerable local magnetic relief. Profiles $D-D^{\prime}$ and $E-E^{\prime}$ show a westward increase in the magnetic field along the west side of the valley, and at the west end of profile $D-D^{\prime}$, the anomaly has a peak. Depth estimates on this anomaly indicate that the feature producing the anomaly is within 1,000 feet of the surface. These anomalies coincide with the volcanics and intrusions in the Amargosa thrust complex along the east foot of the Panamint Range.

On profile $D-D^{\prime}$ there is a decrease in the total intensity as the Black Mountains are approached; on profiles $E-E^{\prime}$ and $F-F^{\prime}$ the total intensity increases toward the Black Mountains. The latter two profiles are in the area where the older Precambrian complex makes up the core of the Black Mountains, and it seems probable that a major part of the rise in the total magnetic intensity is related to the elevation of the Precambrian rock. The local reversal near the east end of profile $G-G^{\prime}$ has a near-surface cause. The magnetic maximum is where the older Precambrian rock of the Mormon Point turtleback extends across the profile. To the east of this outcrop is Cenozoic rock. The magnetic reversal may be related to a high over the older Precambrian rock or to a low over buried volcanic rocks to the east.

The southernmost profile $G-G^{\prime}$ has considerable magnetic relief west of the center of the valley. One anomaly is a local high over Shoreline Butte, which contains a considerable volume of basalt; probably the other anomalies to the west are also produced by volcanic rocks in the Cenozoic fill. From Shoreline Butte the magnetic field increases eastward over the older Precambrian complex in the Black Mountains.

\section{CHANGES IN THE ALTITUDES OF BeNCH MARKs}

Some evidence of continuing deformation in Death Valley is provided by the change in altitudes determined for bench marks between the original level surveys in the valley in 1907 and releveling in 1933-35 and 1942-43. In 1907 the U.S. Geological Survey surveyed level lines into Death Valley to provide vertical control for the $1: 250,000$ topographic maps of the region. Bench marks were set along a line which followed the road along the west side of Badwater Basin, crossed the valley floor at the Devils Golf Course and went around the north and east sides of Cottonball Basin and Mesquite
Flat. Another line crossed the valley from Daylight Pass to Emigrant Canyon. This early leveling although providing adequate control for the topographic mapping, was not sufficiently accurate to provide a measure of the regional deformation when compared with later leveling. However, local deformation within the valley is indicated by comparing the original altitude differences between bench marks in the valley with altitude differences determined on the later surveys (fig. 84). Unfortunately only a few of the original bench marks were recovered in the later surveys, and these provide an incomplete picture.

The indicated general decrease in altitude relative to the reference bench mark near Wingate Pass may be produced by systematic errors in the original -data, but in general the indicated changes within the valley are probably real. The largest subsidence is 0.73 foot for a bench mark along the southwest edge of Badwater Basin. At a bench mark about 5 miles to the southeast near the end of the saltpan the indicated subsidence is 0.16 foot. This is consistent with continued subsidence of the Badwater Basin.

On the east side of Cottonball Basin 3 bench marks over an interval of about 12 miles show changes of $-0.07,+0.01,-0.65$, and -0.03 foot. The bench marks with the -0.07 and +0.01 change are just southwest of the Kit Fox Hills fault with +0.01 bench mark closest to the fault. The -0.65 bench mark lies between the Kit Fox Hills fault and the anticline in the Cottonball Basin. The -0.03 bench mark is south of the anticline and over the gravity nose extending northwest from the Black Mountains.

The data for 3 bench marks southeast of Mesquite Flat indicate subsidence ranging from 0.28 to 0.68 foot.

These indicated subsidences may be due partly to compaction of sediments in the valley fill and partly to structural deformation.

\section{SEISMIC ACTIVITY}

Death Valley is in a seismically stable area at the edge of a highly active area (fig. 69). Fifty miles southwest of Death Valley, epicenters are closely spaced, and a rather sharp northwest-trending line marks the northeast edge of the seismically active area. Only a dozen earthquake epicenters have been located in the valley or in the mountains adjoining it, and none of these was sufficiently intense to be felt by persons in the area. There is no historic record of earthquake damage. Apparently the last major earthquake originating in Death Valley occurred 2,000 years ago when the floor of the valley was tilted 20 feet eastward and the 10-foot escarpment formed along the foot of the Black Mountains (p. A100). The geologic effects of that 
STRATIGRAPHY AND STRUCTURE

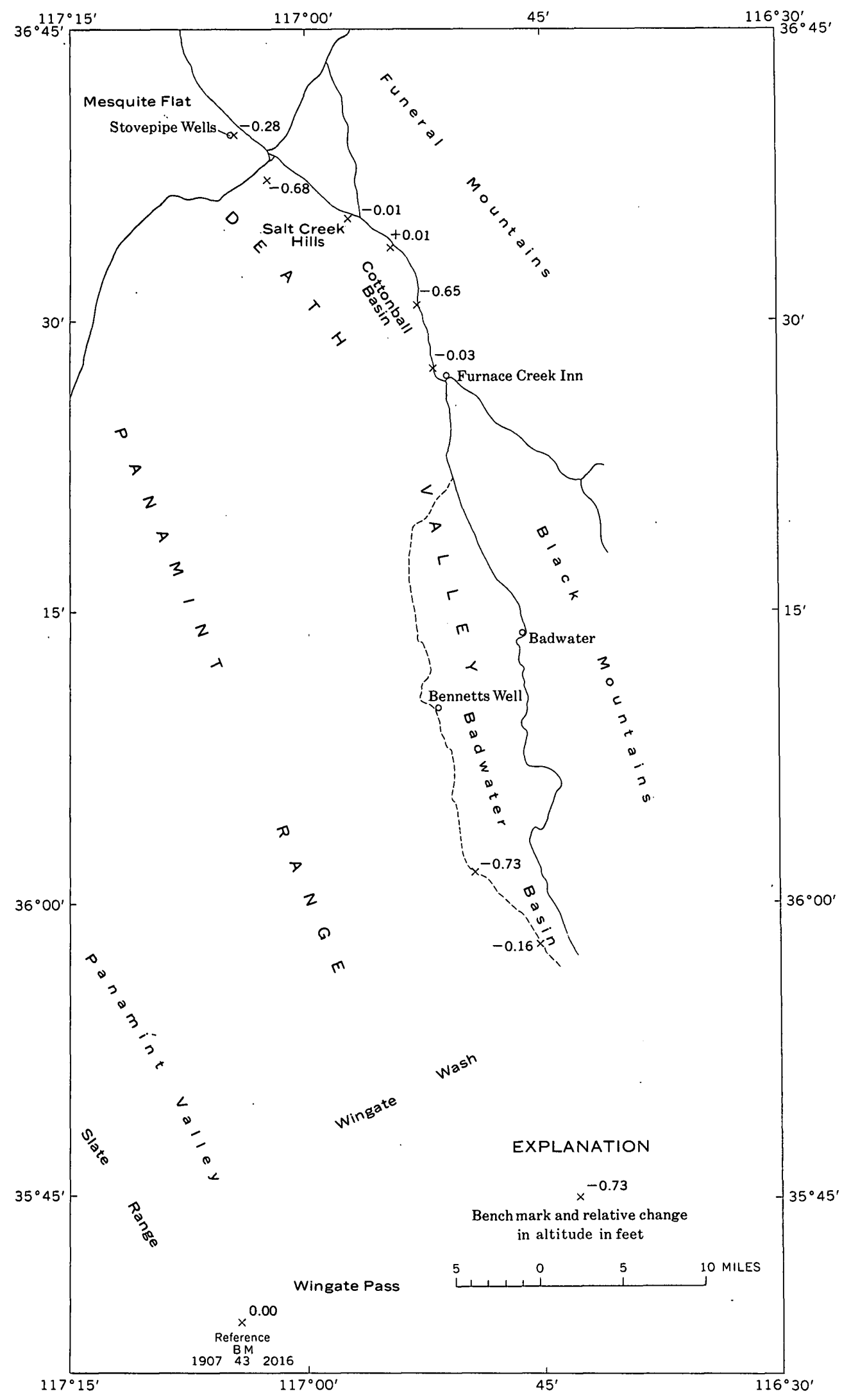

Frourn 84.-Relative changes in altitude of bench marks in Death Valley between unadjusted 1907

U.S. Geological Survey data and adjusted 1933 and 1942-43 U.S. Coast and Geodetic Survey data. The changes are relative to bench mark BM 1907432016 near Wingate Pass. 
earthquake, and perhaps its intensity, approximately duplicated those of the 1959 earthquake at Hebgen Lake in the West Yellowstone area.

In the other direction, northeast of Death Valley, a series of epicenters alined northwesterly roughly along the California-Nevada boundary separates the Death Valley area from a more extensive stable area covering most of the eastern part of the Great Basin. This latter stable area coincides with a regional gravity low (fig. 70). Finally, another series of epicenters is located along the boundary between the Basin and Range province and the Colorado Plateau.

Data on earthquakes in the Death Valley region during the period from 1934 through 1958 were compiled and made available to us by C. R. Allen, of the California Institute of Technology. These data show 12 epicenters in the main part of Death Valley or on the adjoining mountain slopes. These quakes range in magnitude from 2.5 to 4.0 on the Richter scale. The uncertainty in the location of the epicenters is too great to justify any attempts to correlate them with known faults.

Seismic-refraction data indicate that the crust under much of the Great Basin consists of two layers and that it thickens northeastward (Press, 1960; Berg and others, 1960; Diment and others, 1961). The upper layer or layers have a velocity of $6.3 \mathrm{kmps}$ (kilometers per second) or less and are underlain at depths between 20 and $25 \mathrm{~km}$ by a layer having a velocity of 7.6$7.8 \mathrm{kmps}$. The base of this layer slopes northeastward from a depth of about $50 \mathrm{~km}$ in southern Nevada to about $74 \mathrm{~km}$ in northwest Utah. The underlying material has a normal mantle velocity of about $8 \mathrm{kmps}$.

Such layering within the crust is not indicated westward from Death Valley to the Sierra Nevada (Carder and Bailey, 1958). Under the Sierra Nevada, velocities in the crust are uniform. The crust appears to be homogeneous and at least 40 and perhaps more than $50 \mathrm{~km}$ thick. Gravity data (fig. 70) and seismic data indicate that the upper crust in the Death Valley area is little more than half that thiek, say $25 \mathrm{~km}$. Assuming these thicknesses, the base of the upper crust must slope about $15^{\circ}$ westward from Death Valley. The slope to the northeast would be about half that. Death Valley appears to be over a ridge on the mantle.

\section{THLTMETER MEA SUREMENTS}

By Gordon W. Greene METHODS

Seven tiltmeter stations were established in the Death Valley area in 1958 and 1959 to determine if measureable tilt was occurring. The location of the tiltmeter stations is shown on plate 3. A detailed description of the portable liquid tiltmeters used in this study is given by Eaton (1959).

Each tiltmeter station, except those in adits, was laid out in a nearly equilateral triangle with sides $30-50$ meters long. At each apex a machined brass hub was set in concrete upon rock outcrops, and hub tops were established within $\pm 0.5 \mathrm{~cm}$ of a level plane. Variations in the size and shape of the triangles were made because of local terrain. One station, Trail Canyon fan, was established by using large boulders embedded in gravel instead of bedrock outcrops.

Temperature gradients between hubs and rapid changes of air temperature cause erratic readings. To avoid heating of the system by solar radiation, the tiltmeter was used at night, or when the sky was heavily overcast. Heat radiated from the ground at night, especially when the sky is clear, also makes observations difficult. A gentle wind can assist in maintaining a constant temperature in the system.

Under ideal conditions, altitude differences between hubs can be measured with an error of less than three microns. Thus, if the hubs are 30 meters apart, a sensitivity of 1 part in 10 million can be realized. The precision of the measurements is checked by closing the measured altitude differences around the three sides of the triangle.

In practice, closure errors as much as 50 microns were encountered because of the difficulty in maintaining the entire system at a constant temperature. Readings were considered valid if the closure error was less than 10 percent of the total change in hub altitudes.

\section{MEASUREMENTS}

Tiltmeter observations show that the ground surfaces in the Death Valley area are being tilted at present. The direction and magnitude of tilting varies from one station to another, and at any given station both direction and magnitude vary from time to time. Figure 85 shows the tilting observed at five stations in the Death Valley area.

The direction of tilting is consistent with the structural geology and tends to follow the present dip of strata at each station. Tilting is to the northeast at Aguereberry Point, Trail Canyon, and Dantes View. These stations are located on blocks which have been tilted to the east or northeast. At Artists Drive, tilting is predominantly toward the southwest, although there is a distinct tendency at times to tilt southeastward. Here the Tertiary formations dip southeastward, and the overlapping early Pleistocene fanglomerate dips westward. Within the valley, tilting at Trail Canyon fan is chiefly toward the south, which accords with its position on the flank of the anticline north of Badwater Basin. 

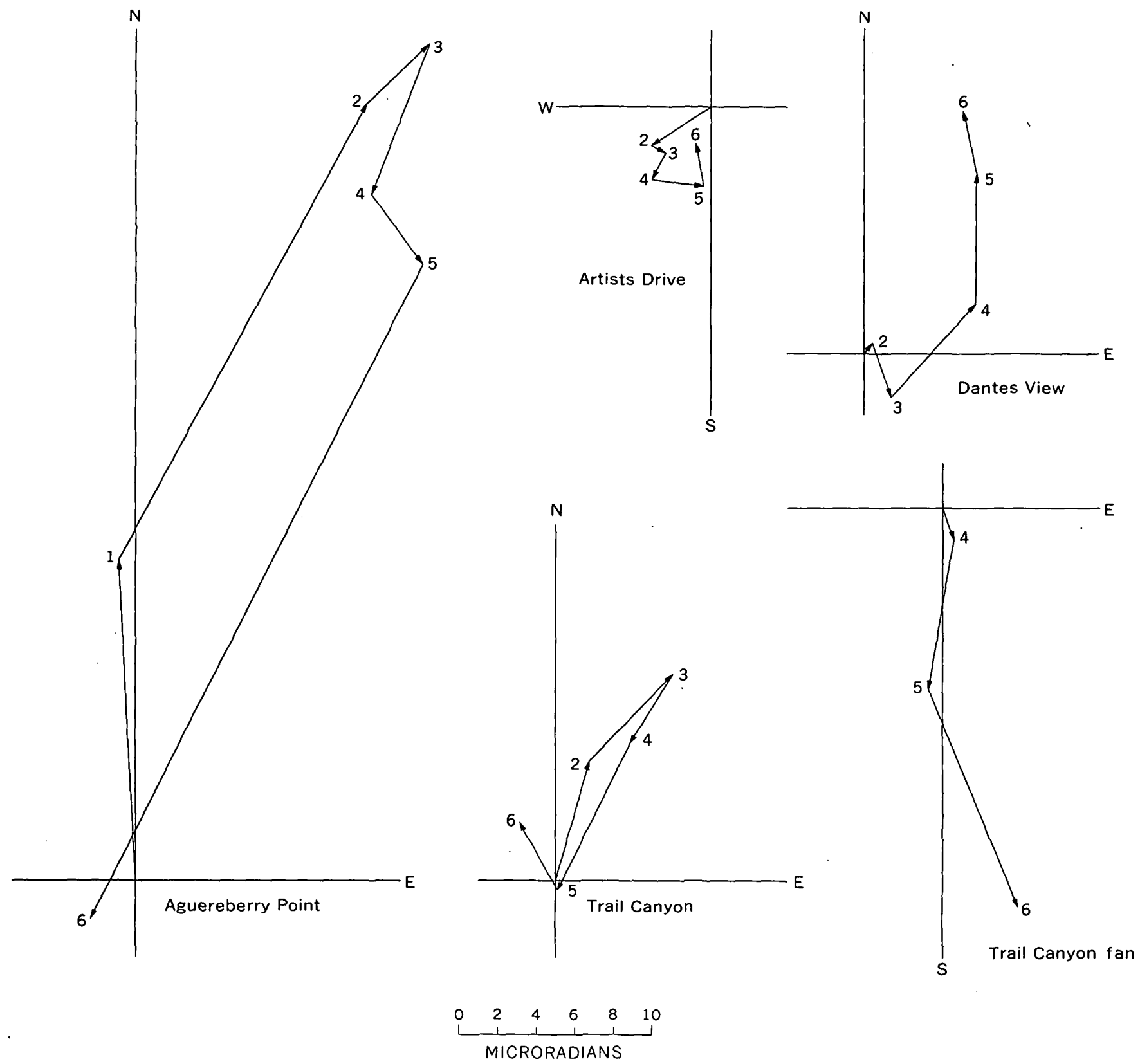

Figurm 85.-Diagrams showing thlting observed in the Death Valley area. Vectors are used to indicate direction and magnitude of tilting between successive observations. Dates of observations: 1 , December $1958 ; 2$, April 1959; 3, October 1959; 4, April 1960; 5 , October $1960 ; 6$, February 1961 .

The rate at which tilting occurs varies widely. Observations have been made at intervals of from 3 to 8 months, averaging about 6 months, and the total change of attitude, or tilting, that has occurred in the interval is measured. There is no evidence to indicate that the tilting has been at a uniform rate during the interval, nor is there any evidence to show that tilting occurred as a result of a single event or a series of events. It is convenient, however, to use "average" tilting rates when comparing tilting at different stations and intervals.
An average rate as low as 0.15 microradian per month at Artists Drive and as high as 12 microradians per month at Aguereberry Point have been observed. Tilting at an average rate of 0.9 microradian per month (11 microradians per year) seems to be common in the Death Valley area.

Tilting at the rate of 11 microradians per year would produce an uplift of 581 feet over a distance of 5 miles in 2,000 years, an amount that is many times too large to be realistic. 
During the years 1958-61, both the direction and magnitude of tilting have varied. At Aguereberry Point, Trail Canyon, and Artists Drive, reversals of tilting have occurred and, at the time this was written, the net tilt at some stations after 3 years was less than it was after 1 or 2 years. Observations over a much longer time are needed to establish the trends.

\section{RELATION BETWEEN TILTING MOVEMENTS AND SEISMIC} ACTIVITY

Because the Death Valley area is relatively free from earthquakes, it has not been possible to relate tilting to seismic activity in the vicinity of the tiltmeter stations. However, since the first tiltmeter measurements were made in May 1958, there have been five earthquakes of moderate intensity in the eastern Sierra Nevada and Owens Valley areas. These earthquakes, which are listed below, were not felt in Death Valley, although the quake of January 1961 was felt at the Defense mine in the Panamint Range where, according to the caretaker, several large rocks were rolled down the mountain.

\begin{tabular}{|c|c|c|}
\hline Date & Epicenter & $\begin{array}{c}\text { Richter } \\
\text { magnitude }\end{array}$ \\
\hline Jan. 5,1959 & Southern Owens Valley_ & 4. 7 \\
\hline Aug. 4,1959 & Northern Owens Valley_ & 5.5 \\
\hline Jan. 28, 1961 & Walker Pass & 5. 3 \\
\hline Feb. 2, 1961 & $\begin{array}{l}\text { Sierra Nevada, east of } \\
\text { Big Pine }\end{array}$ & 5. 0 \\
\hline Oct. 18,1961 & Walker Pass__. & 5.2 \\
\hline
\end{tabular}

There may be some relationship between tilting movements in the Death Valley area and earthquakes about 50 miles away. The average rates of tilting at Aguereberry Point and Trail Canyon fan were greatly increased during the period between October 1960 and February 1961, but there was little change at the other stations. The direction of tilting at two stations, Trail Canyon and Artists Drive, was anomalous during this period, but most of the stations have shown some anomalous tilting in the past.

\section{EARLY PLEISTOCENE STRUCTURAL FEATURES}

Deposits of the Funeral Formation are exposed in fault blocks at the foot of the Black Mountains at Mormon Point and Artists Drive, in the Texas Spring syncline and in some of the anticlines northwest of it, in the Park Village fault blocks, Salt Creek Hills, and along Emigrant Wash (pl. 3). At all these places the deposits are mostly fanglomerate, but they include minor amounts of interbedded basaltic lava and volcanic ash. The fanglomerate is sufficiently faulted, folded, and eroded, so that its original fan form is no longer apparent. The structure of the lower Pleistocene fanglomerates is accordant with that of the upper Pleistocene deposits, but the faulting and folding are much greater.
In discussing structural features involving the lower Pleistocene deposits, it is necessary to recall the uncertainties in correlating the deposits mapped as early Pleistocene. Only in two localities is there paleontologic evidence for dating the deposits mapped as $\mathrm{Fu}$ neral Formation (p. A63).

At Mormon Point the Funeral Formation overlaps and is faulted against the steeply dipping surface on the Precambrian metamorphic rocks (Drewes, 1959). The overlapped surface is a turtleback fault surface, very likely the Amargosa thrust, from which the overlying rocks have been stripped (Noble, 1941; Curry, 1954). Subsequent uplift of the turtleback has raised the fanglomerate a few hundred feet above the valley floor, and the fanglomerate has been faulted valleyward along the contract of overlap. A high-angle fault at the north edge of the Funeral Formation separates it from the younger fill in the saltpan. Displacement on this fault is at least 200 feet (Drewes, 1959). There is difference of opinion about the continuity of the turtleback fault surface with the Amargosa thrust. Noble (1941) and Curry (1954) connect them; Drewes (1959) suggests that the turtleback fault surface is a younger normal fault.

The structural relations at Mormon Point are duplicated along Emigrant Wash where the Funeral Formation overlaps the west-sloping turtleback surface marking the west side of the Tucki Mountain fenster, and the fanglomerate subsequently has been faulted downward along the old fault surface. The dip of the fault is about $25^{\circ}$ to the west. Likewise, as at Mormon Point, a second fault, probably a high-angle one, marks the valley edge of the fanglomerate, and the displacement on this fault must also be down towards the valley, that is, to the west. The displacement on this high-angle fault is at least 500 feet.

The faulting that involves the lower Pleistocene deposits at Mormon Point and along Emigrant Wash raises problems about nomenclature of the faults. The autochthonous block at Mormon Point is regarded as that of the Amargosa thrust; the autochthonous block along the turtleback at Emigrant Wash is that of the Tucki Mountain thrust fault (fig. 86). At both locations two generations of movement are recorded. The latest movement, which involves the Funeral Formation, is sufficiently later than the earlier one for the fault to have been folded anticlinally and the upper plate stripped from it, probably by detachment faulting.

On Artists Drive the Funeral Formation overlaps middle and older Tertiary volcanic rocks. At the time this was mapped, in 1957, it was assumed that the contact was simply a depositional one of overlap. Question now arises whether faulting along that overlap contact 


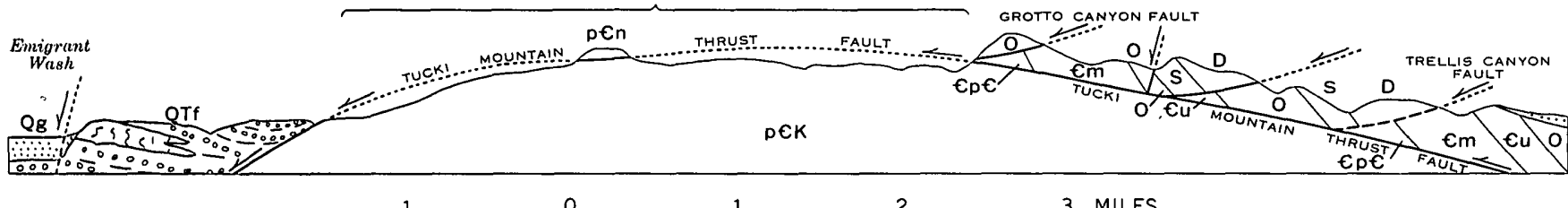

$1 \quad \begin{array}{llll}1 & 2 & 3 & \text { MILES }\end{array}$

Wraurn 86.-Section of Tucki Mountain showing the Tucki Mountain thrust fault and its branches on the east side of the mountain, the turtleback on the west side, and the Funeral Formation in Emigrant Wash that overlapped the turtleback and that was later faulted down ngainst it. pCk, Kingston Peak(?) Formation; p€n, Noonday(?) Dolomite; Cp€, Sterling Quartzite and Lower Cambrian; Cm, Middle Cambrian; Cu, Upper Cambrian; O, Ordovician; S, Sllurian; D, Devonian; QTf, Funeral Formation; Qg, upper Plelstocene fan gravel. Vertical scale not exaggerated.

was overlooked. Faulting is suggested by the occurrence in the fanglomerate of granulated Paleozoic quartzite, like the chaotic blocks associated with the Amargosa thrust (Noble, 1941).

Along the west side of the Artists Drive area, at the edge of the saltpan, are four southwest-trending fault blocks of Funeral Formation. The geomorphology of the ridges suggests that they are separated by as many southwest-trending faults and that each fault is downthrown on the northwest side. The two northerly hills are opposite the anticline buried in the saltpan that separates Badwater Basin from the basins to the north (p. A102). The two southerly hills lie just noirth of the projection of the Mont Blanco fault and between its outcrop on the higher part of Artists Drive and the faults thought to represent its extension in the saltpan. The Mont Blanco fault and its projection in the Artists Drive area marks the southern limit of Funeral Formation exposed in those fault blocks. South of the fault the Funeral Formation either is absent or has been faulted downward and buried under younger valley fill.

North of the Black Mountains the Funeral Formation is downfolded in the Texas Spring sycline (fig. 79) and anticlinally folded over the East Coleman Hills (pl. 3). The structural relief of the Funeral Formation across the Texas Spring syncline and adjoining anticline is at least 750 feet and probably more nearly a thousand. This structural relief is four of five times that of the upper Pleistocene gravels, but probably less than half that of the underlying Furnace Creek Formation (Pliocene).

In the Texas Spring syncline a block of the Funeral Formation ends southeastward at the Mont Blanco fault, which trends northeastward. Displacement on this fault, where it cuts off the fanglomerate, is down to the northwest. This direction of displacement is opposite to the apparent displacement farther southwest along the Mont Blanco fault where it enters the Tertiary formations and seems to have dropped the base of the Furnace Creek Formation downward a thousand. feet on the southeast side against the Artists Drive Formation. Perhaps the displacement in the Tertiary formations is that of a tear fault with right-lateral displacement, and the horizontal displacement was taken up in part by downfolding of the Texas Spring syncline.

In the Park Village block, between Cottonball Basin and the Funeral Mountains, the Funeral Formation forms a northwest-trending ridge bounded by faults. This probably is not a horst, however, because the fault along the northeast side of the ridge very probably is a faultline scarp. The displacement there probably is down to the west, that is, towards the valley, and the Funeral Formation probably has been stripped from the structurally higher fault blocks between the Park Village block and the Funeral Mountains. This interpretation is favored because the Tertiary formations along this fault and others paralleling it in the Furnace Creek fault zone are dropped down towards the valley.

There may have been lateral displacement along the Furnace Creek fault zone (Curry, 1938a). There is some evidence of right-lateral displacement along several faults between the Park Village block and the Funeral Mountains, where the beds on the southwest side of the faults, the downthrown side, show southward drag.

Right-lateral displacement also is indicated along faults at the west foot of the Panamint Range (Maxson, 1950, p. 107) and in the Confidence Hills (Noble and Wright, 1954, p. 157).

In the Salt Creek Hills the Funeral Formation is involved in both anticlinal folding and faulting (fig. 75 ) and has a structural relief measurable in hundreds of feet (p. A103).

Now we attempt to visualize how the physical geography and structure of the Death Valley area might appear if we undo the folding and faulting attributable to middle and late Quaternary time - that is, post-Funeral Formation. The distribution of the lower Pleistocene deposits shows that the Funeral Mountains, Black Mountains, and Tucki Mountain were in existence, but 
structurally they were at least 1,000 feet lower, and probably more nearly 2,500 feet lower.

If we raise the trough of the Texas Spring syncline (fig. 79) by 2,500 feet-that is, unfold it-dips in the Tertiary rocks in the Black Mountains are reduced almost one half, to an average in the neighborhood of $20^{\circ}-$ $25^{\circ}$.

Similarly, if the top of Tucki Mountain (fig. 86) were flattened structurally by 2,500 feet, the eastward dip of the Tucki Mountain thrust fault and the westward slope of the turtleback surface would be reduced to about $5^{\circ}$. The westward dip of the faults branching upward from the Tucki Mountain fault would be approximately doubled to an average of about $25^{\circ}$; the average east dip of the faulted Paleozoic formations would be reduced to roughly $25^{\circ}$.

No basis was found for estimating the amount of middle and late Quaternary uplift along most of the Black Mountains, but in view of the regional structural rise southward (p. A71, 88, 99) the probabilities are that the uplift towards the south was as great or greater than it was at the north. We assume the same amount-2,500 feet.

To continue the attempt to visualize conditions as they were at the beginning of the Quaternary, it is necessary to remove something like 3,000 feet of sediment from the structurally deepest part of Badwater Basin and perhaps 2,000 feet from Cottonball Basin.

It seems doubtful that Death Valley ever was 3,000 feet below sea level. On the contrary, it may even have had exterior drainage during part of the late Pleistocene time. Some of the late Pleistocene lakes may have connected with those at Soda Lake (p. A72) and possible exterior drainage from Death Valley is suggested by the abundant large boulders in certain upper Pleistocene (No. 2) gravel deposits (p. A65). Accordingly, it is reasoned that the floor of Death Valley was no lower than sea level, and probably was higher, at the beginning of the Quaternary. The Black Mountains probably were about half as high above the floor of the valley as they are now.

There is reason to infer that, during the Quaternary, the main part of the Panamint Range was raised much more than has been assumed for Tucki Mountain or for the Black Mountains. The Funeral Formation at the west foot of Tucki Mountain (fig. 86) rises southward in 10 miles to an altitude of 7,400 feet. The fanglomerate may have had a source in or beyond what is now Panamint Valley west of the range (Axelrod and Ting, 1960, p. 22). This suggests the possibility that at the beginning of the Quaternary and during early Quaternary time a structural valley and trough extended southward from Mesquite Flat along the site of Emigrant Wash and connected with the north end of Panamint Valley.

Regardless of the continuity of the trough, its altitude probably was not more than half the maximum now reached by the fanglomerate. Whatever that altitude was, the difference between it and the present maximum altitude of the deposit $(7,400 \mathrm{ft})$ is the amount by which the Panamint Range has been raised during middle and late Quaternary time. If this is assumed to be about 3,500 feet, the structures in the Panamint Range should be rotated westward $5^{\circ}-10^{\circ}$ to restore dips as they were when the Funeral Formation was being deposited.

An upland surface of lower relief is represented on the Panamint Range by broad open valleys about 5,000-6,000 feet in altitude (Maxson, 1950, p. 102). The age of the open valleys is uncertain. One of them, Harrisburg Flat, is eroded partly in Funeral Formation; but the open valley could be as old or even older than the fanglomerate, and the subsequent erosion attributable to the fact that the valley provided a local base level for erosion of the fanglomerate. The open valleys contain upper Pleistocene gravels; therefore they must be middle Pleistocene or older erosional features. Most of the differential uplift of the Panamint Range above Death Valley and Panamint Valley has occurred since the broad open valleys were formed.

\section{IATE TERTIARY STRUCTURAL FEATURES}

The Furnace Creek Formation records the existence of a playa that extended from Mesquite Flat southeastward across the site of the Salt Creek Hills, Cottonball Basin, Furnace Creek fault zone, and north end of the Black Mountains. Facies changes in the Furnace Creek Formation suggests that the playa did not extend southward along the trough that later became the Death Valley saltpan, because conglomerates in the formation in the northern part of the Black Mountains appear to have had a source far to the northwest in the northern part of the Panamint Range (p. A60). Had there been a playa extending southward along the site of the Death Valley saltpan, the gravels should have moved southward and not across the valley to the east side. The playa lasted long enough to accumulate more than 5,000 feet of fine-grained sediments, mostly derived from erosion of volcanic rocks.

Facies changes within the Furnace Creek Formation are not known well enough to reconstruct closely the limits of the trough that contained the playa. The northeast edge probably was at or close to the Kit Fox Hills fault (pl. 3). Major displacement on that fault occurred after the Miocene(?) formations were deposited in the Kit Fox Hills. It is assumed that the 
displacement of this fault, down on the southwest side, progressed while the Furnace Creek Formation was being deposited and that the scarp along the fault formed a northeast edge of the playa in which the Furnace Creek Formation was deposited.

The southwest edge of the trough evidently coincided with the flank of Tucki Mountain. On the Black Mountains there was a pile of older volcanic rocks, the Artist Drive Formation, that shed debris northward into the playa, but those mountains were not high enough or dissected deeply enough to contribute Precambrian debris to the Furnace Creek Formation. To what extent the mountains also had started to be raised as a major fault block is uncertain.

Much of the uplift of the Black Mountains occurred after the Furnace Creek Formation was deposited. At the front of the Black Mountains the Furnace Creek Formation is cut off by the fault along that front, one of the Basin and Range type of block faults, and dropped at least 1,000 feet, and perhaps more, into Death Valley.

Structural relief on the Furnace Creek Formation dipping off the north end of the Black Mountains could be as great as 7,500 feet (fig. 79), but this figure probably is excessive. It seems unlikely that the Furnace Creek Formation under the Texas Spring syncline is so thick because the gravity data (pl. 3) indicate that the bedrock floor there is about 5,000 feet deep, and part of this is Pleistocene.

The conflicting data provided by the gravity measurements and by the dips observed in the Furnace Creek Formation can be resolved by assuming that the playa shifted northeastward while the formation was being deposited. Such shift also is suggested by the fact that the sulfate and chloride zones in the upper members of the formation are north of their positions in the lower members (p. A62). If this shift is assumed, beds in the Furmace Creek Formation would offlap northeastward and would not be so thick under the Texas Spring syncline as would be assumed from the thick steeply dipping section exposed on the flank of the Black Mountains.

The structural significance of this interpretation is that much of the uplift of the Black Mountains may have occurred while the Furnace Creek Formation was being deposited; perhaps no more than half, and possibly much less, of the uplift of the Black Mountains need be attributed to early Pleistocene time after the Furnace Creek Formation had been deposited. We favor this interpretation because it resolves an apparent conflict between the structural and gravity data, and because it accords with an inferred northward shift of the salt zones of the Furnace Creek Formation.
At the Salt Creek Hills the Furnace Creek Formation is exposed in a sharply folded and faulted dome. The fold is asymmetrical. Its southwest flank is almost vertical where it is overlapped by the Pliocene and lower Pleistocene(?) Funeral Formation; the northeast flank dips $20^{\circ}-45^{\circ}$ northeastward. About 3,500 feet of beds assigned to the formation is exposed in the dome, and its indicated structural relief would be at least that much.

Outcrops of upper Tertiary deposits northwest of the Salt Creek Hills (pl. 3) suggest that a major fault trends northwestward for at least 6 miles. Southeastward the fault probably underlies the ridge of lower Pleistocene gravel that extends into the saltpan south of Salt Creek. Projected across Cottonball Basin the fault would join with the frontal fault of the Black Mountains where that fault turns northwestward into Cottonball Basin. Very likely this is one of the faults through which ground water is discharged from Mesquite Flat to maintain the extensive marsh on the west side of Cottonball Basin (Hunt and Robinson, 1960; see also Hunt and others, 1965).

At the Salt Creek Hills, as elsewhere, the Furnace Creek Formation is more strongly folded than the lower Pleistocene fanglomerate, which, in turn, is more folded than the upper Pleistocene gravels.

Reference has already been made to the curious Mont Blanco fault that thends northeast across the north end of the Black Mountains and Texas Spring syncline (p. A103). In the Black Mountains the base of the Furnace Creek Formation is offset to the right, as if the displacement were that of a normal fault down on the southeast side. Yet displacement of the Pleistocene beds in the Texas Spring syncline is down on the northwest.

Many assumptions have had to be made as to conditions at the time the Furnace Creek Formation was deposited, but it is inferred that the playa represented by it occupied a long, narrow, southeast-trending structural trough-at least 40 miles long and no more than 5 miles wide. The trough may have branched southward along the site of the Death Valley saltpan, but this branch was higher than the playa; its subsidence to a level below that of the southeast-trending playa could have occurred late in Pliocene time, but it more probably occurred early in Pleistocene time.

It has been inferred that the Black Mountains were raised structurally about 4,000 feet while the Furnace Creek Formation was being deposited, and that another 3,500 feet of uplift occurred during early Pleistocene time.

To visualize conditions at the beginning of the Pliocene, it is necessary to imagine the valley fill without the Furnace Creek Formation and younger sediments. The 
thickness of these, as suggested by the gravity data, is less than the apparent thickness across the steeply dipping beds, and is assumed to be about 3,500-4,000 feet. To the degree that the Furnace Creek Formation in the valley is underlain by older Tertiary deposits, the thickness assumed for the formation there would have to be even less. Because the amount of uplift inferred at the Black Mountains is about equal to the thickness of sediments under the Texas Spring syncline, the relief across that part of the area probably was little different from what it is at present.

There is no stratigraphic or structural evidence to suggest how the Panamint Range changed during this period. At least the northern part of the range was in existence because it provided some of the conglomerates in the Furnace Creek Formation. The part south of Tucki Mountain may have been much lower. It was certainly partly buried, and may have been largely buried, under the lower Tertiary volcanics that overlap the east side of the range.

\section{MIOCENE(?) AND EARLY TERTIARY STRUCTURAI FEATURES}

Deposits mapped as Miocene(?) are extensive in the Kit Fox Hills, east of Mesquite Flat, and they extend from there southeastward to the foot of the Funeral Mountains. The Kit Fox Hills fault, a straight highangle fault and part of the northwest-trending Furnace Creek fault zone, extends for at least 30 miles along the southwest edge of the deposits. Displacement is down on the southwest side, and the gravity data indicate that displacement totals several thousand feet. Probably the Pliocene deposits southwest of the fault never extended northward across it (p. A117), but if they did, they have been stripped from the upthrown block. Part of the displacement on this fault is Quaternary in age; much of the displacement is Pliocene, and most of it may antedate the Furnace Creek Formation.

Along the northeast side of the Park Village block the Kit Fox Hills fault may be marked by a faultine scarp, as already noted (p. A115).

Between the Kit Fox Hills and the Funeral Mountains are hills of Titus Canyon(?) Formation of Stock and Bode (1935) (Oligocene) that protrude through the fan gravels. The northeast side of the Kit Fox Hills probably is a faultline scarp like that along the east side of the Park Village block. The scarp along the northeast side of the Kit Fox Hills faces northeast and overlooks older formations; it seems too straight to be simply a cuesta at the updip side of Miocene(?) fanglomerate. This fault may be older than the Kit Fox Hills fault.

Along the Keane Wonder fault at the foot of the Funeral Mountains, the Titus Canyon(?) Formation is faulted down against the Precambrian in the mountains. The fault dips $25^{\circ}-40^{\circ}$ towards the valley, about the same as the dip of the Precambrian beds in that part part of the Funeral Mountains, which form a dissected turtleback (fig. 118).

The occurrence of the Titus Canyon(?) Formation along this fault and turtleback surface is like that of the Funeral Formation at the Tucki Mountain turtleback in Emigrant Wash and at the Amargosa thrust fault and turtleback surface at Mormon Point (p. A114). These relations also are duplicated at the Copper Canyon turtleback (Drewes, 1959) (fig. 87). The Keane Wonder fault and the turtleback surface are continuous with the thrust faults at Boundary Canyon and Echo Mountain, along which Cambrian formations are thrust westward onto the Precambrian. The Titus Canyon(?) Formation is faulted against the turtleback surface of the Funeral Mountains; but the main thrust appears to be pre-Titus Canyon in age, because to the north that formation overlies the upper plate. The similarity of this structure to those where the Funeral Formation has overlapped and has been faulted against turtleback surfaces suggests similar histories. If so, the main thrust is old enough to have had the upper plate stripped from the turtleback surface before the Titus Canyon(?) Formation was deposited and faulted against it.

At the north foot of Nevares Peak, beds mapped as Titus Canyon (?) Formation are dragged upward along a smooth fault surface dipping northward off the Cambrian rocks that form that mountain. This feature

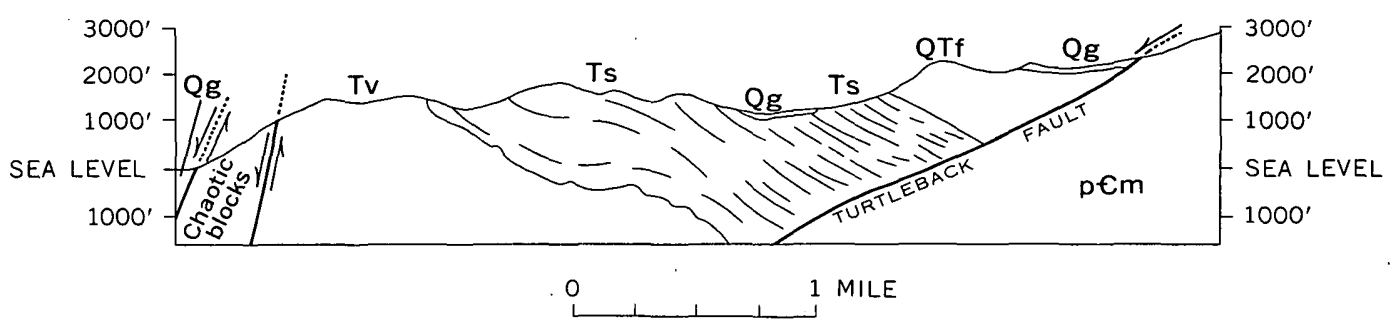

Figure 87.-Section of the Copper Canyon turtleback fault (generalized from Drewes, 1959). pem, Precambrian metamorphic rocks; TV, Tertiary volcanic rocks; Ts, interbedded Tertlary sedimentary rocks and basalt; QTf, Funeral Formation; Qg, upper Pleistocene gravel. 
shows well on the State geologic map of Death Valley (Jennings, 1958).

Mapping of the Miocene(?) formations between Cottonball Basin and the Funeral Mountains suggests that they aggregate more than 4,000 feet. thick. But considering that there must be some Titus Canyon(?) Formation beneath these beds, the thickness seems to be excessive. The gravity data suggest that bedrock is no more than about 4,000 feet deep in that area. The conflicting data can be reconciled by assuming either that the Titus Canyon(?) Formation is denser than was assumed in compiling the gravity data (p. A107) or by assuming an offlap relation in the Tertiary formations valleyward from the Funeral Mountains, as has been inferred for the Furnace Creek Formation northward from the Black Mountains. The latter interpretation seems reasonable because the outcrops of Titus Canyon (?) Formation north of the Kit Fox Hills probably never were buried under Miocene(?) fanglomerate as thick as that exposed in the Kit Fox Hills.

In the northern part of the Black Mountains, the formation at Artists Drive dips northeastward under the Furnace Creek Formation. About 6,000 feet of beds are exposed, mostly volcanics, but these grade northward to and intertongue with playa deposits. The formation must thin northward under the Furnace Creek Formation, for the same reason that the Furnace Creek Formation must thin northward under the Texas Spring syncline. Gravity data indicate a total of about 5,000 feet of Quaternary and Tertiary doposits down to the bedrock under the syncline. Figure 88 is a diagrammatic section illustrating the probable thinning northeastward of the Tertiary and Quaternary formations on the northeast flank of the Black Mountains.

Very likely the bedrock floor under the Tertiary formations is a series of fault blocks, but these cannot be satisfactorily reconstructed. While the formation at Artists Drive was being deposited, the axis of the trough was near A, B and C (fig. 88). At the site of the axis of the Texas Spring syncline, dips were towards the Black Mountains.

At the front of the Black Mountains the formation at Artists Drive is faulted down about 5,000 feet. The blocks faulted down on the Death Valley side are referred to as the Artists Drive fault blocks. The fault is the frontal fault of the Black Mountains, and it continues northward and cuts off the Furnace Creek Formation at the front of the north end of the Black Mountains. The Furnace Creek Formation is displaced at least 1,000 feet by the fault. If there was any displacement on this fault before the Furnace Creek Formation was deposited, the fault remained inactive while the formation was being deposited, because the facies
SW

Black Mountains

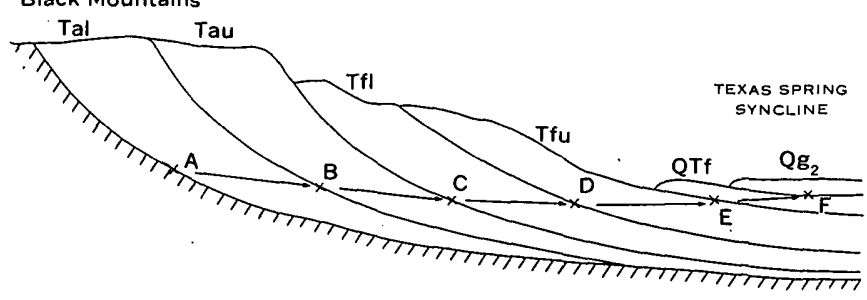

Figdre 88.-Diagrammatic section illustrating probable thinning and offlap of Tertiary and Quaternary formations from the Black Mountains northeastward to the Texas Spring syncline. Length of section about 6 miles. Axes of the troughs in which the formations were deposited shifted progressively northeastward from $A$ to F. Tal, Tau, lower and upper members of the Artist Drive Formation; Tfl, Tfu, lower and upper members of Furnace Creek Formation; QTf, Funeral Formation; Qg, No. 2 gravel.

changes in the formation are cut off by the fault and are not related to it. The probabilities are that the frontal fault along the Black Mountains is a Quaternary structure. Block faulting that outlined the present basins and range elsewhere in the region is regarded as largely of Quaternary age (Gilbert, 1941; Axelrod and Ting, 1960 ).

On the other hand, there was earlier faulting along the northwest-trending Furnace Creek fault zone and along other northwest-trending faults in the region. Near Leadfield, in the Grapevine Mountains north of this area, the Titus Canyon Formation overlaps an earlier northwest-trending high-angle fault (James Gilluly, oral commun. 1960). The block faulting therefore appears to have started as early as Oligocene time. The faulting has continued to the present, but since late Pliocene time the dominant trend of the faults has changed from northwesterly to northerly.

If the north-south faults are mostly Quaternary, the uplift of the Black Mountains that caused the northward offlap and thinning of the formation at Artists Drive and the Furnace Creek Formation is attributed to folding rather than faulting.

The formation at Artists Drive above the Artists Drive fault blocks also is broken by some flat faults that dip only $20^{\circ}-40^{\circ}$ towards Death Valley (fig. 79). Displacements are at least as great as 2,500 feet and in places may be very much greater. These structures were examined only in reconnaissance; they could be dismissed as megabreccia, except for the fact that in that area there are large chaotic blocks of Paleozoic rocks, hundreds of feet in diameter, and the ensemble suggests the possibility that major thrusting, like that of the Amargosa thrust farther south (Noble, 1941), has been overlooked in this part of the Black Mountains.

One of the blocks of Paleozoic rock is dolomite wedged into the Tertiary formations at the frontal fault. Another is granulated quartzite, a monolithologic breccia, under (or in?) the Funeral Formation at 
the northwest end of the Artists Drive fault blocks. The chaotic blocks probably are Cambrian-from the Zabriskie Quartzite and Bonanza King Formation. The blocks are suggestive of the Paleozoic blocks that are mixed with Tertiary ones and associated with the Amargosa thrust. There is no nearby source, and they must have been brought a long distance. The flat faults in the formation at.Artists Drive may be branches from a larger fault that has not yet been identified.

Volcanic rocks along the east foot of the Panamint Range in part at least are Miocene (p. A120), and are similar to and probably correlate with parts of the formation at Artists Drive. The eruptives are tilted $20^{\circ}$ towards the east and overlap more steeply dipping Paleozoic formations (fig. 89), showing that about half the eastward tilt of the Panamint Range has occurred since those eruptions.

\section{GRANITIC INTRUSIONS}

Two large granitic intrusions, probably Cretaceous or early Tertiary, are well exposed at the west edge of the Death Valley area and are shown on the geologic map (pl. 1). One of these, the granite at Skidoo, crops out in an area of about 12 square miles along the north and east sides of Harrisburg Flat and extends southeastward into the head of Trial Canyon. The other, the granite at Hanaupah Canyon, occupies an equal area at the head of Hanaupah and Starvation Canyons. Smaller outcrops of granitic intrusions in the Panamint Range are in Wildrose Canyon about midway between the granites at Skidoo and at Hanaupah Canyon, in Warm Spring Canyon about 15 miles south of Hanaupah Canyon, and along the east foot of the range.

Although labeled on the map as granitic intrusions, and loosely called granite or granitic rocks, most of the intrusions would more nearly be classed as quartz monzonite porphyry. However, the field study was interrupted before chemical analyses were made, and not enough thin sections were examined to be certain of the range in composition of the facies of the intrusions. Under the circumstances, a more precise nomenclature for the few rocks studies would be misleading, and we use the term "granitic intrusion" throughout.

The granites at Skidoo and at Hanaupah Canyon differ texturally and, to a minor degree, mineralogically. The granite at Hanaupah Canyon is porphyritic with distinct fluidal structures; the dark phenocrysts are biotite and hornblende. The granite at Skidoo is mostly gneissic, but a part of it is porphyritic and has fluidal structures; the dark phenocrysts are biotite. The kind and amounts of trace elements in the two intrusions and the trace elements that are in quantities too small to determine are similar, as brought out in table 25. The apparent greater concentration of lead and zinc in the granite at Hanaupah Canyon and the sill east of it, as compared to the granite at Skidoo, may be real, but additional analyses of the rocks are needed.

The three-dimensional form of intrusions probably is the most important criterion for determining the relationship between the intrusions and the structural geology of the region; this relationship, in turn, is basic for understanding the origin of the intrusions. Yet the form must remain a matter of considerable conjecture. We have attempted to apply some of the principles that have been learned about intrusive forms on the Colorado Plateau, where complexities are at a minimum and where exposures are far more complete. As G. K. Gilbert wrote (1876) in citing the Colorado Plateau as a field for geologic study, "with the facts of structure conspicuous and beyond question, the mind is left free to search for causes."

Before attempting to compare these intrusions with those on the Colorado Plateau, which is remote and structurally very different, some similarities may be noted between the intrusions of the Death Valley area and the individual plutons of the Sierra Nevada batho-
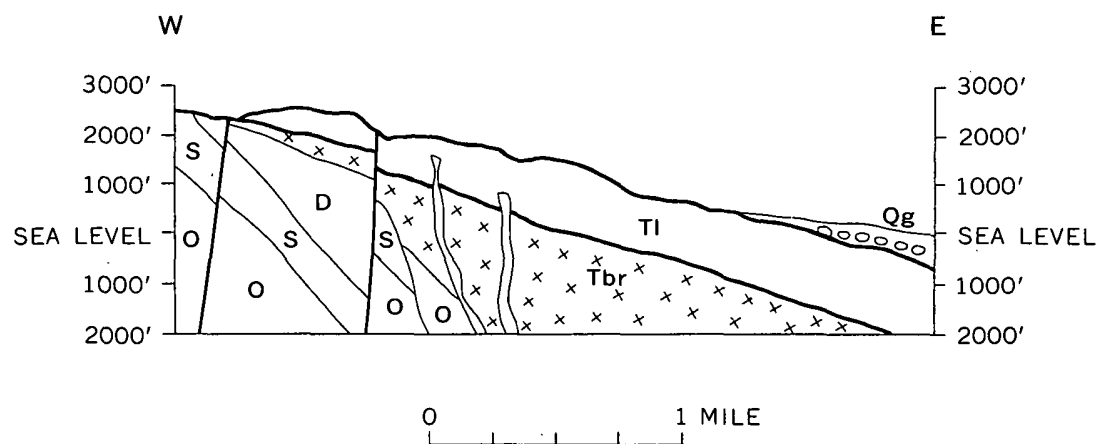

Fiaure 89.- Section along the ridge 3 miles north of Trail Canyon. Felsitic lavas dipping $20^{\circ}$ east overlap more steeply dipping Paleozoic formations. About half the eastward tilt of the Panamint Range has occurred since the lavas were erupted. 0 , Ordovician; S, Silurian; D, Devonian; Tbr, Tertiary volcanic breccias, in part intrusive ; $\mathrm{TI}$, felsitic lavas of Tertiary age; Qg, Quaternary gravel. 
TABLE 25.-Trace elements in the granites at Skidoo and at Hanaupah Canyon

$\mathrm{Cu}, \mathrm{Pb}$, and $\mathrm{Zn}$ determined by colorimetric methods by $\mathrm{H}$. I. Neiman; other determinatlons are semiquantitative spectrographic analyses by $\mathbf{E}$. F. Cooley, percont]

\begin{tabular}{|c|c|c|c|}
\hline \multirow{2}{*}{ Element } & \multirow{2}{*}{$\begin{array}{l}\text { At Skidoo, } \\
\text { gneissic facies }\end{array}$} & \multicolumn{2}{|c|}{ At Hanaupah Canyon } \\
\hline & & $\begin{array}{l}\text { Boulder from } \\
\text { central } \\
\text { intrusion }\end{array}$ & $\begin{array}{l}\text { Sill along fault } \\
\text { east of the } \\
\text { canyon }\end{array}$ \\
\hline 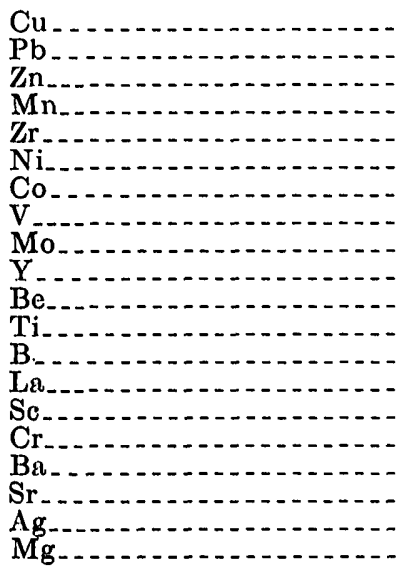 & $\begin{array}{r}4 \\
26 \\
50 \\
300 \\
100 \\
15 \\
5 \\
2 \\
<5 \\
15 \\
1.5 \\
2,000 \\
20 \\
50 \\
<10 \\
30 \\
500 \\
300 \\
<1 \\
0.7\end{array}$ & $\begin{array}{r}4 \\
80 \\
90 \\
1,000 \\
300 \\
15 \\
<5 \\
20 \\
7 \\
30 \\
1.5 \\
2,000 \\
10 \\
100 \\
<10 \\
30 \\
500 \\
200 \\
<1 \\
0.7\end{array}$ & $\begin{array}{r}6 \\
280 \\
80 \\
700 \\
500 \\
10 \\
7 \\
70 \\
5 \\
30 \\
<1 \\
5,000 \\
30 \\
150 \\
10 \\
20 \\
1,500 \\
1,000 \\
<1 \\
1\end{array}$ \\
\hline
\end{tabular}

Note. - All samples contained: As $>1,000 ; \mathrm{Sn}>10 ; \mathrm{Ge}>20 ; \mathrm{Ga}>20$; $\mathrm{Cd}>50$; Bi $>10 ;$ In $>10 ; \mathrm{Sb}>200 ; \mathrm{TI}>100 ; \mathrm{Nb}>50 ; \mathrm{Ta}>50 ; \mathrm{W} 100$.

lith. In the batholith the earliest intrusions were concordant and followed stratigraphic or tectonic boundaries (Cloos, 1932). Where the intrusions are crowded together, this concordance is masked because the later intrusions became guided by the walls or other structures of the earlier ones. There is abundant evidence that the intrusions emplaced themselves more by physical injection than by replacement, assimilation, or stoping (Knopf, 1929 ; Calkins in Matthes, 1930; Cloos, 1932, 1933, 1935, 1936; Bateman, 1958). The batholith plunges northward, and the intrusions at the north end are separated from one another like those to the east in the Death Valley area. The structural settings of the Sierra and Death Valley areas are quite different. Seismic and gravity data indicate that dense rock is shallow under the intrusions just west of Death Valley, but the main part of the batholith, including its north end, is underlain by a considerable thickness of light rock. But even where the intrusions of the batholith are crowded, there has been structural doming.

The earliest intrusions of the Sierra Nevada batholith are along its west edge and are thought to be Late Jurassic or Early Cretaceous (Knopf, 1929, p. 9). Eastward across the batholith the individual plutons are younger and generally less mafic (Calkins in Matthes, 1930; Cloos, 1936, p. 431-434; compare with Bateman, 1961, fig. 5). The intrusions in the Death Valley area may $776-623$ O-66-9 extend this pattern to the east. These age relationships have long been recognized, and the problems they pose have been well stated by Ferguson (1929, p. 118):

It may be that the locus of intrusion moved gradually eastward from the Sierra Nevada to the Rocky Mountain region and that the areas of granitic rocks, intermediate in position between the Sierra Nevada batholiths and the Tertiary batholiths to the east are also intermediate in time (Lindgren, 1915, p. 260), or there may have been two distinct and sharply separated episodes of granitic intrusion.

Whether the Death Valley intrusions should be regarded as part of the composite Sierra Nevada batholith depends on one's definition of the batholith and on assumptions about the form of the buried parts of the intrusions. But regardless of whether the definition, which perforce must be arbitrary, includes or excludes them, clearly these intrusions are genetically related to each other and to the batholith. In the Death Valley area the granitic intrusions may have reached almost to the surface and may have developed into volcanic rocks at the surface. These volcanic rocks äre interbedded with playa and related deposits ranging from Oligocene to Pliocene.

The interpretation presented in this report is that the granitic intrusions in the Death Valley area are related to, but younger than, the batholith to the west and that they are related to, but older than, the volcanism. The granitic intrusions in the Panamint Range are probably Miocene (p. A50) and are interpreted as having immediately preceded the volcanism which continued long thereafter. The intrusions seem to have spread laterally along the Amargosa thrust fault and its branches and to have domed the overlying rocks (figs. 90, 91, 94, 108) because-

1. The intrusions have concordant roofs. There is discordance to be sure, but the degree of discordance is no greater than the discordance of laccoliths at their type area, the Henry Mountains, Utah, where structural relationships are much simpler than in the Death Valley area.

2. The intrusions spread in incompetent formations where they are overlain by competent ones, a favored mechanism of intrusions that are demonstrably floored.

3. Because there is little evidence of reaction along the contacts and little other evidence of assimilation or replacement, the intrusions must have emplaced themselves by physical injection. Despite the large size of the intrusions, hydrothermal effects are little, if any, greater than around intrusions in the Colorado Plateau.

4. The volumes of the structural domes over the intrusons are too small to accommodate physically in- 


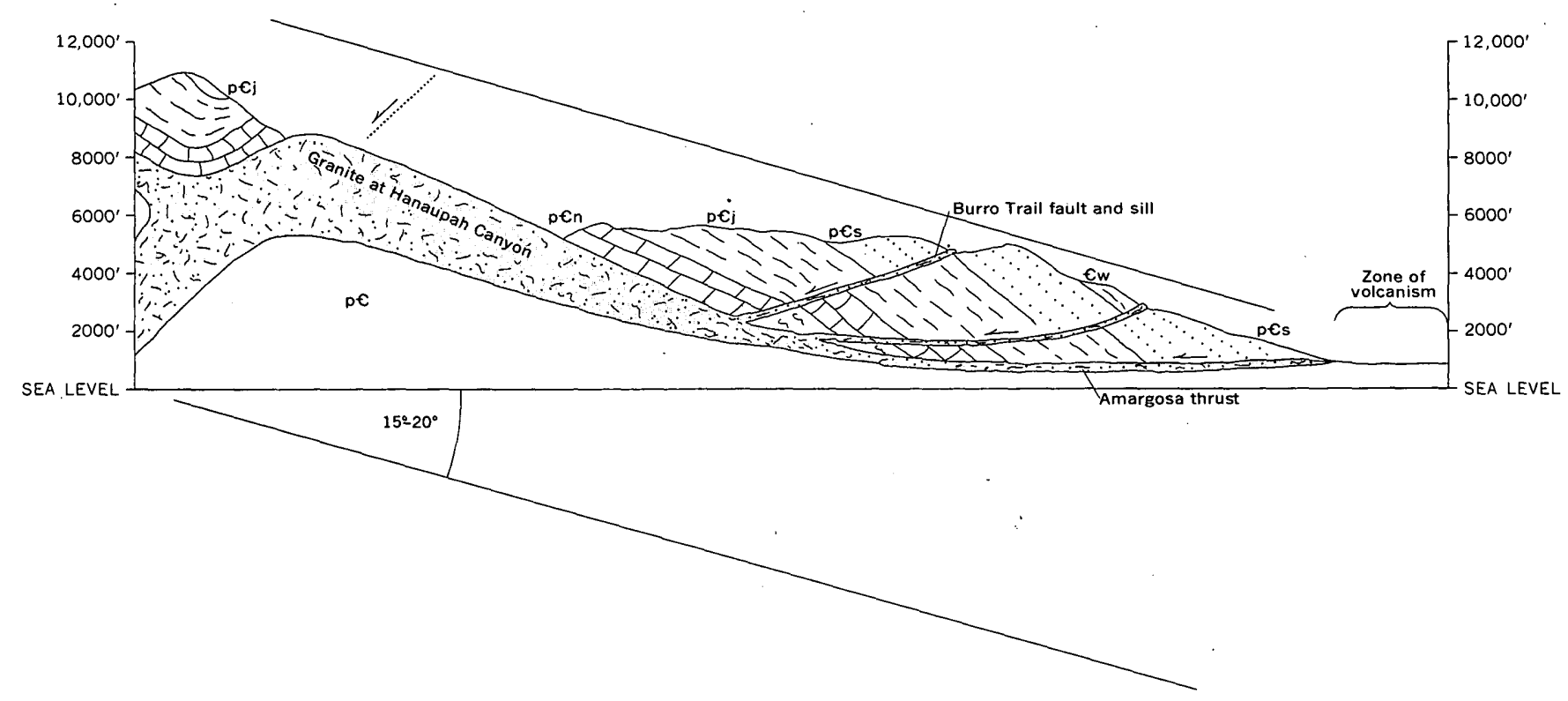

Figure 90.-Cross section of the granite at Hanaupah Canyon. Length of section $81 / 2$. miles; vertical scale not exaggerated. pC, Precambrian metamorphic rocks; p€n, Noonday(?) Dolomite; p€j, Johnnie Formation; p€s, Stirling Quartzite; Cw, Wood Canyon Formation. Since the faulting and intrusion of the granite, the Panamint Range has been tilted $15^{\circ}-20^{\circ}$ east.

jected crosscutting intrusions as wide as these (see Hunt and others, 1953, p. 139).

5. Sills that extend from the granite at Hanaupah Canyon along thrust faults, like the Burro Trail fault and others north of the intrusion (pl. 3), show that the granite is later than the thrust faulting and that part of the granite demonstrably spread laterally along the faults.

Except for their large size, the intrusions are much like those on the Colorado Plateau. They are not like the individual intrusions in the Sierra Nevada batholith where, although the plutons seemingly were forcibly injected, there is abundant evidence of steep contacts (Bateman, 1958; Sherlock and Hamilton, 1958). Nor is there evidence of much assimilation or stoping like that described at some intrusions in the Mojave Desert (McCulloh, 1954, p. 21).

Intrusions in the Great Basin probably are floored to a far greater degree than has generally been assumed. Few workers have considered this problem. Noble (1941, p. 963) inferred that the granite under the Amargosa thrust fault in the Virgin-Spring area was controlled by the fault because the roof of the granite parallels the fault (fig. 108). Hewett (1956, p. 63) interpreted the Teutonia Quartz Monzonite in the Ivanpah quadrangle, 75 miles southeast of Death Valley, as having been intruded along one of the eastward directed thrust faults. He states (p. 63), "There is nothing about the relations of the monzonite to the limiting rocks in any part of the region to indicate that any large part of it is a crosscutting stocklike mass."

Granitic intrusions in the Mina quadrangle in western Nevada have been interpreted as having spread laterally at the thrust faults (Ferguson and others, 1954), and one at the south end of the Panamint Range, in Warm Spring Canyon, is intrusive along a fault (Wasserburg and others, 1959). Granitic intrusions in the southern part of the Panamint Range have emplaced themselves along faults (Johnson, 1957, fig. 2), and some in the Silurian Hills were first localized by the thrusting and later displaced by it (Kupfer, 1960). Intrusions in the Darwin area also have the flat form (W. E. Hall, written commun., 1964).

Mackin $(1947,1954)$ has shown that doming in the Iron Springs district in southwestern Utah is quite like that on the Colorado Plateau. He has been the principal advocate (1960) of the idea that igneous intrusions have been underestimated as a cause of many of the structural features in the Great Basin.

But such interpretations are exceptional for the Great Basin. In most reports the form of the intrusions either is ignored by drawing cross sections away from them, or the cross sections are drawn to indicate that the intrusions widen downward. A case can be made for this interpretation by assuming that the Great Basin is underlain by a granitic batholith and that the stocks are minor apophyses rising upward from it. In favor of such interpretation is seismic refraction evidence 
suggesting that the crust under the Great Basin consists of 2 layers, the upper one having a velocity of 6.3 kmps or less, and the lower one having a velocity of 7.6-7.8 kmps (Press, 1960; Berg and others, 1960; Diment and others, 1961). Such interpretation, however, is not presented, and one gains the impression that the stocks were drawn in cross sections to widen downward chiefly to conceal and dispose of complex structures at depth. A bad effect of this practice, however, is that there has been too little thought given to the three-dimensional forms of the intrusions, the mechanics of how they became emplaced, and their part in the structural history of this complex region.

The granites at Skidoo and at Hanaupah Canyon have domed roofs of Precambrian sedimentary formations that are roughly concordant with the upper surfaces of the granites. The degree of discordance is little greater than over laccoliths in. the Henry Mountains where, despite the simplicity of the structure of the host rocks, even the most orderly laccoliths cut across several hundred feet of beds in a mile. Extensive concordant roofs, like those on the granites at Skidoo and at Hanaupah Canyon, imply equally concordant floors.

Moreover, the area domed by the granites at Skidoo and at Hanaupah Canyon is too small and has too little structural relief to be attributable to doming by steepwalled crosscutting intrusions having cross sections as wide as the exposed granites. On the Colorado Plateau, stocks 1 mile in diameter produce domes having a base 6 miles in diameter and a structural height of almost $11 / 2$ miles (Hunt and others, 1953, p. 139). The intrusions in the Panamint Range are much wider than those in the Colorado Plateau, but the doming is not correspondingly greater. This fact also suggests that the granitic masses have spread laterally and that the steep-walled stocklike source for them is much smaller than the area of granite at and near the surface.

Finally, the roof and side contacts of the intrusions are sharp and contact metamorphism is slight, both of which indicate that there was no great amount of reaction that would cause replacement or assimilation of the country rock by the granite. Indeed, the contact metamorphism is more like that around the floored intrusions than around the stocks on the Colorado Plateau.

The occurrence of a pyritic and an epidotic zone of alteration over the west side of the granite at Hanaupah Canyon is the basis for inferring that the source of that intrusion is under its west side (fig. 90). Pyritic alteration and considerable discordance along the west side of the granite at Skidoo suggest that its source is under its west side. The eastern edge of the granite at Skidoo is inferred to be along the north-trending monocline that forms the head of Tucki and Blackwater Washes.
The intrusions therefore are interpreted to be wedge shaped, the form to which the names sphenolith (Burckhardt, 1906) and harpolith (Cloos, 1921) have been applied.

GRANITE AT SKIDOO

The granite at Skidoo (an abandoned mining camp) crops out in an area about 12 miles long and 1-5 miles wide, elongated north-northwestward parallel to the general strike of the enclosing formations. The age is presumably Cretaceous or Tertiary. The southwest contact is steep and crosscutting; but the roof is concordant, east dipping, and mostly in the Kingston Peak (?) Formation although cutting upward discordantly to the Noonday(?) Dolomite. The structural form (fig. 91) is broadly wedge shaped thinning eastward.

The contact along which the intrusion has spread almost certainly is a thrust fault of the Amargosa fault system. The contact between the Kingston Peak(?) Formation and Noonday (?) Dolomite is a fault; so also is the contact between the Noonday (?) Dolomite and Johnnie Formation. The spreading of the granite has obscured evidence for faulting at the plane of intrusion, and not enough is known about the local stratigraphy of the Kingston Peak (?) Formation and Noonday (?) Dolomite to estimate the thickness of beds cut out by faulting at any particular place-although locally more than a thousand feet of beds have been cut out. The amount of lateral displacement along the fault is uncertain.

The granite at Skidoo has spread in the Kingston Peak (?) Formation, which is an incompetent unit, and under the Noonday (?) Dolomite, which is a competent unit. This relationship duplicates that on the Colorado Plateau where the favored horizons for spreading of floored intrusions are in the upper part of incompetent formations that are overlain by competent ones (Hunt and others, 1953, p. 142).

The roof of the granite at Skidoo is well exposed almost continuously from the head of Trail Canyon to a little beyond the abandoned mining camp at Skidoo. In Trail Canyon the roof is Noonday(?) Dolomite. This roof rises steeply westward to the summit where it flattens. Along the summit from Trail Canyon northward along the east side of Harrisburg Flat, the roof of the granite and the overlying dolomite and limestone dip gently $5^{\circ}-10^{\circ} \mathrm{E}$. The steep dip noted in Trail Canyon, however, extends northward as a monocline $11 / 2$ miles east of the summit, and this fold probably marks the eastern limit of the granite. This interpretation is based partly on the structure (fig. 91) and partly on the occurrence of small intrusions of alaskite along the monocline. The granite, therefore, 
EXPLANATION

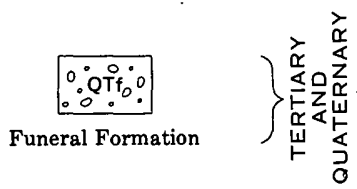

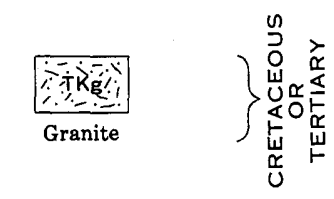

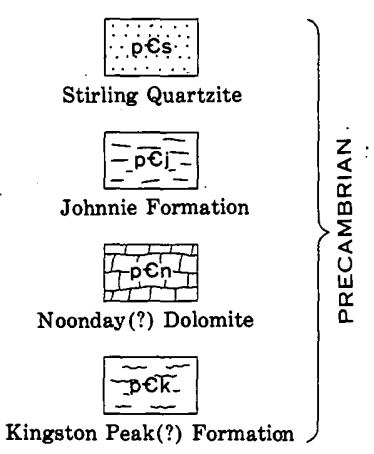

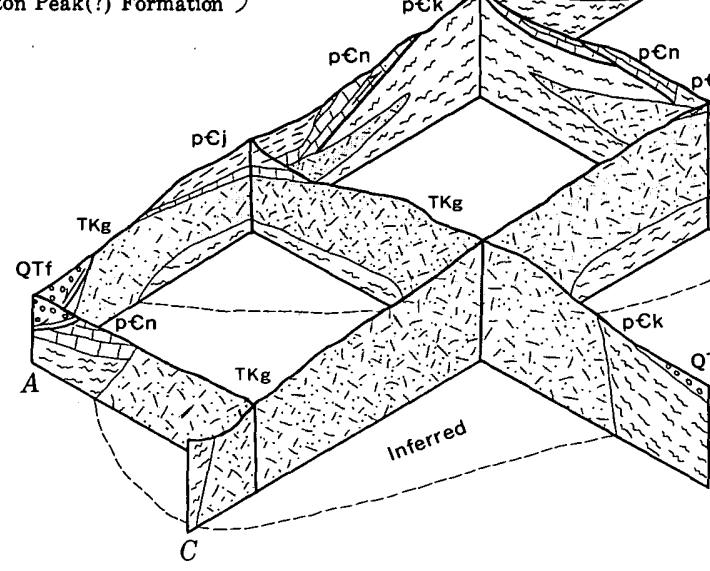

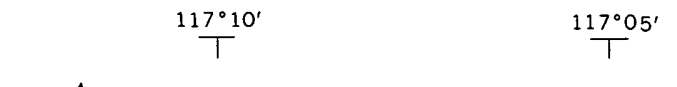

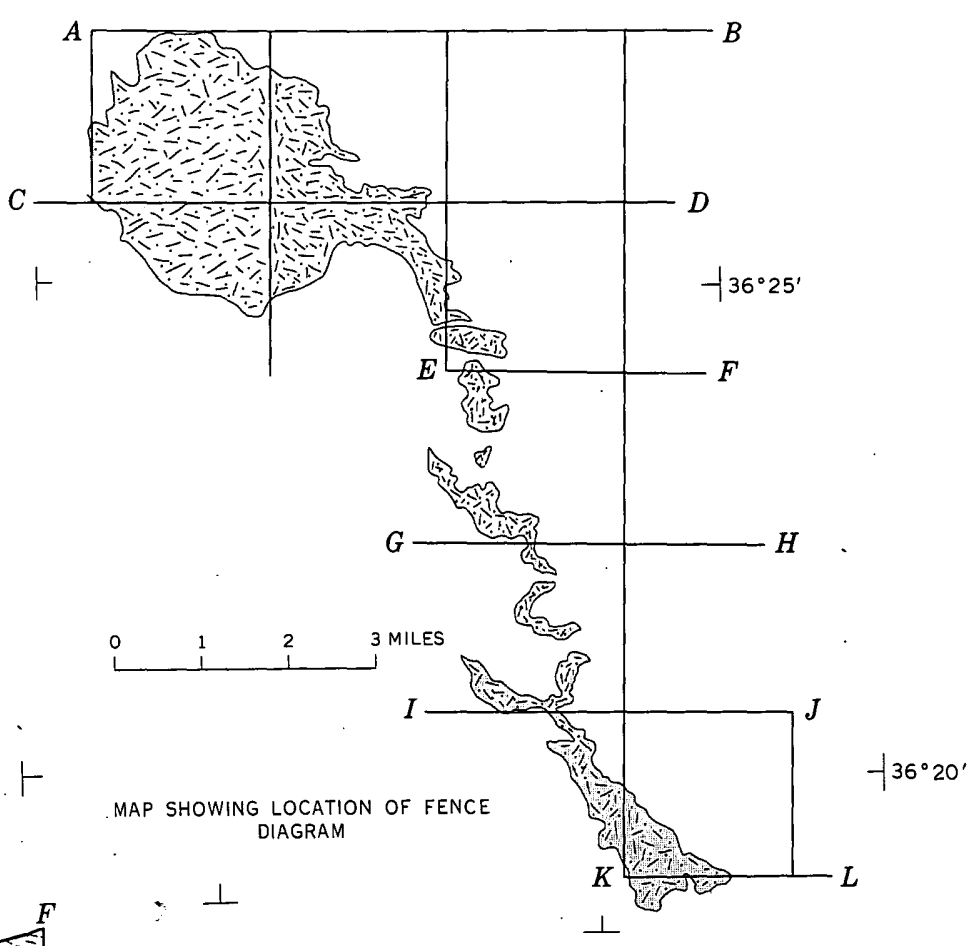

资 
is inferred to have a maximum thickness about equal to the structural relief along the monocline, that is, about 3,500 feet.

At the head of Trail Canyon the Noonday(?) Dolomite above the granite is about 800 feet thick. Within a mile and a half to the north, however, the dolomite has thinned to about 200 feet, probably by faulting, and about 200 feet of shaly beds of the Kingston Peak(?) Formation lies between the dolomite and the top of the granite. Farther north the dolomite again thickens to about 1,000 feet; it overlies the granite at 2 places, but 2 miles southeast of Skidoo, 500 feet of shale, quartzite, and stretched-pebble conglomerate belonging to the Kingston Peak (?) Formation lies under the dolomite and above the granite.

The steep west wall of the granite cuts across faulted and folded beds, mostly belonging to the Kingston Peak (?) Formation. At 2 places about 3 miles southeast of Skidoo the west wall is dolomite, but whether this dolomite is part of the Noonday (?) Dolomite or a part of the Kingston Peak(?) Formation was not determined.

In the vicinity of Skidoo the granite is in the Kingston Peak(?) Formation, and the roof plunges northwestward.

Westward from the north end of Harrisburg Flat and northward along the west edge of the intrusion, Pliocene and lower Pleistocene (?) Funeral Formation has been faulted against the granite. This roof of the granite is sheeted roughly parallel to the faulted contact along Emigrant Canyon; the sheeting and the roof contact strike north and dip about $25^{\circ} \mathrm{W}$. Steeply dipping fissures in the granite also strike north. Dikes of basalt intrude both the sheeted joints and the steeply dipping fissures. Along the canyon there are at least 5 dikes in the upper 250 feet of the granite; their thicknesses range from 6 inches to 10 feet. These dikes are not related to the granite. Probably they are early Pleistocene in age and related to the basaltic lavas and minor intrusions that occur nearby in the Funeral Formation.

The southern third of the granite at Skidoo is porphyritic and clearly an intrusive igneous rock; but the northern two-thirds of the intrusion is banded gneiss, and many outcrops there look like metamorphic Precambrian rocks. Along the monocline east of the outcrop of the granite are small intrusions of alaskite (fig. 92).

The contacts along both the roof and west wall of the granite at Skidoo are sharp. In the porphyritic facies dike-like and sill-like apophyses of granite extend upward into the fractured roof rocks. The contact zone commonly is a few inches wide (fig. 93), about twice as wide but otherwise similar to roof contacts over lac-

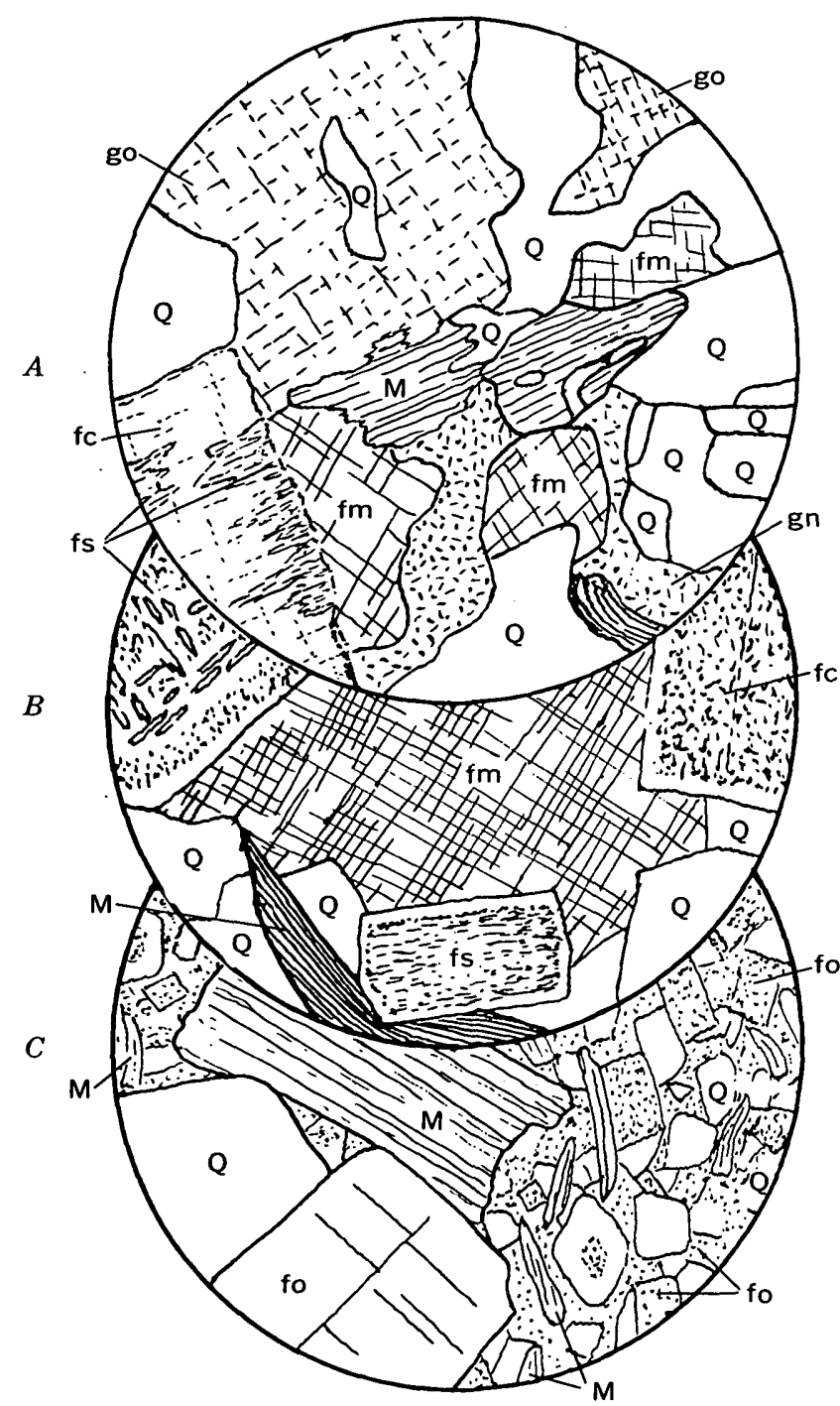

Fradre 92-Micrographs of thin sections of the granite at Skidoo. a, quartz; fo, orthoclase; im microcline; is, sericitized feldspar ; fc, argillized feldspar; go, groundmass oriented; gn, groundmass not oriented. Diameter of field, $2.5 \mathrm{~mm}$. $A$, Gneissic facies. Quartz with strain shadows ( 30 percent); euhedral feldspars (20 percent) altered to sericite and to clay; anhedral microcline (20 percent); muscovite (10 percent) with ragged sides and ends and embayed with quartz; and a feldspathic groundmass (20 percent) with sericite, some of it oriented and some not. $B$, Porphyritic facies. Euhedral plagioclase and orthoclase (30 percent) altered to sericite and to clay. These have clear rims of low index feldspar and are set in microcline (about 30 percent) which occurs in ir regular growths. Other common minerals are quartz (about 30 percent) and biotite (about 10 percent). There is also a trace of augite (not shown). C, Alaskite facies. Consists of quartz ( 30 percent) ; clouded feldspar, probably mostly orthoclase (60 percent); sericite (10 percent) and occasional phenocryst of muscovite (M). Both the quartz and feldspar occur as euhedral crystals in a paste of anhedral quartz and feldspar. A few aggregates of phenocrysts of the same minerals are rounded and may have been floated in from porphyry facies from which this ts believed to have been derived.

coliths in the Henry Mountains on the Colorado Plateau. Four or five inches from the contact is normal porphyry with phenocrysts as much as 1 inch in diameter. Nearer the contact is a zone in which the crystals 


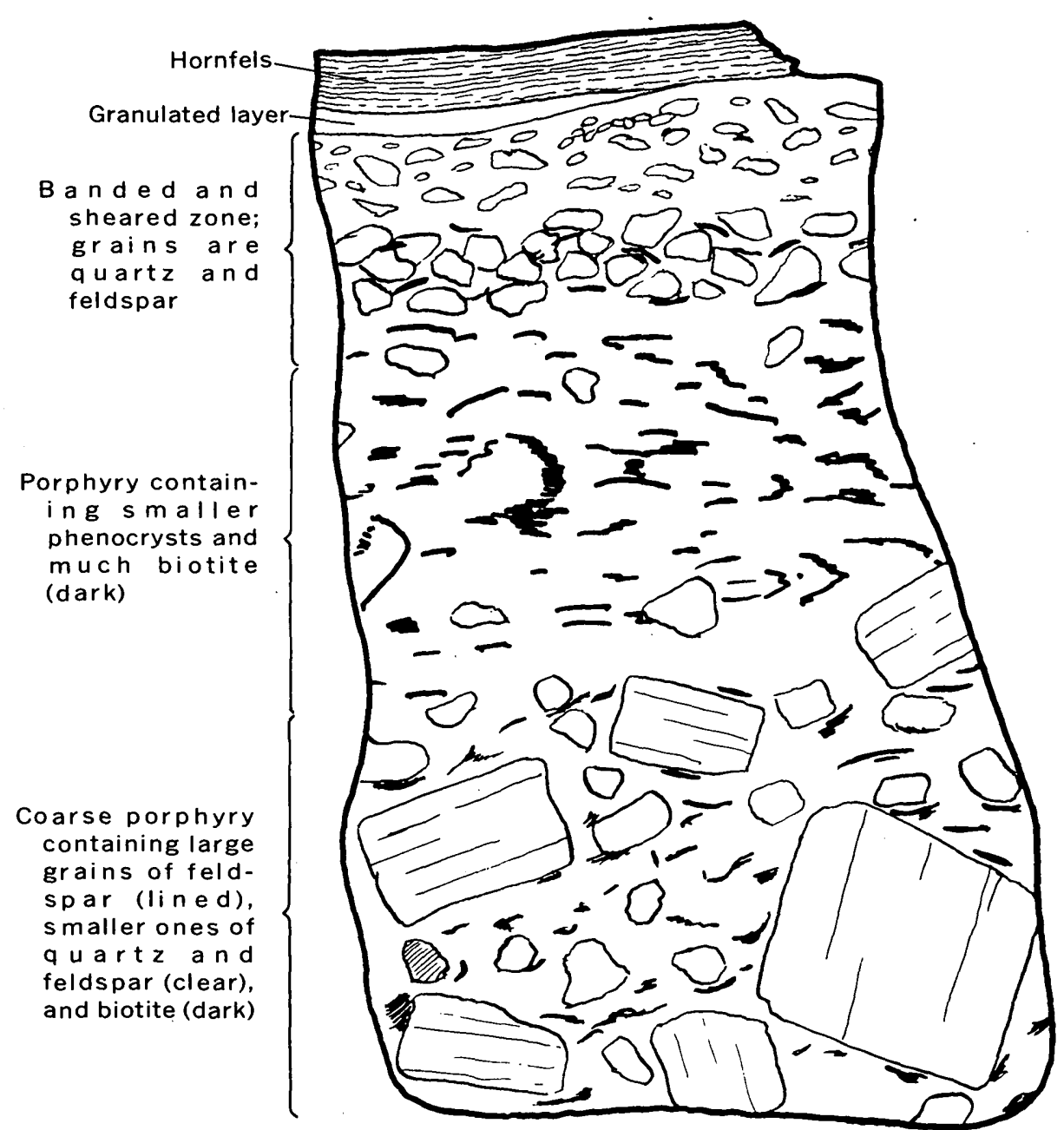

Figure 93.- Hand specimen of roof contact of the porphyry facies of the granite at Skidoo.

are small and not very distinct in hand specimens. A selvage 1 or 2 inches wide at the contact is sheared and banded. At the contact is a granulated layer 2 or $3 \mathrm{~mm}$ wide.

Contact-metamorphic effects are surprisingly slight. Shale and schist are baked to hornfels, and carbonate rocks are bleached-effects that are only a little more intensive and extensive than the alteration zones above the much smaller floored intrusions on the Colorado Plateau.

The gneissic facies may be an ancient granite. There is much brecciation, and cataclastic structures are strongly developed along the roof contact. Quartz veins in the gneissic facies are numerous, and some, like those at Skidoo, have produced gold.

\section{GRANITE AT HANAUPAH CANYON}

A granitic intrusion at the head of Hanaupah Canyon crops out in an oval area about 6 miles long and 3 miles wide extending from Hanaupah Canyon to Starvation Canyon. The roof is highly domed, much more sharply domed than that of the granite at Skidoo. Across the north end of the intrusion and along the northwest side of the roof is Noonday (?) Dolomite. Along the southeast side, which, however, was examined only from the air (p. A8), the granite may cut discordantly upward to the Johnnie Formation.

The structural relief across the top of this intrusion is at least 6,000 feet, but half of this can be attributed to the homoclinal eastward dip of the country rocks. The doming, superimposed on the homoclinal eastward dip, amounts to about 3,000 feet and could be produced by a partly floored intrusion about that thick (fig. 94).

The only part of the granite at Hanaupah Canyon that was examined on the ground is the northern and northwestern contact from 4,000 feet altitude in Hanaupah Canyon to the summit at 10,000 feet. Along this contact the Noonday (?) Dolomite is bleached and has been dragged steeply upward; but the drag is not so steep as the side wall of the granite, which in places cuts upward to the Johnnie Formation. 


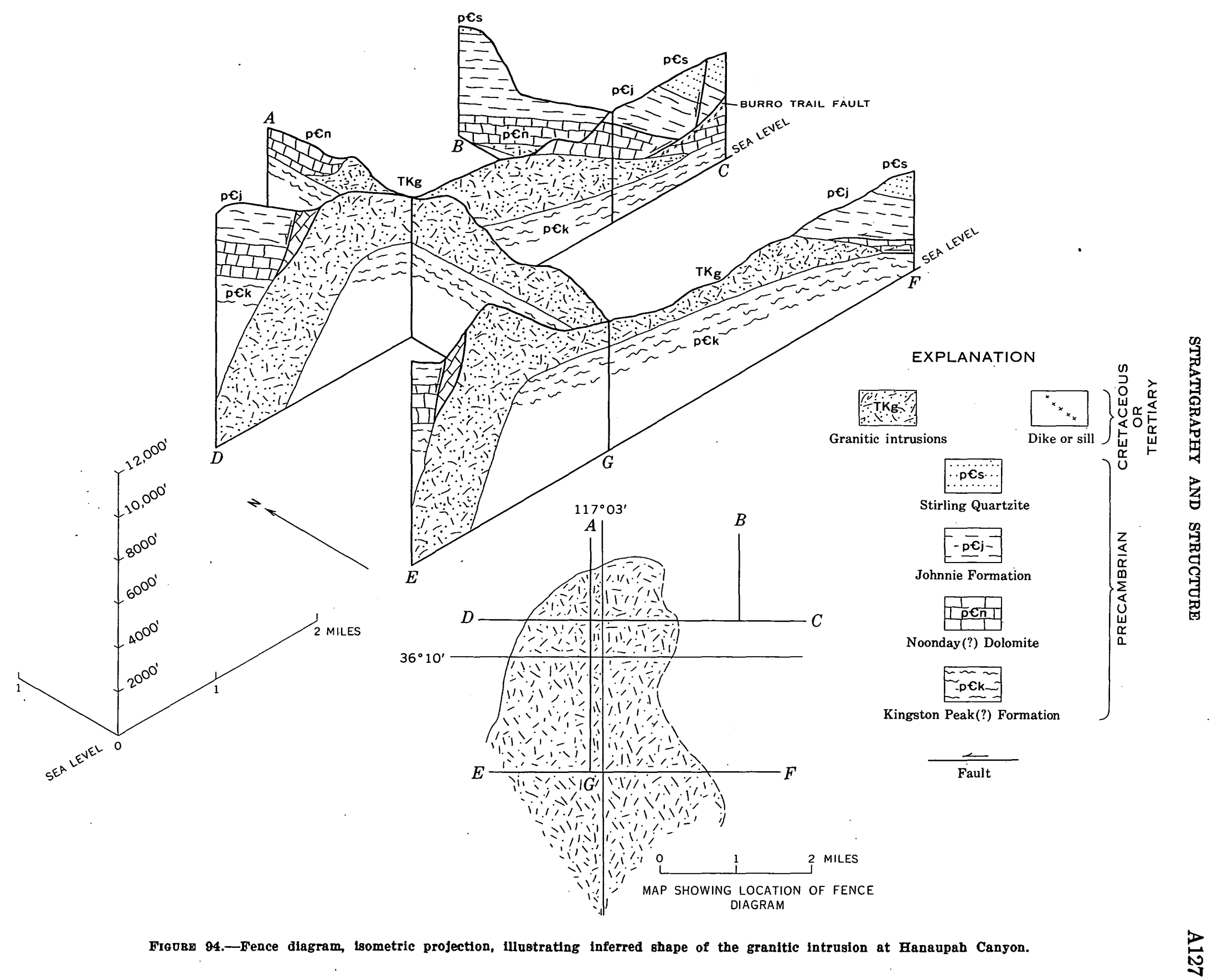




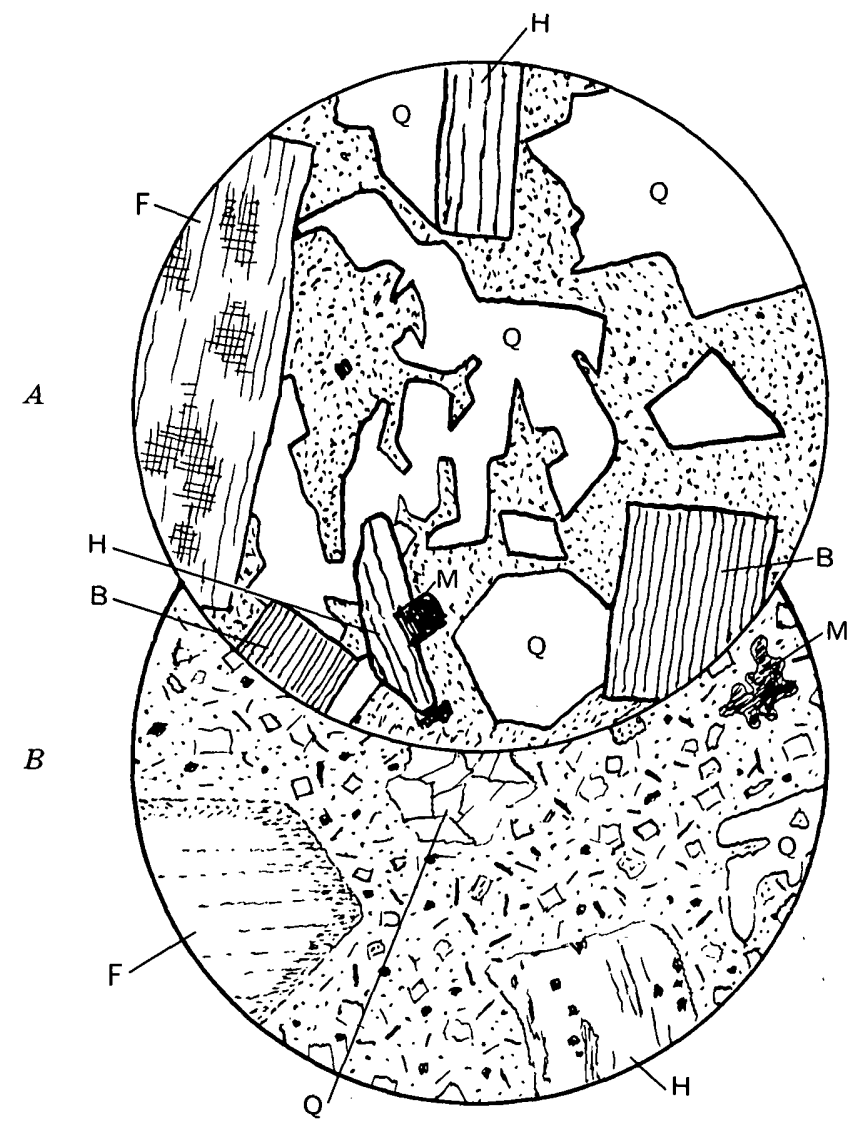

Figore 95.-Micrographs of thin sections of the granitic intrusion at Hanaupah Canyon and associated sill. $Q$, quartz; $F$, feldspar; $H$ hornblende; $B$, biotite; $M$, magnetite. Diameter of field, $2.5 \mathrm{~mm}$ $A$, Quartz monzonite from the intrusion. Phenocrysts of feldspar are mostly ollgoclase mottled with potash feldspar. Most of the rock is a graphic intergrowth of quartz and clouded feldspar stippled areas). Dark minerals are biotite, hornblende and mag netite. $B$, Monzonite porphyry from a sill along the Burro Trail fault. Phenocrysts of olfgoclase have strongly argillized borders. Hornblende is altered to calcite, magnetite, and epidote (?). Quartz occurs as deeply embayed phenocrysts and as secondary nests. Magnetite occurs in small phenocrysts, some of which are embayed like the quartz. The groundmass, strongly argillized, consists of lathlike and rectangular feldspars and ting specks of magnetite.

The granite is a homogeneous porphyry as far as could be judged by examining many boulders from it along Hanaupah and Starvation Canyons and by examining the north edge of the intrusion. The rock contains large phenocrysts of $\mathrm{K}$-feldspar with rims of oligoclase associated with quartz, biotite, hornblende, and some magnetite (fig. 95).

Trace elements in the granite at Hanaupah Canyon (table 25), as already noted, are similar to those in the granite at Skidoo.

The contact at the edge of the granite is sharp like the roof and sides of the porphyry facies of the granite at Skidoo. Porphyry containing large phenocrysts occurs within a few inches of the contact, but at the contact the porphyry is fine grained and granulated (fig. 93).
Contact-metamorphic effects consist of bleaching of the Noonday (?) Dolomite and developemnt of nests of tremolite and calcite. Minor quantities of sulfides have been deposited along faults and fissures extending north from the intrusion. In addition, under the summit ridge for 2 miles north from Telescope Peak, the lower part of the Johnnie Formation and upper part of the Noonday (?) Dolomite are stained brown, presumably because of oxidation of disseminated iron sulfide. Northward from this belt along the summit ridge for another 2 miles the joints and fissures in the Johnnie Formation are coated with epidote.

On the Colorado Plateau, alteration zones like these are found only around the stocks, not around the laccoliths. The position of these alteration zones, therefore, suggests that the source for the granite at Hanaupah Canyon is under the west side of the intrusion, and this is a basis for the interpretation given on figure 94 .

The alteration zones extend 4 miles north-northwestward from the granite to within 2 miles of a granitic body in Wildrose Canyon. The granite in Wildrose Canyon, which is gneissic and contains biotite, more closely resembles the granite at Skidoo than the granite at Hanaupah Canyon.

Dikes and sills extend 2 miles northward from the granite of Hanaupah Canyon, and others occur along the Burro Trail and other faults east of the granite (figs. 94, 96). The dikes and sills are 5-10 feet thick and provide a measure of the fluidity of the magma that was intruding. By contrast, at the laccolithic mountains on the Colorado Plateau, only the latest intrusions were sufficiently fluid to form thin dikes and sills; the earlier ones were highly viscous.

The rocks comprising the dikes and sills tend to be finer grained than the porphyry in the main intrusion, but many closely resemble it (fig. 95). Moreover, their content of trace elements is similar (table 25). Almost certainly the sills along the thrust faults east of the granite are connected with it like those that extend to the north.

The sills along the thrust faults locally have chilled contacts against the faulted surfaces and clearly are later than the faulting. However, there was renewed movement on some thrust faults later in Tertiary time; possibly later movement on the Burro Trail and neighboring faults followed shaly layers above or below the sills without severely fracturing those intrusions.

These sills along the faults are much altered, but it was not determined to what extent the alteration was caused by deuteric action, hydrothermal activity, or to weathering due to ground water percolating along the faults. Throughout the Panamint Range, the thrust faults have served as aquifers. 
CHAOTIC COMPLEX ALONG THE AMARGOSA THRUST

The chaotic complex along the Amargosa thrust, along the east foot of the Panamint Range (p. A51), is structurally arched. Its high part is between Hanaupah and Death Valley Canyons where the thrust fault and underlying Precambrian metamorphic rocks are exposed (fig. 96). The Precambrian rocks are intruded by a granitic mass and a still younger swarm of felsite dikes (fig. 97). At Hanaupah Canyon the upper plate of the thrust is Precambrian Stirling Quartzite. Farther north the upper plate consists of progressively younger Cambrian formations.

At Death Valley Canyon these arched rocks of the complex plunge northward under a mass of volcanic rocks having interlayered slabs of Paleozoic dolomite (fig. 98), a mixture highly suggestive of the chaos which was described by Noble (1941) in the Virgin Spring district 20 miles southeast of here. The swarm of felsitic dikes that intrude the granitic mass and the metamorphic rocks south of Death Valley Canyon also intrude the chaos north of the canyon. The chaos also is cut by felsite plugs.

The thrust and the underlying metamorphic rocks and granitic intrusion are not exposed farther north or south, but in both directions the complex is represented by lavas, dikes, and areas of hydrothermal alteration. Very possibly the granitic mass that underlies the highest part of the structural arch may thin northward and southward and be a main cause of the arching. The thrust fault is well exposed where it crosses the divide a mile north of the mouth of Hanaupah Canyon. There the upper plate is Stirling Quartzite dipping about $45^{\circ}$ $\mathrm{E}$; the fault dips $15^{\circ} \mathrm{W}$. (fig. 96 ). The lower part of the quartzite is thoroughly granulated, in part mylonitized, in a zone about 50 feet thick. Below this, the mylonitized quartzite is mixed with crushed Precambrian metamorphic rocks from the lower plate.

The metamorphic rocks include augen gneiss, feldspar-biotite gneiss, biotite schist, and quartz gneiss. The most conspicuous and most abundant rock is the augen gneiss (figs. 99, 100), which consists of augen of feldspar as much as 1 inch long in a matrix of feldspar and quartz cut by stringers of biotite. The augen make up perhaps 15 percent of the rock. Just below the thrust the augen gneiss is finely layered, and augen are few. The rock there grades into feldspar-quartz-biotite gneiss.

The augen gneiss is about 50 percent quartz. The augen, which constitute about 20 percent of the rock, are altered (silicified or argillized?) feldspar, probably microcline or albite. Some augen contain irregular grains of quartz, plagioclase, and biotite. The rest of the rock is about half plagioclase and half biotite, the latter occurring mostly as bands or layers in the gneissic structure. Zircons from several specimens of augen gneiss are rounded and colorless (Ralph L. Erickson, written common., 1961) (fig. 103). Their lead-uranium and lead-thorium ages are greater than a billion years (T. W. Stern, written commun., 1965).

Some facies of the biotite gneiss contain considerable potassium feldspar, as much as 25 percent. Other constituents are quartz, 40 percent; plagioclase, 20 percent; and biotite, 15 percent. Other facies are without potassium feldspar and contain 60 percent quartz, 20 percent plagioclase, and 15 percent biotite. In some specimens of these rocks Erickson (written Commun., 1961) found two kinds of zircon (fig. 103), mostly colorless and rounded like those in the augen gneiss, but some euhedral and pale pink with rodlike inclusions. More work is needed to determine how these types are distributed in the different facies of the biotite gneiss. Trace elements in the augen gneiss and biotite gneiss are given in table 26 (p. A140).

The gneiss is strikingly foliated and the dips are to the west. There are belts 50-250 feet wide in each of which the dip of the foliation increases westward from about $20^{\circ}-70^{\circ}$ (fig. 101). The parts of the belits having the most steeply dipping folia generally are occupied by dikes.

The dikes cutting the augen gneiss range in width from stringers less than 1 inch to dikes about 6 feet wide. Contacts are sharp and most of them show distinct chilled edges, although some contacts are obscured by subsequent shearing.

The age of the metamorphism and the age of the metamorphosed rock are not clear. The rock is Precambrian (see above), but some of the metamorphism may be very much later, because biotites from these same rocks give a late Miocene potassium-argon age (T. W. Stern, written commu., 1965). This could account for the close spatial association of the augen gneiss with so much volcanic activity and with the Amargosa thrust fault, not only here but also in the Virgin Spring area (Noble, 1941). A close relationship between the fissuring that localized the dikes and the structure of the metamorphism is indicated by the steepened dips in the folia adjacent to dikes. Also, numerous thin stringers of aplite in the augen gneiss are more like the dike rocks than the metamorphic rocks. The aplitic rocks are mostly potassium feldspar (as much as 60 percent) and quartz with only a little plagioclase and biotite.

Part of the metamorphism seems to be later than the thrust faulting. Locally, there has been reaction between the gneiss and the granitic rock, suggesting local assimilation. Augen locally are collected in pegmatitic 


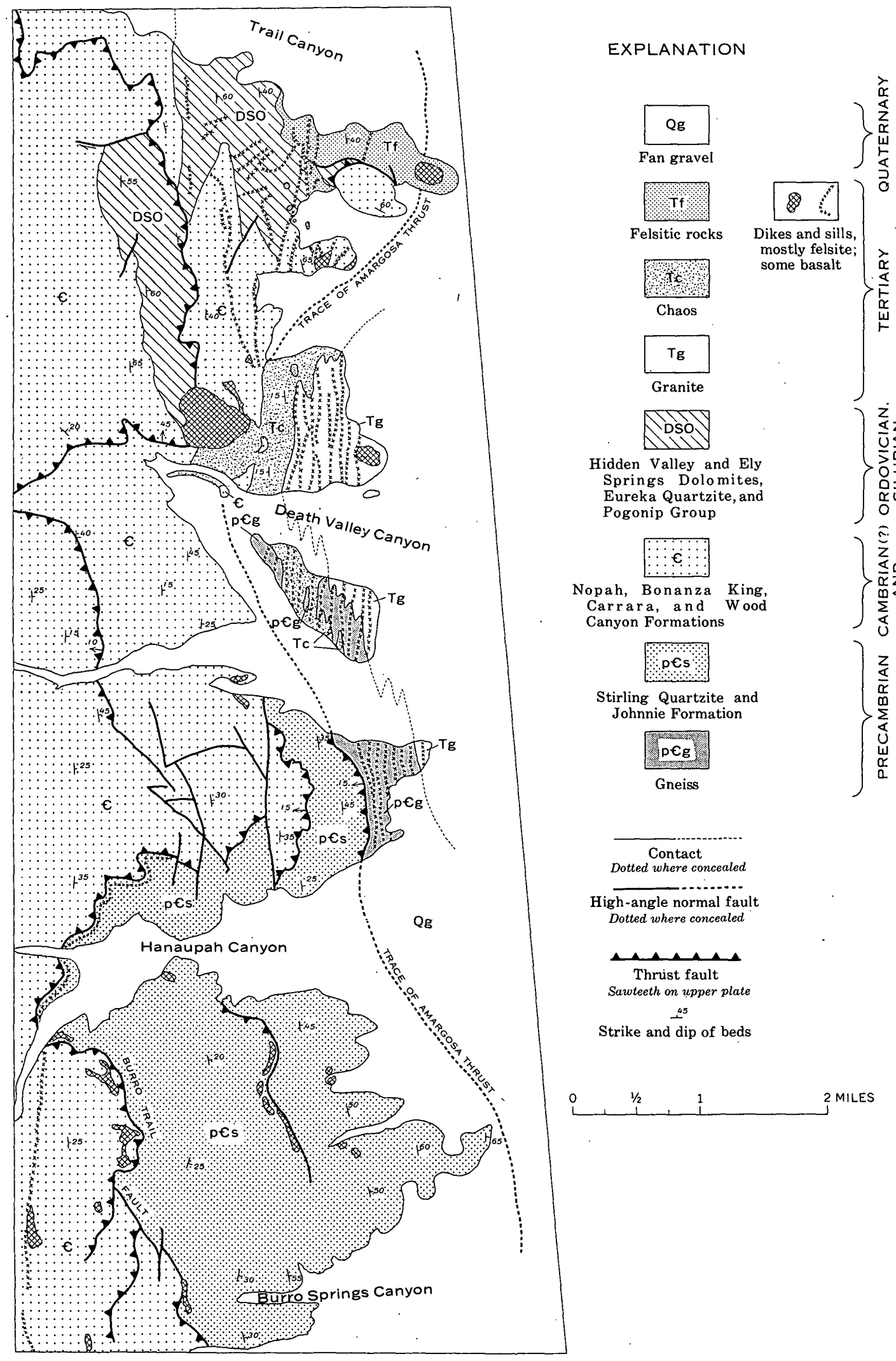

Figurn 96.-Map of Amargosa thrust complex along the east foot of the Panamint Range. 


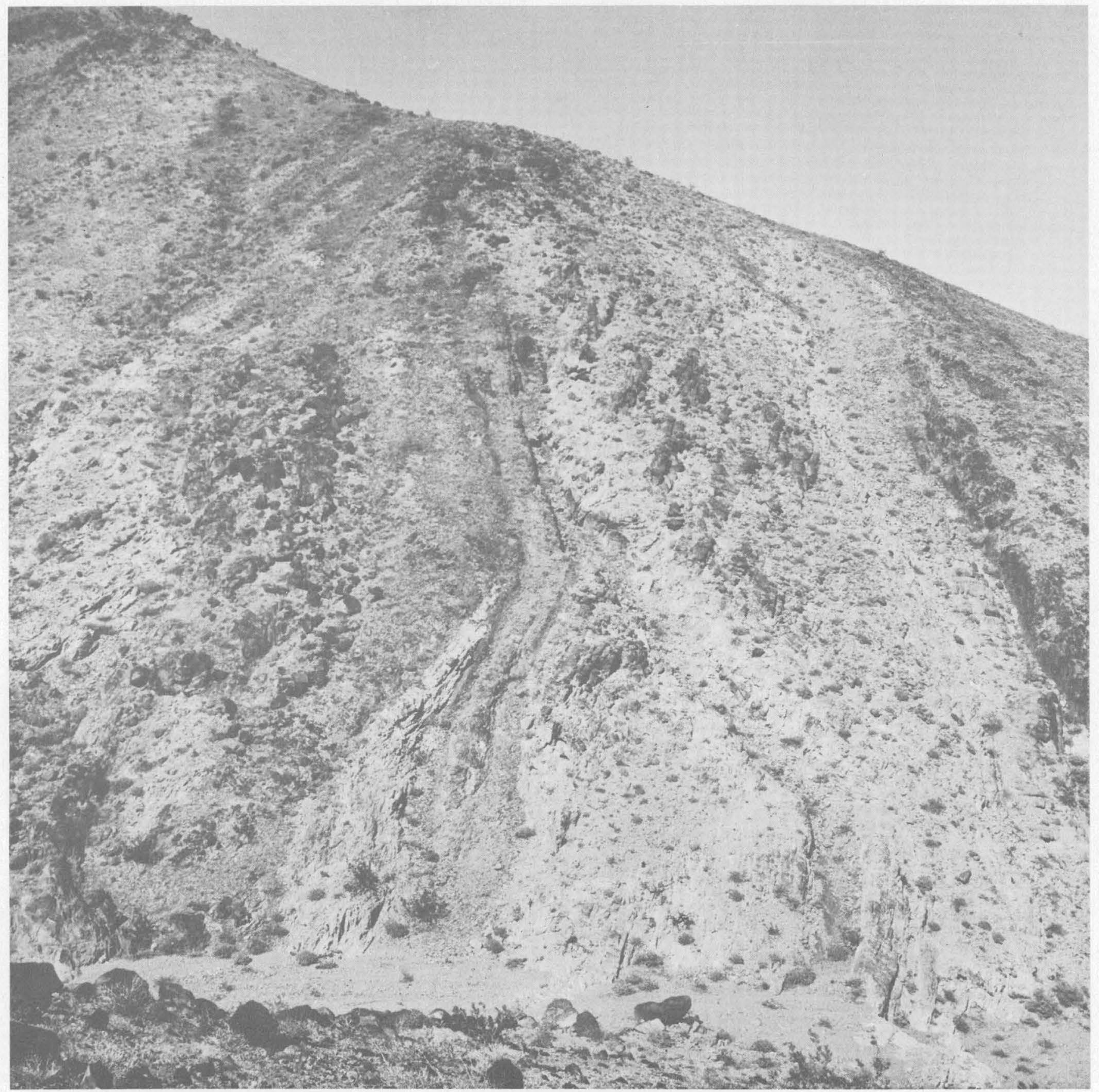

Figure 97.-View of dike swarm in Amargosa thrust complex. At this location, the mouth of Death Valley Canyon, the host rock is a granitic intrusion.

or aplitic masses that seem to provide a gradation between the gneiss and some of the felsitic dikes that cut the gneiss. Also, the trace elements in these rocks are similar (table 26).

Other evidence indicating metamorphism attributable to the igneous activity is the occurrence of incompletely replaced metasediments in the granitic rocks (fig. 102).
Some of the granite and some of the other igneous rocks may have been similarly generated from older rocks along the thrust fault. In short, the concentration of augen gneiss, granite, felsite dikes, and volcanics, together with various kinds of metasediments and partly granitized rocks along the Amargosa thrust, suggests that the fault zone is an old structure which repeatedly 


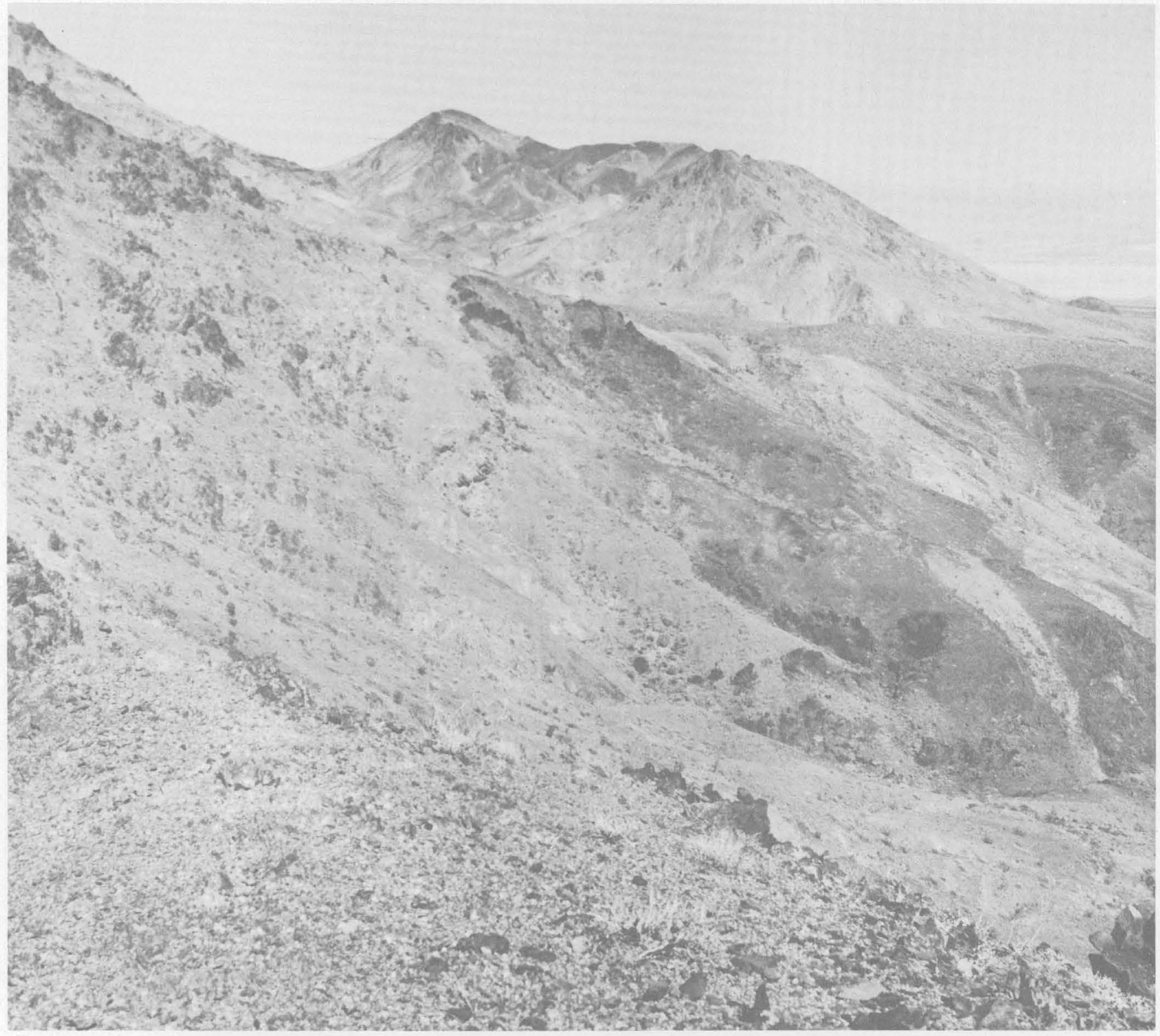

Frgure 98.-View of chaoslike formation in Amargosa thrust complex. The formation consists mostly of volcanic rocks (light colored) having interlayered slabs of Paleozoic dolomite (dark rock in center and foreground). Location is north side of Death Valley Canyon.

has been the site of mylonitization, recrystalliaztion, igneous invasion, metamorphism and granitization, and perhaps of magma generation.

Brecciation of the metamorphic rocks at the Amargosa thrust shows that the metamorphism in part at least antedates the thrust, yet this brecciation could partly be due to renewed movement on the thrust. Probably much of the metamorphism is Precambrian, but part of it may be much younger.

Ralph L. Erickson (written commun., 1961) found two kinds of zircons in the Amargosa complex (fig. 103).
Zircons from the augen gneiss are colorless, rounded, and frosted; zircons from the granite and volcanic rocks are brownish, pink, euhedral, and somewhat laroor. Zircons from the biotite gneiss are mixed, but the colo riety predominates strongly. Zircons in the aplite are th aral pink variety.

The occurrence of these two varieties suggests that the rounded colorless zircons are detrital and much older than the euhedral pink variety, and further, that the augen gneiss and biotite gneiss are metasediments intruded and further metamorphosed by younger granitic rocks.

Along the east side of the arched metamorphic rocks is a granitic intrusion. Its exposed part widens north- 


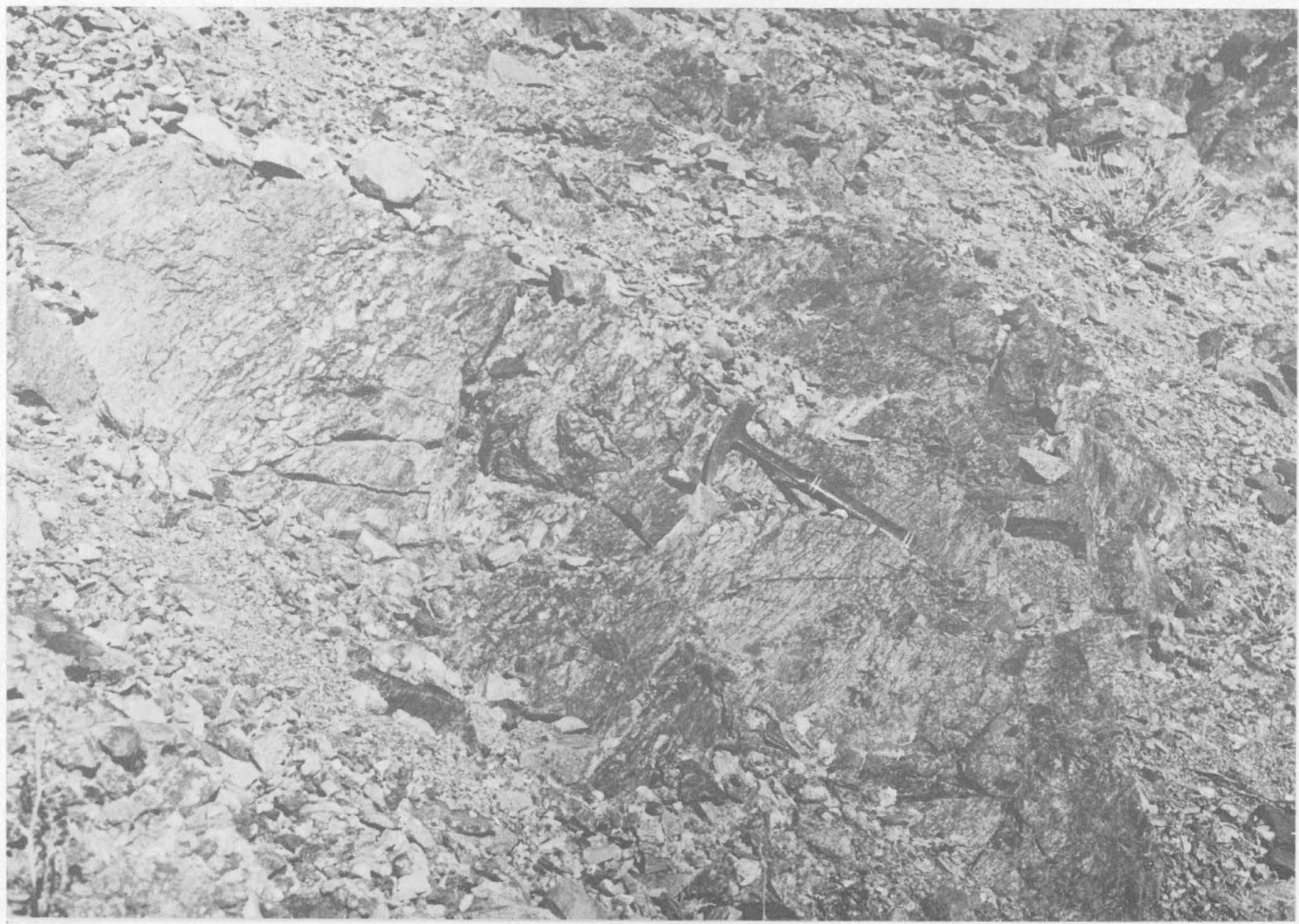

FIGURE 99.-View of augen gneiss in Amargosa thrust complex north of Hanaupah Canyon at the east foot of the Panamint Range.

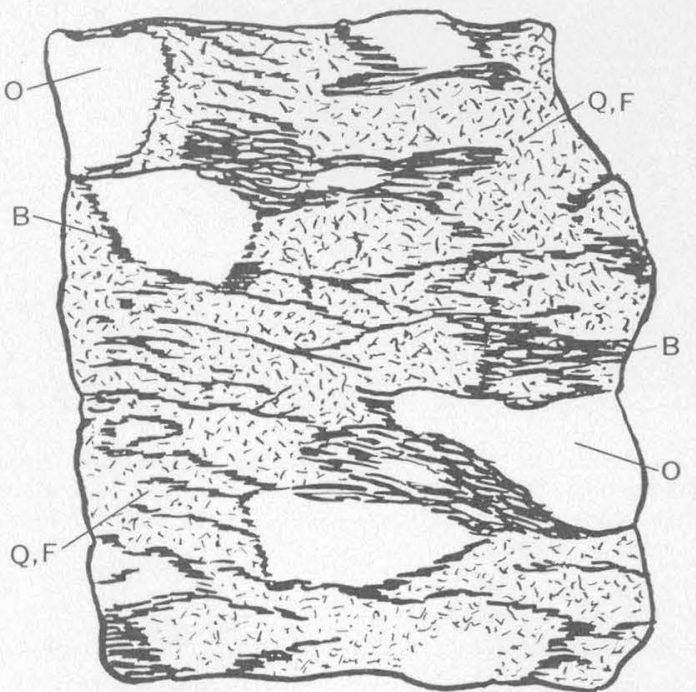

Figure 100.- Specimen of augen gneiss from Amargosa thrust complex 1 mile north of the mouth of Hanaupah Canyon. The rock consists of dark biotite-rich stringers (B) between lighter colored augenlike masses that are mostly fine-grained quartz and feldspar (Q, F) and large augen of orothoclase (O). Natural size.

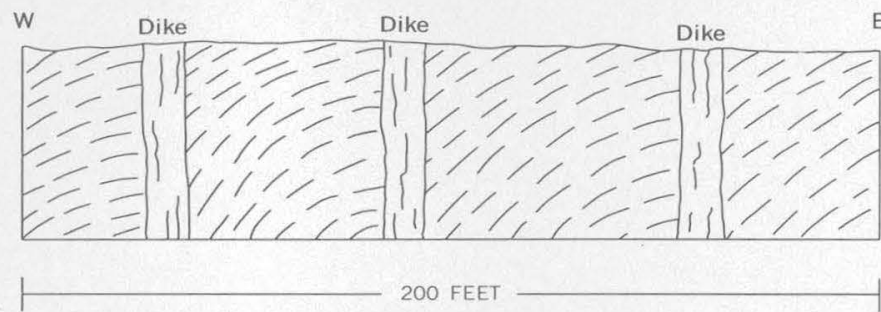

Figure 101.-Diagrammatic section illustrating flattening of foliation of augen gneiss eastward from dikes. The dikes are 1-3 feet wide and are 5-15 feet apart. Along the east wall of many dikes the foliation dips steeply west into the dike, but within a few feet eastward the dip flattens.

ward from the tip of the spur north of Hanaupah Canyon to the north side of the Death Valley Canyon, but not enough of the granite is exposed to reveal its structural form. Probably it is tabular and approximately parallel to the thrust like the similar intrusion below the augen gneiss under the Amargosa thrust fault in the Virgin Spring area (Noble, 1941). The swarm of dikes, mostly felsite, crossing the metamorphic rocks also crosses this granite (figs. 96,97 ). 


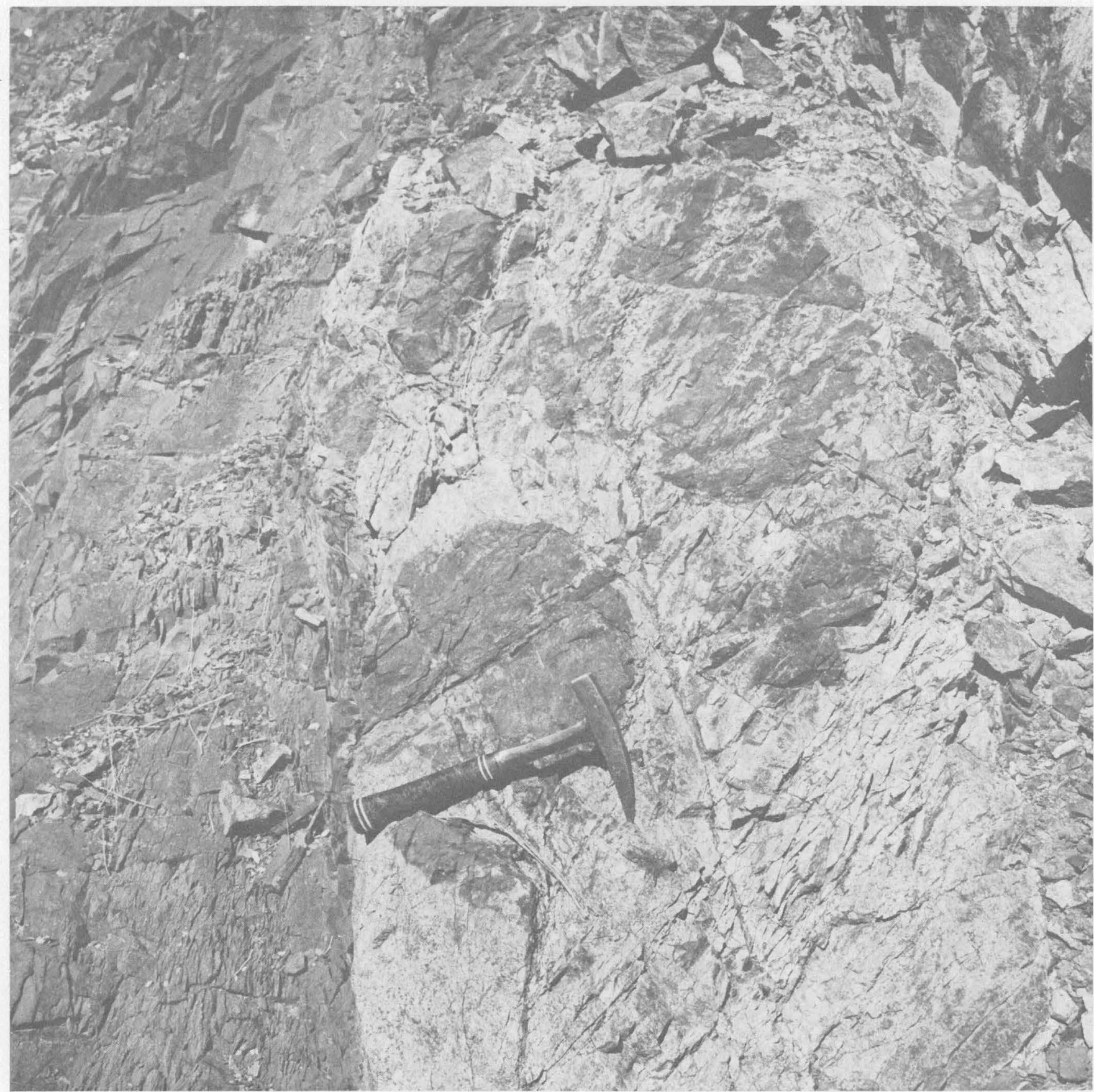

FigUre 102.-Granitized metasediment (light rock) and incompletely replaced metasediment (dark rock above the hammer) in Amargosa thrust complex. At left is a felsite dike. A layer of green argillite containing lenses of mica cuts through the dark rock above the hammer and extends upward to the right as veins of the greenish mineral in the porphyry. Locality is about midway between Hanaupah and Death Valley Canyons.

The rock is finer grained than the granites at Skidoo or at Hanaupah Canyon. It contains roughly 40 percent potassium feldspar, 30 percent plagioclase, 20 percent quartz, and 10 percent biotite. The quartz and orthoclase are in graphic intergrowths (fig. 104). Some facies might be referred to as alaskite. The texture, which is more that of a hypabyssal rock than a deepseated pluntonic one, is intermediate between the textures of the other "granites" and the volcanic rocks. The zircons are the euhedral pink variety (fig. 103).

Above the granite is $400-500$ feet of Precambrian augen gneiss, and above the augen gneiss is the Amar- 


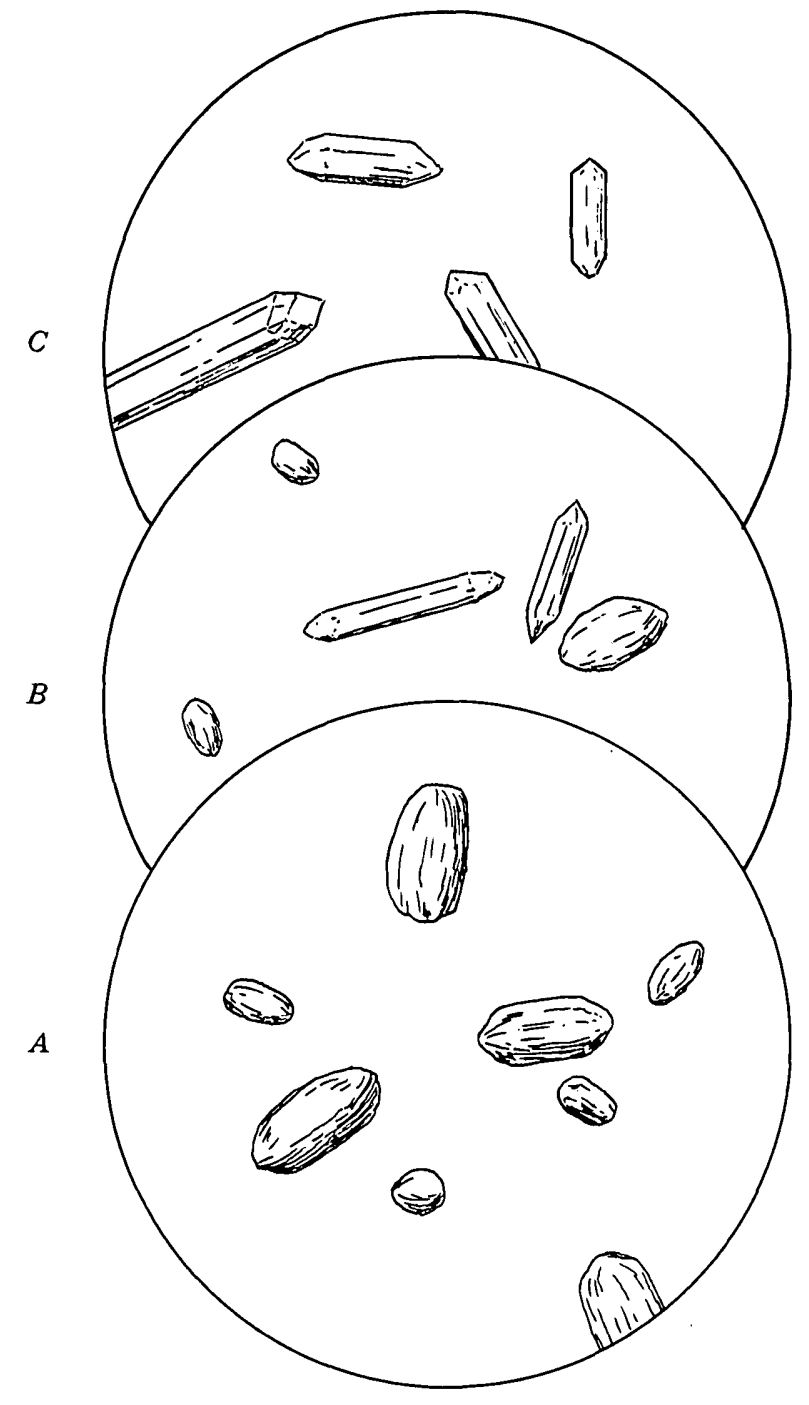

Fraure 103.-Zircons from Amargosa thrust complex between Hanaupah and Death Valley Canyons. The Precambrian augen gnelss contains colorless round zircons $(A)$. The granitic rock in the complex that may have been derived in part by melting such gneiss contains similar round zircons and sharply terminated euhedral pink zircons $(B)$. Dikes cutting the granite, and seemingly in part derived from 1t, contain only the pink euhedral zircons $(C)$. Lead-urantum and lead-thorium ages of zircon from the augen gneiss indicate Precambrian age; lead-alpha ages of zircon from the other rocks indicate middle Tertiary age $(T$. W. Stern, written commun., 1965). Width of flelds, $1.35 \mathrm{~mm}$.

gosa thrust fault, the upper plate of which is Stirling Quartzite. The sequence is very similar to that of the Amargosa thrust in the Virgin Springs district (Noble, 1941) where augen gneiss, identical to that at the east foot of the Panamint Range, lies above a granitic intrusion and below the Amargosa thrust. In the Virgin Springs district the upper plate of the thrust consists of a chaotic mixture of upper Precambrian sedimentary rocks and Tertiary volcanic rocks, a mixture referred to as "chaos" (Noble, 1941).

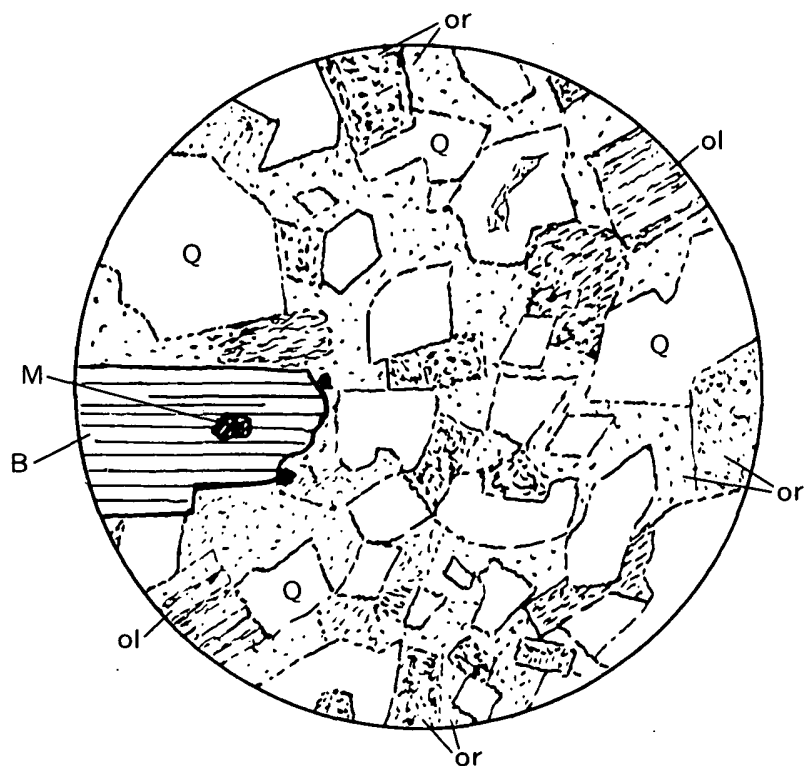

Figurs 104.-Micrograph of thin section of granitic rock in Amargosa thrust complex at Death Valley Canyon. The rock is mostly quartz $(Q)$ and orthoclase (or) in graphic intergrowths. Ollgoclase (ol) and biotite (B) comprise the rest of the rock, and there is a trace of magnetite $(M)$. Diameter of fleld, $2.5 \mathrm{~mm}$.

The gneiss is brecciated at the crush zone along the thrust fault as if the gneiss antedates the fault. In part it probably does, but the relationships may have been complicated by later movements along the fault, and perhaps by some metamorphism dating from the time of the thrusting and the granitic intrusion.

The chaoslike formation exposed at the mouth of Death Valley Canyon is composed mostly of volcanic rocks (fig. 98). Intercalated with these rocks are slabs of Paleozoic dolomite and some slabs of Precambrian metamorphic rock including augen gneiss. Individual slabs are 10-50 feet thick and as much as 500 feet long; they dip at about $25^{\circ} \mathrm{W}$. Some dolomite slabs are bordered by skarn. The dike swarm also cuts this chaos, but the dikes seem to be fewer than in the augen gneiss and granite. In addition to dikes, there are some plugs of felsite (fig. 105). One on the north side of Death Valley Canyon is 1,500 feet in diameter.

The chaos lies above the granitic intrusion and between it and the Cambrian formations in the upper plate of the Amargosa thrust. The contact between the intrusion and the chaos is obscured by shearing, but it seems to dip west about parallel to the sheeting in the chaos.

The structural relationship between this chaos and the Cambrian formations in the upper plate is not at 


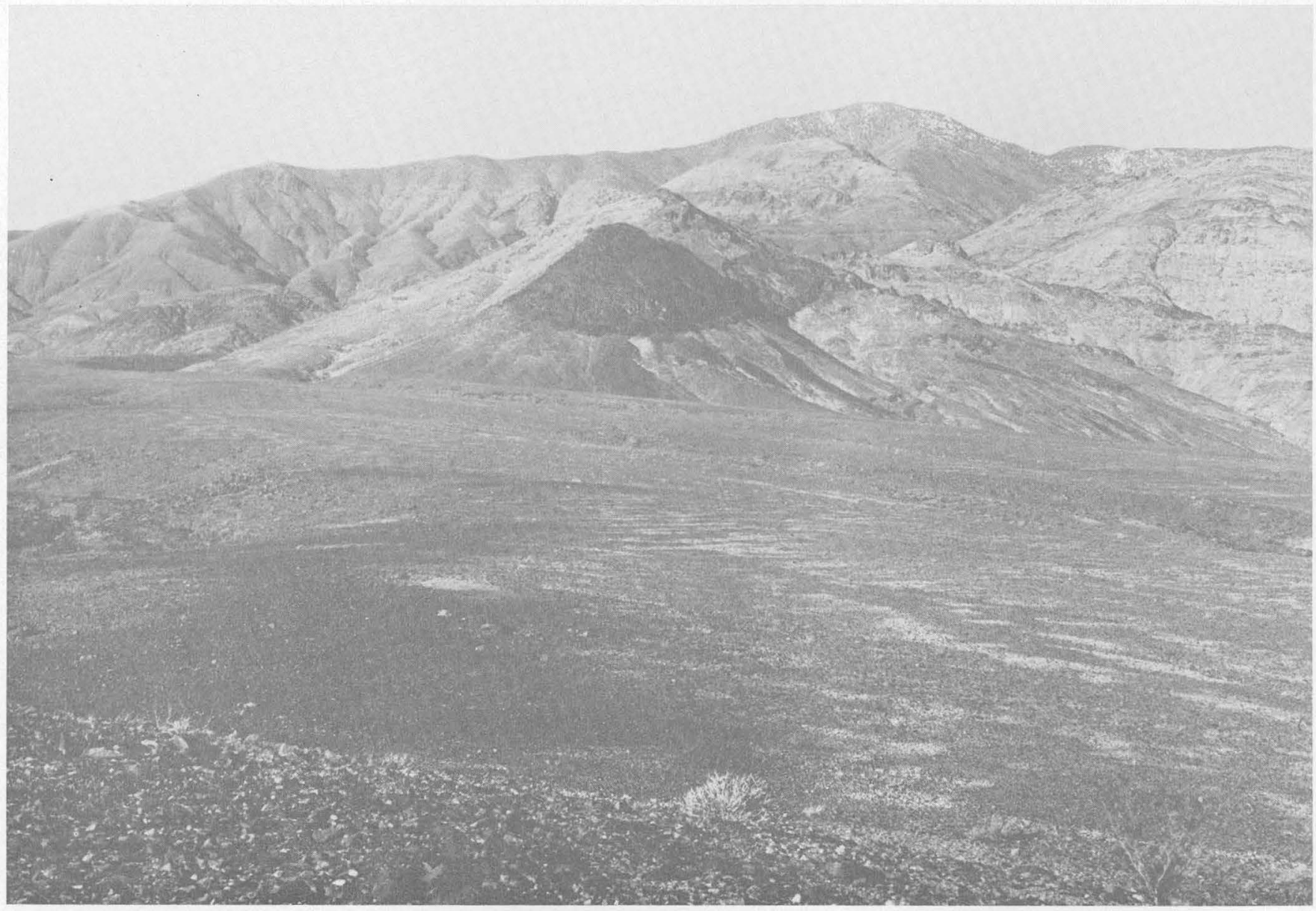

FrgURE 105.-Felsite plug (dark conical hill) in granite in Amargosa thrust complex. The plug is associated with a swarm of dikes trending across the direction of view. Locality is north side of Death Valley Canyon.

all clear, because the contact is obscured by a felsite plug north of the canyon mouth and by faulting.

Between Hanaupah and Death Valley Canyons the dikes, plugs, and other intrusions which are nearly vertical, are restricted to the lower plate. They do not cut the Stirling Quartzite and younger formations in the upper plate.

Moreover, the belt of volcanic activity extends as a narrow linear belt northward and southward from the arched lower plate, indicating that the lower plate was very near the surface at the time of the volcanism.

One of the most extensive eruptive masses is north of Trail Canyon where felsite flows and lapilli tuffs 500 feet thick overlap the Paleozoic formations in the upper plate. The flows dip about $25^{\circ} \mathrm{E}$.; the Paleozoic formations dip about $50^{\circ} \mathrm{E}$. Parallel layering in the eruptives indicates that their eastward dip is not original and depositional; evidently half the eastward tilting of the Panamint Range occurred before and half after these eruptives were formed.

The voleanism north of Trail Canyon also is marked by dikes of felsite and basalt cutting the upper plate, by a felsite plug 2 miles south of Blackwater Wash, by tuffs and basalt flows on each side of the mouth of Blackwater Wash, and by hydrothermal alteration of the Paleozoic formations. The Pogonip Group especially is reddened northward and southward from Trail Canyon.

Southward from Hanaupah Canyon the belt of volcanism similarly is marked by eruptives, dikes, sills, plugs and extensive areas of hydrothermal alteration. The eruptives, mostly tuffs, dip east and overlap westward onto the more steeply dipping rocks of the upper plate.

At Perlite Hill, porphyritic rhyolite is overlain by perlite that is capped by rhyolitic tuff and agglomerate, the whole about 800 feet thick. 
A deposit of lapilli tuff high on the mountain west of Perlite Hill and north of Starvation Canyon (fig. 96 ) is broken by small thrust faults on which the movement has been westward. The tuff deposit south of the mouth of Starvation Canyon is broken by a series of high-angle normal faults. On all these faults the displacements are small, less on the average than the displacements of the neighboring Cambrian and Precambrian formations along similar faults. It seems likely that both the thrusting and the high-angle normal faulting were renewed after the volcanism.

Sills of porphyry intruded along the Burro Trail fault are like the porphyry in the granite at Hanaupah Canyon (fig. 95 ; also table 25). Moreover, these sills occur only along that part of the fault that is nearest the granite-the part from Starvation Canyon to the north side of Hanaupah Canyon. The sills very likely are connected with the granite at Hanaupah Canyon (p. A128), and perhaps the granitic intrusion in the lower plate of the Amargosa thrust north of Hanaupah Canyon is too.

Despite the considerable variation in texture and composition of phenocrysts in the volcanic rocks of the Amargosa thrust complex, the rocks are more alike than different (fig. 106). The dike rocks generally contain considerable potassium feldspar. Plagioclase tends to occur as phenocrysts, whereas the potassium feldspar is mostly in the groundmass. Zircons in these dikes, are the euhedral pink variety (fig. 103). The rocks occurring in the volcanic plugs are like the dike rocks. The distribution and concentration of minor elements in the different rocks are shown in table 26.

The inferred relation of the thrust to the granites and volcanics in the Panamint Range and eastward to the Virgin Spring area is presented in figure 108.

At the time the volcanism occurred the east foot of the Panamint Range had been eroded to within one or two hundred feet of the present surface, because from Trail Canyon north and at Starvation Canyon and farther south, lavas and other eruptives lie at the foot of the Panamint Range and rise part way onto it (fig. 89). Volcanic rocks probably underlie the gravel fans in those areas too, as indicated by magnetic anomalies on the Trail Canyon fan and on the gravel fans south of Hanaupah Canyon. This distribution of the volcanic rocks coupled with the fact that sills from the granite at Hanaupah Canyon spread eastward along branches of the Amargosa thrust, like the Burro Trail fault, suggests that the igneous activity progressed upward and eastward under the Amargosa thrust and erupted when the surface was reached at the east foot of the range. This is the interpretation illustrated on figure 90 .

The suggestion is strong that the chaos in some way is related to the volcanism as well as to the thrust faulting, a relationship also favored by L. F. Noble (written commun.); but what the relationship is, remains to be demonstrated. There was thrust faulting before the volcanism, but in some places there was later thrusting too, both in the Panamint Range (see above) and in the Virgin Spring district (Noble, 1941).

To restore dips in the Panamint Range as they were at the time of the volcanism, the range must be rotated almost $20^{\circ}$ back to the west (fig. 89). This places the highest part of the granite in Hanaupah Canyon (fig. 90) about a mile lower than the surface on which the eruptives spread. In addition, the domes produced by the granitic intrusions should be flattened. These changes practically eliminate the Panamint Range as a topographic feature. The Paleozoic and Precambrian formations composing the Panamint Range would have had only moderate dips to the east, mostly less than $25^{\circ}$, and the Amargosa thrust and its branches would have dipped west $10^{\circ}-45^{\circ}$.

Folding of the Amargosa thrust and removal of upper plate rocks from above the thrust have exposed the gneissic cores of anticlines at three places in the Black Mountains. One of these is at Copper Canyon (fig. 107), another at Mormon Point (fig. 108), and a third at Badwater (fig. 38). The surface of the gneiss at these anticlines is smooth, and the domed surfaces are the so-called turtlebacks (Curry, 1938b, 1954).

Figure 107 is a view of the turtleback at Copper Canyon. Tertiary formations overlap the smooth surface of the gneiss and have been faulted against it. The surface of the Precambrian gneiss is the domed surface of the Amargosa thrust. An interpretation of the relations is that the thrusting, doming, and removal of the chaos from this turtleback occurred before deposition of the Tertiary formations seen in this view. Subsequently these formations were downfaulted against the turtleback surface. Drewes (1963) found boulders of volcanic rocks like those in the chaos in the Tertiary formations in Copper Canyon.

Figure 108 is an interpretation of the relations between the Amargosa thrust, turtleback surfaces, and granitic intrusions in the Black Mountains and their counterparts in the Panamint Range. This interpretation, although arrived at independently, was first suggested by Noble in 1941 . He wrote (p. 995) that "the dominant structure of the Panamint Range may be an anticline in a thrust plate like the Amargosa 'chaos,' in the core of which the Precambrian gneiss of the autoch. thonous block is exposed." 


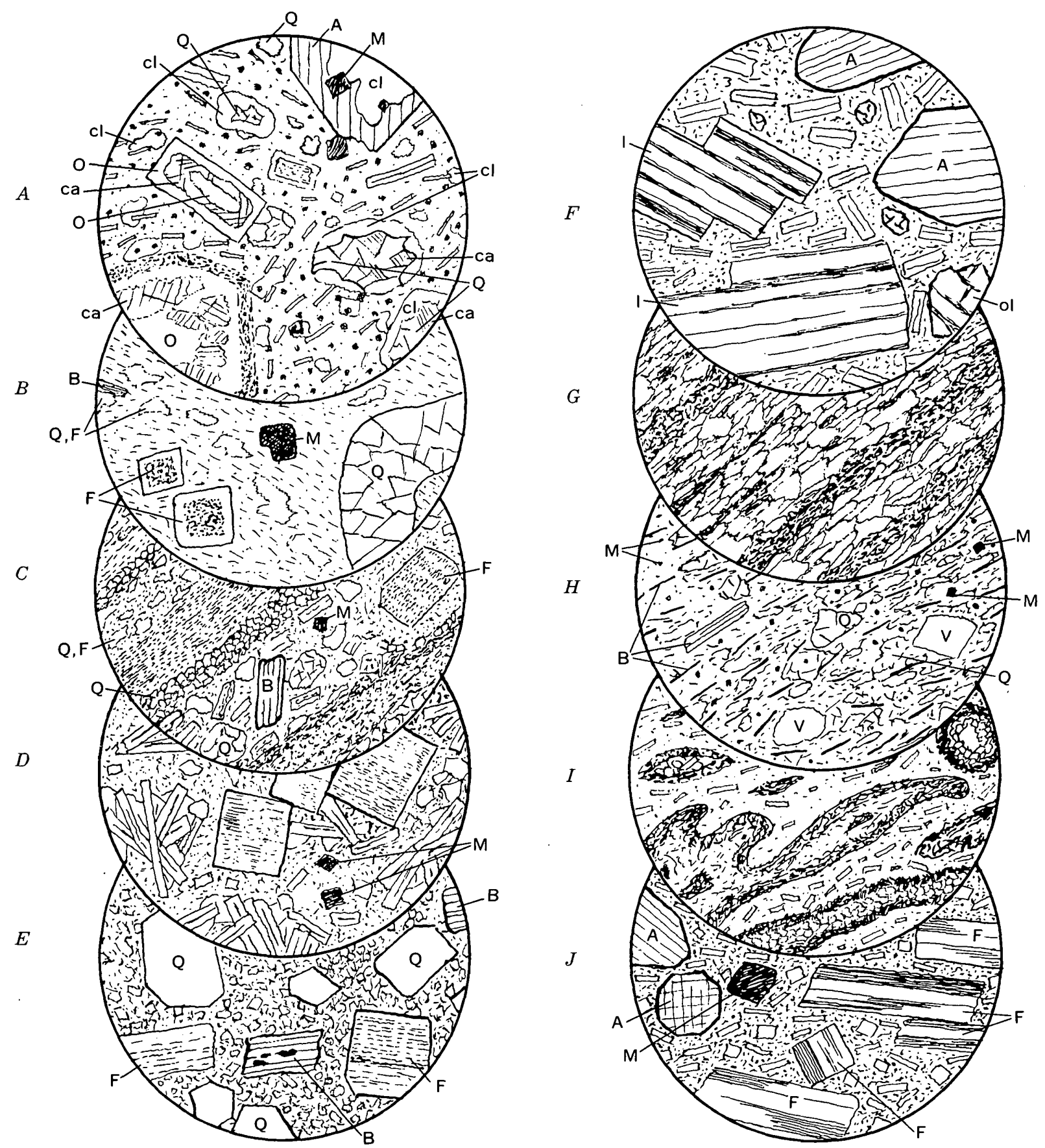

FIGURE 106.-Micrographs of thin sections of volcanic rocks in Amargosa thrust complex at base of the Panamint Range. Diameter of fields, $2.5 \mathrm{~mm}$.
Q, quartz
F, feldspar
londesine in $E$ and $J$ )
0 , oligoclase

L, Lobradorite

$A$, augite

B, biotite

cl, chlorite ol, olivine
M, magnetife
ca, calcite
V, vug 


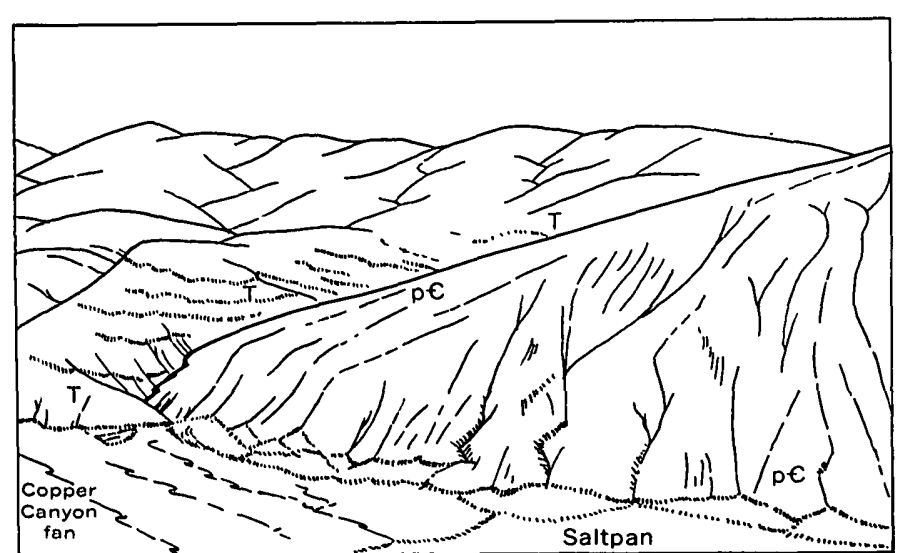

Figurn 107.-Sketch of Copper Canyon turtleback, from oblique aerial photograph. ,Vlew is east. The turtleback, composed of Precamblan gneiss (pC) has a smooth top and forms a smooth but steep front of the mountain rising more than 3,000 feet above the saltpan. Tertlary formations ( $T$ ) overlap the north end of the turtleback and are faulted down agalnst it.

\section{INDICATED GRANITIC ROCK UNDER THE PANAMINT RANGE}

The highest Bouguer gravity-anomaly values in the Death Valley region are over the Precambrian metamorphic rocks in the Black Mountains, and anomalies almost that high were found over the Funeral Mountains and Tucki Mountain. Over the main part of the Panamint Range the anomaly values are low, even on the west side where Precambrian metamorphic rocks are exposed.

The gravity-anomaly values decrease westward towards the Sierra Nevada, but the low values under the Panamint Range are, in large part, a local feature related directly to that range.

The steepness of the gravity gradients on the southeast side of Tucki Mountain suggests that the density contrast producing the anomaly is at least, in part, in the upper few kilometers of the crust. The extent of the anomaly requires that a relatively low density mass underlies most of the Panamint Range south and west of Tucki Mountain. Too, the anomaly values over the metamorphic rocks on the west side of the Panamint Range are lower than those in the metamorphic rocks in the Slate Range, a few miles to the southwest.

If the low density mass underlying the Panamint Range is granitic rock in contact with Precambrian metamorphic rock, the granitic mass must be about 2 miles thick.

In terms of deep crustal structure the combined geological, seismic, and gravity data (p. A107) suggest three quite different possibilities. One is that deep in the crust under the Panamint Range is a large granitic intrusion that is continuous westward with the Sierra Nevada batholith. Its surface would rise irregularly

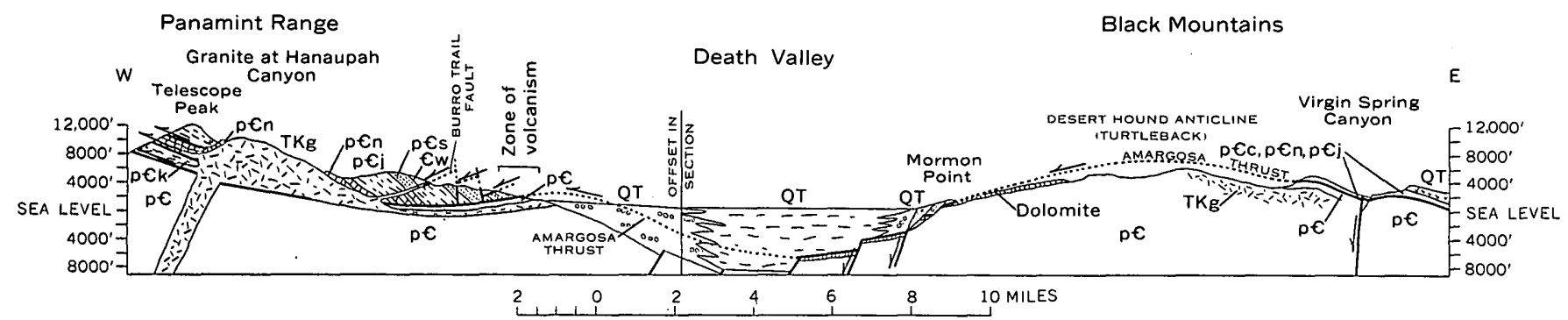

Fraurv 108.-Section of Black Mountains, Death Valley, and Panamint Range showing supposed extent of Amargosa thrust and relations of granitic intrusions and volcanism to it. Section across the Black Mountains from Noble (1941). Qt, Quaternary and Tertiary valley fll ; $T K_{g}$, grantic Intrusions; $\in w$, Wood Canyon Formation; pCs, Stirling Quartzite; p€J, Johnnle Formation; pCn, Noonday Dolomite; p€c, Crystal Spring Formation; p€k, Kingston Peak Formation; pC, Precambrian metamorphic rocks.

\section{FIGURE 106-EXPLANATION}

A. Dark-greenish augite andesite dike from the dike swarm 1 mile north of Hanaupah Canyon. Phenocrysts of augite are altered to chlorite and magnetite. Phenocrysts of oligoclase are altered to icalcite and many have an argillized border. The groundmass consists of laths of olfgoclase and cubes of magnetite. Interspersed with these are nests of chlorite, quartz, and calcite.

$B$. Pink felsite dike, near $A$. Phenocrysts of feldspar are mostly altered to a cryptocrystalline material resembling the groundmass. There are a few phenocrysts of magnetite and biotite. , Vugs conitain secondary quartz. The groundmass consists of microlites of oligoclase in a cryptocrystalline paste and is interrupted by irregular growths of feldspar and quartz.

C. Banded pink feldsite dike, near $A$. The bands differ in texture and composition. Some contain phenocrysts of biotite, argillized feldspar, probably oligoclase, and magnetite. Other layers are mostly quartz, which also occurs as irregular growth in the other layers and as veins.

$D$. Dacite dtke, near $A$. Phenocrysts of andesine and laths of oligoclase with occastonal magnetite are in a cryptocrystalline argillized groundmass.
$E$. Quartz dacite dike, near $A$. Euhedral quartz, andesine, and biotite phenocrysts in granular groundmass of feldspar (ollgoclase?). In the biotite are Irregular growths of magnetite.

F. Basalt dike on north side of Trail Canyon. Phenocrysts of augite and labradorite and a few small ones of olivine. Groundmass has small laths of andesine and small olivine crystals.

G. Felsite, interfor of plug 2 miles south of Blackwater Wash. The rock has thin dark bands of glassy material separating wider and lighter feldspathic bands.

$H$. Contact zone at $G$, dark perilte. Biotite and magnetite occur as small phenocrysts and in the groundmass. The groundmass ts largely feldspar, quartz, and glass. Many vugs are open; others contain quartz.

I. White banded tuff, underlies basalt at The Dinosaur. Feldspathic layers with microlites of oligoclase and tiny flattened blebs of glass are separated by glassy layers that are folded. Some vugs are lined with quartz and feldspar and are surrounded by glass.

$J$. Augite andesite lava at The Dinosaur. Phenocrysts are andesine, augite, and magnetite. The groundmass contains microlites of andesine and some ollvine(?) in a glassy paste. 
TABLE 26.-Trace elements in the Amargosa thrust complex

[Semiquantitative spectrographic analyses by E. F. Cooley, U.S. Geol. Survey. Values in parts per million, except Mg, which is given in percent] ROCKS FROM AMARGOSA THRUST COMPLEX BETWEEN HANAUPAH AND DEATH VALLEY CANYONS Augen gneisg

\begin{tabular}{|c|c|c|c|c|c|c|c|c|c|c|c|c|c|c|c|c|}
\hline $\mathbf{P b}$ & Mn & $\mathrm{Cu}$ & $\mathbf{Z r}$ & $\mathrm{Ni}$ & Co & $\mathbf{v}$ & $\mathbf{Y}$ & $\mathbf{B e}_{\boldsymbol{\theta}}$ & $\mathbf{T i}$ & $\mathbf{L a}$ & B & $\mathrm{Sc}$ & $\mathrm{Cr}$ & $\mathbf{B a}$ & $\mathrm{Sr}$ & $\mathrm{Mg}$ \\
\hline $\begin{array}{r}10 \\
<10 \\
10 \\
70\end{array}$ & $\begin{array}{l}300 \\
200 \\
200 \\
200\end{array}$ & $\begin{array}{l}20 \\
20 \\
10 \\
30\end{array}$ & $\begin{array}{l}150 \\
150 \\
150 \\
300\end{array}$ & $\begin{array}{r}5 \\
5 \\
5 \\
20\end{array}$ & $\begin{array}{r}<10 \\
<10 \\
<10 \\
7\end{array}$ & $\begin{array}{l}50 \\
20 \\
50 \\
50\end{array}$ & $\begin{array}{l}50 \\
20 \\
20 \\
30\end{array}$ & $\begin{array}{r}1 \\
1 \\
<1 \\
<1\end{array}$ & $\begin{array}{l}3,000 \\
3,000 \\
3,000 \\
3,000\end{array}$ & $\begin{array}{l}70 \\
50 \\
70 \\
70\end{array}$ & $\begin{array}{l}10 \\
20 \\
10 \\
20\end{array}$ & $\begin{array}{r}10 \\
<10 \\
10 \\
15\end{array}$ & $\begin{array}{l}20 \\
10 \\
10 \\
50\end{array}$ & $\begin{array}{r}1,500 \\
1,500 \\
1,000 \\
500\end{array}$ & $\begin{array}{r}150 \\
100 \\
100 \\
70\end{array}$ & $\begin{array}{l}1 \\
1 \\
1\end{array}$ \\
\hline \multicolumn{17}{|c|}{ Biotite gneiss } \\
\hline $\begin{array}{r}<10 \\
10 \\
<10 \\
<10 \\
20 \\
<10\end{array}$ & $\begin{array}{l}150 \\
150 \\
100 \\
200 \\
700 \\
200\end{array}$ & $\begin{array}{r}5 \\
70 \\
30 \\
50 \\
50 \\
15\end{array}$ & $\begin{array}{l}300 \\
300 \\
200 \\
200 \\
150 \\
150\end{array}$ & $\begin{array}{r}50 \\
10 \\
5 \\
7 \\
20 \\
7\end{array}$ & $\begin{array}{r}15 \\
10 \\
<10 \\
10 \\
10 \\
<10\end{array}$ & $\begin{array}{l}\mathbf{5 0} \\
50 \\
20 \\
50 \\
70 \\
\mathbf{5 0}\end{array}$ & $\begin{array}{l}30 \\
20 \\
20 \\
20 \\
20 \\
20\end{array}$ & $\begin{array}{r}1 \\
<1 \\
1.5 \\
1 \\
<1 \\
1\end{array}$ & $\begin{array}{l}5,000 \\
5,000 \\
3,000 \\
3,000 \\
3,000 \\
3,000\end{array}$ & $\begin{array}{l}50 \\
50 \\
50 \\
70 \\
70 \\
50\end{array}$ & $\begin{array}{l}20 \\
20 \\
15 \\
10 \\
10 \\
10\end{array}$ & $\begin{array}{r}10 \\
20 \\
<10 \\
10 \\
10 \\
<10\end{array}$ & $\begin{array}{l}50 \\
20 \\
10 \\
15 \\
50 \\
20\end{array}$ & $\begin{array}{r}1,000 \\
700 \\
300 \\
1,000 \\
700 \\
100\end{array}$ & $\begin{array}{r}50 \\
150 \\
200 \\
70 \\
100 \\
70\end{array}$ & $\begin{array}{l}1.5 \\
1 \\
1.7 \\
1.5 \\
1\end{array}$ \\
\hline \multicolumn{17}{|c|}{ Mylonite } \\
\hline$<10$ & 300 & 3 & 200 & 10 & 10 & 50 & 20 & 2 & 2,000 & 50 & 10 & 10 & 20 & 70 & 70 & 2 \\
\hline \multicolumn{17}{|c|}{ Granitoid rocks } \\
\hline $\begin{array}{l}20 \\
10 \\
30 \\
20\end{array}$ & $\begin{array}{l}\mathbf{5 0 0} \\
500 \\
\mathbf{5 0 0} \\
\mathbf{5 0 0}\end{array}$ & $\begin{array}{l}30 \\
20 \\
30 \\
20\end{array}$ & $\begin{array}{l}100 \\
200 \\
200 \\
100\end{array}$ & $\begin{array}{r}<5 \\
\mathbf{5} \\
\mathbf{5} \\
\mathbf{2 0}\end{array}$ & $\begin{array}{l}<10 \\
<10 \\
<10 \\
<5\end{array}$ & $\begin{array}{l}15 \\
20 \\
20 \\
10\end{array}$ & $\begin{array}{l}15 \\
20 \\
10 \\
20\end{array}$ & $\begin{array}{l}1 \\
1 \\
1 \\
1\end{array}$ & $\begin{array}{l}1,500 \\
3,000 \\
2,000 \\
1,500\end{array}$ & $\begin{array}{r}50 \\
70 \\
70 \\
<50\end{array}$ & $\begin{array}{l}10 \\
10 \\
10 \\
20\end{array}$ & $\begin{array}{l}<10 \\
<10 \\
<10 \\
<10\end{array}$ & $\begin{array}{l}10 \\
10 \\
10 \\
30\end{array}$ & $\begin{array}{r}700 \\
1,000 \\
1,000 \\
500\end{array}$ & $\begin{array}{r}150 \\
150 \\
200 \\
70\end{array}$ & $\begin{array}{l}0.2 \\
1 \\
.5 \\
.5\end{array}$ \\
\hline \multicolumn{17}{|c|}{ Felsite dikes } \\
\hline $\begin{array}{r}<10 \\
30 \\
<10 \\
<10 \\
10 \\
20 \\
20 \\
10 \\
10\end{array}$ & $\begin{array}{r}100 \\
700 \\
50 \\
100 \\
50 \\
300 \\
700 \\
200 \\
500\end{array}$ & $\begin{array}{r}30 \\
70 \\
50 \\
5 \\
20 \\
30 \\
30 \\
10 \\
15\end{array}$ & $\begin{array}{l}500 \\
200 \\
150 \\
150 \\
200 \\
150 \\
150 \\
200 \\
150\end{array}$ & & $\begin{array}{l}<10 \\
<10 \\
<10 \\
<10 \\
<10 \\
<10 \\
<10 \\
<10 \\
<10\end{array}$ & $\begin{array}{r}50 \\
<10 \\
<10 \\
10 \\
<10 \\
10 \\
20 \\
10 \\
10\end{array}$ & $\begin{array}{l}20 \\
20 \\
15 \\
20 \\
20 \\
20 \\
20 \\
20 \\
15\end{array}$ & $\begin{array}{ll}1 & \\
2 & \\
1 & \\
1 & \\
1 . & 5 \\
1 & \\
1 & \\
1 & \\
1 & \end{array}$ & $\begin{array}{l}7,000 \\
2,000 \\
1,500 \\
1,000 \\
1,000 \\
1,000 \\
3,000 \\
1,000 \\
2,000\end{array}$ & $\begin{array}{r}70 \\
50 \\
<50 \\
50 \\
50 \\
70 \\
50 \\
70 \\
50\end{array}$ & $\begin{array}{l}20 \\
15 \\
10 \\
20 \\
10 \\
10 \\
10 \\
20 \\
15\end{array}$ & $\begin{array}{r}10 \\
<10 \\
10 \\
<10 \\
<10 \\
<10 \\
<10 \\
<10 \\
<10\end{array}$ & $\begin{array}{r}10 \\
<10 \\
<10 \\
<10 \\
<10 \\
<10 \\
<10 \\
<10 \\
<10\end{array}$ & $\begin{array}{r}2,000 \\
2,000 \\
100 \\
500 \\
300 \\
300 \\
1,500 \\
200 \\
1,000\end{array}$ & $\begin{array}{r}150 \\
200 \\
100 \\
50 \\
50 \\
70 \\
150 \\
70 \\
200\end{array}$ & $\begin{array}{l}1 \\
.7 \\
.1 \\
.1 \\
.15 \\
.2 \\
1.5 \\
.5 \\
.3\end{array}$ \\
\hline \multicolumn{17}{|c|}{ Basaltic dikes } \\
\hline $\begin{array}{r}20 \\
20 \\
-10 \\
20 \\
30\end{array}$ & $\begin{array}{l}1,000 \\
1,000 \\
1,000 \\
1,500 \\
1,000\end{array}$ & $\begin{array}{r}100 \\
70 \\
30 \\
5 \\
70\end{array}$ & $\begin{array}{l}200 \\
200 \\
150 \\
150 \\
700\end{array}$ & $\begin{array}{r}7 \\
5 \\
10 \\
<5 \\
300\end{array}$ & $\begin{array}{l}20 \\
15 \\
20 \\
10 \\
30\end{array}$ & $\begin{array}{l}300 \\
150 \\
100 \\
150 \\
150\end{array}$ & $\begin{array}{l}50 \\
30 \\
30 \\
20 \\
15\end{array}$ & $\begin{array}{r}<1 \\
1 \\
1 \\
1 \\
5\end{array}$ & $\begin{array}{r}10,000 \\
7,000 \\
7,000 \\
10,000 \\
20,000\end{array}$ & $\begin{array}{r}50 \\
70 \\
70 \\
50 \\
150\end{array}$ & $\begin{array}{r}15 \\
15 \\
15 \\
15 \\
<10\end{array}$ & $\begin{array}{l}20 \\
10 \\
15 \\
10 \\
15\end{array}$ & $\begin{array}{r}10 \\
10 \\
20 \\
<10 \\
300\end{array}$ & $\begin{array}{r}1,000 \\
700 \\
1,000 \\
1,500 \\
10,000\end{array}$ & $\begin{array}{r}700 \\
300 \\
500 \\
700 \\
1,500\end{array}$ & $\begin{array}{l}>5 \\
1.5 \\
2 \\
2 \\
>5\end{array}$ \\
\hline
\end{tabular}

DEATH VALLEY CANYON TO TUCKI WASH

Felsitic rocks

\begin{tabular}{|c|c|c|c|c|c|c|c|c|c|c|c|c|c|c|c|c|}
\hline $\begin{array}{r}30 \\
20 \\
20 \\
100\end{array}$ & $\begin{array}{l}100 \\
700 \\
700 \\
300\end{array}$ & $\begin{array}{r}5 \\
15 \\
15 \\
10\end{array}$ & $\begin{array}{l}700 \\
300 \\
300 \\
100\end{array}$ & $\begin{array}{l}10 \\
20 \\
20 \\
20\end{array}$ & $\begin{array}{r}<5 \\
5 \\
7 \\
<5\end{array}$ & $\begin{array}{l}10 \\
20 \\
50 \\
10\end{array}$ & $\begin{array}{l}30 \\
30 \\
20 \\
20\end{array}$ & $\begin{array}{r}1 \\
1 \\
<1 \\
1\end{array}$ & $\begin{array}{l}2,000 \\
3,000 \\
3,000 \\
1,000\end{array}$ & $\begin{array}{r}150 \\
70 \\
70 \\
<50\end{array}$ & $\begin{array}{l}50 \\
30 \\
10 \\
50\end{array}$ & $\begin{array}{r}10 \\
<10 \\
10 \\
<10\end{array}$ & $\begin{array}{l}20 \\
50 \\
70 \\
50\end{array}$ & $\begin{array}{r}1,500 \\
1,000 \\
1,500 \\
500\end{array}$ & $\begin{array}{r}300 \\
300 \\
500 \\
70\end{array}$ & $\begin{array}{r}0.5 \\
.7 \\
1 \\
.3\end{array}$ \\
\hline
\end{tabular}

TRAIL CANYON TO TUCKI WASH

Basaltic rocks

\begin{tabular}{|c|c|c|c|c|c|c|c|c|c|c|c|c|c|c|c|c|}
\hline $\begin{array}{l}10 \\
15\end{array}$ & $\begin{array}{l}1,000 \\
1,000\end{array}$ & $\begin{array}{r}100 \\
20\end{array}$ & $\begin{array}{l}150 \\
150\end{array}$ & $\begin{array}{l}50 \\
15\end{array}$ & $\begin{array}{l}20 \\
20\end{array}$ & $\begin{array}{l}150 \\
200\end{array}$ & $\begin{array}{l}20 \\
20\end{array}$ & $<1$ & $\begin{array}{l}7,000 \\
7,000\end{array}$ & $\begin{array}{l}50 \\
50\end{array}$ & $\begin{array}{l}50 \\
50\end{array}$ & $\begin{array}{l}30 \\
20\end{array}$ & $\begin{array}{r}100 \\
50\end{array}$ & $\begin{array}{r}700 \\
1,000\end{array}$ & $\begin{array}{l}1,000 \\
1,500\end{array}$ & $\begin{array}{l}2 \\
5\end{array}$ \\
\hline
\end{tabular}

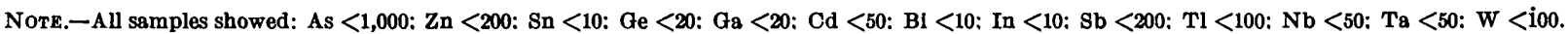


westward, emerge at the Argus Range 20 miles west of the Panamint Range, and, with more interruptions, continue its rise westward to the summit of the Sierra. The floor of the batholith dips westward as the surface rises, greatly increasing the thickness of the granitic rock.

By this interpretation the granitic mass under the Panamint Range would be a bulbous edge of the Sierra Nevada batholith, which thickens northeastward, and would be the source for the injected granitic intrusions represented by the granites at Skidoo and at Hanaupah Canyon.

A second possibility is that the edge of the batholith is west of the Panamint Range and that the range is underlain by several isolated granitic masses. These masses need not be connected with the batholith. If by palingenesis of Precambrian granitic and metamorphic rocks a magma was produced at moderate depth within the crust, the magma could have been the source for the physically injected granitic masses now exposed at the surface of the Panamint Range.

The third possibility is that the low-density rocks underlying the Panamint Range may be Precambrian granite, like that to the east under the Colorado Plateau. Cretaceous (or Tertiary?) intrusions could have been derived from the old granite. According to this interpretation, the boundary between the Precambrian and Sierran granites lies west of the Panamint Range, perhaps where the local reversal of the gravity field coincides with the northeast edge of the seismically active area that extends westward to the coast.

The great height of the Panamint Range combined with the occurrence of a negative gravity anomaly under it suggests that part of the height and uplift may be attributable to local isostatic adjustment. If so, the adjustment began in middle or late Tertiary time, after deposition of the volcanics that overlap the east side of the Panamint Range (p. A120; fig. 89). This was later, and presumably much later, than the time the Skidoo and Hanaupah granites were injected.

\section{STRUCTURE OF PRECAMBRIAN AND PALEOZOIC ROCKS}

The Paleozoic and upper Precambrian sedimentary rocks in the mountains bordering Death Valley occur in a series of folded thrust plates of the Amargosa thrust system. The thrusting moved younger rocks westward onto older ones.

Within a thrust plate the formations have rather uniform homoclinal dips, that, with very few exceptions, are eastward.
In terms of competency and density the formations involved in these structures can be considered in three major groups. At the base is the competent and dense Precambrian metamorphic complex, exposed in the Black Mountains and the west face of the Panamint Range.

Overlying the metamorphic complex is a section of upper Precambrian and lower Paleozoic formations aggregating about 30,000 feet thick and consisting of very thick incompetent shaly units separated by moderately thick competent units. At the base is the Pahrump Series (Crystal Spring Formation, Beck Spring Dolomite, and Kingston Peak Formation), the upper part of which is composed largely of incompetent beds. Above this series is the competent Noonday Dolomite, a thousand feet or more thick. The Noonday is overlain by the highly incompetent Johnnie Formation, a few thousand feet thick; above the Johnnie is the competent quartzite of the Stirling and lower part of the Wood Canyon Formation. At the top is shale of the Wood Canyon Formation, which is Early Cambrian.

The rest of the Paleozoic formations comprise a competent unit of limestone and dolomite aggregating about 25,00 feet thick.

Much of the thrusting here as in other parts of the region (see for example, Kupfer, 1960) has been along bedding planes in the incompetent upper Precambrian formations; this introduces difficulties in evaluating unconformities and determining to what extent evident cutting out of beds is attributable to the angular unconformities or to deformation. Also, it introduces difficulties in estimating displacement along the thrust faults.

At the base of the Noonday Dolomite and top of the Pahrump Series probably is a considerable angular unconformity (Hazzard, 1937b; Hewett, 1956; Kupfer, 1960), 'but in places this contact also may be a thrust fault. It is, to say the least, curious that in the eastern part of the Panamint Range the Noonday Dolomite rests on the Crystal Spring Formation of the Pahrump Series and the Kingston Peak Formation is missing, wheras on the west side of the range a carbonate formation thought to be the Noonday rests on the Kingston Peak (?) Formation which, in turn, rests directly on the Precambrian metamorphic rocks-the Crystal Spring Formation being cut out (fig. 6).

There are no major unconformities in the rest of the Paleozoic section up to the Permian, which contains thick breccias and conglomerates.

Deformation in late Paleozoic or early Mesozoic time in this region is recorded by an unconformity between Permian and overlying Triassic rocks and by the major 
change in lithology between them (Johnson, 1957). The Triassic formations, consisting of metasedimentary and volcanic rocks, 8,000 feet thick, are exposed just south of the area shown on plate 3, in Warm Spring Canyon and Butte Valley.

The thrust faulting and folding of the Amargosa system began before the granitic intrusions were emplaced in this area and continued long into the Tertiary. The faulting may have begun when the granitic intrusions west of here were being emplaced, perhaps during the Cretaceous. The igneous intrusions in this area invade the earlier faults.

\section{TUCKI MOUNTAIN KLIPPE}

In the Virgin Springs area, the type area for the Amargosa thrust, the upper plates are chaos, which in large part consists of Tertiary volcanic rocks. Tucki Mountain provides the prototype of faults in the Amargosa system that involve great plates of Paleozoic formations thrust onto Precambrian formations. The Tucki Mountain klippe, covering more than 35 square miles, consists of a slab of Paleozoic formations dipping steeply to the east and thrust westward onto less steeply dipping Precambrian formations. That the direction of thrusting was westward is shown by the way the thrust slices are shingled on one another (figs. 86, 109) and by drag along the faults. The general structure has long been recognized and is shown quite satisfac- torily on the Death Valley sheet of the State geologic map (Jennings, 1958).

The Tucki Mountain thrust fault is exposed almost continuously for 15 miles-along Mosaic Canyon, across the top of Tucki Mountain, and along the north side of Tucki Wash. Rocks of the upper plate range in age from late Precambrian (Stirling Quartzite) to Permian.

A series of secondary thrusts branch upward from the main thrust and divide the upper plate into a series of shingled thrust plates. On each of these thrusts the direction of movement was westward and carried younger rocks in the upper plates over older rocks in the lower plates. The mountainside along the north side of Tucki Wash provides an excellent exposure of a natural cross section showing the structure; a good view of this can be had from Aguereberry Point.

The Tucki Mountain thrust fault dips northeastward about $20^{\circ}$. It crosses the top of Tucki Mountain at an altitude of 5,600 feet, and it is buried under the northeast foot of the mountain, parts of which are below sea level.

The strike and dip of the thrust fault is oblique to the strike and dip of the formations in the upper plate, which strike almost north and every where dip east more steeply than $45^{\circ}$. At the east foot of the mountain the Pennsylvanian and Permian formations are overturned (pl. 3). The secondary faults that divide the upper plate into separate shingled thrust plates in general

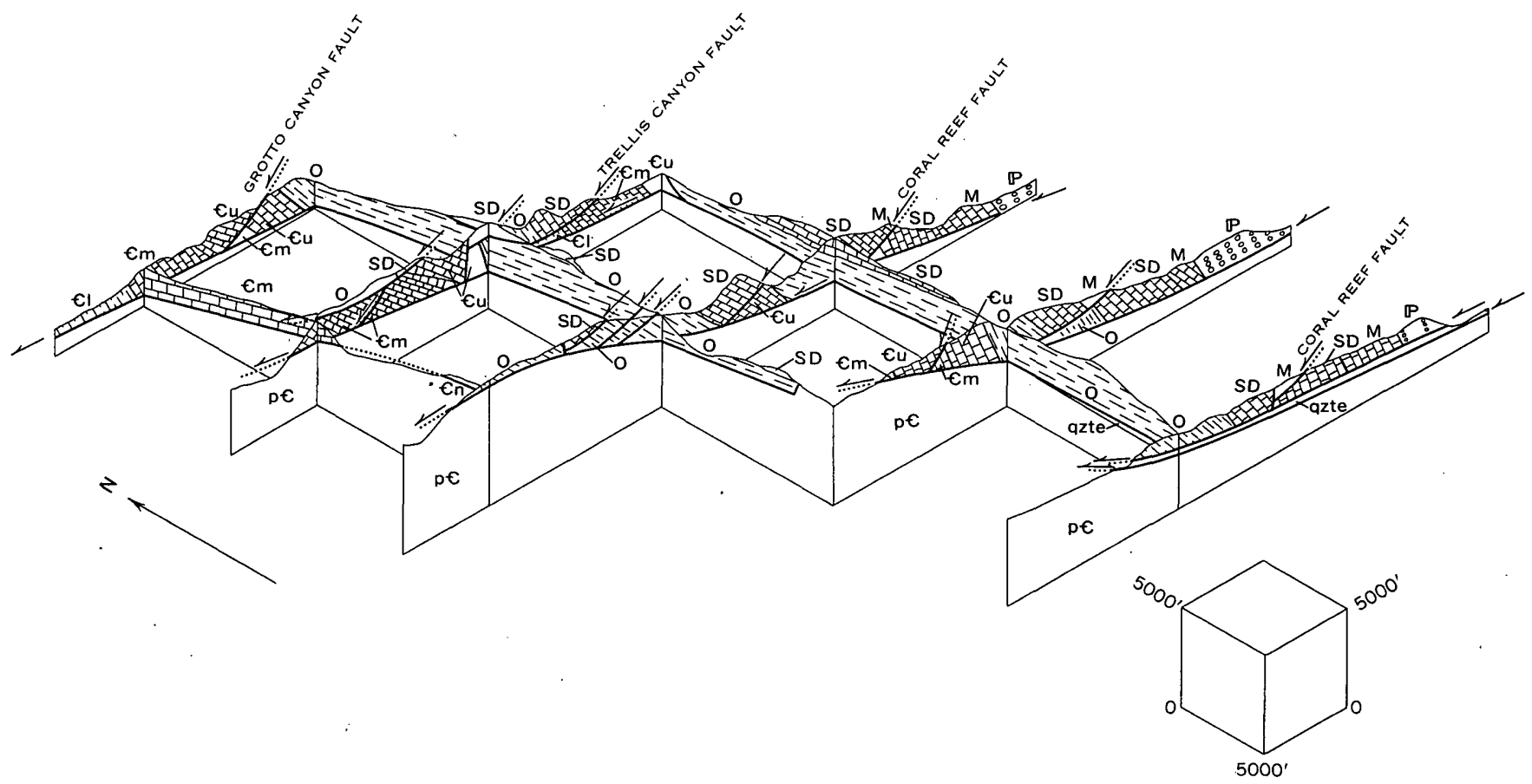

Frgure 109.-Isometric fence diagram of the Tucki Mountain klippe. The Tucki Mountain thrust fault (heary black line) has moved Paleozoic formations westward onto the Precambrian. pC, Precambrian formations (Kingston Peak (?) Formation and Johnnie Formation; qzte, a brecclated quartzite at the thrust at the south edge of the klippe (probably Stirling Quartzite); Cl, Lower Cambrian; Cm, Middle Cambrian ; Cu, Upper Cambrian ; O, Ordovician; SD, Silurian and Devonian ; M, Mississippian; P, Pennsylvanian. 
strike north-northwest, a direction that is intermediate between the strike of the main fault and that of the formations in the upper plates.

The principal secondary faults that divide the upper plate are the Grotto Canyon, Trellis Canyon, and Coral Reef faults. The Grotto Canyon fault, the most westerly of the three, has moved Ordovician, Silurian, and Devonian formations westward onto Middle Cambrian. The displacement is nearly 2 miles to the west.

The Trellis Canyon fault also carries Ordovician, Silurian, and Devonian formations about 2 miles westward onto the Middle Cambrian. Part of this fault is represented by an exhumed surface on the lower plate along the north side of Tucki Wash, 2 miles south of the trace of the fault. This exhumed surface covers about 1 square mile and, when viewed from Aguereberry Point, appears as a level skyline. The topographic contours show it well (fig. 110).

Displacement on these branch faults totals at least 4 miles to the west; displacement on the main fault must be very much greater than that.

The most easterly of the secondary faults, the Coral Reef fault, carries Mississippian rocks about a mile westward onto the Devonian. This fault is branched southward.

At the east foot of the mountain the dips are greatly steepened and locally overturned. The stratigraphic

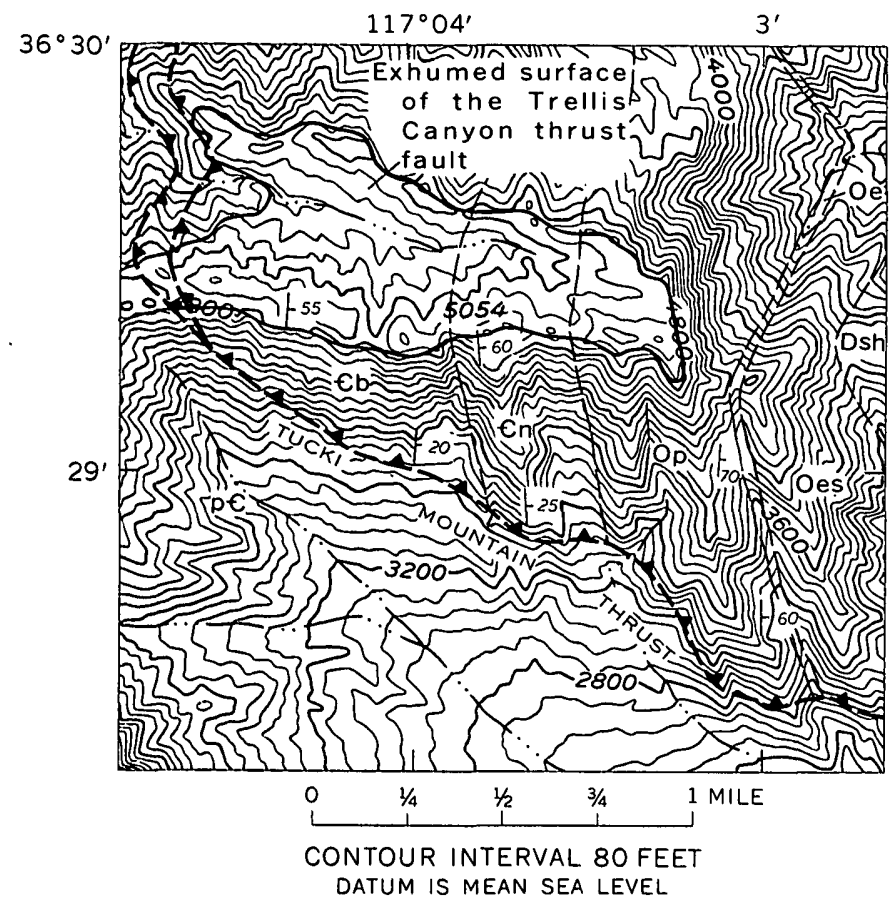

Fradri 110.-Map of the exhumed surface of the Trellis Canyon fault at the south slde of Tuckl Mountain. pe, Precambrian under the Tucki Mountaln thrust fault; $C b$, Bonanza King Formation; Cn, Nopah Formation; Op, Pogonip Group; Oe, Eureka Quartzite ; Oos, Ely Springe Dolomite; DSh, Hidden Valley Dolomite. Topog raphy from Emigrant Canyon quadrangle map. section in this part of the upper plate is confused, because there has been considerable faulting along the bedding.

\section{TUCKI MOUNTAIN FENSTER}

The west and south sides of Tucki Mountain are composed of the late Precambrian Kingston Peak(?) Formation folded into a dome of which the high part is approximately at the mountain top. From the top the beds dip northeastward under the Tucki Mountain thrust fault, westward towards Emigrant Wash, and southward towards the granite at Skidoo (pl. 3). The fenster is a dissected turtleback. Structural relief on the dome is greater than the topographic relief, that is, something more than 7,000 feet.

Capping many of the divides on the west slope of the turtleback are small klippes of carbonate rocks, probably from the Noonday (?) Dolomite but possibly from the Paleozoic. The thrust faults under these klippes are approximately concordant with the dip of the underlying Precambrian strata.

The turtleback ends westward at the Emigrant Spring fault where the Funeral Formation has overlapped the turtleback surface and later has been downfaulted along the overlap contact (p. A114; fig. 86).

Extending southeastward from the top of Tucki Mountain is a steep east-dipping monocline of Noonday (?) Dolomite and overlying Johnnie Formation. The monocline emerges from beneath the Tucki Mountain thrust fault where that fault is joined by the Trellis Canyon fault. The monocline turns southward at Tucki Wash and extends across the head of Blackwater Wash. It approximately parallels the granite at Skidoo and probably marks its eastern limit.

Evidence is conflicting about the relative age of the monocline, the Skidoo granite that is thought to have produced it, and the Tucki Mountain thrust fault. The monocline extends northward under the thrust, but it merges there with the east flank of the dome of the autochthonous rocks. The fact that the monocline is partly cut off by the thrust does not necessarily mean the thrust is later, because incompetent beds may have been folded under competent ones. Further, the westward offset of the Tucki Mountain thrust across the monocline suggests that the monoclinee is later. Detailed mapping would determine the relations, but this mapping is still to be done.

\section{SOUTHERN PART OF THE PANAMINT RANGE}

Fault blocks on the east side of the Panamint Range south of Tucki Mountain can be divided into two major units. From Starvation Canyon southward to Warm Spring Canyon, 11/2 miles south of the area mapped (pl. 3 ), the formations are mostly late Precambrian. They 
dip east and are much broken by high-angle faults. This area is the upper plate of a thrust fault, probably one that is exposed in Warm Spring Canyon. From Starvation Canyon northward to Blackwater Wash the rocks are Paleozoic. They, too, dip east but are broken by west-dipping faults, all of which involve thrusting towards the west and are part of the Amargosa thrust system.

At the head of Galena Canyon, Precambrian schist is overlain by the Crystal Spring Formation of the Pahrump Series. The contact appears to be depositional. Above the Crystal Spring Formation is the Noonday Dolomite; but the contact at its base, which is poorly exposed, may be a thrust fault. Overlying the Noonday is the Johnnie Formation and that contact appears to be depositional, but there are thrust faults both within the Johnnie Formation and at the base of the Stirling Quartzite which is on top of it.

Where rock formations are very much sheared and faulted, it is difficult to represent the dips on a general map. For example, on figure 111, a series of individual fault blocks may each dip $45^{\circ}$, but because of repeated small faults, too small to show, the effective dip is only $30^{\circ}$. On the map (pl. 3), strikes and dips are recorded as measured, but cross sections accompanying this report show the effective dips.

Most of the faults in this part of the area are highangle faults and are closely spaced. The principal ones trend northwest or north. North of Six Spring Canyon, dips are towards the east; south of the canyon the formations are domed. This doming, which shows well in Warm Spring Canyon too (C. T. Wrucke, oral commun., 1961), may be due to doming over a granitic intrusion in Warm Spring Canyon.

Shearing in these formations is reflected in fracture

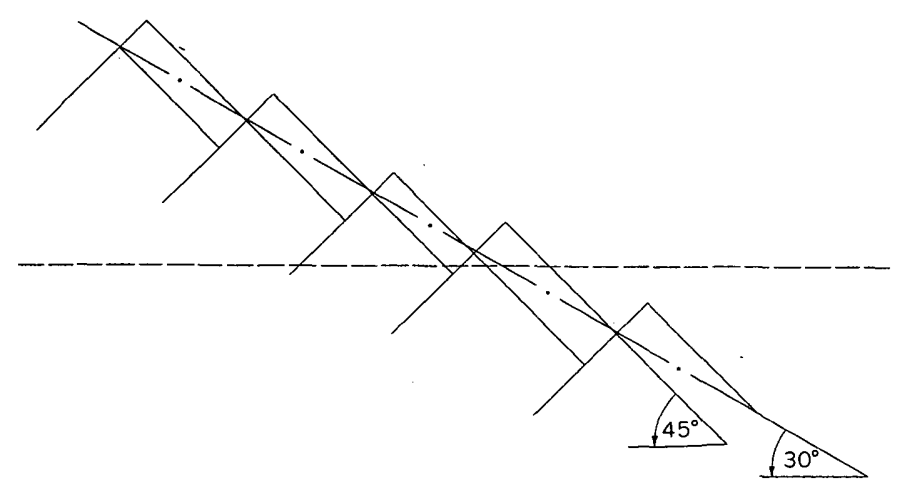

FraUri 111.-Diagram llustrating difference between actual dip and effective dip in a series of fault blocks. The Individual blocks dip $45^{\circ}$, but because of repeated small faults, the effective dip is only $30^{\circ}$. cleavage and discordances along the contacts (fig. 112). The fracture cleavage is nearly horizontal across beds that dip east. The cleavage is about parallel to the faults of the Amargosa thrust system. The relationships are suggestive of those at overturned folds, but the fracture cleavage here evidently is related to the thrust faulting. The beds are not overturned.

North of Starvation Canyon the formations in the mountains are mostly Paleozoic and $\operatorname{dip} 45^{\circ}-60^{\circ}$ E. High on the mountain, structurally and stratigraphically below these formations, are the Stirling Quartzite, Johnnie Formation, and Noonday(?) Dolomite also dipping east. These east-dipping formations a re broken by numerous west-dipping faults along which the upper plates have moved westward. Maximum displacement on these faults is about a mile. They appear to be branches of the Amargosa thrust fault, which is exposed along the east foot of the Panamint Range (p. A129).

Best known of the branch faults is the Burro Trail fault (figs. 113-116). It first appears at the south at Starvation Canyon where a tear fault (fig. 117) that dips steeply northward has been traced 3 miles westward to the west edge of the Bennetts Well quadrangle. This fault may extend along the south edge of the granite at Hanaupah Canyon, which is 3 miles farther west.

North of the mouth of Starvation Canyon the tear fault divides. An upper branch turns northward and flattens into the Burro Trail fault. The lower branch continues northeast and probably connects with the Amargosa thrust where that fault is buried by fan gravel. Eruptives and volcanics, with some admixed Paleozoic or Precambrian rocks suggestive of chaos, occur along the southeast side of this branch of the tear fault. Also, volcanic rocks have been faulted onto the Wood Canyon Formation in the upper plate north of the tear fault (fig. 117).

The Burro Trail fault is well exposed and intruded by monzonite porphyry sills for 6 miles to the north (pl. 3 and fig. 114). The sills extend to the divide north of Hanaupah Canyon, but they are not found north of there. The composition of these sills, together with their distribution in a belt directly east of the granite at Hanaupah Canyon, leaves little doubt that they are connected with that granitic intrusion (fig. 90).

North of Hanaupah Canyon the Burro Trail fault is broken by a series of north-trending high-angle faults that are downthrown to the east (pl. 3). North of this disturbed area the Burro Trail fault separates into several branches, but these join again north of Death Valley Canyon (fig. 113-115). North of Trail Canyon 


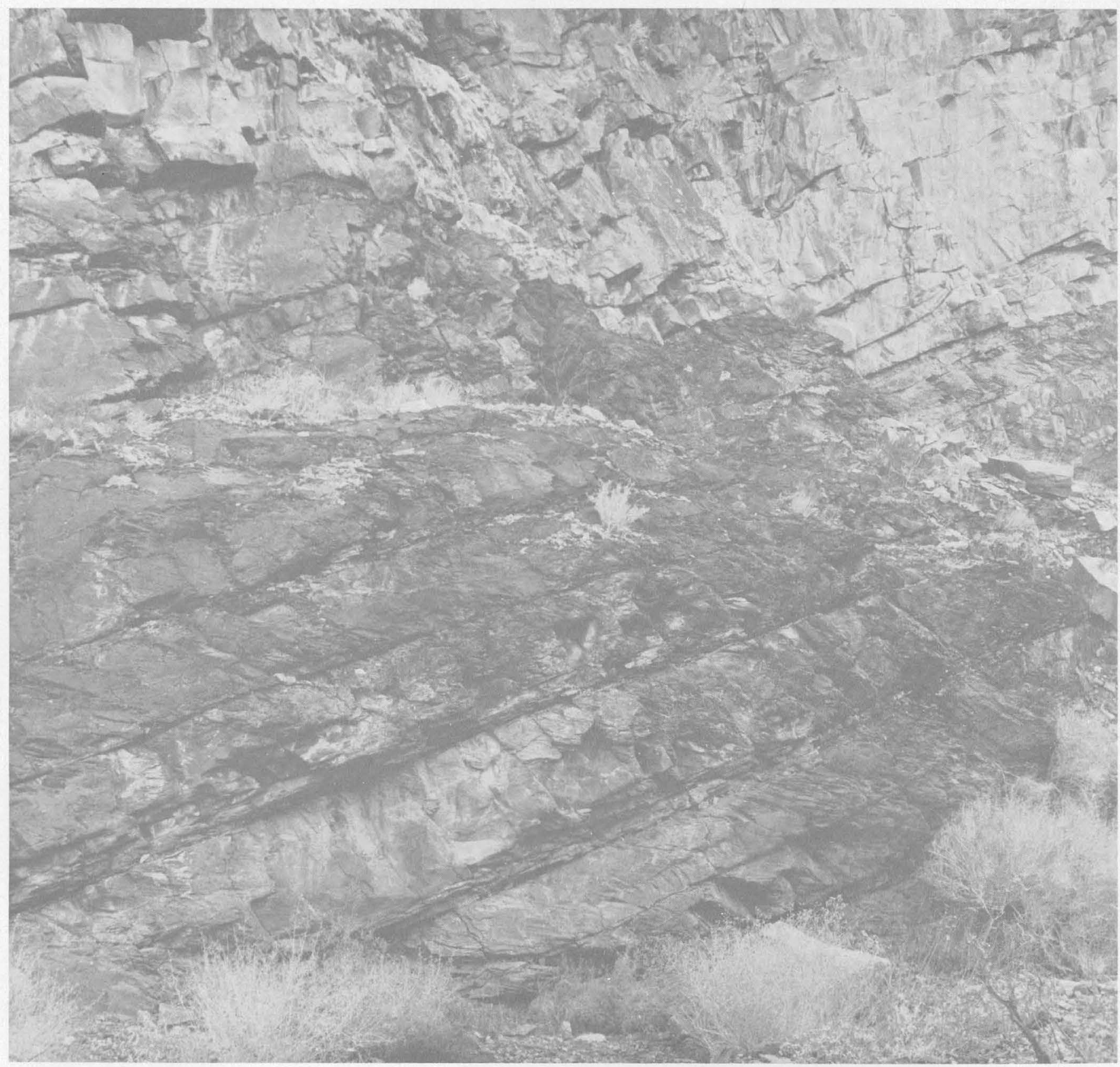

Figdre 112.-Horizontal fracture cleavage in east-dipping shale member of the Stirling Quartzite between Hanaupah and Starvation Canyons. Looking south. The cleavage approximately parallels the faults of the Amargosa thrust system; the beds are not overturned.

the fault again divides into branches along which the displacement commonly is no more than a thousand feet.

On all these faults the hanging-wall rocks are the younger, and the displacement therefore is that of normal faults. Possibly these faults were originally highangle normal faults that later were rotated to dip gently west. But although it is true that the Panamint Range has been rotated east (p. A137), and the faults originally must have dipped moderately steeply to the west, the structures along these faults are not those of high-angle normal faults. Crushing along them is much more intense than along the high-angle faults in this region, and locally the upper-plate rocks are almost concordant on the fault, as in Trail Canyon (fig. 116).

The Burro Trail fault, although a striking feature, probably is only a minor fault in the Amargosa system. It probably connects at depth with the Amargosa thrust under the Panamint Range and branches upward from 


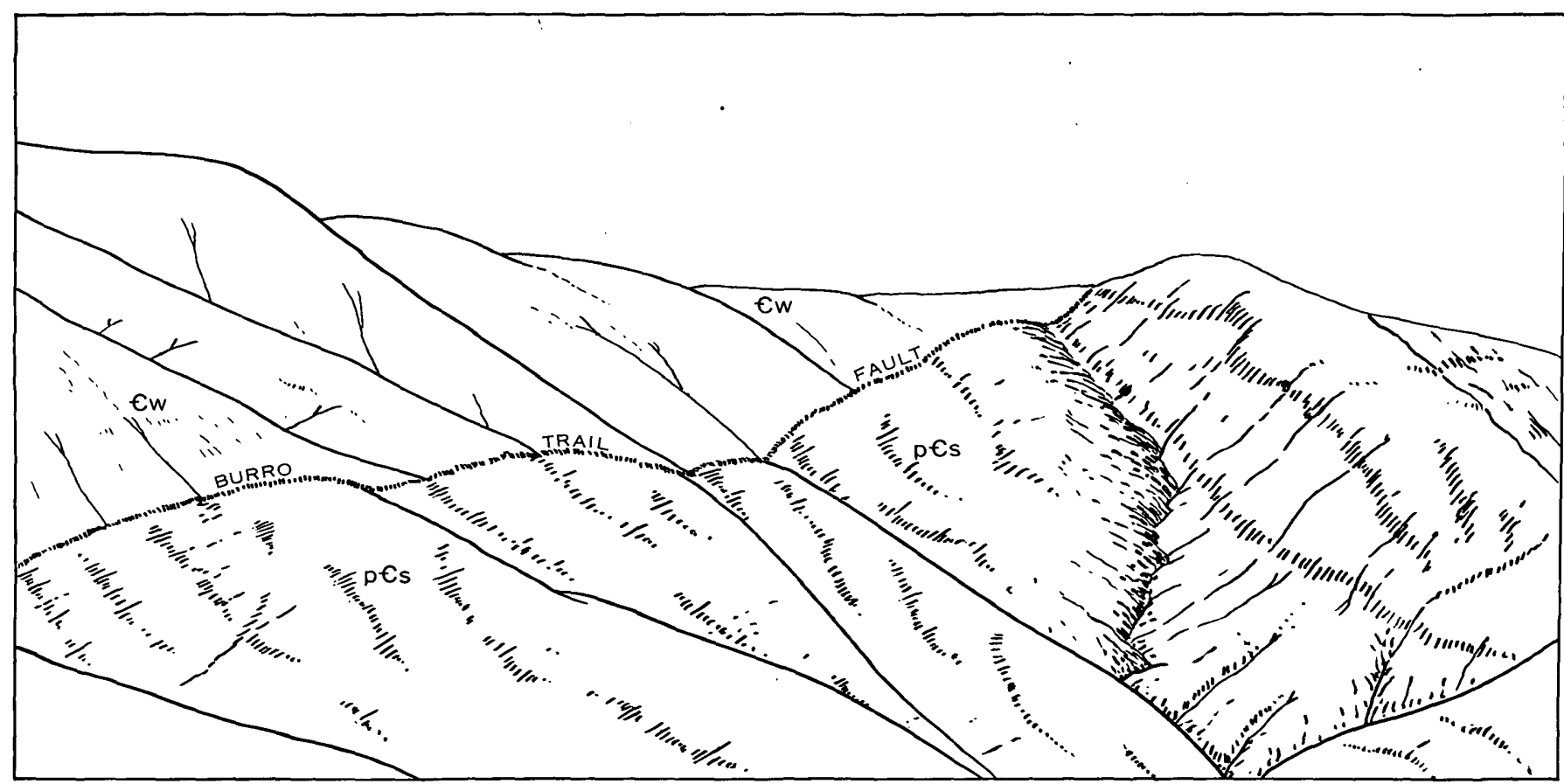

Figure 113.-Burro Trall fault. View north from the divide north of Starvation Canyon. The Wood Canyon Formation (Cw) has been faulted westward onto Stirling Quartzite (p€s). Both formations dip about $25^{\circ} \mathrm{E}$.; the fault dips about $30^{\circ} \mathrm{W}$.

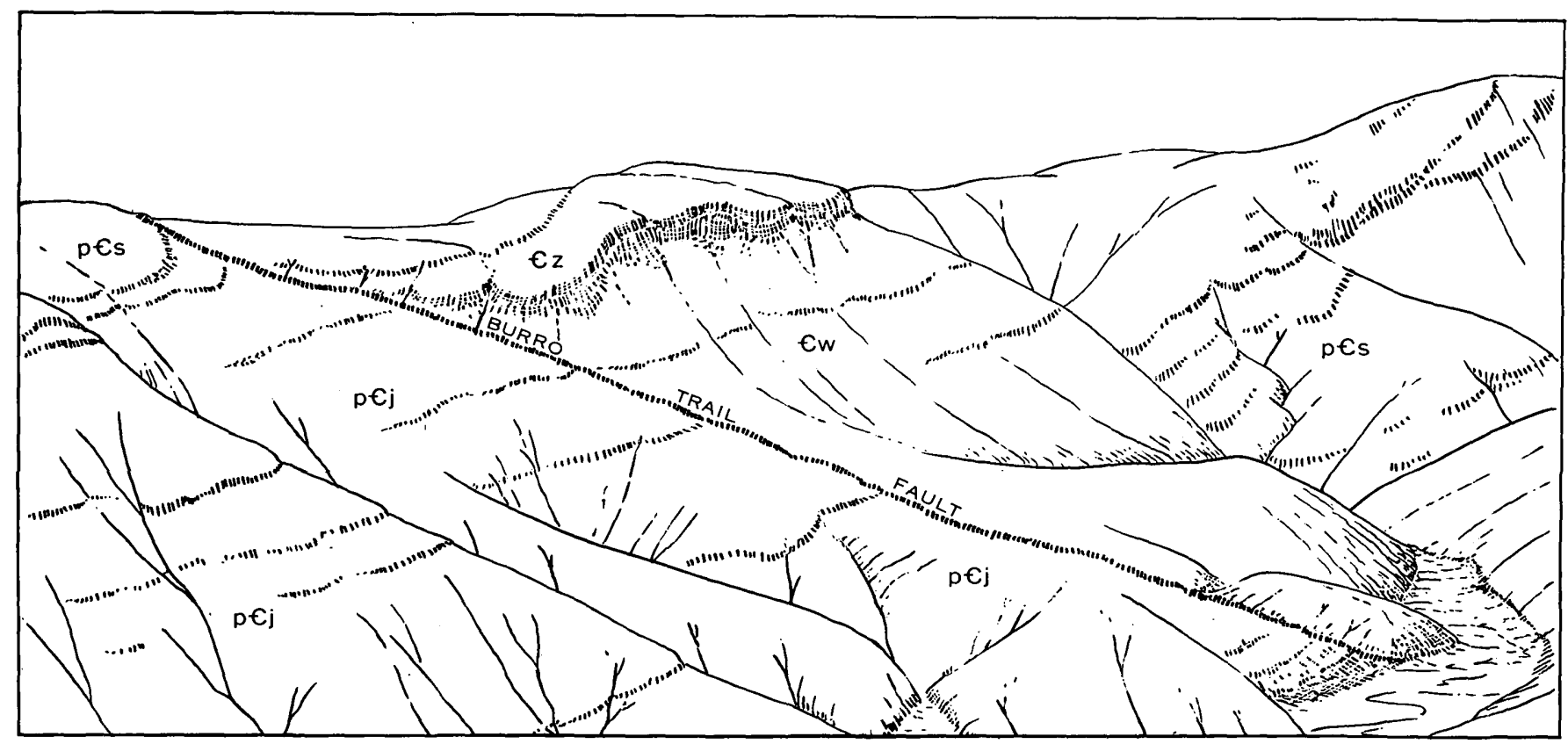

Figurn 114.-Burro Trail fault. View south across Hanaupah Canyon. Stirling Quartzite (p€s) at the right and overlying Wood Canyon Formation ( $C w$ ) and Zabriskie Quartzite $\left(C_{z}\right)$ are faulted westward onto Johnnie Formation (pCj) and Stirling Quartzite. The forma. tions dip about $25^{\circ} \mathrm{E}$; ; the fault dips $20^{\circ} \mathrm{W}$. Small sills of monzonite porphyry are intruded along the fault. 


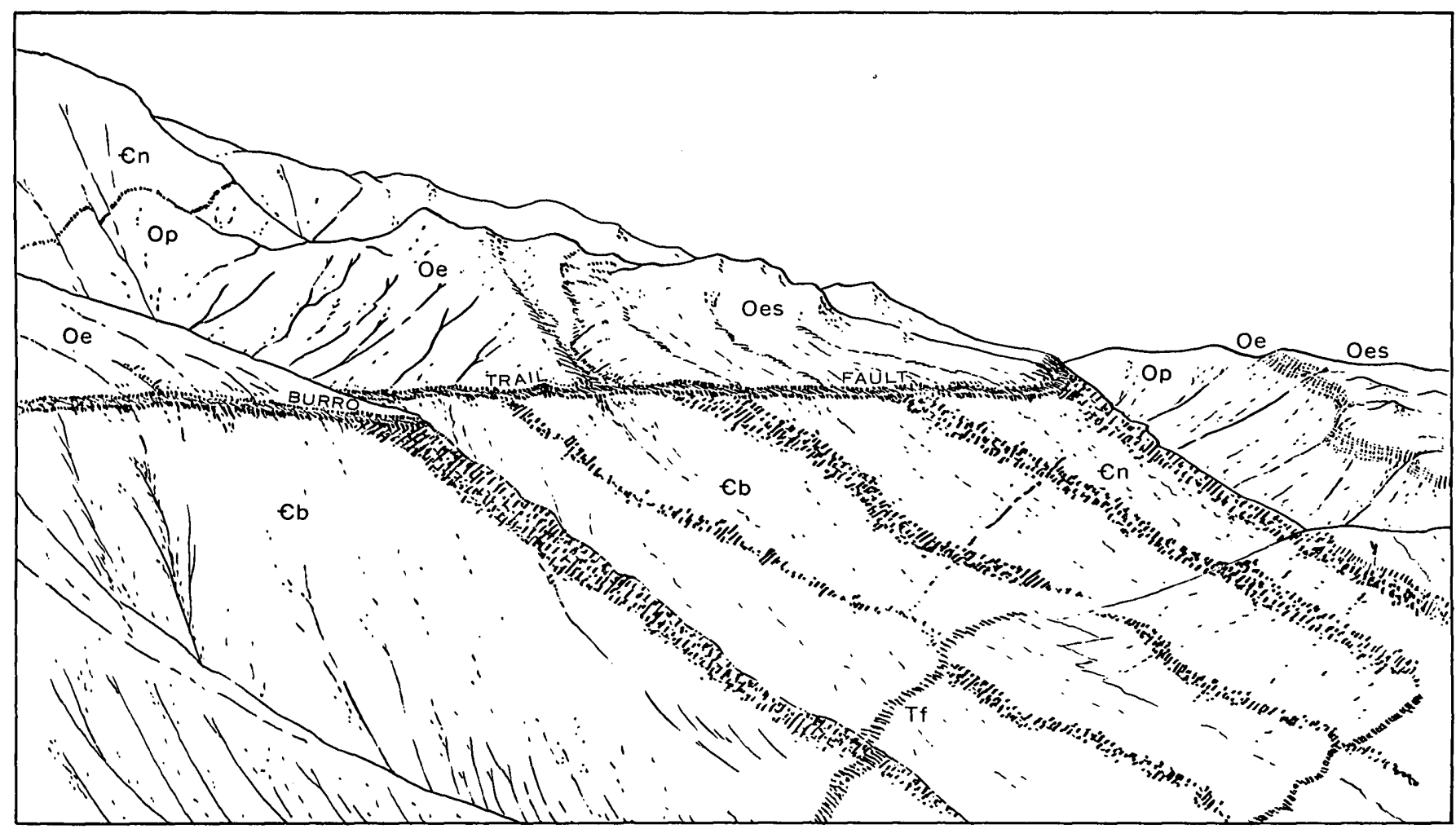

Finure 115.-Burro Trafl fault. View north between Death Valley and Trail Canyons. The upper plate in thls view is mostly Ordoviclan it has moved westward on top of Middle Cambrian. Cb, Bonanza King Formation; Cn, Nopah Formation; Op, Pogonip Group; Oe, Dureka Quartzite; Oos, Ely Springs Dolomite. Felsitic dikes (Tf) intrude the lower plate.

it, as the Grotto Canyon, Trellis Canyon, and Coral Reef faults branch upward from the Tucki Mountain thrust fault (fig. 109).

\section{BLACK MOUNTAINS FENSTER}

The Black Mountains expose the domed lower plate of the Amargosa thrust. Precambrian metamorphic rocks which form the lower plate are exposed for 20 miles northward from Mormon Point to the north end of the Badwater turtleback (pl. 3). The Amargosa complex exposed along the east foot of the Panamint Range north of Hanaupah Canyon (p. A129) represents the domed lower plate of the thrust on the west side of Death Valley, and probably is the westward continuation of the faulted anticlines represented by the Black Mountains.

The Amargosa thrust fault is exposed along the east side of the Black Mountains. The fault was first recognized and named in the Virgin Springs district a few miles southeast of Mormon Point (Noble, 1941).

At the north the formations at Artists Drive overlap and are faulted against the Precambrian metamorphic rocks that comprise the Badwater turtleback. The Black Mountains between the Virgin Springs district and the Badwater turtleback have been mapped by Drewes (1963).
The folding and faulting of the Black Mountains has produced three turtlebacks that have been described by Curry (1938b, 1954). Axes of the turtlebacks plunge northwestward into Death Valley at Mormon Point, Copper Canyon, and Badwater. These structures are oblique to the northward-trending block mountain, but they are reflected in Quaternary structures on the floor of Death Valley (p. A100). The folds seem to have continued to develop through the stage of block faulting.

In brief, the anticlinal uplift of the Black Mountains evidently began during middle Tertiary time by folding along the northwest-trending axes represented by the turtlebacks. Uplift continued into Qaternary time when block faulting along the faults trending northsouth further raised the mountain block (p. A116).

\section{FUNERAL MOUNTAINS FENSTMER AND FUNERAL MOUNTAINS KIIPPE}

The Funeral Mountains comprise two very different structural units. At the north is Precambrian Kingston Peak (?) Formation in an anticlinal uplift having a northwest-trending axis and representing a fenster between thrust plates in the Grapevine Mountains to the north and in the southern part of the Funeral Mountains (pl. 3). The fenster is a dissected turtleback 


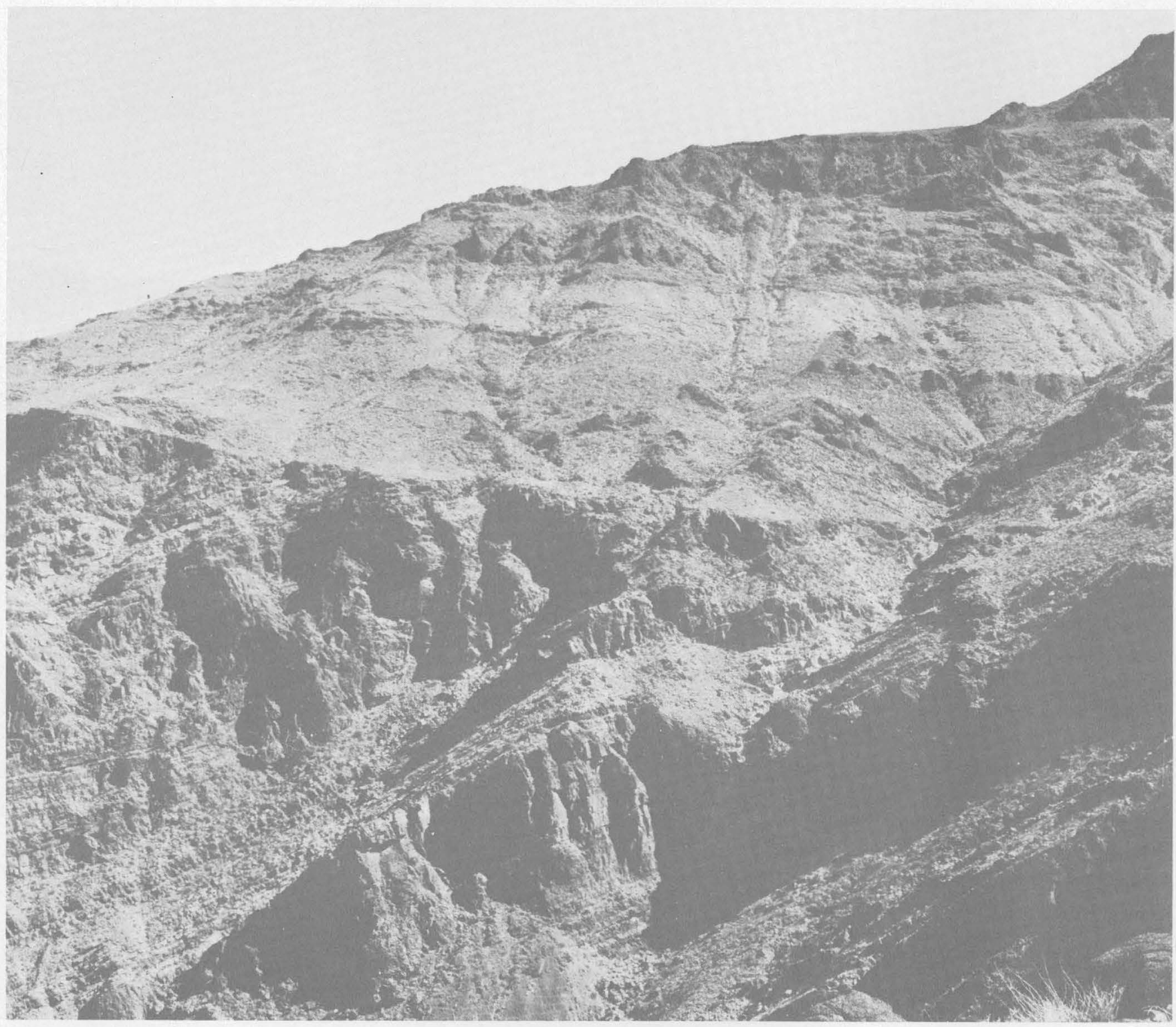

Frgure 116.-View of Burro Trail fault on the south side of Trail Canyon. Nopah Formation in the upper plate lies almost horizontally on the almost horizontal thrust fault. The lower plate is Bonanza King Formation.

much like the west side of Tucki Mountain. The turtleback surface approximately conforms to the dip of the Precambrian formations and to the dip of the thrust faults.

The northern end of the fenster is at Boundary Canyon, a mile north of the area mapped, where a thrust fault carries Lower Cambrian formations westward onto the Precambrian. The southwest edge of the fenster is at the Keane Wonder fault which trends northwest along the foot of the mountain and dips $25^{\circ}-40^{\circ}$ toward Death Valley. At Hells Gate the hanging wall is Lower Cambrian overlain by beds correlated with the Titus Canyon(?) Formation of Stock and Bode (1935), but from there southeast to the edge of the quadrangle the hanging wall consists of crushed and contorted beds of the Titus Canyon (?) Formation (fig. 118).

The age of this faulting is equivocal. At least part of the displacement is younger than the Titus Canyon (?) Formation, which is faulted against the Precambrian. But the structural geology is very similar to that along the west side of the Tucki Mountain turtleback where the Funeral Formation has overlapped and has been faulted against that turtleback surface (p. A114). Along the southwest side of the Funeral Mountains fenster the Titus Canyon(?) Formation is similarly faulted against both the upper and lower plates, and probably the thrust faulting occurred before the Titus Canyon (?) Formation was deposited. The Titus 


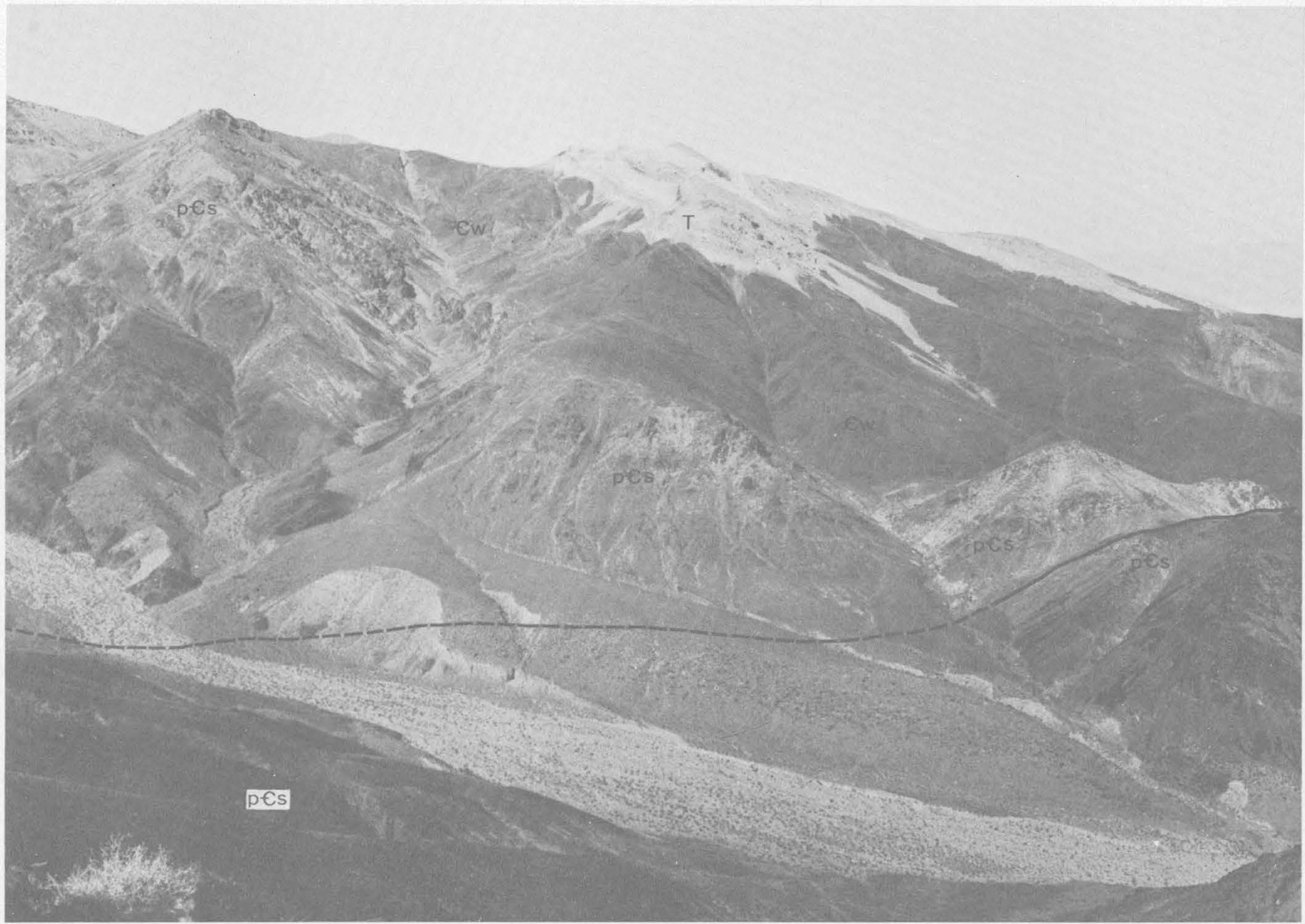

FIgURE 117.-View north across tear fault in Starvation Canyon. pCs, Stirling Quartzite; Cw, Wood Canyon Formation; T, Tertiary volcanic rocks faulted onto the Wood Canyon. This tear fault marks the southern end of the Burro Trail fault.

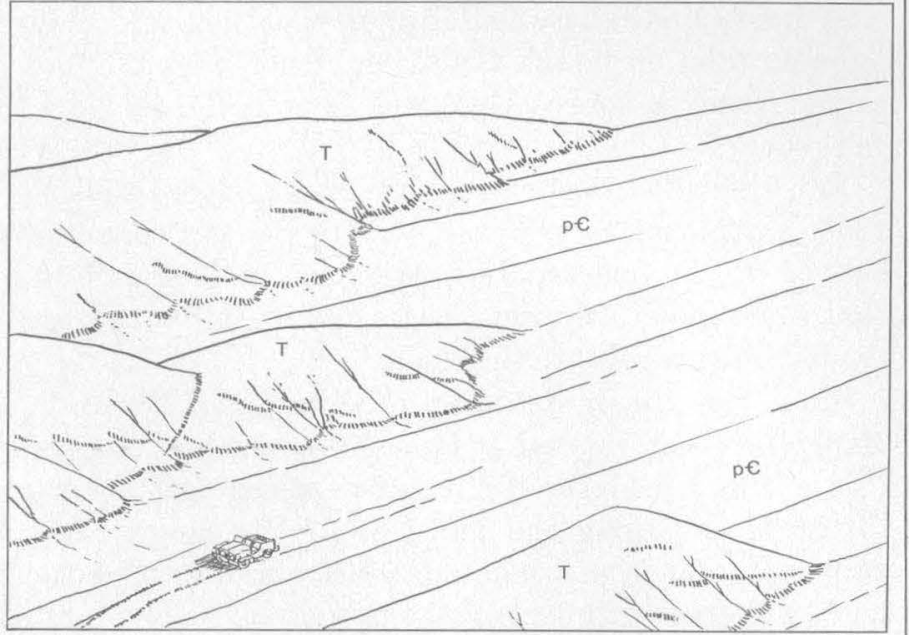

Figura 118.-View northwest along the turtleback fault surface marking the Keane Wonder fault. Crushed and contorted beds correlated with the Titus Canyon(?) Formation of Stock and Bode (1935), ( $T t)$, are faulted against the smooth turtleback surface on the Precambrian formations (p€).
Canyon(?) Formation may have overlapped both the upper plate and the turtleback. By this interpretation the faulting of the Titus Canyon(?) Formation against the turtleback along the Keane Wonder fault is attributable to renewed anticlinal folding of the fenster.

Volcanic rocks have been reported in thrust breccia along what is presumed to be the Keane Wonder fault east of this area (James Gilluly, oral commun., 1960). Some possible relationships between the thrust faulting and early volcanism have already been discussed ( $p$. A137). Whether the occurrence along the Keane Wonder fault is evidence of early volcanism or of late movement along the fault remains unresolved.

Along the southeast side of the Funeral Mountains klippe the overthrust plates are folded steeply downward toward Death Valley. East of Nevares Peak is a north-trending high-angle fault that drops Middle Cambrian formations down on the west against the Lower Cambrian and Precambrian (fig. 119).

At the north base of Nevares Peak, the Titus Canyon(?) Formation is downfaulted against a smooth 


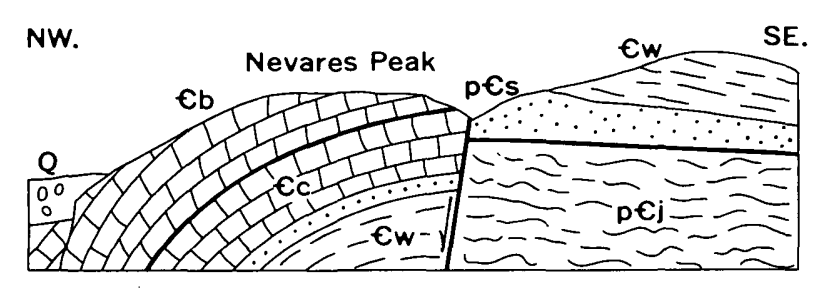

FIGURv 119.- Section of west end of Funeral Mountains klippe. Middle Cambrian formations at Nevares Peak are downfolded and downfaulted into Death Valley and downfaulted against Lower Cambrian and Precambrian formations on the

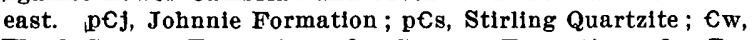
Wood Canyon Formation; $\epsilon_{c}$, Carrara Formation; $\epsilon_{b}$, Bonanza King Formation; $Q$, Quaternary gravel. Length of section, 3 miles; vertical scale not exaggerated.

fault surface on the Cambrian formations (p. A118). The downfolding and faulting of these formations into Death Valley seem to have antedated the Titus Canyon (?) Formation, but there was later movement, too, as there was along the Keane Wonder fault (fig. 118). Beds tentatively correlated with the Titus Canyon(?) Formation, on the southeast spur of the Funeral Mountains klippe, have the same dip as the underlying Paleozoic formations (C.S. Denny, oral commun., 1961); the dips in that part of the klippe are post-Titus Canyon(?), indicating eastward rotation of the upper plate like that in the Panamint Range.

The relationships at Nevares Peak can be interpreted as due to vertical movements with little or no horizontal displacement along the high-angle fault, but another interpretation could be that the Cambrian formations under Nevares Peak have moved laterally 2 miles northwestward from where these formations form the upper plate of the thrust and extend to the mountain front.

The Mont Blanco fault, on which there has been Pleistocene movement (p. A115), may extend northeastward through the Funeral Mountains klippe, for the Ryan quadrangle map, just to the east, show a conspicuous trough extending northeastward through that part of the Funeral Mountains to the Amargosa Desert.

\section{SOUTHERN GRAPEVINE MOUNTAINS}

The southern part of the Grapevine Mountains (pl. 3 ) is composed of Cambrian formations in one or more thrust plates resting on Kingston Peak (?) Formation and Noonday (?) Dolomite at the north end of the Funeral Mountains fenster. The thrust fault is arched anticlinally across the north end of the Funeral Mountains; the anticlinial axis trends about northwest.

At Hells Gate the thrust fault exposed in Boundary Canyon either is cut off by a high-angle fault, down to the west, or the thrust there dips steeply west. The structure is buried under Quaternary gravel, but it probably is like that at Nevares Peak (fig. 119) where the Funeral Mountains klippe is dragged steeply downward into Death Valley.

\section{ORIGIN OF THE STRUCTURAL FEATURES}

It still does not appear possible to offer a satisfactory explanation for the structural features in the Death Valley area. The structure of the thrust slices in the Amargosa thrust system is very similar to that of a group of landslid blocks (Mason, 1948). The similarities are so great that one feels the thrust must have moved by gravity (Sears, 1953). But none of these thrust slices has yet been found overriding surficial deposits attributable to an old land surface, so that the parts of the faults of the Amargosa system that are now exposed are presumed to be subsurface features.

We do not refer to these thrust slices as megabreccia (Longwell, 1951), but prefer to restrict that term to fractured blocks that can be related to an existing or a preexisting land surface like the clearly landslid megabreccia at the east foot of the Funeral Mountains (C.S. Denny, written commun., 1965). A similar distinction has been noted by Jahns and Engel (1950) and by Kupfer (1960). It is not possible, with present information, to relate the thrusts in the Panamint Range to a preexisting surface. Etymologically, of course, the range is a megabreccia but so, too, is any other broken-up part of the earth's crust.

The parent block from which the Tucki Mountain thrust plates were torn must have contained a virtually complete section of Paleozoic formations, one above the other in an orderly plateaulike structure, because 30,000 feet of Paleozoic formations are represented in the thrust blocks, and their dips are homoclinal to the east. The angle between the dipping beds and basal faults (such as the Tucki Mountain and Amargosa faults) is about $45^{\circ}$. The angle between the beds and the faults that branch upward from the basal ones approaches $90^{\circ}$. The homoclinal eastward dip of the beds and their angular relation to the faults could not have been obtained from a source that was complexly folded or faulted.

It is difficult to believe that there ever was a 30,000 foot escarpment facing west with a plateau that high east of it. It seems more likely that the thrust faults that are exposed represent segments of faults that extended downward into the crust.

Since the thrust faulting occurred, the Panamint Range has been rotated at least $20^{\circ}$ to the east, because this is the dip of the Tertiary eruptives that overlap thrust blocks along the east side of the range. It is supposed, then, that when the thrust faults formed they had an average dip westward of about $45^{\circ}$. The faults are concave upward, so that the dip would be flatter at depth and to the west and steeper upward and to the east. The dip of the formations in the upper plates need have been no more than a third as great as the 
present dip, somewhere around $5^{\circ}-10^{\circ} \mathrm{E}$. in the southern part of the range and $10^{\circ}-20^{\circ} \mathrm{E}$. in the northern part.

The rocks in the upper plates are spread over more area today than they were before they were faulted to their present position. That this is so can be determined by measuring the length of individual beds in individual fault slices (see fig. 119 or pl. 1). These show 4 miles of displacement within the upper plate, between the westernmost and easternmost thrust slices, and with less than 1 mile length of displaced beds. The deficiency can only be made up by imagining it all in a block to the west that has since been destroyed by erosion. The length of individual beds averages only about 20 percent of the length of the area across which they are spread.

Faults like those in the Amargosa system are numerous across the Death Valley subsection (Longwell, 1945), and they appear very similar to some reported at the edge of the Colorado Plateau (fig. 120) that apparently were derived from a plateaulike block.

There is considerable evidence suggesting that the thrust faulting was in some way related to the intrusion of the granites and to the volcanism, because igneous activity accompanied the faulting. This relationship is reported in the Silurian Hills too (Kupfer, 1960).

Many features of the Amargosa fault system are suggestive of the detachment thrust faults described by Pierce (1957) in Wyoming. The similarities are that the thrust blocks have moved onto older rocks along thrust faults that have no roots, and the geometry strongly suggests that gravity was important as a propelling force. Also, there is a suggestion that both may have been triggered by volcanic or other igneous activity. A major difference is that the detachment: thrusts in Wyoming must have moved onto a ground surface, but the faults of the Amargosa system seemingly extended downward. Despite this, the temptation is strong to attribute the turtleback fault surfaces to detachment thrusting and tectonic denudation.

Perhaps detachment thrusts developed from the upper plate of the Amargosa and other thrusts. The detached blocks could have moved off the areas now represented as fensters and be buried in the valleys under the fill. The block off the Funeral Mountains fenster would be composed of Paleozoic rocks and would have had to become detached before the Titus Canyon(?) Formation was deposited; a similar block of Paleozoic rocks off the west side of Tucki Mountain would have had to be detached before the Funeral Formation was deposited in Emigrant Wash. The blocks off the turtlebacks on the Black Mountains would be composed of chaotic blocks of volcanic and Paleozoic rocks.

The suggestion requires that all the detached blocks slid westward, but this direction of displacement would be favored in any case because the thrust faults converge westward. Slight movement eastward and valleyward of the Tucki Mountain klippe may be indicated by the increasingly steeper dips in the thrust plate eastward toward the base of the mountain. At the east foot of Tucki Mountain the Permian beds are overturned.

Such might be the explanation for the turtlebacks; we still need to try to explain the main Amargosa thrust.

In Late Cretaceous time the Death Valley subsection must have been high land contributing its share of sedi-

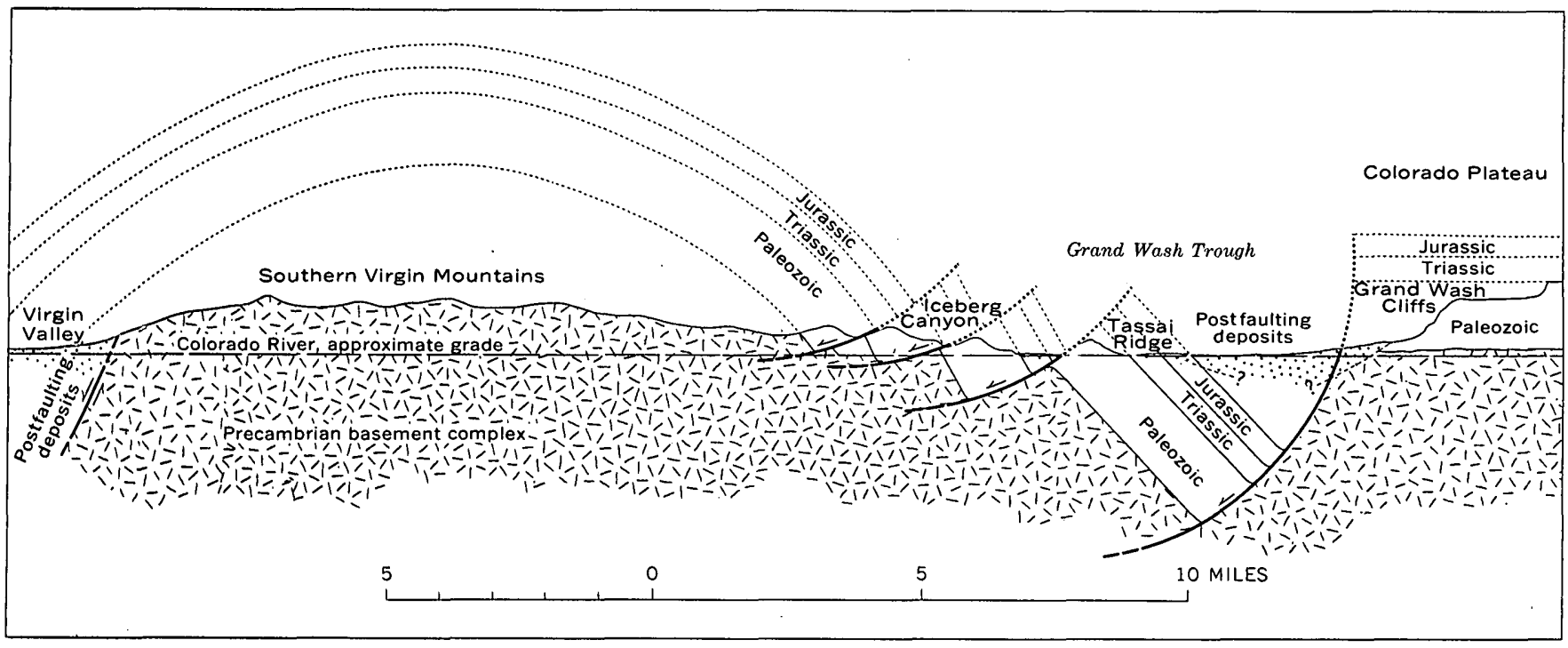

Figdrg 120.-Low-angle faults at west edge of the Colorado Plateau have displacements like those of the Amargosa thrust. From Longwell (1945). 
ments to the geosyncline that extended eastward a thousand miles from somewhere along the east edge of what is now the Great Basin. There may have been a narrow belt of folding and thrusting at the position of the Keystone and other thrust faults 60 miles east of Death Valley, but from there westward must have been a simple plateau-type structure that could serve as source for the homoclinal dips in the upper plates of the Amargosa thrust faults. Perhaps the Keystone thrust had not yet developed; it may be younger than has been assumed.

The high part of this ancient plateau may have been across the section that lies between Death Valley and the folded belt to the east. In Late Cretaceous time, while part of the granitic batholith was being formed to the west, the site of Death Valley was on the west flank of this broad arched highly elevated plateau. The imagined plateau had to be high enough to contribute sediments to the geosyncline to the east, and its structure had to be simple enough to provide homoclinal dips in the fault blocks moved westward from it.

Longwell suggested (1945) that the flat faults in the region were due to collapse of an anticline (fig. 120), but there do not seem to be adequate west flanks for such folds. The dips are homoclinal to the east and are largely, if not wholly, those attributable only to an eastern limb. We visualize, instead of an anticline, a series of plateaulike blocks all tilted towards the east. In effect, these would comprise a series of west-facing and east-dipping blocks, perhaps continuous with the Colorado Plateau. The blocks would be normal faults, downthrown to the west. The westernmost part of the Colorado Plateau, between the Grand Wash Cliffs and the Hurricane fault, may be such a block still attached to the plateau.

Assuming this approximates the structural setting from which the Death Valley subsection evolved, we visualize a high plateau surfaced with flat-lying Triassic and Jurassic sediments. But all the formations thicken greatly westward. Along the belt of the Keystone thrust the Triassic and Jurassic rocks are about 4,000 feet thick, the Paleozoic rocks are about 9,000 feet thick, and the late Precambrian sedimentary formations are thin or absent (Hewett, 1931, p. 9). In the Death Valley area the Triassic is 8,000 feet thick (p. A50), and there was an unknown thickness of additional Triassic and Jurassic above this. The Paleozoic formations are 30,000 feet thick, and the late Precambrian are at least 13,000 feet thick. In the 60 miles from the Keystone thrust to Death Valley the section thickens westward about threefold. The base of the sedimentary formations would have dipped west almost $10^{\circ}$.

If this ancestral plateau be divided into major blocks by fractures that extended to the base of the crust, the high block of the series may have been the one at the present area of high gravity values extending from Death Valley to the folded belt 60 miles to the east. The Keystone thrust would be one of the fractures. Its extension into the lower part of the crust could very well cause remobilization of the Precambrian granite which would become forcibly intruded upward along the fault and along the secondary fractures branching from it in the shallower levels of the crust. Such could well have been the history of the extensive Teutonia Quartz Monzonite which spread along thrust faults in the Ivanpah quadrangle (Hewett, 1956, p. 61-63).

A second major fracture extending to the base of the crust may have been at the west edge of a block where the present seismic and gravity data indicate that the base of the crust begins sloping steeply westward under the Sierra Nevada (p. A139). This would be along a line trending northwest about at the Panamint Range.

This fracture, too, could have been the cause or effect of remobilization of Precambrian granite in the deep levels of the crust and upward movement of that granite to form the intrusions that are clustered along that belt and to the west.

From this fracture west to the Sierra Nevada, the base of the crust, or layers deep within the crust, slope westward perhaps as steeply as $15^{\circ}$. We already have noted a $10^{\circ}$ westward dip at the base of the sedimentary part of the crust. With such slopes, the structural setting would seem to be favorable for westward sliding on fractures as they became lubricated by igneous activity.

\section{SUMMARY OF THE STRUCTURAL FEATURES}

The principal structural features of Death Valley were developed during late Mesozoic and Cenozoic time. There had been structural deformation during late Precambrian, Permian, and Permian and Triassic time, but little is known about the kind and extent of the ancient structures that were developed. The late Mesozoic and Cenozoic structures are of four principal kinds and developed at four principal stages:

1. Stage 1 was in Cretaceous, or possibly Jurassic time. The area is visualized as being a high plateau that became fragmented by northwest-trending rifts extending to, or nearly to, the base of the crust where granitic intrusions rose along the rifts. The base of the crust slopes west. As the lower parts of the rifts, downslope, became lubricated, the blocks began sliding westward. This began the Amargosa thrust system; later the thrusting was accompanied by folding.

2. Stage 2 was in early Tertiary time. During this stage the granitic intrusions reached the upper 
levels of the crust, spread along the thrust faults, and the thrust plates above the intrusions became domed.

3. Stage 3 was in middle Tertiary time. During this stage folding continued, the igneous activity developed into volcanism. Blocks of the upper plates of the thrust faults became detached, slid off the uplifts, and left the lower plates exposed.

4. Stage 4 is the period of Basin and Range type block faulting; this began in middle Tertiary time and is continuing.

Thrust faults of the first stage strike northerly or northwesterly and involve the thrusting (sliding) of younger rocks westward onto older ones. The folds that developed during the latter part of this stage and during stages 2 and 3 are asymmetrical with their steep flanks facing west. Fold axes trend northwest; all the lesser ones plunge northwest. The axes of these lesser folds are arranged en echelon in northward-trending belts.

The granitic intrusions that were injected during stage 2 spread along the thrust faults. The long axes of the intrusions and of the anticlines over them parallel the strike of the thrust faults.

During stage 3 folding continued, and probably there was continued thrust frulting. During this stage, though, blocks of the upper plates became detached from the steep west flanks of the folds, slid into the synclinal valleys, and left the lower plate rocks exposed as westward-sloping turtleback surfaces.

The earliest block faults, illustrated by those of the Furnace Creek fault zone, trend northwest and are downthrown on the southwest side. These faults fur. ther accentuate the asymmetry of the northwest-trending folds as if the folding of the steep flanks progressed to the point of fracturing. This faulting probably began before the deposition of the Titus Canyon(?) Formation of Stock and Bode (1935), but we cannot be sure how enrly these synclinal basins of deposition became faulted. However, the faulting and the downfolding of the northwest-trending synclines has continued to the present.

Bloak faulting during Quntermary time developed the north-south trough represented by Death Valley, but some of the individual faults outlining the tronch mav trend northwest and be arranged en echelon like the steep flnnks of the folds to which they seem related. The plopabuties are that Denth Valley is as low today as it has ever been, and that the valley floor has been sinking in altitude as well as in relation to the adjoining mountains. There is a little evidence, not at all satisfactory, that Death Valley drained southward in middle or late Pleistocene time (p. A65).

\section{REFERENCES}

Axelrod, D. I., 1940, A record of Lyonothamus in Death Valley, California : Jour. Geology, v. 48, p. 526-531.

Axelrod, D. I., and Ting, W. S., 1960, Late Pliocene floras east of the Sierra Nevada: California Univ., Dept. Geology Sci. Bull., v. 39, no. 1, p. 1-118.

Bailey, G. E., 1902, The saline deposits of California : California Mining Bur. Bull. 24, 216 p.

Bateman, P. C., 1958, Characteristics of some eastern Sierra Nevada granites [California] [abs.] : Washington Acad. Sci. Jour., v. 48, no. 4, p. 132-133.

1961, Granitic formations in the east-central Sierra Nevada near Bishop, California: Geol. Soc. America Bull., v. 72, p. 1521-1537.

Berg, J. W., Jr., Oook, K. L., Narans, H. D., and Dolan, W. M., 1960 , Seismic investigations of crustal structure in the eastern part of the Basin and Range province: Seismol. Soc. America Bull., v. 50, p. 511-535.

Blackwelder, Eliot, 1933, Lake Manly, an extinct lake of Death Valley : Geog. Rev., v. 23, no. 3, p. $464-471$.

1948, Historical significance of desert lacquer [abs.]: Geol. Soc. America Bull., v. 59, p. 1367.

- 1954, Pleistocene lakes and drainage in the Mojave region, southern California, [pt.] 5 in Chap. 5 of Jahns, R. H., ed., Geology of southern California : California Div. Mines Bull. 170, p. $35-40$

Blackwelder, Eliot, and Ellsworth, E. W., 1936, Pleistocene lakes of the Afton Basin, California : Am. Jour. Sci. 5th ser., v. 31 , no. 186 , p. $453-463$.

Bowen, O. E., 1954, Geology and mineral deposits of the Barstow quadrangle, San Bernardino County, California : California Div. Mines Bull. 165, 208 p.

Burckhardt, Carlos, 1906, Géologie de la Sierra de Mazapil et Santa Rosa [Mexico] : Internat. Geol. Cong., 10th, Mexico 1906, Guide Excursions 26, $40 \mathrm{p}$.

Carder, D. S., and Bailey, L. F., 1958, Seismic wave travel times from nuclear explosions: Seismol. Soc. America Bull., v. 48 , no. 4 , p. 377-398.

Clements, T. D., and Clements, Lydia, 1953, Evidence of Pleistocene man in Death Valley, California: Geol. Soc. America Bull., v. 64, p. 1189-1203.

Cloos, Ernest, 1932, Is the Sierra Nevada batholith a batholith?: Washington Acad. Sci. Jour., v. 22, p. 319-320.

1933. Structure of the Sierra Nevada batholith : Internat.

Geol. Cong., 16th, Washington 1932, Guidebook 16, p. 40-45. 1935, Mother Lode and Sierra Nevada batholiths: Jour. Geology, v. 43, no. 3, p. 225-249.

1936, Der Sierra-Nevada-Pluton in Californien: Neues Jahrb., Beilage-Band 76. no. 3, pt. B. p. 355-450.

Cloos, Hans, 1921. Der Mechanismus tiefvulkanischer Vorgänge: Branunschweig, Vieweg \& Sohn, $95 \mathrm{p}$.

Oornwall, H. R., and Kleinhampi, is. J., Ijviz, Geology of the Bare Mountain auadrangle, Nevada : U.S. Geol. Survey Geol. Quad, Map CQ-157.

Coville, F. V., 1893, Botany of the Death Valley Expedition: U.S. Dept. Agriculture, Contr. U.S. Natl. Herbarium, v. 4, 363 p.

Curry, H. D., 1938a, Strike-slip faulting in Death Valley, CalIfornia [abs.] : Geol. Soc. America Bull., v. 49, p. 1874-1875. - 1938b, "Turtleback" fault surfaces in Death Valley, Californta [abs] : Geol. Soc. America Bull., v. 49 p. 1875. 1939, Tertiary and Pleistocene mammal and bird tracks in Death Valley [abs.]: Geol. Soc. America Bull., v. 50, p. 1971-1972. 
Curry, H. D., 1954, Turtlebacks in the central Black Mountains, Death Valley, California, [pt.] 7 in Ohap. 4 of Jahns, R. H., ed., Geology of southern California : California Div. Mines Bull. 170, p. 53-59.

Davis, W. M., 1925, The Basin Range problem : Natl. Acad. Sci. Proc., v. 11, no. 7, p. 387-392.

1926, Biographical memoir of Grove Karl Gilbert, 18431918: Natl. Acad. Sci. Mem., v. 21, 5th mem., 303 p.

Diment, W. H., Stewart, S. W., and Roller, J. C., 1961, Crustal structure from the Nevada Test Site to Kingman, Arizona, from selsmic and gravity observations: Jour. Geophys. Research, v. 66, p. 201-214.

Drewes, Harald, 1959, Turtleback faults of Death Valley-a reinterpretation: Geol. Soc. America Bull., v. 70, p. 14971508.

- 1963, Geology of the Funeral Peak quadrangle, California on the east flank of Death Valley: U.S. Geol. Survey Prof. Paper 413, $78 \mathrm{p}$.

Dutton, C. E., 1880, Geology of the high plateaus of Utah: U.S. Geog. and Geol. Survey Rocky Mtn. Region (Powell), 307 p.

Baton, J. P., 1959, A portable water-tube tiltmeter: Seismol. Soc. America Bull., v. 49, p. 301-316.

Easton, W. H., chm., and others, 1953, Revision of stratigraphic units in Great Basin : Am. Assoc. Petroleum Geologists Bull., v. 37, p. 143-151.

Engel, C. G., and Sharp, R. P., 1958, Chemical data on desert varnish [California]: Geol. Soc. America Bull., v. 69, p. 487-518.

Ferguson, H. G., 1929, The mining districts of Nevada: Econ. Geology, v. 24, p. 115-148.

Ferguson, H. G., Muller, S. W., and Cathcart, S. H., 1954, Geology of the Mina quadrangle, Nevada: U.S. Geol. Survey Geol. Quad. Map GQ-45, scale $1: 125,000$.

Gale, H. S., 1914, Notes on the Quaternary lakes of the Great Basin, with special reference to the deposition of potash and other salines: U.S. Geol. Survey Bull. 540, p. 339-406.

Gilbert, C. M., 1941, Late Tertiary geology southeast of Mono Lake, California : Geol. Soc. America Bull,, v. 52, p. 781-815.

Gilbert, G. K., 1875, Report on the geology of portions of Nevada, Utah, California, and Arizona, examined in the years 1871 and 1872: U.S. Geog. and Geol. Surveys W. 100th Meridian (Wheeler), v. 3, p. 17-187.

- 1876, The Colorado Plateau province as a field for geological study: Am. Jour. Sci., 3d ser., v. 12, 16-24, 85-103.

— 1890, Lake Bonneville: U.S. Geol. Survey Mon. 1, 438 p.

Grose, L. T., 1959, Structure and petrology of the northeast part of the Soda Mountains, San Bernardino County, California : Geol. Soc: America Bull., v. 70, p. 1509-1547.

Hack, J. T., 1941, Dunes of the western Navajo country : Geog. Rev., v. 31, no. 2, p. 240-263.

1942, The changing environment of the Hopi Indians of Arizona: Harvard Univ., Peabody Mus. Am. Archeol. and Ethnol. Papers, v. 35, no. 1, 85 p.

Hague, Arnold, 1883, Abstract of report on the geology of the Eureka district, Nevada : U.S. Geol. Survey, 3d Ann. Rept., p. $237-290$.

1892, Geology of the Eureka district, Nevada : U.S. Geol. Survey Mon. 20, 419 p. ; atlas.

Hall, W. E., and MacKevett, E. M., 1958, Economic geology of the Darwin quadrangle, Inyo County, California: California Div. Mines Spec. Rept. 51, 73 p.

Hazzard, J. C., 1937a, Lower Triassic rocks in San Bernardino County, California [abs.]: Geol. Soc. America Proc. 1936, p. 329 . 1937b, Paleozoic section in the Nopah and Resting Springs Mountains, Inyo County, California : California Jour. Mines and Geology, v. 33, p. 273-339.

Hazzard, J. C., 1951, Revision of Devonian and Carboniferous sections, Nopah Range, Inyo Oounty, California [abs.] : Geol. Soc. America Bull., v. 62, p. 1503.

Hazzard, J. C., and Mason, J. F., 1936, Middle Cambrian formations of Providence and Marble Mountains, California : Geol. Soc. America Bull., v. 47, p. 229-240.

Hewett, D. F., 1931, Geology and ore deposits of the Goodsprings quadrange, Nevada : U.S. Geol. Survey Prof. Paper 162, 172 p. 1940, New formation names to be used in the Kingston Range, Ivanpah quadrangle, California: Washington Acad. Sci. Jour., v. 30, no. 6, p. 239-240.

1955, Structural features of the Mojave Desert region [California], in Poldervaart, Arie, ed., Crust of the eartha symposium: Geol. Soc. America Spec. Paper 62, p. 377-390.

1956, Geology and mineral resources of the Ivanpah quadrangle, California and Nevada: U.S. Geol. Survey Prof. Paper 275, 172 p.

Hintze, L. F., 1949, Ordovician system of Utah, in Hansen, G. H., and Bell, M. M., The oil and gas possibilities of Utah : Utah Geol. and Mineralog. Survey, p. 38-54.

1951, Lower Ordovician detailed stratigraphic sections for western Utah: Utah Geol. and Mineralog. Survey Bull. 39, $100 \mathrm{p}$.

Hopper, R. H., 1947, Geologic section from the Sierra Nevada to Death Valley, Oalifornia: Geol. Sec. America Bull., v. 68, p. $393-432$.

Hunt, A. P., 1960, Archeology Death Valley salt pan, California : Utah Univ. Anthropol. Papers, 47, 313 p., 87 figs.

Hunt, O. B., 1953, Pleistocene-Recent boundary in the Rocky Mountain region: U.S. Geol. Survey Bull. 996-A, p. 1-25. 1956, Cenozoic geology of the Colorado Plateau : U.S. Geol. Survey Prof. Paper 279, 99p.

1960, Some observations on geologic mapping by helicopter : GeoTimes, v. 4, no. 7, p. 12-14, 40.

1965, Plant ecology, Death Valley, California, with $a$ section on Distribution of fungi and algae, by Charles $B$. Hunt and L. W. Durrell : U.S. Geol. Survey Prof. Paper 509 (in press).

Hunt, C. B., and others, 1965, Hydrologic basin, Death Valley, California : U.S. Geol. Survey Prof. Paper 494-B (in press).

Hunt, C. B., assisted by Averitt, Paul, and Miller, R. L., 1953, Geology and geography of the Henry Mountains region, Utah : U.S. Geol. Survey Prof. Paper 228, 234 p.

Hunt, C. B., and Robinson, T. W., 1960, Possible interbasin circulation of ground water in the southern part of the Great Basin, in Short papers in the geological sciences: U.S. Geol. Survey Prof. Paper 400-B, p. B273-B274.

Huntington, Ellsworth, 1907, Some characteristics of the glacial period in nonglaciated regions: Geol. Soc. America Bull., v. 18, p. 351-388.

Jahns, R. H., and Engel, A. E. J., 1950, Chaotic breccias in southern California ; tectonic or sedimentary? [abs.] : Geol. Soc. America Bull., v. 61, p. 1474.

Jennings, C. W., 1958, Geologic map of California, Death Valley sheet; Olaf P. Jenkins ed.: California Div. Mines, scale $1: 250,000$.

Johnson, B. K., 1957, Geology of a part of the Manly Peak quadrangle, southern Panamint Range, California: California Univ. Dept. Geol. Sci., v. 30, no. 5, p. 353-423. 
Johnson, M. S., and Hibbard, D. E., 1957, Geology of the Atomic Energy Commission Nevada proving grounds area, Nevada : U.S. Geol. Survey Bull. 1021-K, p. 333-384.

Keyes, C. R., 1909, Erosional origin of the Great Basin ranges: Jour. Geology, v. 17, p. 31-37.

King, Clarence, 1878, Systematic geology: U.S. Geol. Explor. 40th Parallel (King), v. 1, 803 p.

Kirk, B., 1933, The Eureka quartzite of the Great Basin region: Am. Jour. Sci., 5th ser., v. 26, p. 27-44.

Knopf, A., 1918, A geologic reconnaissance of the Inyo Range and the eastern slope of the Sierra Nevada, California, with a section on the stratigraphy of the Inyo Range, by Edwin Kirk : U.S. Geol. Survey Prof. Paper 110, 130 p.

1929, The Mother lode system of California: U.S. Geol. Survey Prof. Paper 157, 88 p.

Kupfer, D. H., 1960, Thrust faulting and chaos structure, Silurian Hills, San Bernardino County, California : Geol. Soc. America Bull., v. 71, p. 181-214.

Lawson, A. O., 1915, The epigene profiles of the desert: California Univ., Dept. Geology Bull., v. 9, p. 23-48.

Leathen, W. W., McIntyre, L. D., and Braley, S. A., 1951, A medium for the study of the bacterial oxidation of ferrous iron: Science, new ser., v. 114, p. 280-281.

Lindgren, Waldemar, 1915, The igneous geology of the Cordilleras and its problems, in Problems of American geology: New Haven, Conn., Yale Univ., Silliman Found., p. 234-286.

Longwell, C. R., 1926, Structural studies in southern Nevada and western Arizona: Geol. Soc. America Bull., v. 37, p. 551583.

- 1928, Geology of the Muddy Mountains, Nevada, with a section through the Virgin Range to the Grand Wash Cliffs, Arizona : U.S. Geol. Survey Bull. 798, 152 p.

- 1945, Low-angle normal faults in the Basin-and-Range Province: Am. Geophys. Union Trans., v. 26, pt. 1, p. 107-118. 1949, Structure of the northern Muddy Mountain area, Nevada : Geol. Soc. America Bull., v. 60, p. 923-967.

- 1951, Megabreccia developed downslope from large faults : Am. Jour. Sci., v. 249, no. 5, p. 343-355.

Louderback, G. D., 1904, Basin Range structure of the Humboldt region [Nevada] : Geol. Soc. America Bull., v. 15, p. 289-346.

Mabey, D. R., 1960, Regional gravity survey of part of the Basin and Range province, in Short papers in the geological sciences: U.S. Geol. Survey Pror. Paper 400-B, p. B283-B285.

McAllister, J. F., 1952, Rocks and structure of the Quartz Spring area, northern Panamint Range, California : California Div. Mines Spec. Rept. 25, 38 p.

McAllister, J. F., 1955, Geology of mineral deposits in the Ubehebe Peak quadrangle, Inyo County, California: California Div. Mines Spec. Rept. 42, $63 \mathrm{p}$.

- 1956, Geology of the Ubehebe Peak quadrangle, California : U.S. Geol. Survey Geol. Quad. Map CQ-95.

McCulloh, T. H., 1954, Problems of the metamorphic and igneous rocks of the Mojave Desert, [pt.] 2 in Chap. 7 of Jahns, $\mathbf{R}$. H., ed., Geology of southern California: California Div. Mines Bull. 170, p. 13-24.

Mackin, J. Hoover, 1947, Some structural features of the intrusions in the Iron Springs district [Utah] : Utah Geol. Soc. Guidebook no. 2, 62 p.

- 1954, Geology and iron ore deposits of the Granite Mountain area, Iron County, Utah: U.S. Geol. Survey Mineral Inv. Field Studies Map MF-14, scale, $1: 12,000$.

1960, Structural significance of Tertiary volcanic rocks southwestern Utah : Am. Jour. Sci., v. 258, p. 81-131.
Mason, J. F., 1948, Geology of the Tecopa area, southeastern California: Geol. Soc. America Bull., v. 59, p. 333-352.

Matthes, F. E., 1930, Geologic history of the Yosemite Valley: U.S. Geol. Survey Prof. Paper 160, 137 p.

Maxson, J. H., 1950, Physiographic features of the Panamint Range, California : Geol. Soc. America Bull., v. 61, p. 99-114.

Means, T. H., 1932, Death Valley : San Francisco, Calif., Sierra Club Bull., v. 17, p. 67-76.

Merriam, C. W., and Hall, W., 1957, Pennsylvanian and Permian rocks of the southern Inyo Mountains, California: U.S. Geol. Survey Bull. 1061-A, p. 1-15.

Miller, R. R., 1948, The cyprinodont flshes of the Death Valley system of eastern Callfornia and southwestern Nevada: Michigan Univ. Mus. Zoology, Misc. Pub. 68, 155 p.

Murphy, F. M., 1930, Geology of the Punamint silver district, California: Econ. Geology, v. 25, no. 4, p. 305-325.

1932, Geology of a part of the Panamint Range, California : California Jour. Mines and Geology, v. 28, p. 329-356.

Noble, L. F., 1926a, Note on a colemanite depasit near Shoshone, California, with a sketch of the geology of a part of Amargosa Valley : U.S. Geol. Survey Bull. t85-D, p. 63-75.

1926b, The San Andreas rift and some other active faults in the desert region of southeastern California: Carnegie Inst. Washington Year Book no. 25, p. 415-428.

1934, Rock formations of Death Valley, California: Science, new ser., v. 80, no. 2069, p. 173-178.

1941, Structural features of the Virgin Spring area, Death Valley, California : Geol. Soc. America Bull., v. 52, p. 941 1000.

Noble, L. F., and Wright, L. A., 1954, Geology of the central and southern Death Valley region, California, [pt.] 10 in Chap. 2 of Jahns, R. H., ed., Geology of southern California : California Div. Mines Bull. 170, p. 143-160.

Nolan, T. B., 1929, Notes on the stratigraphy and structure of the northwest portion of Spring Mountain, Nevada: Am. Jour. Sci., 5th ser., v. 17, p. 461-472.

1943. The Basin and Range province in Utah, Nevada, and California : U.S. Geol. Survey Prof. Paper 197-D, p. 141196.

Nolan, T. B., Merriam, C. W., and Williams, J. S., 1956, The stratigraphic section in the vicinity of Eureka, Nevada: U.S. Geol. Survey Prof. Paper 276, 77 p.

Palmer, A. R., 1956, The Cambrian system of the Great Basin in western United States, in Rodgers, John, ed., El Sistema Cambrico, su paleogeografia y el problema de su basesymposium, Pt. 2 : Internat. Geol. Cong., 20th, Mexico 1956, p. $663-681$.

Palmer, A. R., and Hazzard, J. C., 1956, Age and correlation of Cornfield Springs and Bonanza King formations in southeastern California and southern Nevada: Am. Assoc. Petroleum Geologists Bull., v. 40, no. 10, p. 2494-2499.

Pettijohn, F. J., 1949, Sedimentary rocks : New York, Harper \& Bros., $526 \mathrm{p}$

Pierce, W. G., 1957, Heart Mountain and South Fork detachment thrusts of Wyoming: Am. Assoc. Petroleum Geologists Bull., v. 41, no. 4, p. 591-626.

Pollard, A. L., and Smith, P. B., 1951, The absorption of manganese by algal polysaccharides: Science, new ser., v. 114, p. $413-414$

Press, Frank, 1960, Crustal structure in the California-Nevada region : Jour. Geophys. Research, ₹. 65, no. 3, p. 1039-1051.

Rich, J. L., 1935, Origin and evolution of rock fans and pediments: Geol. Soc. America Bull., v. 46 no. 6, p. 999-1024. 
Roosma, Aino, 1958, A climatic record from Searles Lake, California : Science, v. 128, no. 3326, p. 716.

Russell, I. C., 1885, Geological history of Lake Lahontan, a Quaternary lake of northwestern Nevada: U.S. Geol. Survey Mon. 11, 288 p.

1889, The Quaternary history of Mono Valley, California : U.S. Geol. Survey Ann. Rept., v. 8, p. 261-394.

Sears, D. H., 1953, Origin of Amargosa chaos, Virgin Spring area, Death Valley, California: Jour. Geology, v. 61, p. 182-186.

Sherlock, D. G., and Hamilton, W. B., 1958, Geology of the north half of the Mount Abbot quadrangle, Sierra Nevada, California: Geol. Soc. America Bull., v. 69, p. 1245-1267.

Shimer, H. W., and Shrock, R. R., 1944, Index fossils of North America : New York, John Wiley \& Sons, 837 p.

Spurr, J. E., 1901, Origin and structure of the Basin ranges: Geol. Soc. America Bull., v. 12, p. 217-270.

Stock, Chester, and Bode, F. D., 1935, Occurrence of lower Oligocene mammal-bearing beds near Death Valley, California : Natl. Acad. Sci. Proc., v. 21, no. 10, p. 571-579.

Temple, K. L., and Koehler, W. A., 1954, Drainage from bituminous coal mines: West Virginia Univ. Bull., Eng. Expt. Sta. Research Bull. 25, $35 \mathrm{p}$.

U.S. Geological Survey, 1964, The Hebgen Lake, Montana, earthquake of August 17, 1959 : U.S. Geol. Survey Prof. Paper 435, $242 \mathrm{p}$.
Wasserburg, G. J., Wetherill, G. W., and Wright, L. A., 1959, Ages in the Precambrian terrane of Death Valley, California : Jour. Geology, v. 67, no. 6, p. 702-708.

Westgate, L. G., and Knopf, A., 1932, Geology and ore deposits of the Pioche district, Nevada: U.S. Geol. Survey Prof. Paper 171, $79 \mathrm{p}$.

Wheeler, H. E., 1947, Base of the Cambrian system: Jour. Geology, v. 55, p. 153-159.

Woodford, A. O., 1925, The San Onofre breccia; its nature and origin: California Univ., Dept. Geol. Sci. Bull., v. 15, no. 7, p. $159-280$.

Woollard, G. P., 1958, Areas of tectonic activity in the United States as indicated by earthquake epicenters: Am. Geophys. Union Trans., v. 39, no. 6, p. 1135-1150.

Wright, L. A., 1952, Geology of the Superior talc area, Death Valley, California : California Div. Mines Specs. Rept. 21, $22 \mathrm{p}$.

1954, Geology of the Alexander Hills area, Inyo and San Bernardino Counties, Map Sheet no. 17 of Jahns, R. H., ed., Geology of southern California : California Div. Mines Bull. 170.

Wright, L. A., Chesterman, C. W., and Norman, L. A., Jr., 1954, Occurrence and use of nonmetallic commodities in southern California [pt.] 7 in Chap. 8 of Jahns, R. H., ed., Geology of southern. California : California Div. Mines Bull. 170, p. 59-74. 


\section{INDEX}

[Italic page numbers indicate major references]

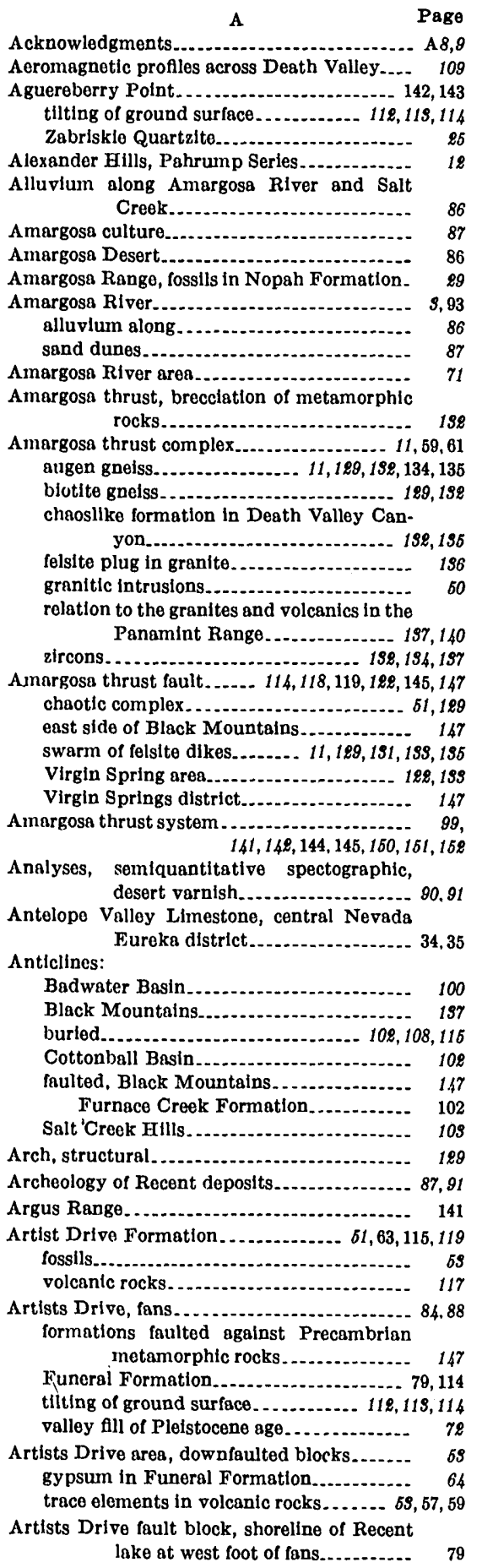

Page Funeral Formation........................ 63,114 Augen gneiss, Amargosa thrust complex ..... 11, $129,152,134,135$ Amargosa thrust complex, trace elements. 129 , B

Badwater, drill hole near................. 72 Badwater Basin.................. 100, 101, 102, 108, 116 aeromagnetic profle...................... 110 anticlines...................-. 100

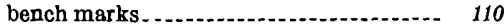
gr8vity low............................ 107, 108 Recent lake sand dunes. valley fill of Pleistocene age...............- 78

Badwater turtleback of Precambrian gneiss_- 51 , $104,157,147$

Bare Mountain, Nev., Carrara Formation.-.- 25 Pogonip Group...

Basalt dikes, Emigrant Canyon

Beatty area, Ely Springs Dolomite...........- 36 Eureka Quartzite........................... 36

Beatty Junction gravel bar of late Pleistocene Lake Manly. $\quad 69$

Beck Spring Dolomite..................... 12,13 description ................................ 14 Panamint Range 14 Bench marks, changes in altitudes........... 110 Bennetts Well Berdan, J. M., quoted......................... 41 Biotite gneiss in Amargosa thrust complex.. 199, 192 trace elements........................... 129, 140

Bird Spring Formation ................ 49,50

Black Mountains................ $\$, 63,65,70,115,119$ Amargosa thrust fault along east side..--- 147 anticlines.................................... 197 faulted.

borate deposits debris avalanche of Precambrian rocks...- $\quad 69$ Funeral Formation in fault blocks at foot. 114 Furnace Creek Formation............... $\quad 59$ gravel fans................................ 87, 106 hanging valleys at front of ................ 104 Precambrian metamorphic rocks, Bouguer gravity-anomaly values............

Precambrian rocks. crystalline basement................. mapping Recent fault scarp along foot.............. 110 damage caused by erosion. .......... 97,100 $\begin{array}{cr}\text { damage caused by erosion. } \ldots \ldots \ldots & 97,100 \\ \text { Tertiary formations. . . . } & 51\end{array}$ trace elements in Presambrian gneiss.... 12 turtleback ridges........................ 100 uplift............................. 117,118,119,147 Black Mountains fenster..................... 147 Blackwater Wash . ..................... 88, 123, 196

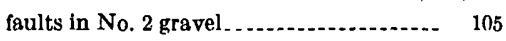
stratigraphic section of Wood Canyon Formation......................... Zabriskie Quartzite................................

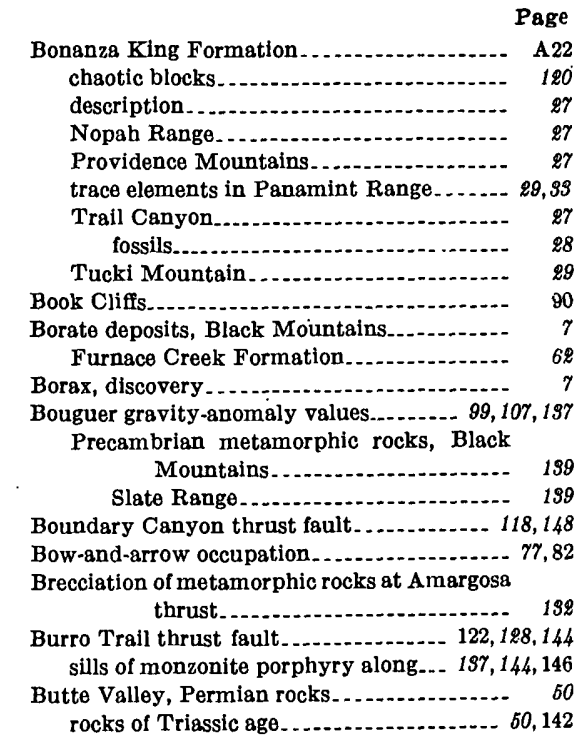

C

Caliche, calcium carbonate. ................... 79,8 calcium sulfate Cambrian formations.......................... 195

Cambrian System........................... $\quad 2 Q$

Carrara Formation.

Bare Mountain, Nev

Cossil collections

fossils.

Funeral Mountains.

Panamint Range.

stratigraphic section in Funeral Mountains in Echo Canyon ............ 26

trace elements.......................... $26,28,29$

trilobite-trash beds........................ 26

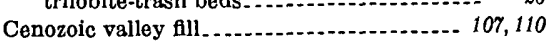

Central Nevada Eureka district.............. 34

Chaos, Virginia Springs district ......- $11,51,129,195$ $\begin{array}{ll}\text { Chaotic complex along Amsrgosa thrust fault. } \quad 51, & 129\end{array}$

Cleavage, fracture ............................... 144

Climatic changes during late Pleistocene time............................. 97

Coffin Canyon fan..................... 88

Colorado Plateau, desert varnish . .

fault block........................... 152

fauits................. 151

intrusions. ............ 120,121,182, 129, 126,188

Composite section of Johnnie Formation in Six Spring Canyon and Johnson Canyon .............................

Confidence Hills, gravity-anomaly values..... 108

Contact between Crystal Spring Formation and Noonday Dolomite.

Contact between Kingston Peak Formation and underlying crystalline rocks.. 


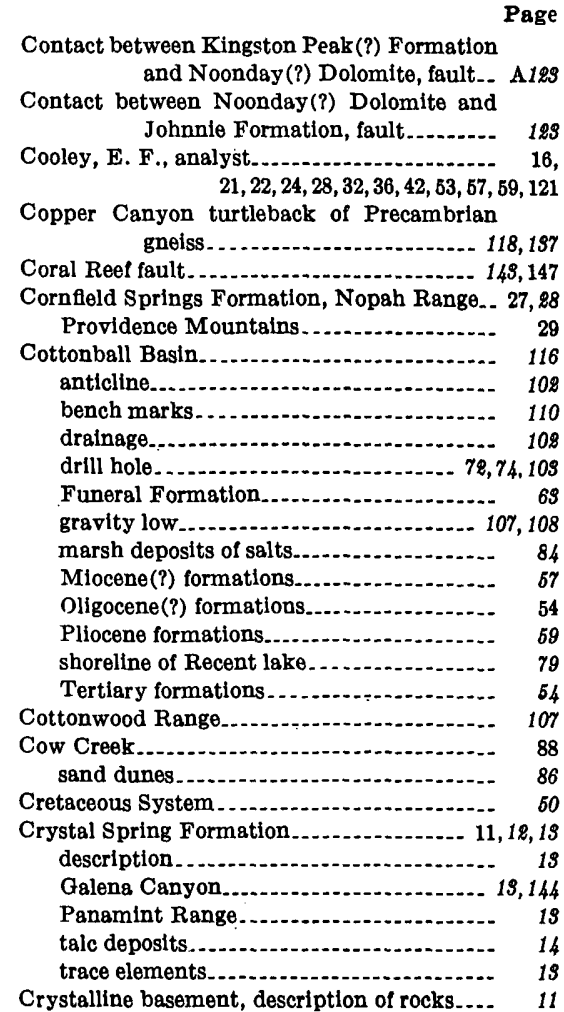

D

Dantes Vlew, tilting of ground surface

Darwin area.

Ely Springs Dolomite.

Lost Burro Formation

Death Valley Canyon, chaosilke formation in Amargosa thrust complex........ 192, 195

faults in No. 2 grevel .................... 105

Precambrian metamorphlc rocks.......... 189

Death Valley National Monument........... $\gamma$

Death Valley occupation, I. .................... 87,81

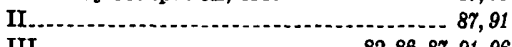

III............................. 82, 86, 87, 91,96

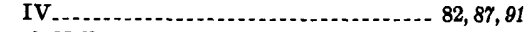

Death Valley trough

Deformation, late Pledstocene................ 109

structural $\ldots . . . . . . . . . . .110,141$

Description of valley......................... \&

Desert pavement, No. 2 gravel ............. 64,65,67 No. 3 gravel ............................. 67 Pleistocene(?) and Recent(?) No. 3 gravel. $\quad 77$

Desert varnish, description................... $\quad 90$

Egypt................................... $\theta_{1}$ semiquantitative spectrographic analyses. 80,91 Southwest............................... 81,98

Desert varnish on, Colorado Plateau.......... $\quad 01$

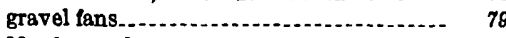
No. 2 gravel .............................. 90,91

No. 3 gravel.......................... 76,77, 90

Desolation Canyon, hanging valley ............ 104

Devils Golf Course............................ 108

drill hole................................... 74, 101

Dovils Speedway . ........................... 95

Devonian formations, trace elements.......... $\quad 41$

Devonian System.............................. 88,40

Dikes, along fault east of Hanaupah Canyon.- 128 basalt, Emigrant Canyon.................... 125

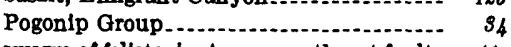
swarm of feliste, in Amargosa thrust fault. 11 ,

swarm of Tertiary

$129,181,183,186$

Dissolved solids at marshes.................... 89

\section{NDEX}

Domes, structural, ovier granitic intrusions Page

128, 187

Doming of upper Pleistocene gravel at Salt Creek Hills..........................

Drainage, Cottonball Basin.................. 108

exterior........... 110

Middle Basin.

on No. 2 gravel.

Drewes, Harald, cited.

chasin 108

Funeral Formation.........................

Duncan, Helen, fossils identified by

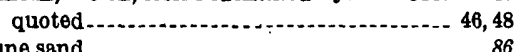

Dune sand

\section{$\mathbf{E}$}

Early Pleistocene, structural features......-. 114 Early Tertiary, structural features............. 118

Earthquake epicenters. .................. 110

Earthquakes:

eastern Sierra Nevada area ................ 114 Hebgen Lake, West Yellowstone area... 100,112 major, Death Valley ...................... 110

Owens Valley area

East Coleman Hills, fanglomerate of Funeral Formation............................ faults in No. 2 gravel.

Pliocene playa beds. ........................

Echo Canyon ....................................... stratigraphic section, basal shale member of Nopah Formation.-.......... Carrara Formation in Funeral Moun-
talns.

Zabriskie Quartzite...........................

Echo Canyon Wash..............................

Echo Mountaln thrust fault.....................

Egypt, desert varnish.

Ely Springs Dolomite, description................ Ely Springs Range........................ fossil collections...

fossills............................. trace elements................................. Ely Bprings Range, Ely Springs Dolomite....

Emigrant Canyon...............................

Emigrant Spring fault.......................... $\quad 143$

Emigrant Wash, Funeral Formation........ 69,114

Erickson, R. L., quoted......................

Erosion, damage to roads and flood-control ditches in 25 years

damage to prehistoric archeological features...

damage to Recent fault scarn along foot of Black Mountains damage to tralls about 50 years old ....... extent of destruction caused by ............ in mountains hordering Death Valley.... of flood-control embankments............ of road shoulder along old bladed road from Beatty Junction.

on Quaternary deposits...............................

Escarpment, Furnace Creek to Mormon Point Hanaupah, west side of saltpan..........

Eureka Quartzite, Beatty area.................. description.

Funeral Mountains.

Little Bridge Canyon

Nopah Range.

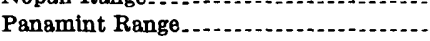
stratigraphic section, Trail Canyon...... trace elements.

Tuckl Mountain.

\section{F}

Fault zone, Furnace Creok.

Faults:

affecting saltpan ........................ 100 at foot of Funeral Mountains.......... 54, 57, 59
Faults-Continued

block.

Page Artists Drive............... 25, 70, 72, 77, 119

Funeral Formation................ 69, 114 shoreline of Recent lake at west foot of fans............................... 79 at foot of Black Mountains............ 114 Colorado Plateau...................... 152 downfaulted, Artists Drive area...... $\quad 63$

Funeral Formation............ 101,114,115 mountains........................ 9,98 Panamint Range..................... 3,148 Park Village, Funeral Formation. $70,114,115$ Colorado Plateau......................... 151 Coral Reef............................. 149, 147

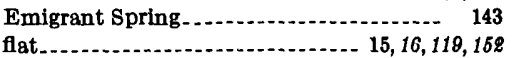
Stirling Quartzite................... 22 Funeral Formation...................... 114 gravel fans............................. 109 Grotto Canyon......................... 149, 147 Hanaupah escarpment.................. 77 high-angle_...................... 114, 119, 144, 149 high-angle normal . ..................... 197 Hurricane............................... 152 Keane Wonder, foot of Funeral Mountains.................. 118,148,149,150 Kit Fox Hills............................. 110, 118 displacement. .................... 116 Mont Blanco.................. 109, 115, 117, 150 No. 2 gravel ............................ 108, 105

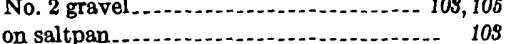
$\begin{array}{lr}\text { on saltpan..... } & 109 \\ \text { overthrust_... } & 99\end{array}$ overthrust_............. 99 Panamint Range............. 115, 145 Amargosa $\ldots 114,118,118,128,145,147$ chaotic complex along-
swarm of felsite dikes.- $11,129,191,198,195$ swarm of felsite dikes.. $11,129,191,198,195$
Boundary Canyon................ 118,148 Burro Trail _._................. 122,188, 144 sills of monzonite porphyry

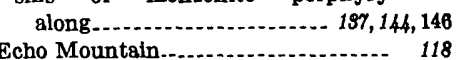

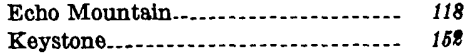
Panamint Range................... 188 Tucki Mountain..... 46, 50,114,116,142,160 Wyoming

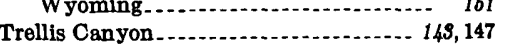
with vertical displacement............... 107 Felsite plug in granite in Amargosa thrust complex.......................... 156

Fenster, Black Mountains . Funeral Mountains................... 147,151 Tucki Mountain .......................... 114, 149 Ferguson, H. G., quoted.............. 121 Flood plain, saltpan ...................... 95, 87, 100 Flood-plain deposits of alluvium, along Amargosa River and Salt Creek.........

Flood-plain deposits of salts....................

Floods, in washes..................................

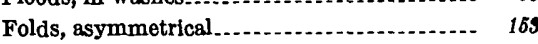

on gravel fans.

Fossil collections:

Carrara Formation........................ 20

conglomerate of Permian age. . . .

Ely Springs Dolomite..

Furnace Creek Formation

limestone of Pennsylvanian age ...........

Lost Burro Form

Nopah Formation........................

Paleozolc formations. .......................

Pogonip Group . -

Rest Spring Shal

Tin Mountain Limestone................... 48,48

Wood Canyon Formation. ................

Fossils:

Artist Drive Formation . ...................

Bonanza King Formation, Trail Canyon.

Carrara Formation. ....................

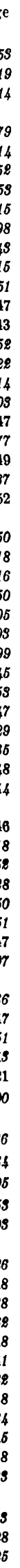

e

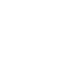

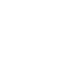

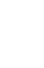

.

.

.

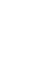

. 


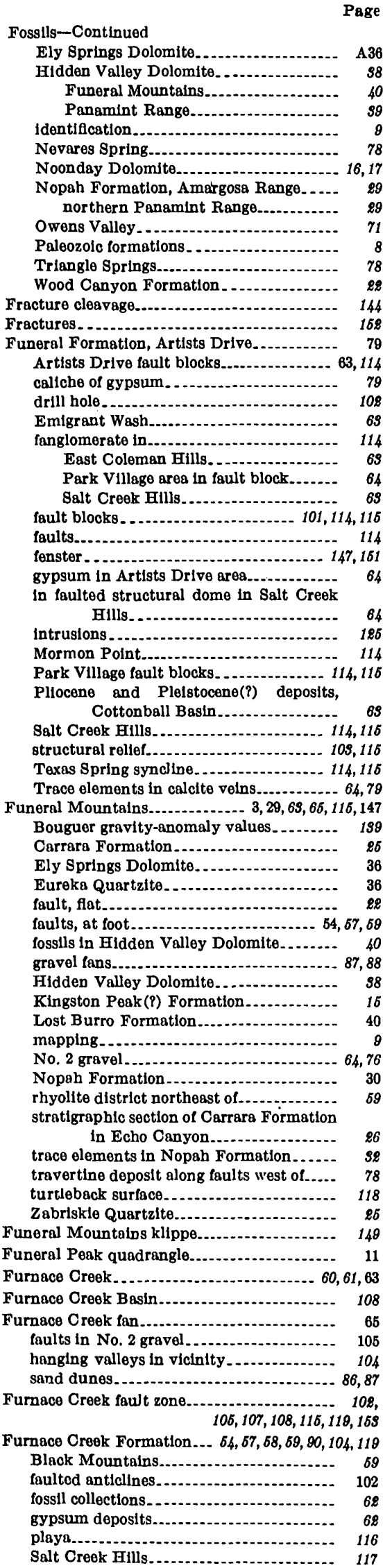

Furnace Creek Formation-Continued structural reliefTexas Spring syncline ine trace elements Furnace Creek Ranch fresh-water snails. Furnace Creek Wash.................... 61, 69, 65, 93 travertine deposit overlapping bank...... $\quad 78$

\section{G}

Gale, H. S., quote 69
88 Galena Canyon.

Crystal Spring Formation

Noonday Dolomite Precambrian rocks of the crystalline basement.

stratigraphic section of Crystal Spring Formation.

trace elements in Precambrian schist...

Galena Canyon fan. . . .............................

Geomorphology of gravel fans..................

Gilbert, G. K., quoted

Gneiss, Precambrian

Gold, Skidoo mining district.

Golden Canyon, hanging valley.

Goodsprings quadrangle, Nevada, Bird Spring Formation

Goodwin Formation, central Nevada Eureka district.

Gordon, Mackenzie, quoted 34

Gower Gulch, hanging valley

Grabens. 109

Granitic intrusions. Mina quadrangle, Nevada............... 128 satellites of Slerra Nevada batholith..... 50 ,

99, 120, 121 Grapevine Mountains.......... 198

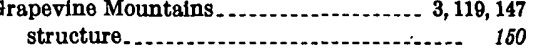
Gravel fans. ...................... 64, 65, 66, 79, 98,95 Black Mountains..................... 87, 106 desert varnish erosion and sedimentation

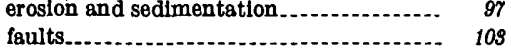
colds _. Funeral Mountains ..................... 87, 88 geomorphology ....................... 108 $\begin{array}{lr}\text { geomorphology } & \\ \text { mapping } & \end{array}$ mapping physlography.......................... 87 overlapping .............. 85 sandy playa deposits.................. \begin{tabular}{rr} 
sandy playa deposits $\ldots$ & 76 \\
\hline
\end{tabular} Gravel Well Gravity studies, Great Basin..............
Great Basin 107 gravity studies............ 107 intrusions 182 structural geology subsections.

Greenwater Valley

Groom district, Nevada

Grotto Canyon..

stratigraphlc section of shale member of base of Nopah Formation.

Grotto Canyon fault ................. 148, 147 Ground surfaces in Death Valley area, tilting. 118 Gypsum, Funeral Formation . ............... Gypsum deposits, Furnace Creek Formation. massive.

\section{$\mathbf{H}$}

Hanaupah Canyon, granite granitic intrusion, trace elements $\ldots \ldots, 120$ $121,128,144$ gravel fans, magnetic anomalies........... 197 section of Johnnie Formation............. 19 sllls from granite....................... 182, 197
Page

Hanaupah Canyon fan $\ldots . . . \ldots \ldots \ldots \ldots . . . . . . .465,66,77$ Hanaupah escarpment, fault................-. $\quad 77$ faults in No. 2 gravel. ................... 105 west side of saltpan

Hanaupah Formation.................. 18

Hanging valloys............................... 104

Hanging wall, Hells Gate................ 148

Harrisburg Flat......................... 116, 128, 186

Kingston Peak (?) Formation............- 16 Hebgen Lake, West Yellowstone area, earthquake..................... 100,118

Hells Gate, hanging wall ............... 148

Henry Mountains, Utah............. 90, 121, 129, 125 Hidden Valley Dolomite, fossils....... 38 Panamint Range......... 98 fossils.

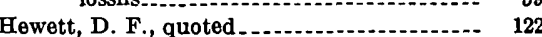

Hurricane fault

Ibex Hills, Pahrump Series.....................

Indians, mesquite storage pits constructed by trails used by Inyo Mountains, Triassic sedimentary rocks. $\quad 50$

Iron Springs district, Utah, doming .......... 122

Ivanpah quadrangle, Teutonla Quartz Monzonite.....................

$\mathbf{J}$

Johnnie Formation .................. 9, 87, 126, 128 composite section in Six Spring Canyon and Johnson Canyon...............

description. . ..................................... stratigraphic section, in Hanaupah Canyon in Trall Canyon........ trace elements........................... 20,21

Johnson Canyon, composite section of Johnnle Formation

faulted gravel fans......................... 103

Stirling Quartzite.......... 20

Johnson Canyon fan............................ 65

Jurassic rocks

\section{K}

Karst topography .......................... 66 Keane Wonder fault, foot of Funeral Mountains .................. 118,148,149,160

Keystone thrust fault........................ 152 Kingston Peak Formation.......... 18,1s Panamint Range........ 19

Kingston Peak(?) Formation........ 129, 125, 149, 147 description............................... 16 Funeral Mountains Panamint Range. trace elements.......... 16, 21 Tucki Mountain.......................... 15

Kit Fox Hills, faultline scarp.................. 118 Tertiary deposits...................... 54,66, 67 Kit Fox Hills fault . ...................... 110,118 displacement.

L

Lake Manly, Pleistocene.............. 64, 69, 71, 105 Lake Mojave culture..................... 87 Las Vegas quadrangle, Bird Spring Formation.

Late Paleozolc formations, Panamint Range. Late Pleistocene deformation Late Tertiary structural features............... 116 Little Bridge Canyon, Eureka Quartzite...... $\quad s 6$ Logs of wells drilled by Pacific Coast Borax

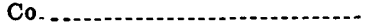

118
(1) . . ,

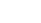

(1)

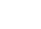

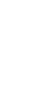
.

\section{.}

18

.

16

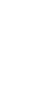




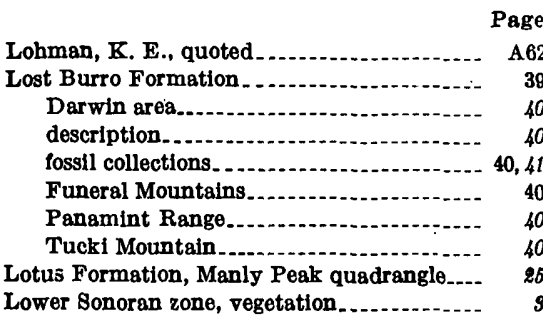

McAllister, J. F., quoted.................... McLean Bprings.

Manly, Lake, Pleistocene............. 64,69,71, 105 Manly Peak quadrangle, Lotus Formation

Mapping of the valley

Marsh deposits of sulfate salts around edge of saltpan.

Marshes, dissolved solids. ......................

Marvel Dolomitic Limestone

Merriam, C. W. quoted

$71,72,78,86,110$ aeromagnetic profile..................... 110 bench marks. ................. 110

gravity low.................................. 107

sand dunes. 87

Mesquite storage pits constructed by Indians. . . 100, 10

Mexican Highland.

Middle Basin, drainage

Mins quadrangle, Nevada, granitic intrusions . 122

Minerals, lead, Noonday Dolomite.............. 16

Mlocene, volcanic rocks.

Miocene(?) deposits, trace elements...........

Miocene(?) formations, Cottonball Basin. .... $\quad 57$

Miocene(?) structural features

Mississippian 8ystem........................... 48,44

Mojave, Lake, culture............ 87

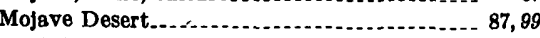

Intrusions............................. 122

Mojave River................ 71,99

Monocline Noonday(?) Dolomite and overlying Johnnie Formation.............. 149

Mont 'Blanco fault................... 108, 115, 117, 150

Monzonite porphyry sills along Burro Trail thrust fault .

Mormon Point................. 69, 69, 70, 71, 72, 97, 103 faults in No. 2 gravel................ 105 Funeral Formation...................... 114

Precambrian rocks of the crystalline basement

Mormon Point turtleback of Precambrian
gneiss Mormon Point turtleback surface...... 110,114, 187

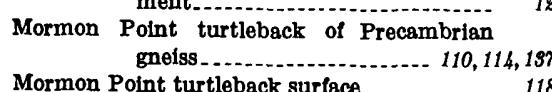

Mormon Point turtleback surface............. 118

Mosaic Canyon............... 22, 29

Mountains, fault-block

Muddy Creek Formation...................

Mudflows, destructive.

In washes, recent.

Mustard Canyon, faults in No. 2 gravel....... 105

\section{$\mathbf{N}$}

Nelman, H. L., analyst

Nevada Test Site.

121

Pogonip Group. $34,35,36$

Nevares Peak, Titus Canyon(?) Formation of Stock and Bode (1935) ........... 118,148

Nevares Spring, fossils.

travertine deposit

Ninemile Formation, central Nevada Eureka district............................ 34

No. 2 gravel ................ $8,64,76,77,85,90,96,116$ desert pavement. . ..................... $64,65,67$

desert varnish.......................... 90,91

disintegration of stones..................... 97
No. 2 gravel-Continued

drainage........... A66

faults................. 108, 105

Funeral Mountains......................... 64,76

in canyons of Panamint Range........... 66

rock alinements ......................... 96

rock circles....... 96

salt_...... 65,66

terracettes..................... 68,96

Tucki Wash....................... $\gamma$

No. 3 gravel.............. 76,89,96,97 desert pavement. . ..................... 67

desert varnish......................... $76,77,90$

rock circles............................... 96

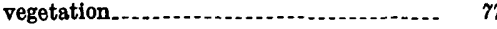

No. 4 gravel ................... 84, 86,97

Noble, L. F., quoted.................. 137

Noonday Dolomite...............................

deposits of lead minerals................. 16

description................ 16

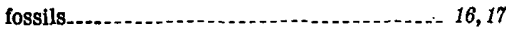

Galena Canyon.......................... 16

Six Spring Canyon.

trace elements.................................. 16

unconformity between top of Pahrump

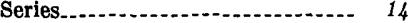

Noonday(?) Dolomite............... 183, 185, 126, 128 Panamint Range ....................... 15, 16,17

Noonday(?) Dolomite and overlying Johnnie Formation, monocline...........

Nopah Formation

description.

fossil collections

fossils, Amargosa Range

Funeral Mountain

Nopah Range...

Panamint Range
stratigraphic section, north side of Trail Canyon.

of basal shale member, south side Echo Canyon........................... f shale member, Grotto Canyon.... trace elements.

Tucki Mountains.

Nopah Range, Bonanza King Formation

Cornfield Springs Formation .

Ely Springs Dolomite

Eureka Quartzit

fossils, Bonanza King Formation.

Noonday Dolomite.

Nopah Formation

Pogonip Group.

Stirling Quartzite.

Sultan Limestone.

Zabriskie Quartzite

Nova Formation

\section{o}

Oda, Uteana, analyst

12 Oligocene(?) formations around Cottonball Basin.

Oliver, w. A., Jr., fossils identifled by ......... 38,41 Ordorician rocks, trace elements in Panamint

$$
\text { Range. }
$$

Ordovician System

Origin of the structural features

35,36

Owens Valley, fossils

\section{$\mathbf{P}$}

Paciflc Coast Borax Co., logs of wells drilled..-Pahrump Series, description..

metamorphosed sedimentary rocks. ..... unconformity between Noonday Dolomite.

Pahrump Valley, Pahrump Series.
149

$$
\text { Perd }
$$

Pennsylvanian(?) System

Perdido Formation, Panamint Range.......

Perlite Hill

Permian rocks, Butte Valley . . ................ 50

unconformity between overlying Triassic rocks..

Permian System..

Pioche district......................................... 33

Plateau, ancient............ 150,152

Playa, Furnace Creek Formation.............. 116

sand and silt . .......................... 76

Playa deposits, Pliocene...................... 59,61

Pleistocene, Lake Manly deposits ............. $\quad 71$

debris avalanche.......................... 69

Pleistocene deposits, valley fll................. $\quad 72$

Pleistocene lake deposits....................... 69

shoreline features...................... $69,71,105$

Pleistocene time, climatic changes............ 97

\section{2} 50

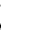

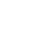

.


Page
Pleistocene(?) deposits...................... A6s, 76

Plíocene deposits.

Pliocene formations around Cottonball Basin

Pliocene playa beds, East Coleman Hills...

Pliocene playa deposits........................ 68,61

Pogonlp Group, Bare Mountain, Nev......... description

dikes

fossil collectlons

Nevada Test Site

Nopah Range.

Panamint Range.

, south side of Tral Canyon.

Trall Canyon.

Pottery occupation

Precambrlan metamorphlc complex, Black Mountains and west face of Panamint Range

Precambrlan rocks, age of schist

Black Mountains...

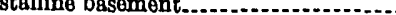

debris avalanche at foot of Black Moun tains......................

gneiss

Mormon Point turtleback ...... 110,114, 197

granite............................... 99,158

metamorphlc........................... $0,189,135$

lower plate of Amargosa thrust....... 147

trace elements..................... 18

structure.................................. 141

thickness

Precambrian System, rocks of the Crystalline basement.............................

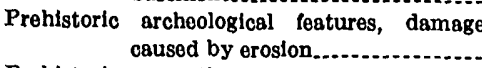

Prehistorio archeological features, damage
caused by erosion................

Prehistoric occupations........................

Providence Mountains, Bonanza King Formation.

Cornfleld Springs Formation.

Triassic sedimentary rocks

\section{Q}

Quartz Spring area, Racetrack Dolomite......

Quaternary deposits, erosion. ..................

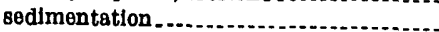

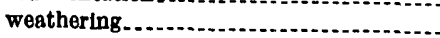

Quaternary fll in Death Valley.............. $98, \theta 7$

Quaternary Bystem.......................... 64

\section{$\mathbf{R}$}

Racetrack Dolomite, Quartz Bpring area .....

Radcllff Formation. . . ...................................

Rain...

Rainfall...

annual..

Recent deposits.

archeology .............................. 87

No. 4 gravel.......................... 76, $77,84,86$

older salines. .....................

Recent fault scarp along foot of Black Mountains........ 110

damage caused by erosion................. 87,100

Recent lake. .................. 76, 85, 84, 87, 92, 100,101

Recent lakes, shoreline features.............. 79

$\begin{array}{lr}\text { Recent lakes, shoreline features............... } & 79 \\ \text { Recent tilting of the saltpan................. } & 100\end{array}$

Recent(?) deposits.......................... $\quad 76$

Redlands Dolomitio Limestone. .............. 16

Reliof....................................... $s$ magnetio............. 108 Panamint Range........................... 116 structural ............................ 109,115, 149 granite at Hanaupah Canyon...... 126

Rest Spring Shale........................... 49,47 description.

fossil collections
Rest Spring Shalo-Continued

Panamint Range.

trace elements

48,45

Tuck1 Mountain............................. 46,49

Rhyolite district northeast of Funeral Mountains....

Rock Alinement Wash. ...........................

Rock alinements on No. 2 gravel

Rock circles, along rims of washes.

Rock salt....

massive

rough silty

smooth silty.................................. 89,103

Ross, R. J., Jr., sections measured by . .... 23, 26, 35

Runoff. ........................................... 95,86

Ryan quadrangle ............................ $\quad 160$

\section{$\mathbf{8}$}

Baline deposits forming at present............. 84

Balt, No. 2 gravel

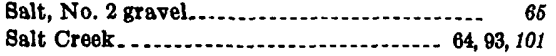
alluvium along........................... 86 sand dunes.................................. 86

Salt Creek Hills. ...................... 59, 72, 77 doming of upper Pleistocene gravel....... 105 fanglomerate of Funeral Formation........ 69 faults in No. 2 gravel........................ 105 Funeral Formation...................... 114,115 in faulted structural dome........... 64 Furnace Creek Formation................ 117 playa beds in an asymmetrical ant1cline.

shoreline of Recent lake

Salt Crook Hills anticline 109

Salt crust, on saltpan. structures affecting ........................... 100

Salt deposits forming at present............... 84

Salt Well...................................... 86, 87

Saltpan _...... 62, 63, 65, 76, 79, 82, 88, 86, 87, $98,97,116$ depth of fill under........................ 99

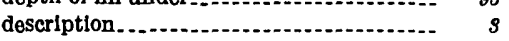
faults. faults affecting.-... flood plain.......................... 95, 97, 100 mapping -....

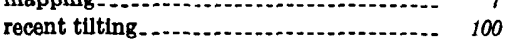
structural features............................ 100 valley fll under............................ 108

Sand and silt In the playa. .................. 76

Sand dunes.................................... 76, 88, 86

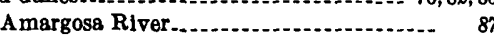
Badwater Basin.

Cow Creek...

Furnace Creet fan

Mesquite Flat

Selt Creek

vegetation.

Scientiflc contributions

Searles Lake-........ 71

Sedimentation on Quaternary deposits . .

Seismic activity ................................. $\quad 110$ relation between tilting movements......- 114

Sentinel Dolomite.............................. 16

Shoreline Butte _.

Shoreline features, Pleistocene lake deposits.- 69.71

Shortys Well................................. 77

Slerra Nevada.

Slerra Nevada area, earthquakes.............. 114

Slerra Nevada batholith...................... 50,189 Intrusions................................... 120,128

Sills, along fault east of Hanaupah Canyon.... 128 from granite at Hanaupah Canyon...... 128, 187 monzonite porphyry along Burro Trail thrust fault................ 197, 144, 146

Sllurian Hills.

granitic intrusions......................... 129

Pahrump Series.

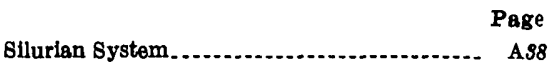

S1x Spring Canyon ........................... 88

composite section of Johnnie Formation.- $\quad 18$

faults in No. 2 gravel ....................... 105

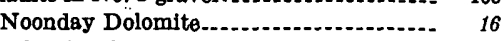

volcanlc ash................................. 66

Six Spring Canyon fan...................... 79

Skddoo, granite................ 15, 50,60,120,129, 148 granitic intrusion, trace elements........ 120, 181 Skidoo mining district, gold..

Slate Range, Precambrian metamorphlc rocks, Bouguer gravity-anomaly values. 199

Soda Lake........................... 71, 116 Sods Mountain, Triassic sedimentary rocks.. $\quad 50$ Bonoran Desert................................. 90 Southwest, Desert varnish..................... 81,82 Spring Mountains, Stirling Quartzite.........- 21 Springs, with potable water.................. s Spurr, J. E., quoted........................... 98 Starvation Canyon........... 84, 88, 126, 128, 197, 143 faulted gravel fans.......................... 103 Stirling Quartzite Starvation Canyon fan

Stirling Quartzite................... 8, 11, 36, 189, 135

description.

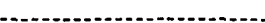

Johnson Canyon.

Nopah Range.

Spring Mountains

Starvation Canyon.

trace elements

Stocks, 8pophyses from sranitic batholith,

Stone artifacts........................... $70,77,91,96$

Stratigraphlc section, Carrara Formation in Funeral Mountains in Echo Canyon............................................

Crystal Spring Formation in Galena Canyon

Eureka Quartzite, Trail Canyon

Johnnie Formation, Hanaupah Canyon..

Trall Canyon

Nopah Formation, basal shale member, south side Echo Canyon...........

north side of Trall Canyon............

shale member of base, Grotto Canyon.

northeastward from Cottonball Basin to Funeral Mountains

Pogonip Group, south side of Trail Canyon.

Tertlary formations, Artists Drive area..-

Tin Mountain Limestone and younger Mississippian limestone...........

Titus Canyon(?) Formation of Stock and Bode (1935)

Wood Canyon Formation along Blackwater Wash . ......................

Zabriskle Quartzite north side of Echo Canyon...................................

Stratigraphy.

Structural arch

domes over granitic intrusions...... 121

Structural features, early Plelstocene......... 129,114 early Tertiary...

late Tertiary............................ 116

Miocene(?)............................. 118

origin

principal_................................ 158

summary............................... 158

Structural geology, Great Basin................ $\quad 97$

Recent and late Pleistocene. . ............. 100

Structural relief............................... 149

Funeral Formation................. 10s, 116

Furnace Creek Formation................ 116, 117

granite at Hanaupah Canyon............ 126

Structural setting of Death Valley .............. 88

Structure of Precambrian and Paleozolc rocks_ 141

Sultan Limestone, Nopah Range............. 40 


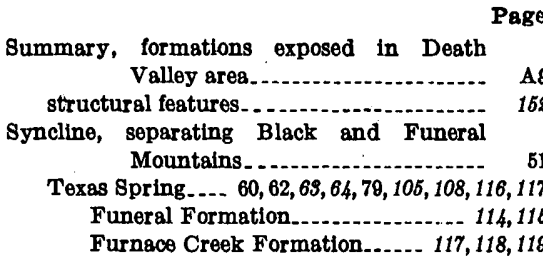
$\mathbf{T}$

Talc, production.......

Talc deposits, Crystal Spring Formation. Tank Hill Limestone of the Ploche district... Taylor, D. W., fossils identifled by........... Temperature.

Terracettes, No. 2 gravel......................... Tertiary deposits, composition

Kit Fox Hills

Tertiary dikes

Tertiary fll

Tertiary formations, around Cottonball Basin. Black Mountains.

stratigraphic section, Artists Drive area

Tertiary plays deposits

Tertlary System . .

Tertlary volcanic rocks................... $51,89,114$

Teutonia Quartz Monzonite, Ivanpah quad. rangle

Texas Spring, travertine deposit............... 78

Texas Spring syncline. $62,69,64,79,105,108,116,117$

Funeral Formation...............

Tilting, of ground surfaces in Death Valley area.

Recent, of the saltpan.................... 100, 109

Tilting messurements, methods........... 118

relation between tilting movements and seismic activity . ...........-...-

Tiltmeter measurements

T1ltmeter stations............................... 118

Tin Mountain Limestone, description......... 49

fossil collections........ 48,48

Panamint Range

stratigraphic section.

Titus Canyon Formation of Stock and Bode (1935)

Titus Canyon(?) Formation of Stock and Bode (1935) ............. 58, 54, 59,118,148

Nevares Peak . . . ........................ 118, 149

stratigraphic section ....................... 54,56

trace elements in beds correlated with.... $\quad 57$

Topography, karst................. -.. 66

Trace elements, augen gneiss in A josa thrust complex ................ 129,140

beds correlated with Titus Canyon(?) Formation of Stock and Bode (1935)

biotite gneiss in Amargosa thrust complex 129,140

Bonanza King Formation in Panamint Range calcite veins in Funeral Formation...... 64,79 Carrara Formation................... 26, 28, 29 Crystal Spring Formation................. 19 Devonian and younger Paleozoic forma-

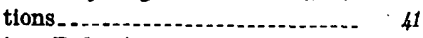

Ely Springs Dolomite................ $\$ 6, s 8$ Eureka Quartzite_............... 36 Furnace Creek Formation.........-.-.-- 68 granitic intrusion at, Hanaupah Canyon. 120

Skidoo . . . . . . . . . Johnnie Formation Kingston Peak(?) Formation............. 15, 21

Miocene(?) deposits..................... $\quad 69$
Page

Trace element-Continued

Noonday Dolomite.

32

..... $\$ 5,36$

Pennsylvanian and Permian formations on Tucki Mountain.

Precambrian metamorphic rocks. . .... 48,48

Rest Spring Shale. spring-deposited travertine 78

Stirling Quartzito.......................

volcanic rocks in Artists Drive area....... 69,57

Wood Canyon Formation . . . . .......... 24, 26

Zabriskie Quartzite

Trail Canyon

Bonsnza King Formation. fossills.

Ely Springs Dolomite.

exposure of roof of granite at stidoo _ 129,12

Gulted gravel fans

fossils in Bonanza King Formation.......

Hidden Valley Dolomite. ................ \$8

Pogonip Group......................... \$\$, 196

stratigraphic section, Eureka Quartzite...

Johnnie Formation

Nopah Formation.

Pog of ground sur

112,11

volcanlsm north of ................ 186

magnetic anomalies.

tilting of ground surface

travertine deposit.

Trails, damage to

Travertine, trace elements in spring-deposited.

Travertine deposit, along faults west of $\mathrm{Fu}$ neral Mountains

Nevares Spring

overlapping bank of

Texas Spring

Trall Canyon fan

Travertine Springs.

Trellis Canyon fault

Dormation

Triangle Springs, fossils

Triassic formations, thickness............... 8,148

Triassic rocks. unconformity between Permian rocks...- 141

Triassic troughs

Triassic System $\quad 50$

Trough, Death Valley

Troughs, Triassic . . .

Tucki Mountain

Bonanza King Formation ............ 29

Bouguer gravity-anomaly values.......... 199

Ely Springs Dolomite. .................... 36

Eureka Quartzite....

Hidden Valley Dolomite......

Kingston Peak(?) Formation ...........

limestone conglomerate of Permian age.

limeston 0

limestone of Pennsylvanian age

Lost Burro Formation

Nopah Formation.

Rest Spring Shale.............

trace elements in Pennsylvanian and Permian formations.

turtleback surface on west foot....... 68,116

Tucki Mountain fenster ................... 114,148

Tucki Mountain klippe.

Tucki Mountain thrust fault.............. 46 ,

Tucki Mountain turtleback in Emigrant Wash. 118

Tucki Wash................. 22, 37, 88, 123, 142,143 faulted gravel fans....................... 103 faults in No. 2 gravel................... 105 No. 2 gravel.
Page

Turtleback, Copper Canyon................ A118, 197 Tucki Mountain, in Emigrant Wash..... 118 Turtleback of Precambrian gneiss, above Bad-

$$
\text { water... }
$$

Copper Canyon

$51,104,157,147$

Mormon

Turtleback ridges, Black Mountains.......... 110, 114, 190

Turtleback surface, of Funeral Mountains...-.- 118 of Mormon Point........................ 118 on west foot of Tucki Mountain......... 68, 116

Unconformity, between base of Noonday Dolomite and top of Pahrump Series...

between Permian and overlying Trlassic rocks..

Uper Pleistocene gravel, doming at Salt Creek Hills...........................

\section{$\mathrm{V}$}

Valley fll, gravity features..................... 107 magnetic features Pleistocene deposits........................ 78

Vegetation on sand dunes.

Pleistocene(?) and Recent(?) No. 3 gravel

Virgin Spring area A margosa thrust foult 20

Virgin Springs district, Amargosa thrust fault.-................... 147 chros_............................. 11, 51,129, 195 Volcanic rocks, Tertiary .................... $51,89,114$

Volcanism, north of Trail Canyon........... 186$$
\text { W }
$$

Warm Spring Canyon ranitic intrusion (50,142

Washes........................... 88, 80 floods rock circles along rims

Wells, logs

ron

Weathering on Quaternary deposits.........

West Side Borax Camp.

Wildrose Canyon, granite granitic intrusion.........

grantics, bench mark

Wingato Wash fan

Wood Canyon Formation. description ............... 28

fossil collections.......................... 28 fossils.......................................... stratigraphic section along Blackwater

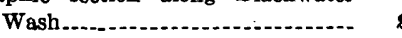

trace elements........................... 24, 26

Wyoming, thrust faults........................ 151

\section{$\mathbf{Y}$}

Yellow Hill Limestone of the Pioche district.. 33

Zabriskie Point

Zabriskie Quartzite....................... 22,36

Aguerberry Point........... 25

Blackwater Wash..........

chrotic blocks................ 120

description. ...................... 24

Funeral Mountains

Nopah Range. ................................

stratigraphic section north side of Echo Canyon......................... 25

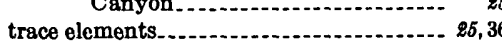

Zircons, in A margosa thrust complex.... 198, 134, 197

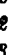

(1)

(1)

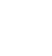

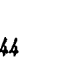
. 